



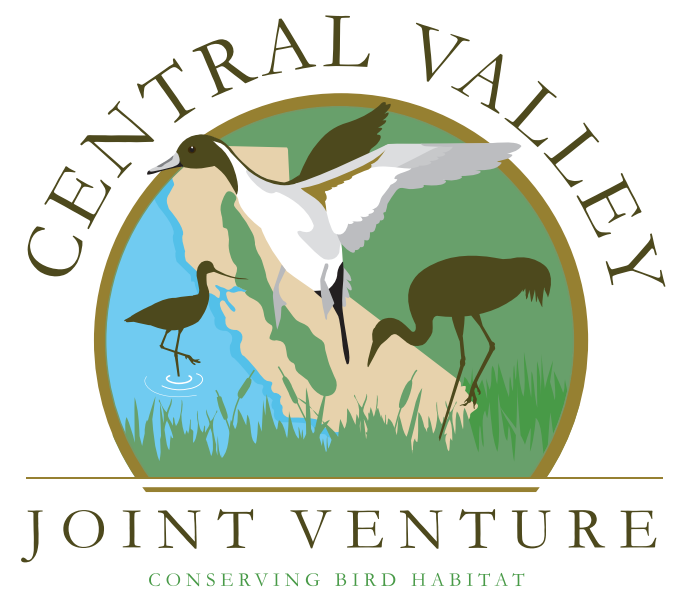

\section{IMPLEMENTATION PLAN}

When referring to this document, please use the following: Central Valley Joint Venture, 2006.

Central Valley Joint Venture Implementation Plan - Conserving Bird Habitat.

U.S. Fish and Wildlife Service, Sacramento, CA.

Cover photos: Northern pintails, Bob McLandress, CWA; Faith Ranch, Lake Marie, Gary Zahm 



\section{ACKNOWLEDGEMENTS}

\section{Special Recognition Goes To:}

- Former Central Valley Joint Venture Coordinators, Gary Kramer and Dave Paullin, for developing the 1990 Implementation Plan and establishing the foundation for a successful and enduring partnership.

- Mark Petrie, Ducks Unlimited, Inc., who was the Project Manager and combined his unique planning and modeling skills with technical expertise and writing ability to prepare a number of chapters including: Accomplishments, Basin Characteristics, Breeding Waterfowl, Wintering Waterfowl, Wintering Shorebirds, and Summary.

- Geoff Geupel, Catherine Hickey, and Diana Stralberg, PRBO Conservation Science for their work on the Riparian Songbirds and Breeding Shorebirds chapters.

- Dale Garrison, Fish and Wildlife Service, Joel Miller, Joel Miller Environmental Consulting, and Dave Widell, Ducks Unlimited, Inc. for their work on the Wetland Water Supplies chapter.

- Barbara Hennelly, who did all graphic design work, and Jim Holt, Holt Print Services for print management.

- Dave Feliz, California Department of Fish and Game, Dale Garrison, Fish and Wildlife Service, Brian Gilmore, Bob McLandress, California Waterfowl Association, Jill Shirley, Central Vally Joint Venture, Carley Sweet, TRC Essex, and Gary Zahm for the use of their photographs throughout the Plan.

- Kevin Petrik and Xiangyue Wei, Ducks Unlimited, Inc., for producing the maps in this report (unless otherwise noted).

- JV staff members Rob Holbrook, Ruth Ostroff, and Jill Shirley, who dedicated hundreds of staff hours writing and editing the Plan.

\section{Plan Contributors:}

\section{Organizations}

Audubon California - Julia Levin, Glenn Olson, Vance Russell, Dan Taylor

California Association of Resource Conservation Districts - Tacy Currey

California Rice Commission - Paul Buttner

California Waterfowl Association - Ed Burns, Rob Capriola, Bill Gaines, Mark Hennelly, Dan Loughman, Bob McLandress, Jake Messerli, Dennis Orthmeyer, Jason Rhine, Chadd Santerre, Greg Yarris

Colusa Basin Drainage District - Anjanette Martin

Conaway Conservancy - Mike Hall

Defenders of Wildlife - Kim Delfino

Delta Protection Commission - Margit Aramburu

Ducks Unlimited Inc. - Theresa Allen-Hurst, Mark Biddlecomb, Dan Connelly, Mike Eichholz, Dan Fehringer, Jay Dee Garr, Virginia Getz, Greg Green, Chris Hildebrandt, Luke Naylor, Mark Petrie, Kevin Petrik, Fritz Reid, Ruth Spell, Xiangyue Wei, Dave Widell, Olen Zirkle

Grassland Water District - Scott Lower, Don Marciochi, Bob Nardi, Tim Pool 
PRBO Conservation Science - Ann Chrisney, Ellie Cohen, Geoff Geupel, Jeanne Hammond, Catherine Hickey, Chrissy Howell, Kim Kreitinger Gary Page, Dave Shuford, Hilde Spautz, Diana Stralberg, Julian Wood

River Partners - John Carlon, Tom Griggs

Suisun Resource Conservation District - Steve Chappell, Kristin Garrison, Craig Haffner, Bruce Wickland

The Nature Conservancy - Mike Conner, Mike Eaton, Greg Golet, Sam Lawson, Ryan Luster, Ramona Swanson, Chris Unkel, Dawit Zeleke

Trust for Public Land - Nelson Mathews, Erik Vink

Tulare Basin Wetland Association - Bob Bowman, Jeff Thomson, Jack Thomson, Fran Burgess

Tulare Basin Wildlife Partners - Carole Combs, Rob Hanson, Dick Moss

University California Davis - Josh Ackerman, John Eadie, Shaun Oldenburger

University Nevada Reno - Jim Sedinger

\section{State Agencies}

California Department of Fish and Game - John Anderson, Andy Atkinson, John Beam, Ryan Broddrick, Brad Burkholder, Bill Cook, Dave Feliz, Paul Forsberg, Steve Juarez, Dean Kwasny, Bill Loudermilk, Carol Oz, Ed Penny, Glenn Rollins, Jeff Single, Dave Smith, Carl Wilcox, Dan Yparraguirre, Dave Zezulak

California Department of Water Resources - Dale Hoffman-Floerke, Jim Martin, Kent Nelson, Michael Perrone

California Resources Agency - Jay Chamberlin

California State Parks - Ruth Coleman, Nina Gordon

California Wildlife Conservation Board - Marilyn Cundiff, Peter Perrine

\section{Federal Agencies}

Army Corps of Engineers - Miki Fujitsubo, Mario Parker

Bureau of Land Management - Rick Cooper, Tony Danna, Steve Laymon, Larry Saslaw, Jim Weigand

Bureau of Reclamation - Frank Michny, Carl Dealy, Georgiana Gregory, Ned Gruenhagen, Mike Heaton, Pamela Hodapp, Jon Jay, Myrnie Mayville, Dan Meier, Michael Monroe, Sonya Nechanicky, Nigel Quinn, Patricia Rivera, John Thomson, Basia Trout

Environmental Protection Agency - Carolyn Yale

Fish and Wildlife Service - Brad Bortner, Lorna Daskalu, Steve Dyer, John Engbring, Kim Forrest, Scott Frazer, Dale Garrison, Michael Green, Matt Hamman, Dave Hardt, Tom Harvey, Craig Isola, Rob Holbrook, Tom McCabe, Ken McDermond, Greg Mensik, Shawn Milar, Maura Naughton, Ruth Ostroff, Dave Paullin, Mark Pelz, Loren Rupport, Bob Shaffer, Debra Schlafmann, Mike Wolder, Dennis Woolington, Bea Treiterer, Tara Zimmerman

Natural Resources Conservation Service - Alan Forkey, Tom Moore, Larry Norris, Malia Ortiz

U.S. Geological Survey - Mike Casazza, Joe Fleskes, Mike Miller

\section{Others}

Central Valley Bird Club - John Sterling

Ghostwriters - Jean Duncan

Greenfield Management Strategies - Bob Greenfield

Hedgerow Farms - John Anderson

Joel Miller Environmental Consulting - Joel Miller

North American Waterfowl Management Plan Committee - Eldridge "Red" Hunt

Wildlife Consultants - Gary Ivey, John McCaull

ii Acknowledgements 


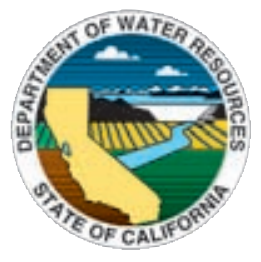

FPan

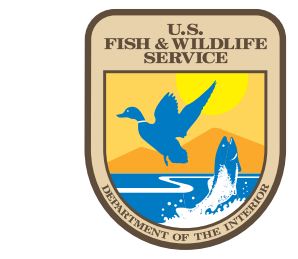

TheNature $1 / 3$

SAVING THE LAST GREAT PLACES ON EAB

Audubon calforniA

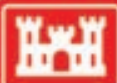

US Army Corps

of Engineers.

Sacramento District

\section{ONRCS $=$}

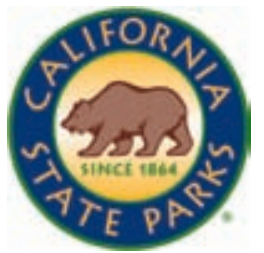

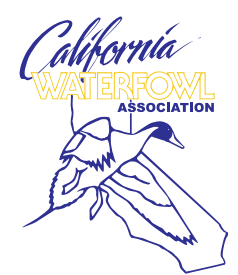
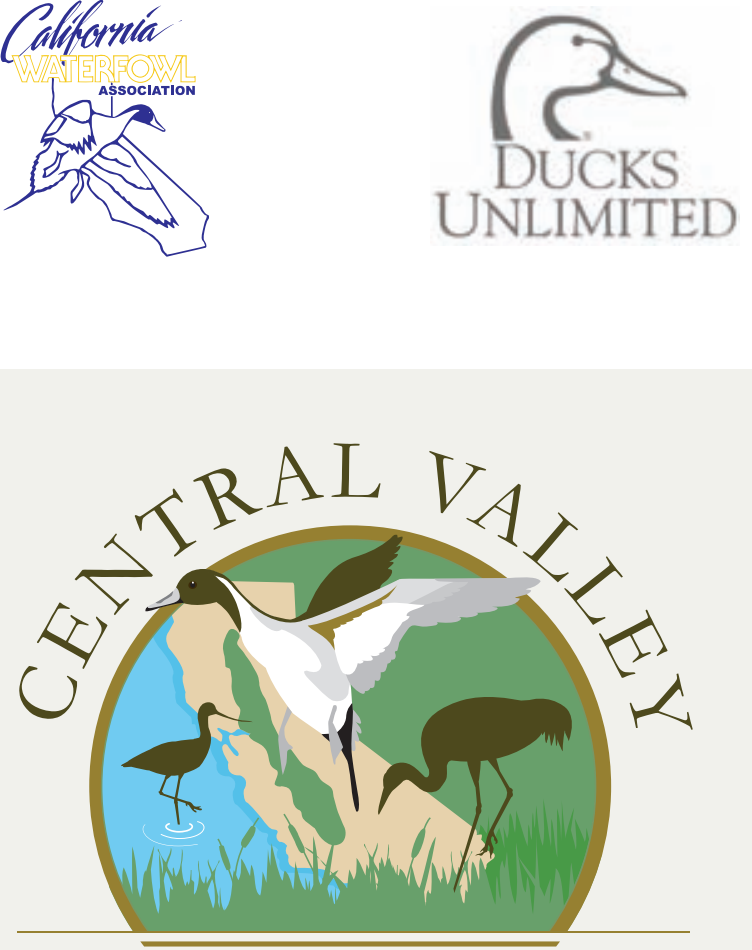

J O I N T VE N T UR E

\section{PARTNERS}

The mission of the Central Valley

Joint Venture is to work collabora-

tively through diverse partnerships

to protect, restore, and enhance

wetlands and associated habitats

for waterfowl, shorebirds,

waterbirds, and riparian songbirds,

in accordance with conservation

actions identified in the Joint

Venture's Implementation Plan.

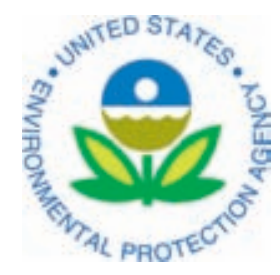

TRUST

for

PUBLIC

LAND

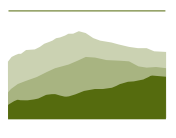

CAIIFORNIA
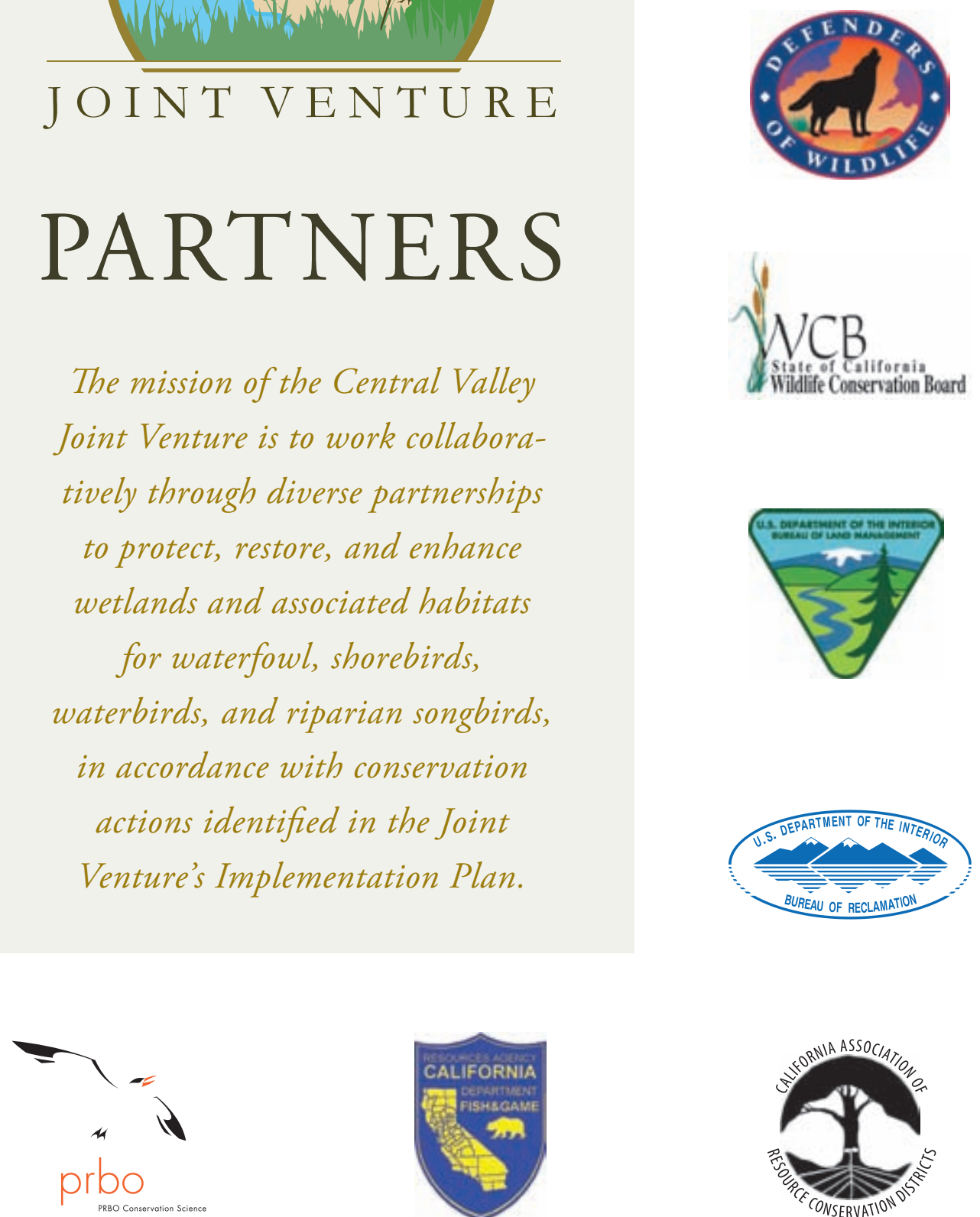

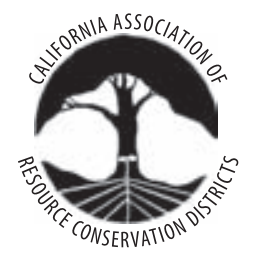

Acknowledgements iii 


\section{CENTRAL VALLEY JOINT VENTURE TENETS}

The Central Valley Joint Venture (CVJV) Management Board is comprised of representatives from the agencies and organizations that form the joint venture partnership. Their purpose is to provide overall leadership, guidance, resources and support for bird habitat conservation within the CVJV administrative boundary. Each member is responsible for ensuring that their agency or organization contributes to the overall goals of the CVJV.

The following provides a general framework for accomplishing the CVJV mission. The CVJV focuses on waterfowl, but integrates the needs of other bird groups, as outlined in its Implementation Plan. The focus will broaden, subject to future funding opportunities, to implement bird conservation strategies consistent with the CVJV mission statement.

\section{Land Use Principles:}

The CVJV will accomplish its habitat goals by means of land protection, restoration, and enhancement. Terms are defined as follows:

- Protection - the removal of a threat to land via fee title acquisition, perpetual conservation easement or perpetual agricultural easement from willing sellers. This action does not result in a gain in habitat acreage. Unprotected is defined as any privately owned land not covered by perpetual easement.

- Restoration - the physical manipulation of a former wetland or upland site with the goal of mimicking natural/historic functions. Only restoration under long-term protection will be counted as acreage gained.

- Enhancement - the physical manipulation of a wetland or upland site to repair or improve natural/historic functions or to manipulate successional stages of vegetation for the benefit of wildlife. Any manipulations for wildlife habitat improvements on lands protected less than perpetually will be counted as enhancement. This action does not result in a habitat acreage gain.

- The CVJV strongly encourages the assurance of adequate long-term water supplies with all wetland protection, restoration, and enhancement projects.

- The CVJV encourages land conservation through fee title acquisition or perpetual conservation easements. The CVJV will also support non-perpetual conservation programs. However, they will not count towards the JV's protection objectives.

- Habitat objective accomplishments do not transfer from one basin to another.

- The CVJV encourages non-regulatory actions prior to mitigation whenever possible.

- The CVJV seeks at least $50 \%$ of the energetic requirement for waterfowl from wetlands in each basin.

\section{Biological Principles:}

- The basis of the CVJV biological principles is to provide habitat for six bird groups, as addressed in the Implementation Plan. These bird groups include the following: breeding and non-breeding waterfowl, breeding and non-breeding shorebirds, riparian dependent songbirds, and waterbirds.

- The CVJV Implementation Plan objectives will not be implemented at the expense of other native/sensitive habitats such as vernal pools, remnant native grasslands, etc. 


\section{TABLE OF CONTENTS}

Acknowledgements

Central Valley Joint Venture Partners

Central Valley Joint Venture Tenets

Table of Contents

List of Figures

List of Tables

xiii

Executive Summary

Chapter 1: Introduction

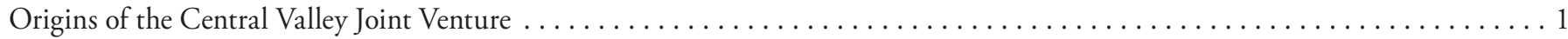

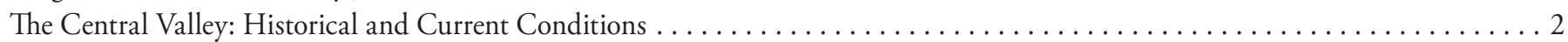

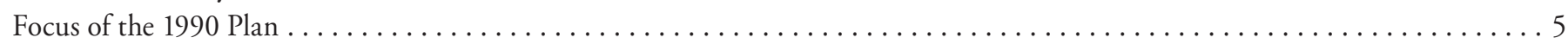

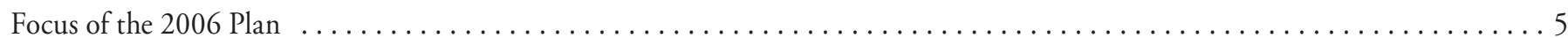

Chapter 2: Joint Venture Accomplishments 9

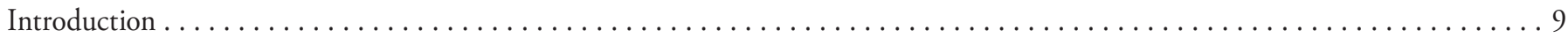

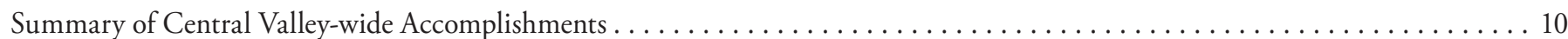

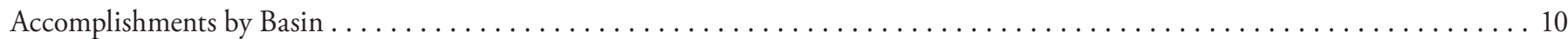

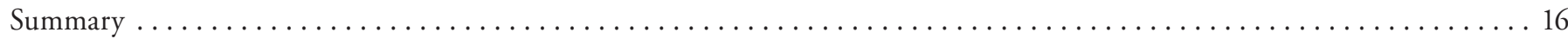

Chapter 3: Basin Characteristics $\quad 17$

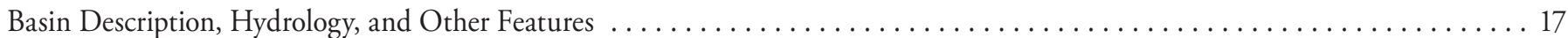

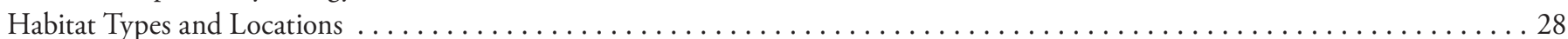

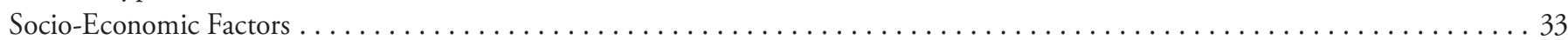

$\begin{array}{lr}\text { Chapter 4: Wintering Waterfowl } & 39\end{array}$

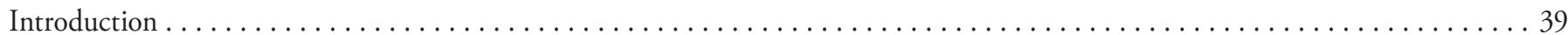

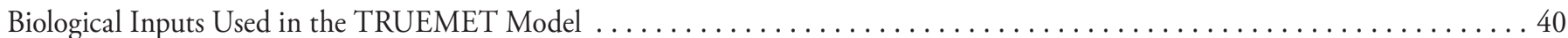

Overall Assessment of Habitat Conditions in the Central Valley . . . . . . . . . . . . . . . . . . . . . . . . . . . . . . . . . . . . . . 49

Methods for Establishing and Prioritizing Conservation Objectives for Winter Waterfowl in Each Basin $\ldots \ldots \ldots \ldots \ldots \ldots . \ldots 52$

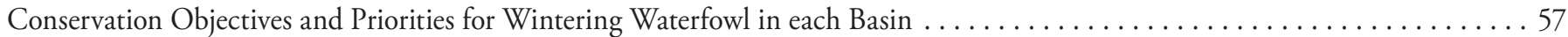

Chapter 5: Breeding Waterfowl 113

Introduction . . . . . . . . . . . . . . . . . . . . . . . . . . . . . . . . . . . . . . . . . . . . . . . . . . . . 113

A Review of Planning Information Available for Breeding Mallards in the Central Valley . . . . . . . . . . . . . . . . . . . . 114

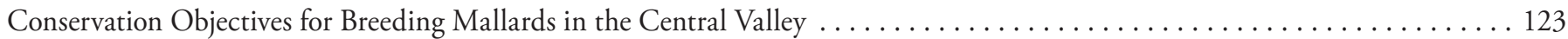

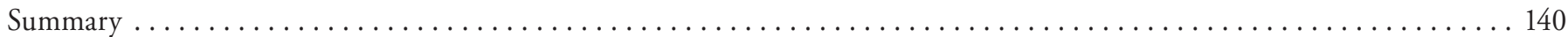

Appendix 5-1: A Review of Conservation Planning for Breeding Waterfowl in the U.S. Prairie Pothole Region ........... 140

Chapter 6: Wintering Shorebirds 145

Need and Approach . . . . . . . . . . . . . . . . . . . . . . . . . . . . . . . . . . . . . . . . . . . . . . . . . 145

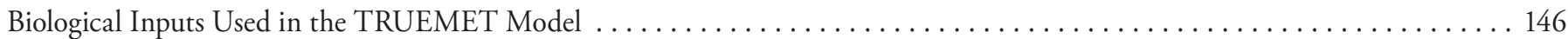

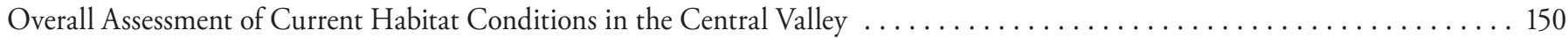

Methods for Establishing Conservation Objectives for Wintering Shorebirds. . . . . . . . . . . . . . . . . . . . . . . . . . . . . . . 150

Conservation Objectives for Wintering Shorebirds within Planning Regions . . . . . . . . . . . . . . . . . . . . . . . . 161

Summary . . . . . . . . . . . . . . . . . . . . . . . . . . . . . . . . . . . . . . . . . . . . . . . . . . . . . . . . . . 187 
Introduction . . . . . . . . . . . . . . . . . . . . . . . . . . . . . . . . 191

A Review of Planning Information Available for Breeding Shorebirds in the Central Valley. . . . . . . . . . . . . . . . . . . 192

Conservation Objectives for Breeding Shorebirds . . . . . . . . . . . . . . . . . . . . . . . . . . . . . . . . . 195

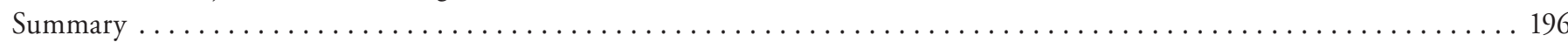

$\begin{array}{ll}\text { Chapter 8: Waterbirds } & 197\end{array}$

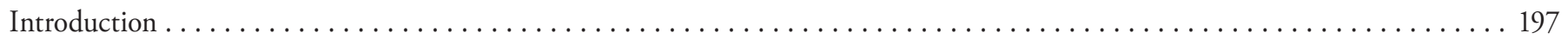

Approach Used to Develop Conservation Objectives for Waterbirds. . . . . . . . . . . . . . . . . . . . . . . . . . . . . . . . . 198

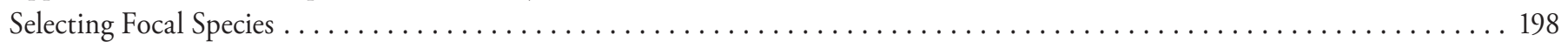

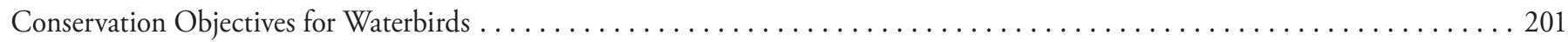

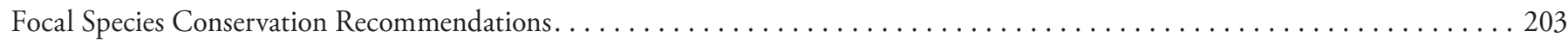

$\begin{array}{ll}\text { Chapter 9: Breeding Riparian Songbirds } & 207\end{array}$

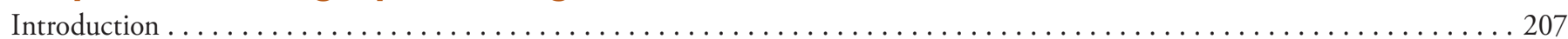

Use of Focal Species to Establish Conservation Objectives for Breeding Riparian Songbirds . . . . . . . . . . . . . . . . . 208

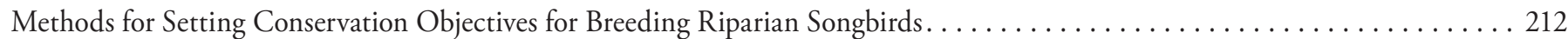

Conservation Objectives for Breeding Riparian Songbirds in the Central Valley . . . . . . . . . . . . . . . . . . . . . . . 219

Chapter 10: Wetland Water Supplies $\quad 227$

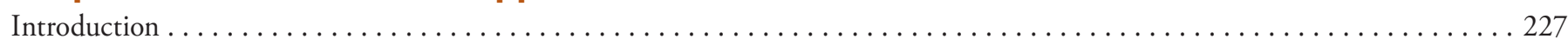

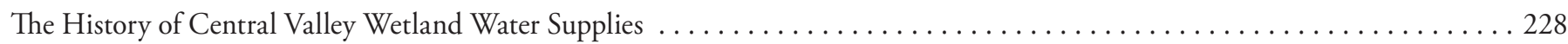

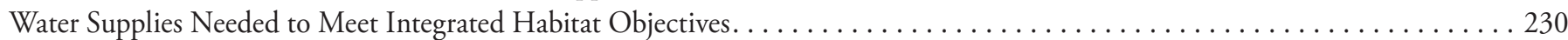

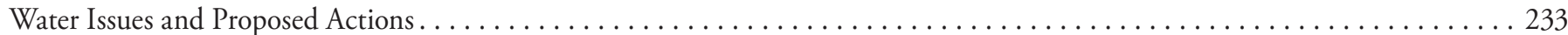

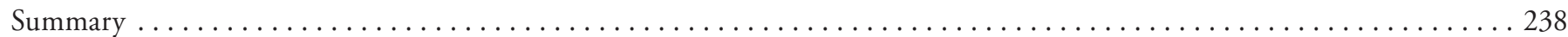

$\begin{array}{lr}\text { Chapter 11: Summary } & 239\end{array}$

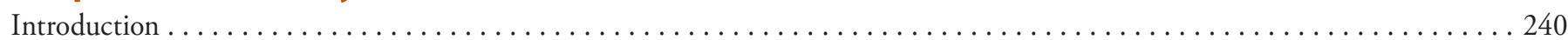

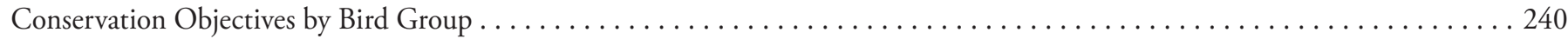

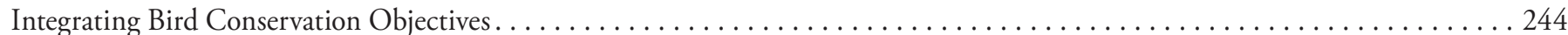

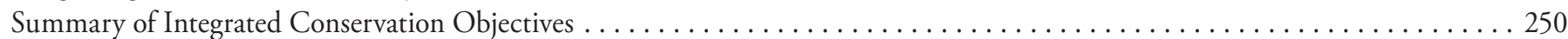

Estimated Costs of Meeting Integrated Bird Conservation Objectives . . . . . . . . . . . . . . . . . . . . . . . . . . 251

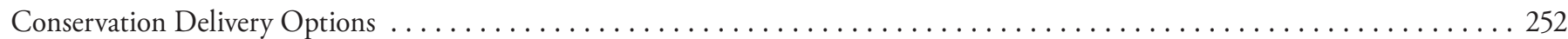

$\begin{array}{ll}\text { Literature Cited } & 253\end{array}$ 


\section{LIST OF FIGURES}

\section{Chapter 1}

Figure 1-1

Figure 1-2

Figure 1-3

\section{Chapter 2}

Figure 2-1

Figure 2-2

Figure 2-3

\section{Chapter 3}

Figure 3-1

Figure 3-2

Figure 3-3

Figure 3-4

Figure 3-5

Figure 3-6

Figure 3-7

Figure 3-8

Figure 3-9

Figure 3-10

Figure 3-11

Figure 3-12

Figure 3-13

Figure 3-14

Figure 3-15

Figure 3-16

Figure 3-17

Figure 3-18

Figure 3-19

\section{Chapter 4}

Figure 4-1

Figure 4-2

Figure 4-3

Figure 4-4

Figure 4-5

Figure 4-6

Figure 4-7

Figure 4-8

Figure 4-9(a)

Figure 4-9(b)

Figure 4-9(c)

Figure 4-10
Changes in Central Valley wetlands and associated habitats from 1900 to 1990 . . . . . . . . . . . . . . . . 3

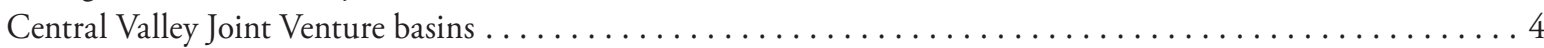

Central Valley Joint Venture boundary and focus areas $\ldots \ldots \ldots \ldots \ldots \ldots \ldots \ldots \ldots \ldots \ldots \ldots$

Progress in meeting conservation objectives as a percentage of objectives identified in the 1990 Plan . . . . . 10 1990 Wetland restoration objectives (acres) vs. wetlands restored between 1990 and 2003

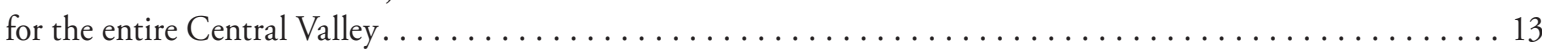

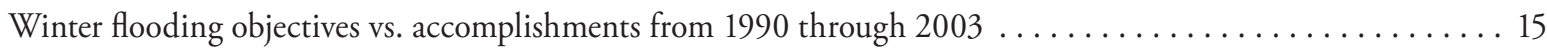

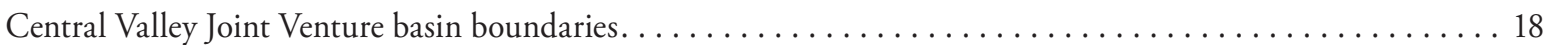

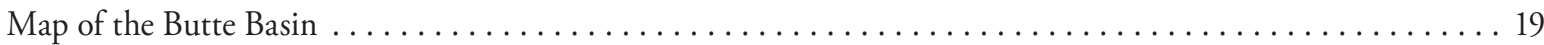

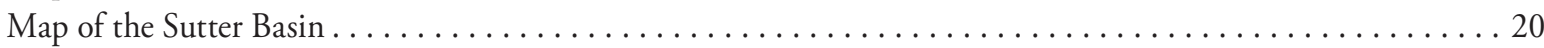

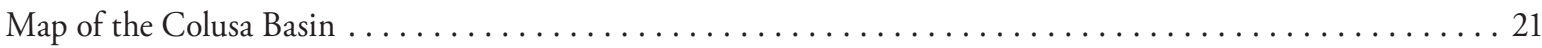

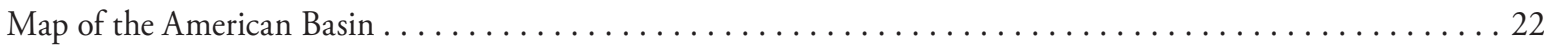

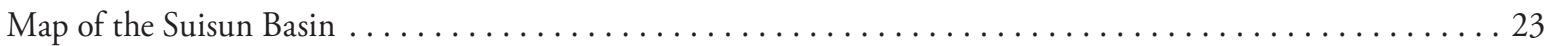

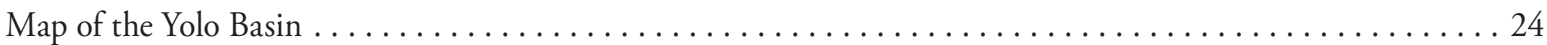

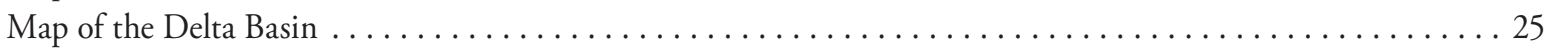

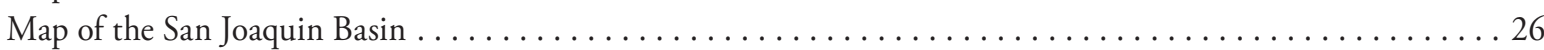

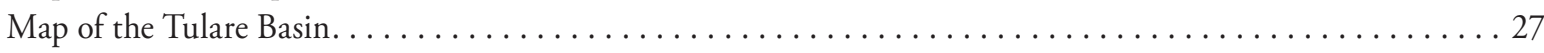

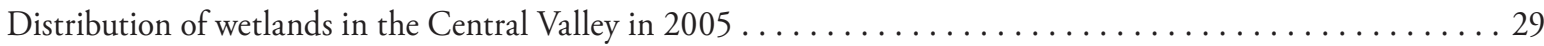

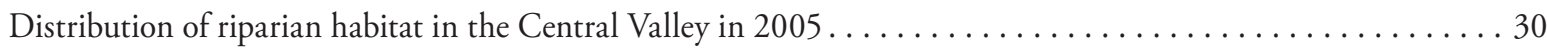

Distribution of native vegetation, pasture, and grain and hay crops in the Central Valley . . . . . . . . . 32

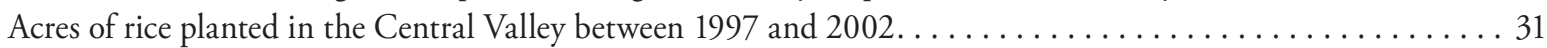

Distribution of rice in the Central Valley. . . . . . . . . . . . . . . . . . . . . . . . . . 34

Population increases (millions) for the Central Valley and for California as a whole $\ldots \ldots \ldots \ldots \ldots \ldots \ldots 35$

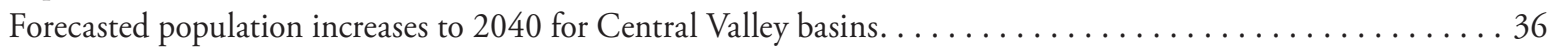

The relationship between population growth and loss of irrigated farmland for 11 Central Valley counties

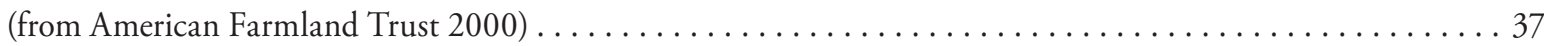

Projected loss of irrigated farmland by 2040 for Central Valley basins. . . . . . . . . . . . . . . . . . . 38

Basic energy model used to assess the availability of foraging habitat relative to waterfowl needs. . . . . . . 40

Waterfowl population energy demand and food energy supplies in a hypothetical example of the

TRUEMET model. .................................................. 40

Population objectives by 15 -day intervals for ducks in the Central Valley $\ldots \ldots \ldots \ldots \ldots \ldots \ldots \ldots \ldots 42$

Population objectives by 15 -day intervals for dark geese in the Central Valley $\ldots \ldots \ldots \ldots \ldots \ldots \ldots \ldots 43$

Population objectives by 15 -day intervals for white geese in the Central Valley $\ldots \ldots \ldots \ldots \ldots \ldots \ldots \ldots 43$

Percent of planted rice harvested by time period in the Central Valley. . . . . . . . . . . . . . . . 46

Flooding schedules for managed public and private seasonal wetlands in the Central Valley.

A "combined" flooding schedule for private and public wetlands was estimated using the relative

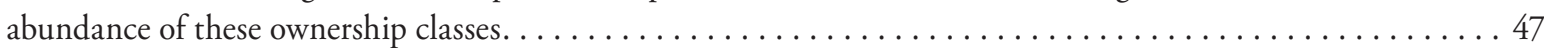

Winter-flooding schedule for harvested rice fields in the Central Valley. This flooding schedule was

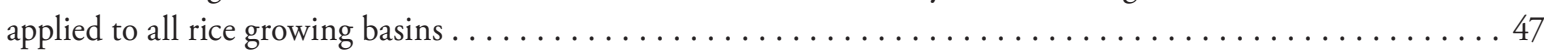

Seasonal wetland flooding schedules for basins in the Sacramento Valley $\ldots \ldots \ldots \ldots \ldots \ldots \ldots \ldots \ldots . \ldots \ldots$

Seasonal wetland flooding schedules for the San Joaquin Basin $\ldots \ldots \ldots \ldots \ldots \ldots \ldots \ldots \ldots \ldots \ldots$

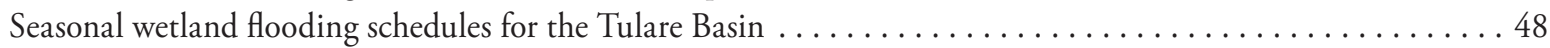

Population energy demand vs. food energy supply for ducks in the Central Valley when duck

populations are at NAWMP goals . . . . . . . . . . . . . . . . . . . . . . . . . . . 50

Table of Contents vii 
Dark goose population energy demand vs. food energy supplies for the Central Valley $\ldots \ldots \ldots \ldots \ldots \ldots . \ldots 1$

Figure 4-11(b)

Figure 4-12

Figure 4-13

Figure 4-14

Figure 4-15

Figure 4-16

Figure 4-17

Figure 4-18

Figure 4-19

Figure 4-20

Figure 4-21(a)

Figure 4-21(b)

Figure 4-22

Figure 4-23

Figure 4-24

Figure 4-25

Figure 4-26

Figure 4-27

Figure 4-28

Figure 4-29

Figure 4-30(a)

Figure 4-30(b)

Figure 4-31

Figure 4-32

Figure 4-33

Figure 4-34

Figure 4-35

Figure 4-36

Figure 4-37

Figure 4-38

Figure 4-39

Figure 4-40(a)

Figure 4-40(b)

Figure 4-41

Figure 4-42

Figure 4-43

Figure 4-44

Figure 4-45
White goose population energy demand vs. food energy supplies for the Central Valley . . . . . . . . . . 51 Population energy demand vs. food energy supply for ducks in the Central Valley during the 1970's . . . . . . 51 Population energy demand vs. food energy supply for ducks in the Central Valley if only public lands

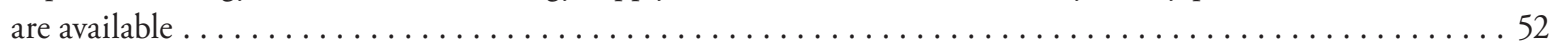
Monthly water requirements, acre-feet per acre, for seasonal wetlands in each of the Central Valley's basins. ... 54 Forecasted changes in rice acreage for a hypothetical basin compared to the basin's agricultural

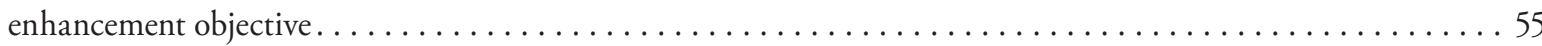

Factors used to identify which conservation objectives may be emphasized in a hypothetical basin . . . . . 57 Population objectives by 15 -day intervals for ducks in the American Basin $\ldots \ldots \ldots \ldots \ldots \ldots \ldots \ldots$

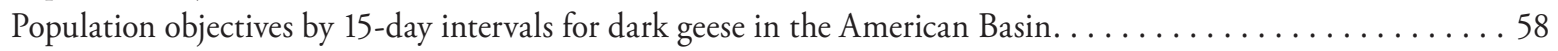
Population objectives by 15 -day intervals for white geese in the American Basin . . . . . . . . . . . . . 59 Population energy demand vs. food energy supply for ducks in the American Basin when duck

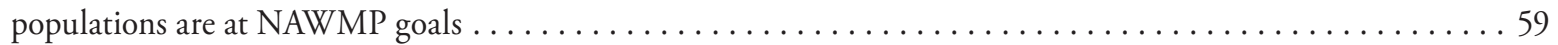

Dark goose population energy demand vs. food energy supplies in the American Basin $\ldots \ldots \ldots \ldots \ldots \ldots 60$ White goose population energy demand vs. food energy supplies in the American Basin $\ldots \ldots \ldots \ldots \ldots 60$ Population energy demand vs. food energy supply for ducks in the American Basin when no agricultural

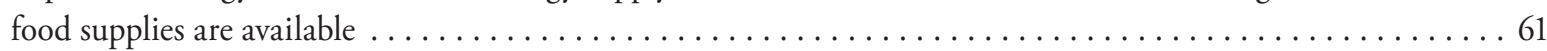

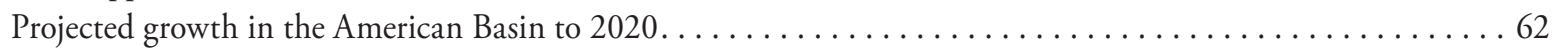
Forecasted changes in rice acreage for the American Basin compared to the basin's agricultural

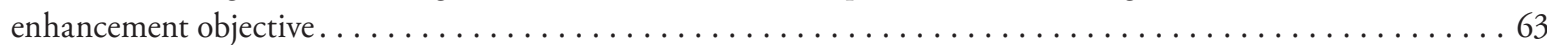
Factors used to identify conservation objective priorities for the American Basin . . . . . . . . . . . 63

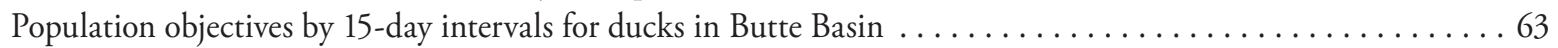
Population objectives by 15 -day intervals for dark geese in Butte Basin . . . . . . . . . . . . . 64 Population objectives by 15 -day intervals for white geese in Butte Basin $\ldots \ldots \ldots \ldots \ldots \ldots \ldots \ldots \ldots$ Population energy demand vs. food energy supply for ducks in Butte Basin when duck populations are

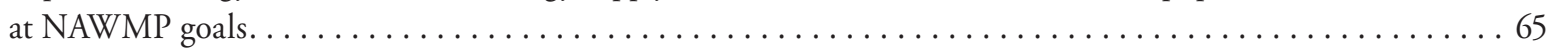

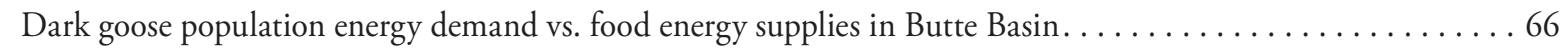
White goose population energy demand vs. food energy supplies in Butte Basin . . . . . . . . . . 66 Population energy demand vs. food energy supply for ducks in Butte Basin when no agricultural food

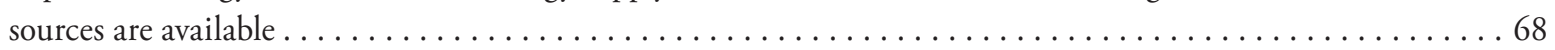
Population energy demand vs. food energy supply for ducks in Butte Basin if ducks are restricted to

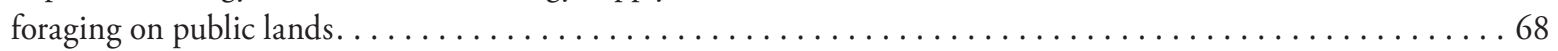
Forecasted changes in rice acreage for Butte Basin compared to the basin's agricultural enhancement

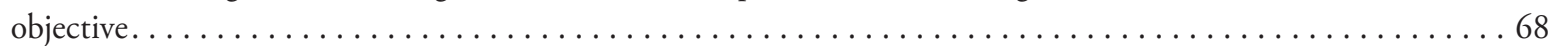

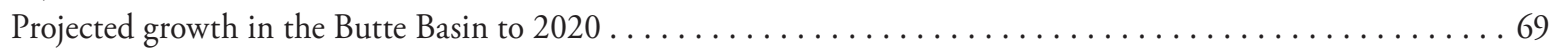
Information used to identify conservation objective priorities for Butte Basin $\ldots \ldots \ldots \ldots \ldots \ldots \ldots \ldots 70$ Population objectives by 15 -day intervals for ducks in Colusa Basin $\ldots \ldots \ldots \ldots \ldots \ldots \ldots \ldots \ldots \ldots$ Population objectives by 15 -day intervals for dark geese in Colusa Basin $\ldots \ldots \ldots \ldots \ldots \ldots \ldots \ldots \ldots \ldots$ Population objectives by 15 -day intervals for white geese in Colusa Basin $\ldots \ldots \ldots \ldots \ldots \ldots \ldots \ldots \ldots 72$ Population energy demand vs. food energy supply for ducks in Colusa Basin when duck populations

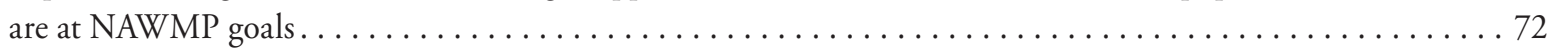
Dark goose population energy demand vs. food energy supplies in Colusa Basin. $\ldots \ldots \ldots \ldots \ldots \ldots \ldots 73$ White goose population energy demand vs. food energy supplies in Colusa Basin $\ldots \ldots \ldots \ldots \ldots \ldots \ldots 73$ Population energy demand vs. food energy supply for ducks in Colusa Basin if no agricultural foods

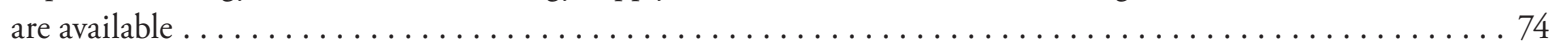
Population energy demand vs. food energy supply for ducks in Colusa Basin if ducks are restricted to foraging on public habitats. . . . . . . . . . . . . . . . . . . . 74 Forecasted changes in rice acreage for the Colusa Basin compared to the basin's agricultural

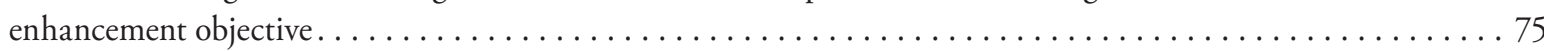

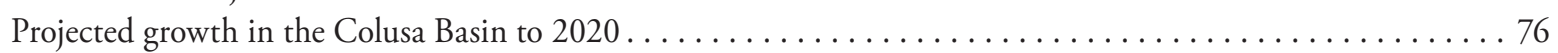
Information used to identify conservation objective priorities for Colusa Basin $\ldots \ldots \ldots \ldots \ldots \ldots \ldots \ldots 75$ 
Figure 4-46

Figure 4-47

Figure 4-48

Figure 4-49

Figure 4-50(a)

Figure 4-50(b)

Figure 4-51

Figure 4-52

Figure 4-53

Figure 4-54

Figure 4-55

Figure 4-56

Figure 4-57

Figure 4-58

Figure 4-59

Figure 4-60

Figure 4-61

Figure 4-62

Figure 4-63

Figure 4-64

Figure 4-65

Figure 4-66(a)

Figure 4-66(b)

Figure 4-67

Figure 4-68

Figure 4-69

Figure 4-70

Figure 4-71

Figure 4-72

Figure 4-73

Figure 4-74

Figure 4-75

Figure 4-76

Figure 4-77

Figure 4-78

Figure 4-79

Figure 4-80

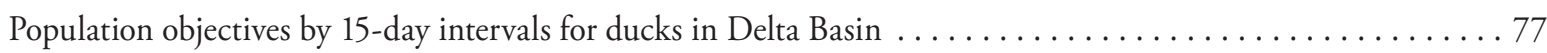

Population objectives by 15 -day intervals for dark geese in Delta Basin $\ldots \ldots \ldots \ldots \ldots \ldots \ldots \ldots \ldots \ldots$

Population objectives by 15 -day intervals for white geese in Delta Basin $\ldots \ldots \ldots \ldots \ldots \ldots \ldots \ldots \ldots \ldots \ldots$

Population energy demand vs. food energy supply for ducks in Delta Basin when duck populations

are at NAWMP goals . . . . . . . . . . . . . . . . . . . . . . . . . . . . . . . . . 79

Dark goose population energy demand vs. food energy supplies in Delta Basin. . . . . . . . . . . . . . . 79

White goose population energy demand vs. food energy supplies in Delta Basin . . . . . . . . . . . . 80

Population energy demand vs. food energy supplies for ducks in Delta Basin when no agricultural food

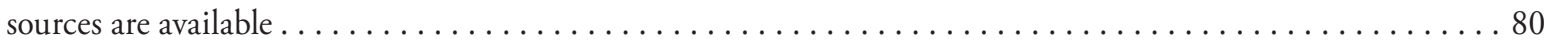

Population energy demand vs. food energy supplies for ducks in Delta Basin if ducks are restricted to

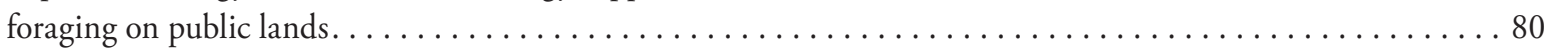

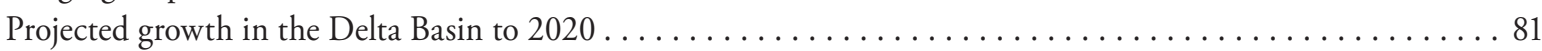

Information used to identify conservation objective priorities for Delta Basin $\ldots \ldots \ldots \ldots \ldots \ldots \ldots \ldots 2$

Population objectives by 15 -day intervals for ducks in San Joaquin Basin $\ldots \ldots \ldots \ldots \ldots \ldots \ldots \ldots \ldots$

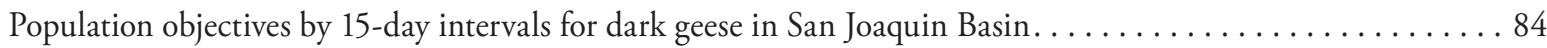

Population objectives by 15 -day intervals for white geese in San Joaquin Basin $\ldots \ldots \ldots \ldots \ldots \ldots \ldots \ldots 4$

Population energy demand vs. food energy supplies for ducks in San Joaquin Basin when duck

populations are at NAWMP goals . . . . . . . . . . . . . . . . . . . . . . . . . . 85

Population energy demand vs. food energy supply for ducks in San Joaquin Basin if ducks are restricted

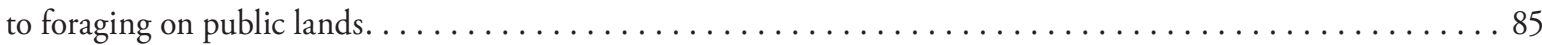

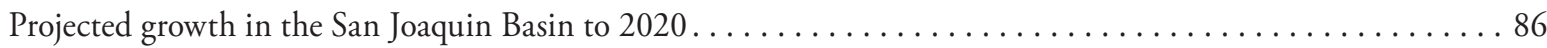

Information used to identify conservation objective priorities for San Joaquin Basin $\ldots \ldots \ldots \ldots \ldots \ldots \ldots 7$

Population objectives by 15 -day intervals for ducks in Sutter Basin $\ldots \ldots \ldots \ldots \ldots \ldots \ldots \ldots \ldots \ldots$

Population objectives by 15 -day intervals for dark geese in Sutter Basin $\ldots \ldots \ldots \ldots \ldots \ldots \ldots \ldots \ldots$

Population objectives by 15 -day intervals for white geese in Sutter Basin $\ldots \ldots \ldots \ldots \ldots \ldots \ldots \ldots \ldots$

Population energy demand vs. food energy supply for ducks in Sutter Basin when duck populations

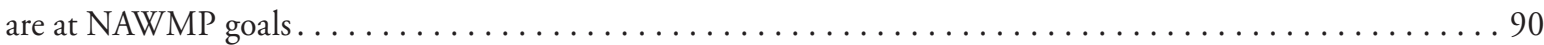

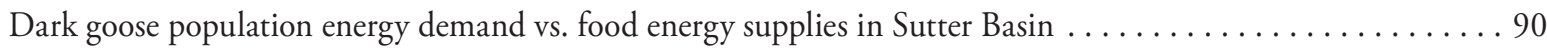

White goose population energy demand vs. food energy supplies in Sutter Basin $\ldots \ldots \ldots \ldots \ldots \ldots \ldots$

Population energy demand vs. food energy supply for ducks in Sutter Basin when no agricultural

food sources are available . . . . . . . . . . . . . . . . . . . . . . . . . . . . . . . . 91

Population energy demand vs. food energy supply for ducks in Sutter Basin if ducks are restricted

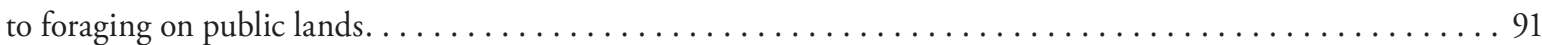

Forecasted changes in rice acreage for the Sutter Basin compared to the basin's agricultural

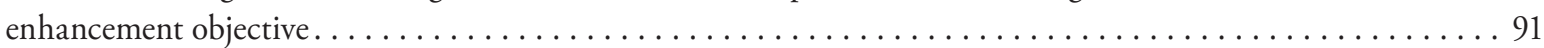

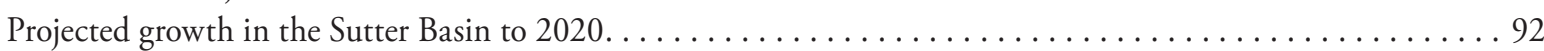

Information used to identify conservation objective priorities for Sutter Basin $\ldots \ldots \ldots \ldots \ldots \ldots \ldots \ldots 9$

Population objectives by 15 -day intervals for ducks in Suisun Marsh $\ldots \ldots \ldots \ldots \ldots \ldots \ldots \ldots \ldots \ldots$

Population objectives by 15 -day intervals for dark geese in Suisun Marsh $\ldots \ldots \ldots \ldots \ldots \ldots \ldots \ldots \ldots 94$

Population objectives by 15 -day intervals for white geese in Suisun Marsh $\ldots \ldots \ldots \ldots \ldots \ldots \ldots \ldots \ldots 94$

Population energy demand vs. food energy supply for ducks in Suisun Marsh if wetland seed

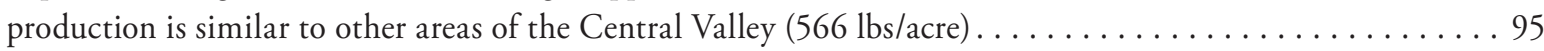

Population energy demand vs. food energy supply for ducks in Suisun Marsh if wetland seed production

is similar to other areas of the Central Valley (566 lbs/acre), and tidal flow is restored to 5,000 acres of

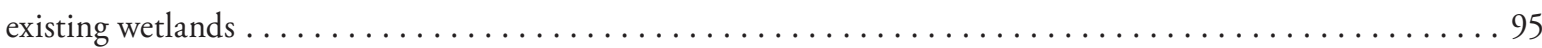

Population energy demand vs. food energy supply for ducks in Suisun Marsh if wetland seed production

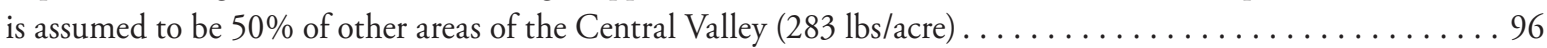

Population energy demand vs. food energy supply for ducks in Suisun Marsh if wetland seed production

is assumed to be $50 \%$ of other areas of the Central Valley ( $283 \mathrm{lbs} / \mathrm{acre}$ ), and tidal flow is restored to

5,000 acres of existing wetlands . . . . . . . . . . . . . . . . . . . . . . . . . . . 96

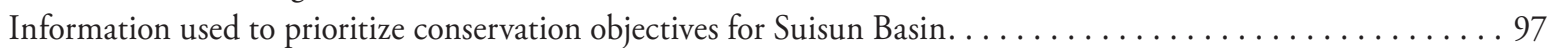

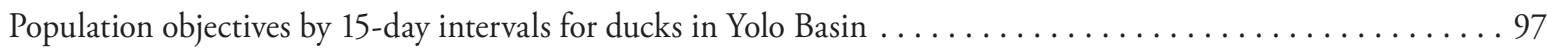

Table of Contents ix 
Figure 4-81

Figure 4-82

Figure 4-83

Figure 4-84(a)

Figure 4-84(b)

Figure 4-85

Figure 4-86

Figure 4-87

Figure 4-88

Figure 4-89

Figure 4-90(a)

Figure 4-90(b)

Figure 4-90(c)

Figure 4-91

Figure 4-92

Figure 4-93

Figure 4-94

Figure 4-95

Figure 4-96

\section{Chapter 5}

Figure 5-1

Figure 5-2

Figure 5-3

Figure 5-4

Figure 5-5

Figure 5-6

Figure 5-7

Figure 5-8

Figure 5-9

Figure 5-10

Figure 5-11

Figure 5-12

Figure 5-13

Figure 5-14

Figure 5-15

Figure 5-16

Figure 5-17

Figure 5-18

Figure 5-19

Figure 5-20

Figure 5-21

Figure 5-22

\section{Chapter 6}

Figure 6-1

Figure 6-2
Population objectives by 15 -day intervals for dark geese in Yolo Basin . . . . . . . . . . . . . . . 99

Population objectives by 15 -day intervals for white geese in Yolo Basin . . . . . . . . . . . . . . . 99

Population energy demand vs. food energy supply for ducks in Yolo Basin when duck populations

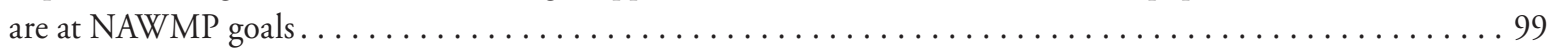

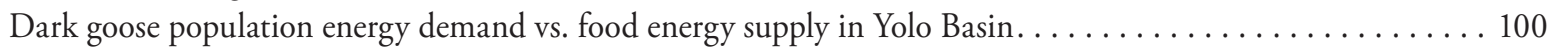

White goose population energy demand vs. food energy supply in Yolo Basin $\ldots \ldots \ldots \ldots \ldots \ldots \ldots$

Population energy demand vs. food energy supply for ducks in Yolo Basin when no agricultural food

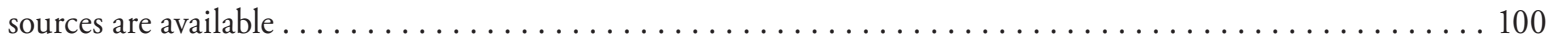

Population energy demand vs. food energy supply for ducks in Yolo Basin when ducks are restricted

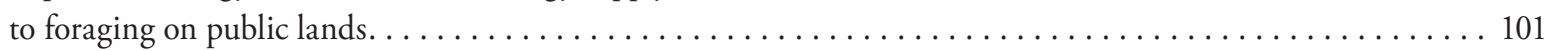

Forecasted changes in rice acreage for the Yolo Basin compared to the basin's rice habitat objective $\ldots \ldots \ldots 101$

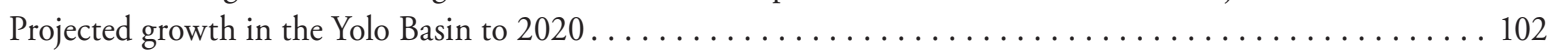

Information used to prioritize conservation objectives for Yolo Basin $\ldots \ldots \ldots \ldots \ldots \ldots \ldots \ldots \ldots \ldots 1$

Migration chronology of ducks in Tulare Basin as determined from waterfowl surveys conducted in

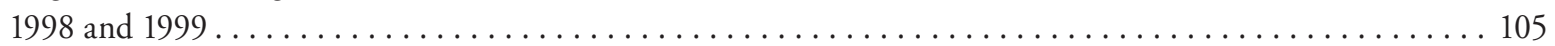

Migration chronology of ducks in Tulare Basin as determined from waterfowl surveys conducted in $1973 \ldots 105$

Migration chronology of ducks in Tulare Basin that results from combining waterfowl surveys from

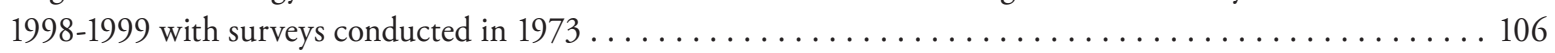

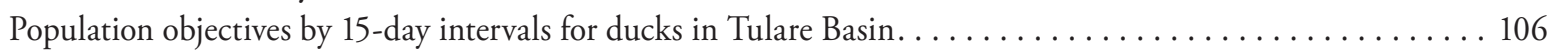

Population objectives by 15 -day intervals for dark geese in Tulare Basin $\ldots \ldots \ldots \ldots \ldots \ldots \ldots \ldots \ldots$

Population energy demand vs. food energy supply for ducks in Tulare Basin when duck populations

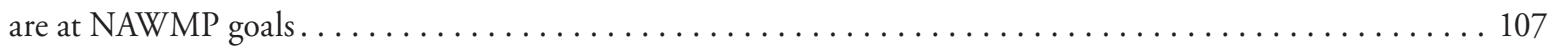

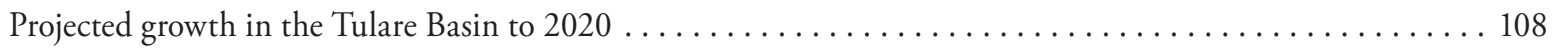

Information used to prioritize conservation objectives for Tulare Basin . . . . . . . . . . . . . . 109

Progress in meeting seasonal wetland restoration objectives in the Central Valley . . . . . . . . . . . 111

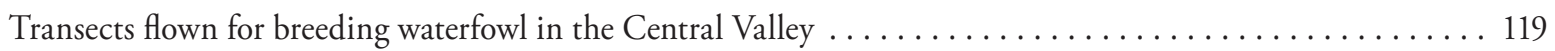

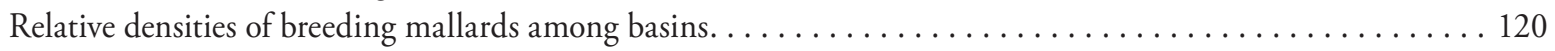

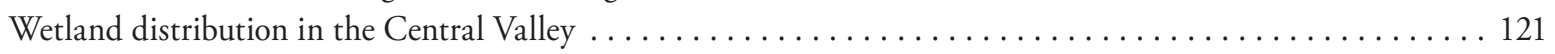

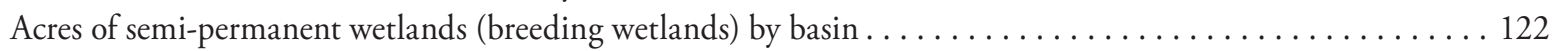

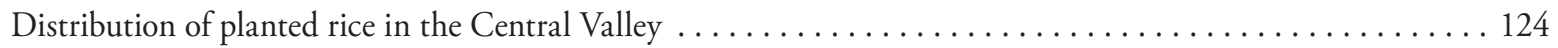

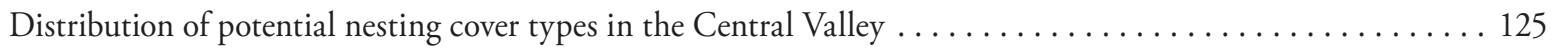

Distribution of potential nesting cover in the Central Valley . . . . . . . . . . . . . . . . . . 126

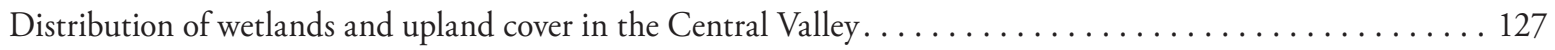

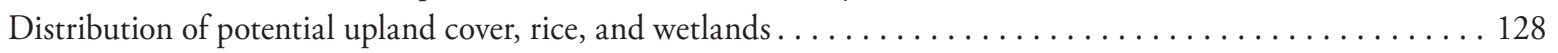

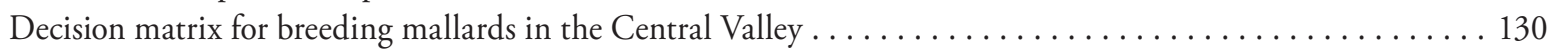

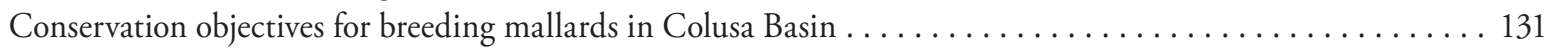

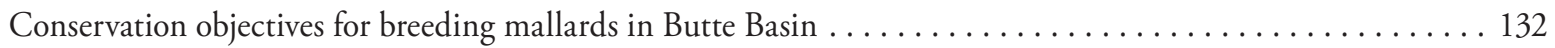

Conservation objectives for breeding mallards in American Basin . . . . . . . . . . . . . . . . 133

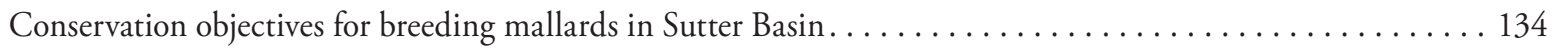

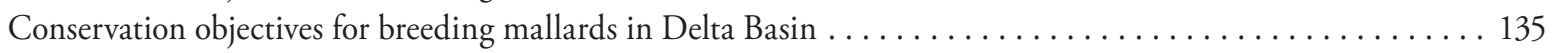

Conservation objectives for breeding mallards in San Joaquin Basin $\ldots \ldots \ldots \ldots \ldots \ldots \ldots \ldots \ldots \ldots \ldots$

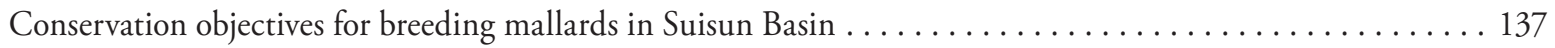

Conservation objectives for breeding mallards in Tulare Basin $\ldots \ldots \ldots \ldots \ldots \ldots \ldots \ldots \ldots \ldots \ldots \ldots \ldots$

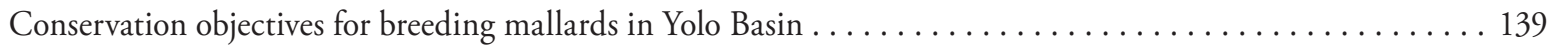

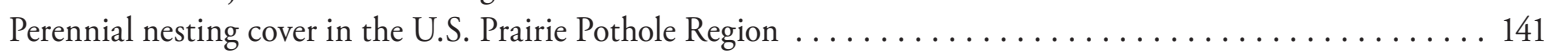

Breeding waterfowl densities in the U.S. Prairie Pothole Region $\ldots \ldots \ldots \ldots \ldots \ldots \ldots \ldots \ldots \ldots \ldots \ldots \ldots$

Spatial planning tool for breeding waterfowl in the U.S. Prairie Pothole Region $\ldots \ldots \ldots \ldots \ldots \ldots \ldots \ldots$

Basic energy model used to assess the availability of foraging habitat relative to shorebird need . . . . . . 146

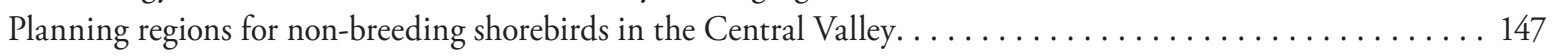




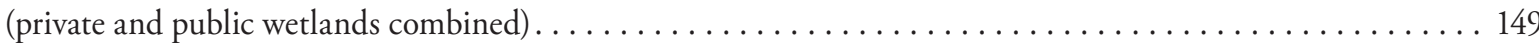

Figure 6-4

Flooding and draw down schedules for winter flooded rice in the Central Valley

Figure 6-5

Shorebird population objectives vs. flooding schedules for managed seasonal wetlands for the Central Valley.

Shorebird population objectives are expressed as the fraction of peak population; wetlands are expressed

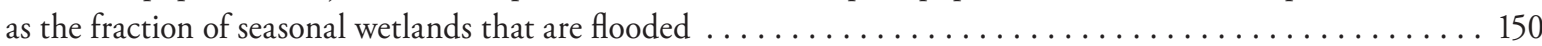

Figure 6-6

Shorebird population objectives for the Central Valley vs. flooding schedules for winter flooded rice $\ldots \ldots \ldots 151$

Figure 6-7

Shorebird population objectives vs. flooding schedules for managed seasonal wetlands and rice. Shorebird

population objectives are expressed as the fraction of peak population; wetlands and rice are expressed as

the fraction of these habitats that are flooded. . . . . . . . . . . . . . . . . . . . . . . . . 151

Figure 6-8 Seasonal wetland objectives for shorebirds in the Fall Flooding Period by 15-day intervals for a hypothetical

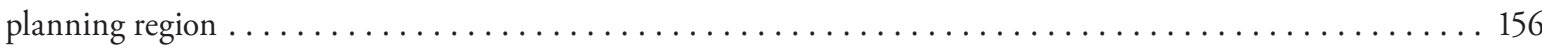

Figure 6-9 Changes in the depth ratio for shorebirds in the Fall Flooding Period. The fraction of potential shorebird

habitat (seasonal wetlands) that must be $<10 \mathrm{~cm}$ deep declines from August through November . . . . . . 156

Figure 6-10

Seasonal wetland objectives for shorebirds in the Winter Flooding Period by 15-day intervals for a

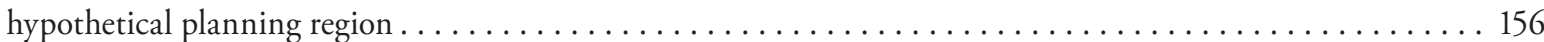

Figure 6-11 Changes in the required depth ratio for seasonal wetlands in the Winter Flooding Period for a hypothetical

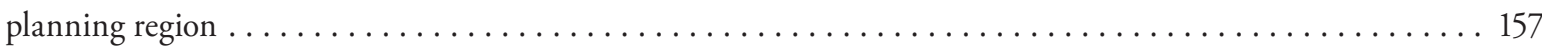

Figure 6-12

Figure 6-13

Seasonal wetland objectives for shorebirds in the Spring Flooding Period by 15 -day intervals for a

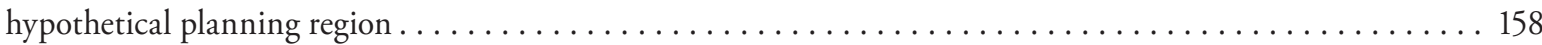

Figure 6-14

Figure 6-15

Figure 6-16

Figure 6-17

Changes in the seasonal wetland depth ratio for shorebirds during the Spring Flooding Period. . . . . . . . 158

Rice habitat objectives for shorebirds by 15 -day intervals for a hypothetical planning region $\ldots \ldots \ldots \ldots \ldots 159$

Changes in the required depth ratio for rice habitat between October and March . . . . . . . . . . . . . 159

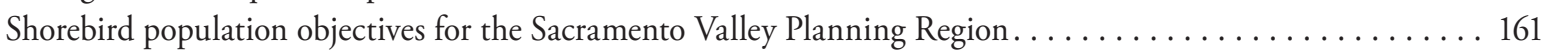

Shorebird population objectives vs. flooding schedules for managed seasonal wetlands and rice for the

Sacramento Valley Planning Region. Shorebird population objectives are expressed as the fraction of peak

population; wetlands and rice are expressed as the fraction of these habitats that are flooded $\ldots \ldots \ldots \ldots \ldots 1$

Figure 6-18 Seasonal wetland objectives for shorebirds in the Fall Flooding Period by 15-day intervals for the

Sacramento Valley Planning Region. . . . . . . . . . . . . . . . . . . . . . . . . . . . . . 163

Figure 6-19 Changes in the required depth ratio for seasonal wetlands in the Fall Flooding Period for the Sacramento

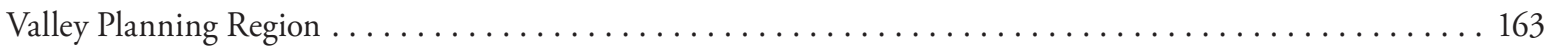

Figure 6-20 Seasonal wetland objectives for shorebirds in the Winter Flooding Period by 15-day intervals for the

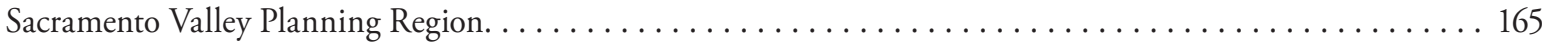

Figure 6-21 Changes in the required depth ratio for seasonal wetlands in the Winter Flooding Period for the

Sacramento Valley Planning Region. . . . . . . . . . . . . . . . . . . . . . . . . . . . . . 165

Figure 6-22 Seasonal wetland objectives for shorebirds in the Spring Flooding Period by 15-day intervals for the

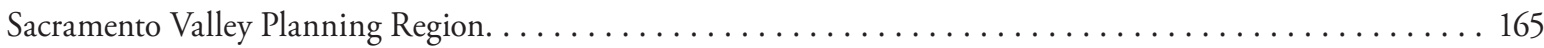

Figure 6-23 Rice habitat objectives for shorebirds by 15-day intervals for the Sacramento Valley Planning Region. . . . . . 167

Figure 6-24

Changes in the required depth ratio for rice habitat in the Sacramento Valley Planning Region . . . . . . . . . 167

Figure 6-25

Shorebird population objectives for the Delta Planning Region

Figure 6-26

Shorebird population objectives vs. flooding schedules for managed seasonal wetlands and rice for the Delta

Planning Region. Shorebird population objectives are expressed as the fraction of peak population; wetlands

and rice are expressed as the fraction of these habitats that are flooded $\ldots \ldots \ldots \ldots \ldots \ldots \ldots \ldots \ldots \ldots$

Figure 6-27 Seasonal wetland objectives for shorebirds in the Fall Flooding Period by 15-day intervals for the Delta

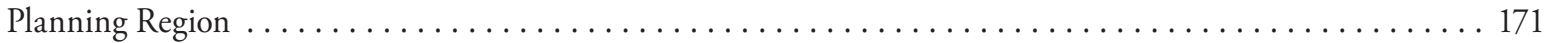

Figure 6-28 Changes in the required depth ratio for seasonal wetlands in the Fall Flooding Period for the Delta

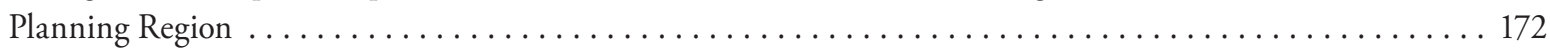

Figure 6-29 Seasonal wetland objectives for shorebirds in the Winter Flooding Period by 15-day intervals for the Delta

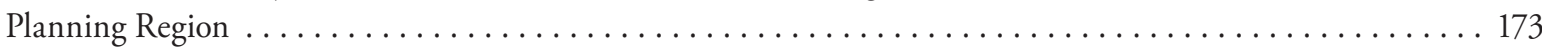

Figure 6-30 Changes in the required depth ratio for seasonal wetlands in the Winter Flooding Period for the Delta

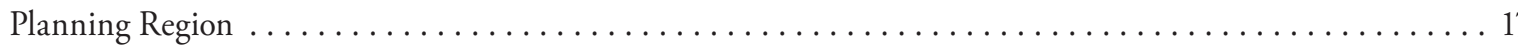




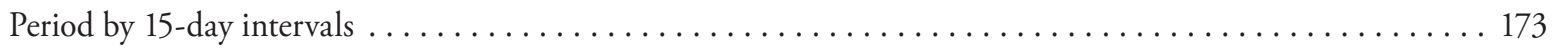

Figure 6-32 Rice habitat objectives for shorebirds by 15 -day intervals in the Delta Planning Region $\ldots \ldots \ldots \ldots \ldots \ldots 174$

Figure 6-33 Changes in the required depth ratio for rice habitat in the Delta Planning Region $\ldots \ldots \ldots \ldots \ldots \ldots \ldots 174$

Figure 6-34

Figure 6-35

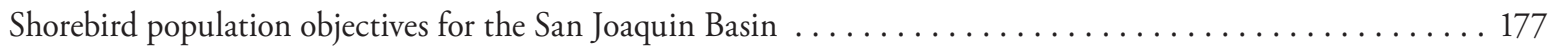

Shorebird population objectives vs. flooding schedules for managed seasonal wetlands for the San

Joaquin Basin. Shorebird population objectives are expressed as the fraction of peak population; wetlands

are expressed as the fraction of seasonal wetlands that are flooded $\ldots \ldots \ldots \ldots \ldots \ldots \ldots \ldots \ldots \ldots \ldots$

Figure 6-36 Seasonal wetland objectives for shorebirds in the Fall Flooding Period by 15-day intervals for the San

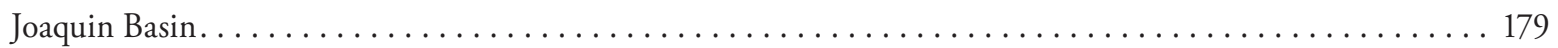

Figure 6-37 Changes in the required depth ratio for seasonal wetlands in the Fall Flooding Period for the San Joaquin Basin. . . . 179

Figure 6-38 Seasonal wetland objectives for shorebirds in the Winter Flooding Period by 15-day intervals for the

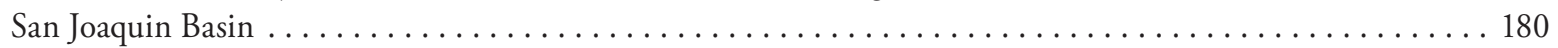

Figure 6-39 Changes in the required depth ratio for seasonal wetlands in the Winter Flooding Period for the San

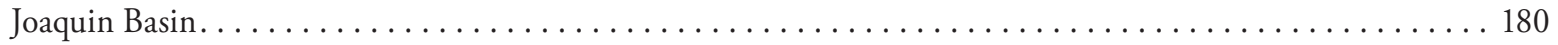

Figure 6-40 Seasonal wetland objectives for shorebirds in the San Joaquin Basin during the Spring Flooding Period

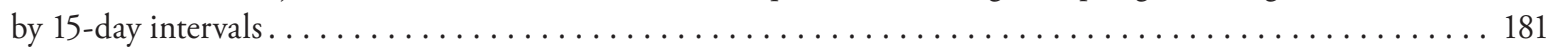

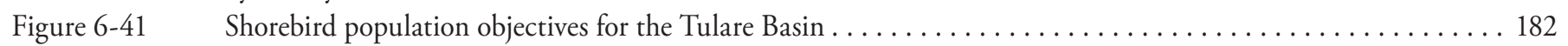

Figure 6-42 Shorebird population objectives vs. flooding schedules for managed seasonal wetlands for the Tulare Basin.

Shorebird population objectives are expressed as the fraction of peak population; wetlands are expressed as

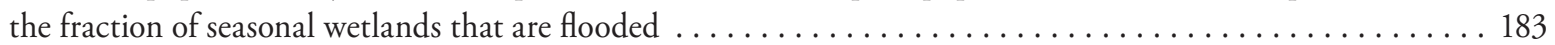

Figure 6-43 Seasonal wetland objectives for shorebirds in the Fall Flooding Period by 15-day intervals for the Tulare Basin ... .184

Figure 6-44 Changes in the required depth ratio for seasonal wetlands in the Fall Flooding Period for the Tulare Basin . . . 184

Figure 6-45 Seasonal wetland objectives for shorebirds in the Winter Flooding Period by 15-day intervals for the

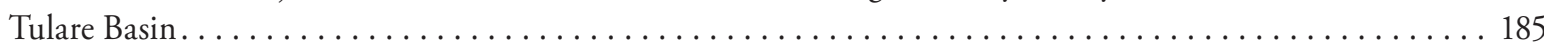

Figure 6-46 Changes in the required depth ratio for seasonal wetlands in the Winter Flooding Period for the

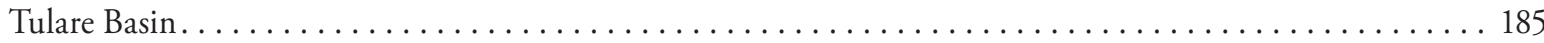

Figure 6-47 Seasonal wetland objectives for shorebirds in the Tulare Basin during the Spring Flooding Period by

15 -day intervals . . . . . . . . . . . . . . . . . . . . . . . . . . . . . . . . . . 186

Chapter 7

No figures in this chapter

\section{Chapter 8}

Figure 8-1

Waterbird planning regions of the Central Valley Joint Venture .

\section{Chapter 9}

Figure 9-1

Preferred nesting substrates of selected songbird species breeding in California riparian habitat illustrating

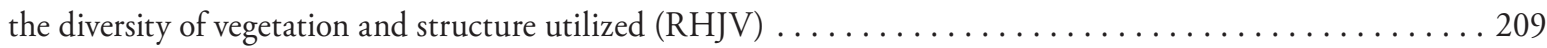

Figure 9-2 Black-headed grosbeak trend in response to age of restoration on the Sacramento River. Trend

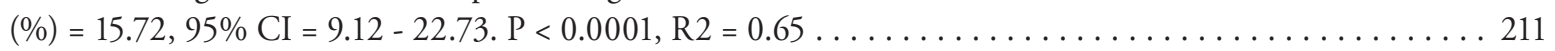

Figure 9-3 Existing and potentially restorable riparian habitat within the Central Valley ................. 214

Figure 9-4 Species richness indices for riparian songbirds at sites with standardized bird monitoring in California . . . . 215

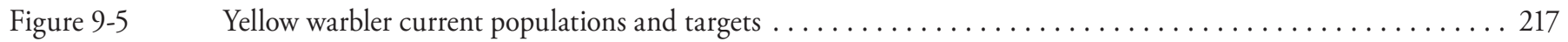

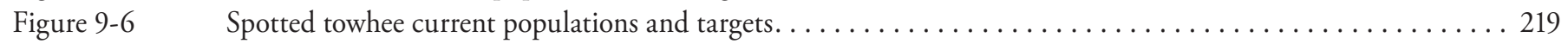

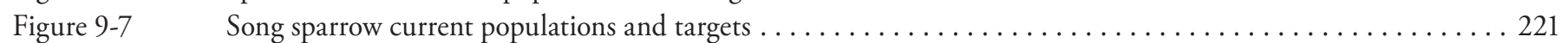

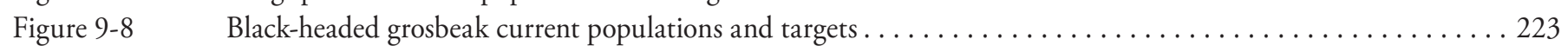

\section{Chapter 10}

No figures in this chapter

\section{Chapter 11}

No figures in this chapter 


\section{LIST OF TABLES}

\section{Executive Summary}

Table S-1 Central Valley-wide conservation objectives and strategies combined across all bird groups for all basins .......S-3

\section{Chapter 1}

No tables in this chapter

\section{Chapter 2}

Table 2-1

Table 2-2

Table 2-3

Table 2-4

Table 2-5

\section{Chapter 3}

Table 3-1

Table 3-2

Table 3-3

Table 3-4

Table 3-5

Table 3-6

\section{Chapter 4}

Table 4-1

Table 4-2

Table 4-3

Table 4-4

Table 4-5

Table 4-6

Table 4-7

Table 4-8

Table 4-9

Table 4-10

Table 4-11

Table 4-12

Table 4-13

Table 4-14

Table 4-15

Table 4-16

Table 4-17

Table 4-18

Table 4-19

Table 4-20

Table 4-21

Table 4-22

Table 4-23

Table 4-24

Table 4-25

Table 4-26
1990 Wetland Protection objectives by basin. Basins are listed in priority based on the percent of wetlands

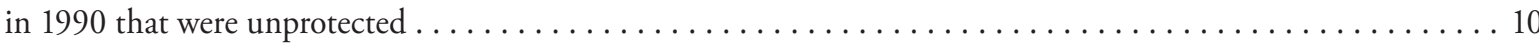
1990 Wetland Protection objectives vs. accomplishments. Basins are listed in priority based on the percent

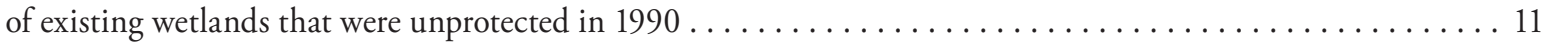
Water supply needs (acre-feet) identified in the 1989 Report on Refuge Water Supply Investigations, Central Valley Hydrologic Basin, California . . . . . . . . . . . . . . . . . . . . . . . . . . . . . . . . 12 Wetland restoration objectives (acres) and accomplishments in the Central Valley by basin 1990 to 2003 . . . . 14 Agricultural enhancement objectives and accomplishments for wintering waterfowl by basin $\ldots \ldots \ldots \ldots \ldots$

Acres of managed seasonal wetlands (SW) and semi-permanent wetlands (SPW) in the Central Valley ...... 28

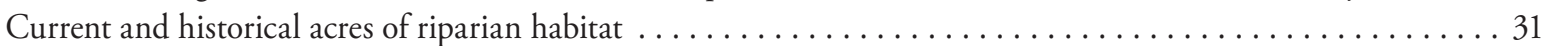

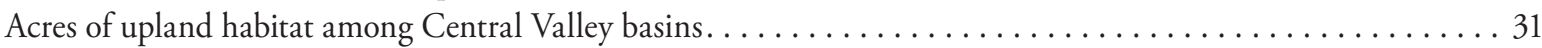

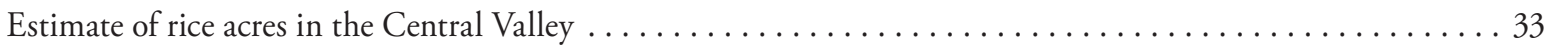
Estimates of planted corn for Central Valley basins . . . . . . . . . . . . . . . . . . . . . . . . . . 35

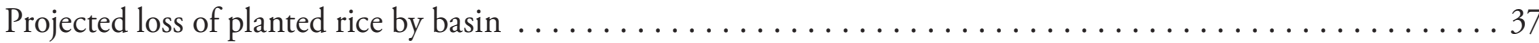

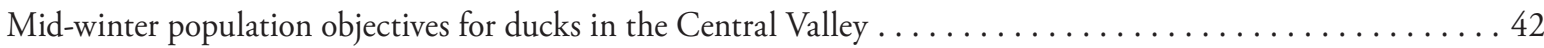

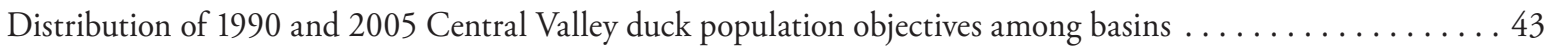

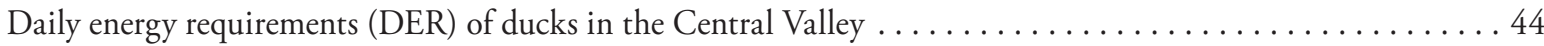

Daily energy requirements (DER) for dark goose populations in the Central Valley $\ldots \ldots \ldots \ldots \ldots \ldots \ldots .45$

Daily energy requirements (DER) for white goose populations in the Central Valley $\ldots \ldots \ldots \ldots \ldots \ldots \ldots 45$

Foraging habitats available to wintering waterfowl in the Central Valley $\ldots \ldots \ldots \ldots \ldots \ldots \ldots \ldots \ldots$

Densities (lbs/acre) and true metabolizable energy (TME) of important waterfowl foods in the Central Valley . . . .49

Foraging habitats available to wintering waterfowl in the American Basin $\ldots \ldots \ldots \ldots \ldots \ldots \ldots \ldots \ldots$

Annual wetland enhancement objectives for American Basin $\ldots \ldots \ldots \ldots \ldots \ldots \ldots \ldots \ldots \ldots \ldots \ldots$

Water needs for seasonal wetlands in American Basin . . . . . . . . . . . . . . . . . . . . . . . . . 61

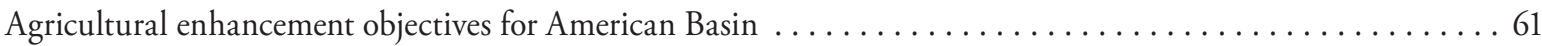

Conservation objectives for wintering waterfowl in American Basin . . . . . . . . . . . . . . . . . . . . 61

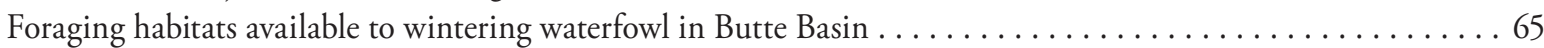

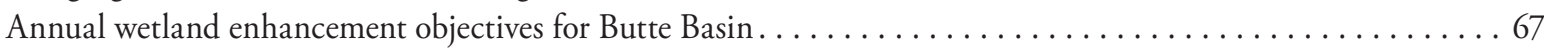

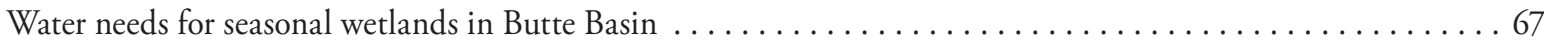

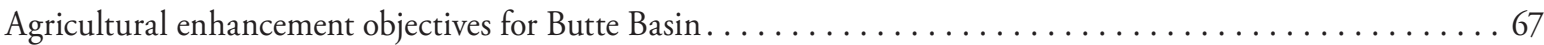

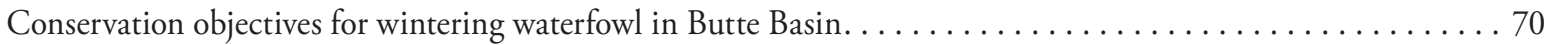

Foraging habitats (acres) available to wintering waterfowl in Colusa Basin $\ldots \ldots \ldots \ldots \ldots \ldots \ldots \ldots \ldots . . \ldots 72$

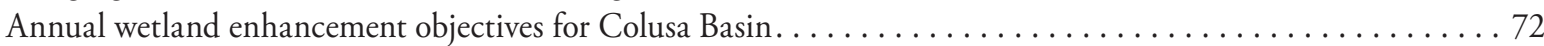

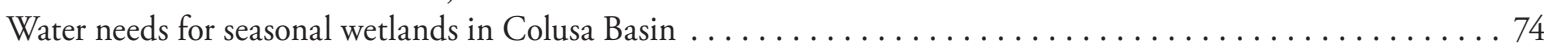

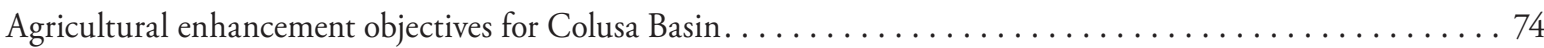

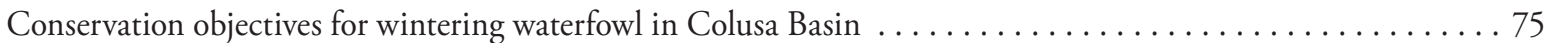

Foraging habitats available to wintering waterfowl in Delta Basin $\ldots \ldots \ldots \ldots \ldots \ldots \ldots \ldots \ldots \ldots \ldots 77$

Annual wetland enhancement objectives for Delta Basin . . . . . . . . . . . . . . . . . . . 82

Water needs for seasonal wetlands in Delta Basin when wetland restoration objective is met. . . . . . . 82

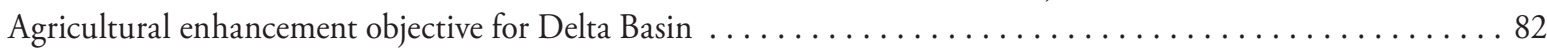


Table 4-27

Table 4-28

Table 4-29

Table 4-30

Table 4-31

Table 4-32

Table 4-33

Table 4-34

Table 4-35

Table 4-36

Table 4-37

Table 4-38

Table 4-39

Table $4-40$

Table 4-41

Table 4-42

Table 4-43

Table 4-44

Table 4-45

Table 4-46

Table 4-47

Table 4-48

Table 4-49

\section{Chapter 5}

Table 5-1

Table 5-2

\section{Chapter 6}

Table 6-1

Table 6-2

Table 6-3

Table 6-4

Table 6-5

Table 6-6

Table 6-7

Table 6-8

Table 6-9

Table 6-10

Table 6-11

Table 6-12

Table 6-13

Table 6-14

Table 6-15

Table 6-16

Table 6-17
Conservation objectives for wintering waterfowl in Delta Basin. $\ldots \ldots \ldots \ldots \ldots \ldots \ldots \ldots \ldots \ldots 2$

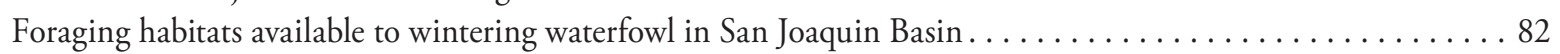

Annual wetland enhancement objectives for San Joaquin Basin. . . . . . . . . . . . . . . . 84

Water needs for seasonal wetlands in San Joaquin Basin when wetland restoration objective is met $\ldots \ldots \ldots 85$

Conservation objectives for wintering waterfowl in San Joaquin Basin $\ldots \ldots \ldots \ldots \ldots \ldots \ldots \ldots \ldots . \ldots . \ldots \ldots$

Foraging habitats available to wintering waterfowl in Sutter Basin. . . . . . . . . . . . . . . . 89

Annual wetland enhancement objectives for Sutter Basin $\ldots \ldots \ldots \ldots \ldots \ldots \ldots \ldots \ldots \ldots \ldots$

Water needs for seasonal wetlands in Sutter Basin when wetland restoration objective is met . . . . . . . 89

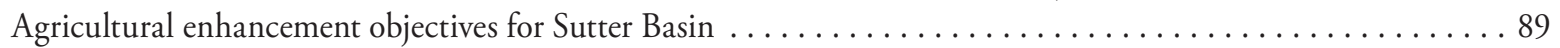

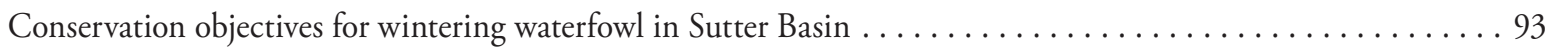

Foraging habitats available to wintering waterfowl in Suisun Marsh $\ldots \ldots \ldots \ldots \ldots \ldots \ldots \ldots \ldots \ldots$

Water needs for seasonal wetlands in Suisun Marsh. . . . . . . . . . . . . . . . . . . . . . 95

Conservation objectives for wintering waterfowl in Suisun Marsh . . . . . . . . . . . . . . . 97

Foraging habitats available to wintering waterfowl in Yolo Basin $\ldots \ldots \ldots \ldots \ldots \ldots \ldots \ldots \ldots \ldots$

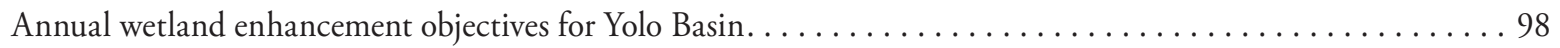

Water needs for seasonal wetlands in Yolo Basin when wetland restoration objective is met $\ldots \ldots \ldots \ldots \ldots 98$

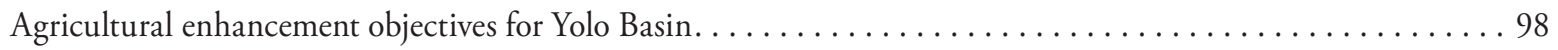

Conservation Objectives for wintering waterfowl in Yolo Basin . . . . . . . . . . . . . . . . . 99

Foraging habitats available to wintering waterfowl in Tulare Basin $\ldots \ldots \ldots \ldots \ldots \ldots \ldots \ldots \ldots \ldots$

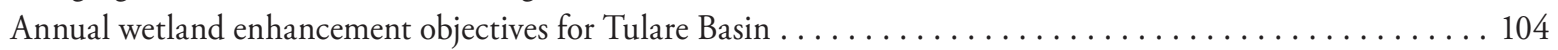

Water needs for seasonal wetlands in Tulare Basin when wetland restoration objectives have been met. . . . . 104

Conservation objectives for wintering waterfowl in Tulare Basin . . . . . . . . . . . . . . . . . 109

Conservation objectives for wintering waterfowl in the Central Valley of California $\ldots \ldots \ldots \ldots \ldots \ldots \ldots$

Vital rates that may limit the growth of duck populations including mallards that breed in the Central

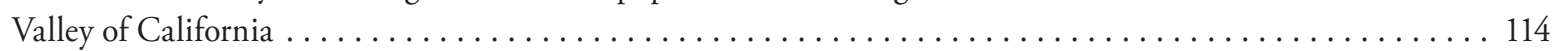

Vital rates estimates available for mallards breeding in the Central Valley of California . . . . . . . . 115-116

Average shorebird counts in the Central Valley from 1992-1994 . . . . . . . . . . . . . . . . . 146

Non-breeding shorebird population objectives for the Central Valley $\ldots \ldots \ldots \ldots \ldots \ldots \ldots \ldots \ldots \ldots$

Distribution of wintering shorebirds in the Central Valley by region and time period . . . . . . . . . . . 148

Weighted body mass for shorebirds in the Central Valley in each of the four survey periods . . . . . . . . 148

Acres of managed wetlands and intentionally flooded rice in the Central Valley . . . . . . . . . . . 148

Habitat resources and associated flooding schedules for a hypothetical shorebird planning region. . . . . . . 148

Habitat needs of non-breeding shorebirds in a hypothetical planning region $\ldots \ldots \ldots \ldots \ldots \ldots \ldots \ldots 4$

Seasonal wetland objectives (acres) for shorebirds in the Fall-Flooding Period of a hypothetical

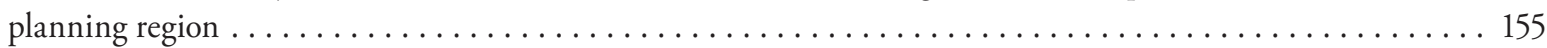

Seasonal wetland objectives (acres) for shorebirds in the Winter-Flooding Period of a hypothetical

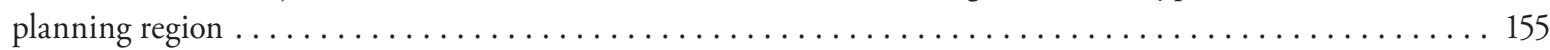

Seasonal wetland objectives (acres) for shorebirds in the Spring-Flooding Period of a hypothetical

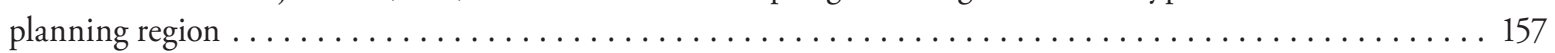

Rice habitat objectives (acres) for shorebirds between early October and the end of March in a

hypothetical planning region . . . . . . . . . . . . . . . . . . . . . . . . . . . . 159

Conservation objectives for non-breeding shorebirds in a hypothetical planning region $\ldots \ldots \ldots \ldots \ldots \ldots$

Acres of managed wetlands and intentionally flooded rice in the Sacramento Valley Planning Region . . . . . 162

Habitat objectives for shorebirds in the Sacramento Valley Planning Region during the Summer

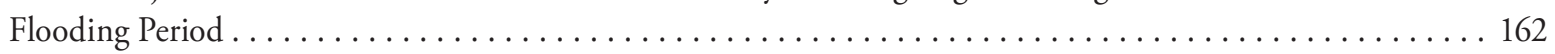

Overall habitat needs for shorebirds in the Sacramento Valley Planning Region during the Fall

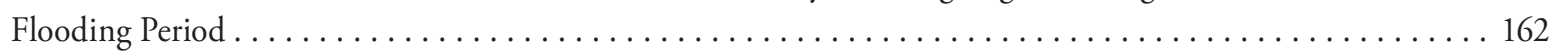

Seasonal wetland objectives (acres) for shorebirds in the Sacramento Valley Planning Region during the

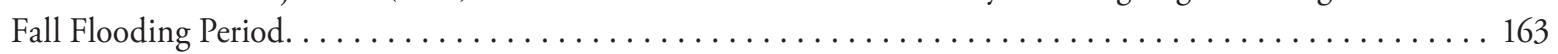

Overall habitat needs for shorebirds during the Winter Flooding Period $\ldots \ldots \ldots \ldots \ldots \ldots \ldots \ldots \ldots$

xiv Table of Contents 


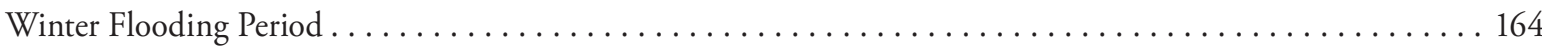

Table 6-19

Seasonal wetland objectives (acres) for shorebirds in the Sacramento Valley Planning Region during the

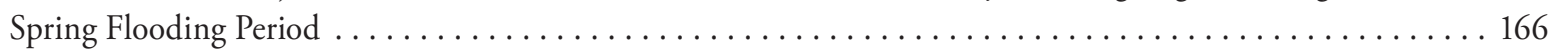

Table 6-20 Rice habitat objectives (acres) for shorebirds between early October and the end of March in the

Sacramento Valley Planning Region. . . . . . . . . . . . . . . . . . . . . . . . . . 166

Table 6-21

Table 6-22

Conservation Objectives for non-breeding shorebirds in the Sacramento Valley Planning Region . . . . . . . 168

Table 6-23

Table 6-24

Foraging habitats (acres) available to wintering shorebirds in the Delta Planning Region . . . . . . . . . . . . 169

Table 6-25

Habitat objectives for shorebirds in the Delta Planning Region during the Summer Flooding Period . . . . . . 170

Overall habitat needs for shorebirds in the Delta Planning Region during the Fall Flooding Period . . . . . . 171

Seasonal wetland objectives (acres) for shorebirds in the Delta Planning Region during the Fall

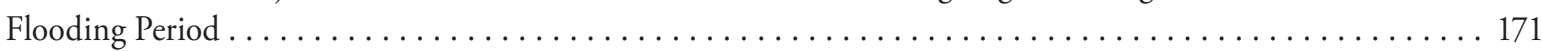

Table 6-26

Table 6-27

Table 6-28

Overall habitat needs for shorebirds in the Delta Planning Region during the Winter Flooding Period. ...... 172

Seasonal wetland objectives (acres) for shorebirds in the Delta Planning Region during the Winter

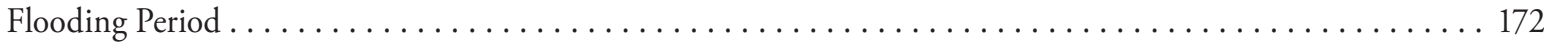

Seasonal wetland objectives (acres) for shorebirds in the Delta Planning Region during the Spring

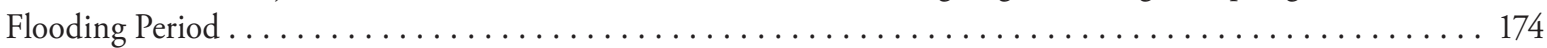

Table 6-29 Rice habitat objectives (acres) for shorebirds between early October and the end of March in the Delta

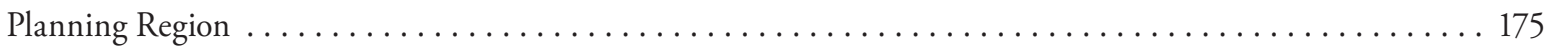

Table 6-30 Conservation Objectives for non-breeding shorebirds in the Delta Planning Region ............... 176

Table 6-31

Table 6-32

Table 6-33

Table 6-34

Table 6-35

Table 6-36

Table 6-37

Table 6-38

Table 6-39

Table 6-40

Table 6-41

Table 6-42

Table 6-43

Table 6-44

Foraging habitats (acres) available to wintering shorebirds in the San Joaquin Basin . . . . . . . . . . . 177

Habitat objectives for shorebirds in the San Joaquin Basin during the Summer Flooding Period. . . . . . . 178

Seasonal wetland objectives (acres) for shorebirds in San Joaquin Basin during the Fall Flooding Period . . . . 178

Seasonal wetland objectives (acres) for shorebirds in San Joaquin Basin during the Winter Flooding Period. . . 179

Seasonal wetland objectives (acres) for shorebirds in Joaquin Basin during the Spring Flooding Period. . . . . . 180

Conservation Objectives for non-breeding shorebirds in San Joaquin Basin $\ldots \ldots \ldots \ldots \ldots \ldots \ldots \ldots \ldots 1$

Foraging habitats (acres) available to wintering shorebirds in the Tulare Basin $\ldots \ldots \ldots \ldots \ldots \ldots \ldots \ldots . \ldots \ldots 2$

Habitat objectives for shorebirds in Tulare Basin during the Summer Flooding Period $\ldots \ldots \ldots \ldots \ldots \ldots$

Seasonal wetland objectives (acres) for shorebirds in Tulare Basin during the Fall Flooding Period.......... 183

Seasonal wetland objectives (acres) for shorebirds in Tulare Basin during the Winter Flooding Period . . . . . 185

Seasonal wetland objectives (acres) for shorebirds in Tulare Basin during the Spring Flooding Period. . . . . . . 186

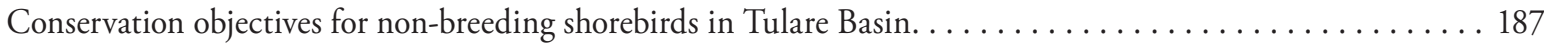

Seasonal wetlands objectives (acres) for shorebirds in the Central Valley . . . . . . . . . . . . . . . 188

Semi-permanent wetland objectives (acres) for shorebirds in the Central Valley . . . . . . . . . . . . . 189

Table 6-45

Winter Flooded Rice objectives (acres) for shorebirds in the Central Valley. . .

\section{Chapter 7}

Table 7-1

Table 7-2

Table 7-3

Table 7-4

Table 7-5

\section{Chapter 8}

Table 8-1

Table 8-2

Table 8-3

Table 8-4

Table 8-5

Table 8-6
Numbers (\%) of breeding black-necked stilts in various habitat types by planning regions of the Central

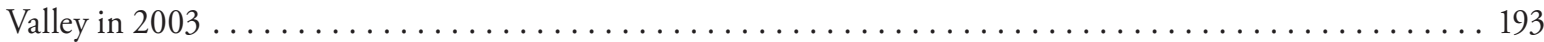

Numbers (\%) of breeding American avocets in various habitat types by planning regions of the Central

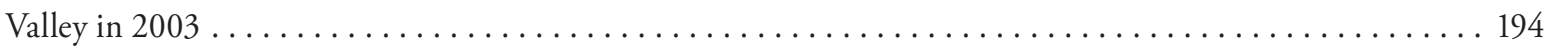

Existing breeding shorebird habitats (acres) in the Central Valley . . . . . . . . . . . . . . . . . . . 194

Five-year wetland restoration objectives for breeding shorebirds in the Central Valley. . . . . . . . . . . 196

Annual wetland water needs (acre-feet) to meet 5 -year breeding shorebird habitat objectives $\ldots \ldots \ldots \ldots \ldots$

Breeding and wintering distribution of waterbirds among waterbird planning regions. . . . . . . . . . 200

Conservation status of selected waterbirds among various bird conservation plans $\ldots \ldots \ldots \ldots \ldots \ldots \ldots 200$

North American Waterbird Conservation Plan level of conservation threats to focal waterbird species . . . . . 201

Seasonal habitat use by focal waterbird species in the Central Valley of California $\ldots \ldots \ldots \ldots \ldots \ldots \ldots 2$

Five-year conservation objectives for breeding and non-breeding waterbirds in the Central Valley of

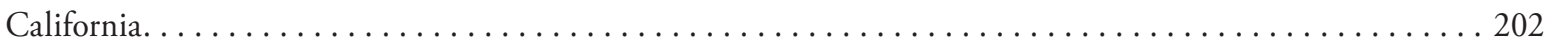

Summary of conservation needs of focal waterbird species of the Central Valley Joint Venture . . . . . . . . . 204 


\section{Chapter 9}

Table 9-1

Table 9-2

Table 9-3

Table 9-4

Table 9-5

Table 9-6

Table 9-7

Table 9-8

Table 9-9

Table 9-10

Table 9-11

Table 9-12

Table 9-13

\section{Chapter 10}

Table 10-1

Table 10-2

Table 10-3

Table 10-4

\section{Chapter 11}

Table 11-1

Table 11-2

Table 11-3

Table 11-4

Table 11-5

Table 11-6

Table 11-7

Table 11-8

Table 11-9

Table 11-10

Table 11-11

Table 11-12

Table 11-13

Table 11-14

Table 11-15

Table 11-16

Table 11-17

Table 11-18

Table 11-19

Table 11-20
Current and potentially restorable riparian habitat and number of bird point count stations per basin . . . . 213 Detectability coefficients derived from sites where point counts overlaid spot-mapping plots ('double sampling')

Values = point count-derived birds per hectare divided by \# of spot-map-derived birds per hectare . . . . . 216 Minimum management goals for subpopulations, pairs, and reforestation of suitable habitat, based on

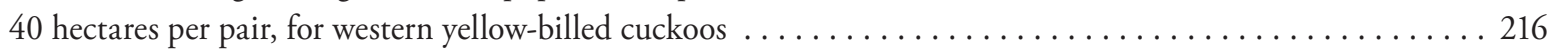

Observed Mayfield (1975) estimates of survival by planning regions and recommend values of nest success and adult survivorship as determined by source-sink (lambda) models $\ldots \ldots \ldots \ldots \ldots \ldots \ldots \ldots \ldots 218$

Five-year riparian restoration and enhancement objectives for breeding riparian songbirds in the

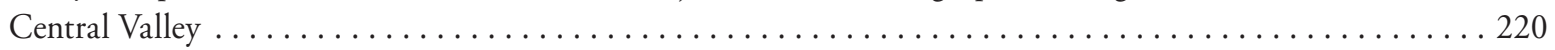

Current and potential population densities and population targets for song sparrow $\ldots \ldots \ldots \ldots \ldots \ldots 220$

Current and potential population densities and population targets for yellow-breasted chat $\ldots \ldots \ldots \ldots 221$

Current and potential population densities and population targets for black-headed grosbeak. . . . . . 222

Current and potential population densities and population targets for common yellowthroat . . . . . . . 222

Current and potential population densities and population targets for yellow warbler . . . . . . . . . 222

Current and potential population densities and population targets for spotted towhee $\ldots \ldots \ldots \ldots \ldots \ldots 223$

Basins ranked in order of importance to riparian birds based on inputs for setting conservation objectives . . . 224

Comparison of NAWCA proposals submitted spring 2003, based on contribution to riparian songbird targets . . 224

Annual water requirements (acre-feet per acre) by habitat type and basin $\ldots \ldots \ldots \ldots \ldots \ldots \ldots \ldots \ldots \ldots$

Total annual water needs for existing wetland habitats in the Central Valley $\ldots \ldots \ldots \ldots \ldots \ldots \ldots \ldots 231$

Total annual water needs for additional wetland habitats that must be restored to fully meet integrated

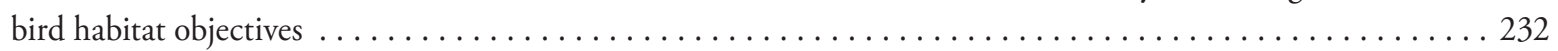

Total annual water needs for wetland and winter-flooded agricultural habitats in the Central Valley

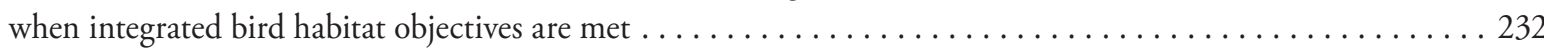

Central Valley-wide conservation objectives and strategies combined across all bird groups for all basins . . . . 239

Scale at which conservation objectives were established for each bird group. . . . . . . . . . . . . 240

Conservation objectives for wintering waterfowl in the Central Valley $\ldots \ldots \ldots \ldots \ldots \ldots \ldots \ldots \ldots . \ldots 241$

Conservation objectives for breeding waterfowl in the Central Valley . . . . . . . . . . . . . . . . 242

Conservation objectives for wintering shorebirds in the Central Valley $\ldots \ldots \ldots \ldots \ldots \ldots \ldots \ldots \ldots 242$

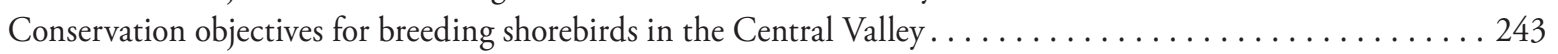

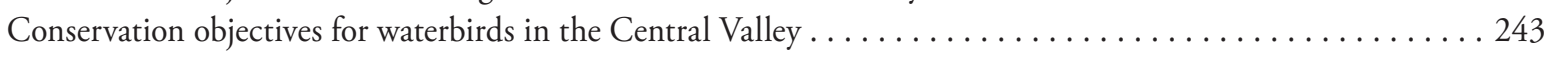

Conservation objectives for riparian songbirds in the Central Valley $\ldots \ldots \ldots \ldots \ldots \ldots \ldots \ldots \ldots \ldots 243$

Integrated seasonal wetland objectives (acres) for wintering waterfowl and wintering shorebirds in the

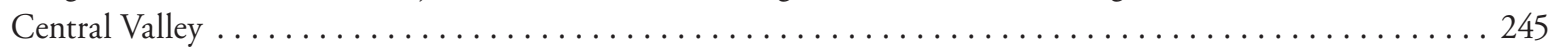

Integrated seasonal wetland enhancement objectives for wintering waterfowl and wintering shorebirds

in the Central Valley . . . . . . . . . . . . . . . . . . . . . . . . . . . . . . 246

Integrated semi-permanent wetland objectives for breeding waterfowl, wintering shorebirds, breeding

shorebirds, and waterbirds in the Central Valley . . . . . . . . . . . . . . . . . . . . . 247

Integrated riparian habitat objectives for songbirds and waterbirds in the Central Valley . . . . . . . . . 248

Integrated winter-flooded rice objectives for wintering waterfowl and wintering shorebirds in the

Central Valley . . . . . . . . . . . . . . . . . . . . . . . . . . . . . . . . . 248

Integrated Type I agricultural easements for wintering waterfowl and waterbirds in the Central Valley. . . . . . 249

Integrated Type II agricultural easements for wintering waterfowl and waterbirds in the Central Valley . . . . . 249

Integrated bird conservation objectives for wetland habitats in the Central Valley . . . . . . . . . . . 250

Integrated bird conservation objectives for agricultural habitats in the Central Valley . . . . . . . . . . 250

Total annual water needs for wetland and winter-flooded agricultural habitats in the Central Valley

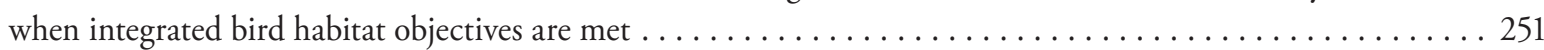

Annual water requirements (acre-feet per acre) by habitat type and basin $\ldots \ldots \ldots \ldots \ldots \ldots \ldots \ldots \ldots \ldots \ldots$

Estimated costs of meeting wetland and riparian restoration objectives for the Central Valley . . . . . . 252 


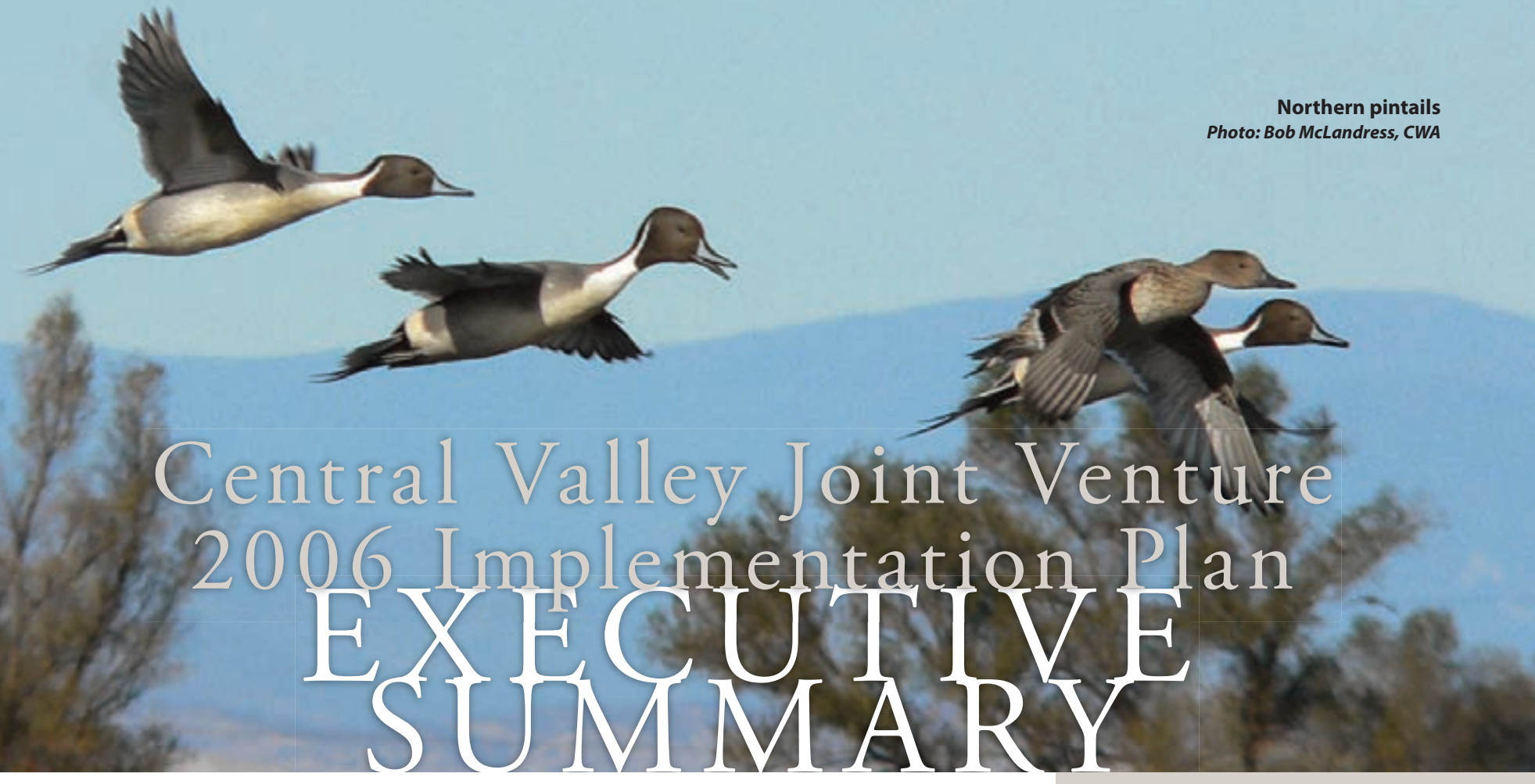

\section{Plan Background}

The 2006 Central Valley Joint Venture Implementation Plan (2006 Plan) allows the Central Valley Joint Venture (JV) and its individual partners to examine the habitat needs of various bird groups in the nine basins within the Central Valley, and to formulate and prioritize activities to meet those needs. The 2006 Plan updates the 1990 Central Valley Habitat Joint Venture Implementation Plan (1990 Plan; USFWS 1990), the original guiding document for wetland habitat conservation in the Central Valley of California. The 2006 Plan will direct the efforts of the JV for the next five years.

The 2006 Plan brings together research, monitoring data and evaluation from many sources, and represents the combined expertise of a wide range of professionals from conservation organizations, State and Federal agencies, and the private sector. Their knowledge and experience comprise the foundation for this plan.

\section{Historical and Current Conditions of the Central Valley}

The Central Valley stretches 450 miles down the center of California. It totals approximately 10 million acres, or $10 \%$ of the state, and includes portions of 19 counties. The Valley provides some of the most important bird habitat in North America, hosting one of the largest concentrations of migratory birds in the world during the fall and winter.

In the 1800s, the Central Valley contained more than 4 million acres of wetland habitats, supporting an estimated 20 to 40 million waterfowl annually. Grassland and riparian habitats once bordered most of these wetlands. Since then, agricultural and urban development have destroyed or modified more than $95 \%$ of the historic wetlands and over $90 \%$ of all riparian habitats. Today, just over 205,000 acres of managed wetlands remain in the Central Valley, and of those, two thirds are in private ownership. 


\section{Origins of the Central Valley Joint Venture}

In 1986, United States and Canadian wildlife agencies developed the North American Waterfowl Management Plan (NAWMP). The NAWMP recognized that wide-ranging degradations to wetlands and associated uplands across the continent required a comprehensive response to improve landscapes using public policies, wildlife friendly agriculture, and traditional habitat restoration programs. The purpose of the plan was, and remains, to sustain abundant waterfowl populations by conserving landscapes, through self-directed partnerships (joint ventures) guided by sound science.

The Central Valley Habitat Joint Venture was formally organized in 1988 and was one of the original six priority joint ventures formed under the NAWMP. Renamed the Central Valley Joint Venture in 2004, the Management Board has expanded from nine to twenty conservation organizations, and State and Federal agencies. With this growth, the JV has broadened its focus from exclusively waterfowl to include the conservation of habitats for other birds, consistent with major national and international bird conservation plans, and the North American Bird Conservation Initiative.

\section{Organization and Content}

The 2006 Plan incorporates new information and broadens the scope of conservation activities to include objectives for breeding waterfowl, breeding and non-breeding shorebirds, waterbirds, and riparian-dependent songbirds. It has identified specific goals and objectives for these species, stepped down to each of the Valley's nine basins. The 2006 Plan relies on both quantitative and qualitative approaches for establishing bird-group conservation objectives, and considers both biological and non-biological factors.

Chapter 1 explains the origin and purposes of the JV, the background for this updated implementation plan, and the historical and current conditions of the Central Valley.

Chapter 2 identifies the conservation objectives provided in the 1990 Plan, and summarizes accomplishments both Valley-wide and by basin for each objective. It also describes challenges faced in meeting certain objectives.

Chapter 3 provides a description of significant basin characteristics within the JV. The Central Valley is divided into nine basins that reflect regional differences in drainage patterns, and these serve as conservation planning units in the 2006 Plan for most bird groups.

Chapter 4 identifies the conservation objectives for wintering waterfowl, defined as non-breeding migrating or wintering ducks, geese, and swans using the Central Valley between August and March.

Chapter 5 discusses the habitat needs and corresponding limiting factors associated with the conservation of breeding waterfowl for basins in the Central Valley.

Chapter $\mathbf{6}$ addresses the needs of wintering shorebirds, defined as non-breeding shorebirds that occupy the Central Valley between July and May, each year.

Chapter 7 addresses the needs of seven species of shorebirds that breed within the Central Valley.

Chapter 8 addresses conservation needs within the Central Valley for waterbirds, a large and diverse group that includes seabirds, coastal waterbirds, wading birds and marshbirds that rely on aquatic habitats.

Chapter 9 addresses the conservation needs and strategies associated with breeding riparian songbirds in the Central Valley and is based on a suite of focal bird species that breed primarily in riparian habitat.

Chapter 10 outlines the need for water supplies for Central Valley wetlands and alternatives for obtaining needed water supplies to meet the 2006 Plan objectives. It summarizes the history of wetland water supplies and includes a topical summary of the most current and pressing water related issues within each basin.

Chapter 11 collates conservation objectives by habitat, and by basin or regional planning unit, for all bird groups addressed in this Plan. Table 11-1 lists these objectives by habitat type as follows: 
Table S-1. Central Valley-wide conservation objectives and strategies combined across all bird groups for all basins.

\begin{tabular}{|c|c|c|}
\hline \multicolumn{3}{|c|}{ Central Valley-wide objectives by habitat type } \\
\hline Habitat type & Strategy & Objective \\
\hline SEASONAL WETLANDS & Protection & $\begin{array}{l}\text { PROTECT ALL UNPROTECTED WETLANDS WITH } \\
\text { FEE OR CONSERVATION EASEMENTS }\end{array}$ \\
\hline SEASONAL WETLANDS & RESTORATION & 108,527 ACRES \\
\hline SEASONAL WETLANDS & ENHANCEMENT & 23,884 ACRES ANNUALLY ${ }^{a}$ \\
\hline SEMI-PERMANENT WETLANDS & Restoration & 12,500 ACRES \\
\hline RIPARIAN AREAS & RESTORATION & 10,000 ACRES \\
\hline RICE CROPLAND & ENHANCEMENT $^{b}$ & 170,000 ACRES \\
\hline AgRiCULTURAL CROPLAND & $\begin{array}{c}\text { Protection using Type I }^{c} \text { And Type } \text { II }^{d} \\
\text { Agricultural Easements }\end{array}$ & RECOMMENDED FOR SPECIFIC BASINS ${ }^{c, d}$ \\
\hline AGRICULTURAL CROPLAND & ENHANCEMENT TO BENEFIT WATERFOWL & 307,000 ACRES \\
\hline
\end{tabular}

${ }^{a}$ Annual enhancement needs when restoration goals have been met.

${ }^{b}$ Post-harvest (winter flooding) of rice cropland.

'Type I agricultural easements: easements that protect waterfowl food sources, focused in the American, Butte, and Sutter Basins.

${ }^{d}$ Type II agricultural easements: easements that buffer existing wetlands from urban and residential development, focused in the American, Butte,

Sutter, Delta, and San Joaquin Basins.

The JV has made considerable progress toward achieving the goals of its 1990 Plan. This success has been due to the efforts of many partners and a wide range of habitat programs. In addition, JV partners have invested in research to evaluate biological assumptions on which the 1990 Plan was based. This investment has considerably strengthened the biological foundation of the 2006 Plan.

The JV's efforts to protect, restore and enhance wetlands have significantly increased wildlife habitat resources in the Central Valley, not only for waterfowl, but for numerous other wetland dependent species as well. These benefits have also included improved water quality, flood control, and increased recreational opportunities. Using a collaborative, non-regulatory approach, and guided by the 2006 Plan, the JV will work together to insure that those benefits continue to expand for wildlife and the general public. 
S-4 Executive Summary 

The Central Valley Habitat Joint Venture (CVHJV) was formally organized in 1988 and was one of the original six priority joint ventures formed under the NAWMP. California Waterfowl Association, Defenders of Wildlife, Ducks Unlimited Inc., National Audubon Society, The Nature Conservancy, Trust for Public Land, Waterfowl Habitat Owners Alliance, CA Department of Fish and Game, and U.S. Fish and Wildlife Service (USFWS) were the nine founding partners and comprised the CVHJV's first Management Board (Board). Renamed the Central Valley Joint Venture in 2004, the Board now enjoys the membership of twenty conservation organizations, state and federal agencies. The partners have combined their efforts to cooperatively

meet the habitat needs of migrating and resident bird species in the Central Valley of California associated with four international bird conservation initiatives.

In 1990, the CVHJV partnership developed its first strategic plan to deliver partnership-based waterfowl habitat conservation, the Central Valley Habitat Joint Venture Implementation Plan (1990 Plan). This 2006 Central Valley Joint Venture Implementation Plan (2006 Plan) incorporates new information and broadens the scope of conservation activities to include objectives for shorebirds, waterbirds, and riparian songbirds.

The USFWS provides guidance for the establishment and organization of migratory bird joint ventures: "A joint venture is a selfdirected partnership of agencies, organizations, corporations, tribes, or individuals that has formally accepted the responsibility of implementing national or international bird conservation plans within a specific geographic area or for a specific taxonomic group, and has received general acceptance in the bird conservation community for such responsibility" (U.S. Fish and Wildlife Service 2005).

The JV is currently administered through a coordination office within the USFWS, and is guided by a Management Board that receives input and recommendations from a variety of working committees.

\section{The Central Valley: Historical and Current Conditions}

The Central Valley averages 40 miles wide and stretches 450 miles from north to south. It is bordered by the foothills of the Coast Range on its west and the Sierra Nevada on its east. The valley consists of two lesser valleys drained by California's two largest rivers, the Sacramento in the north and the San Joaquin in the south. These rivers flow from opposite directions and converge 40 miles southwest of Sacramento in a maze of channels, marshes and islands known as the Sacramento-San Joaquin Delta. These waters eventually reach the San Francisco Bay and empty into the Pacific Ocean.

The Central Valley totals about 10 million acres, or $10 \%$ of the State, and includes portions of 19 counties. Prior to the Gold Rush of the mid-1800s, the valley contained more than 4 million acres of wetland habitat. Most of these wetlands were bordered by grassland and riparian habitats. Many wetlands were seasonal in nature and resulted from over-bank flooding of rivers and streams that inundated large areas of the valley during winter and spring. Estimates from the 1800s suggest these habitats supported between 20 million and 40 million waterfowl annually. By the 1970s waterfowl numbers were estimated to be between 6 to 7 million, but declined significantly by the late 1980s (Heitmeyer 1989). Unfortunately, loss of these habitats has been dramatic. More than 95\% of historic wetlands and $98 \%$ of all riparian habitats have been destroyed or modified. The remnant intensively managed wetlands and associated agricultural habitats now support an average of 5.5 million waterfowl annually. Few places on earth have greater concentrations of wintering waterfowl than the Central Valley.

Today, just over 205,000 acres of managed wetlands remain in the Central Valley (Figure 1-1), and of these, two thirds are in private ownership. The over-bank flooding that once characterized the valley is essentially gone. Dams, levees, and flood bypasses confine these historic flows to controlled pathways. 

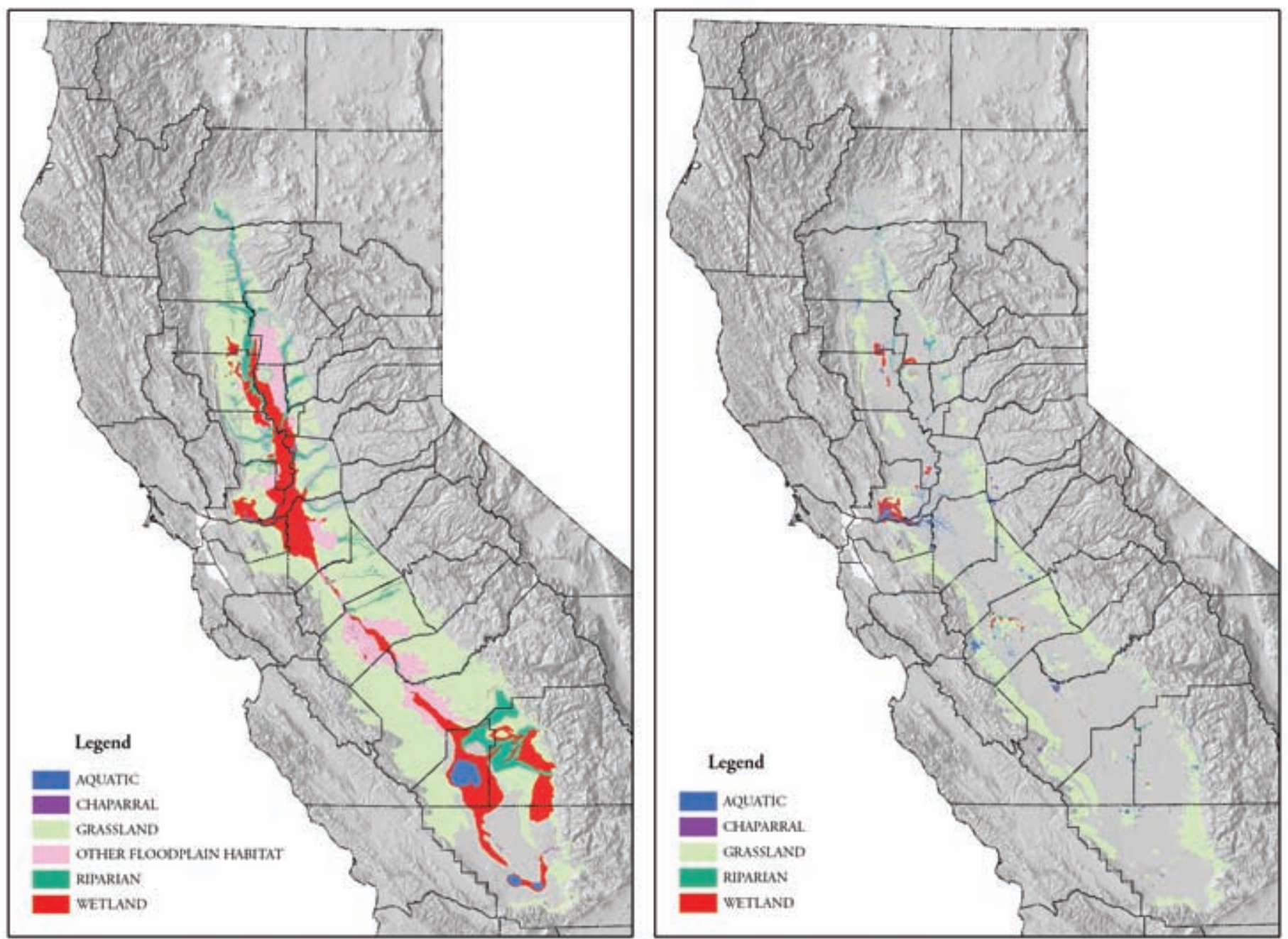

Data Sourcest GIC Central Valley Historic Mapping Project, Chico State USGS 3-Are Second Digital Elevation Model

Figure 1-1. Changes in Central Valley wetlands and associated habitats from 1900 (left) to 1990 (right).

Threats to wildlife habitat in the Central Valley continue to grow. Most of the valley's wetlands now rely on the application of water through managed systems. The long term reliability and affordability of water supplies for these wetlands is uncertain, as other water users compete for this limited resource. Water shortages in California are expected to grow as urban demand for water increases. The likely result is that water supplies needed for wetland management will become increasingly expensive, or worse yet, unavailable. According to the California Department of Finance, there are currently more than 34 million people in the state. This number is projected to reach 59 million by 2040, with an increase in the Central Valley from 5.4 million to 15.6 million. California's Central Valley ranks number one among the nation's twenty most threatened farming regions (American Farmland Trust 1997). The state's projected population increase will be accompanied by a loss of nearly one million acres of irrigated farmland within the valley (American Farmland Trust 1995), some of which contributes to meeting the needs of waterfowl and other wetland dependent wildlife.

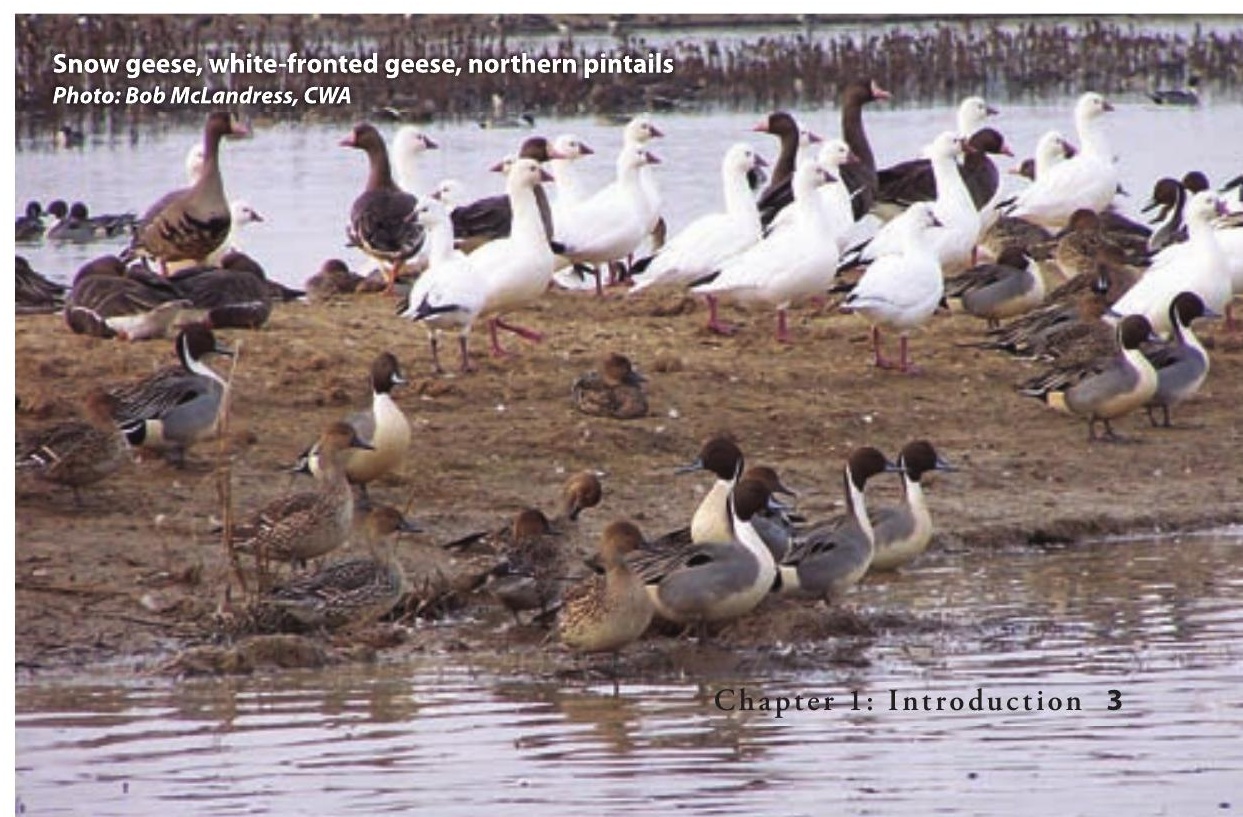




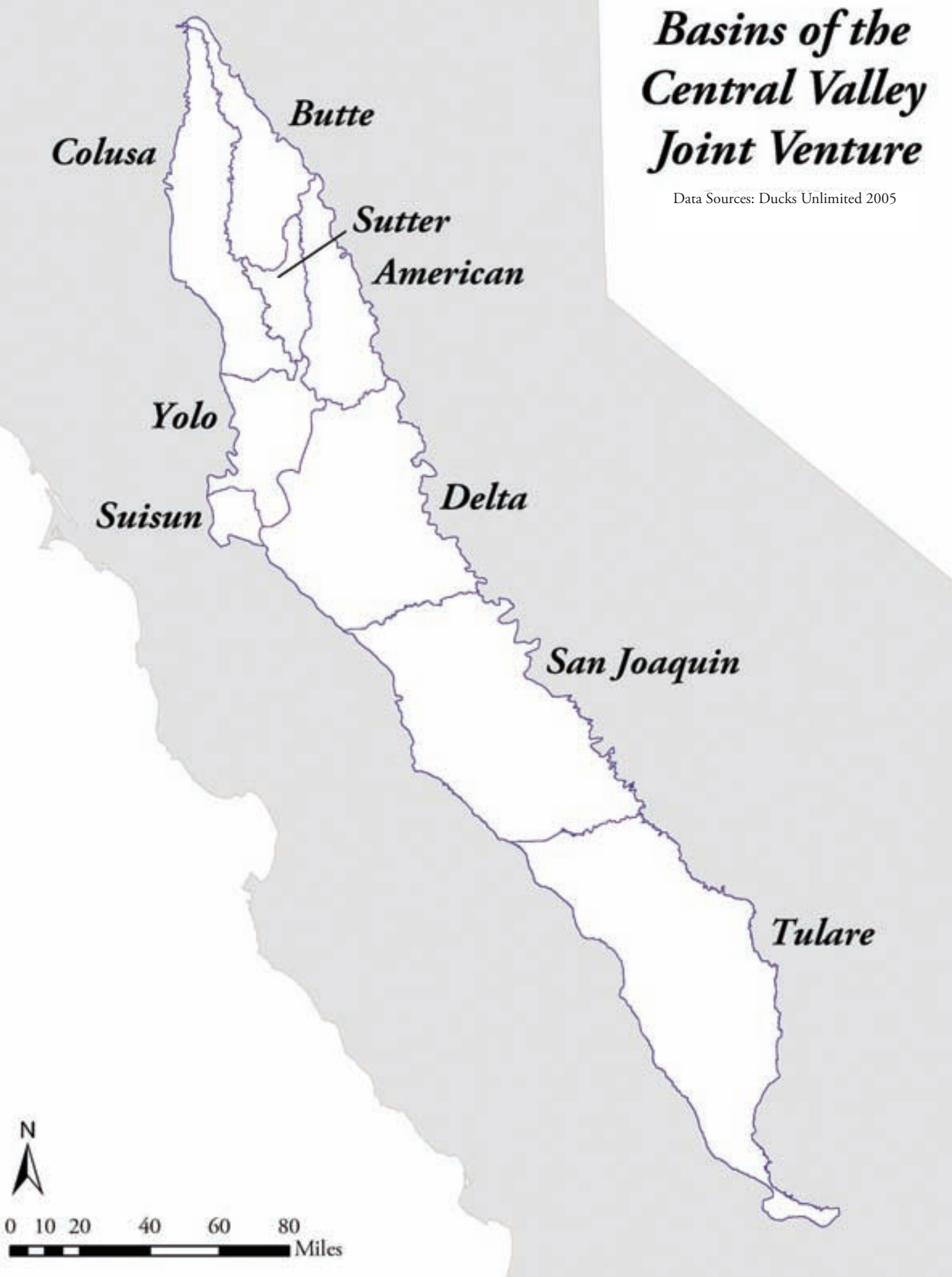

Figure 1-2. Central Valley Joint Venture basins. 


\section{Focus of the 1990 Plan}

In 1990, the JV developed its first planning document, the Central Valley Habitat Joint Venture Implementation Plan. The 1990 Plan primarily focused on the needs of wintering waterfowl (herein defined as non-breeding waterfowl that rely on the Central Valley floor during August-March). Breeding waterfowl needs were also addressed, although to a lesser degree. Waterfowl population objectives were generally linked to the NAWMP. Six conservation objectives were established to meet the habitat needs of Central Valley waterfowl:

1. Protect 80,000 additional acres of existing wetlands through acquisition of fee-title or perpetual conservation easements.

2. Secure an incremental, firm 402,450 acre-foot water supply that is of suitable quality and is delivered in a timely manner for use by National Wildlife Refuges (NWR), State Wildlife Areas (WA), and the Grasslands Resource Conservation District (GRCD).

3. Secure Central Valley Project power for NWRs, WAs and GRCD, and other public and private lands dedicated to wetland management.

4. Increase wetland acres by 120,000 acres and protect these wetlands in perpetuity by acquisition of fee-title or conservation easement.

5. Enhance wetland habitats on 291,555 acres of public and private lands.

6. Enhance waterfowl habitat on 443,000 acres of agricultural lands.

Each of these objectives was based mainly on the foraging habitat needs of wintering waterfowl, and also on enhancement of upland cover for breeding waterfowl in the Central Valley. The objectives were then stepped down to the valley's nine basins, based on historic waterfowl distribution. These basins served as planning units in the 1990 Plan (Figure 1-2).

The JV has made considerable progress toward achieving the goals of its $1990 \mathrm{Plan}$, and these accomplishments are detailed in Chapter 2. During the past 15 years, Joint Venture partners have invested in research to evaluate biological assumptions on which the 1990 Plan was based. This investment has considerably strengthened the biological foundation of the 2006 Plan.

\section{Focus of the 2006 Plan}

As previously stated, the 1990 Plan focused mainly on the needs of wintering waterfowl. Although meeting waterfowl needs remains central to the JV's purpose, the 2006 Plan has been expanded to include multiple bird groups.

In 1999, the North American Bird Conservation Initiative (NABCI) was formed to advance integrated bird conservation by capitalizing on partnership opportunities, promoting all-bird planning, and developing nation-wide Bird Conservation Regions. Joint ventures offer an existing structure for achieving the NABCI vision of integrating the goals of the various bird conservation plans. The USFWS encourages joint ventures to develop the capacity to deliver partnership based migratory bird habitat conservation (U.S. Fish and Wildlife Service 2005), although to date this direction has not come with additional funding sources to accomplish the task. The JV has consequently expanded its planning efforts to include six bird groups. Information for some bird groups is lacking compared to migrating and wintering waterfowl. However, the 2006 Plan is a first step in developing sound conservation objectives for each of the following:

- Wintering Waterfowl

- Breeding Waterfowl

- Non-breeding Shorebirds

- Breeding Shorebirds

- Waterbirds

- Breeding Riparian Songbirds

As part of its expanded responsibility to provide habitat for shorebirds, waterbirds and riparian birds along with waterfowl, the JV has increased its boundaries to include most of the Central Valley watershed, and has identified secondary and tertiary areas of focus within this expanded area. (Figure 1-3). Although the 2006 Plan continues to focus on the nine basins identified in the 1990 Plan, future planning efforts by the JV will reflect habitat needs within the expanded boundaries. 


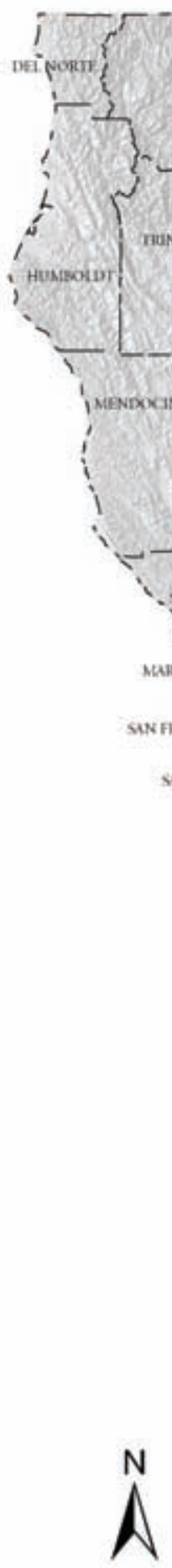

\section{Legend}

Primary Focus Area (under 300ft)

Secondary Area of Interest

(300-3,000ft)

Tertiary Area of Interest CVJV Boundary (3,000ft to summit)

Data Sources CVIV Focus Areas 2005, USGS 3-Arc Serond DEM. 
8 Chapter 1: Introduction 


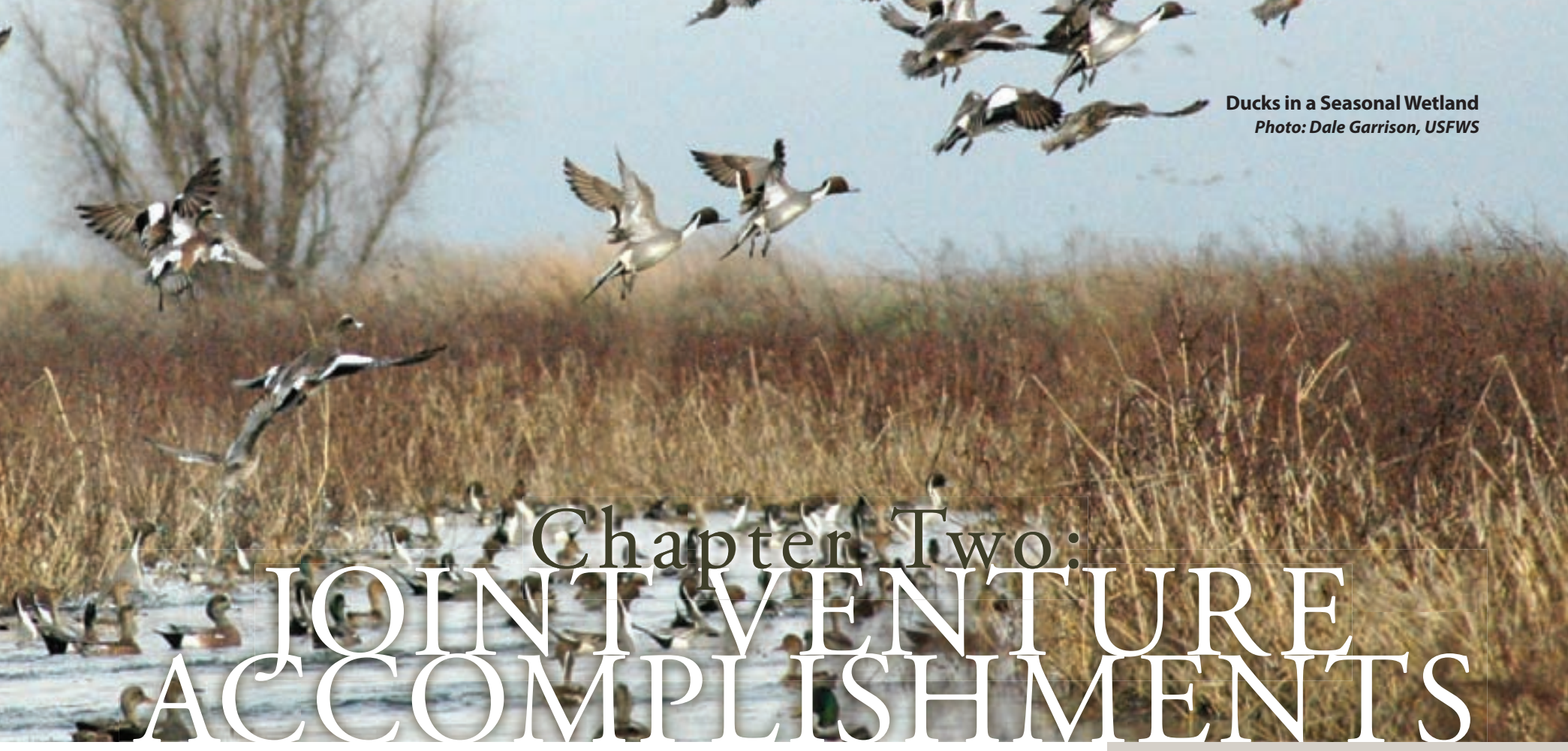

This chapter identifies the conservation objectives provided in the 1990 Central Valley Habitat Joint Venture Implementation Plan, and summarizes accomplishments both valley-wide and by basin for each objective. It also describes challenges faced in meeting certain objectives.

\section{Introduction}

The Central Valley Joint Venture partnership (JV) has an impressive record of accomplishment since its inception in 1988, and has made excellent progress towards meeting the objectives adopted in the 1990 Central Valley Habitat Joint Venture Implementation Plan (1990 Plan). The 1990 Plan established conservation objectives outlined in Chapter 1 and are summarized below:

- Wetland Protection: Protect in perpetuity 80,000 acres of existing wetland habitats.

- Wetland Water Supplies: Secure adequate power and water supplies for wetland management.

- Wetland Restoration: Restore and protect in perpetuity 120,000 acres of former wetlands.

- Wetland Enhancement: Enhance all existing wetlands.

- Agricultural Land Enhancement: Enhance waterfowl habitat on 443,000 acres of agricultural lands.
"The Central Valley Joint Venture is internationally recognized as an outstanding model of cooperative conservation, where partnerships working collectively toward common goals have protected, enhanced and restored thousands of acres of wetland, riparian, and associated upland habitat in the Central Valley for the benefit of migratory birds, resident wildlife and the public."

\section{David Paullin}

Coordinator

National Joint Venture

Assessment Team 


\section{Summary of Central Valley-wide Accomplishments}

The JV has reached $71 \%$ of the Wetland Protection objective through the purchase or donation of fee title and conservation easements from willing sellers. Significant progress has been made toward the Water Supply objective through the passage of the Central Valley Project Improvement Act (CVPIA) Title 34 of Public law 102-575, passed by Congress on October 30, 1992. The purpose of the CVPIA was to achieve optimum water supplies for all public wetlands and private wetlands within the GCRD.The CVPIA provided for $72 \%$ of the wetland water supply needs identified by the JV. Fifty-nine percent of the Wetland Restoration objective has been met. Since the Wetland Enhancement objective involves annual habitat enhancements of 50,000 to 75,000 acres per year, it is not expressed here as an accomplishment percentage. Agricultural Enhancement objectives for wintering waterfowl are $119 \%$ of the 1990 goal due to tremendous increases in winter-flooded rice.

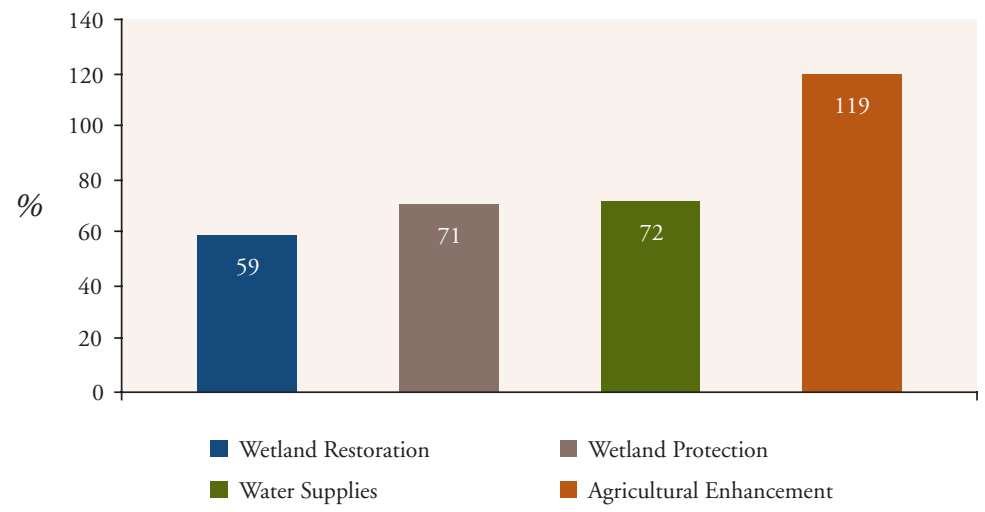

Figure 2-1. Progress in meeting conservation objectives as a percentage of objectives identified in the 1990 Plan.

The JV's efforts to protect, restore, and enhance wetlands have significantly increased wildlife habitat resources in the Central Valley (Figure 2-1), not only for waterfowl, but numerous other wetland dependent species as well. These benefits have also included improved water quality, flood control, and increased recreational opportunities.

\section{Accomplishments by Basin}

\section{Wetland Protection}

\section{Protect In Perpetuity 80,000 Acres of Existing Wetland Habitats}

The 1990 Plan had a stated objective of protecting 80,000 acres of existing privately owned wetlands through acquisition of fee-title or perpetual conservation easements. The 1990 Plan assumed 291,555 acres of wetlands were present in the Central Valley and that fifty nine percent of these wetlands (172,665 acres) were already protected through fee-title acquisition, perpetual easements or legislative actions. Accordingly, this left 118,810 acres of unprotected wetlands in the Central Valley.

Although the JV preferred that all wetlands receive protection, it recognized that many private wetland owners would be unwilling sellers or would not wish to enlist their properties in easement programs. Therefore, the JV adopted a wetland protection objective of 80,000 acres, which represented $67 \%$ of all remaining unprotected wetlands. This objective was seen as feasible, challenging, and large enough to make a significant difference to
Table 2-1. 1990 Wetland Protection objectives by basin. Basins are listed in priority based on the percent of wetlands in 1990 that were unprotected.

\begin{tabular}{|ccc|} 
Basin & $\begin{array}{c}\text { Unprotected } \\
\text { Wetlands (acres) }\end{array}$ & $\begin{array}{c}\text { JV Protection } \\
\text { Objective }^{a} \text { (acres) }\end{array}$ \\
\hline YoLO & 8,700 & 5,000 \\
\hline AMERICAN & 3,150 & 2,000 \\
\hline SAN JOAQUIN & 67,000 & 52,500 \\
\hline TULARE & 19,560 & 5,000 \\
BUTTE & 12,200 & 10,000 \\
DELTA & 4,300 & 3,000 \\
COLUSA & 3,400 & 2,000 \\
SUISUN & $0^{\mathrm{b}}$ & NO OBJECTIVE \\
SUTTER & 500 & 500 \\
TOTAL & $\mathbf{1 1 8 , 8 1 0}$ & $\mathbf{8 0 , 0 0 0}$ \\
\hline
\end{tabular}

"These acres reflect two thirds of the estimated unprotected wetlands in the Central Valley in 1990, and was considered to be a reasonable and achievable objective for the JV at that time.

${ }^{b}$ The entire 58,000 acre Suisun Marsh was assumed to be protected by the Suisun Marsh Protection Act of 1977. 
Water objectives in the 1990 Plan for NWRs, WAs, and the GRCD are presented in Table 2-3. Level 1 supply equaled reliable water supplies that were available by 1990, while Level 2 supplies equaled the average delivery of water to public habitats and the GRCD prior to the 1990 Plan. Of the 363,000 acre-feet annually delivered to public habitats and the GRCD by 1990, only 95,200 acrefeet were considered reliable (Table 2-3). Level 3 water supplies in the 1990 Plan equaled the amount of water needed for optimum management of existing wetland habitats, while Level 4 equaled the amount of water needed to permit full habitat development on public wetland areas and the GRCD.

Passage of the CVPIA automatically guaranteed Level 2 water supplies for NWRs, WAs, and the GRCD. The CVPIA also stipulated that Level 4 water supplies would be achieved in 10\% increments between 1993 and 2002. This would include securing reliable water through annual water purchases, and the necessary construction of conveyance facilities to refuges not yet in place but needed to carry these water supplies. Although the intent of the CVPIA was to reach reliable Level 4 supplies through incremental gains over a ten-year period, this has not been achieved because of chronic funding shortages and ongoing competition with other CVPIA programs for limited funds. Mendota WA, as well as Kern and Pixley NWRs, also lack the facilities to convey Level 4 supplies. Gray Lodge WA conveyance facilities were only recently completed in 2005. The result is that water purchases for public habitats and the GRCD remain unreliable.

Water acquisition to achieve Level 4 supplies relies upon spot market purchases by the Bureau of Reclamation from willing sellers every year. The escalating cost of water makes these purchases increasingly expensive. For example, average costs for water have increased from $\$ 50$ per acre-foot to $\$ 125$ per acre-foot during the last five years, despite normal rainfall amounts. An extended drought in California could make future water purchases prohibitively expensive. Chapter 10 discusses the challenges and issues that will most likely affect the JV's ability to secure water for wetlands in the near future.

Table 2-3. Water supply needs (acre-feet) identified in the 1989 Report on Refuge Water Supply Investigations, Central Valley Hydrologic Basin, California.

\begin{tabular}{|c|c|c|c|c|c|}
\hline Area & Level $1^{a}$ & Level $2^{b}$ & Level $3^{c}$ & Level $4^{d}$ & Objective $^{e}$ \\
\hline SACRAMENTO NWR & 0 & 46,400 & 50,000 & 50,000 & 50,000 \\
\hline Delevan NWR & 0 & 20,950 & 25,000 & 30,000 & 30,000 \\
\hline Colusa NWR & 0 & 25,000 & 25,000 & 25,000 & 25,000 \\
\hline SutTer NWR & 0 & 23,500 & 30,000 & 30,000 & 30,000 \\
\hline GRAY LODGE WA & 8,000 & 35,400 & 41,000 & 44,000 & 36,000 \\
\hline GRASSLAND RCD & 50,000 & 125,000 & 180,000 & 180,000 & 130,000 \\
\hline Volta WA & 10,000 & 10,000 & 13,000 & 16,000 & 6,000 \\
\hline Los Banos WA & 6,200 & 16,670 & 22,500 & 25,000 & 18,800 \\
\hline KESTERSON NWR & 3,500 & 3,500 & 10,000 & 10,000 & 6,500 \\
\hline SAN LUIS NWR & 0 & 13,350 & 19,000 & 19,000 & 19,000 \\
\hline Merced NWR & 0 & 13,500 & 16,000 & 16,000 & 16,000 \\
\hline Mendota WA & 25,500 & 18,500 & 24,000 & 29,650 & 4,150 \\
\hline PIxley NWR & 0 & 1,280 & 3,000 & 6,000 & 6,000 \\
\hline KeRN NWR & 0 & 9,950 & 15,050 & 25,000 & 25,000 \\
\hline TотAL & 103,200 & 353,050 & 473,550 & 505,650 & 402,450 \\
\hline
\end{tabular}

${ }^{a}$ Existing firm water supply in 1990

${ }^{b}$ Average annual water deliveries prior to 1990 Plan

'Full use of existing development (as it existed in 1990)

${ }^{d}$ Water needed to permit full habitat development

'Additional firm water needs identified in the 1990 Plan (Level 4 minus Level 1) 


\section{Wetland Restoration}

\section{Restore and Protect In Perpetuity 120,000 Acres of Former Wetlands}

The 1990 Plan had a stated objective of restoring 120,000 acres of wetland habitat. Restoration of 9,668 acres of wetlands in the Central Valley between 1986 and 1989 was applied towards this conservation objective, leaving an actual restoration objective of 110,332 acres.

The 1990 Plan identified 291,555 acres of existing wetlands in the Central Valley, but this number actually included a significant number of upland acres on federal, state, and private lands. Improved wetland inventory capabilities have shown that this initial number of wetland acres was an overestimation, and it has been revised in the 2006 Plan to 140,363 acres, in order to more accurately reflect the actual number of Central Valley wetlands that existed in 1990.

As of April 1, 2003 managed wetlands in the Central Valley totaled 205,554 acres. This represents a gain of 65,191 acres of wetland habitat, or $59 \%$ of the 1990 revised wetland acres (Figure 2-2). It also represents a 46\% increase in the acres of managed wetlands that were present in 1990 .

Wetland restoration objectives and accomplishments are presented by basin in Table 2-4. While significant progress has been made in meeting the 1990 wetland restoration objective for the entire Central Valley, there is disparity among basins. JV progress in meeting 1990 wetland restoration objectives for the American, Delta, and Sutter Basins lags well behind the overall figure of 59\% for the Central Valley. In contrast 1990 wetland restoration objective for the San Joaquin Basin has been exceeded.

\section{Yolo Basin Wildlife Area wetland restoration} Photo: Jill Shirley, CVJV

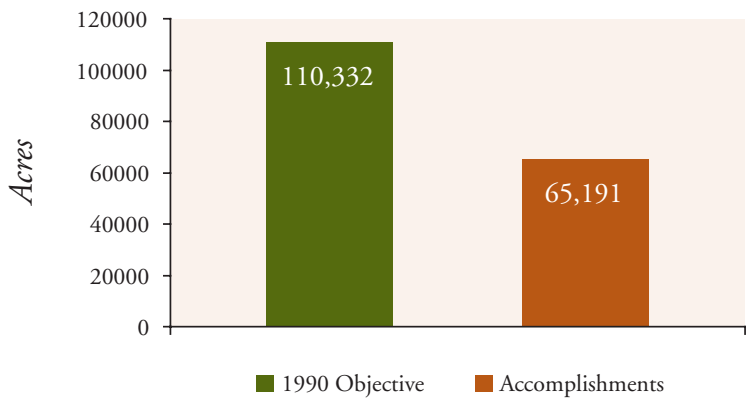

Figure 2-2. 1990 Wetland restoration objectives (acres) vs. wetlands restored between 1990 and 2003 for the entire Central Valley. 
Table 2-4. Wetland restoration objectives (acres) and accomplishments in the Central Valley by basin 1990 to 2003.

\begin{tabular}{|cccc|}
\hline Basin & 1990 Objective & $\begin{array}{c}\text { Wetlands Restored } \\
1990-2003\end{array}$ & $\begin{array}{c}\text { Percent of } \\
\text { Objective }\end{array}$ \\
\hline AMERICAN & 9,517 & 2,658 & $28 \%$ \\
BUtTE & 28,080 & 17,793 & $63 \%$ \\
COLUSA & 12,990 & 6,079 & $47 \%$ \\
DeLTA & 19,060 & 4,226 & $22 \%$ \\
SAN JOAQUIN & 19,980 & 22,742 & $114 \%$ \\
SUISUN & No OBJECTIVE & 234 & N/A \\
SUTTER & 10,960 & 760 & $7 \%$ \\
TULARE & No OBJECTIVE & 6,445 & N/A \\
YOLO & 9,745 & 4,254 & $44 \%$ \\
TOTAL & $\mathbf{1 1 0 , 3 3 2}$ & 65,191 & $59 \%$ \\
\hline
\end{tabular}

"The entire 58,000 acre Suisun Marsh was assumed to be already in wetlands, therefore, no wetland restoration objective was established for this basin. Tidal restoration was not considered in the 1990 Plan, due to limited waterfowl benefits.

${ }^{b}$ No restoration was proposed in the 1990 Plan, but this did not preclude future restoration efforts by public or private interests.

\section{Wetland Enhancement}

\section{Enhance All Existing Wetlands}

The 1990 Plan had a stated objective of enhancing all acres of existing public and privately managed wetlands. Although wetland enhancement in the Central Valley has proven difficult to track. Wetland enhancement has been redefined for the 2006 Plan (see Chapter 4), and the JV has developed a new web-based system to track accomplishments. This system will allow the JV to better measure progress in meeting enhancement objectives.

\section{Agricultural Land Enhancement}

\section{Enhance Waterfowl Habitat On 443,000 Acres of Agricultural Lands Annually}

The JV has made great strides towards its 1990 objective by enhancing over 384,000 acres of agricultural lands (J.D. Garr, Ducks Unlimited, Inc., personal communication). The 1990 Plan had a stated objective of annually enhancing waterfowl habitat on 443,000 acres of agricultural land. This conservation objective was broadly divided into two categories:

1. Enhancement of 332,290 acres of grain fields to help meet the food energy needs of wintering waterfowl, and

2. Enhancement of 110,800 acres of upland habitat to ensure adequate nest success for breeding waterfowl.

Enhancement of grain fields for wintering waterfowl was further divided into 83,075 acres of deferred tillage and 249,215 acres of winter flooding. 
Table 2-5. Agricultural enhancement objectives and accomplishments for wintering waterfowl by basin.

\begin{tabular}{|c|c|c|c|c|c|c|}
\hline Basin & $\begin{array}{l}1990 \text { Winter } \\
\text { Flooding Goal }^{a}\end{array}$ & $\begin{array}{l}\text { Current Winter } \\
\quad \text { Flooding }\end{array}$ & $\begin{array}{c}1990 \text { Deferred } \\
\text { Tillage Goal }\end{array}$ & $\begin{array}{c}\text { Current Deferred } \\
\text { Tillage }\end{array}$ & $\begin{array}{l}1990 \text { Basin }^{2} \\
\text { Total Goal }^{b}\end{array}$ & $\begin{array}{c}\text { Current Basin } \\
\text { Total }^{c}\end{array}$ \\
\hline AMERICAN & 11,140 & 72,049 & 3,713 & 0 & 14,853 & 72,049 \\
\hline Butte & 72,151 & 99,494 & 24,050 & 0 & 96,201 & 99,494 \\
\hline Colusa & 63,268 & 141,895 & 21,093 & 0 & 84,361 & 141,895 \\
\hline Delta & 39,078 & 30,495 & 13,026 & 0 & 52,104 & 30,495 \\
\hline SAN JOAQUIN & 0 & 0 & 0 & 0 & 0 & 0 \\
\hline SuIsun & 0 & 0 & 0 & 0 & 0 & 0 \\
\hline SutTer & 33,845 & 33,168 & 11,282 & 0 & 45,127 & 33,168 \\
\hline Tulare & 14,854 & UnKNOWN & 4,951 & 0 & 19,805 & UNKNOWN \\
\hline YoLO & 14,879 & 7,020 & 4,960 & 0 & 19,839 & 7,020 \\
\hline TOTAL & 249,215 & 384,121 & 83,075 & 0 & 332,290 & 384,121 \\
\hline
\end{tabular}

"Winter flooding refers exclusively to winter flooding of rice habitat with the exception of the Delta Basin where 29,488 acres of winter flooded corn and 1007 acres of winter flooded rice are estimated. Winter flooded acres in Tulare Basin are unknown but not believed to be large.

${ }^{b}$ Sum of Winter Flooding and Deferred Tillage goals in the 1990 Plan.

'Estimated sum of current Winter Flooding and Deferred Tillage acres as of 2003. Current Deferred Tillage is zero in all basins.

Deferred tillage increases the amount of waste grain available to waterfowl by not deep plowing fields immediately after harvest, while winter flooding increases bird access to agricultural food resources. Although agricultural enhancement objectives were developed to provide additional habitat for breeding waterfowl, no upland programs for nesting waterfowl have been developed since 1990 . Instead, efforts to meet the agricultural enhancement objectives in the 1990 Plan have largely focused on improving waterfowl access to agricultural foods during migration and winter.

Winter flooding, particularly of rice lands, has proved to be so widespread since 1990 that the conservation objective was achieved without relying on other approaches. Winter flooding of agricultural habitats in the Central Valley is now estimated at over 384,000 acres, with over ninety percent of this habitat being rice (information on how winter flooding was estimated is provided in Chapter 3). This estimate exceeds the 1990 objective for winter flooding by 135,000 acres (Figure 2-3). Although a pilot program to encourage deferred tillage was initiated in 1989 , the JV partners did not actively pursue this program. Winter flooding alone now exceeds the 1990 objective of enhancing 332,000 acres of agricultural habitat. Therefore, the lack of a deferred tillage program has not prevented the JV from meeting its overall conservation objectives for farmed lands. If winter flooding declines and post-harvest disking becomes more common, the JV may need to revisit the issue of deferred tillage.

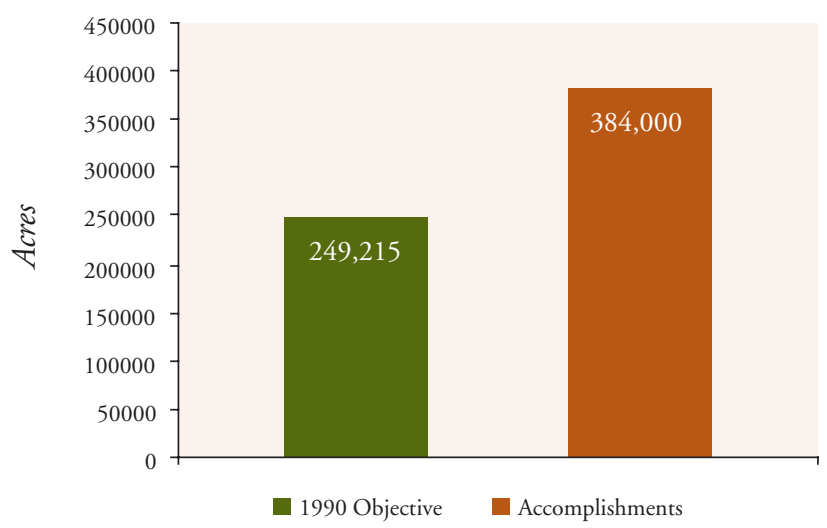

Figure 2-3. Winter flooding objectives vs. accomplishments from 1990 through 2003.

The overall objective of enhancing 332,000 acres of grain fields to help meet the food energy needs of wintering waterfowl was divided among the American, Butte, Colusa, Delta, Sutter, and Yolo Basins. No agricultural enhancement objectives for wintering waterfowl were developed for the San Joaquin, Tulare, and Suisun Marsh Basins (Table 2-5). Agricultural enhancement objectives have been exceeded for the American, Butte, and Colusa Basins. Current estimates of winter flooding in the Yolo Basin are less than half of the 1990 objective. While winter flooding objectives for this basin exceed 14,000 acres, rice production averaged only 9,750 acres in Yolo Basin between 1997 and 2001. Therefore, this objective was unlikely to be met. Although the Delta and Sutter Basins each approached their goals for winter flooding, the overall objective for agricultural enhancement (winter flooding + deferred tillage) was not met for either basin (Table 2-5). 


\section{Summary}

The JV has reached $71 \%$ of the Wetland Protection objective through the purchase or donation of fee title and conservation easements from willing sellers. Significant progress has been made toward the Water Supply objective through the passage of the Central Valley Project Improvement Act (CVPIA). The CVPIA provided for $72 \%$ of the wetland water supply needs identified by the JV. Fifty-nine percent of the Wetland Restoration objective has been met. Every year 50,000 to 70,000 acres of wetlands are enhanced. Agricultural Enhancement objectives for wintering waterfowl are 119\% of the 1990 goal due to tremendous increases in winter-flooded rice.

The JV's efforts to protect, restore, and enhance wetlands have significantly increased wildlife habitat resources in the Central Valley, not only for waterfowl, but numerous other wetland dependent species as well. These benefits have also included improved water quality, flood control, and increased recreational opportunities. 
This chapter provides a description of important basin characteristics within the JV. The Central Valley is divided into nine basins that reflect regional differences in drainage patterns (Figure 3-1), and these serve as conservation planning units in the 2006 Plan for most bird groups. The first section describes each basin, its general location, size, and hydrology. The second provides a summary of habitat conditions in each basin including a description of wetland, agricultural and associated habitat resources that are important to specific bird groups. The final section of this chapter discusses anticipated human population growth and associated changes in land use.

\section{Basin Description, Hydrology, and Other Features}

\section{Butte Basin}

The Butte Basin encompasses 1,100 square miles and extends 75 miles from Red Bluff south to the Sutter Buttes. The basin is bordered by the Sacramento River on its west, and the Sierra Nevada foothills and Feather River on its east (Figure 3-2). Butte Creek drains the basin between the city of Chico and the Sutter Buttes. Historically, creeks north of Chico flooded adjacent lands. However, these lands are now protected by levees and have
"Each of the nine Central Valley hydrologic basins is unique, providing its own set of biological values for wintering and breeding birds. The JV has been adept at working directly with those individuals, agencies and organizations with the greatest local knowledge, effectively gathering the best information available to develop landscape-level habitat objectives for all of the major bird groups."

\section{Peter Perrine}

Wetlands Program Manager California Wildlife Conservation Board 


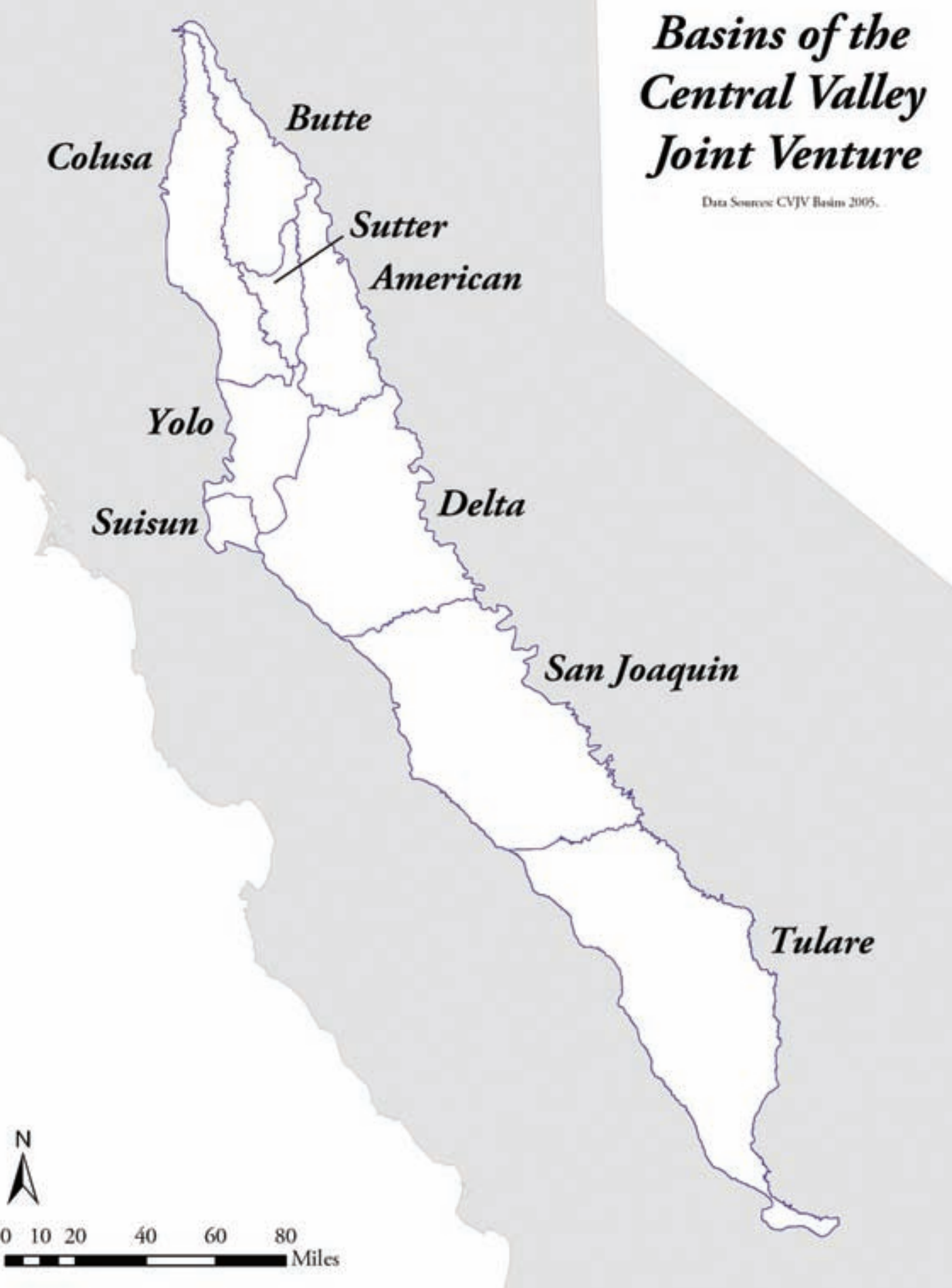

Figure 3-1. Central Valley Joint Venture basin boundaries. 
been developed for urban and agricultural use. Below Chico, over-bank flooding from Butte Creek and the Sacramento River produced large tracts of seasonal wetlands. Some of these overflows reached the Butte Sink, a large marsh in the southern portion of the basin. However, in the early 1900s, a series of levees and drainage facilities was built to contain these floodwaters as well. The southwestern part of the basin is now managed by the Sacramento River Flood Control District to convey flood flows into the Sutter Bypass.

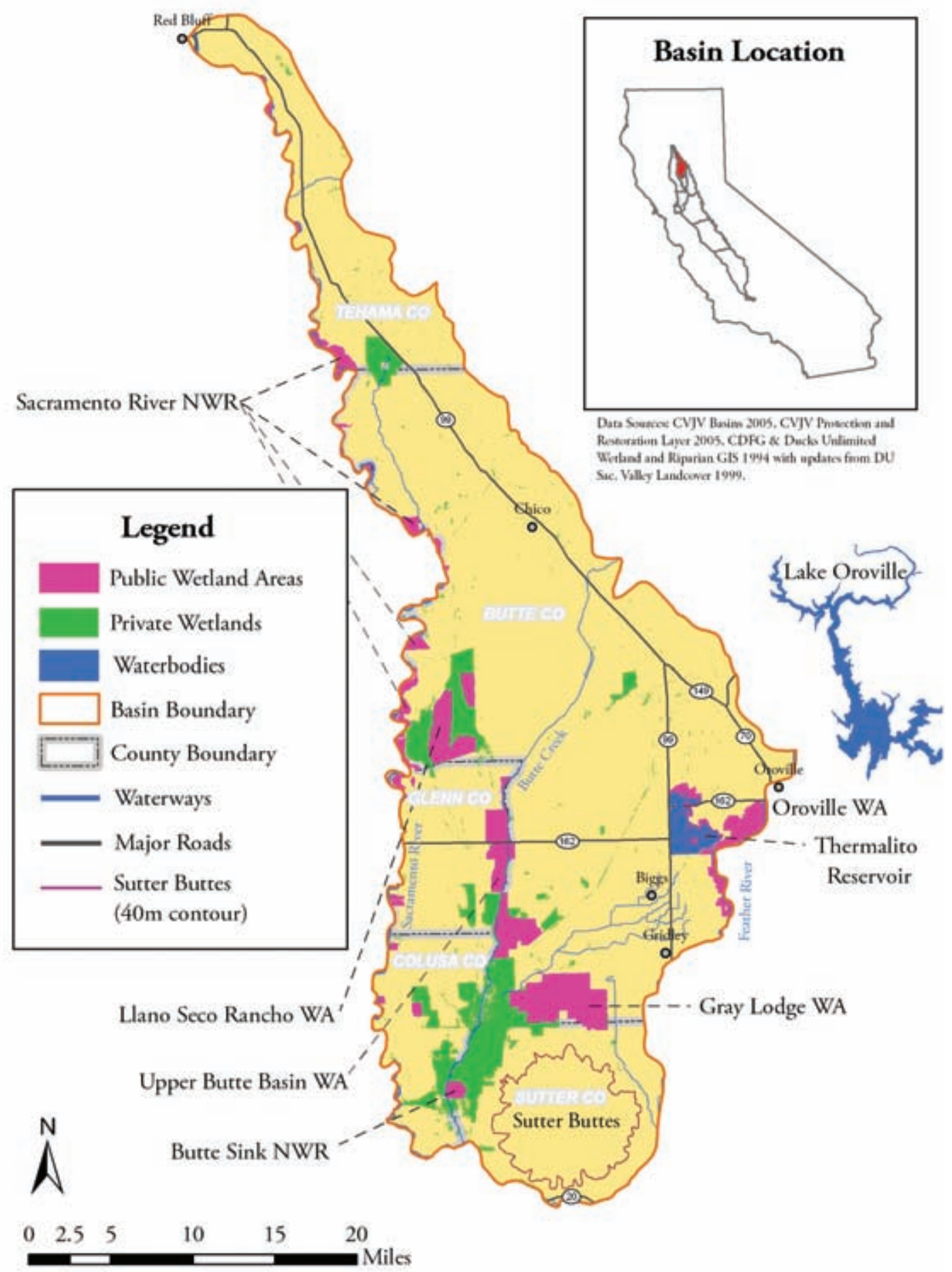

Figure 3-2. Map of the Butte Basin 


\section{Sutter Basin}

The Sutter Basin totals 350 square miles and extends south from the Sutter Buttes to the confluence of the Feather and Sacramento Rivers. These rivers also border the basin to its east and west (Figure 3-3). Overflow from the Sacramento and Feather Rivers and the Butte Sink historically flooded 40,000 to 50,000 acres of wetlands. Although construction of the Sutter Bypass and flood control systems on the Sacramento and Feather Rivers have eliminated most of this overflow, portions of the bypass continue to provide wetland habitat.

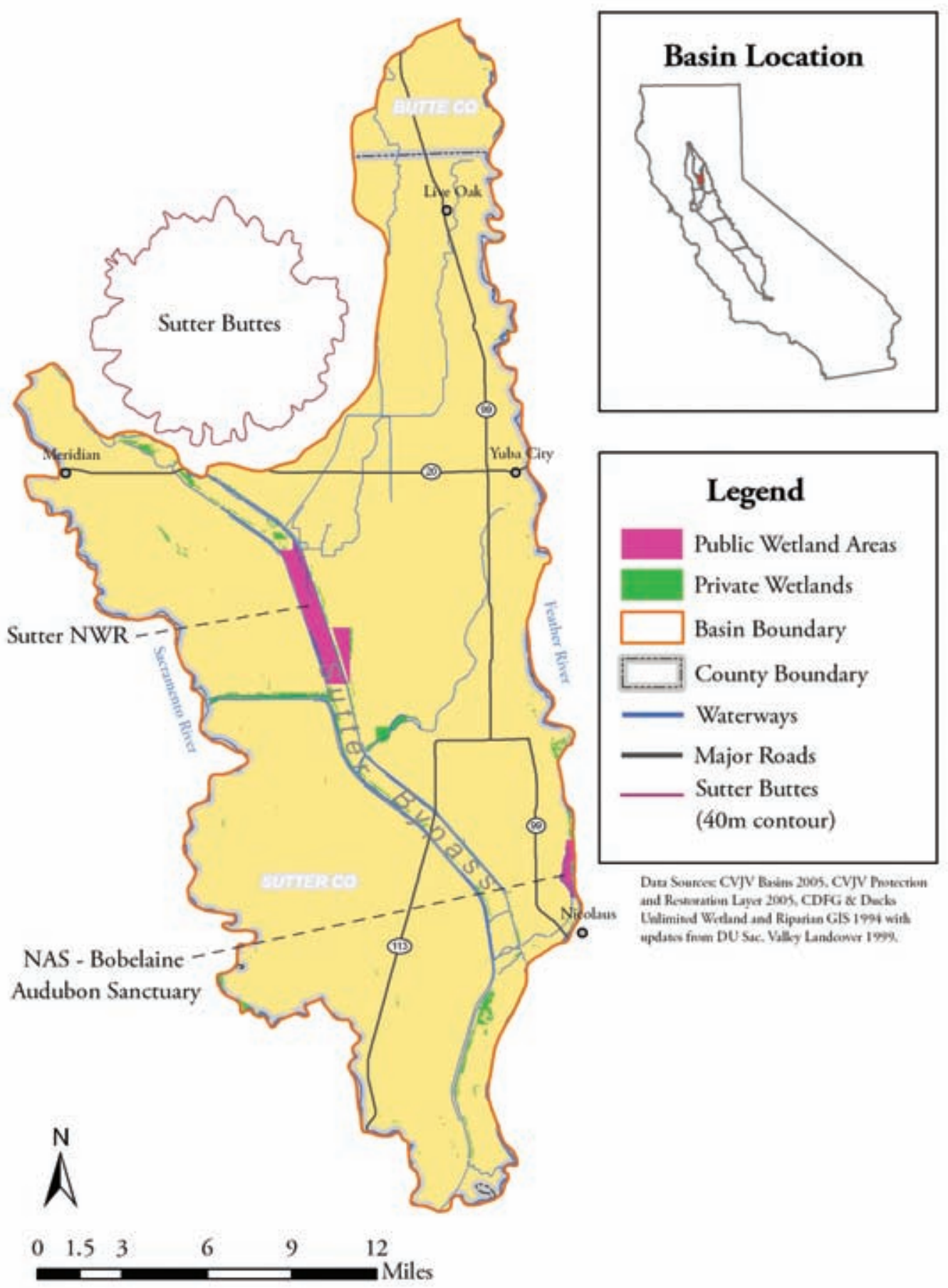

Figure 3-3. Map of the Sutter Basin 


\section{Colusa Basin}

The Colusa Basin extends 106 miles from Red Bluff south to Cache Creek and is bordered on the east by the Sacramento River and on the west by the Coast Range. The basin totals 1,600 square miles, though most wetland habitat is located south of the Stony Creek drainage (Figure 3-4). Colusa Trough, a naturally formed depression that enters the Sacramento River near Knight's Landing, drains the basin. Historically, overflow from the Sacramento River joined with streams draining the east slopes of the Coast Range to flood basin marshes in winter and spring. The development of levee networks, drains, and pumping stations have eliminated those flood events in all but the wettest years.

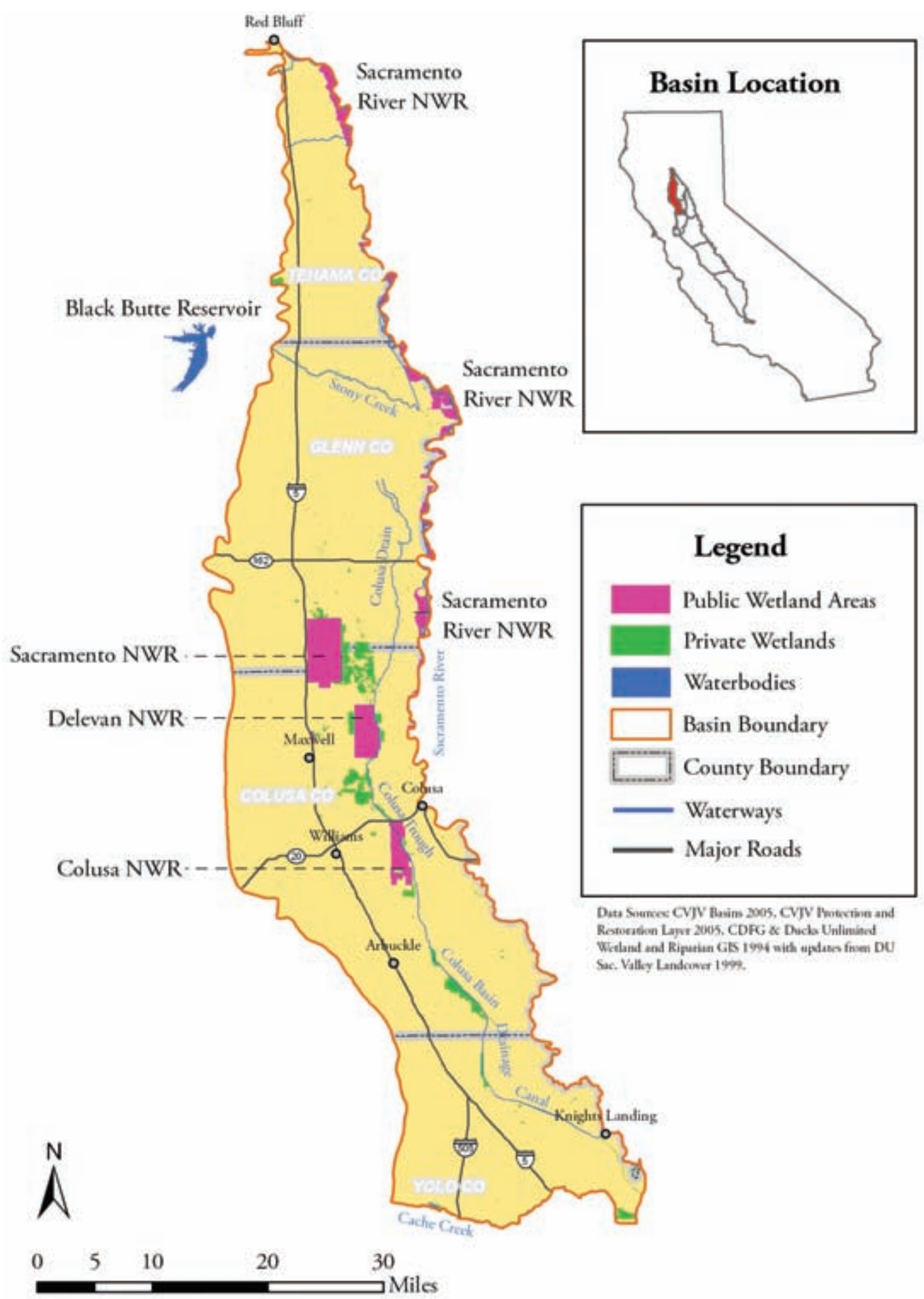

Figure 3-4. Map of the Colusa Basin 


\section{American Basin}

The American Basin lies east of the Sacramento and Feather Rivers and west of the Sierra Nevada foothills from Oroville in the north to the American River in the south. The basin totals about 860 square miles (Figure 3-5). Historically, water from the American, Yuba, Feather, Sacramento, and Bear Rivers flooded this area. This basin includes the District 10 and Honcut Creek areas, which constitutes a large block of privately owned wetlands. Construction of flood control reservoirs, levees, and dams at Folsom, Oroville, and Bullards Bar, have eliminated most of this over-bank flooding.

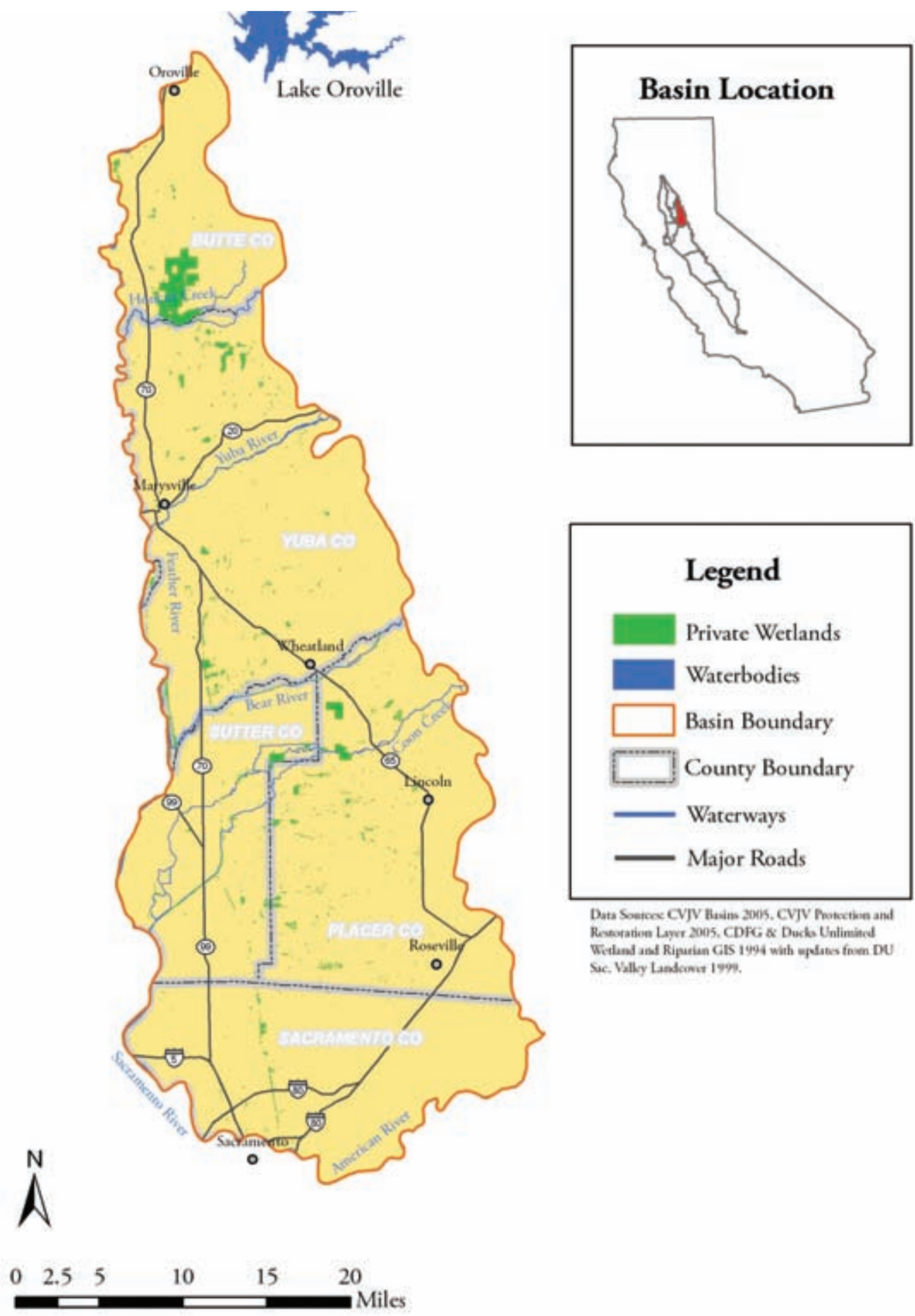

Figure 3-5. Map of the American Basin 


\section{Suisun Basin}

The Suisun Basin encompasses 170 square miles in southern Solano County and is bordered on the east by the Sacramento-San Joaquin Delta and on the west by the Carquinez Strait (Figure 3-6). Suisun Marsh dominates the basin, and is the largest brackish (diked, managed) wetland remaining in California. In 1963 landowners created the 116,000-acre Suisun Resource Conservation District (Suisun RCD), which includes a complex of managed and unmanaged wetlands as well as upland habitat. There are 158 privately owned wetlands in the Suisun Basin. There are also 15,000 acres owned by the California Department of Fish and Game in the Grizzly Island Wildlife Area complex. Landowners must meet standards for wetland habitat and water quality set by the Suisun Marsh Preservation Act of 1977, enacted by the State of California.

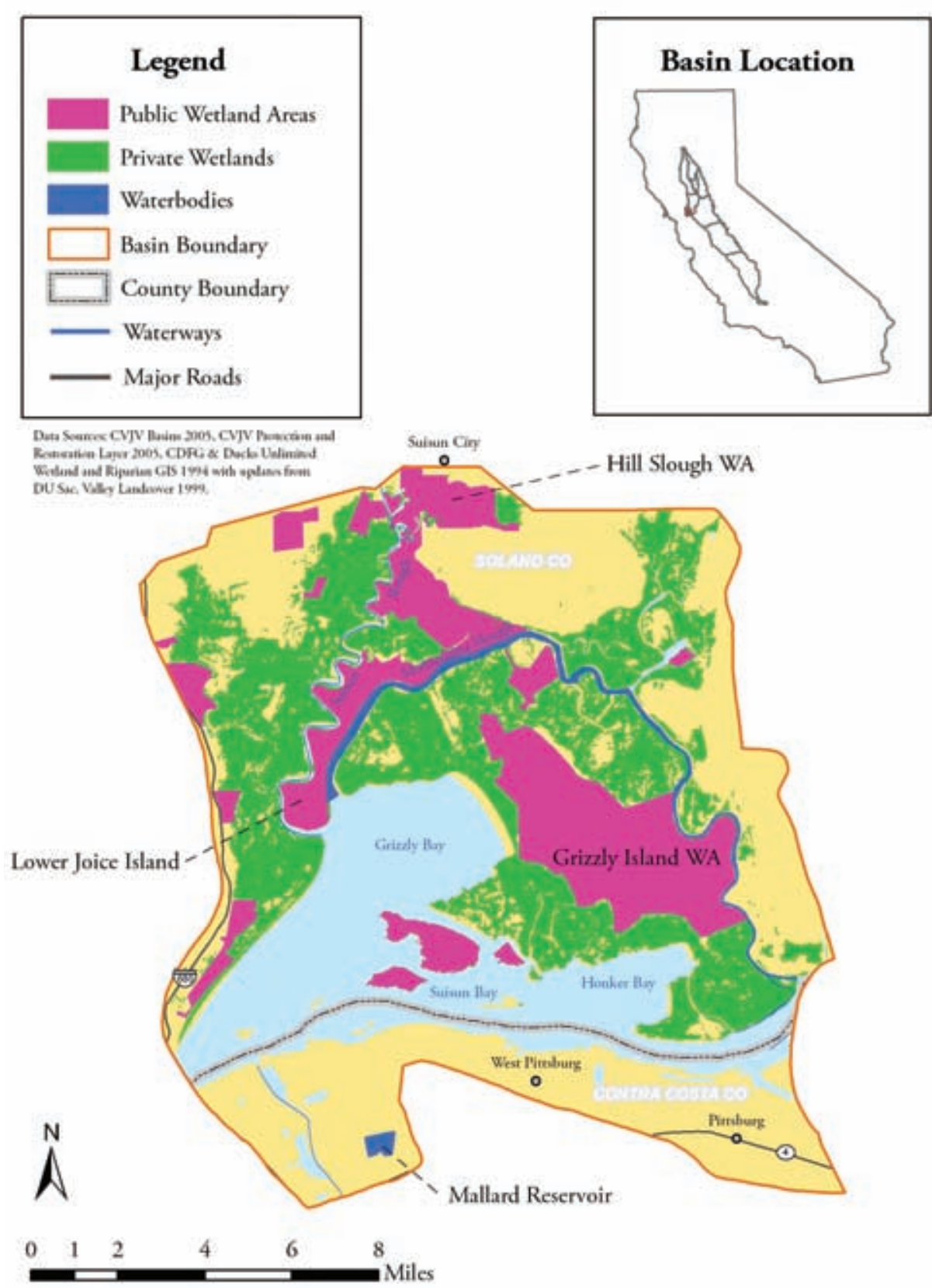

Historically, the Suisun Marsh was a tidally influenced basin that totaled 74,000 acres. Large portions of the marsh were submerged daily until levee construction in the 1850 s restricted tidal flows. Tide gates and levees currently protect most of the Marsh from flooding, however salinities have gradually increased because of freshwater diversions from the San Joaquin and Sacramento Rivers. Vegetation communities in the marsh reflect this increase in salinity, as many common plant species are salt tolerant (Heitmeyer et al. 1989).

Figure 3-6. Map of the Suisun Basin 


\section{Yolo Basin}

The Yolo Basin lies west of the Sacramento River between Cache Creek to the north and the Montezuma Hills and the Delta Basin to the south, and totals about 800 square miles (Figure 3-7). The basin historically received overflow waters from the Sacramento River as well as Cache, Putah, and Ulatis Creeks. Low lying areas near the Delta were tidally influenced and supported permanent marshes, while flooding at higher elevations produced seasonal wetland habitat. Like much of the Central Valley, the hydrology of the Yolo Basin has been modified by levees and flood control structures. The Yolo Bypass was developed along the east side of the basin, and provides flood protection for adjacent lands when flows in the Sacramento River are high.

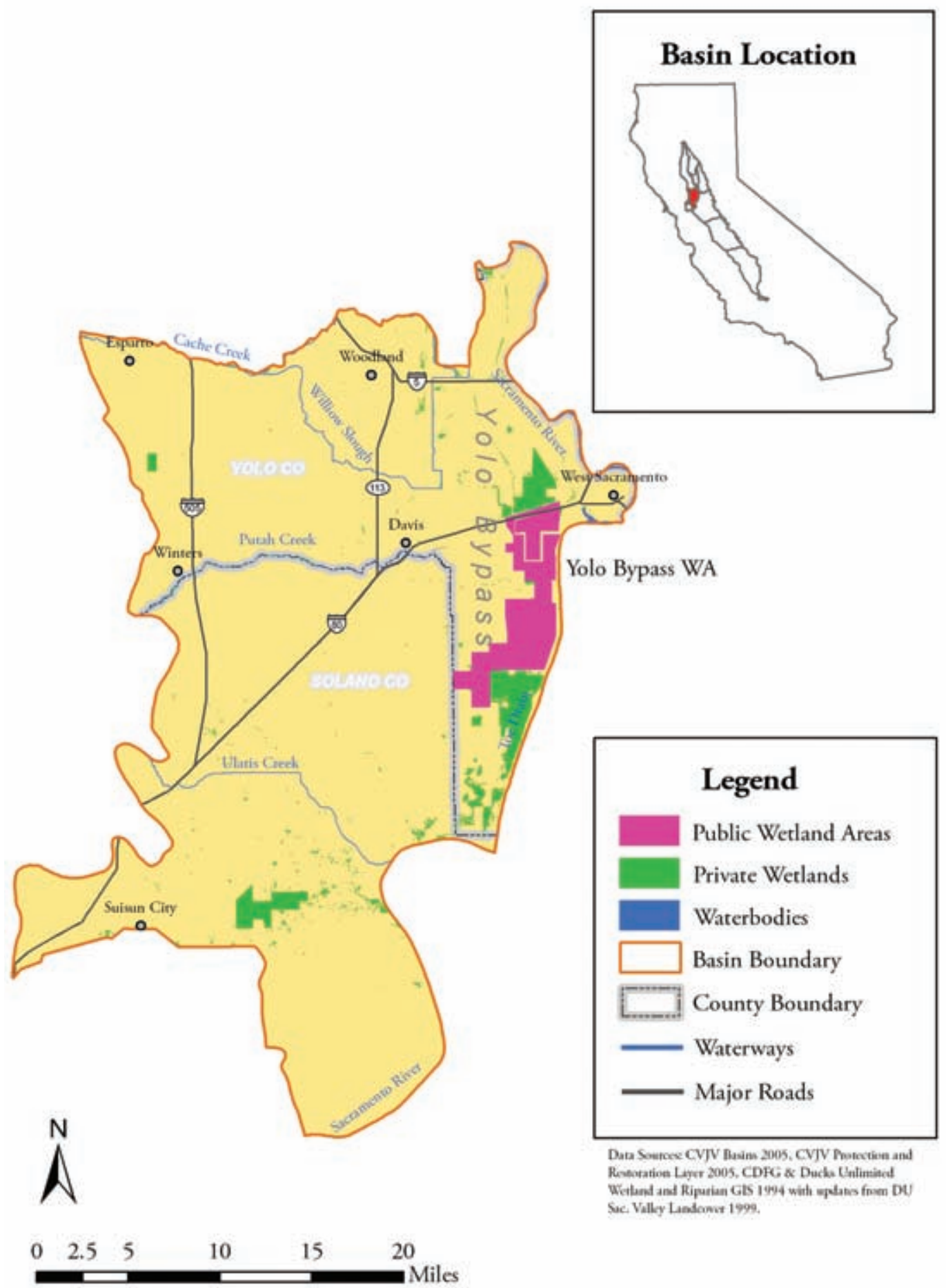

Figure 3-7. Map of the Yolo Basin 


\section{Delta Basin}

The Delta Basin totals 2,100 square miles and extends from the American River in the north, to the Stanislaus River in the south. Other borders are the Sierra Nevada foothills to the east, the Sacramento River to the northwest, and the Coast Range to the southwest (Figure 3-8). Prior to the mid-1800s, the Delta Basin was tidally influenced and part of a larger estuary that included Suisun Marsh and the San Francisco Bay. Development of the basin began in the 1850s, when the Swamp Land Act transferred ownership of all "swamp and overflow land" from the federal government to the State. By the early 1900s, nearly all the Delta's wetlands had been converted to agriculture.

The basin is formed by the convergence of the Sacramento, San Joaquin, Cosumnes, Mokelumne, and Calaveras Rivers. This confluence is subject to tidal movement and water diversions as it flows into the San Francisco Bay. A 1,000-mile network of levees has reclaimed sixty former wetland islands in the Delta. These islands are intensively farmed and some are managed as duck hunting clubs after crop harvest.

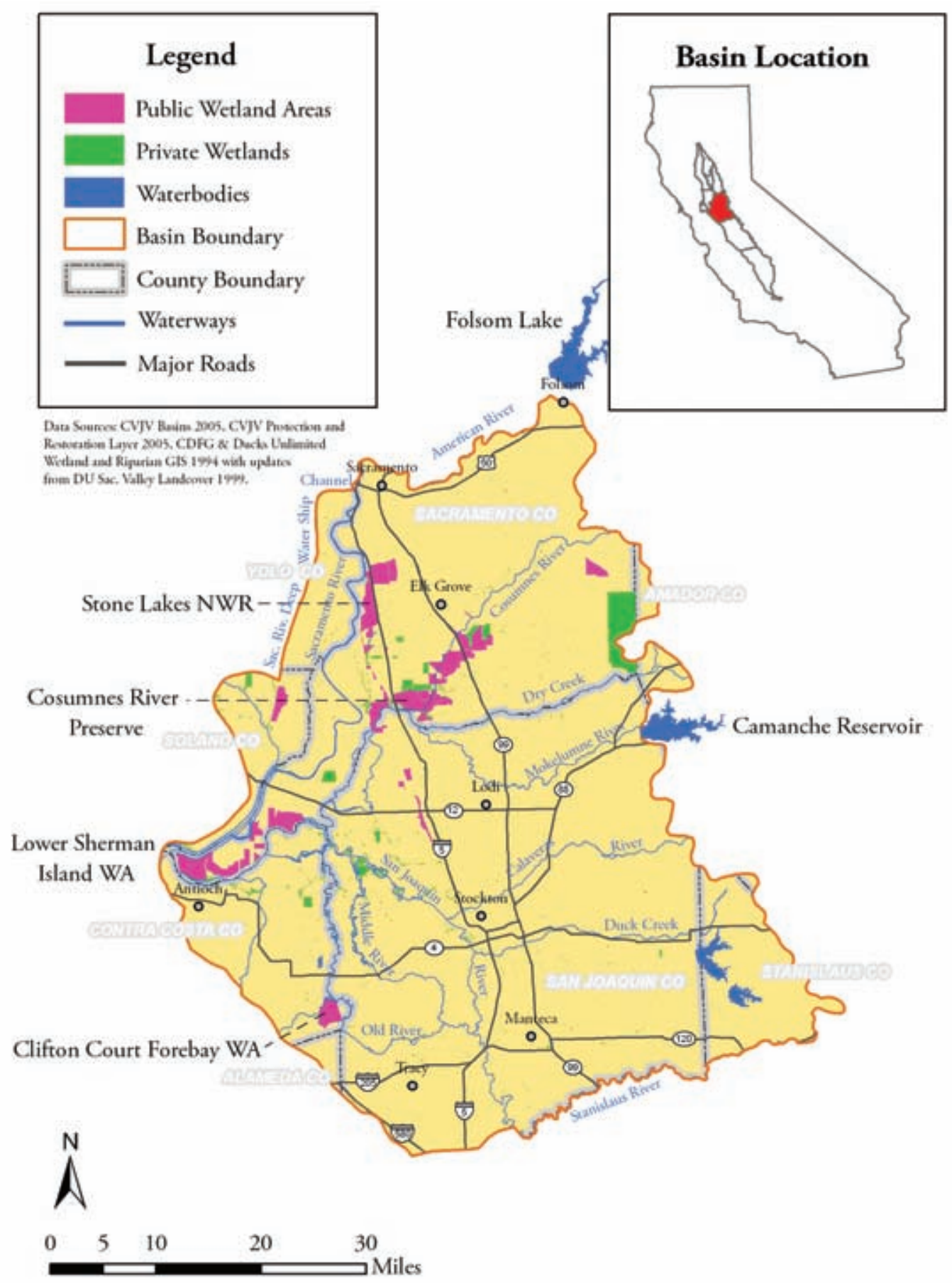

Figure 3-8. Map of the Delta Basin. 


\section{San Joaquin Basin}

The San Joaquin Basin totals 2,900 square miles, extending from the Stanislaus River in the north, to the San Joaquin River in the south. The 80-mile-long basin is bordered on its west by the California Aqueduct, and on its east by the foothills of the Sierra Nevada (Figure 3-9). Major tributaries to the San Joaquin River include the Chowchilla, Merced, and Tuolumne Rivers.

Most private wetlands as well as several federal and state areas in the San Joaquin Basin are located in the Grassland Resource Conservation District (GRCD) on the western edge of the basin. Many of these private wetlands have been permanently protected by U.S. Fish and Wildlife Service conservation easements. Wetland areas in existence in 1991 have been guaranteed average annual (Level 2) water supplies as a result of the Central Valley Project Improvement Act (CVPIA) of 1992. Soils on the western side of the San Joaquin Basin are derived from marine sediments that are high in salts and trace elements. Post-harvest irrigation was formerly used to leach these substances from the upper soil, and return flows were used as a wetland water source. Selenium concentrations in this tailwater proved damaging to a wide range of birds and consequently, use of this water has been greatly restricted.

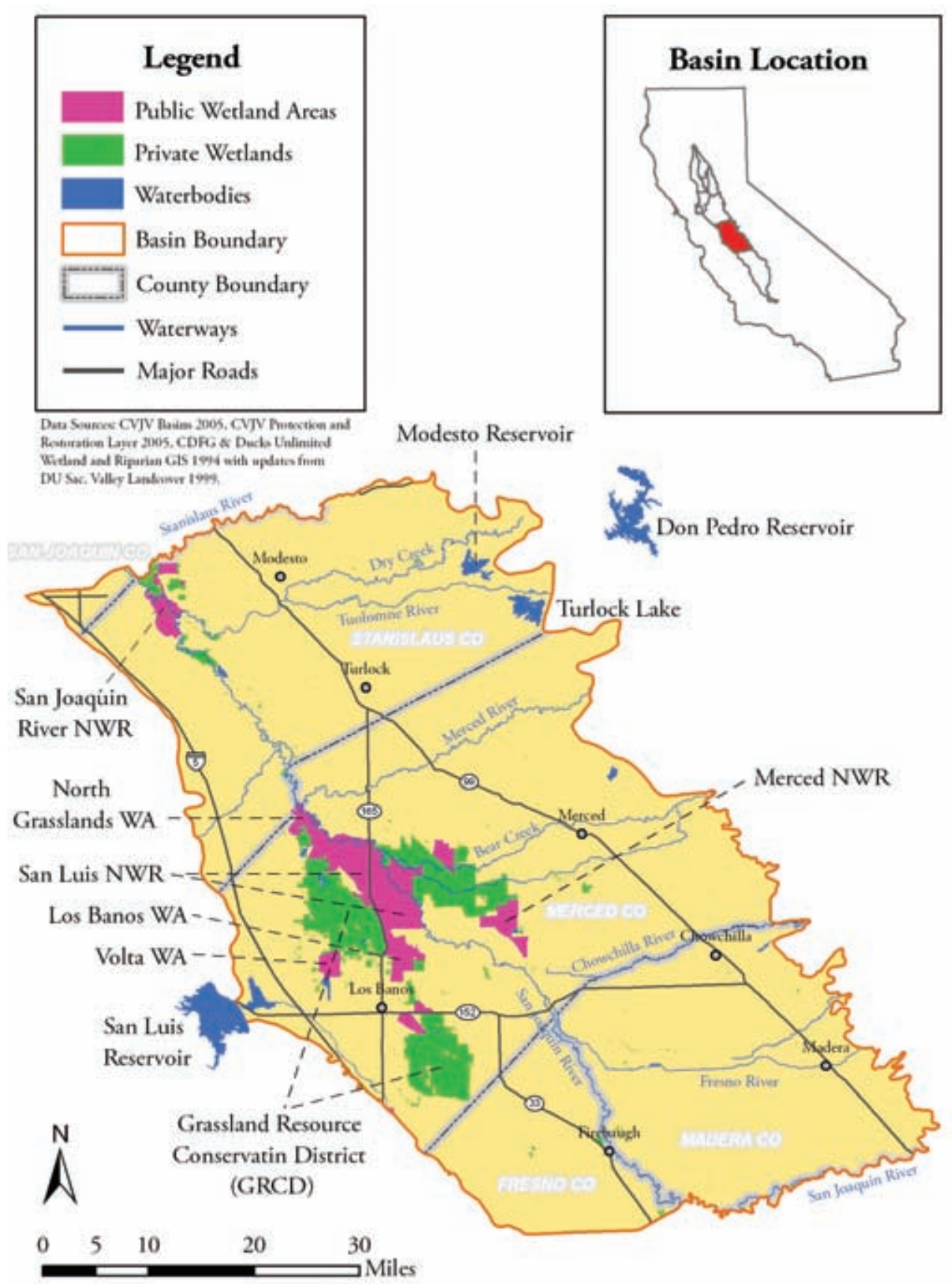

Figure 3-9. Map of the San Joaquin Basin 


\section{Tulare Basin}

Tulare Basin is the largest basin in the Central Valley and totals 5,600 square miles. This basin is 135 miles long and is bordered to the west by the Coast Range, and to the east by the southern Sierra Nevada foothills (Figure 3-10). The San Joaquin River divides the Tulare and San Joaquin Basins.

Despite being the driest region of the Central Valley, the Tulare Basin once contained the largest single block of wetland habitat in California and provided over 500,000 acres of permanent and seasonal wetlands. During most years the basin functioned as a sink, where water from the Sierra Nevada flowed down a number of streams including the Kern, Kings, and Tule Rivers, into a series of shallow lake basins within the sink. These lakes provided habitat for millions of migrant waterfowl and shorebirds. During exceptionally wet years, water flowed north from these lakes into the San Joaquin River.

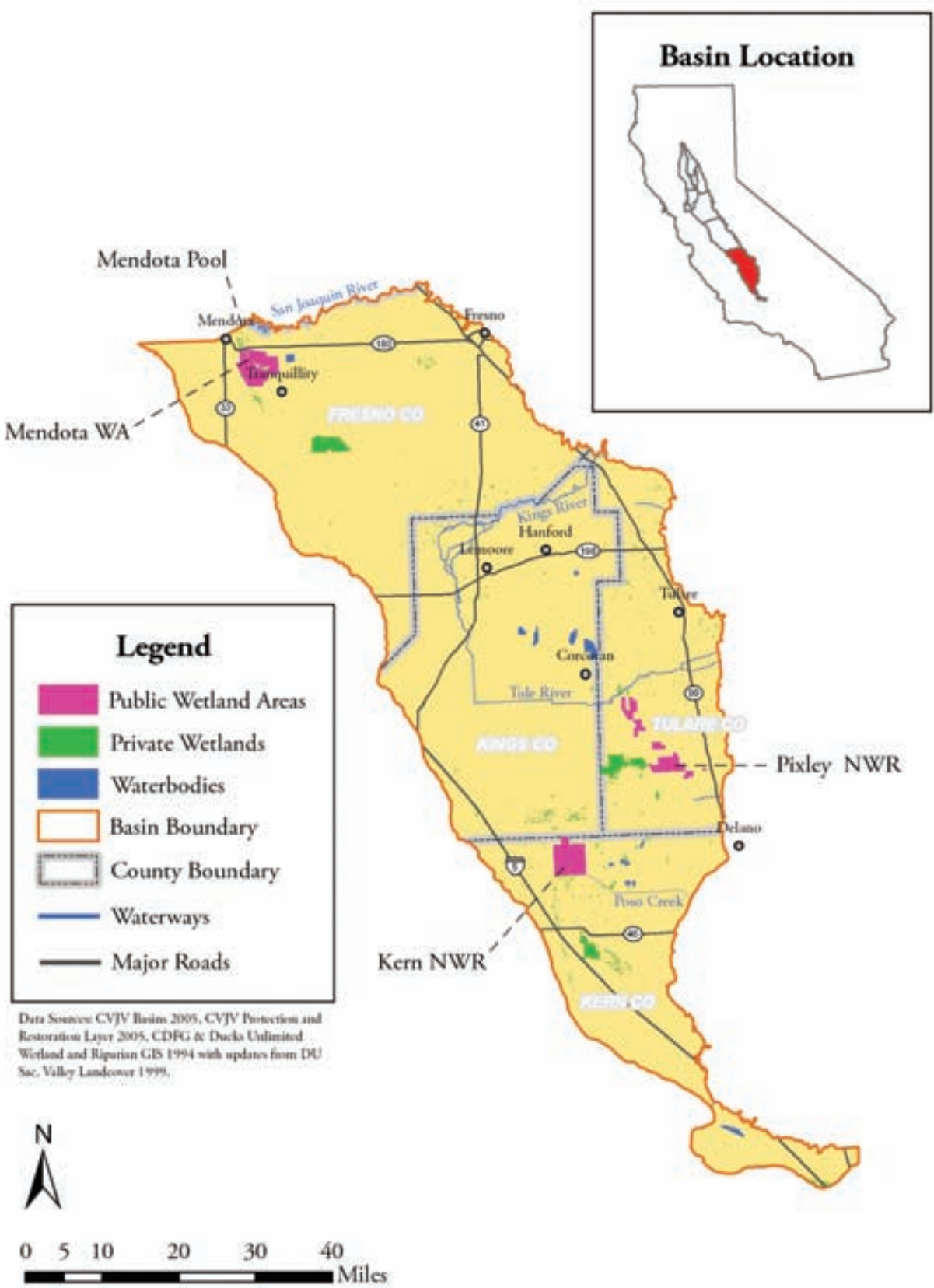

Diversion of water for agricultural and municipal purposes ultimately drained the Tulare Basin lakebeds, and allowed these wetlands to be reclaimed for agriculture. These lakebeds now remain dry in all but the wettest years and the amount of wetland habitat remaining in the Tulare Basin is less than one percent of historic levels. Although agriculture dominates the basin, surface water supplies are not sufficient to meet crop needs. As a result, agricultural producers rely heavily on groundwater to augment supplies. The end result is that surface water supplies for private wetland management are virtually non-existent in many parts of the basin, and landowners are forced to rely on groundwater. Many private wetland owners are unable to afford the high pumping costs for groundwater, resulting in a loss of nearly half of the wetlands over the past two decades. Although the Tulare Basin poses significant challenges for the JV, the area sees tremendous waterbird use during wet years. This use testifies to the historical and continuing importance of the basin within the Central Valley.

Figure 3-10. Map of the Tulare Basin 


\section{Habitat Types and Locations}

\section{Wetlands}

Managed wetlands in the Central Valley are broadly categorized as seasonal, semi-permanent or permanent. Seasonal wetlands are typically flooded in the fall, with drawdown occurring between March and May. Semi-permanent wetlands are usually flooded from early fall through early July, while permanent wetlands are flooded year round. Since the majority of these non-seasonal wetland habitats are semi-permanent, for planning purposes, semi-permanent and permanent wetlands are combined.

Refined estimates of managed wetlands indicate that wetland acreage was overestimated in the 1990 plan. The 2000 Central Valley Wetland Water Supply Investigations, CVPIA 3406 (d)(6)(A,B), A Report to Congress (Water Report; USFWS 2000) stated that there were 165,834 acres of managed wetland acres as of November 1996. The Water Report relied on satellite imagery to estimate wetland acres during winter 1993-1994, and JV accomplishments from 1993-1994 to November 1996 were added. Wetland acreage estimates were updated from the Water Report by adding JV accomplishments from December 1, 1997 to April 1, 2003. To date, 205,554 acres of managed wetlands are estimated for the Central Valley. Wetland acres by type and ownership are presented for each basin in Table 3-1.

About two thirds of all managed wetlands in the Central Valley are privately owned, while nearly $90 \%$ of all wetlands are managed on a seasonal basis. Seventy-seven percent of all wetlands are located in four basins: Butte, Colusa, Suisun, and San Joaquin. The San Joaquin Basin alone contains a third of all wetlands in the Valley, most within the Grassland Resource Conservation District (GRCD). The overall distribution of wetlands in the Central Valley is depicted in Figure 3-11.

Table 3-1. Acres of managed seasonal wetlands (SW) and semi-permanent wetlands (SPW) in the Central Valley. ${ }^{\mathrm{a}}$

\begin{tabular}{|c|c|c|c|c|c|c|c|}
\hline Basin & Private SW & Public SW & Private SPW & Public SPW & Total SW & Total SPW & Total Wetlands \\
\hline AMERICAN & 3,187 & 0 & 562 & 0 & 3,187 & 562 & 3,749 \\
\hline Butte & 16,170 & 7,170 & 2,853 & 1,266 & 23,340 & 4,119 & 27,459 \\
\hline Colusa & 11,086 & 11,304 & 1,956 & 1,995 & 22,390 & 3,951 & 26,341 \\
\hline Delta & 3,741 & 2,608 & 661 & 460 & 6,349 & 1,121 & 7,470 \\
\hline SAN JOAQUIN & 46,857 & 14,156 & 5,206 & 1,573 & 61,013 & 6,779 & 67,792 \\
\hline SUISUN & 25,364 & 6,868 & 4,476 & 1,212 & 32,232 & 5,688 & 37,920 \\
\hline SutTer & 247 & 1,704 & 43 & 301 & 1,951 & 344 & 2,295 \\
\hline Tulare & 6,718 & 13,494 & 746 & 1,499 & 20,212 & 2,245 & 22,457 \\
\hline YoLO & 5,803 & 2,755 & 1,027 & 485 & 8,558 & 1,512 & 10,070 \\
\hline TotaL & 119,173 & 60,059 & 17,530 & 8,792 & 179,232 & 26,322 & 205,554 \\
\hline
\end{tabular}




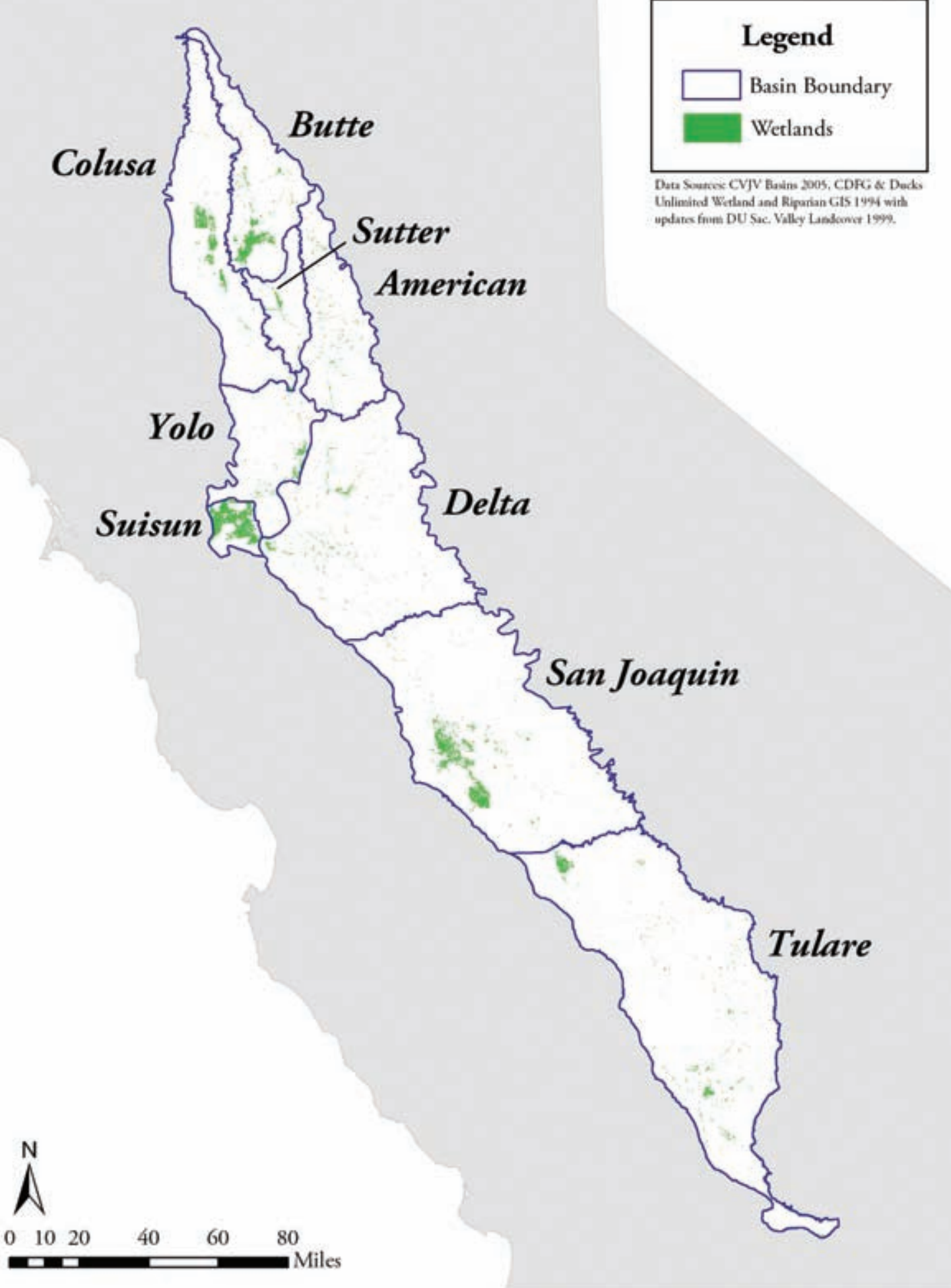

Figure 3-11. Distribution of wetlands in the Central Valley in 2005. 


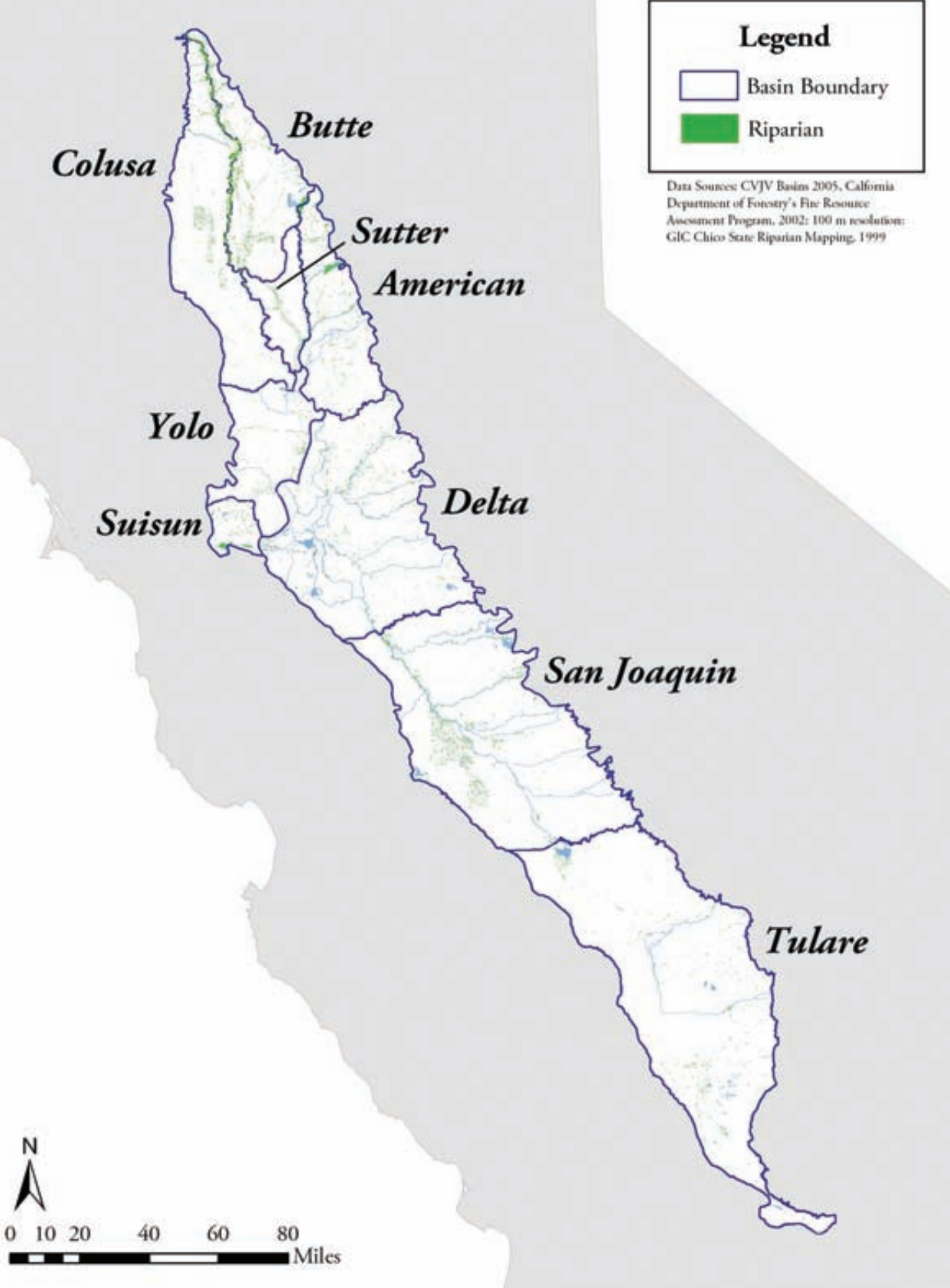

Figure 3-12. Distribution of riparian habitat in the Central Valley in 2005. 


\section{Riparian}

Current and historical acre estimates for the extent of riparian habitat are presented for each basin in Table 3-2. Riparian habitat is defined as plant communities supporting woody vegetation along rivers, creeks, and streams. Riparian habitat estimates were obtained using multiple GIS layers, as there is no single riparian data layer for the Central Valley (D. Stralberg, PRBO Conservation Science, personal communication). The overall distribution of riparian habitat in the Central Valley is presented in Figure 3-12.

\section{Upland}

Upland areas that may serve as waterfowl nesting habitat in the Central Valley include grain and hay crops, grasslands, and pasture (McLandress et al. 1996). The distribution of these three cover types was mapped using data from the California Department of Water Resources (Figure 3-13). Acres of each habitat by basin are presented in Table 3-3.

\section{Agriculture}

\section{Rice}

U.S. Department of Agriculture (USDA) statistics indicate that planted rice in the Central Valley averaged 502,600 acres between 1997 and 2002, and varied between 460,000 and 550,000 acres during this 5-year period (Figure 3-14).

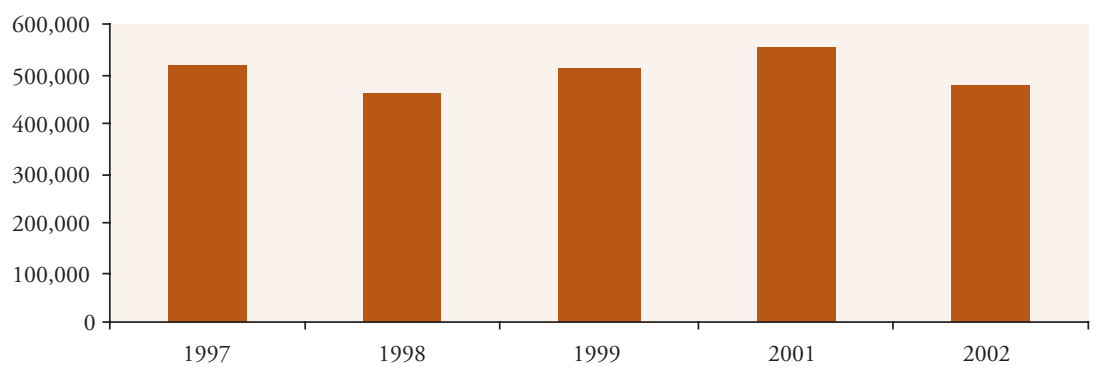

Figure 3-14. Acres of rice planted in the Central Valley between 1997 and 2002.

\begin{tabular}{|cccc|}
\hline Basin & Grassland & Pasture & Grain \& Hay \\
\hline AMERICAN & 170,649 & 30,026 & 19,042 \\
\hline BUTTE & 174,539 & 20,423 & 19,636 \\
\hline COLUSA & 330,681 & 81,802 & 116,942 \\
\hline DELTA & 206,300 & 167,611 & 112,138 \\
\hline SAN JOAQUIN & 357,244 & 279,516 & 74,528 \\
\hline SUISUN & 21,235 & 517 & 983 \\
\hline SUTTER & 8,750 & 3,387 & 11,626 \\
\hline TULARE & 452,355 & 318,573 & 239,177 \\
\hline YoLO & 121,633 & 57,973 & 90,657 \\
\hline TotAL & $\mathbf{1 , 8 4 3 , 3 8 6}$ & $\mathbf{9 5 9 , 8 2 8}$ & $\mathbf{6 8 4 , 7 2 9}$ \\
\hline
\end{tabular}

Table 3-3. Acres of upland habitat among Central Valley basins.

Historic Acres

\begin{tabular}{|ccc|}
\hline Basin & Current Acres & Historic Acres \\
\hline AMERICAN & 16,370 & 67,520 \\
BUtTE & 32,535 & 105,452 \\
COLUSA & 19,798 & 171,013 \\
DELTA & UNAVAILABLE & UnAVAILABLE \\
SAN JOAQUIN & 12,245 & 48,755 \\
SUISUN & UNAVAILABLE & UnAVAILABLE \\
SUTTER & 3,641 & 20,338 \\
TULARE & 7,195 & 272,158 \\
YoLO & 3,569 & 48,320 \\
TotAL & $\mathbf{1 0 7 , 8 1 3}$ & $\mathbf{7 3 3 , 5 5 6}$ \\
\hline
\end{tabular}




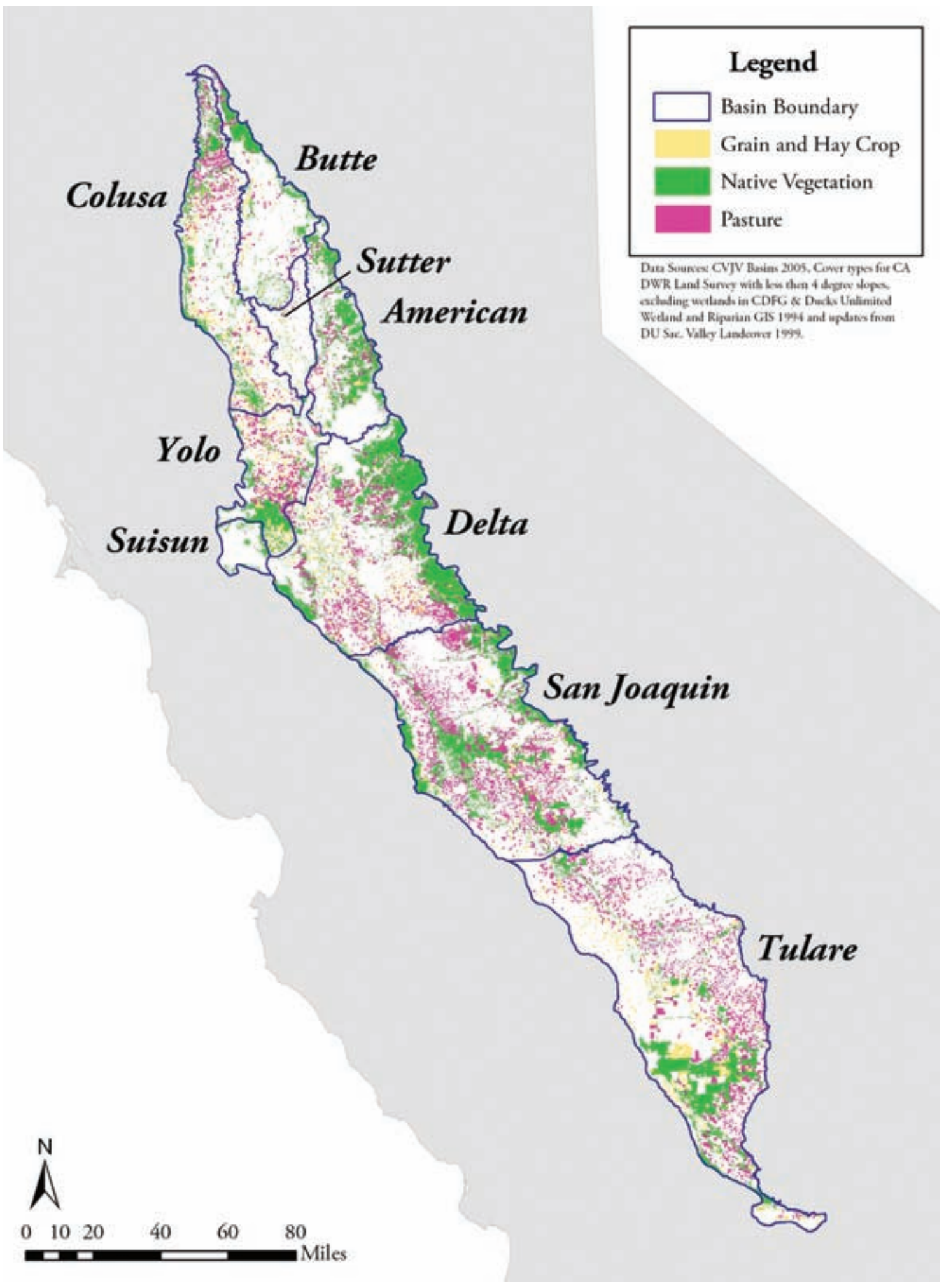

Figure 3-13. Distribution of native vegetation, pasture, and grain and hay crops in the Central Valley. 
Because USDA statistics are countybased, they cannot be used to estimate basin rice acres, as counties frequently cross basin boundaries. In both 1998 and 1999 the amount of rice planted in each basin, as well as for the entire Central Valley, was estimated using satellite imagery. Rice acre totals estimated from imagery were slightly less than USDA crop statistics for the 1998 and 1999 growing seasons, so basin estimates were adjusted upward to reflect these differences. The JV chose to use the 1998 imagery when making this adjustment because the agreement between crop statistics and rice image estimates was slightly better for 1998 than 1999 .
Table 3-4. Estimate of rice acres in the Central Valley.

\begin{tabular}{|cccc|}
\hline Basin & Planted Acres & Winter-Flooded Acres & Non-Flooded Acres \\
\hline AMERICAN & 100,068 & 72,049 & 28,019 \\
BUtTE & 138,186 & 99,494 & 38,692 \\
COLUSA & 197,076 & 141,895 & 55,181 \\
DELTA & 1,399 & 1,007 & 392 \\
SUTTER & 46,066 & 33,168 & 12,898 \\
YOLO & 9,750 & 7,020 & 2,730 \\
TotAL & 492,545 & 354,633 & $\mathbf{1 3 7 , 9 1 2}$ \\
\hline
\end{tabular}

${ }^{a}$ Excludes the 10,000 acres of rice annually planted in San Joaquin Basin. Post harvest treatment of rice in this basin is believed to render it of little use to wetland dependent species.

Rice acreage in the Central Valley varies from one year to the next, so 1998 imagery estimates were further adjusted to reflect the average acres of rice planted between 1997 and 2001 (Table 3-4). The distribution of rice in the Central Valley is depicted in Figure 3-15.

The value of rice habitat for wetland dependent birds is increased by winter flooding in the post-harvest period. Beginning in 19951996, growers were interviewed to determine the amount of rice that is winter-flooded for waterbirds and/or straw decomposition. These annual surveys included between 180 and 220 growers that accounted for over $40 \%$ of all rice grown (J.D. Garr, Ducks Unlimited, unpublished report).

The total area of winter-flooded rice has increased as a result of an increase in total rice acreage, the 1992 legislated ban on rice straw burning, a growing awareness of the environmental benefits of this agricultural practice, and improved agronomics (Fleskes et.al. 2005). During winter 1995-1996, half of all rice acreage was winter-flooded. By 2002-2003, this figure had increased to over $70 \%$. The 2006 Plan assumes that $72 \%$ of all rice grown in the Central Valley is now intentionally flooded in winter (J.D. Garr, Ducks Unlimited, unpublished report). This estimate was applied to all major rice growing basins (Table 3-4).

\section{Corn}

Corn acreages are available for all counties in the Central Valley according to USDA crop statistics summaries. Because parts of some counties occur outside the Valley, corn acres were "deleted" from these outlying areas using GIS when estimating the amount of corn planted in a basin. Although substantial amounts of corn are grown in the San Joaquin and Tulare Basins, most is harvested as silage for the dairy industry. As a result, corn was not considered as a potential habitat in these two basins (Table 3-3).

Many harvested cornfields are intentionally flooded in the Delta Basin to provide waterfowl habitat, and to minimize subsidence of Delta soils that are high in organic content. Surveys to determine the amount of flooded corn were conducted in Delta Basin, and these estimates are used in the 2006 Plan (M. Casazza, U.S. Geological Service, unpublished data).

\section{Socio-economic Factors}

\section{Human Population Growth}

Human population growth forecasts for all of California as well as for individual counties are available to 2040 (California State Department of Finance). Human populations in California are projected to increase from 34.7 million in 2000 to 58.7 million by 2040, an increase of nearly 70\%. Forecasts for Central Valley counties predict a population increase from 5.7 million to 13.1 million people over the same period, a 130\% gain (Figure 3-16). To understand how population growth forecasts differ by basin, population 


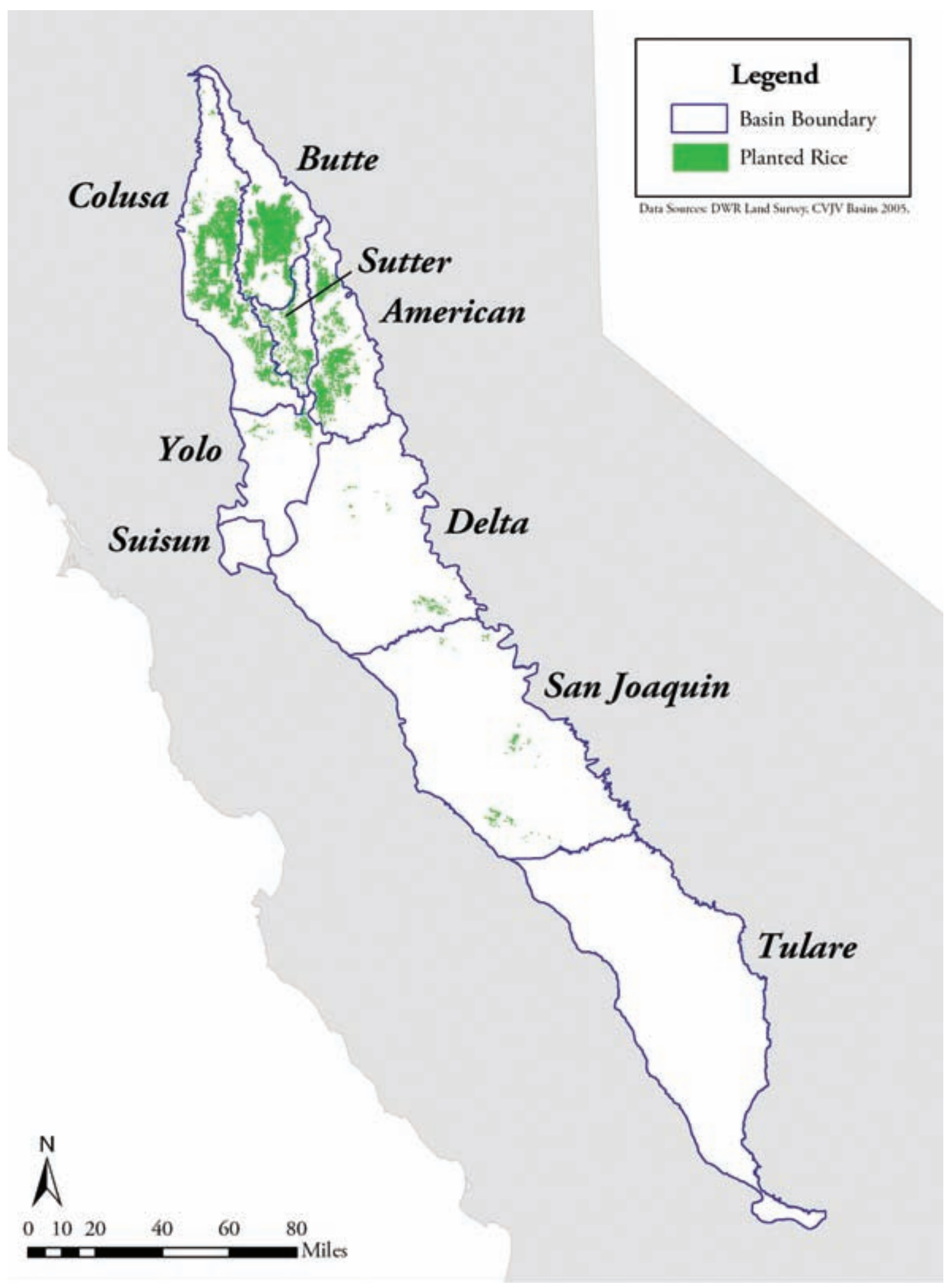

Figure 3-15. Distribution of rice in the Central Valley. 
projections were combined for all counties in a basin. These forecasts suggest higher growth rates in the southern half of the Central Valley (Figure 3-17). Population increases by 2040 are expected to exceed 2 million in both the Tulare and Delta Basins, while increases in the San Joaquin Basin will surpass one million people. Growth forecasts for the northern basins vary between 100,000 and 500,000. The southern portion of the American Basin provides an exception to this south to north trend because of its proximity to Sacramento. Sacramento County, which leads the Central Valley in projected growth, includes parts of both the Delta and American Basins. However, all these population increases have been assigned to the Delta Basin, as forecasts cannot be divided at less than a county level. In reality, much of the growth forecasted for Sacramento County is likely to occur in the southern end of the American Basin, as housing developments north of the city of Sacramento continue to expand.

\section{Changes in Land Use}

Population growth within the Central Valley will result in substantial increases in urban development, mostly occurring on agricultural lands. The effects of land conversion are twofold and include loss of agricultural habitats important to wetland dependent birds, and loss of agricultural buffers that increase the quality of wetland and riparian habitats. Probable urban development patterns for the Central Valley have been mapped using 2040 population forecasts and actual development trends from 1988 to 1992 (American Farmland Trust 1995). These mapping efforts identified three major areas of urban development centered on the cities of Fresno, Modesto, and Sacramento. A general corridor of development was identified along Highway 99 from Bakersfield to Yuba City.

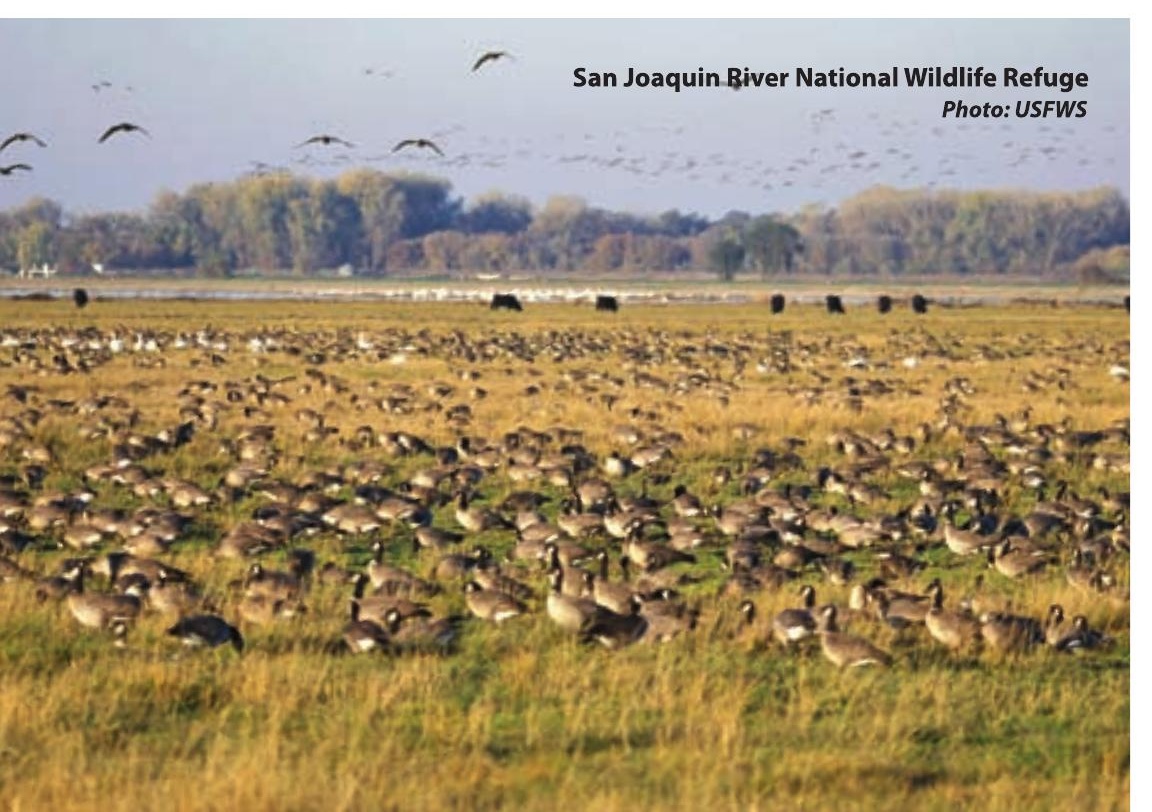

The effect of population growth on agricultural crops was also estimated for the Central Valley to 2040 (American Farmland Trust 1995). Crop type in the Central Valley is broadly categorized as irrigated or non-irrigated, and acreage losses in each of these categories were estimated for eleven of nineteen Central Valley counties (American Farmland Trust). The JV assumes that irrigated crop types (e.g., rice) represent the most important agricultural habitat types for wetland dependent birds, though not all irrigated crops have wildlife value (e.g., vineyards). Thus, only forecasted losses of irrigated cropland to 2040 were considered. 


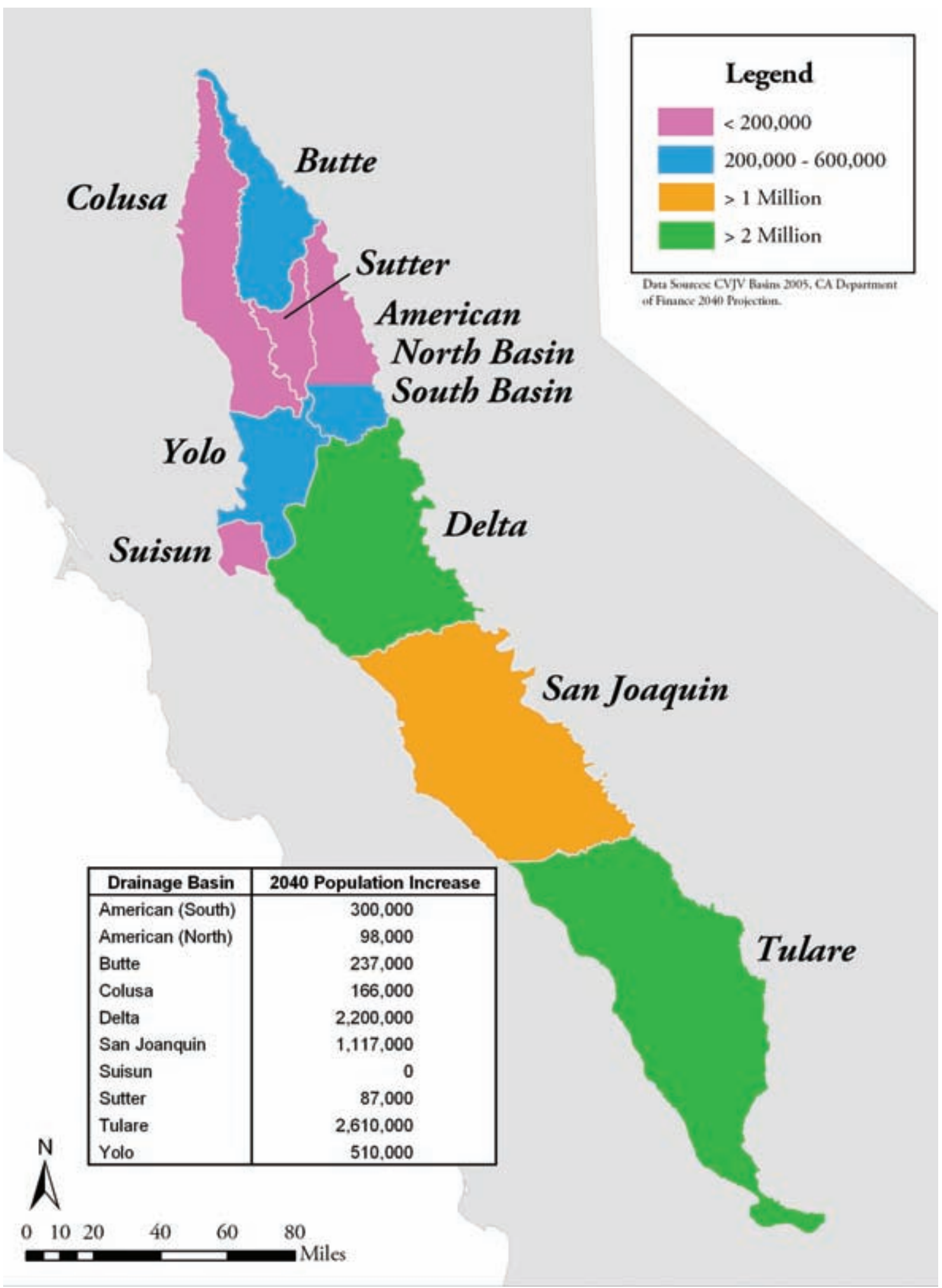

Figure 3-17. Forecasted population increases to 2040 for the Central Valley basins. 
There is a strong relationship between population growth forecasts and loss of irrigated cropland for the eleven counties included in the urban growth analysis (Figure 3-18). This relationship suggests that one acre of irrigated farmland is lost for every 10 additional people. On this basis, the JV used population forecasts to predict loss of irrigated cropland for Central Valley counties not included in the American Farmland Trust report.

County estimates of irrigated cropland loss were combined to provide information on farmland conversion for each basin. The predicted loss of irrigated cropland was highest for the Tulare, San Joaquin, and Delta Basins, as well as for the south end of American Basin (Figure 3-19). In contrast, basins in the Sacramento Valley were expected to experience only modest losses in irrigated farmland by 2040 . Finally, the loss of rice habitat to 2040 was estimated for each basin by assuming that loss rates for rice were similar to that for other irrigated crops. The loss of rice acreage was generally small for all basins, and the total predicted loss of rice was less than 40,000 acres (Table 3-6). This is equivalent to $6 \%$ of the rice base in the Central Valley, and agrees with the 3\% rice loss predicted by 2020 (California Department of Water Resources 1998).

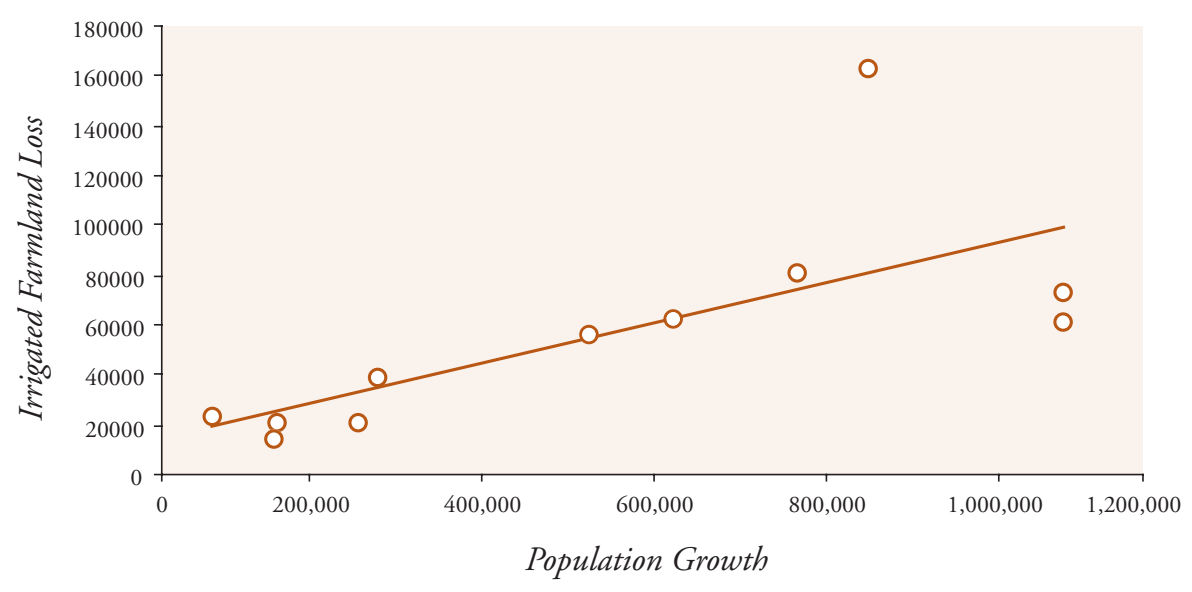

Figure 3-18. The relationship between population growth and loss of irrigated farmland for 11 Central Valley counties (from American Farmland Trust 1995).

Table 3-6. Projected loss of planted rice by basin.

\begin{tabular}{|ccc|}
\hline Basin & Current Acreage & $\begin{array}{c}\text { Forecasted } \\
\text { Acre Loss } 2040\end{array}$ \\
\hline AMERICAN & 100,068 & 16,211 \\
\hline BUTTE & 138,186 & 12,851 \\
COLUSA & 197,076 & 3,350 \\
DELTA & 1,399 & 256 \\
SUTTER & 46,066 & 3,593 \\
YoLO & 9,750 & 809 \\
TotAL & 492,545 & 37,070 \\
\hline
\end{tabular}




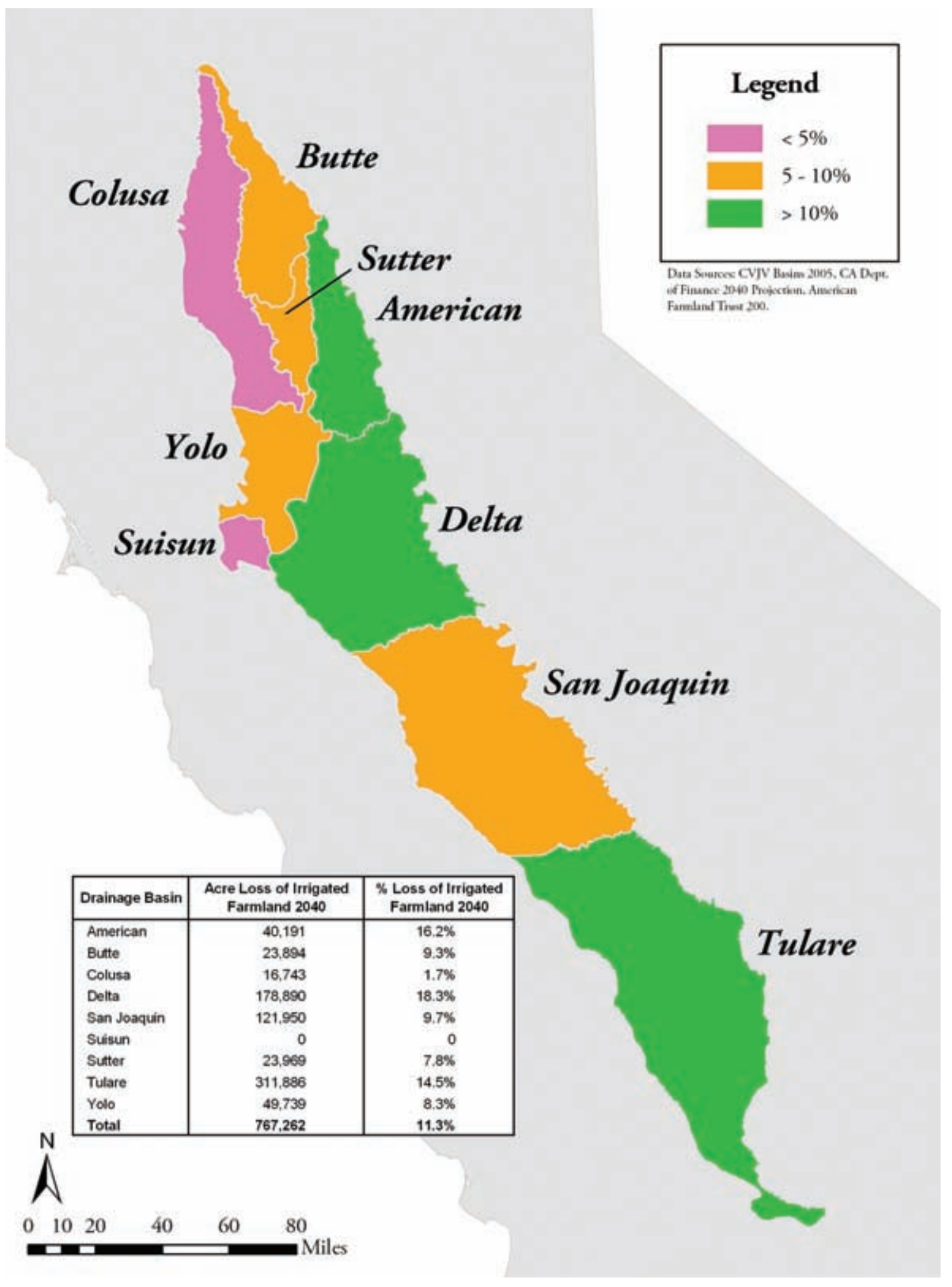

Figure 3-19. Projected loss of irrigated farmland by 2040 for Central Valley basins. 


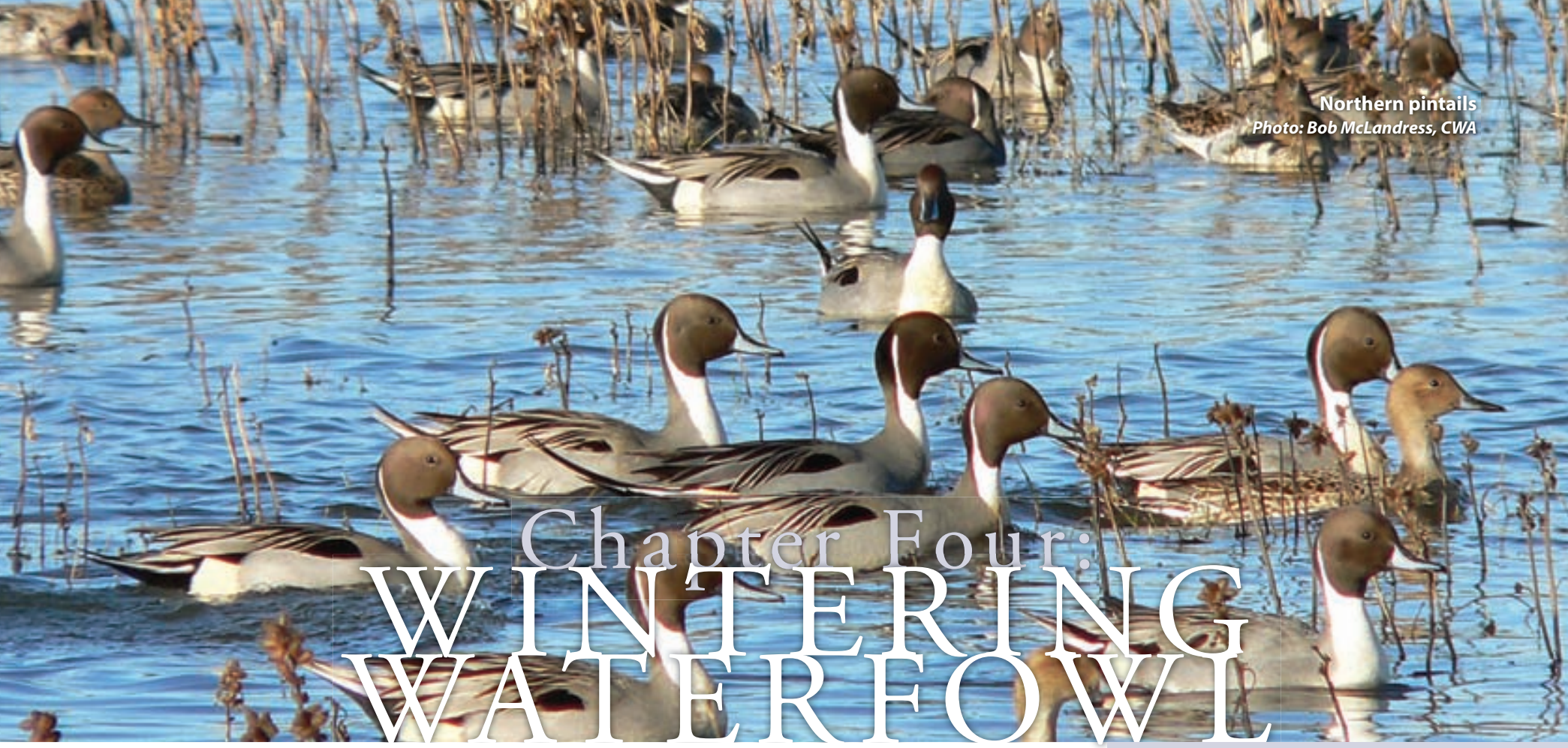

This chapter identifies the conservation objectives for wintering waterfowl, defined as non-breeding migrating or wintering ducks, geese, and swans using the Central Valley between August and March. The chapter is divided into five sections: (1) Introduction; (2) Biological inputs used in the TRUEMET model; (3) Overall assessment of habitat conditions in the Central Valley; (4) Methods for establishing and prioritizing conservation objectives for winter waterfowl in each basin; and (5) Conservation objectives and priorities for wintering waterfowl in each basin.

\section{Introduction}

The Central Valley of California is the most important waterfowl wintering area in the Pacific Flyway, supporting up to $60 \%$ of the total Flyway population in some years. Food availability is a key factor limiting waterfowl populations during migration and winter (Miller 1986, Conroy et al. 1989, Reinecke et al. 1989), and habitat conditions on the wintering grounds may influence reproductive success (Heitmeyer and Fredrickson 1981, Kaminski and Gluesing 1987, Raveling and Heitmeyer 1989). The JV assumes that food limits waterfowl populations during migration and winter. Specifically, food is the primary need of waterfowl during migration and winter. Adequate foraging habitat will ensure that survival outside of the breeding season does not limit population growth.

The Central Valley Habitat Joint Venture Implementation Plan (1990 Plan, "Central Valley Habitat Joint Venture 1990) included a food energy model that linked population and habitat objectives for wintering waterfowl. Using this approach the food energy needs of waterfowl populations in the Central Valley were converted into foraging habitat objectives. Figure 4-1 depicts this model. Waterfowl energy needs are a product of population objectives and the daily energy requirement (DER) of an average bird, while food supplies are a product of habitat acres and the amount of food provided by each acre. Foraging habitat is adequate when food supplies equal or exceed waterfowl energy needs.

"The Central Valley of California is, and will always remain, one of the critical wintering areas for waterfowl in North America. We have an enduring obligation to ensure the vitality and viability of our remaining wetlands and associated agricultural habitats upon which millions of wintering waterfowl and other wetlanddependent wildlife rely."

John Eadie, Ph.D.

Professor, Department of Wildlife, Fish \& Conservation Biology University of California, Davis 
The JV has retained the food energy approach for the 2006 Plan. However, research efforts by JV partners over the past decade have greatly improved the biological inputs used in the energetic model. In addition, a computer model (TRUEMET) was developed for use in the 2006 Plan. The model calculates population energy demand and population energy supplies for specific time periods, and can incorporate effects like food decomposition and temporal variation in habitat availability (Figure 4-2). The model was used to evaluate the current status of waterfowl food resources in the Central Valley based on a defined set of habitats and to estimate conservation objectives for wintering waterfowl in each basin.

\section{The TRUEMET Model}

Most joint ventures use a food energy approach when establishing habitat objectives for wintering waterfowl. The TRUEMET model was developed to estimate waterfowl habitat requirements by comparing food energy needs to food energy supplies. The model calculates population energy needs from the daily energy requirement of a single bird and from time specific population objectives. Food energy supplies are dependant on the availability and amount of waterfowl habitat, as well as the quantity and quality of foods contained in these habitats. The model accounts for the effects of waterfowl food consumption, decomposition of foods over time, and changes in habitat availability that result from flooding schedules or other events like freezing. Waterfowl populations can also be divided into foraging guilds to reflect differences in the foods eaten. Although the model may be useful for assessing current habitat conditions for wintering waterfowl, it can also be used to predict how changes in policy, land use, or habitat programs might impact the birds. For example, the loss of agricultural habitats can be evaluated and habitat programs needed to offset these losses can be identified.

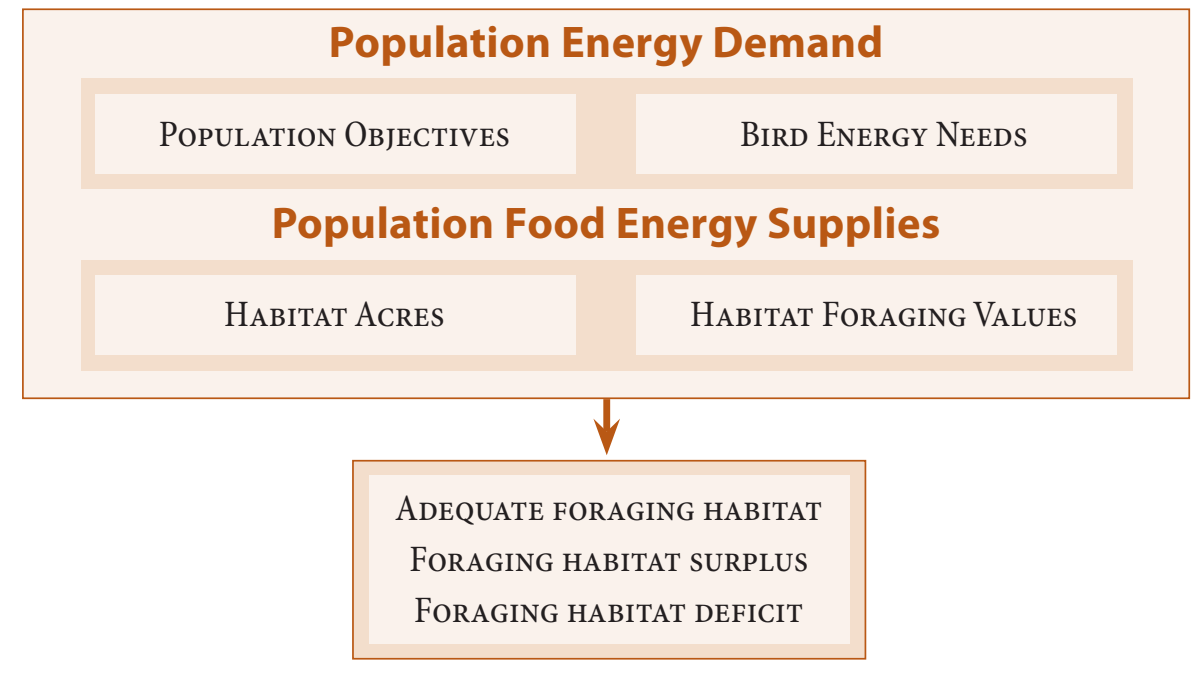

Figure 4-1. Basic energy model used to assess the availability of foraging habitat relative to waterfowl needs.

\section{Biological Inputs Used in the TRUEMET Model}

Biological inputs used in the TRUEMET model include: (1) population objectives; (2) daily energy requirements for individual birds; (3) habitat acreage; and (4) habitat foraging values (energy density). This section describes how these inputs were derived and describes many of the assumptions made for wintering waterfowl in the 2006 Plan. Some biological inputs are applied to all basins, while other inputs are basin-specific. Inputs that are applied across basins are presented here to avoid redundancy. However, basin-specific inputs are presented in the final section of this chapter when establishing conservation objectives for wintering waterfowl. Biological inputs that were used to provide an overall assessment of habitat conditions in the Central Valley are also reported in this section.

TRUEMET MODEL

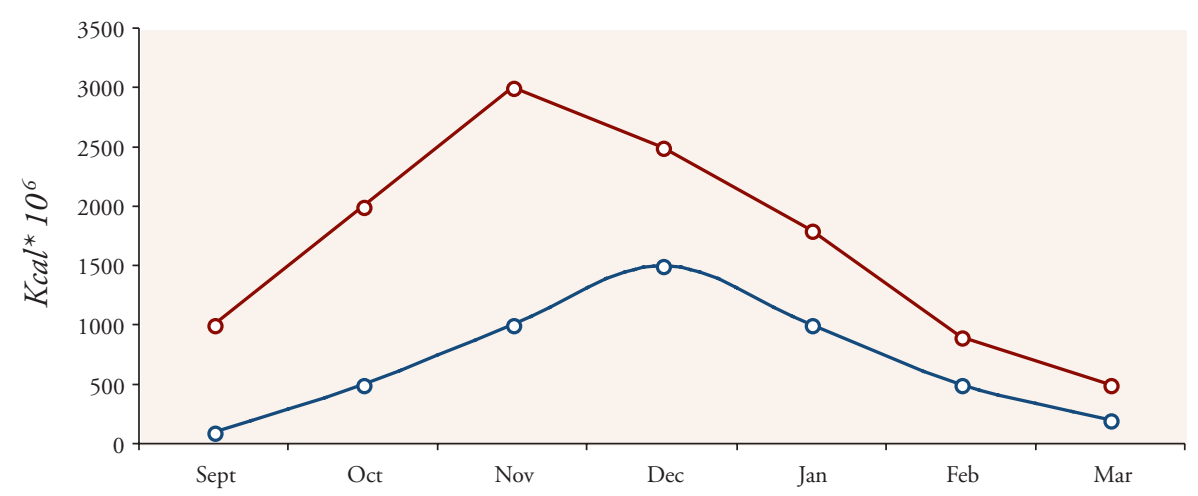

Figure 4-2. A hypothetical example of the TRUEMET model. Population energy demand (blue) vs. food energy supplies (red). 


\section{Population Objectives}

\section{Ducks}

In 1986 the North American Waterfowl Management Plan (NAWMP; North American Waterfowl Management Plan Committee 1986) developed population objectives for North American duck species based on environmental conditions and breeding waterfowl numbers from 1970-1979. Waterfowl populations in the 1970's met the demands of both consumptive and non-consumptive users and provided a basis for future conservation efforts. The 1990 Implementation Plan identified a peak population objective of 4.7 million ducks in the Central Valley. Populations were assumed to peak in late December or early January and decline thereafter. Because the 1990 objective was based on the annual mid-winter inventories (MWI), waterfowl numbers in the Central Valley between 1970 and 1979 provided a direct link to the NAWMP. However, MWI counts alone are not suitable for establishing population objectives, because they do not represent bird numbers at other times. In addition, the pattern of waterfowl use varies among the JV basins, and peak use in some basins does not occur at the time of the mid-winter survey, as was assumed in the 1990 Plan (Fleskes 2000).

Duck population objectives from the NAWMP have recently been stepped down to each Joint Venture. By combining information from the mid-winter waterfowl survey with estimates of waterfowl harvest and mortality, population objectives for the mid-winter period (late December-early January) were estimated for every county in the U.S. Counties were then combined to develop Joint Venture population objectives (Koneff 2003). Population objectives stepped down from the NAWMP only apply to the late December-early January period. However, wintering waterfowl rely on the Central Valley from August through March and therefore, population objectives must be developed for this entire period. As a result, population objectives from the NAWMP (Table 4-1) were combined with information on migration chronology for the Central Valley to generate population objectives at fifteen-day intervals between August 16 and March 31 (Figure 4-3). Migration chronology was determined from monthly surveys of waterfowl between September and March of 1998-1999 and 1999-2000 (Figure 4-3, Fleskes et al. 2000).

Duck populations stepped down from the NAWMP were modified for some species. The NAWMP objective for gadwall ducks (Anas strepera) in the Central Valley is 102,420 birds during mid-winter (Table 4-1). However, the MWI in 1999 reported 223,800 gadwalls in the Central Valley, with nearly 150,000 birds observed in 1998 (Fleskes et al. 2000). These surveys suggest that NAWMP goals for gadwalls in the Central Valley have been exceeded. This was expected because gadwall populations in the late 1990's were substantially higher than populations in the 1970's, and NAWMP objectives are based on bird numbers from this earlier period. To "adjust" gadwall population objectives, the JV assumed that gadwall and wigeon were observed with equal probability during the 1998 and 1999 surveys. The ratio of gadwall to wigeon averaged 0.35 during these two years, with wigeon populations at or near NAWMP goals. The mid-winter NAWMP population objective for wigeon is $1,103,440$ (Table 4-1). As a result, the gadwall objective was adjusted upward to 386,204 birds $(1,103,440 \mathrm{x} 0.35)$. Population objectives for other duck species were also adjusted because some foods eaten by these species were not included in the energetic model. For example, invertebrates make up $49 \%$ of northern shoveler diets during fall and winter in the Central Valley; while seeds from managed wetlands make up the other 51\% (Heitmeyer 1989). The biomass and type of invertebrates eaten by shovelers have not been estimated for Central Valley wetlands, though these habitats obviously provide some of these food resources. In contrast, seed abundance has been estimated for managed wetlands, and this food source is included in the energetic model. Using NAWMP objectives for shovelers would overestimate the impact shovelers have on seed resources in managed wetlands, because the model would assume that $100 \%$ of their energy requirements are met from seeds. This leads to an overestimate of duck habitat needs. To correct this overestimate, shoveler numbers were reduced to $51 \%$ of the NAWMP objective when using the energetic model to estimate habitat needs. 
Table 4-1. Mid-winter population objectives for ducks in the Central Valley.

\begin{tabular}{|c|c|c|}
\hline Species & NAWMP Objective & $\begin{array}{l}\text { Duck numbers used } \\
\text { in TRUEMET model }\end{array}$ \\
\hline MALlaRd (Anas platyrhynchos) & 670,074 & 670,074 \\
\hline NORTHERN PINTAIL (Anas acuta) & $2,418,339$ & $2,418,339$ \\
\hline GADWALL (Anas strepera) ${ }^{b}$ & $102,420(386,204)^{a}$ & 270,343 \\
\hline AMERICAN WIGEON (Anas americana) ${ }^{b}$ & $1,103,440$ & 772,408 \\
\hline GREEN-WINGED TEAL (Anas crecca) & 486,215 & 486,215 \\
\hline CinNAMON TEAL (Anas cyanoptera) & 2,990 & 2,990 \\
\hline NORTHERN SHOVELER (Anas clypeata) ${ }^{b}$ & 581,999 & 296,819 \\
\hline Wood DucK (Aix sponsa) & 106,137 & 106,137 \\
\hline Total DabBlers & $5,471,613$ & $5,023,325$ \\
\hline REDHEAD (Aythya americana) $)^{b}$ & 1,007 & 504 \\
\hline CANVASBACK (Aythya valisineria) $)^{b}$ & 39,336 & 19,668 \\
\hline GREATER AND LESSER SCAUP (Aythya marila, A. affinis) ${ }^{b}$ & 223,406 & 111,703 \\
\hline RING-NECKED DUCK (Aythya collaris) ${ }^{b}$ & 42,327 & 21,164 \\
\hline RUdDY DUCK (Oxyura jamaicensis) ${ }^{b}$ & 155,167 & 77,584 \\
\hline Total Divers & 461,243 & 230,623 \\
\hline Total Ducks & $5,932,856$ & $5,253,948$ \\
\hline
\end{tabular}

${ }^{a}$ Gadwall objectives were adjusted to reflect population increases from the 1970's.

${ }^{b}$ Population objectives for these duck species were adjusted because some foods eaten by these species were not included in the energetic model.

Bird number adjustments based on diet were also made for wigeon and gadwall, as well as for all diving ducks (Table 4-1). Food habitat studies indicate that plant material other than seeds make up 30\% of wigeon diets in the Central Valley (Heitmeyer 1989), and gadwall were assumed to have a similar diet. As a result, bird numbers for these two species were reduced to 70\% of NAWMP goals in the model. Food habit studies indicate that seeds make up half the diet of diving ducks, and bird numbers for these species were reduced by $50 \%$ (Table $4-1$ ).

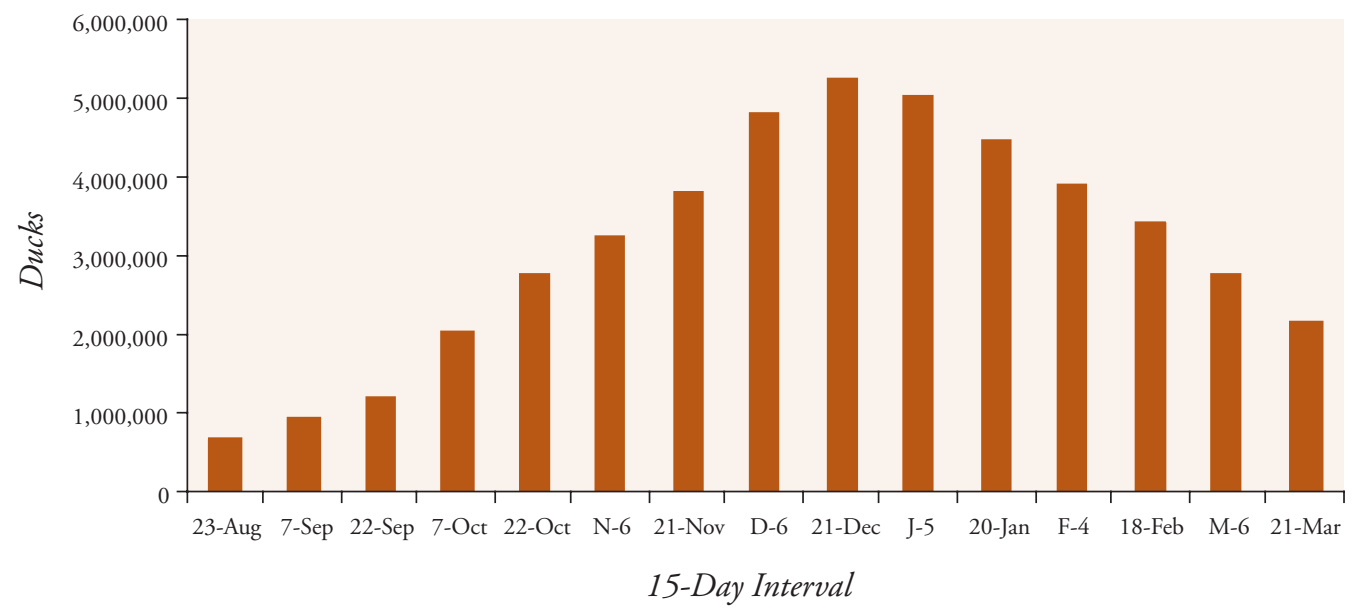

Figure 4-3. Population objectives by 15-day intervals for ducks in the Central Valley.

Correcting population objectives based on diet assumes that food sources not included in the energy model are available to the birds. For example, the JV assumes that plant materials other than seeds are available in quantities $>30 \%$ of wigeon energy needs. Although these assumptions can lead to an underestimate of habitat needs, duck population objectives used in the 2006 Plan were $90 \%$ of the original NAWMP goal (Table 4-1). In addition, the peak mid-winter population objective of 4.7 million birds used in the 1990 Plan was close to the 5.3 million peak adopted in the 2006 Plan. 
Population objectives for Central Valley ducks were divided among basins to reflect current and historic waterfowl distribution. The distribution of duck objectives closely followed the 1990 Plan, although objectives did change for some basins (Table 4-2). Population objectives stepped down to the basins were further divided into 15day intervals by using information from waterfowl surveys conducted between September and March 1998-1999 and 1999-2000 (Fleskes et al. 2002).

\section{Geese and Swans}

Although goose populations have been stepped down from the NAWMP, Joint Ventures have been advised to use recent goose counts for establishing population objectives (M. Koneff, U.S. Fish and Wildlife Service, personal communication). As a result, waterfowl surveys between September and March 1998-1999 and 1999-2000 were used to develop population objectives for geese and swans (Fleskes 2000). There are three groups of geese in the Central Valley; (1) "white geese” [lesser snow geese (Chen caerulescens), Ross's geese (C. rossii) and tundra swans (Cygnus columbianus)]; (2) white-fronted geese [Greater Pacific (Anser albifrons) and Tule (A.a. gambelli)subspecies); and (3) Canada geese [primarily Aleutian Canada geese (Branta canadensisia leucopareia)]. All swans were assumed to be tundra swans (Fleskes et al. 2000). White-fronted geese and Canada geese were combined to establish "dark goose" population objectives because these two species exploit similar habitat types. Swans were also included with white geese because the two bird groups rely on similar habitats in the Central Valley. Dark and white goose population objectives for each fifteen-day interval were established for the entire Central Valley, as well as for individual basins (Figure 4-4 and 4-5).

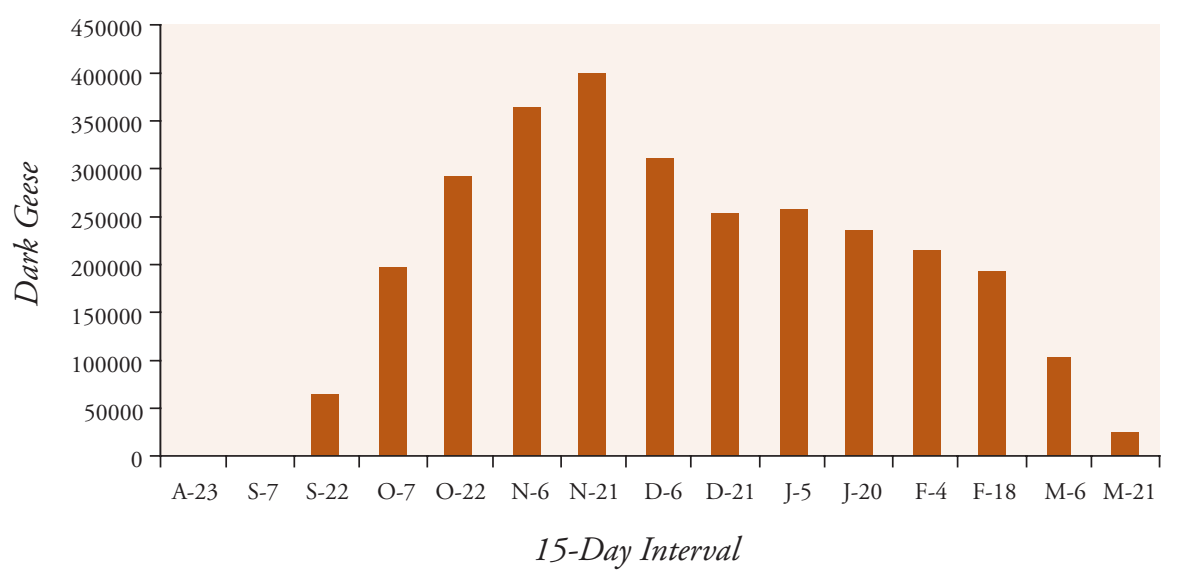

Figure 4-4. Population objectives by 15-day intervals for dark geese in the Central Valley.

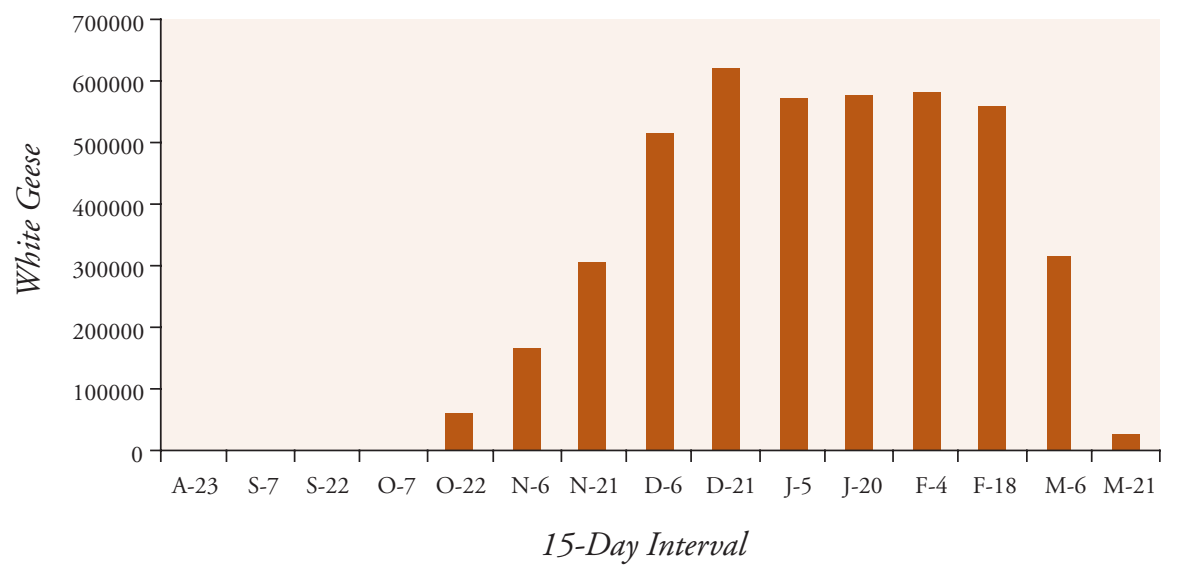

Figure 4-5. Population objectives by 15-day intervals for white geese in the Central Valley. 


\section{Habitat Acreage}

Although waterfowl rely on a variety of wetland and agricultural habitats to meet their food energy needs, specific assumptions were made about the types of habitats used by ducks and geese and the foods consumed in these habitats. Ducks were assumed to rely on seed resources in managed wetlands, waste grain in rice fields that are winterflooded, and waste grain in harvested cornfields, regardless if these fields are flooded. Ducks undoubtedly exploit food resources in unmanaged wetlands. However, the JV lacks an estimate of the amount of unmanaged habitat available to waterfowl in the Central Valley, and the food resources that are provided by these habitats. While managed wetlands are available in most years, it is not clear how reliable unmanaged habitats are from one year to the next. For these reasons, the JV did not include unmanaged habitats in the TRUEMET model when evaluating waterfowl food supplies. However, the importance of understanding the role of unmanaged wetlands in meeting waterfowl needs in the Central Valley and how the JV might address maintaining these habitats is recognized. Finally, the JV assumed that ducks consumed macro-invertebrate food resources in managed wetlands in late winter and early spring (see following section on invertebrate food resources in managed wetlands). Although this assumption appears to contradict our earlier statement that invertebrate food resources used by shovelers were not included in the TRUEMET model, shovelers rely heavily on non-macroinvertebrates (e.g., zooplankton), for which there is no available information.

Dark geese were assumed to rely on seed resources in managed wetlands and waste grain in winter-flooded rice fields, dry rice fields and harvested cornfields. It was assumed that white geese and swans use the same agricultural habitats as dark geese, though swans are largely restricted to flooded agricultural habitats. The JV also assumed that white geese and swans did not exploit food resources in managed wetlands (see Habitat Foraging Values Section). Table 4-6 provides a summary of the natural and agricultural habitats available to wintering waterfowl in the Central Valley. As with the 1990 Plan, the JV assumed that $25 \%$ of all dry or unflooded rice is unavailable to waterfowl because of post-harvest practices. The $\mathrm{JV}$ also assumed that $50 \%$ of all unflooded corn is unavailable to waterfowl because of post-harvest practices (M. Casazza, U.S. Geological Survey, personal communication). These assumptions were applied to all basins except the San Joaquin and Tulare Basins where post harvest practices make all corn unavailable to waterfowl on private lands. Basin specific totals for each foraging habitat are presented later in this chapter. Information on how habitat estimates were derived is presented in Chapter 3.
Table 4-4. Daily energy requirements (DER) for dark goose populations in the Central Valley.

\begin{tabular}{|cccc|} 
Interval & $\begin{array}{c}\text { Canada goose DER } \\
\text { (Kcal/Day) }\end{array}$ & $\begin{array}{c}\text { White-fronted goose } \\
\text { DER (Kcal/Day) }\end{array}$ & $\begin{array}{c}\text { Dark goose } \\
\text { DER (Kcal/Day) })^{a}\end{array}$ \\
\hline AUG 23 & 387 & 523 & 0 \\
SEPT 7 & 387 & 523 & 0 \\
SEPT 22 & 387 & 523 & 522 \\
OCT 7 & 387 & 523 & 522 \\
OCT 22 & 387 & 523 & 522 \\
Nov 6 & 387 & 539 & 538 \\
NOV 21 & 387 & 539 & 538 \\
DEC 6 & 365 & 547 & 544 \\
DEC 21 & 365 & 547 & 540 \\
JAN 5 & 365 & 506 & 497 \\
JAN 20 & 365 & 506 & 498 \\
FEB 4 & 365 & 563 & 553 \\
FEB 19 & 365 & 563 & 553 \\
MAR 6 & 365 & 563 & 549 \\
MAR 21 & 365 & 563 & 538 \\
\hline
\end{tabular}

${ }^{a}$ Dark goose DER based on the relative abundance of Canada geese and white-fronted geese in the Central Valley during each 15-day interval.

Table 4-5. Daily energy requirements (DER) for white goose populations in the Central Valley.

\begin{tabular}{|cccc|} 
Interval & $\begin{array}{c}\text { Snow/Ross's goose } \\
\text { DER (Kcal/Day) }\end{array}$ & $\begin{array}{c}\text { Swan DER } \\
\text { (Kcal/Day) }\end{array}$ & $\begin{array}{c}\text { White goose } \\
\text { DER (Kcal/Day) })^{a}\end{array}$ \\
\hline AUG 23 & 499 & 1106 & 0 \\
\hline SEPT 7 & 499 & 1106 & 0 \\
SEPT 22 & 499 & 1106 & 499 \\
OCT 7 & 499 & 1106 & 499 \\
OCT 22 & 499 & 1106 & 632 \\
Nov 6 & 499 & 1106 & 632 \\
Nov 21 & 499 & 1106 & 636 \\
DEC 6 & 486 & 1106 & 635 \\
DEC 21 & 486 & 1106 & 622 \\
JAN 5 & 486 & 1106 & 575 \\
JAN 20 & 486 & 1106 & 557 \\
FEB 4 & 488 & 1106 & 541 \\
\hline FEB 19 & 488 & 1106 & 525 \\
MAR 6 & 488 & 1106 & 520 \\
MAR 21 & 488 & 1106 & 503 \\
\hline
\end{tabular}

a'White goose DER based on the relative abundance of snow/Ross's geese and swans in the Central Valley during each 15-day interval. 
Temporal variation in habitat availability can strongly influence the food supplies available to ducks and geese. To better understand when food resources become available to waterfowl, information on flooding schedules was obtained for public and privately managed wetlands, as well as for harvest and flooding of important agricultural crops. Timing of rice harvest was based on earlier work in the Colusa Basin, and is assumed to be representative of other rice growing regions in the Central Valley (Figure 4-6).

Flooding schedules were developed for public and privately managed wetlands in the Central Valley (Figure 4-7), as well as for rice habitat that is winter-flooded (Figure 4-8). Flooding schedules were also developed for private and public wetlands in the Sacramento Valley and applied to basins in the region (Figure 4-9). Flooding schedules that are specific to public and private wetlands in the San Joaquin and Tulare Basins were also developed (Figure 4-9).

\section{Habitat Foraging Values}

The 1990 Implementation Plan assumed that managed wetlands in the Central Valley provided an average of 750 lbs of food per acre. This estimate was based on studies of managed wetlands in the Midwest. The 2006 Plan updates this information by using food production estimates from several sites in the Central Valley during fall and winter of 1999-2000 (hereafter 2000) and 2000-2001 (hereafter 2001).

Three major habitat types were sampled: (1) semi-permanent wetlands that are primarily managed for brood habitat; (2) seasonal wetlands managed for watergrass (Echinochloa crusgalli); and (3) seasonal wetlands managed for swamp timothy (Crypsis schoenoides, (Naylor et al. 2002). In both 2000 and 2001, seasonal wetlands dominated by watergrass and swamp timothy were sampled in the Sacramento Valley and San Joaquin Basin. These sampling efforts focused exclusively on seed density, and included both irrigated and non-irrigated seasonal wetlands. Semi-permanent wetlands were sampled only in 2000, because results indicated few seeds available in this habitat type (Naylor et al. 2002).

Food density estimates for seasonal wetlands were based on 2001 results because sample sizes were larger in 2001. Sampling also began earlier in 2001 and provided a better estimate of food density in the Central Valley prior to bird arrival. Differences in food density between seasonal wetlands dominated by watergrass vs. swamp timothy were not significant, nor were differences in food abundance between the Sacramento Valley and San Joaquin Basin (Naylor et al. 2002). As a result, the average value of 566 lbs/ acre reported for these two plant communities was used (Naylor et al. 2002) and applied to all seasonal wetlands in all basins (see exceptions for the Suisun and Tulare Basins).

Waterfowl do not consume all the foods available in wetlands because foraging efficiency declines with decreasing food densities (Reinecke et al. 1989). To estimate this "foraging threshold," seed density left in wetlands after spring migration was estimated in 2000 and 2001 (Naylor et al. 2002). These densities were lower in 2000 than 2001, and the 2000 result (about 30 lbs/acre) was

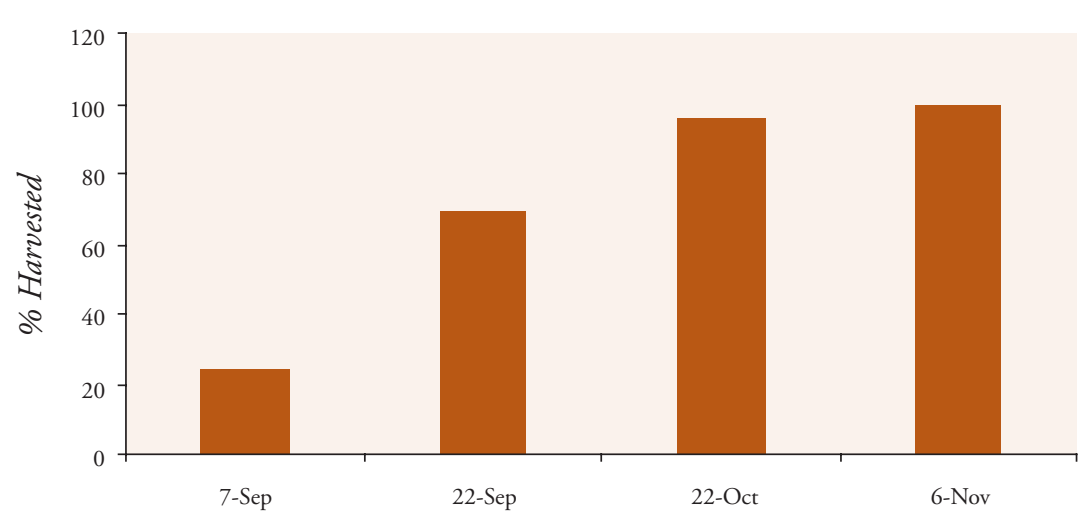

Figure 4-6. Percent of planted rice harvested by time period in the Central Valley. adopted as the foraging threshold for wetland habitats. This figure was subtracted from the seed density estimate of $566 \mathrm{lbs} / \mathrm{acre}$ to yield a seasonal wetland food density of $533 \mathrm{lbs} /$ acre.

Results from 2000 indicate that seed density in semi-permanent wetlands was less than the $30 \mathrm{lbs} /$ acre foraging threshold (Naylor et al. 2002). As a result, semi-permanent wetlands were assumed to provide no food for either ducks or dark geese. However, waterfowl may consume the leaf, stem, and root/tuber 
material of some wetland plants. Although these foods do not appear to be important for ducks in the Central Valley (Euliss and Harris 1987, Miller 1987), geese may exploit them. For example, snow geese are known to consume alkali bulrush in semi-permanent wetlands throughout the Central Valley (C. Isola, U.S. Fish and Wildlife Service, personal communication). Semi-permanent wetlands only account for $10-15 \%$ of all wetlands in a basin. However, a better understanding of food resources in this habitat type would allow a better assessment of waterfowl needs in the future.

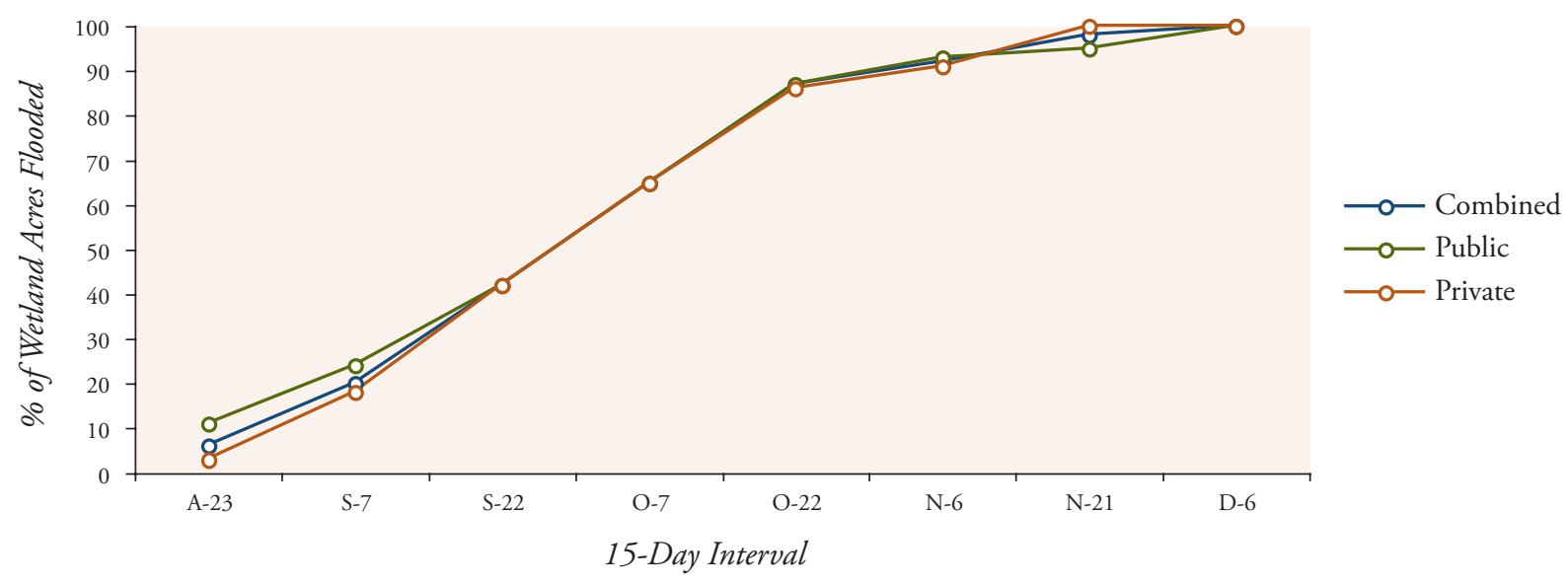

Figure 4-7. Flooding schedules for managed public and private seasonal wetlands in the Central Valley. A "combined" flooding schedule for private and public wetlands was estimated using the relative abundance of these ownership classes.

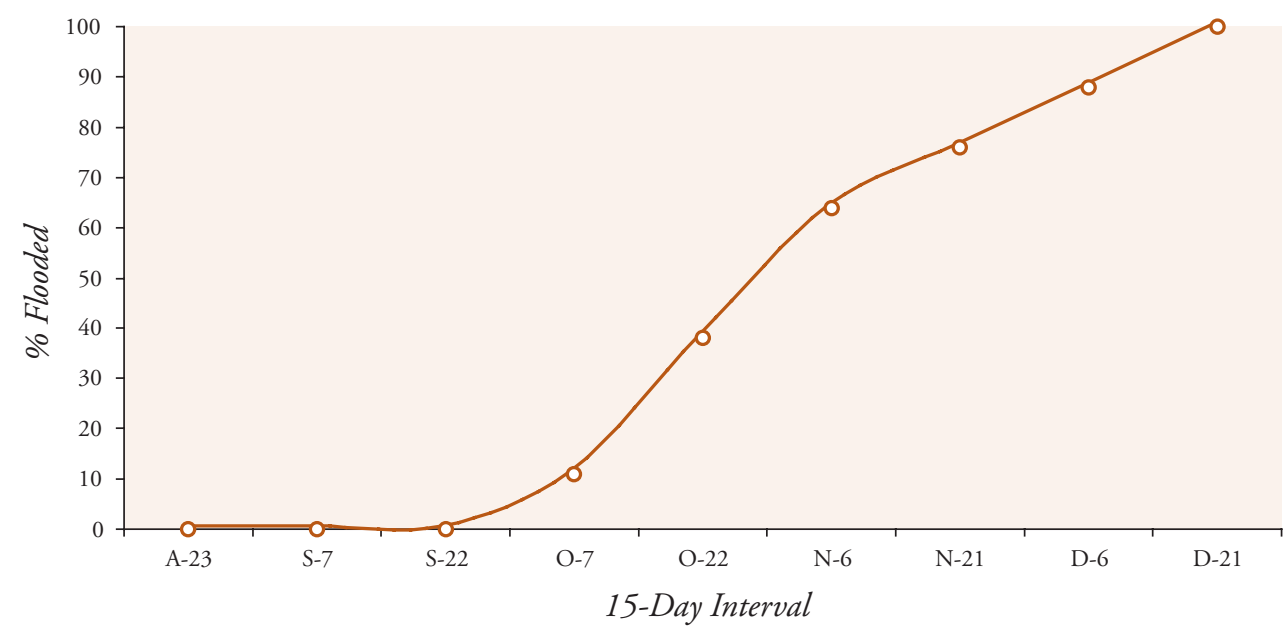

Figure 4-8. Winter-flooding schedule for harvested rice fields in the Central Valley. This flooding schedule was applied to all rice growing basins. 


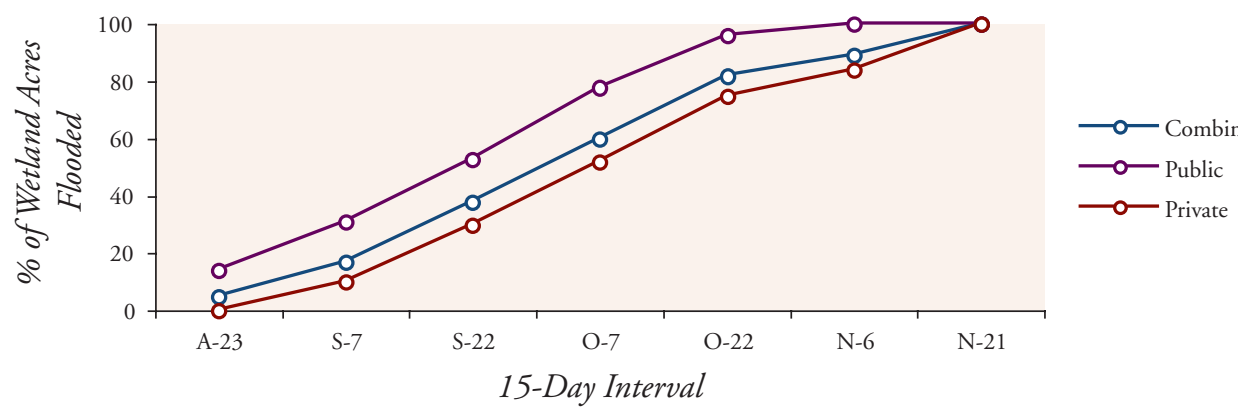

Figure 4-9(a).

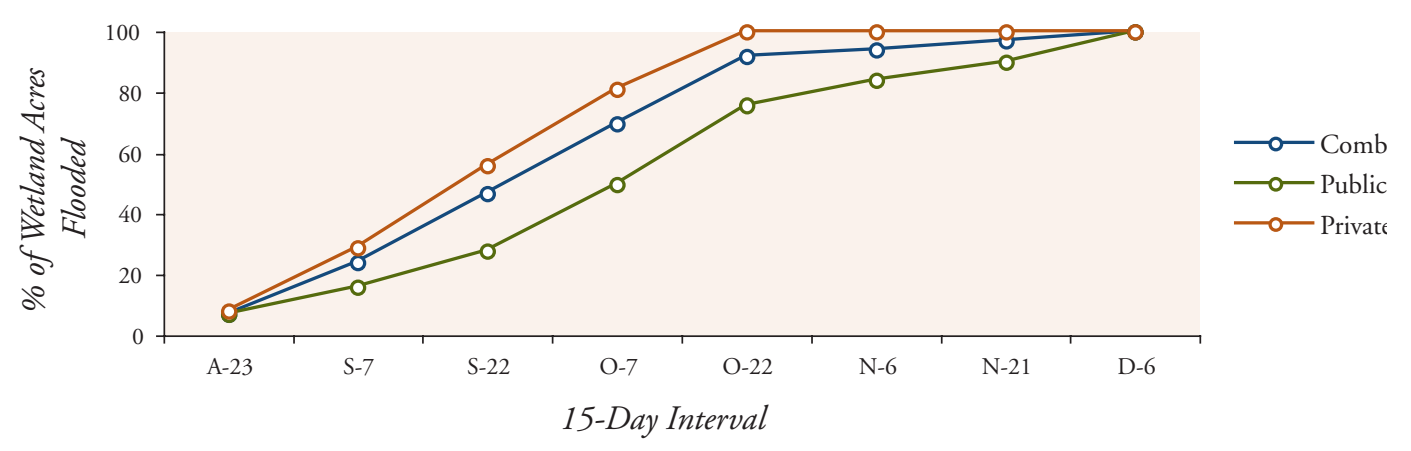

Figure 4-9(b).

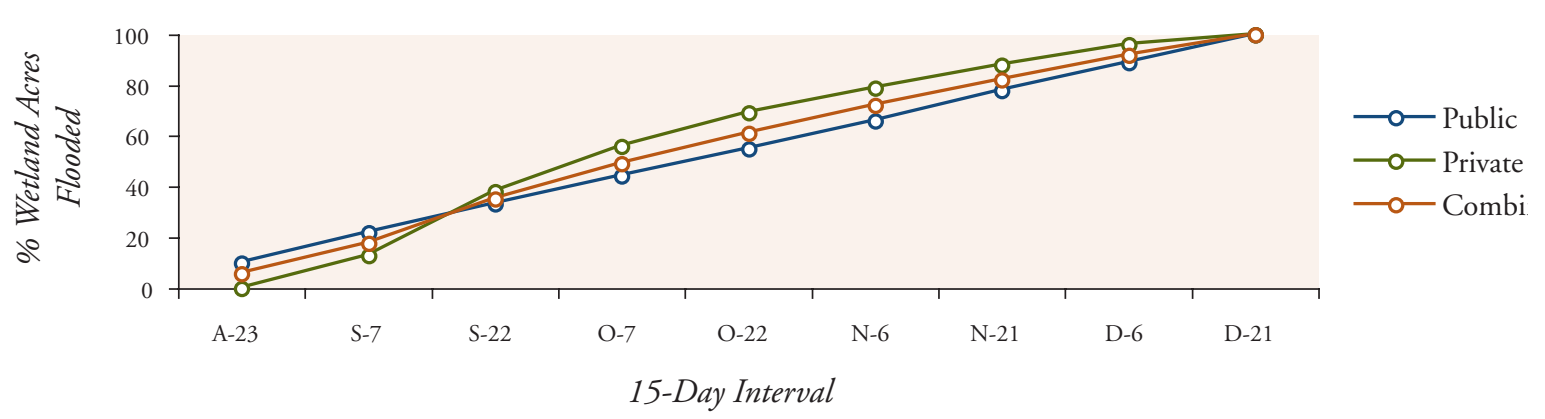

Figure 4-9(c).

Figure 4-9. Seasonal wetland flooding schedules for basins in Sacramento Valley (a), San Joaquin Basin (b), and Tulare Basin (c).

Food habitat studies in the Central Valley indicate that invertebrates become increasingly important to dabbling ducks in late winter and spring (Euliss and Harris 1987), and may be important throughout the wintering period in some habitats in the Tulare Basin (Euliss 1984, J. Fleskes, U.S. Geological Survey, personal communication). Unfortunately, information on invertebrate biomass is lacking for Central Valley wetlands. However, there is evidence that increases in invertebrate populations in late winter and spring correspond to increased waterfowl consumption (Batzer et al. 1993). Seasonal shifts in diet suggest that invertebrate consumption by most Central Valley ducks is minimal prior to January. However, invertebrates can make up twenty-five percent of the diet from January through March (Euliss and Harris 1987). To recognize the importance of invertebrates during late winter in the Central Valley, the JV estimated that seasonal wetlands provide $28 \mathrm{lbs}$ of macro-invertebrate matter per acre beginning January 1 . This estimate is based on late winter estimates of invertebrate biomass for seasonal wetlands in the Mississippi Alluvial Valley (Manley 1999).

The 1990 Plan assumed that rice and corn habitats provide $250 \mathrm{lbs}(280 \mathrm{Kg} / \mathrm{ha})$ of food per acre. This estimate equaled the amount of rice left in fields that are burned after harvest in the Sacramento Valley (Heitmeyer 1989). Although the 1990 Plan recognized that moist-soil and invertebrate food resources were likely present in rice, the amount of these food resources was unknown. Thus, 1990 foraging values were based solely on waste rice availability. The food density of corn was assumed to be the same as for rice because no information was available for this habitat type. 
Miller et al. (1989) estimated that 349 lbs/acre of rice was left in conventionally harvested fields in the mid-1980's. Rice harvest technique has changed in the last decade to include "strip harvest" that may leave less rice in the field (Miller and Wylie 1996). Postharvest treatment of rice has also changed in response to air quality restrictions and the new strip harvest methods. For example, few rice fields are now burned in the Central Valley and current manipulation of straw in harvested fields (e.g., disking, bailing, and flooding) may have reduced the amount of waste rice that is accessible to waterfowl. The 2006 Plan also assumes that 349 lbs/acre of rice is available to waterfowl immediately after harvest (Miller et al. 1989). Consumption of rice by non-waterfowl species reduces the amount of grain available to ducks and geese between harvest, bird arrival, and winter flooding of rice fields. As a result, 15\% of waste rice is assumed to be eaten by non-waterfowl species based on estimates of this loss in the Mississippi Alluvial Valley; (Stafford et al. 2006), leaving $297 \mathrm{lbs} /$ acre. Moist-soil food resources average $25 \mathrm{lbs} / \mathrm{acre}$ in California rice fields (M.R. Miller, U.S. Geological Survey, unpublished data). This further increased the food density for rice habitat to $322 \mathrm{lbs} / \mathrm{acre}$. Finally the $30 \mathrm{lb} / \mathrm{acre}$ foraging threshold established for wetland habitats was applied to rice, which reduced food density in this habitat to $292 \mathrm{lbs} /$ acre. Although work in the Mississippi Alluvial Valley indicates that invertebrates average five to six lbs/acre in rice fields in winter (Hohman et al. 1996, Manley 1999), invertebrates were not included as a food resource in the Central Valley due to uncertainty over the type, biomass, and seasonal availability of invertebrates in rice fields.

Food densities used for rice in the 2006 Plan were based on twenty-year-old estimates. Increases in harvest efficiency, rice yields, and changing post-harvest practices may have reduced the amount of waste grain now available to waterfowl. Although these uncertainties do not affect wetland restoration goals, they do reduce the JV's ability to estimate the amount of rice that must be available to meet waterfowl needs.

Table 4-7. Densities (lbs/acre) and true metabolizable energy (TME) of important waterfowl foods in the Central Valley.

\begin{tabular}{|ccc|}
\hline Food $^{a}$ & Density (lbs/acre) & TME (Kcal/g) \\
\hline MOIST-SOIL $^{b}$ & 533 & 2.5 \\
INVERTEBRATES $^{c}$ & 28 & 2.39 \\
RICE $^{d}$ & 292 & 3.0 \\
CORN $^{e}$ & 463 & 3.9 \\
\hline
\end{tabular}

${ }^{a}$ Does not include agricultural foods unique to Tulare Basin.

${ }^{b}$ TME estimates for moist-soil seeds from Checkett et al. 2002.

'TME estimates for invertebrates from Checkett et al. 2002.

${ }^{d} T M E$ estimates for rice from Reinecke et al. 1989.

'TME estimates for corn from Petrie et al. 1997.
While rice provides most of the agricultural habitat for waterfowl in the Central Valley, corn is an important food source in some areas, particularly the Delta Basin. Food density of corn was determined by multiplying average corn yields for the Central Valley by the amount of corn remaining on the ground after harvest (5.6\%). Non-waterfowl consumption of corn was assumed to be the same as for rice, as was the $30 \mathrm{lb} /$ acre foraging threshold. Overall, cornfields are assumed to provide $463 \mathrm{lbs} /$ acre of waste grain (Table 4-7). In the Tulare Basin, waterfowl rely heavily on post-harvest flooded fields of several different crop types during August-October (e.g., safflower, barley/wheat, alfalfa; Fleskes et al. 2003).

Waterfowl carrying capacity is strongly dependant on food densities. However, the energy or calories provided by these foods also influences waterfowl carrying capacity. As a result, metabolizable energy density estimates for moist soil seeds, rice, corn, and invertebrates were obtained from published studies for use in the energetic model (Table 4-7).

Moist soil seeds and agricultural grains decompose under flooded conditions, and deterioration of these foods can significantly reduce waterfowl energy supplies. Decomposition rates for moist soil seeds have been determined from fall through spring in the Central Valley (Naylor et al. 2002), while decomposition rates for rice and corn have been determined for agricultural habitats in the Mississippi Alluvial Valley (Nelms and Twendt 1996). These decomposition rates were incorporated into the energetic model when estimating waterfowl food supplies between August and March.

\section{Overall Assessment of Habitat Conditions in the Central Valley}

Habitat conditions for wintering waterfowl were evaluated for the entire Central Valley, as shown in Figure 4-10. This figure depicts the relationship between food energy supplies and population energy demand for all ducks in the Central Valley between August and March as estimated by the TRUEMET model. Duck food supplies are adequate even when duck populations are at NAWMP goals. Prior to mid-September energy supplies are low, as few seasonal wetlands are flooded and no winter-flooded rice is available. However, food supplies are well above population needs by late October, as the majority of public and private wetlands are flooded for opening of hunting season. Habitat conditions continue to improve for ducks well into November, as winter-flooded rice becomes 
available. Duck energy supplies begin to decline by mid to late December as fewer habitats are added to the landscape, and the effects of waterfowl consumption and food decomposition begin to take effect. However, food supplies remain well above population needs through March when most ducks begin leaving the Valley (Figure 4-10).

Food supplies for both dark and white goose populations in the Central Valley are also well above population needs (Figure 4-11). Geese begin arriving in the valley at the peak of rice harvest and food supplies become increasingly available through November. Although food supplies begin to decline after this point, both dark and white goose populations continue to have access to abundant food resources throughout winter and early spring (Figures 4-11a and 4-11b).

Wetland restoration efforts over the past two decades coupled with increases in winter-flooded rice have substantially improved habitat conditions for Central Valley ducks. To illustrate, food supplies in the 1970's were compared to duck energy needs. Seasonal wetlands in the 1970's were estimated at 140,000 acres by subtracting the number of acres restored between 1986 and 2003 from current wetland estimates. Wetland restoration was not tracked prior to 1986. Winter-flooded rice was estimated at 50,000 acres based on interviews with resource professionals, while corn acres were assumed to be the same. Waterfowl populations during the 1970's were assumed to be at NAWMP goals.

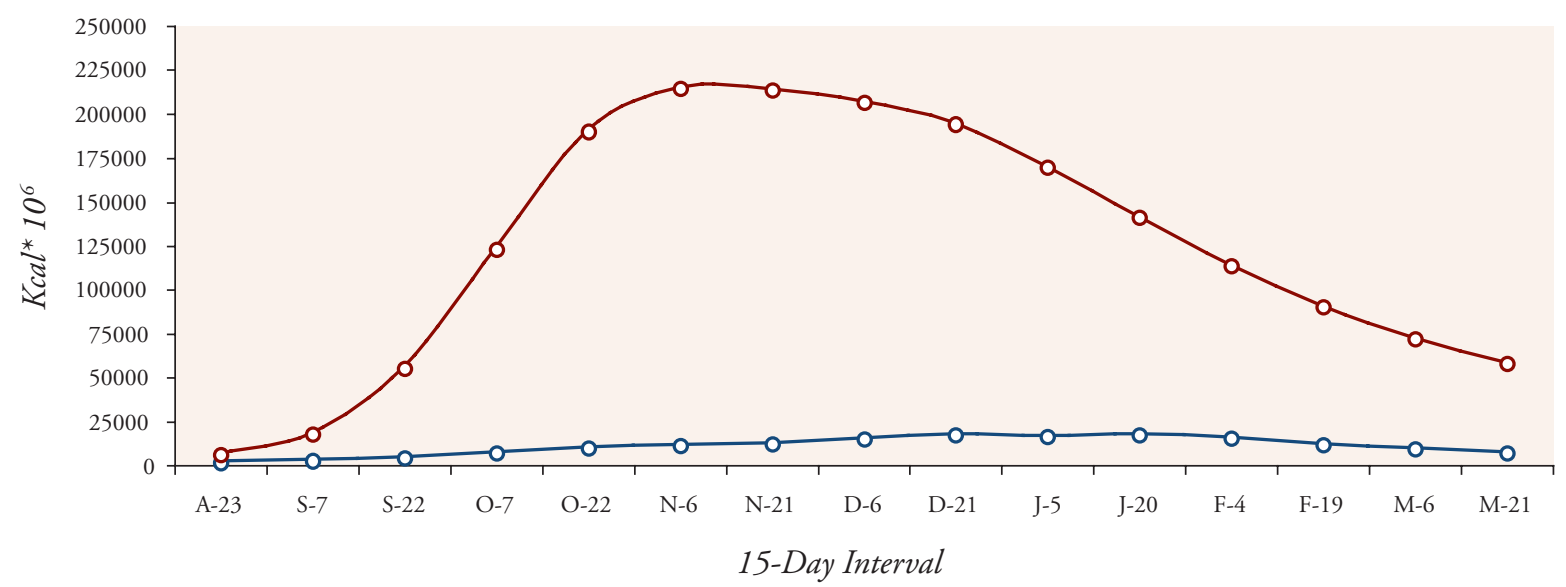

Figure 4-10. Population energy demand (blue) vs. food energy supply (red) for ducks in the Central Valley when duck populations are at NAWMP goals.

Food supplies for dabbling ducks during the 1970s may have been inadequate after late January (Figure 4-12). The likelihood that duck populations in the Central Valley are limited by conditions on the wintering grounds has almost certainly declined during the past twenty-five years.

Approximately two-thirds of the waterfowl habitat in the Central Valley is privately owned. To demonstrate the importance of these habitats, ducks were restricted to foraging on public lands in the TRUEMET model. Duck food resources in this "public lands only" scenario were exhausted by early November (Figure 4-13). This result demonstrates the importance of private lands for waterfowl and the need to develop conservation objectives for these habitats.

Food resources for ducks in the Central Valley are adequate even when populations are at NAWMP goals. However, $68 \%$ of all food resources are provided by agricultural habitats, with winter-flooded rice providing the bulk of these foods. Agricultural habitats are currently afforded little or no long-term protection. As a result, conservation objectives should be aimed at increasing the security of waterfowl food resources in each of the valley's basins. 


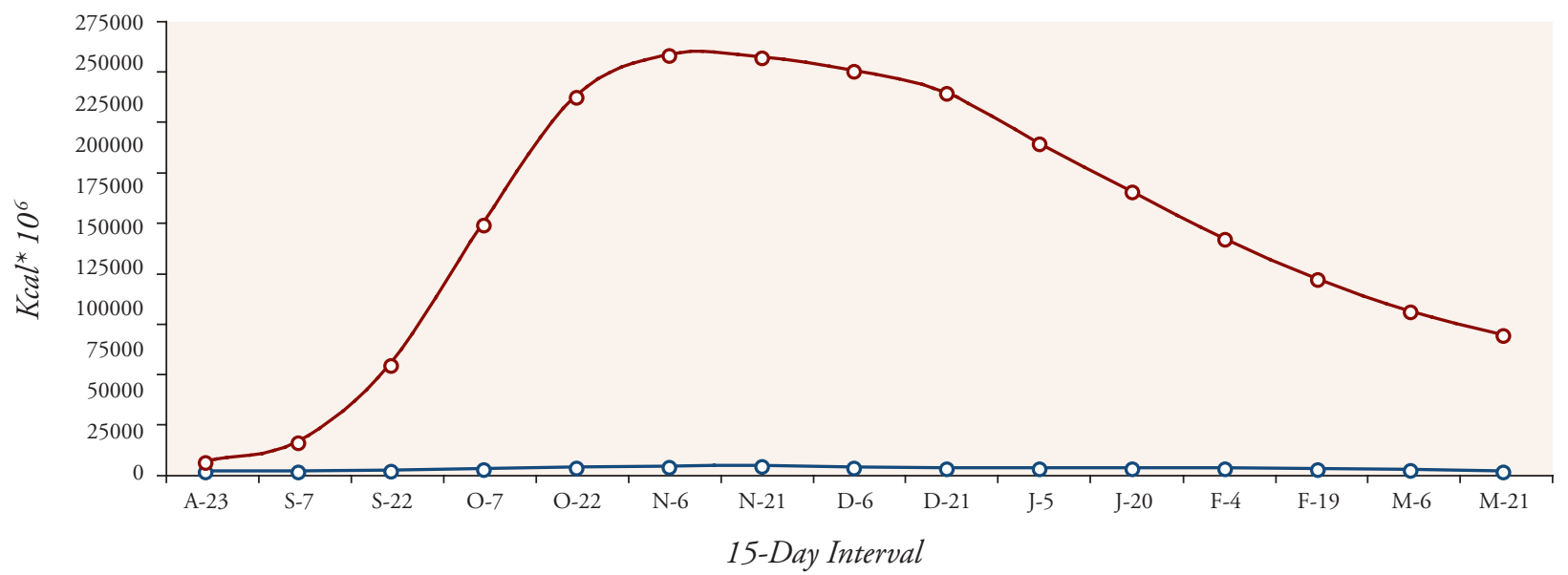

Figure 4-11(a). Dark goose population energy demand (blue) vs. food energy supplies (red) for the Central Valley.

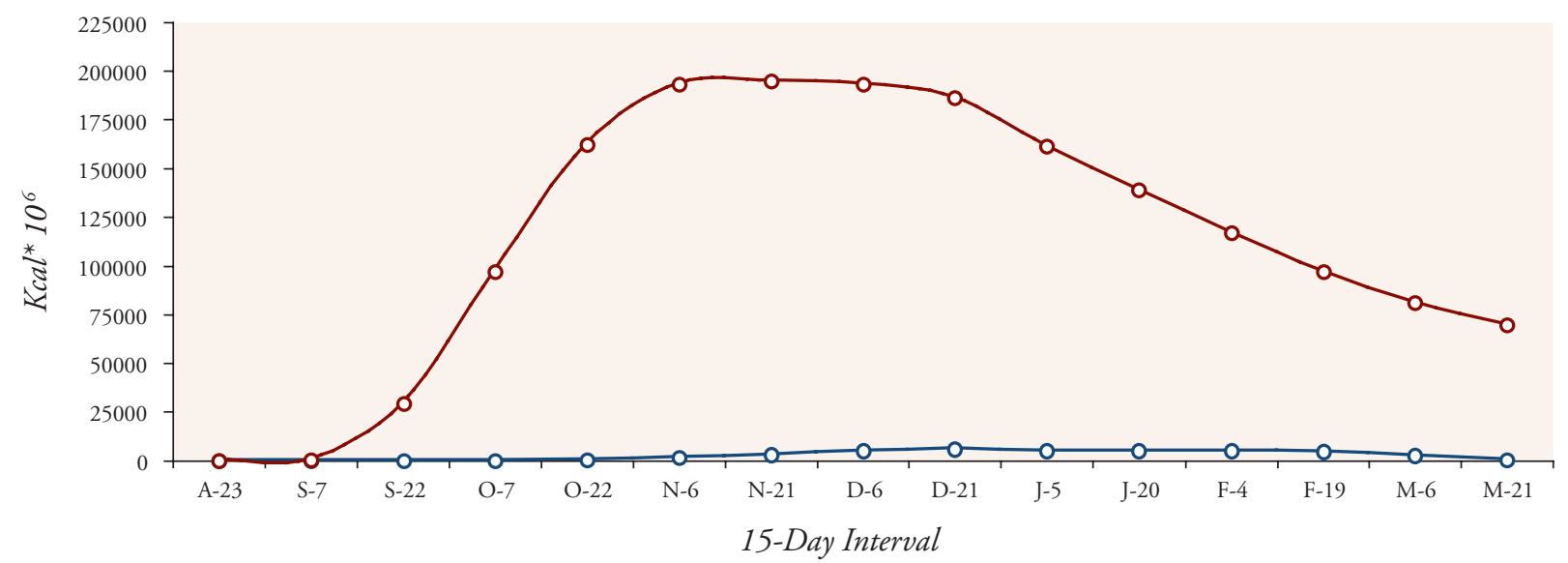

Figure 4-11(b). White goose population energy demand (blue) vs. food energy supplies (red) for the Central Valley.

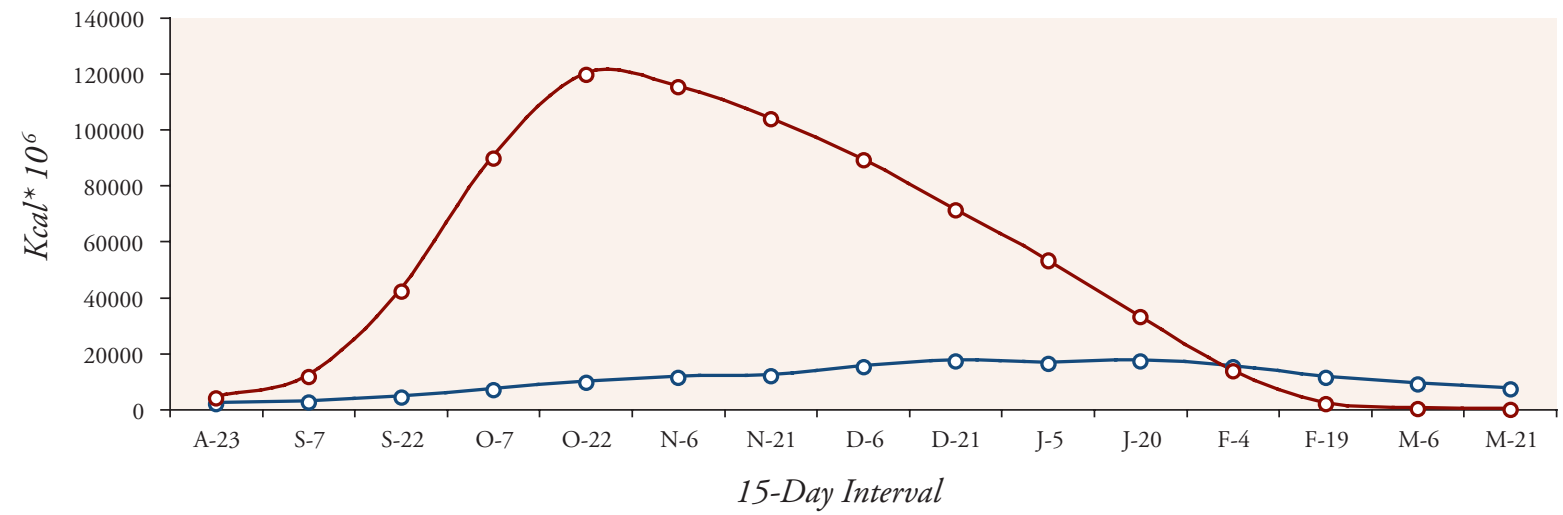

Figure 4-12. Population energy demand (blue) vs. food energy supply (red) for ducks in the Central Valley during the 1970s. 


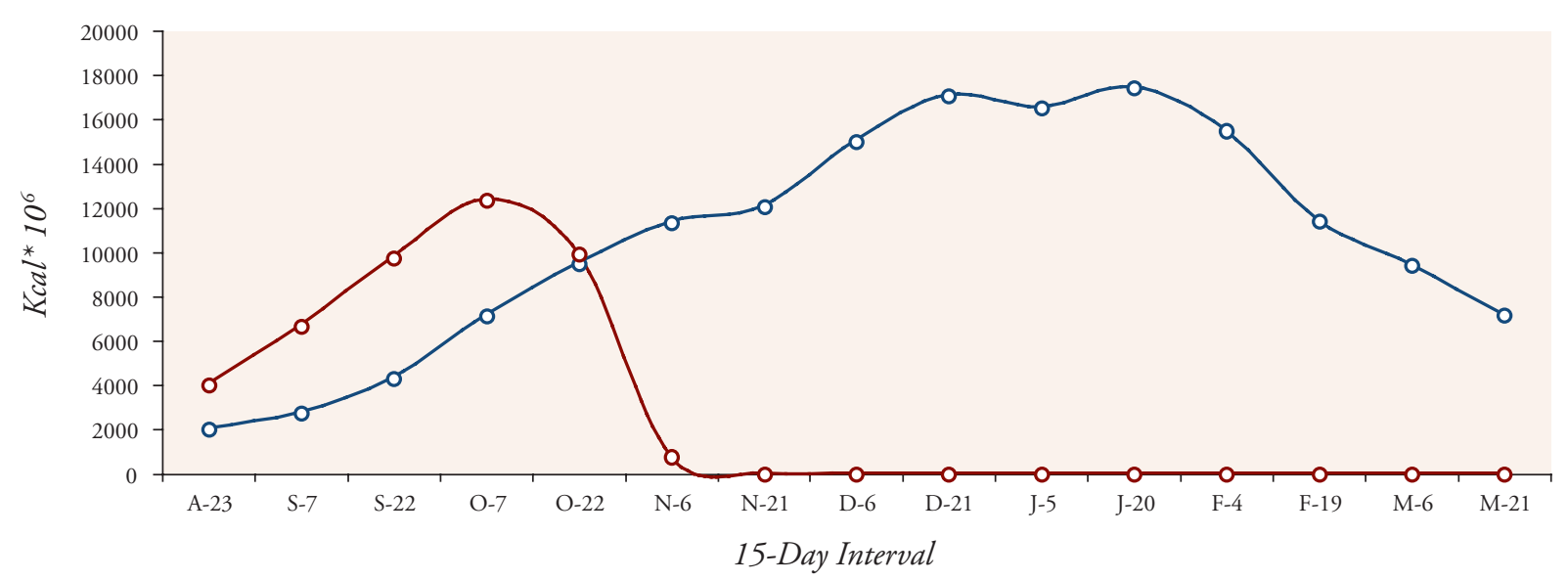

Figure 4-13. Population energy demand (blue) vs. food energy supply (red) for ducks in the Central Valley if only public lands are available.

\section{Methods for Establishing and Prioritizing Conservation Objectives for Wintering Waterfowl in Each Basin}

Conservation objectives for wintering waterfowl in the Central Valley were established at the basin scale. The 1990 Plan identified five conservation objectives for wintering waterfowl including: (1) Wetland restoration; (2) Protection of existing wetland habitats; (3) Wetland enhancement; (4) Adequate power and water supplies for wetland management; and (5) Agricultural land enhancement. Two additional conservation objectives were added in the 2006 Plan to recognize the agricultural community's critical role in meeting waterfowl needs and to provide greater flexibility in working with landowners. These include farmland easements that maintain waterfowl food resources on agricultural land (Type I), and farmland easements that buffer existing wetlands from urban and residential growth (Type II). Type I easements seek to maintain waterfowl-friendly practices on agricultural land in perpetuity (e.g., winter-flooding of rice, use of wildlife friendly crop types and post-harvest practices). Type II easements are designed to serve as buffers between wetland habitats and industrial and residential development. This type of easement would not require landowners to provide waterfowl food sources, but would place development restrictions on a property (the legal conditions and qualifications of both easement types are beyond the scope of this document).

For the 2006 Plan, the JV elected to meet at least $50 \%$ of all duck energy needs through managed seasonal wetlands; hereafter this is referred to as the "wetland constraint." This planning goal was applied to all basins. The decision to meet 50\% of all duck energy needs from wetlands considered both biological and socio-economic factors. Captive studies of non-breeding waterfowl indicate that ducks require a balance of natural and agricultural foods (Loesch and Kaminski 1989), and the JV favors habitat complexes that provide a mixture of agricultural and wetland resources. In addition, increases in harvest efficiency and changing agricultural markets could significantly reduce the food resources provided by grain crops. These events are largely beyond the control of the JV, and seeking a long-term balance between agricultural and wetland habitat is prudent. Agriculture now provides almost $70 \%$ of all waterfowl food resources in the Central Valley.

The same approach was used to establish conservation objectives in each basin. First, the relationship between population energy demand and existing food supplies was evaluated for ducks, dark geese, and white geese using the TRUEMET model. Second, the relative contribution that agriculture and managed seasonal wetlands make to waterfowl food supplies in the basin was estimated. Finally, changes in waterfowl carrying capacity that would result from the loss of agriculture were evaluated, as was the ability of public lands to meet duck energy needs. This overview of basin conditions provided the basis for establishing habitat conservation objectives, and may help identify which of these objectives should receive priority. Methods for establishing conservation objectives are described below.

\section{Wetland Restoration Objectives}

To determine how much wetland habitat was needed for each basin under the wetland constraint, duck population objectives in a basin were reduced by $50 \%$ and the TRUEMET model was used to estimate the wetland acres needed to meet the energy demands of 
this reduced population. Acres of wetland habitat were incrementally added to the basin until TRUEMET simulations indicated that food energy supplies remained above population energy demand for the entire August to March period. No agriculture was included. The number of wetland acres needed to achieve this result was compared to current wetland acres in the basin. The difference between these two figures represents the wetland restoration objective.

\section{Wetland Enhancement}

Water management is critical to producing sufficient quantities of waterfowl food in Central Valley wetlands. However, water control structures, levees, and water conveyance networks used to manage water levels must be periodically repaired or enhanced to maintain or improve food production. Interviews with resource professionals suggest that wetlands in the Valley should undergo some level of structural enhancement every ten to fifteen years. The JV assumes that managed wetlands in the Central Valley need some form of enhancement on average every twelve years. As a result, enhancement objectives are expressed on an annual basis and are perpetual. For example, a basin containing 24,000 acres would have an annual enhancement objective of 2,000 acres. Wetland acres will increase in most basins because of restoration efforts. As a result, enhancement objectives were calculated by 2,000-acre increments between existing wetland acres and basin wetland objectives. Failure to at least maintain the management capabilities of these wetlands will mean a decline in food production over time. These declines would result in an underestimate of the acres of wetlands needed to meet duck energy requirements.

The JV also recognizes the importance of management-based enhancement (e.g., vegetative manipulation and timing of drawdowns), and the cost-sharing programs that promote these activities. However, it is beyond the scope of this document to prescribe site specific enhancement recommendations. The JV assumes that wetland managers are best prepared to determine and to implement these activities.

\section{Water Supplies for Seasonal Wetland Management}

The Central Valley Wetlands Water Supply Investigations (Water Report; US Fish and Wildlife Service 2000) provides an estimate of the amount of water needed for optimal management of seasonal wetlands in the Central Valley. These water requirements differ by both time period and basin and this information was used when estimating basin water needs (Figure 4-14). These estimates assumed that wetland restoration objectives have been met, and represent the amount of reliable and affordable water needed for wetland management on public and private lands. Note that the water supply objective equals the amount of water needed for seasonal wetlands, and not the amount of water that is currently secured for wetland management.

\section{Wetland Protection}

The 1990 Plan estimated that forty percent of managed wetlands in the Central Valley were unprotected. Tracking of JV accomplishments indicate that most of these wetlands have received long-term protection (likely > 95\%; see Chapter 2). Independent estimates of unprotected wetlands also indicate that less than five percent of managed wetlands in the Central Valley remain

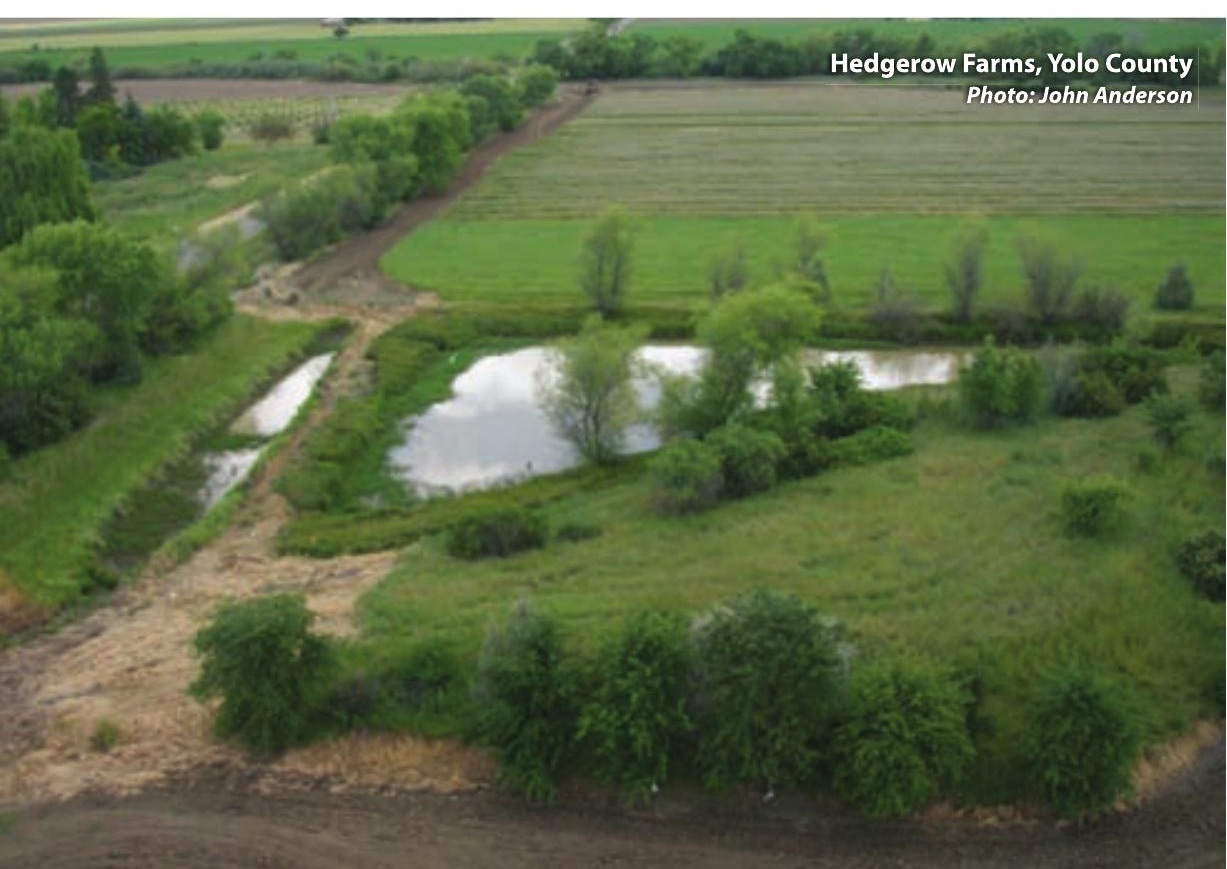
unprotected (K. Petrik, Ducks Unlimited, Inc., personal communication). Although most wetlands are now protected, the JV is unable to determine how many acres of managed wetlands remain unsecured in each basin. As a result, no wetland acreage protection objectives were established in the 2006 Plan. However, the JV will seek to secure long term protection as these wetlands are identified. The JV will document the amount of unprotected habitat in each basin in the immediate future, and these efforts will form the basis of new wetland protection goals in the next plan update. 


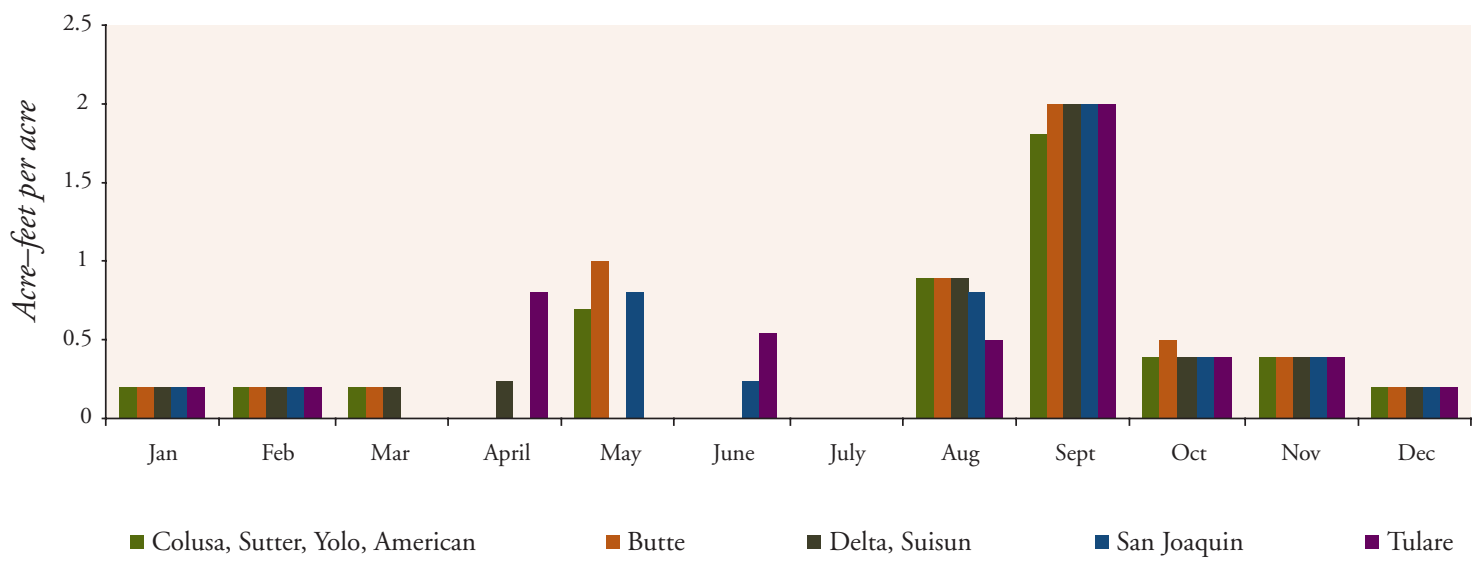

Figure 4-14. Monthly water requirements, acre-feet per acre, for seasonal wetlands in each of the Central Valley's basins.

\section{Agricultural Enhancement}

The Joint Venture's wetland constraint provides a balanced mix of agricultural and wetland habitat for each basin, as the JV assumes that agriculture will likely continue to provide $50 \%$ of all duck energy needs in most basins. The agricultural enhancement objective represents the amount of agricultural habitat that must be maintained for ducks, even when wetland restoration objectives are met in a basin. For ducks, agricultural enhancement includes rice fields that are winter-flooded or cornfields that are either winter-flooded and/or not deep plowed following harvest.

Geese in the Central Valley rely heavily on agricultural food sources to meet their daily energy requirements. Agricultural enhancement objectives that are based solely on duck needs may not be adequate for geese. As a result, TRUEMET was used to estimate the amount of agricultural habitat that must be maintained to meet the needs of ducks and geese when wetland restoration goals are met. The JV defines agricultural habitat types necessary to meet duck and goose energy requirements as waterfowl-friendly rice and/or waterfowlfriendly corn, depending on the basin. For basins dominated by rice, the waterfowl-friendly agricultural objective is divided into flooded and non-flooded categories because ducks are limited to winter-flooded fields, while geese would utilize dry fields provided they are not deep plowed. For basins dominated by corn, the waterfowl-friendly agricultural enhancement objective reflects the amount of corn that is either winter-flooded and/or not deep plowed following harvest.

\section{Agricultural Easements for Maintaining Waterfowl Food Production (Type I)}

Agricultural enhancement objectives represent the amount of farmland needed to meet waterfowl food energy needs when wetland restoration objectives are met. Agricultural easements that permanently maintain waterfowl food sources on farmlands (e.g., winter flooding of rice) contribute to this objective. This plan does not identify specific areas that are candidates for this type of agricultural easement. Instead, it provides background information that may be helpful to the JV in identifying what basins require an easement program in the immediate future and the general location within the basin where these easements might be sought. Three criteria were evaluated for each basin: (1) the importance of agricultural food resources in meeting waterfowl needs in the basin (e.g., Suisun Marsh Basin has no agriculture); (2) the extent to which these agricultural lands are threatened by human population growth and associated land conversion (see Chapter 3); and (3) wetland restoration goals. Most wetland restoration in rice growing basins will occur on rice ground. While wetland restoration provides obvious benefits, it also reduces the rice habitat available to waterfowl. Changes in rice habitat must consider the loss of riceland to development and conversion of rice to wetland habitat. This process is demonstrated using a hypothetical basin (Figure 4-15). The basin has 100,000 acres of planted rice. Seventy thousand acres are winter-flooded, while 20,000 acres are dry but are not deep plowed following harvest and thus, provide waterfowl food resources. The remaining 10,000 acres are dry and are deep plowed following harvest. The agricultural enhancement objective for the basin is 80,000 acres of waterfowl-friendly rice. Within the basin 20,000 acres will be lost to development and 10,000 acres will be converted to wetlands to meet the JV's wetland restoration objective. This leaves a planted rice base of only 70,000 acres, which is insufficient to meet the basin's agricultural enhancement goal (Figure 4-15). 
Basins where waterfowl meet most of their food energy needs from agricultural habitats, and where these habitats are threatened by development are likely candidates for an easement program. Geographic Information Systems and local knowledge provided by the JV's basin working groups were used to assess development threats to agricultural habitats in each basin. Large wetland restoration objectives that further reduce the rice base may contribute to the need for a Type I easement program.

\section{Agricultural Easements that Buffer Urban and Residential Growth (Type II)}

The quality of existing wetlands may be reduced where urban or residential growth occurs at or near wetland boundaries. Easements that maintain land in agricultural production can buffer this development, even though these lands may contain no waterfowl foods. The 2006 Plan does not identify specific areas that are candidates for this type of agricultural easement. Instead, the 2006 Plan provides background information that may be helpful to the JV in identifying what basins require an easement program of this type (Type II), and generally where in the basin these easements might be sought. Basins that contain large blocks of private and/or public wetlands in areas of high urban or residential growth are likely candidates for an easement program. Geographic Information Systems and local knowledge provided by basin working groups were used to assess development threats to wetlands in each basin.

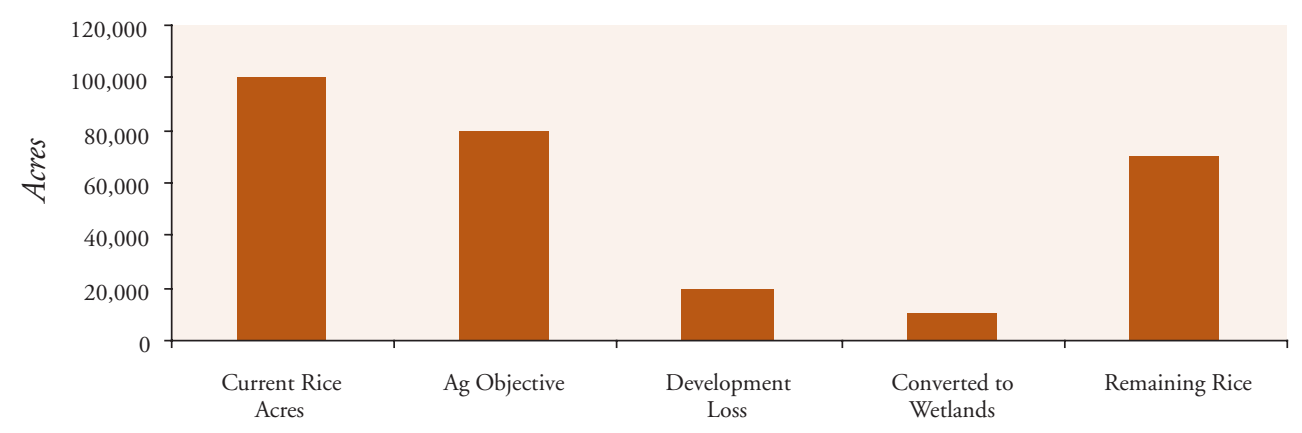

Figure 4-15. Forecasted changes in rice acreage for a hypothetical basin compared to the basin's agricultural enhancement objective.

\section{Conservation Objective Priorities}

Each conservation objective described above represents important habitat needs for ducks and geese. However, the JV recognizes that some of these objectives may need to be emphasized, at least in the short term. For example, should wetland restoration be highlighted in a basin or should efforts focus on enhancing agricultural habitats? In some cases multiple conservation objectives may be emphasized at the same time, especially where funding sources are tailored to specific objectives. To provide some insight into which objectives may be most important in the near future, the JV reviewed five biological and socio-economic factors that are described below. Some of these socio-economic factors were reviewed in Chapter 3 and this information is frequently referenced. The intent here is not to establish a rigid list of conservation objective priorities for each basin (i.e., there is no scoring process). Instead, the 2006 Plan seeks to provide resource managers with material that may help determine which objectives should be emphasized in the short and long term.

\section{Population Energy Demand vs. Food Energy Supplies: Current Conditions}

Overall, food resources in the Central Valley are currently adequate for waterfowl, even if duck populations were at NAWMP goals. However, food resources in some basins may not meet population energy needs. The extent to which existing food supplies now meet waterfowl needs in a basin when duck populations are at NAWMP goals was categorized as low ( $<$ than $75 \%$ of waterfowl energy needs met), moderate (75\%-100\% of waterfowl energy needs met), or high (> 100\% of food energy needs met). In general, conservation objectives aimed at increasing the protection of existing habitats may be favored where waterfowl food energy supplies are already high in the basin. 


\section{Habitat Protection}

The majority of waterfowl food resources in the Central Valley are found on agricultural lands that have little or no long-term protection. In contrast, most managed wetlands are afforded long-term protection through fee title purchases and conservation easements. However, the contributions that agricultural and wetland habitats make to total food supplies differ among basins. Current habitat protection for each basin was estimated as the percent of duck energy needs now supplied by wetlands, although the JV recognizes that not all wetlands are protected. One example involves a basin where $50 \%$ of duck energy needs are to be met through a wetland base of 30,000 acres, while the remaining $50 \%$ is met by a 50,000-acre agricultural enhancement objective. If 15,000 acres of wetland currently exist (leaving a 15,000 acre wetland restoration goal), then $25 \%$ of the food sources needed by ducks are currently protected (this assumes no current agricultural protection). This level of protection would increase as the wetland restoration goal is met and easements are obtained on farmland, provided that restored wetlands are also afforded permanent protection. Four levels of overall habitat protection were recognized: (1) very low (0-25\%); (2) low (26-50\%), (3) moderate (51-75\%), and (4) high (76-100\%).

\section{Progress in Meeting Wetland Needs}

Wetland restoration objectives are critical to offsetting the long-term risks of meeting waterfowl needs on unprotected agricultural habitat. The degree to which wetland acres in a basin meet the Joint Venture's $50 \%$ wetland constraint was categorized as; (1) very low (0-25\%); (2) low (26-50\%); (3) moderate (51-75\%); and (4) high (76-100\%). For example, "Progress in Meeting Wetland Needs" would be "very low" in a basin having 2,500 acres of wetlands, but needing 10,000 acres of wetlands to provide 50\% of duck energy needs.

\section{Human Population Growth}

Although human populations in the Central Valley are predicted to increase by $130 \%$ over the next four decades, this growth will not be uniform among basins. Some basins will experience substantial increases in population growth by 2040, while growth in other basins will be modest. Forecasts for population growth were made earlier for each basin (Chapter 3). Four categories of population growth to 2040 were recognized when establishing conservation objective priorities: (1) very low (<200,000); (2) low (200,000600,000); (3) moderate (> 1,000,000); and (4) high (> 2,000,000). Geographic Information systems were also used to depict the spatial pattern of this growth relative to wetland and agricultural habitats.

\section{Changes in Land Use}

Changes in land use track increases in human populations. Some basins are projected to lose substantial amounts of irrigated farmland by 2040 . This loss is important in basins where agriculture provides the majority of waterfowl food supplies. Estimates of farmland loss were made for each basin in Chapter 3. Estimates of rice loss were also made for basins where rice is an important crop. Three categories of pre-irrigated farmland or rice loss by 2040 were recognized: (1) low (<5\%); (2) moderate (5-10\%); and (3) high (> 10\%).

The 2006 Plan established some guidelines when interpreting these five factors. First, agricultural easements are emphasized in areas that are predicted to experience substantial urban or residential growth. Less emphasis is placed on easements in basins where little growth is predicted (an alternative view may be to emphasize easements in these basins as easements costs may be lower because of less competition from development). Second, wetland enhancement is emphasized in basins where wetland objectives are closer to being

56 Chapter 4: Wintering Waterfowl 
met. Enhancement is also necessary in basins that are farther from meeting their wetland restoration objectives, though restoration may ultimately be emphasized. It bears repeating that some resource managers may reach different conclusions when deciding what objectives to emphasize. However, the purpose here is to provide information that allows informed decisions when considering conservation priorities, not to develop a rigid list of those priorities.

Figure 4-16 describes conditions in a hypothetical basin. The basin contains 5,000 acres of seasonal wetlands and 50,000 acres of flooded rice. All 5,000 wetland acres are protected, while no agricultural habitat is under easement. Fifteen thousand acres of seasonal wetlands are needed to meet the JV's wetland constraint. This leaves a wetland restoration objective of 10,000 acres. Forty thousand acres of flooded rice are needed when the wetland restoration objective is met (i.e., when 15,000 acres of wetlands are present in the basin). An assessment of food energy demand vs. food energy supply concluded that the food resources provided by these existing habitats exceed $100 \%$ of duck needs (high). Although $100 \%$ of the basin's wetlands are protected (complete protection), the overall level of habitat protection was rated very low because only 5,000 of the 15,000 acres of wetlands needed are present, resulting in an overall level of habitat protection of less than $17 \%$. (If wetland restoration objectives were met $50 \%$ of duck energy needs would be provided by protected habitats. Because only a third of these 15,000 acres are present, the current level of habitat protection is only $16.7 \%$ or $0.33 \times 0.5)$.

Progress in meeting wetland needs was rated low because only $33 \%$ of needed wetlands are present $(5,000 / 15,000)$. Most food resources are found on agricultural lands that are unprotected. However, population growth is forecasted as very low $(<200,000)$. As a result, loss of irrigated farmland is also expected to be low $(<5 \%)$.

Wetland restoration is emphasized for the hypothetical basin described in Figure 4-16. While most food resources are provided by agriculture, there is little evidence that these habitats are threatened by development prior to 2040. This lack of development may increase opportunities for wetland restoration, as land prices are not influenced by real estate speculation. Focusing on wetland restoration now may offset agricultural losses that occur after 2040.

\begin{tabular}{|c|c|c|c|c|c|}
\hline $\begin{array}{l}\text { Current Food } \\
\text { Supplies }\end{array}$ & $\begin{array}{c}\text { Habitat } \\
\text { Protection }\end{array}$ & $\begin{array}{l}\text { Progress in Meeting } \\
\text { Wetland Needs }\end{array}$ & $\begin{array}{l}\text { Population } \\
\text { Growth }\end{array}$ & $\begin{array}{l}\text { Loss of Irrigated } \\
\text { Farmland }\end{array}$ & $\begin{array}{c}\text { Conservation } \\
\text { Objective Priorities }\end{array}$ \\
\hline HigH & High & $\mathrm{HIGH}$ & $\mathrm{HIGH}$ & HigH & $\begin{array}{c}\text { WETLAND } \\
\text { RESTORATION }\end{array}$ \\
\hline Moderate & Moderate & Moderate & Moderate & Moderate & \\
\hline \multirow[t]{2}{*}{ Low } & Low & Low & Low & Low & \\
\hline & VERY LOW & VERY LOW & VERY LOW & & \\
\hline
\end{tabular}

Figure 4-16. Factors used to identify which conservation objectives may be emphasized in a hypothetical basin.

\section{Conservation Objectives and Priorities for Wintering Waterfowl in Each Basin}

\section{American Basin}

\section{Population Energy Demand vs. Food Energy Supplies: Current Conditions}

Population objectives for wintering waterfowl in the American Basin are presented in Figures 4-17 through 4-19. Duck population objectives are highest during late winter, while population objectives for dark and white geese peak during November and early January respectively. Rice provides the majority of foraging habitat, as there are few privately owned wetlands and no publicly managed habitats (Table 4-8).

Food supplies for American Basin ducks are adequate in all time periods with peak supplies occurring in November and December (Figure 4-20). However, duck energy needs do not peak until late winter when food supplies are well below the November-December maximum. Food supplies for dark and white geese are also well above population needs, with peak use coinciding with maximum food resources (Figure 4-21). Agricultural habitat provides 95\% percent of the food energy available to ducks in the American Basin. Loss of these agricultural foods would significantly reduce carrying capacity, as food supplies would be exhausted by early December if ducks are restricted to foraging in wetlands (Figure 4-22). 


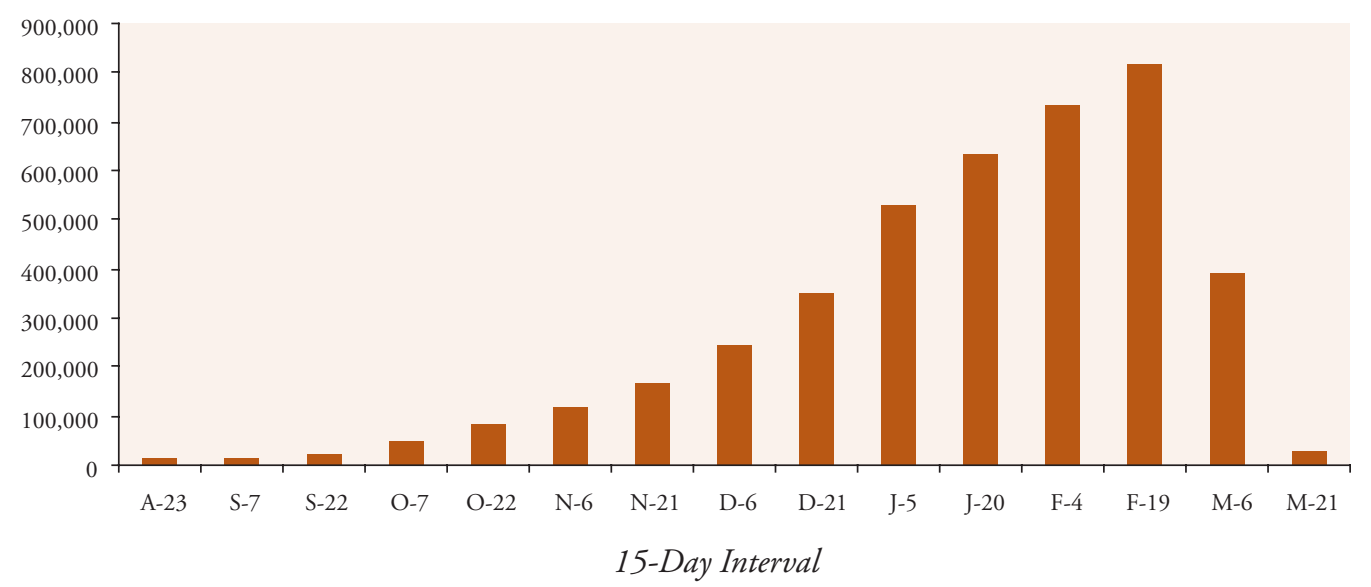

Figure 4-17. Population objectives by 15-day intervals for ducks in American Basin.

\section{Conservation Objectives}

\section{Wetland Restoration}

The amount of seasonal wetlands required to meet 50\% of duck energy needs in American Basin is estimated at 23,187 acres. There are currently 3,187 acres of seasonal wetland habitat in the basin, leaving a wetland restoration objective of 20,000 acres.

\section{Wetland Enhancement}

The annual enhancement objective for existing wetlands in American Basin is 266 acres/year. Wetland enhancement objectives increase to 1,932 acres/year when wetland restoration objectives are met for the basin (Table 4-9).

\section{Water Supplies for Seasonal Wetland Management}

Annual management of seasonal wetlands in American Basin will require 115,945 acre-feet of water when wetland restoration objectives in the basin have been met. These annual water requirements are further broken down by time period to reflect flooding and summer irrigation needs (Table 4-10).

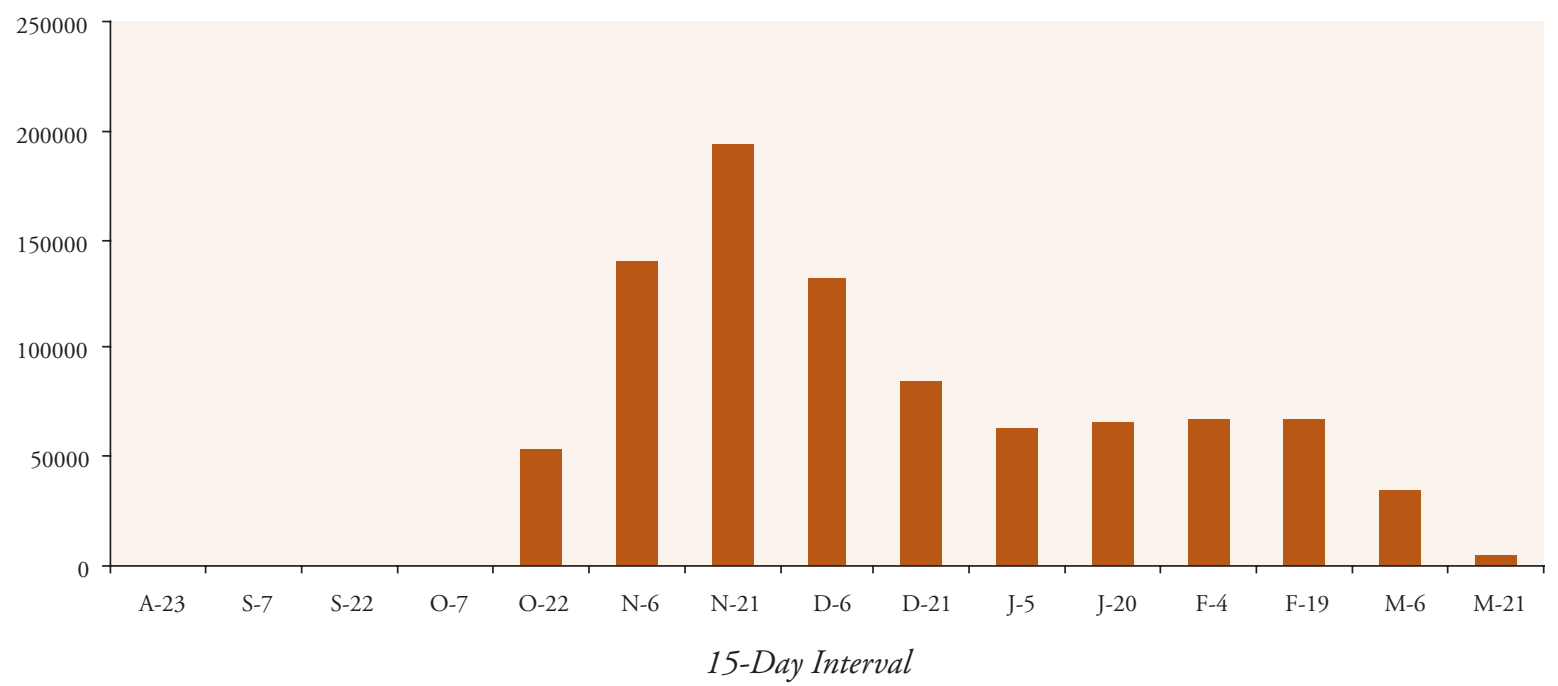

Figure 4-18. Population objectives by 15-day intervals for dark geese in American Basin. 


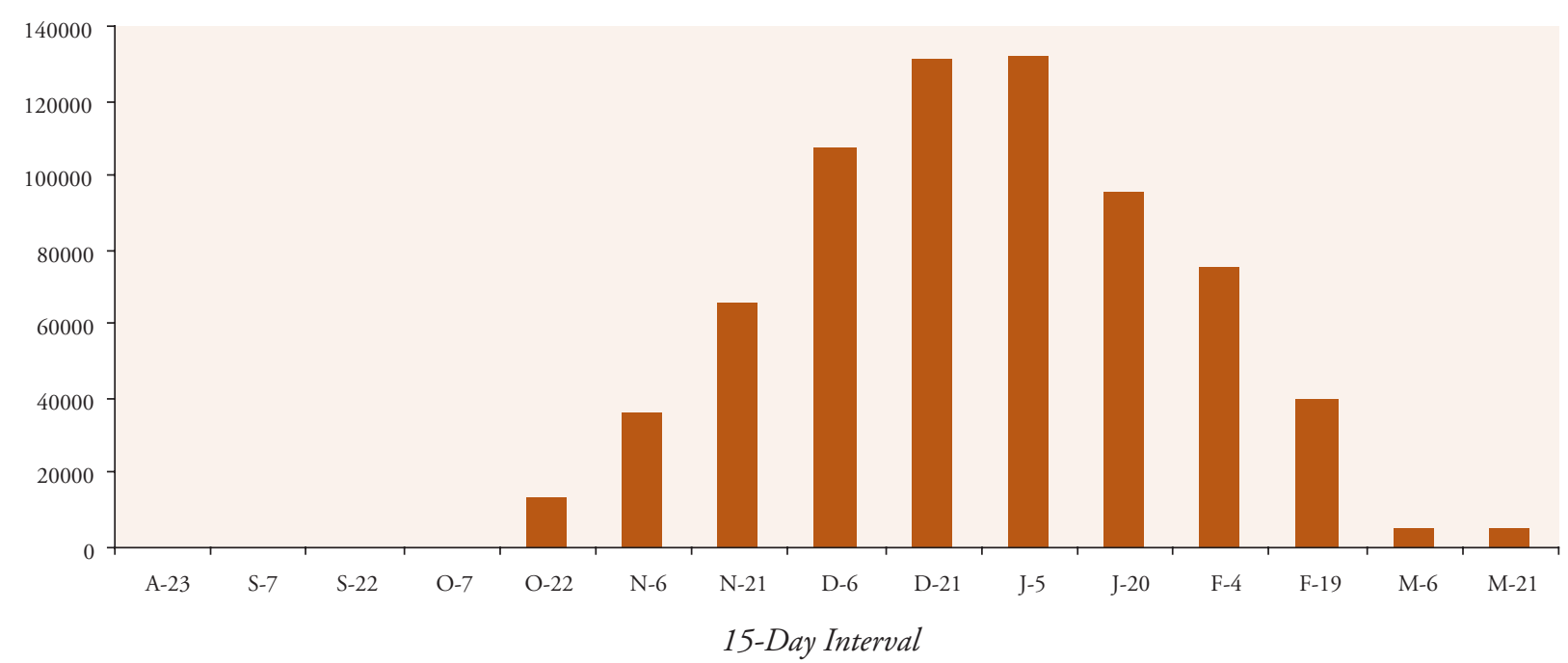

Figure 4-19. Population objectives by 15-day intervals for white geese in American Basin.

Table 4-8. Foraging habitats available to wintering waterfowl in the American Basin.

\begin{tabular}{|cccc|}
$\begin{array}{c}\text { Seasonal } \\
\text { Wetlands }\end{array}$ & $\begin{array}{c}\text { Flooded } \\
\text { Rice }\end{array}$ & $\begin{array}{c}\text { Unflooded } \\
\text { Rice }\end{array}$ & Corn \\
\hline 3,187 & 72,049 & 21,014 & 1,146 \\
\hline
\end{tabular}

\section{Agricultural Enhancement}

The agricultural enhancement objective for American Basin is 69,000 acres, all of which is assumed to be rice. This objective represents the amount of rice habitat that must be maintained in a waterfowl-friendly state when wetland restoration objectives have been met for the basin. Fifty thousand of these acres must be winter-flooded to meet duck energy needs. Waterfowl-friendly rice habitat in the basin is currently estimated at over 93,000 acres with over 72,000 of these acres winterflooded (Table 4-11). Agricultural enhancement objectives are currently exceeded for the basin.

\section{Agricultural Easements for Maintaining Waterfowl Foods (Type I)}

Agricultural habitats are extremely important to waterfowl in American Basin and provide $95 \%$ of the food energy now available to ducks (Figure 4-22). The loss of irrigated farmland in the basin by 2040 is predicted to be 40,000 acres or $16 \%$ of all irrigated lands (Figure 3-15). At least 16,000 acres will be riceland. This projected loss of rice should be considered a minimum because most development is occurring in rice growing areas and is not equally distributed among the different types of irrigated farmland (Figure 4-23). Most wetland restoration occurs on rice ground, and meeting wetland restoration goals for the basin could reduce rice acreage by an additional 20,000 acres. Planted rice in the basin is estimated at about 100,000 acres (Table 3-4). However, this figure could be reduced by a minimum of 36,000 acres if growth projections are accurate and wetland restoration objectives are met. This reduction in the rice base would make it extremely difficult to meet the basin's 69,000 acre objective for waterfowl-friendly rice (Figure 4-24). These forecasts suggest that easements to maintain agricultural foods are needed in the basin.

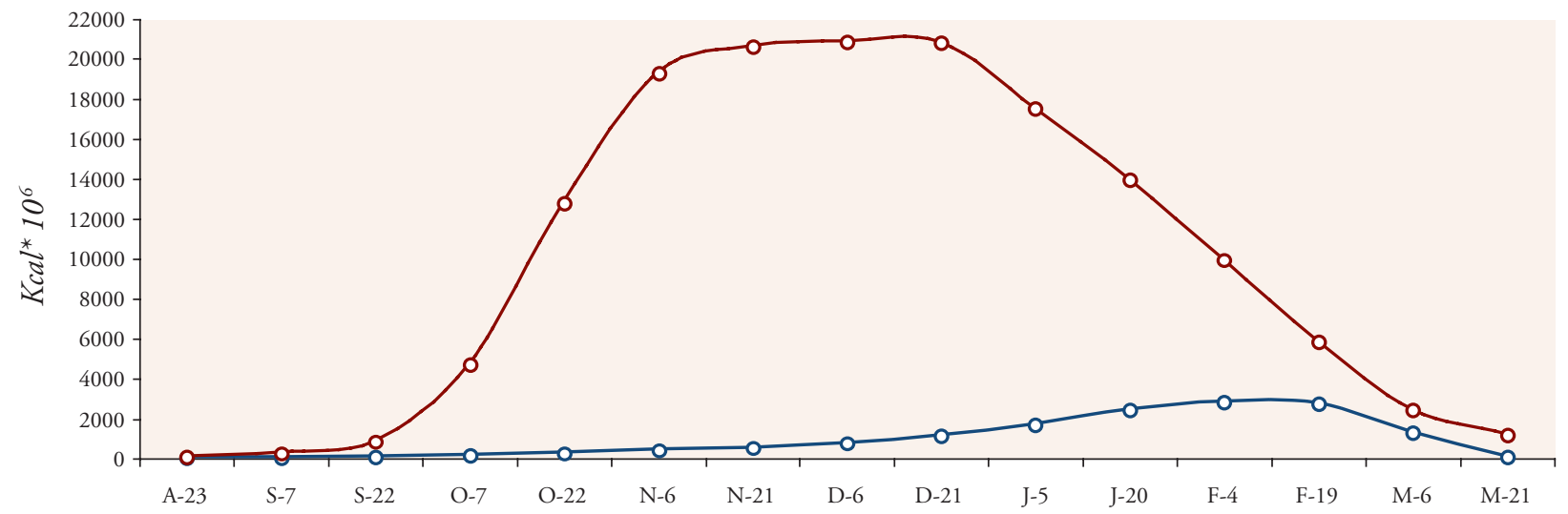

Figure 4-20. Population energy demand (blue) vs. food energy supply (red) for ducks in American Basin when duck populations are at NAWMP goals. 


\section{Agricultural Easements To Buffer Residential and Urban Growth (Type II)}

Large wetland complexes that would benefit from Type II agricultural easements are currently lacking in the American Basin. However these complexes will develop if wetland restoration objectives are met. Agricultural easements to buffer the effects of growth will likely be needed at that time given growth projections for the basin.

\section{Conservation Objective Priorities}

Conservation objectives for the American Basin are summarized in Table 4-12. The information used to prioritize conservation objectives for American Basin is presented in Figure 4-25. Food supplies exceed 100\% of duck needs and were classified as high, though habitat protection was rated as very low (7\%). Progress in meeting wetland needs is also very low (3,178 acres present vs. 23,178 needed; or $13.7 \%$ of need). Loss of irrigated farmland is predicted to be high, and future reductions in the basin's rice acreage may make it difficult to meet agricultural enhancement objectives.

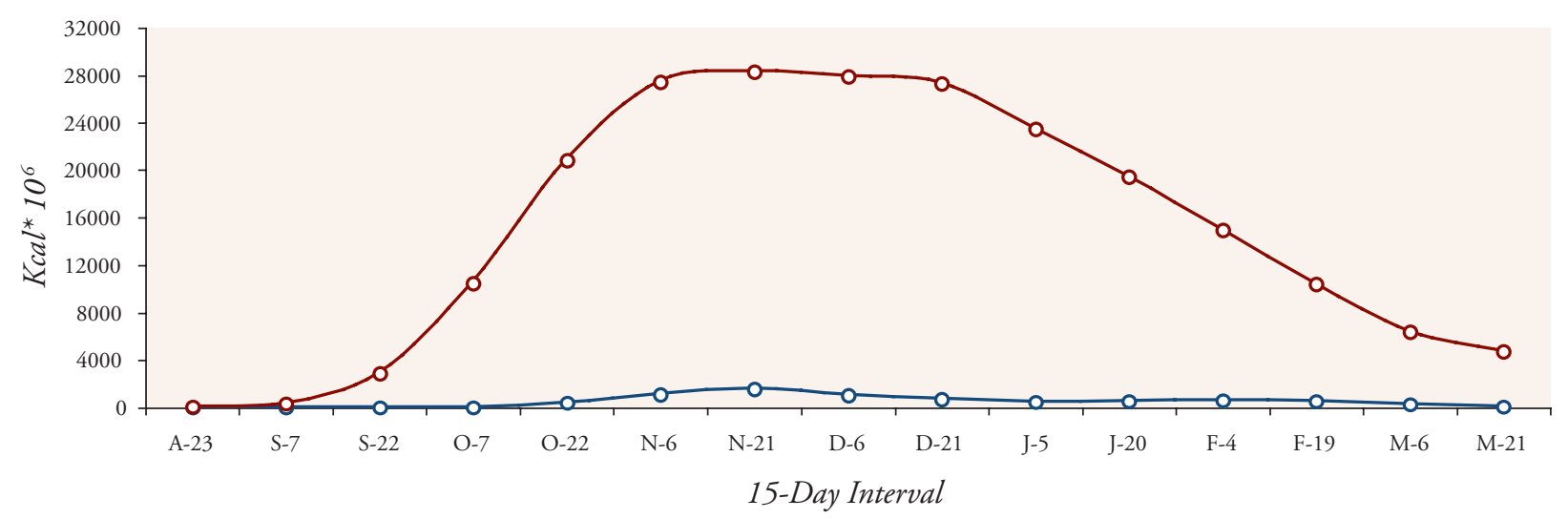

Figure 4-21 (a). Dark goose population energy demand (blue) vs. food energy supplies (red) in American Basin.

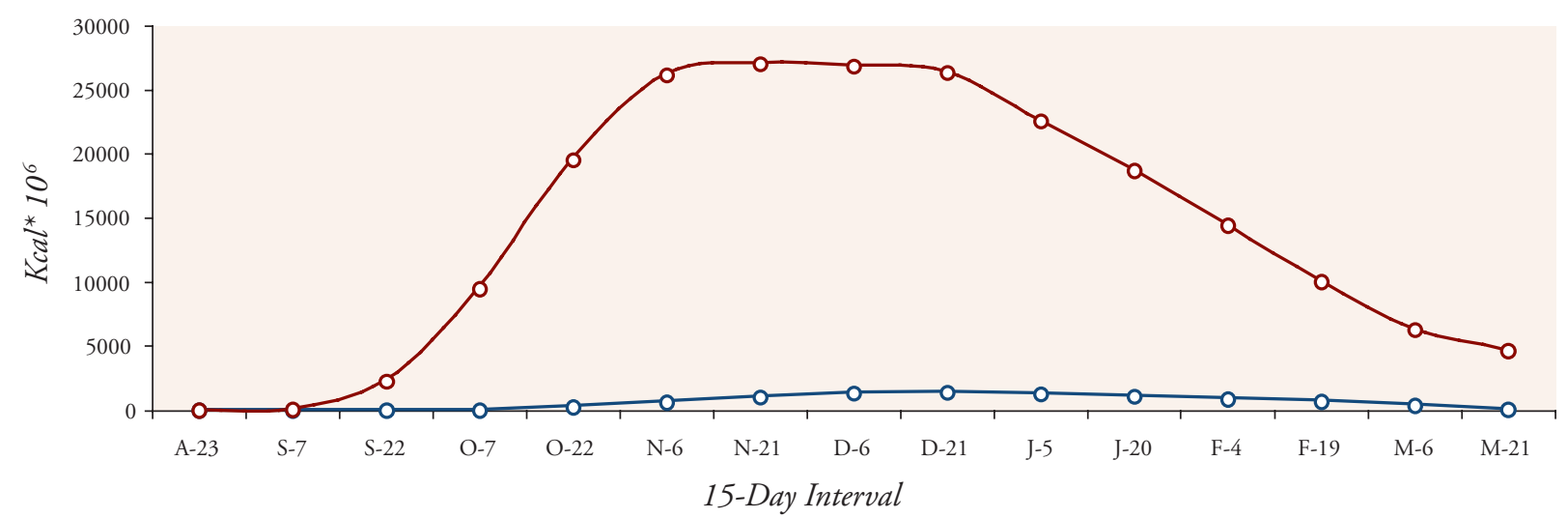

Figure 4-21 (b). White goose population energy demand (blue) vs. food energy supplies (red) in American Basin. 


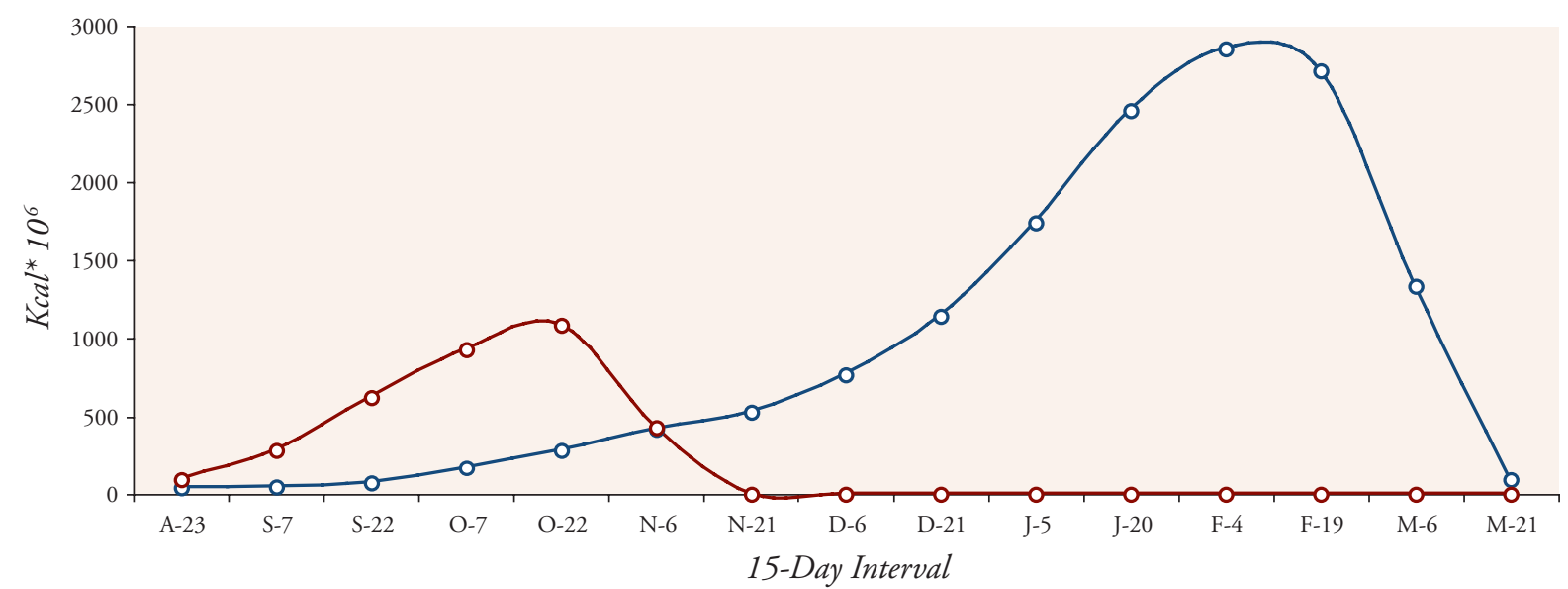

Figure 4-22. Population energy demand (blue) vs. food energy supply (red) for ducks in American Basin when no agricultural food supplies are available.

Wetland restoration is a priority for American Basin, because less than $14 \%$ of wetland needs have been met for ducks. Establishing an easement program to protect agricultural food sources should also be considered a priority in the immediate future.

Table 4-9. Annual wetland enhancement objectives for American Basin.

\begin{tabular}{|cc|}
\hline Wetland Acres & $\begin{array}{c}\text { Annual Enhancement } \\
\text { Objective }^{(\text {Acres) }}{ }^{c}\end{array}$ \\
\hline $3,187^{a}$ & 266 \\
5,187 & 432 \\
7,187 & 599 \\
9,187 & 766 \\
11,187 & 932 \\
13,187 & 1,098 \\
15,187 & 1,265 \\
17,187 & 1,432 \\
19,187 & 1,599 \\
21,187 & 1,766 \\
$23,187^{b}$ & 1,932 \\
\hline
\end{tabular}

${ }^{a}$ Current acres of wetlands in the American Basin.

${ }^{b}$ Acres of wetlands in the American Basin when wetland restoration objectives are met.

'Annual enhancement objectives reflect progress in meeting wetland restoration objectives for American Basin.
Table 4-10. Water needs for seasonal wetlands in American Basin.

\begin{tabular}{|cc|} 
Month & $\begin{array}{c}\text { Water Need } \\
\text { (Acre-Feet) }\end{array}$ \\
\hline JANUARY & 4,636 \\
FEBRUARY & 4,636 \\
MARCH & 4,636 \\
APRIL & 0 \\
MAY & 16,225 \\
JUNE & 0 \\
JULY & 0 \\
\hline AUGUST & 20,860 \\
SEPTEMBER & 41,720 \\
OCTOBER & 9,271 \\
NOVEMBER & 9,271 \\
DECEMBER & 4,636 \\
ANNUAL NeED & $\mathbf{1 1 5 , 8 9 0}$ \\
\hline
\end{tabular}

Table 4-11. Agricultural enhancement objectives for American Basin.

\begin{tabular}{|c|c|c|}
\hline & $\begin{array}{l}\text { Waterfowl- } \\
\text { friendly Rice }{ }^{a}\end{array}$ & $\begin{array}{l}\text { Flooded } \\
\text { Rice }\end{array}$ \\
\hline ОвJестіVе & 69,000 & 50,000 \\
\hline Current & $93,063^{b}$ & 72,049 \\
\hline
\end{tabular}

${ }^{a}$ Waterfowl-friendly rice includes rice that is flooded and rice that is not deep plowed following harvest but which remains dry. ${ }^{b}$ Planted rice acreage in American Basin is estimated at 100,000 acres (Table 3-6). The $J V$ assumes that 93,063 of these acres provide waterfowl-friendly habitat.

Table 4-12. Conservation objectives for wintering waterfowl in American Basin.

\begin{tabular}{|c|c|c|c|c|c|}
\hline $\begin{array}{c}\text { Wetland Restoration } \\
\text { (Acres) }\end{array}$ & $\begin{array}{c}\text { Wetland } \\
\text { Enhancement } \\
\text { (Acres) }\end{array}$ & $\begin{array}{l}\text { Water Supplies } \\
\text { (Acre-Feet) }\end{array}$ & $\begin{array}{c}\text { Agricultural } \\
\text { Enhancement } \\
\text { (Acres) }\end{array}$ & $\begin{array}{c}\text { Type I Agricultural } \\
\text { Easements }\end{array}$ & $\begin{array}{c}\text { Type II Agricultural } \\
\text { Easements }\end{array}$ \\
\hline
\end{tabular}

"Annual enhancement objective when the wetland restoration objective is met.

${ }^{b}$ Annual water supply need when the wetland restoration objective is met.

'Total acres of rice that must be enhanced (includes 50,000 acres that must be flooded). Objective has been met.

${ }^{d}$ Total acres of rice that must be flooded out of the total enhancement objective of 69,000 acres. Objective has been met. 


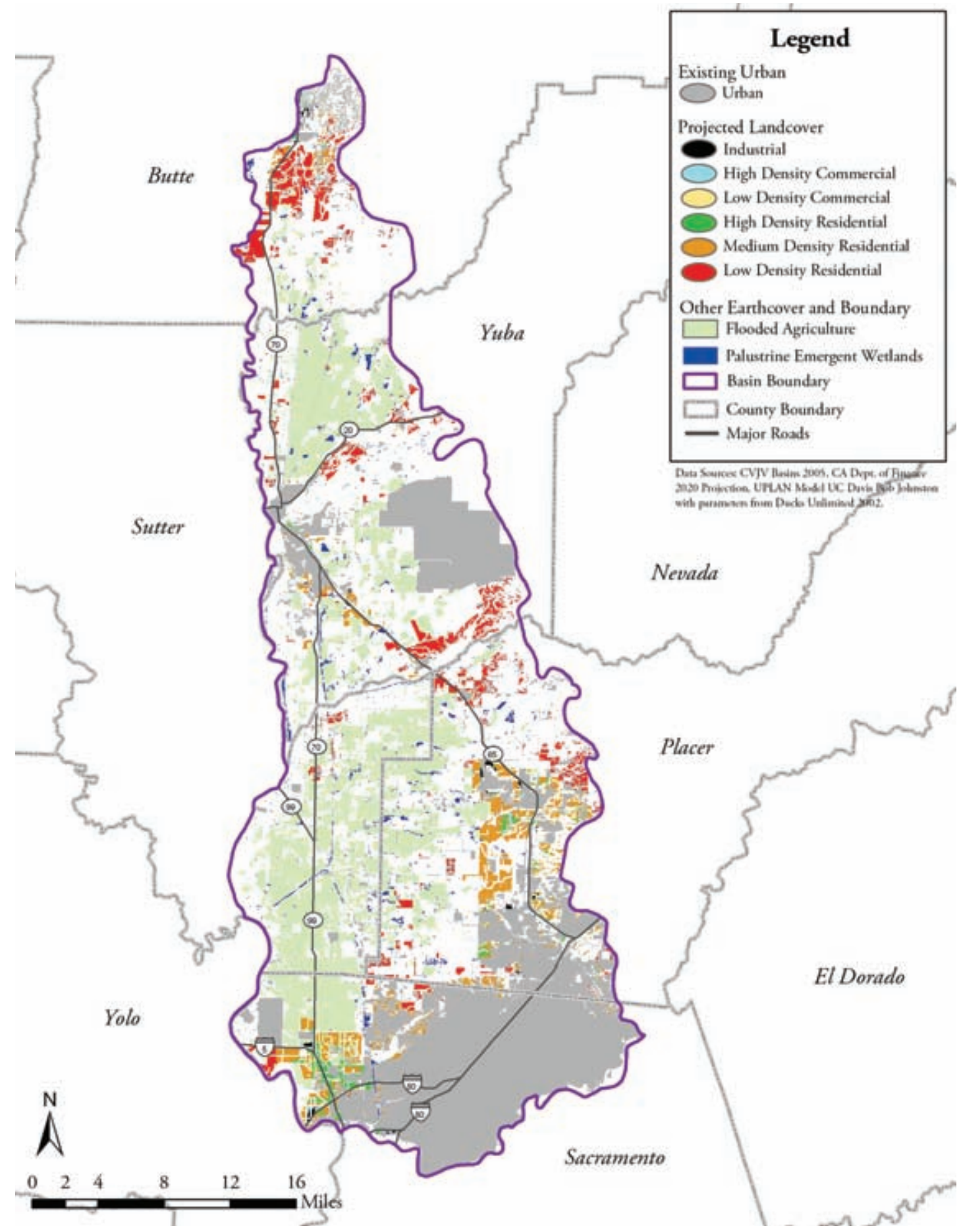

Figure 4-23. Projected growth in American Basin to 2020. 


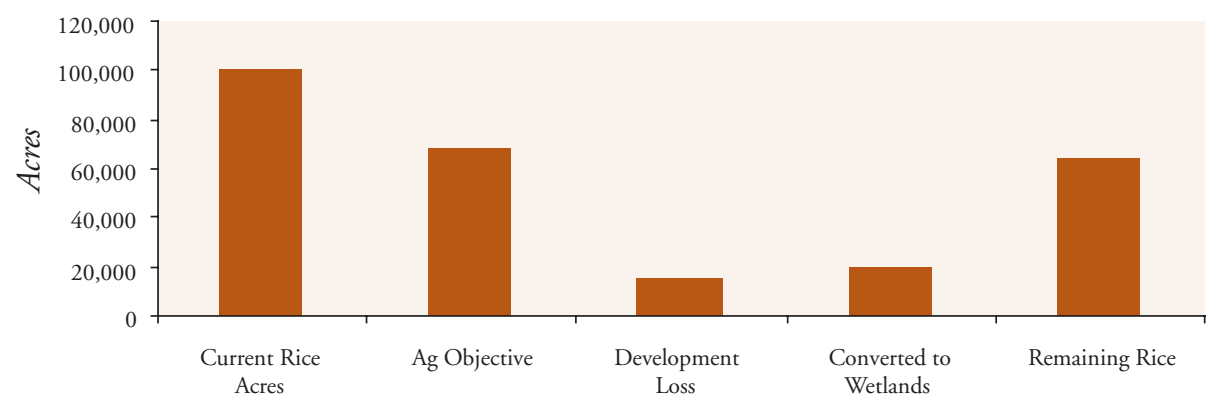

Figure 4-24. Forecasted changes in rice acreage for the American Basin compared to the basin's agricultural enhancement objective.

\begin{tabular}{|c|c|c|c|c|c|}
\hline $\begin{array}{l}\text { Current Food } \\
\text { Supplies for } \\
\text { Ducks }\end{array}$ & $\begin{array}{c}\text { Overall Level } \\
\text { of Habitat } \\
\text { Protection }\end{array}$ & $\begin{array}{c}\text { Progress } \\
\text { in Meeting } \\
\text { Wetland Need }\end{array}$ & $\begin{array}{l}\text { Population } \\
\text { Growth }\end{array}$ & $\begin{array}{l}\text { Loss of Irrigated } \\
\text { Farmland }\end{array}$ & $\begin{array}{c}\text { Conservation } \\
\text { Objective Priorities }\end{array}$ \\
\hline High & High & High & $\mathrm{HIGH}$ & High & $\begin{array}{c}\text { WETLAND } \\
\text { RESTORATION }\end{array}$ \\
\hline Moderate & Moderate & Moderate & Moderate & Moderate & $\begin{array}{c}\text { Type I Agricultural } \\
\text { EASEMENTS }\end{array}$ \\
\hline \multirow[t]{2}{*}{ Low } & Low & Low & Low & Low & \\
\hline & VERY LOW & VERY LOW & VERY LOW & & \\
\hline
\end{tabular}

Figure 4-25. Factors used to identify conservation objective priorities for American Basin.

\section{Butte Basin}

\section{Population Energy Demand vs. Food Energy Supplies: Current Conditions}

Population objectives for wintering waterfowl in Butte Basin are presented in Figures 4-26 through 4-28. Duck and white goose population objectives are highest during late December, while population objectives for dark geese peak during November. Although rice provides the majority of foraging habitat in the basin, seasonal wetlands exceed 23,000 acres (Table 4-13).

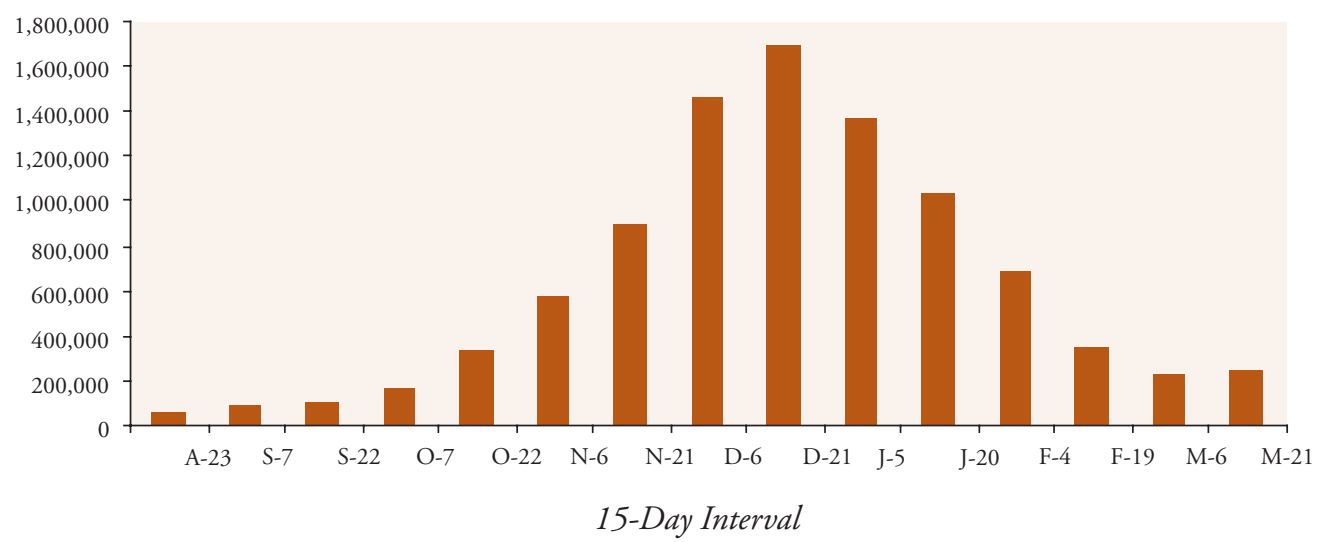

Figure 4-26. Population objectives by 15-day intervals for ducks in Butte Basin. 
Food supplies for Butte Basin ducks are adequate in all time periods. Peak food supplies occur in November and December and coincide with high duck use of the basin (Figure 4-29). Dark and white goose food supplies are also well above population needs and large food surpluses occur in all time periods (Figure 4-30). Agricultural habitats provide $74 \%$ of the food energy available to ducks in the basin. Loss of these agricultural foods would significantly reduce carrying capacity, because food supplies are exhausted by mid-December if ducks are restricted to foraging in wetlands (Figure 4-31). Public wetlands alone can only meet duck needs through early November (Figure 4-32), though most duck use of the basin occurs after this date.

\section{Conservation Objectives}

\section{Wetland Restoration}

The amount of seasonal wetlands required to meet $50 \%$ of duck energy needs in Butte Basin is estimated at 40,340 acres. There are currently 23,340 acres of seasonal wetlands in the basin, leaving a wetland restoration goal of 17,000 acres.

\section{Wetland Enhancement}

The annual enhancement objective for existing wetlands in Butte Basin is 1,945 acres/year. Wetland enhancement objectives increase to 3,362 acres/year when wetland restoration objectives are met for the basin (Table 4-14).

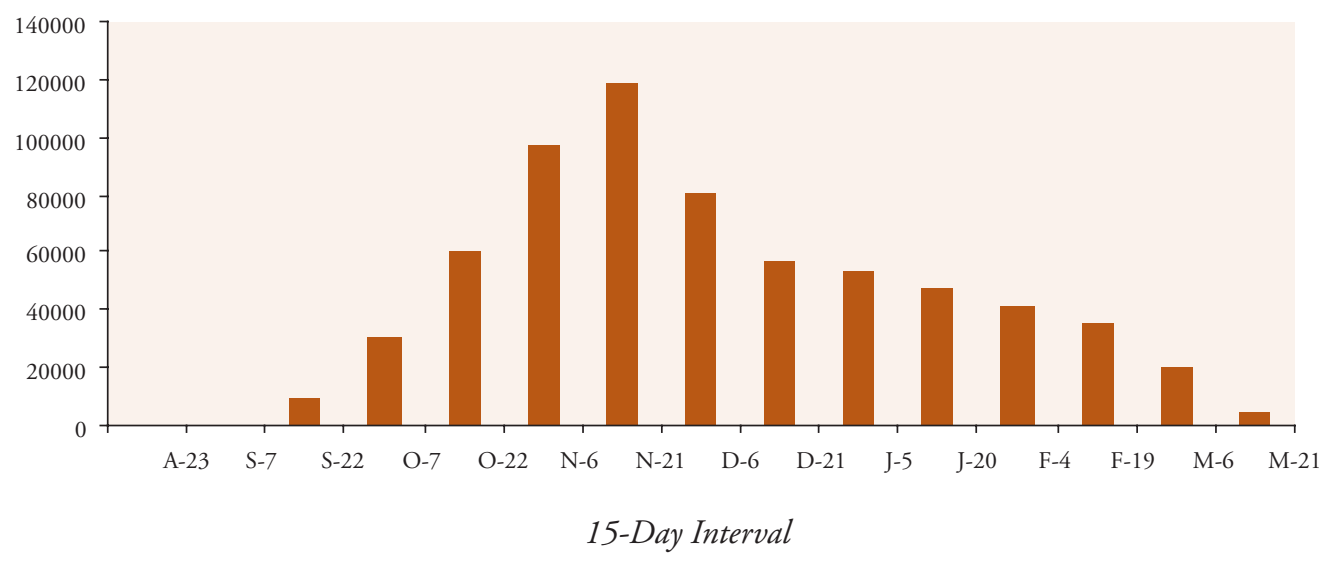

Figure 4-27. Population objectives by 15-day intervals for dark geese in Butte Basin.

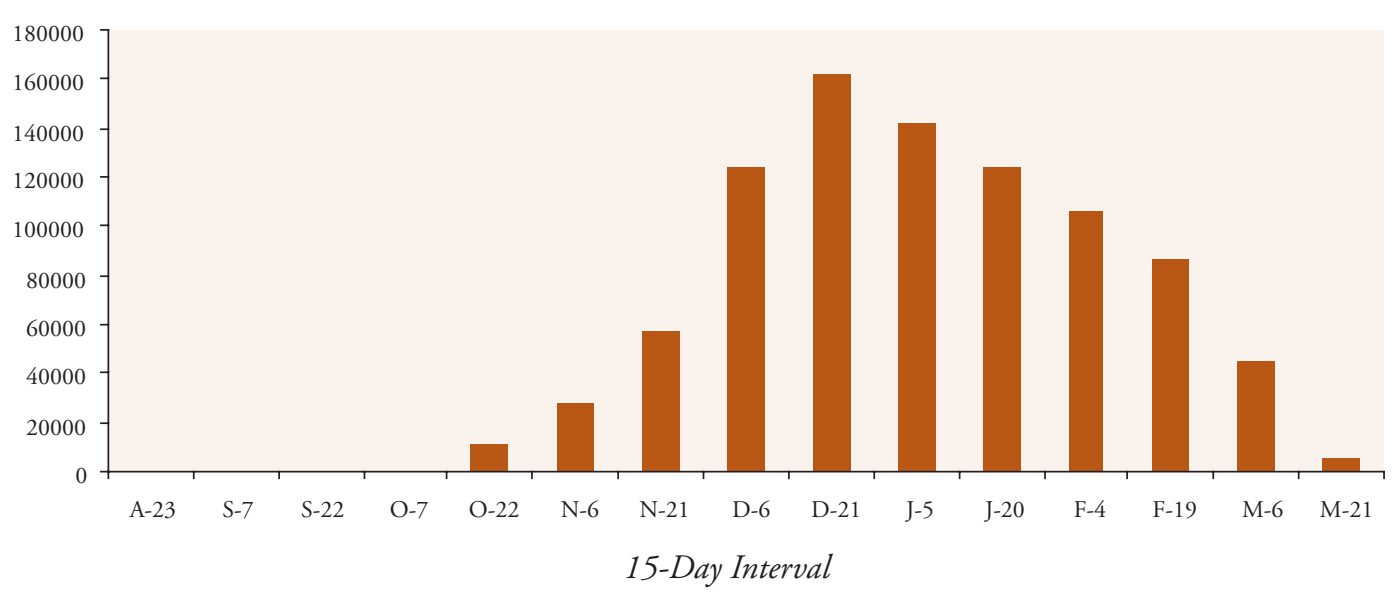

Figure 4-28. Population objectives by 15-day intervals for white geese in Butte Basin. 


\begin{tabular}{|cccc|}
\hline Seasonal Wetlands & Flooded Rice & Unflooded Rice & Corn \\
\hline 23,340 & 99,494 & 29,019 & 2,510 \\
\hline
\end{tabular}

\section{Water Supplies for Seasonal Wetland Management}

Annual management of seasonal wetlands in Butte Basin will require 225,904 acre-feet of water when wetland restoration objectives in the Basin have been met. These annual water requirements are further broken down by time period to reflect flooding schedules and summer irrigation needs (Table 4-15).

\section{Agricultural Enhancement}

The agricultural enhancement objective for Butte Basin is 104,000 acres, all of which is assumed to be rice. This objective represents the amount of rice habitat that must be maintained in a waterfowl-friendly state when wetland restoration objectives have been met for the basin. Sixty-two thousand of these acres must be winter-flooded to meet duck energy needs. Waterfowl-friendly rice habitat in the basin is currently estimated at over 128,000 acres with nearly 100,000 of these acres winter-flooded (Table 4-16). Agricultural enhancement objectives are currently exceeded for the basin.

\section{Agricultural Easements for Maintaining Waterfowl Foods}

Agricultural habitats are extremely important to waterfowl in Butte Basin and provide $74 \%$ of the food energy now available to ducks (Figure 4-31). The loss of irrigated farmland in the basin by 2040 is predicted to be almost 24,000 acres or $9 \%$ of existing lands (Figure 3-15). Nearly 13,000 of these acres are predicted to be rice (Table 3-4). Most wetland restoration occurs on rice ground, and meeting wetland restoration goals for the basin could reduce rice acreage by an additional 17,000 acres. (Table 4-16). Planted rice in the basin is estimated at 138,000 acres (Table 3-4). However, that figure may be reduced by 30,000 acres if growth projections are accurate and wetland restoration objectives are met. This reduction in the rice base could make it increasingly difficult to meet the basin's 104,000 acre objective for waterfowl-friendly rice (Figure 4-33).

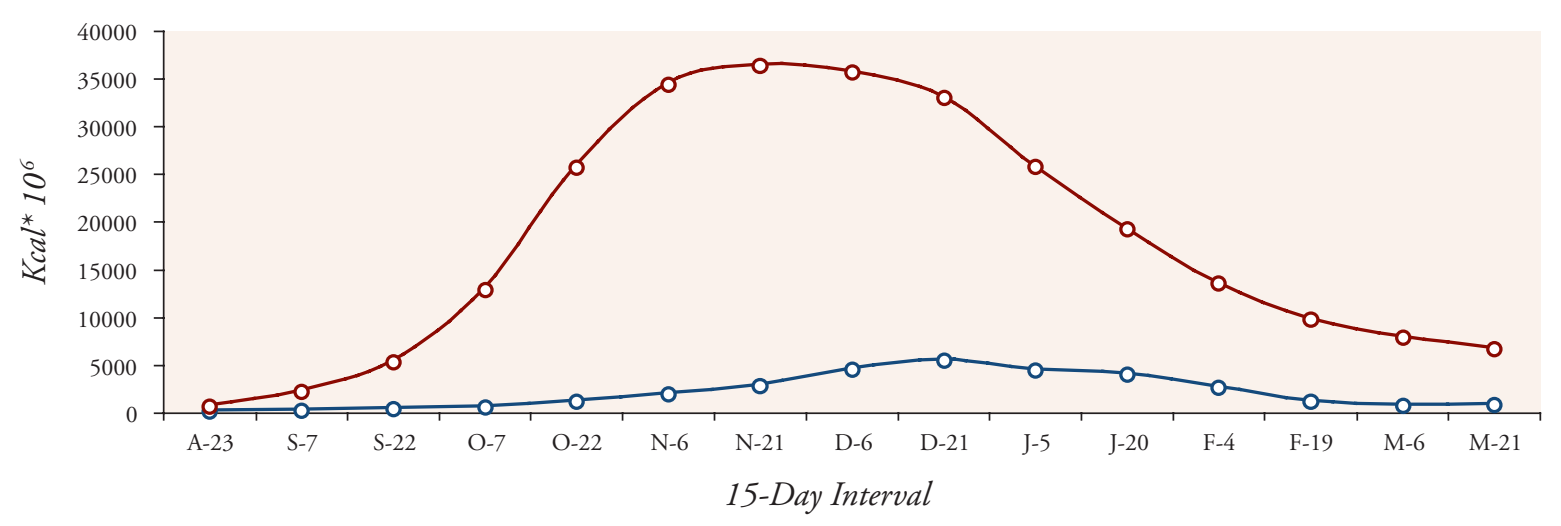

Figure 4-29. Population energy demand (blue) vs. food energy supply (red) for ducks in Butte Basin when duck populations are at NAWMP goals.

\section{Agricultural Easements to Buffer Residential and Urban Growth}

Growth projections for Butte Basin indicate that low-density residential housing southeast of Gridley may eventually abut key wetland habitats in the Butte Sink area, especially near Gray Lodge Wildlife Area (Figure 4-34). An easement program northeast of Gray Lodge could buffer the effects of this development. 


\section{Conservation Priorities}

Conservation objectives for the Butte Basin are summarized in Table 4-17. The information used to prioritize these objectives is provided in Figure 4-35. Food supplies exceed 100\% of duck needs and were classified as high, though habitat protection in the basin is low (29\%). Progress in meeting wetland needs was rated medium (23,340 acres present vs. 40,340 acres needed; or $58 \%$ of need), while 2040 population forecasts for the basin are low at 237,000 people. Although agricultural enhancement objectives are currently met for the basin, the loss of rice habitat to development is projected to be 13,000 acres by 2040 . Therefore, meeting wetland restoration objectives may diminish the planted rice base by a further 17,000 acres.

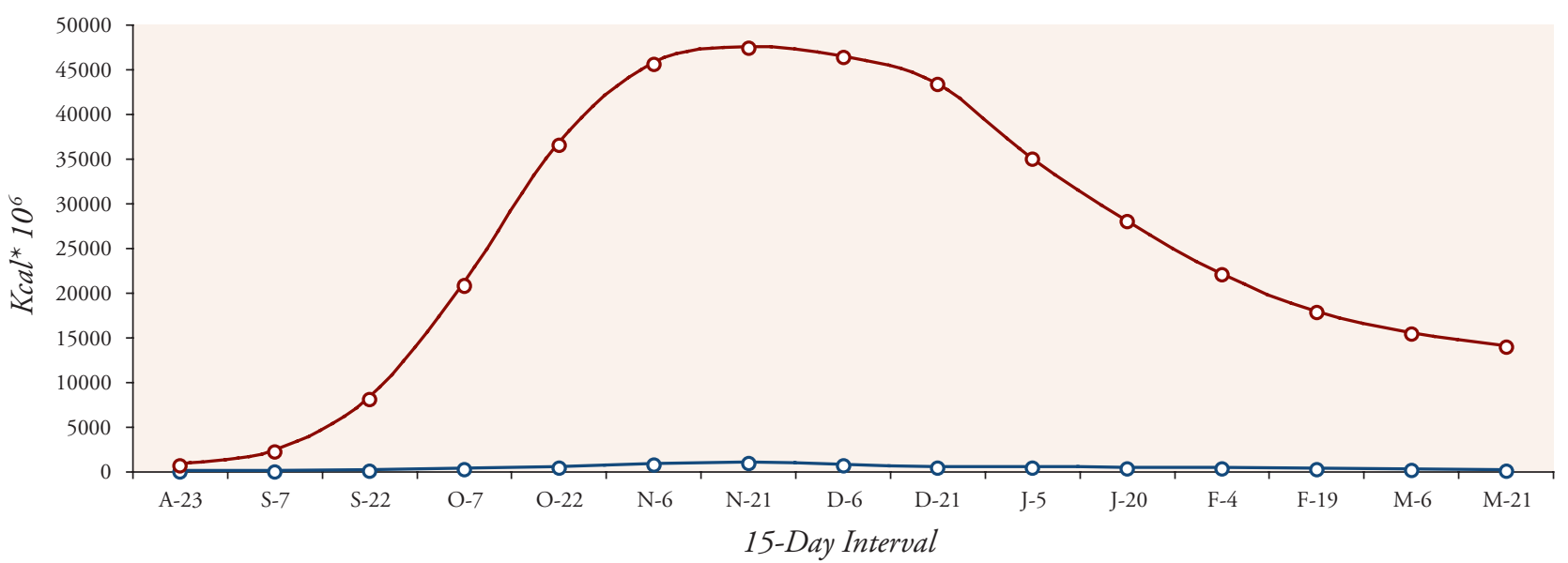

Figure 4-30 (a). Dark goose population energy demand (blue) vs. food energy supplies (red) in Butte Basin.

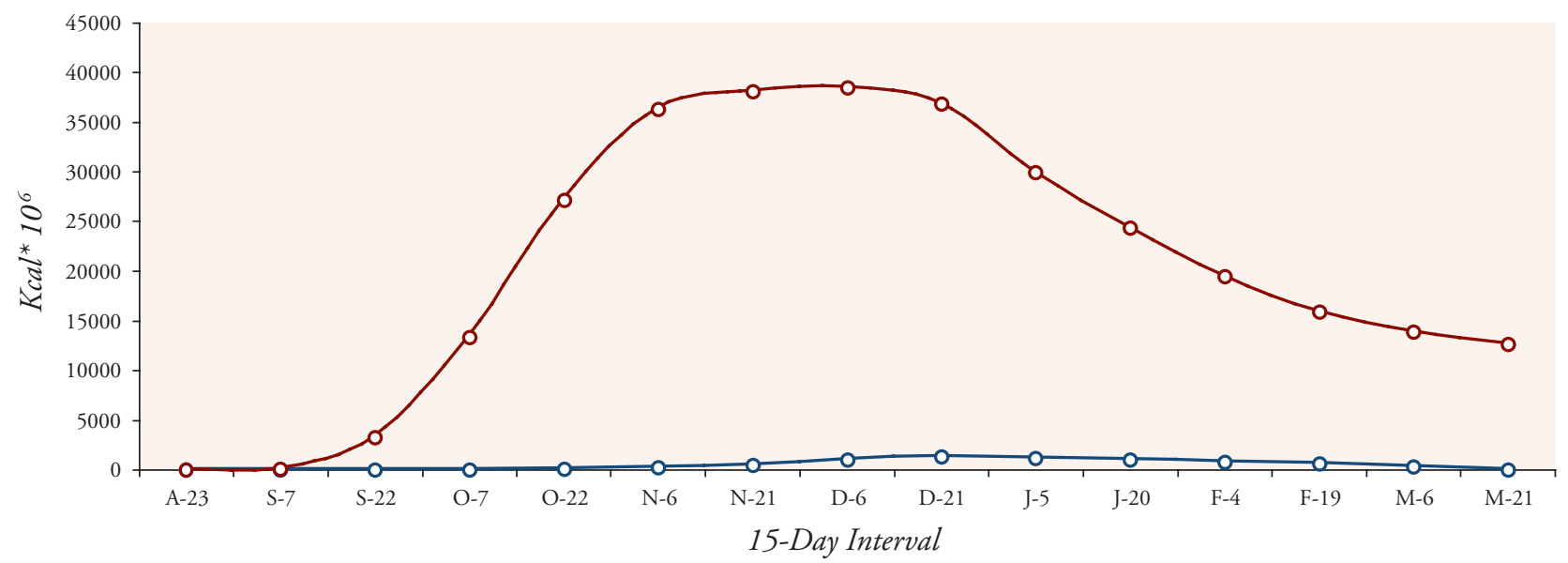

Figure 4-30 (b). White goose population energy demand (blue) vs. food energy supplies (red) in Butte Basin.

Wetland restoration may be a priority for Butte Basin, especially in the short term, as less than $60 \%$ of wetland needs have been met for ducks. Although agricultural enhancement objectives are currently met, forecasted declines in the basin's rice acreage may require an easement program that maintains agricultural food supplies. 
Table 4-14. Annual wetland enhancement objectives for Butte Basin.

\begin{tabular}{|cc|}
$\begin{array}{c}\text { Wetlands } \\
\text { Acres }\end{array}$ & $\begin{array}{c}\text { Annual Enhancement } \\
\text { Objective (Acres) }\end{array}$ \\
\hline $23,340^{a}$ & 1,945 \\
25,340 & 2,112 \\
27,340 & 2,278 \\
29,340 & 2,445 \\
31,340 & 2,612 \\
33,340 & 2,778 \\
35,340 & 2,945 \\
37,340 & 3,112 \\
39,340 & 3,278 \\
$40,340^{b}$ & 3,362 \\
\hline
\end{tabular}

${ }^{a}$ Current acres of wetlands in Butte Basin. ${ }^{b}$ Acres of wetlands in Butte Basin when wetland restoration objectives are met.

'Annual enhancement objectives reflect progress in meeting wetland restoration objectives for Butte Basin.
Table 4-15. Water needs for seasonal wetlands in Butte Basin.

\begin{tabular}{|cc|} 
Month & $\begin{array}{c}\text { Water Need } \\
\text { (Acre-Feet })\end{array}$ \\
\hline JANUARY & 8,068 \\
FEBRUARY & 8,068 \\
MARCH & 8,068 \\
APRIL & 0 \\
MAY & 40,340 \\
JUNE & 0 \\
JULY & 0 \\
\hline AUGUST & 36,306 \\
SEPTEMBER & 80,680 \\
OCTOBER & 20,170 \\
NOVEMBER & 16,136 \\
DECEMBER & 3,227 \\
ANNUAL NeED & $\mathbf{2 2 5 , 9 0 4}$ \\
\hline
\end{tabular}

Table 4-16. Agricultural enhancement objectives for Butte Basin

\begin{tabular}{|ccc|}
\hline & $\begin{array}{c}\text { Waterfowl- } \\
\text { friendly } \text { Rice }^{a}\end{array}$ & $\begin{array}{c}\text { Flooded } \\
\text { Rice }\end{array}$ \\
\hline OBJECTIVE & 104,000 & 62,000 \\
CURRENT & $128,513^{b}$ & 99,494 \\
\hline
\end{tabular}

${ }^{a}$ Waterfowl-friendly rice includes rice that is flooded and rice that is not deep plowed following harvest but which remains dry. ${ }^{b}$ Planted rice acreage in Butte Basin is estimated at 138,186 acres (Table 3-6). The $J V$ assumes that 128,513 of these acres provide waterfowl-friendly habitat. 


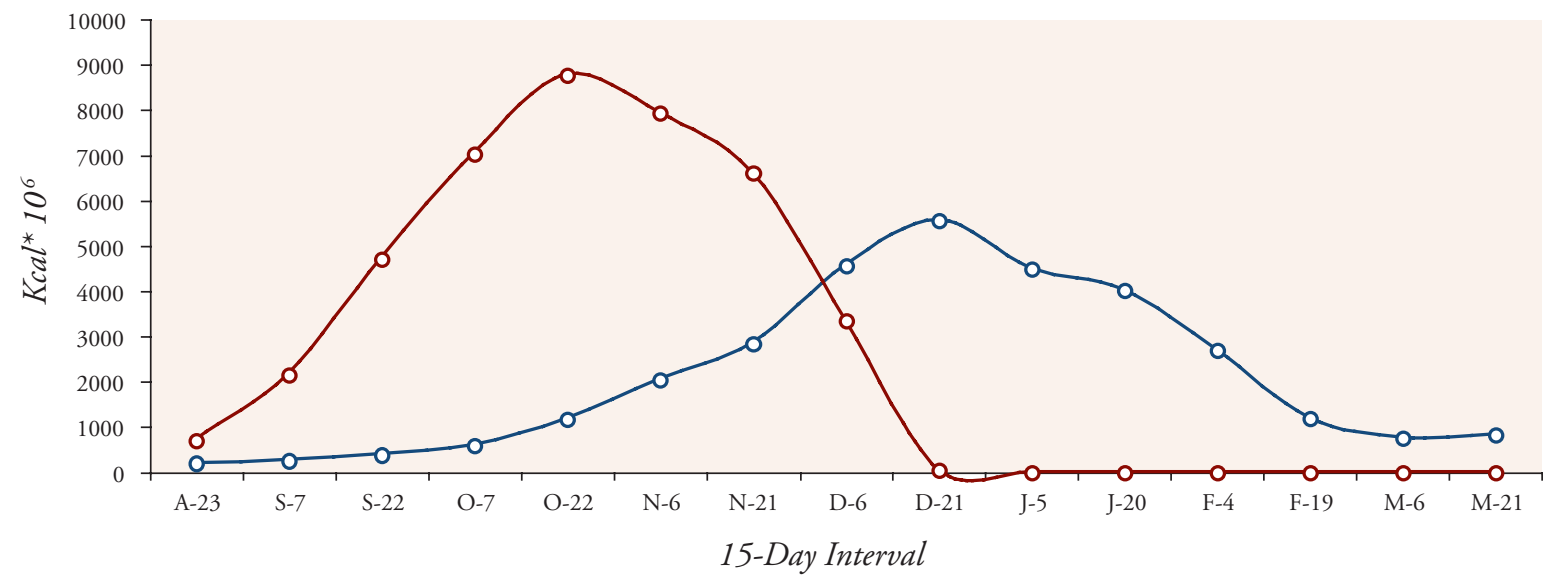

Figure 4-31. Population energy demand (blue) vs. food energy supply (red) for ducks in Butte Basin when no agricultural food sources are available.

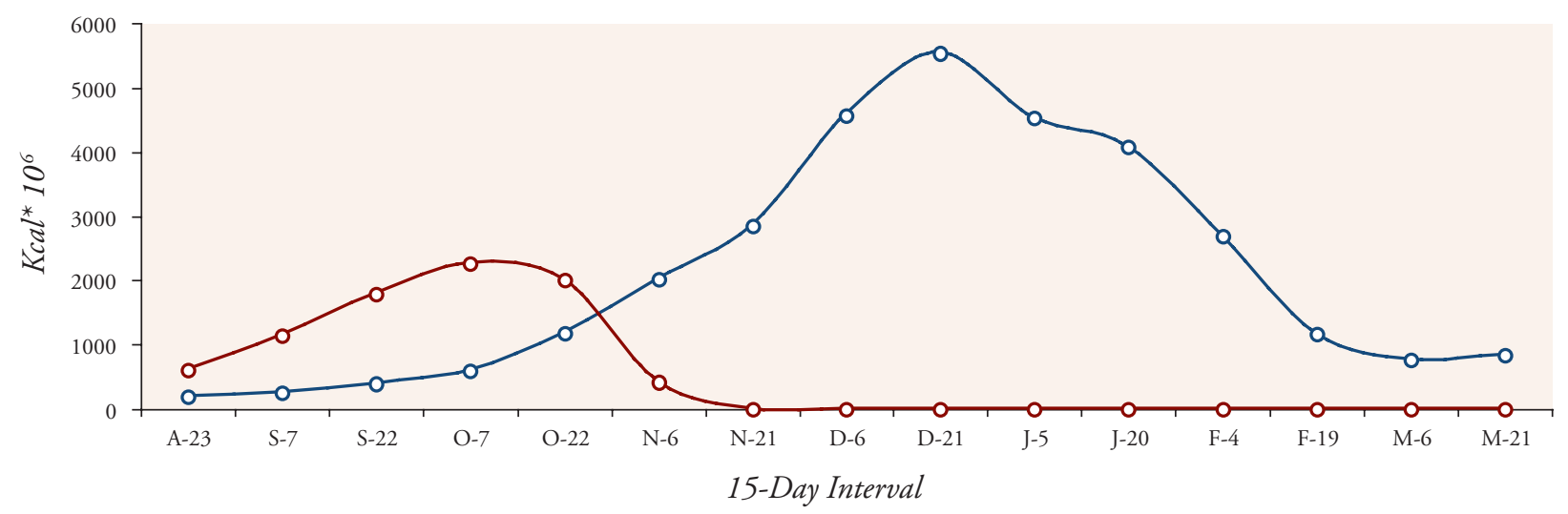

Figure 4-32. Population energy demand (blue) vs. food energy supply (red) for ducks in Butte Basin if ducks are restricted to foraging on public lands.

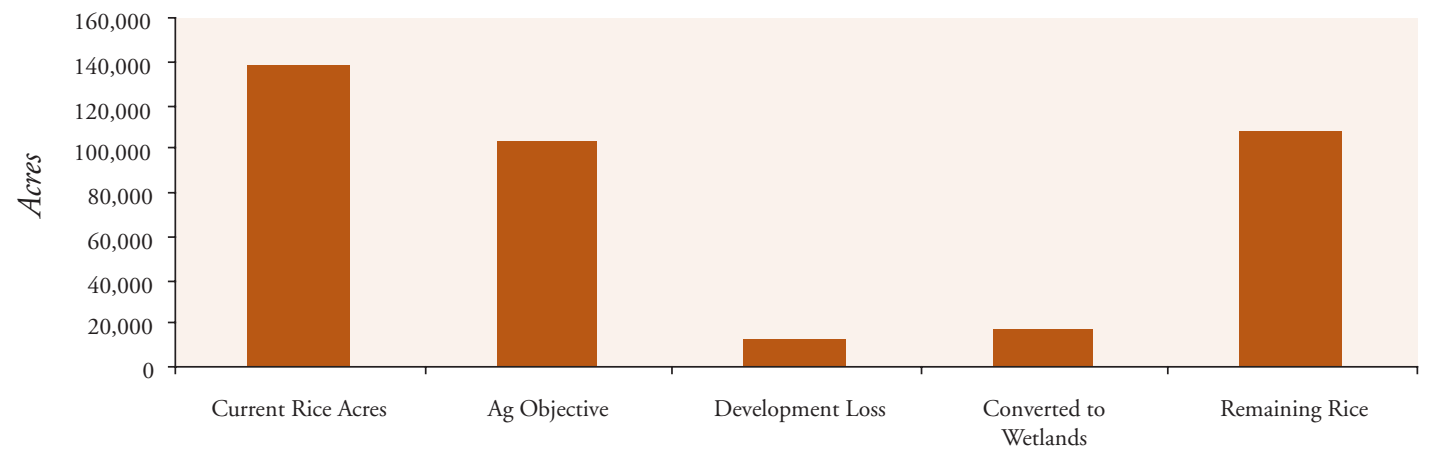

Figure 4-33. Forecasted changes in rice acreage for Butte Basin compared to the basin's agricultural enhancement objective. 


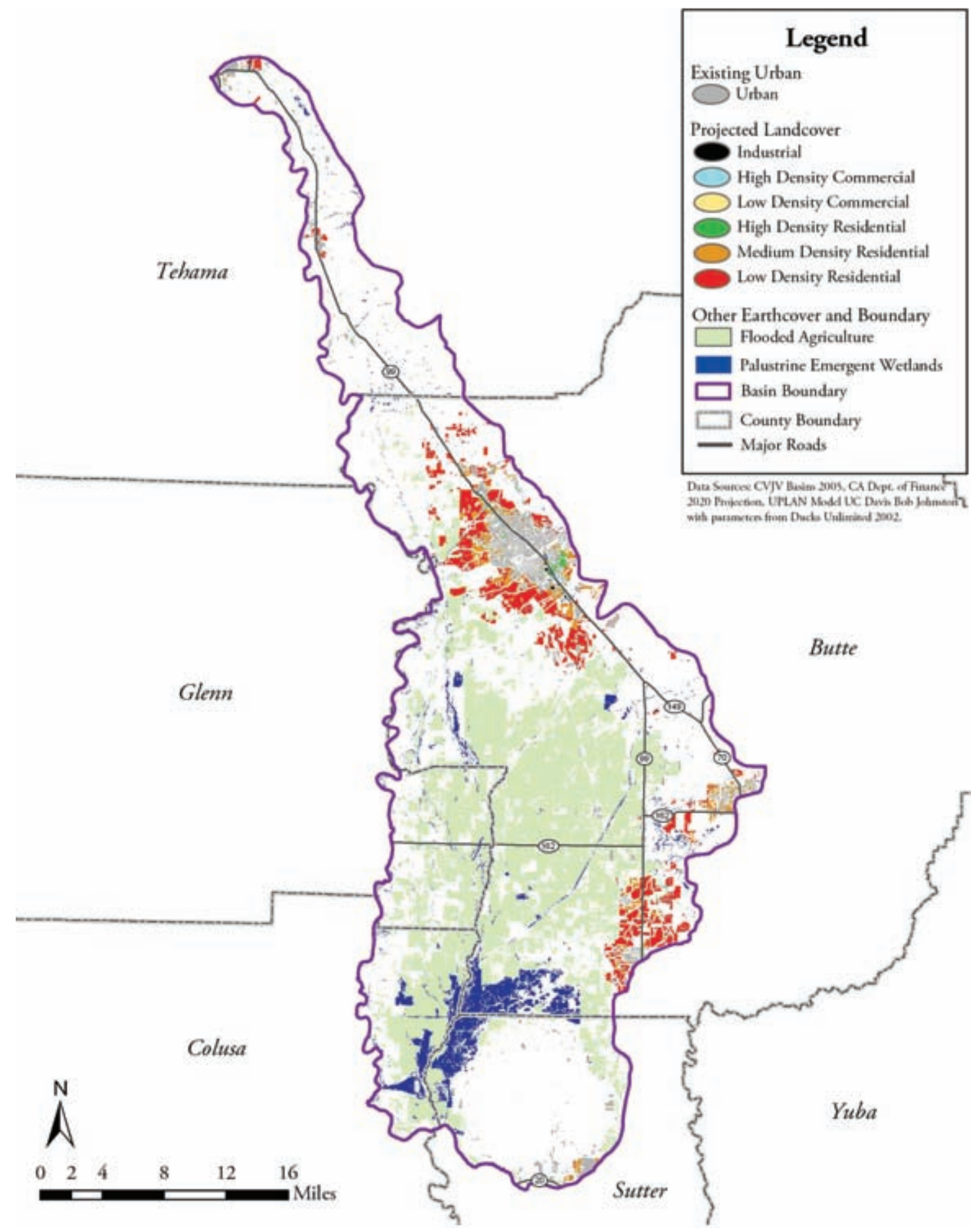

Figure 4-34. Projected growth in Butte Basin to 2020. 
Table 4-17. Conservation objectives for wintering waterfowl in Butte Basin.

\begin{tabular}{cccccc|}
$\begin{array}{c}\text { Wetland } \\
\text { Restoration } \\
\text { Acres) }\end{array}$ & $\begin{array}{c}\text { Wetland } \\
\text { Enhancement } \\
\text { (Acres) }\end{array}$ & $\begin{array}{c}\text { Water Supplies } \\
\text { (Acre-Feet) }\end{array}$ & $\begin{array}{c}\text { Agricultural } \\
\text { Enhancement } \\
\text { (Acres) }\end{array}$ & $\begin{array}{c}\text { Type I } \\
\text { Agricultural } \\
\text { Easements }\end{array}$ & $\begin{array}{c}\text { Type II } \\
\text { Agricultural } \\
\text { Easements }\end{array}$ \\
\hline 17,000 & $3362^{a}$ & $225,904^{b}$ & $\begin{array}{c}104,000^{c} \\
62,000^{d}\end{array}$ & NEEDED & NEEDED \\
\hline
\end{tabular}

"Annual enhancement objective when the wetland restoration objective is met.

${ }^{b}$ Annual water supply need when the wetland restoration objective is met.

'Total acres of rice that must be maintained in a waterfowl-friendly state (includes 62,000 acres that must be flooded).

Objective has been met.

${ }^{d}$ Total acres of rice that must be flooded out of the total enhancement objective of 104,000 acres.

Objective has been met.

\begin{tabular}{|c|c|c|c|c|c|}
\hline $\begin{array}{c}\text { Current Food } \\
\text { Supplies }\end{array}$ & $\begin{array}{c}\text { Habitat } \\
\text { Protection }\end{array}$ & $\begin{array}{c}\text { Progress } \\
\text { in Meeting } \\
\text { Wetland Needs }\end{array}$ & $\begin{array}{l}\text { Population } \\
\text { Growth }\end{array}$ & $\begin{array}{l}\text { Loss of Irrigated } \\
\text { Farmland }\end{array}$ & $\begin{array}{c}\text { Conservation } \\
\text { Priorities }\end{array}$ \\
\hline HigH & High & High & High & $\mathrm{HIGH}$ & $\begin{array}{c}\text { WETLAND } \\
\text { RESTORATION }\end{array}$ \\
\hline Moderate & Moderate & Moderate & Moderate & Moderate & $\begin{array}{c}\text { Type I } \\
\text { Agricultural } \\
\text { EASEMENTS }\end{array}$ \\
\hline \multirow[t]{2}{*}{ Low } & Low & Low & Low & Low & \\
\hline & VERY LOW & VERY LOW & VERY LOW & & \\
\hline
\end{tabular}

Figure 4-35. Information used to identify conservation objective priorities for Butte Basin.

\section{Colusa Basin}

\section{Population Energy Demand vs. Food Energy Supplies: Current Conditions}

Population objectives for migrating and wintering waterfowl in Colusa Basin are presented in Figures 4-36 through 4-38. Duck and white goose population objectives are highest during mid-winter, while population objectives for dark geese peak during October. Rice provides the majority of foraging habitat in the basin, though seasonal wetlands exceed 22,000 acres (Table 4-18).

Food supplies for Colusa Basin ducks are adequate in all time periods, with peak supplies occurring in late December (Figure 4-39). Food supplies are also well above the needs of both dark and white geese, and large food surpluses occur in all time periods (Figures 4-40a and 4-40b). Agricultural habitats provide $83 \%$ of the food energy available to ducks in the basin. Although loss of these food resources would significantly decrease carrying capacity, there are enough wetland acres to meet duck energy needs through midJanuary (Figure 4-41). Public wetlands alone could meet duck needs through late November (Figure 4-42).

\section{Conservation Objectives}

\section{Wetland Restoration}

The amount of seasonal wetland habitat needed to provide $50 \%$ of duck energy needs in Colusa Basin is estimated at 24,396 acres. There are currently 22,396 acres of seasonal wetlands in the basin, leaving a wetland restoration goal of 2,000 acres.

\section{Wetland Enhancement}

The annual enhancement objective for existing wetlands in Colusa Basin is 1,866 acres/year. Wetland enhancement objectives increase to 2,033 acres/year when wetland restoration objectives are met for the basin (Table 4-19). 
Annual management of seasonal wetlands in Colusa Basin will require 121,980 acre-feet of water when wetland restoration objectives for the basin have been met. These annual water requirements are further broken down by time period to reflect flooding schedules and summer irrigation needs (Table 4-20).

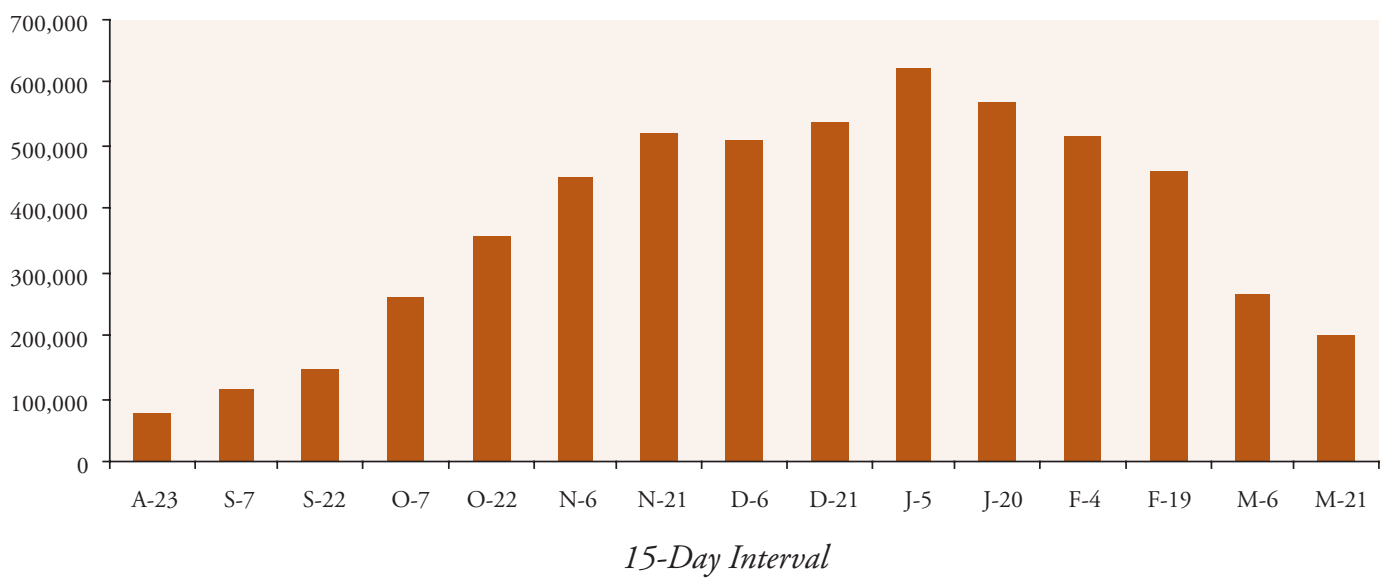

Figure 4-36. Population objectives by 15-day intervals for ducks in Colusa Basin.

\section{Agricultural Enhancement}

The agricultural enhancement objective For Colusa Basin is 85,000 acres, all of which is assumed to be rice. This objective represents the amount of rice habitat that must be maintained in a waterfowl-friendly state when wetland restoration objectives have been met for the basin. Forty-five thousand of these acres must be winter-flooded to meet duck energy needs. Waterfowl-friendly rice habitat in the basin is currently estimated at over 183,000 acres with nearly 142,000 of these acres winter-flooded (Table 4-21). Agricultural enhancement objectives are currently exceeded for the basin.

\section{Agricultural Easements for Maintaining Waterfowl Foods (Type I)}

Agricultural habitats are extremely important to waterfowl in Colusa Basin and provide $83 \%$ of the food energy now available to ducks (Figure 4-41). The loss of irrigated farmland by 2040 is estimated at nearly 17,000 acres or 1.7\% of existing lands (Figure 3-15). Approximately 3,300 of these acres are predicted to be rice (Table 3-4). Although most wetland restoration occurs on rice ground, wetland restoration objectives for the basin only total 2,000 acres. Planted rice in the basin is now estimated at 197,000 acres, and the loss of 5,300 acres to development and wetland restoration should not impair the JV's ability to meet its 85,000 acre agricultural enhancement objective (Figure 4-43). As a result, agricultural easements to maintain waterfowl foods may not be needed in the near future.

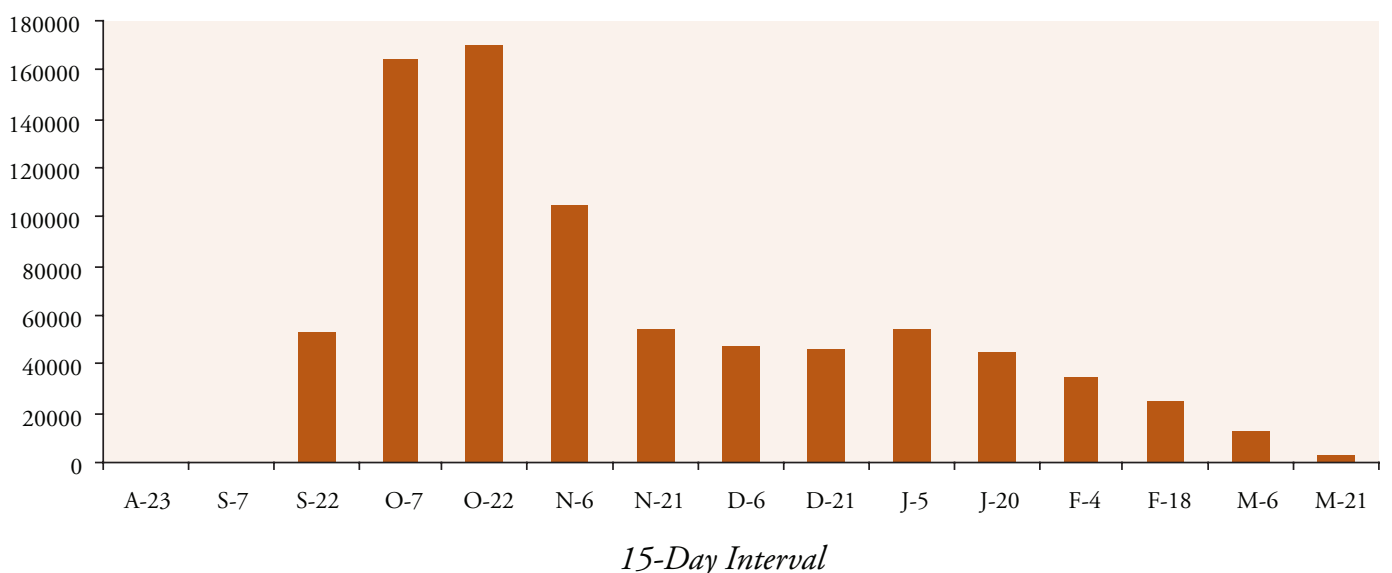

Figure 4-37. Population objectives by 15-day intervals for dark geese in Colusa Basin. 


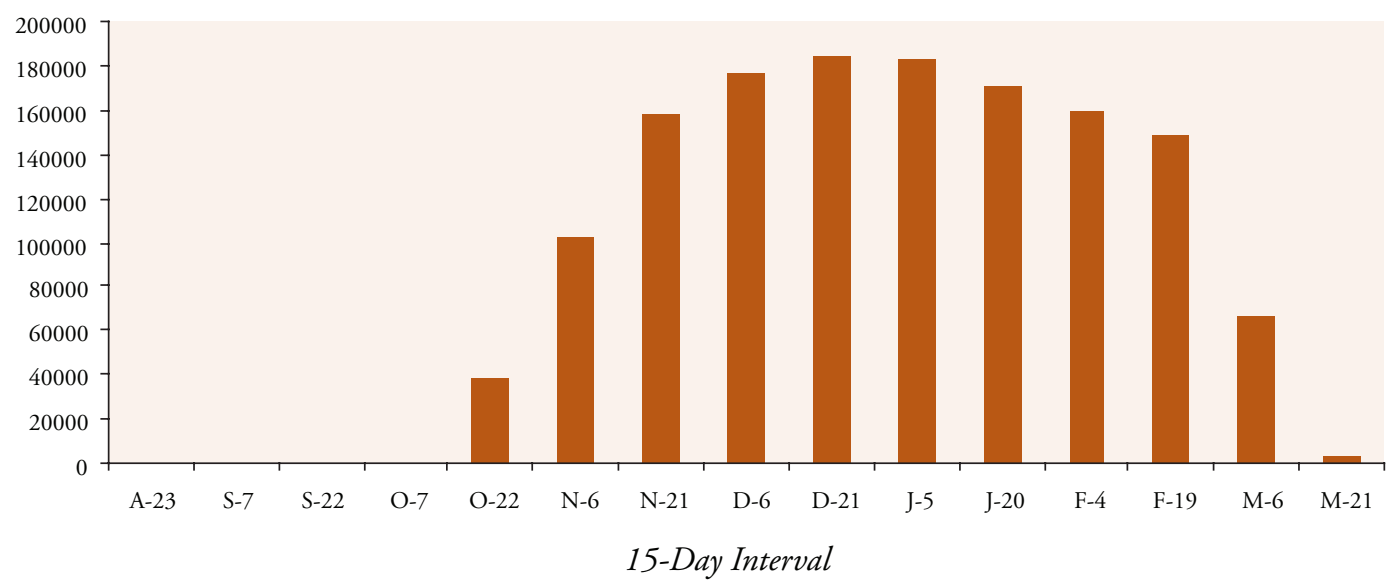

Figure 4-38. Population objectives by 15-day intervals for white geese in Colusa Basin.

\section{Agricultural Easements To Buffer Residential and Urban Growth (Type II)}

Growth projections for Colusa Basin indicate that little residential or urban development will occur near existing wetlands (Figure 4-44). As a result, no agricultural easements to buffer growth are suggested for the basin.

\section{Conservation Objective Priorities}

Conservation objectives for Colusa Basin are summarized in Table 4-22. The information used to prioritize these objectives is provided in Figure 4-45. Current food supplies exceed $100 \%$ of duck needs and were rated high, while habitat protection was rated low (but approaching moderate at $46 \%$ ). Progress in meeting wetland needs was rated as high (23,396 present vs. 24,396 needed; or $92 \%$ of need). Population increase forecasts were very low and loss of rice land was rated as low.

Wetland enhancement was identified as a conservation priority for Colusa Basin. Wetland restoration objectives are nearly met, while agricultural enhancement objectives are exceeded by several thousand acres. A wetland enhancement program in the basin should track when wetlands were last enhanced, and should periodically determine when future maintenance or repair is needed. The JV is developing a database that will include these tracking functions. Wetlands in the basin could be placed on a formal schedule for assessing enhancement needs and this system could be applied to other basins as other conservation objectives are met.

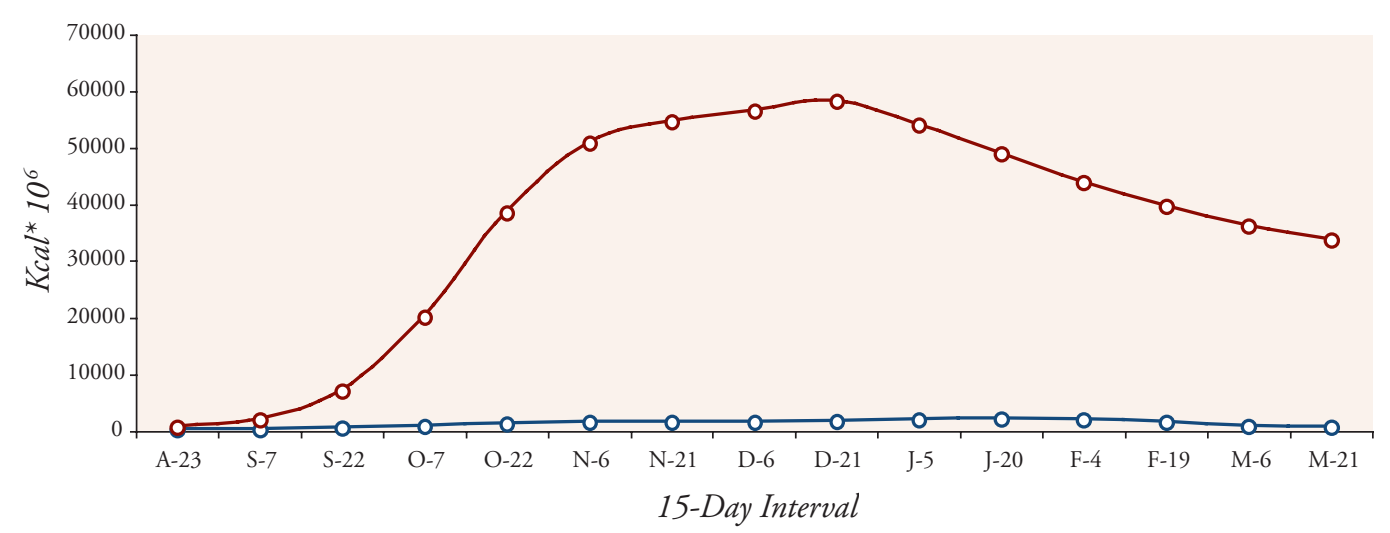

Figure 4-39. Population energy demand (blue) vs. food energy supply (red) for ducks in Colusa Basin when duck populations are at NAWMP goals.
Table 4-18. Foraging habitats (acres) available to wintering waterfowl in Colusa Basin.

\begin{tabular}{cccc|}
$\begin{array}{c}\text { Seasonal } \\
\text { Wetlands }\end{array}$ & $\begin{array}{c}\text { Flooded } \\
\text { Rice }\end{array}$ & $\begin{array}{c}\text { Unflooded } \\
\text { Rice }\end{array}$ & Corn \\
\hline 22,396 & 141,895 & 41,386 & 13,421 \\
\hline
\end{tabular}

Table 4-19. Annual wetland enhancement objectives for Colusa Basin.

\begin{tabular}{|cc|}
\hline $\begin{array}{c}\text { Wetland } \\
\text { Acres }\end{array}$ & $\begin{array}{c}\text { Annual Enhancement } \\
\text { Objective }(\text { Acres) }\end{array}$ \\
\hline $22,396^{a}$ & 1,866 \\
$24,396^{b}$ & 2,033 \\
\hline
\end{tabular}

${ }^{a}$ Current acres of wetlands in Colusa Basin. ${ }^{b}$ Acres of wetlands in Colusa Basin when wetland restoration objectives are met.

'Annual enhancement objectives reflect progress in meeting wetland restoration objectives for Colusa Basin. 

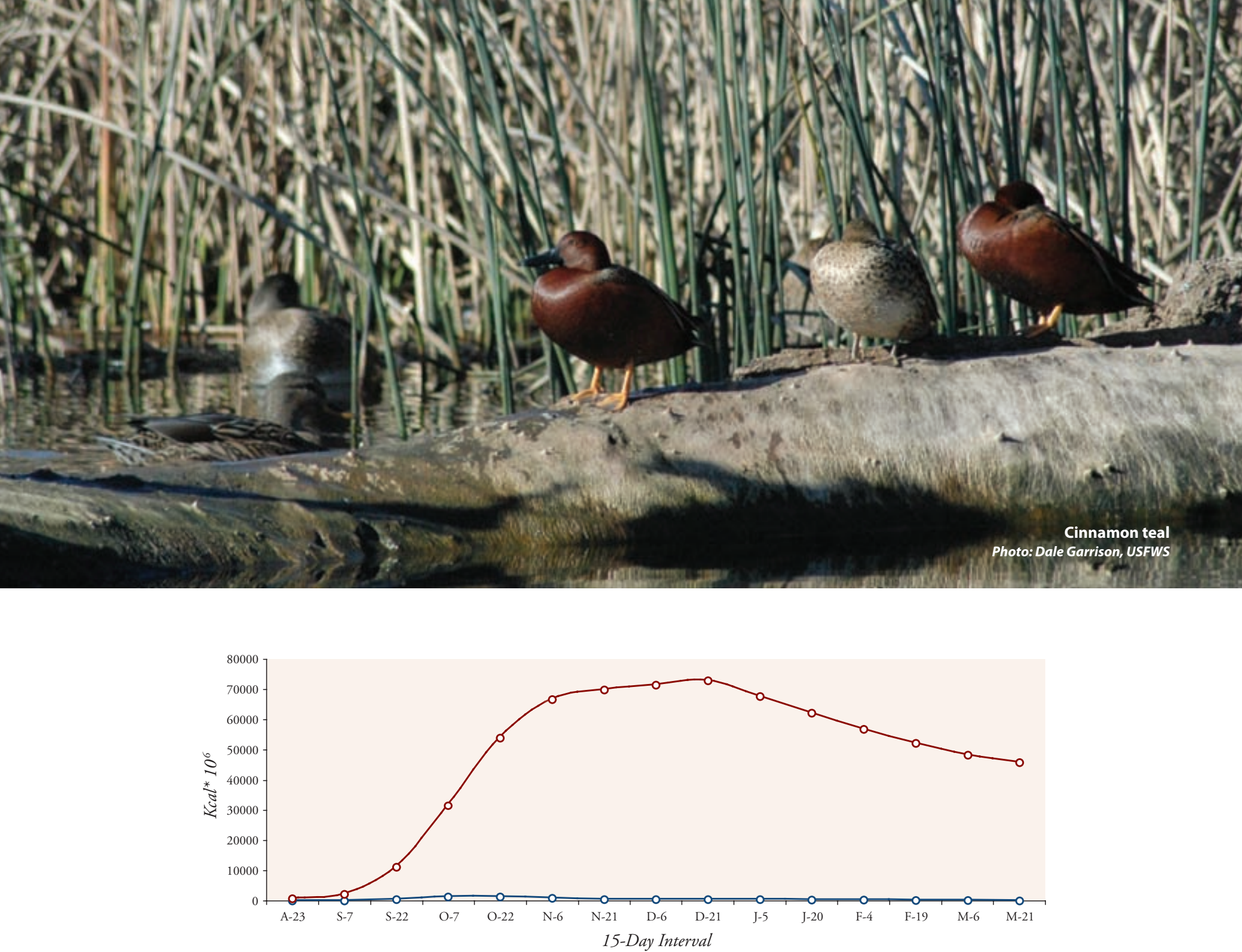

Figure 4-40 (a). Dark goose population energy demand (blue) vs. food energy supplies (red) in Colusa Basin.

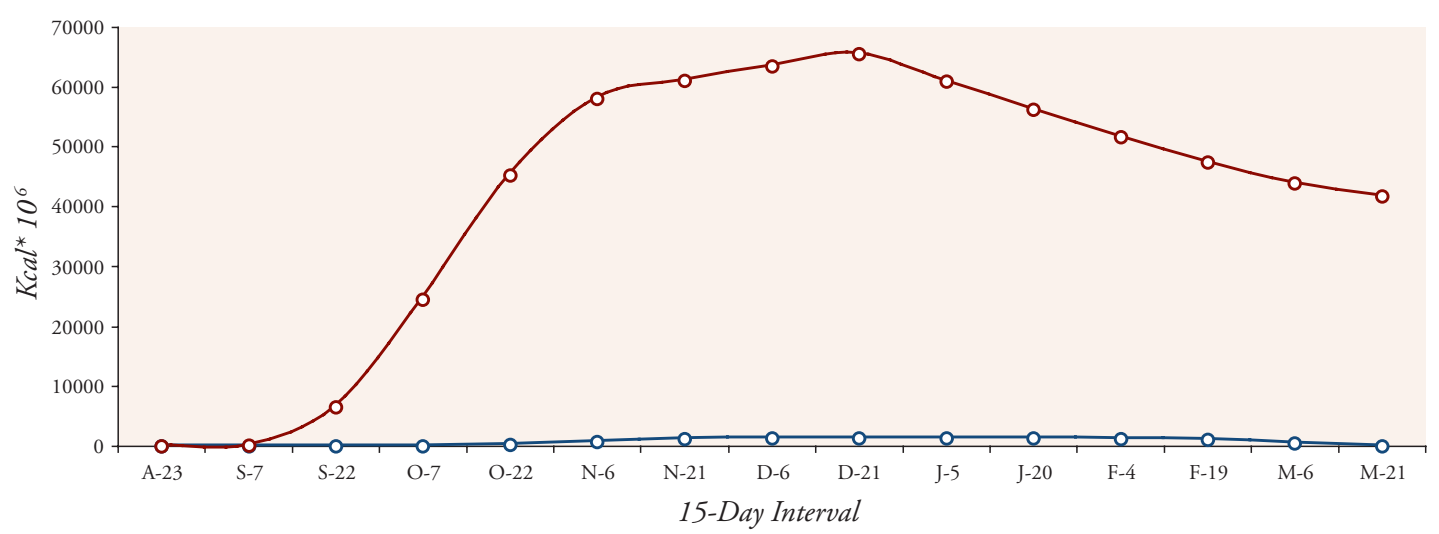

Figure 4-40 (b). White goose population energy demand (blue) vs. food energy supplies (red) in Colusa Basin. 


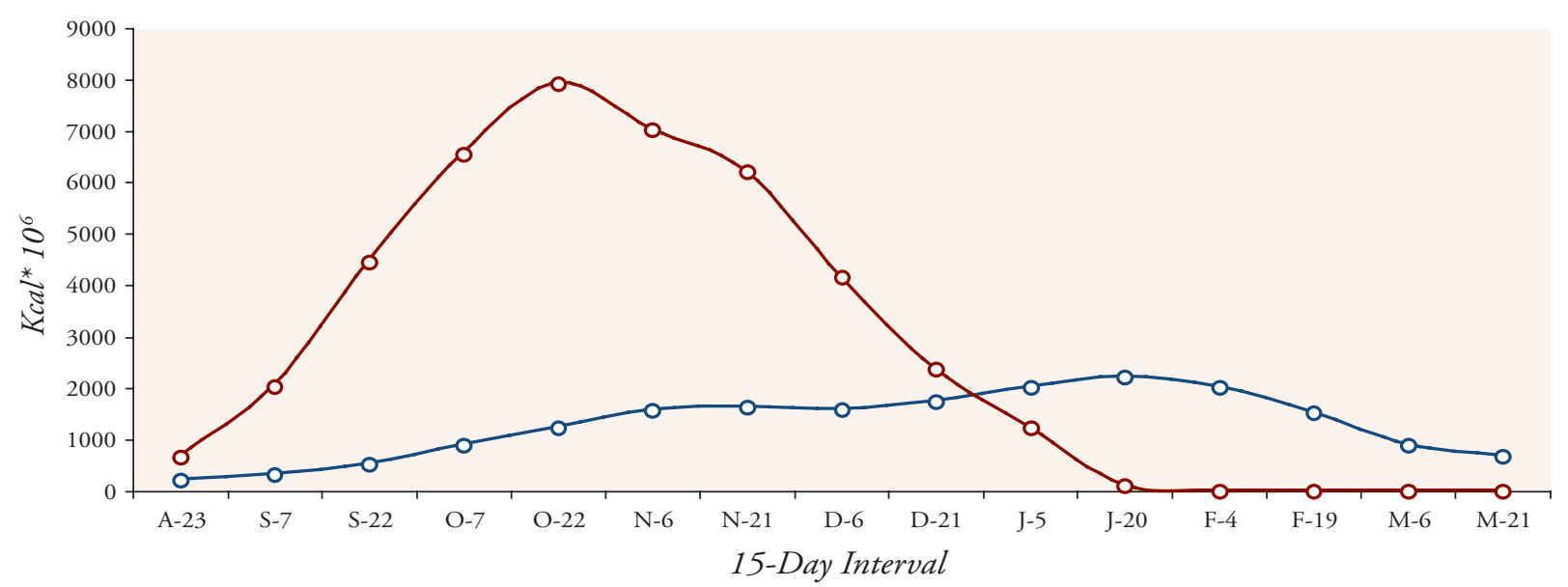

Figure 4-41. Population energy demand (blue) vs. food energy supply (red) for ducks in Colusa Basin if no agricultural foods are available.

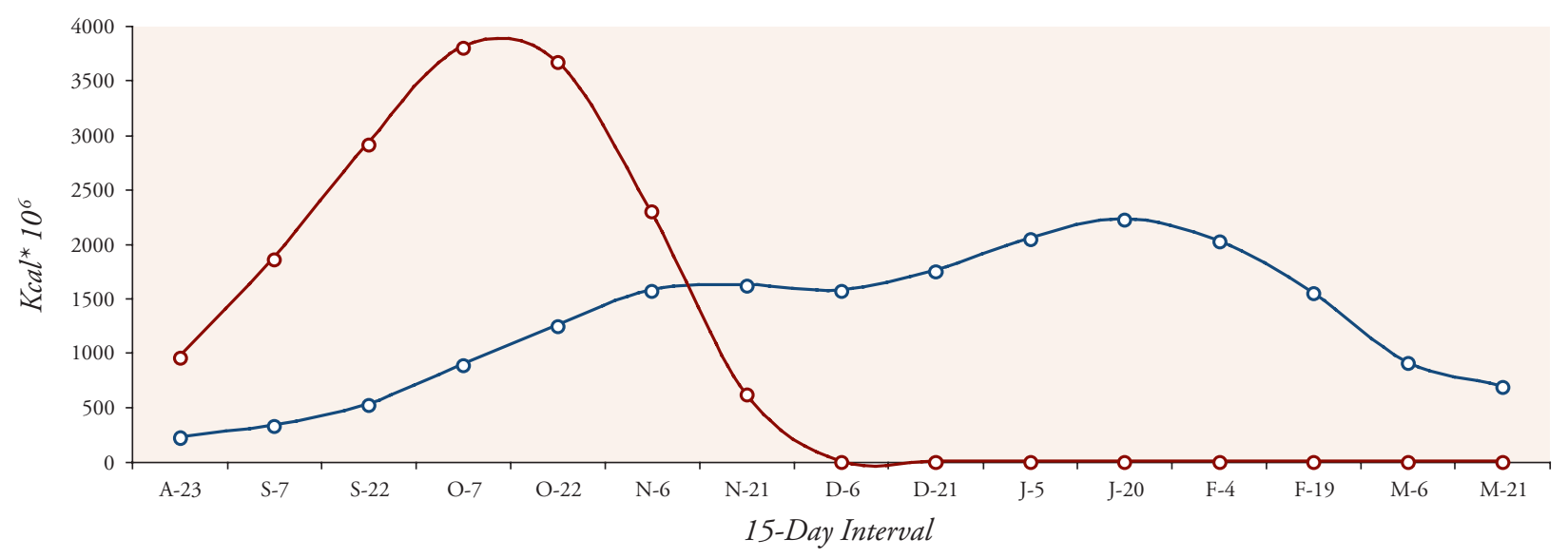

Figure 4-42. Population energy demand (blue) vs. food energy supply (red) for ducks in Colusa Basin if ducks are restricted to foraging on public habitats.

Table 4-20. Water needs for seasonal wetlands in Colusa Basin.

\begin{tabular}{|cc|}
\hline Month & $\begin{array}{c}\text { Water Need } \\
\text { (Acre-Feet) }\end{array}$ \\
\hline JANUARY & 4,879 \\
\hline FEBRUARY & 4,879 \\
\hline MARCH & 4,879 \\
\hline APRIL & 0 \\
\hline MAY & 17,077 \\
\hline JUNE & 0 \\
\hline JULY & 0 \\
\hline AUGUST & 21,956 \\
\hline SEPTEMBER & 43,913 \\
OCTOBER & 9,758 \\
\hline NOVEMBER & 9,758 \\
\hline DECEMBER & 4,879 \\
\hline ANNUAL NeED & $\mathbf{1 2 1 , 9 8 0}$ \\
\hline
\end{tabular}

Table 4-21. Agricultural enhancement objectives for Colusa Basin.

\begin{tabular}{|c|c|c|}
\hline & $\begin{array}{c}\text { Waterfowl- } \\
\text { friendly Rice }{ }^{a}\end{array}$ & $\begin{array}{c}\text { Flooded } \\
\text { Rice }\end{array}$ \\
\hline ОвJестіVе & 85,000 & 45,000 \\
\hline CuRrent & $183,281^{b}$ & 141,895 \\
\hline
\end{tabular}

${ }^{a}$ Waterfowl-friendly rice includes rice that is flooded and rice that is not deep plowed following harvest but which remains dry.

${ }^{b}$ Planted rice acreage in Colusa Basin is estimated at 197,076 acres (Table 3-6). The JV assumes that 183,281 of these acres provide waterfowl-friendly habitat.

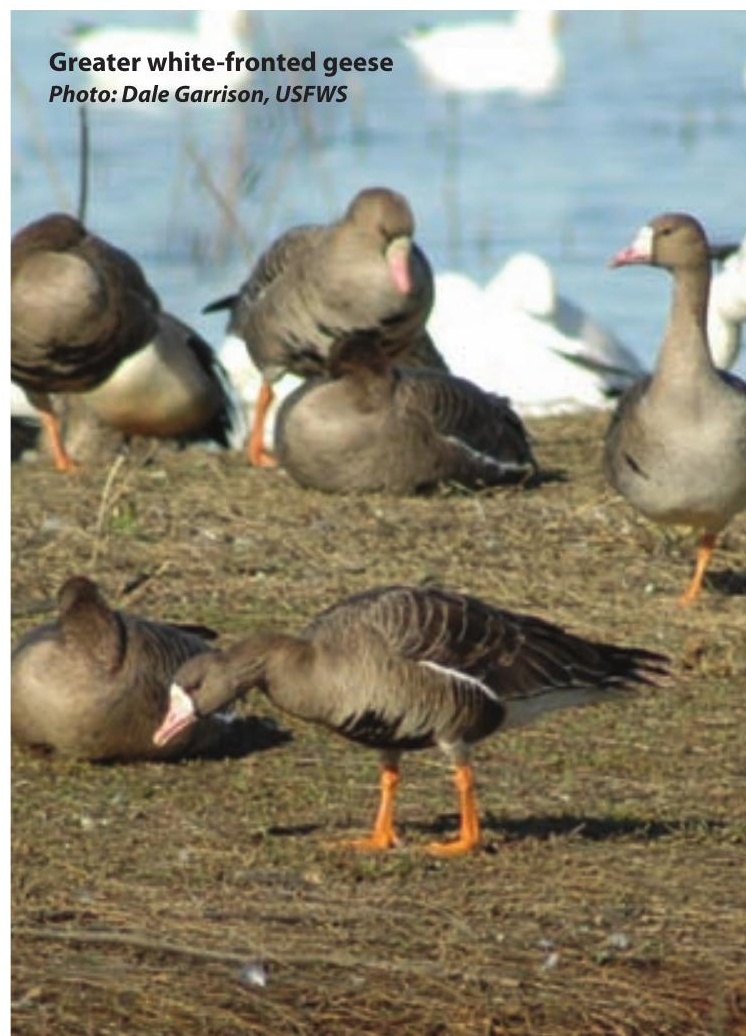



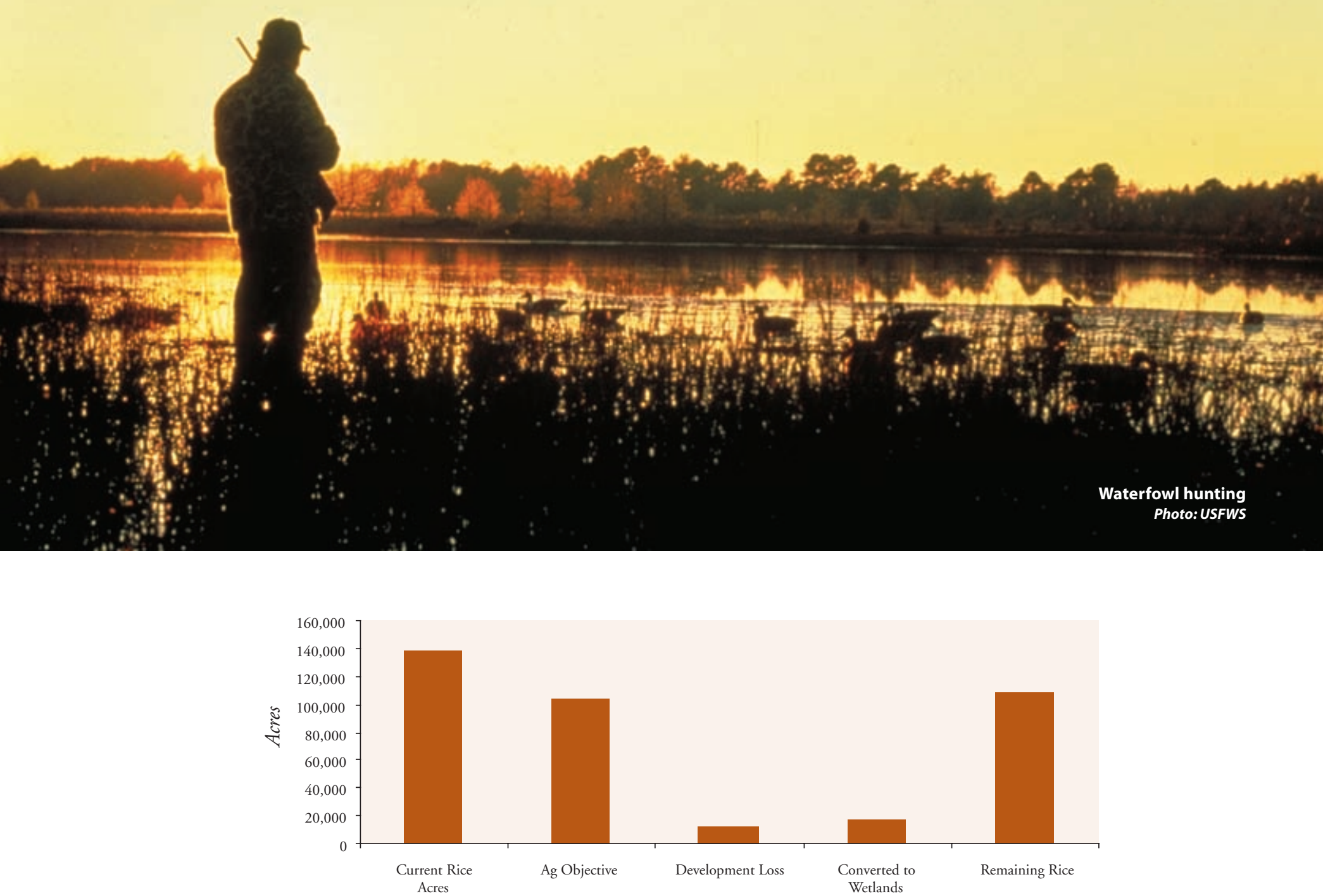

Figure 4-43. Forecasted changes in rice acreage for Colusa Basin compared to the basin's agricultural enhancement objective.

Table 4-22. Conservation objectives for wintering waterfowl in Colusa Basin.

\begin{tabular}{cccccc}
$\begin{array}{c}\text { Wetland } \\
\text { Restoration } \\
\text { (Acres) }\end{array}$ & $\begin{array}{c}\text { Wetland } \\
\text { Enhancement } \\
\text { (Acres) }\end{array}$ & $\begin{array}{c}\text { Water Supplies } \\
\text { (Acre-Feet) }\end{array}$ & $\begin{array}{c}\text { Agricultural } \\
\text { Enhancement } \\
\text { (Acres) }\end{array}$ & $\begin{array}{c}\text { Type I } \\
\text { Agricultural } \\
\text { Easements }\end{array}$ & $\begin{array}{c}\text { Type II } \\
\text { Agricultural } \\
\text { Easements }\end{array}$ \\
\hline 2,000 & $2,033^{a}$ & $121,980^{b}$ & $\begin{array}{c}85,000^{c} \\
45,000^{d}\end{array}$ & NoNE & NoNE \\
\hline
\end{tabular}

"Annual enhancement objective when the wetland restoration objective is met.

${ }^{b}$ Annual water supply need when the wetland restoration objective is met.

'Total acres of rice that must be enhanced (includes 45,000 acres that must be flooded). Objective has been met.

${ }^{d}$ Total acres of rice that must be flooded out of the total enhancement objective of 85,000 acres. Objective has been met.

\begin{tabular}{|c|c|c|c|c|c|}
\hline $\begin{array}{l}\text { Current Food } \\
\text { Supplies }\end{array}$ & $\begin{array}{c}\text { Habitat } \\
\text { Protection }\end{array}$ & $\begin{array}{c}\text { Progress } \\
\text { in Meeting } \\
\text { Wetland Needs }\end{array}$ & $\begin{array}{l}\text { Population } \\
\text { Growth }\end{array}$ & $\begin{array}{l}\text { Loss of Irrigated } \\
\quad \text { Farmland }\end{array}$ & $\begin{array}{c}\text { Conservation } \\
\text { Priorities }\end{array}$ \\
\hline High & High & High & High & High & $\begin{array}{c}\text { WETLAND } \\
\text { ENHANCEMENT }\end{array}$ \\
\hline Moderate & Moderate & Moderate & Moderate & Moderate & \\
\hline \multirow[t]{2}{*}{ Low } & Low & Low & Low & Low & \\
\hline & VERY LOW & VERY LOW & VERY LOW & & \\
\hline
\end{tabular}

Figure 4-45. Information used to identify conservation objective priorities for Colusa Basin. 


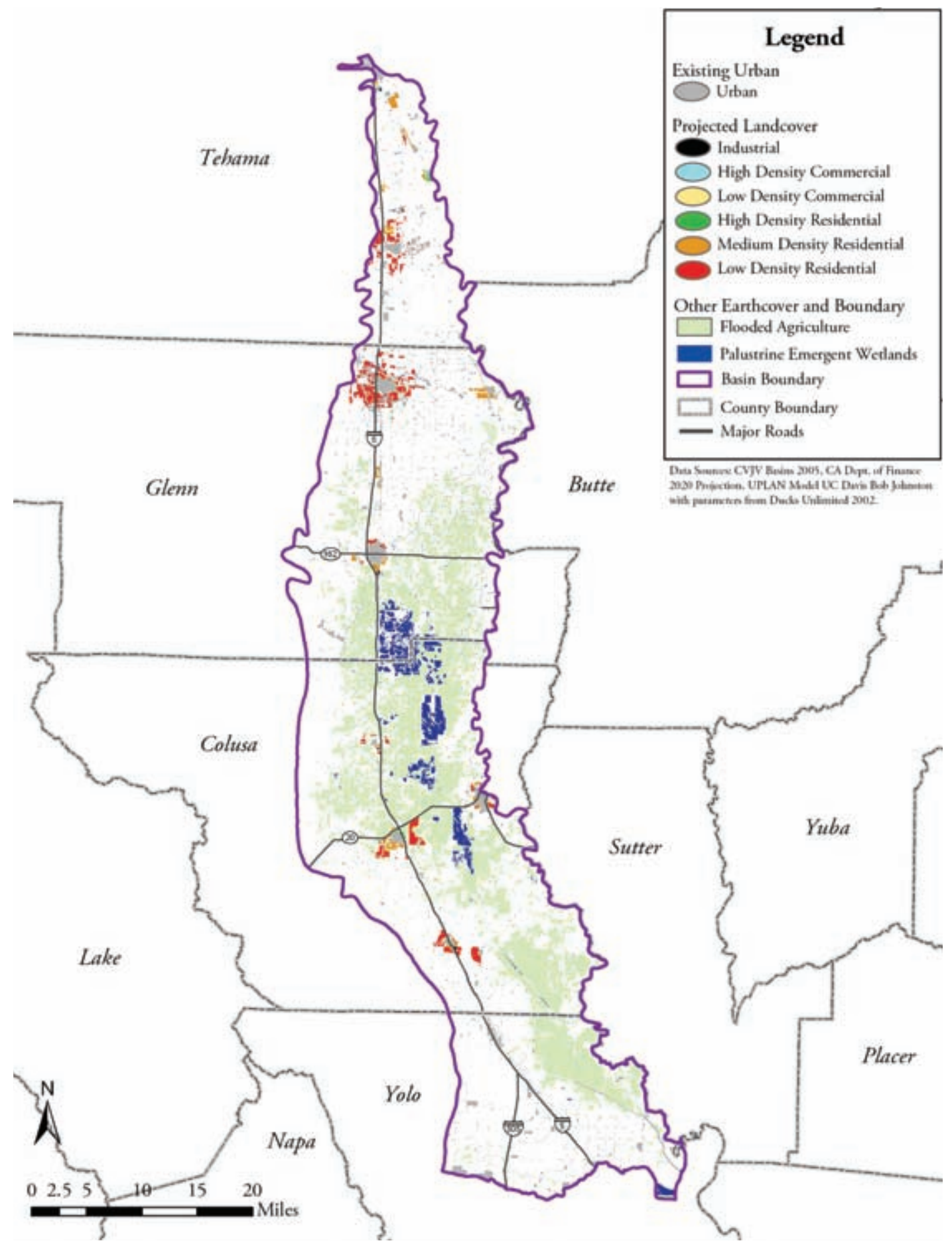

Figure 4-44. Projected growth in Colusa Basin to 2020. 


\section{Population Energy Demand vs. Food Energy Supplies: Current Conditions}

\begin{tabular}{|cc|}
\hline Habitat Type & Acres \\
\hline SEASONAL WETLANDS & 6,349 \\
\hline FLOODED CORN & 29,488 \\
UNFLOODED CORN & 29,488 \\
FLOODED RICE & 1,399 \\
\hline UNFLOODED RICE & 294 \\
\hline
\end{tabular}

Population objectives for wintering waterfowl in Delta Basin are presented in Figures 4-46 through 4-48. Duck population objectives are highest in late December and early January, while population objectives for dark and white geese peak during December. Corn provides the majority of foraging habitat in the basin, while seasonal wetlands total less than 6,500 acres (Table 4-23).

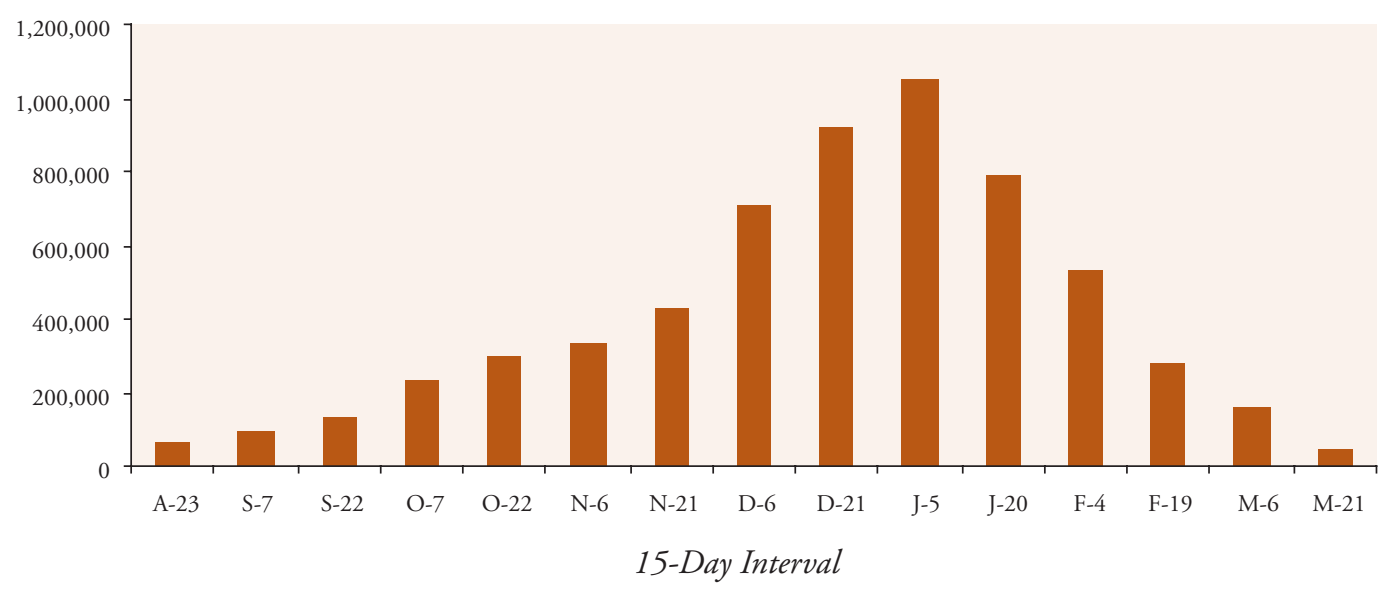

Figure 4-46. Population objectives by 15-day intervals for ducks in Delta Basin.

Duck food supplies in Delta Basin are adequate from fall through spring with peak supplies occurring in early November. Duck energy needs remain high from late November through early February (Figure 4-48). Food supplies are also adequate for dark and white geese with large food surpluses occurring in most time periods (Figure 4-49).

Agricultural habitats provide $81 \%$ of the food energy available to ducks in the basin. Loss of these agricultural foods would significantly decrease duck carrying capacity, as food supplies are exhausted by mid-November if ducks are restricted to foraging in wetlands (Figure 4-50). Public wetlands alone can only meet duck energy needs through early October (Figure 4-51).

\section{Conservation Objectives}

\section{Wetland Restoration}

The amount of seasonal wetland habitat required to meet $50 \%$ of duck energy needs in Delta Basin is estimated at 25,349 acres. There are currently 6,349 acres of seasonal wetlands in the basin, leaving a wetland restoration goal of 19,000 acres. 


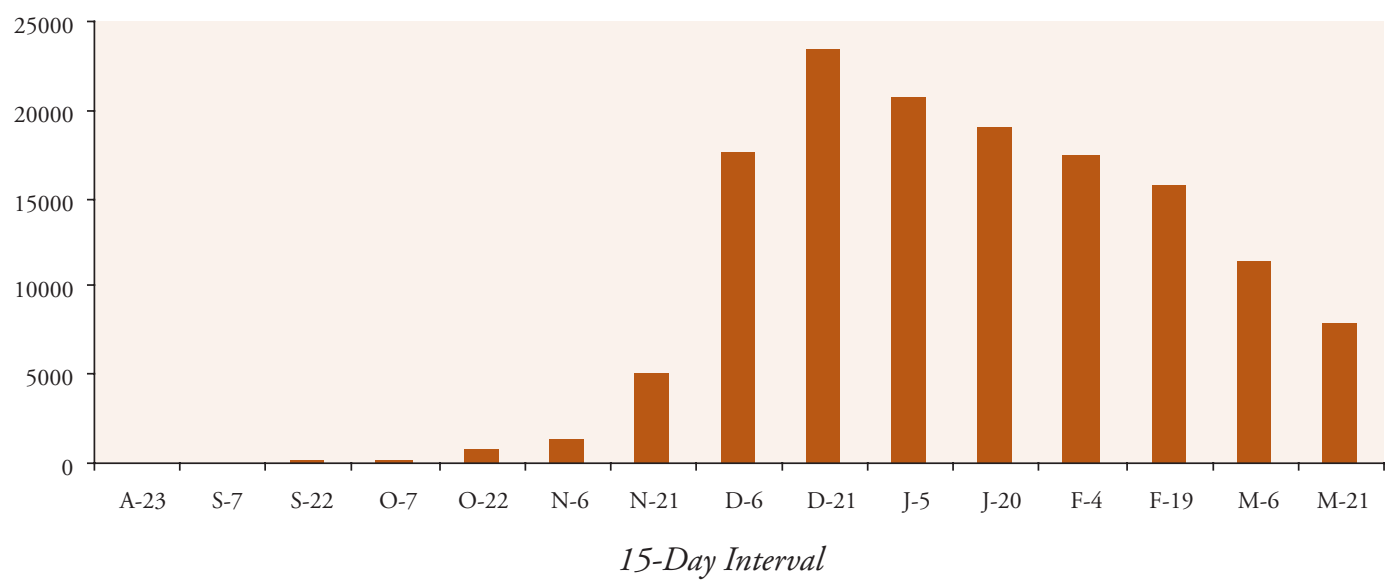

Figure 4-47. Population objectives by 15-day intervals for dark geese in Delta Basin.

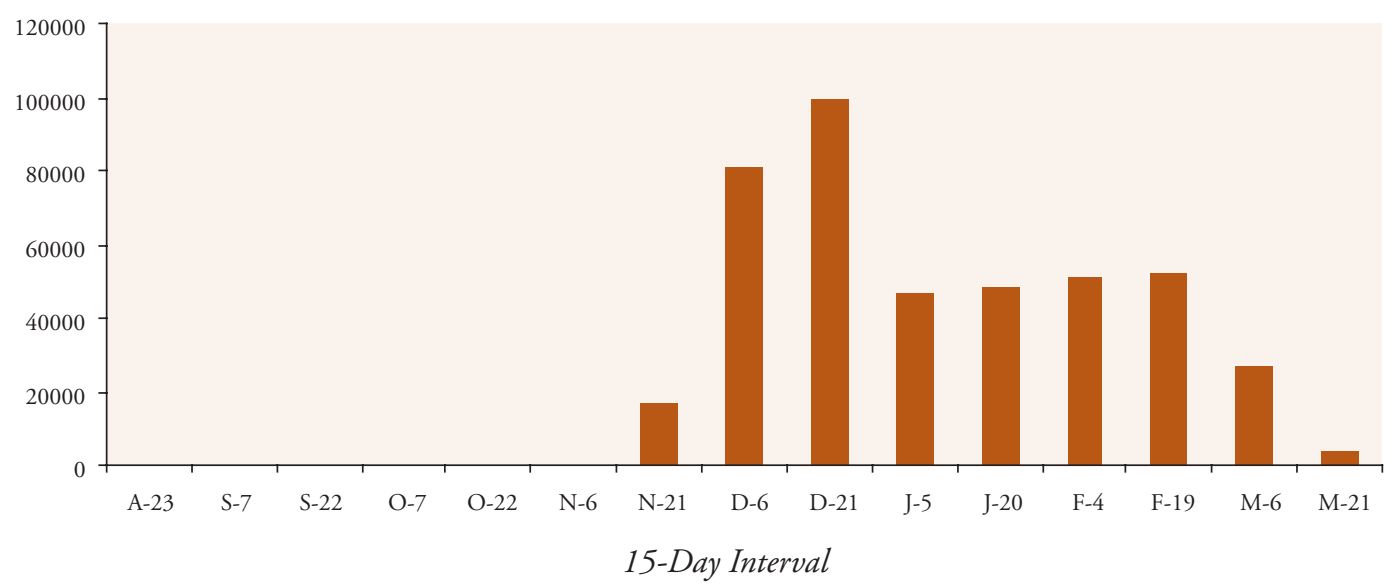

Figure 4-48. Population objectives by 15-day intervals for white geese in Delta Basin.

\section{Wetland Enhancement}

The annual enhancement objective for existing wetlands in Delta Basin is 529 acres/year. Wetland enhancement objectives increase to 2,112 acres/year when wetland restoration objectives are met for the basin (Table 4-24).

\section{Water Supplies for Seasonal Wetland Management}

Annual management of seasonal wetlands in Delta Basin will require 120,408 acre-feet of water when wetland restoration objectives for the basin are met. These annual water requirements are further broken down by time period to reflect flooding schedules and summer irrigation needs (Table 4-25).

\section{Agricultural Enhancement}

The agricultural enhancement objective for Delta Basin is 23,000 acres, all of which is assumed to be corn. This objective represents the amount of corn habitat that must be maintained in a waterfowl-friendly state when wetland restoration objectives have been met for the basin. Corn habitat in the basin is currently estimated at 58,976 acres (4-26). Agricultural enhancement objectives are currently exceeded for the basin. 


\section{Agricultural Easements for Maintaining Waterfowl Foods}

The loss of irrigated farmland in the Delta Basin is estimated at nearly 180,000 acres or 18.3\% of existing lands by 2040 (Figure 3-15). Much of this loss will result from residential and urban growth along the I-99 corridor from Manteca to Sacramento (Figure453). Although most of this agricultural land may not be used by waterfowl, the ongoing urbanization of Brentwood, Oakley, and Discovery Bay does threaten agricultural areas that have been traditionally important to ducks and geese. Similar growth around Tracy, Lathrop, and Stockton also threaten agricultural lands used by waterfowl (B. Burkholder, California Department of Fish and Game, personal communication). These land use projections suggest that Type I agricultural easements may be needed in the basin, especially in the southern portion of the Sacramento-San Joaquin River Delta.

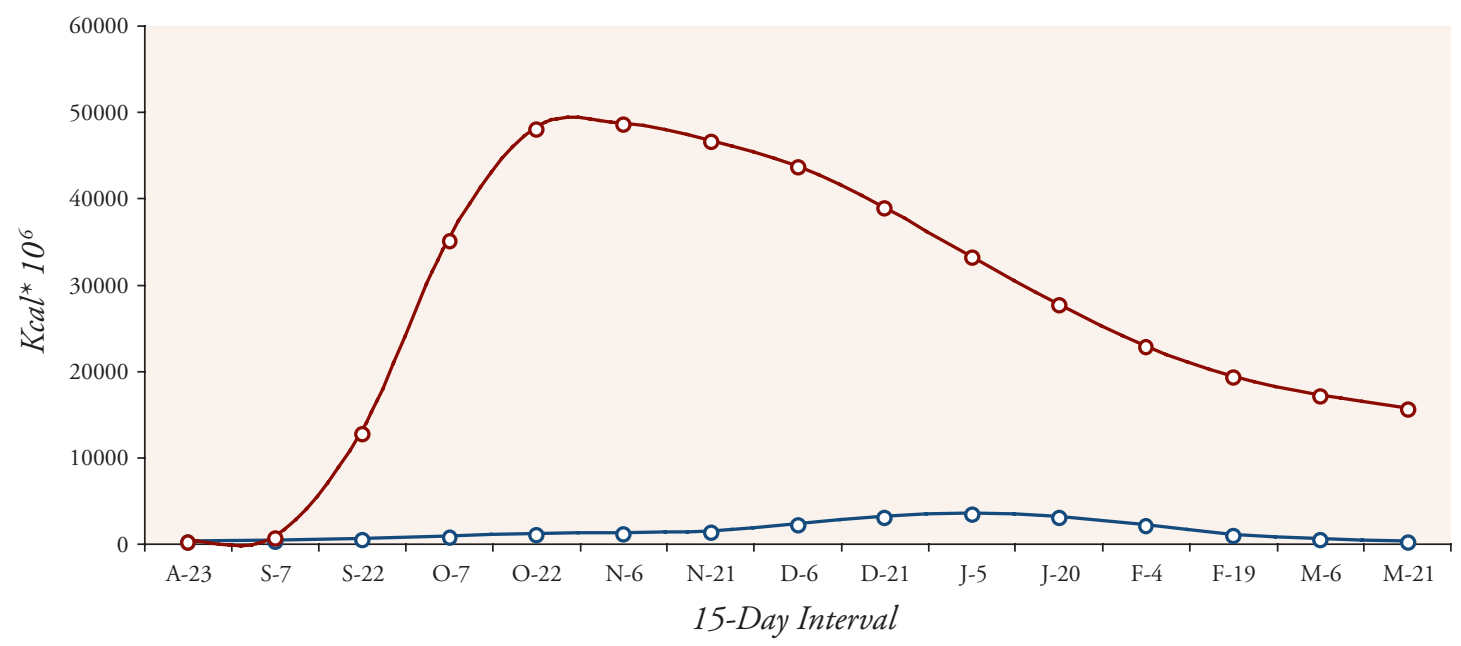

Figure 4-49. Population energy demand (blue) vs. food energy supply (red) for ducks in Delta Basin when duck populations are at NAWMP goals.

\section{Agricultural Easements to Buffer Urban Growth}

Many wetlands in the Delta Basin lie west of the I-99 corridor and outside areas of intensive growth. However, development in the cities of Elk Grove and Galt has continued to move south and west. The Stone Lakes National Wildlife Refuge and a portion of the Cosumnes River Preserve are located in the City of Elk Grove Planning Area for future development, while Galt continues to expand west and north. An easement program that buffers existing wetlands from growth of Elk Grove and Galt may be needed.

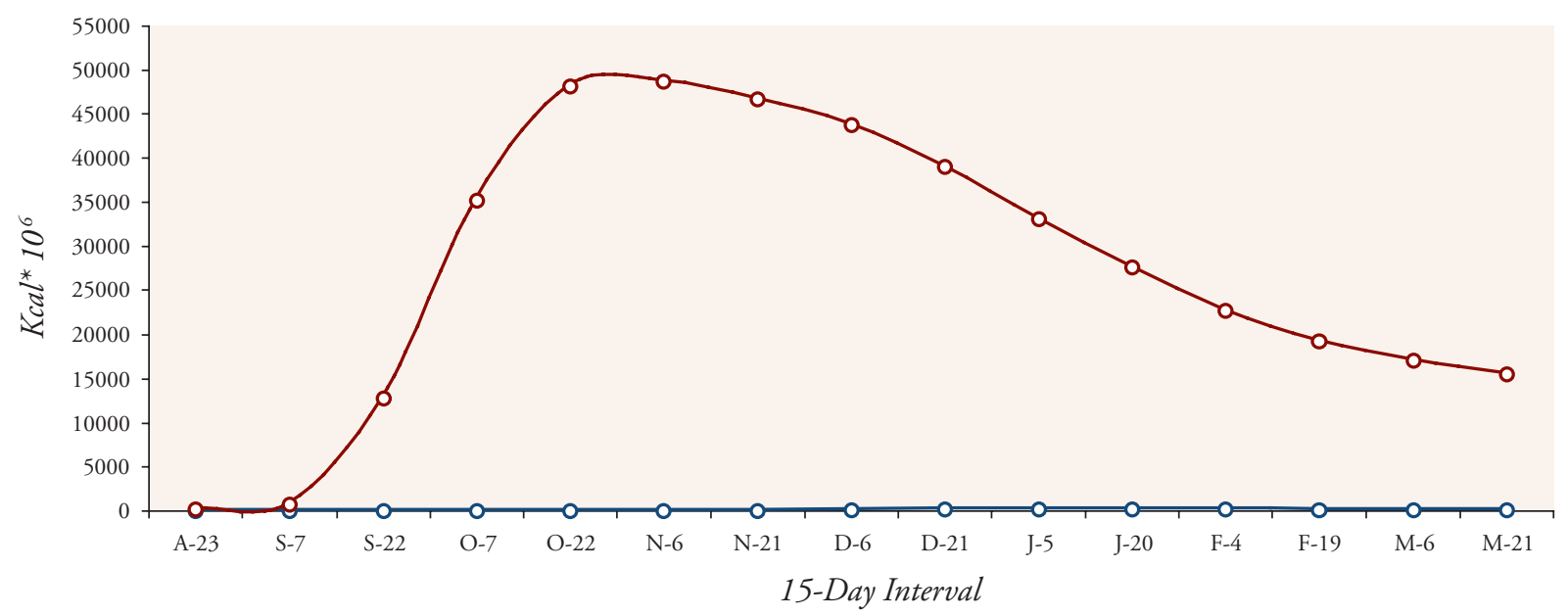

Figure 4-50 (a). Dark goose population energy demand (blue) vs. food energy supplies (red) in Delta Basin. 


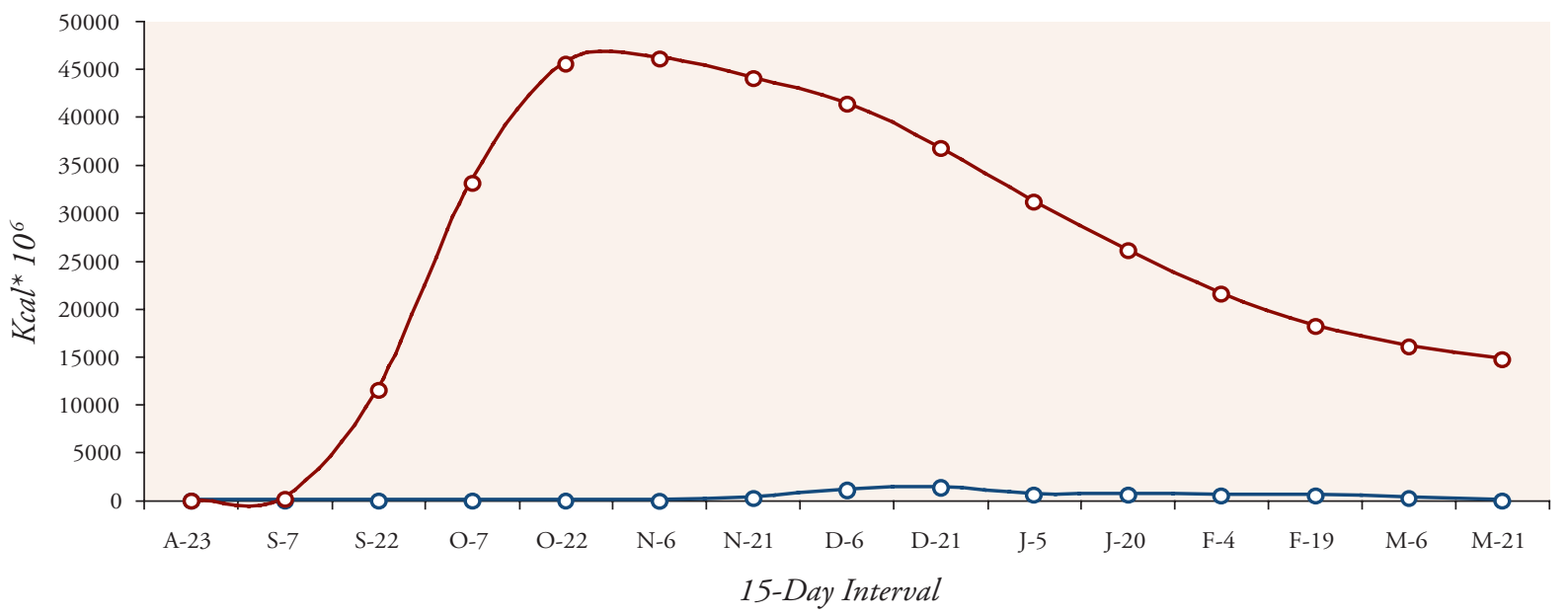

Figure 4-50 (b). White goose population energy demand (blue) vs. food energy supplies (red) in Delta Basin.

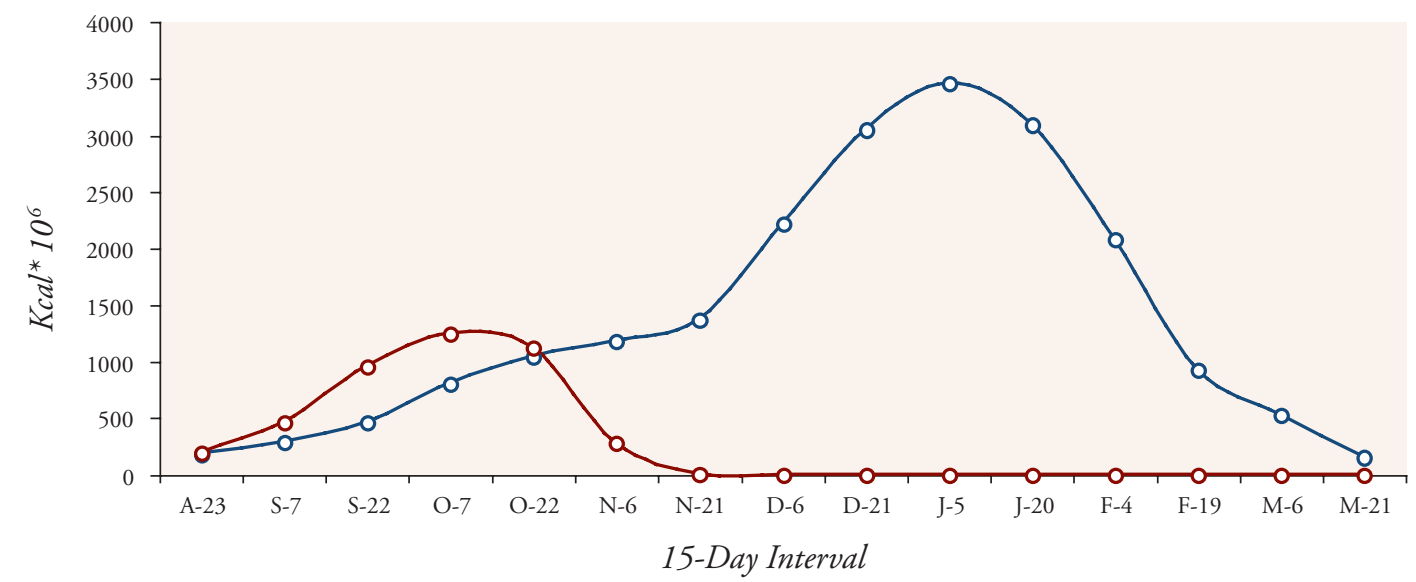

Figure 4-51. Population energy demand (blue) vs. food energy supplies (red) for ducks in Delta Basin when no agricultural food sources are available.

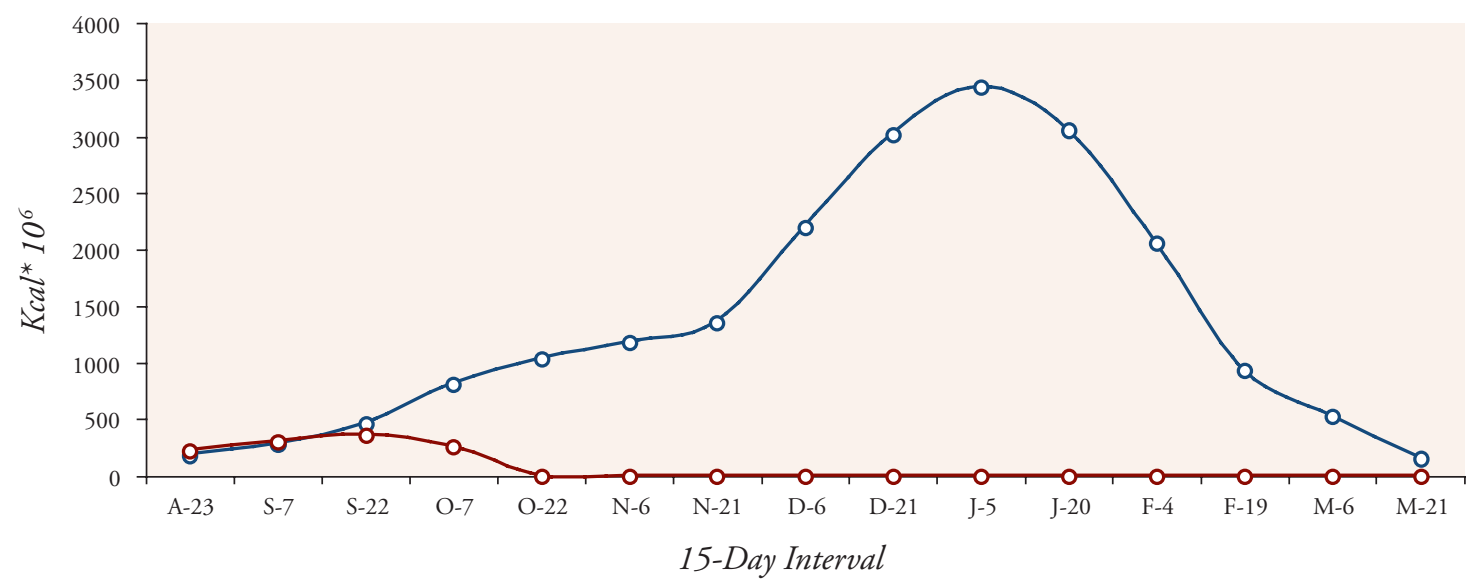

Figure 4-52. Population energy demand (blue) vs. food energy supplies (red) for ducks in Delta Basin if ducks are restricted to foraging on public lands. 


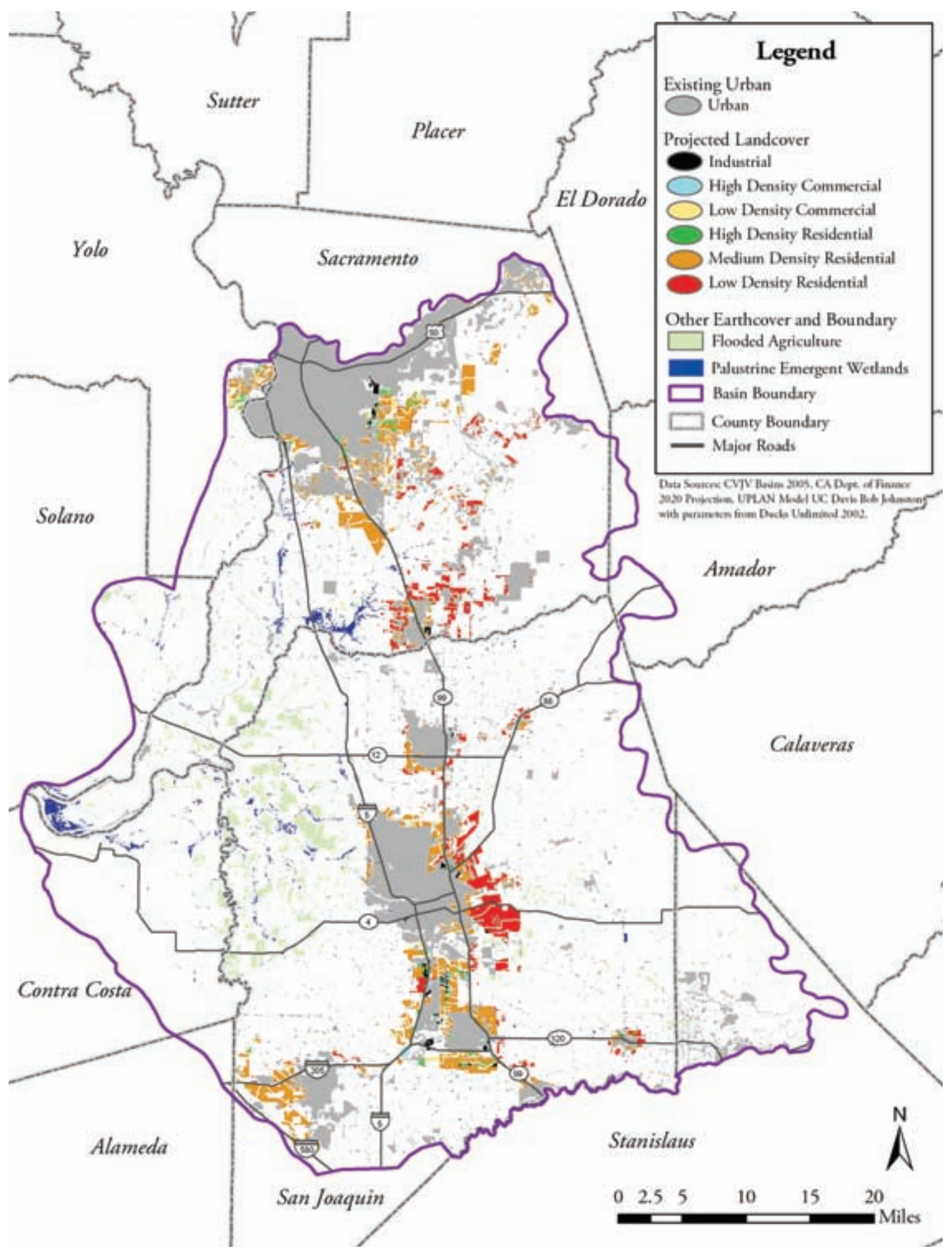

Figure 4-53. Projected growth in Delta Basin to 2020. 


\begin{tabular}{|c|c|c|c|c|c|}
\hline $\begin{array}{l}\text { Current Food } \\
\text { Supplies }\end{array}$ & $\begin{array}{l}\text { Level of Habitat } \\
\quad \text { Protection }\end{array}$ & $\begin{array}{c}\text { Progress in } \\
\text { Meeting Wetland } \\
\text { Needs }\end{array}$ & $\begin{array}{l}\text { Population } \\
\text { Growth }\end{array}$ & $\begin{array}{l}\text { Loss of Irrigated } \\
\text { Farmland }\end{array}$ & $\begin{array}{c}\text { Conservation } \\
\text { Objective } \\
\text { Priorities }\end{array}$ \\
\hline High & High & High & High & High & $\begin{array}{c}\text { WETLAND } \\
\text { RESTORATION }\end{array}$ \\
\hline Moderate & Moderate & Moderate & Moderate & Moderate & $\begin{array}{c}\text { Type II } \\
\text { EASEMENTS }\end{array}$ \\
\hline \multirow[t]{2}{*}{ Low } & Low & Low & Low & Low & \\
\hline & VERY LOW & VERY LOW & VERY LOW & & \\
\hline
\end{tabular}

Figure 4-54. Information used to identify conservation objective priorities for Delta Basin.

Table 4-24. Annual wetland enhancement objectives for Delta Basin.

\begin{tabular}{|cc|} 
Wetland Acres & $\begin{array}{c}\text { Annual Enhancement } \\
\text { Objective (Acres) }\end{array}$ \\
\hline $6,349^{a}$ & 529 \\
8,349 & 696 \\
10,349 & 862 \\
12,349 & 1,029 \\
14,349 & 1,196 \\
16,349 & 1,362 \\
18,349 & 1,529 \\
20,349 & 1,696 \\
22,349 & 1,862 \\
24,349 & 2,029 \\
$25,349^{b}$ & 2,112 \\
\hline
\end{tabular}

${ }^{a}$ Current acres of wetlands in Delta Basin. ${ }^{b}$ Acres of wetlands in Delta Basin when wetland restoration objectives are met. 'Annual enhancement objectives reflect progress in meeting wetland restoration objectives for Delta Basin.

Table 4-26. Agricultural enhancement objective for Delta Basin.

\begin{tabular}{|ccc|}
\hline & $\begin{array}{c}\text { Total } \\
\text { Corn }\end{array}$ & Flooded Corn \\
\hline OBJECTIVE & 23,000 & UNDETERMINED \\
\hline CURRENT & 58,976 & 29,488 \\
\hline
\end{tabular}

Table 4-25. Water needs for seasonal wetlands in Delta Basin when wetland restoration objective is met.

\begin{tabular}{|cc|} 
Month & $\begin{array}{c}\text { Water Need } \\
\text { (Acre-Feet })\end{array}$ \\
\hline JANUARY & 5,070 \\
\hline FEBRUARY & 5,070 \\
\hline MARCH & 5,070 \\
\hline APRIL & 6,337 \\
MAY & 0 \\
\hline JUNE & 0 \\
\hline JULY & 0 \\
\hline AUGUST & 22,814 \\
\hline SEPTEMBER & 50,698 \\
OCTOBER & 10,140 \\
NOVEMBER & 10,140 \\
\hline DECEMBER & 5,070 \\
\hline ANNUAL NEED & $\mathbf{1 2 0 , 4 0 8}$ \\
\hline
\end{tabular}
wintering waterfowl in San Joaquin Basin.

\begin{tabular}{|cc|}
\hline Habitat Type & Acres \\
\hline SeASONAL WeTLANDS & 61,013 \\
\hline
\end{tabular}

\section{Conservation}

\section{Objective Priorities}

Conservation objectives for Delta Basin are summarized in Table 4-27. The information used to identify conservation objective priorities for the basin is presented in Figure 4-54. Food supplies exceed $100 \%$ of duck needs and were rated high. Habitat protection is very low at $13 \%$, as is progress in meeting wetland needs (6,349 acres present vs. 25,349 needed or $25 \%$ of need). Population growth and loss of irrigated farmland were rated high for the basin. Wetland restoration is a priority for the basin as only $25 \%$ of seasonal wetland needs have been met. Agricultural easements that buffer existing wetlands from growth may also be a conservation priority.

Table 4-27. Conservation objectives for wintering waterfowl in Delta Basin.

\begin{tabular}{cccccc}
$\begin{array}{c}\text { Wetland } \\
\text { Restoration } \\
\text { (Acres) }\end{array}$ & $\begin{array}{c}\text { Wetland } \\
\text { Enhancement } \\
\text { (Acres) }\end{array}$ & $\begin{array}{c}\text { Water Supplies } \\
\text { (Acre-Feet) }\end{array}$ & $\begin{array}{c}\text { Agricultural } \\
\text { Enhancement } \\
\text { (Acres) }\end{array}$ & $\begin{array}{c}\text { Type I } \\
\text { Agricultural } \\
\text { Easements }\end{array}$ & $\begin{array}{c}\text { Type II } \\
\text { Agricultural } \\
\text { Easements }\end{array}$ \\
\hline 19,000 & $2,112^{\mathrm{A}}$ & $120,408^{\mathrm{B}}$ & 23,000 & NEEDED & NEEDED \\
\hline
\end{tabular}

annual enhancement objective when the wetland restoration objective is met.

${ }^{b}$ Annual water supply need when the wetland restoration objective is met. 


\section{San Joaquin Basin}

\section{Population Energy Demand vs. Food Energy Supplies: Current Conditions}

Population objectives for migrating and wintering waterfowl in San Joaquin Basin are presented in Figures 4-55 through 4-57. Duck population objectives are highest from mid-October through early November, while population objectives for dark and white geese peak during late winter. Wetlands are assumed to provide all the food resources available to ducks, because post-harvest treatment of most rice and corn in the basin makes these foods unavailable to waterfowl (Table 4-28).

The energetic model predicts that food supplies for ducks in the San Joaquin Basin are completely depleted by early February (Figure 4-58). This result assumes that ducks are at NAWMP goals. However, pintails make up $46 \%$ of the Central Valley's duck population objective, and pintails have been well below NAWMP goals since the early 1980s. Therefore, it is unlikely that duck food supplies are now exhausted prior to spring migration. Duck use of the basin generally tracks food supplies. Peak populations occur during periods of maximum food energy, while declines in duck numbers track the depletion of food resources. Ducks in the basin are assumed to rely exclusively on wetlands so the loss of agriculture has no affect on duck carrying capacity. However, $75 \%$ of all managed wetlands in the basin are privately owned and public habitats can only sustain duck populations through mid-October (Figure 4-59).

The JV did not model food supplies for geese in the San Joaquin Basin because of uncertainty over the type and amount of foraging habitat available to geese. However, some food resources are clearly available given goose population estimates for the basin. For example, management efforts in the San Luis NWR complex include providing corn for Aleutian and Ross's geese, as well as managing grasslands for the benefit of geese (M. Miller, U.S. Geological Survey, personal communication). Future JV planning efforts will better define the food resources available to geese in the San Joaquin Basin.

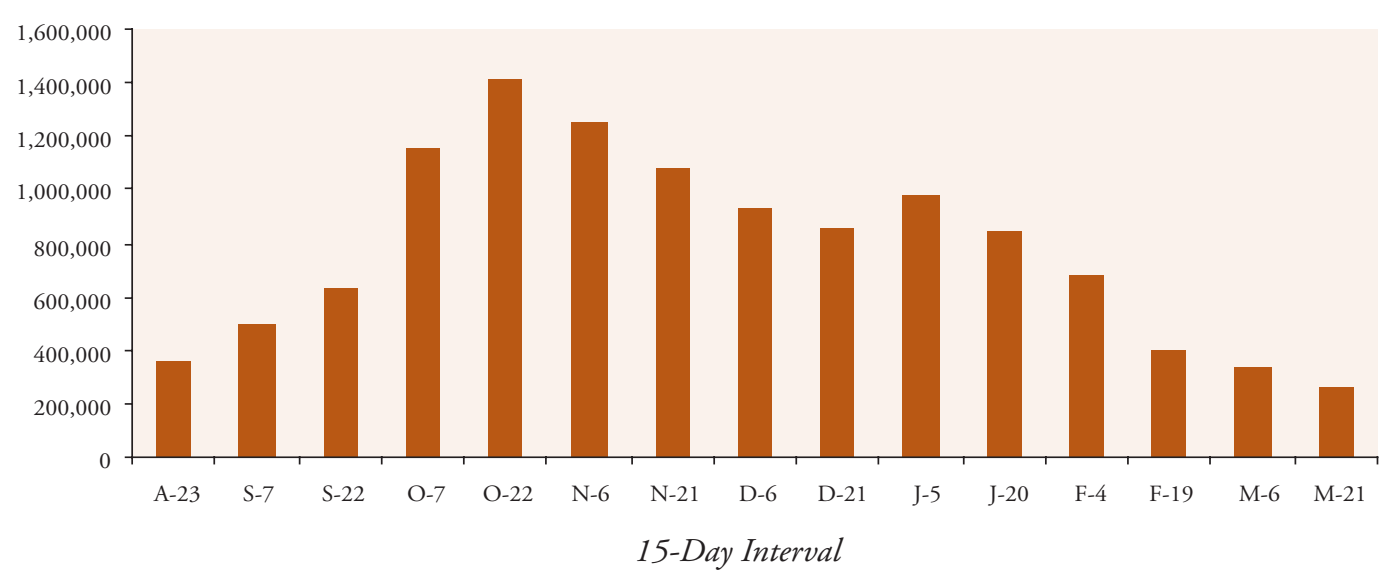

Figure 4-55. Population objectives by 15-day intervals for ducks in San Joaquin Basin.

\section{Conservation Objectives}

\section{Wetland Restoration}

Wetland restoration objectives for San Joaquin Basin assume that $100 \%$ of duck energy needs are met from wetland food sources. The amount of seasonal wetland habitat needed to provide this food is estimated at 81,013 acres. There are currently 61,013 acres of seasonal wetlands in the basin leaving a wetland restoration goal of 20,000 acres.

\section{Wetland Enhancement}

The annual enhancement objective for existing wetlands in San Joaquin Basin is 5,084 acres/year. Wetland enhancement objectives increase to 6,751 acres/year when wetland restoration objectives are met for the basin (Table 4-29).

\section{Water Supplies for Wetland Management}

Annual management of seasonal wetlands in San Joaquin Basin will require 441,521 acre-feet of water when wetland restoration objectives for the basin have been met. These annual water requirements are further broken down by time period to reflect flooding schedules and summer irrigation needs (Table 4-30). 


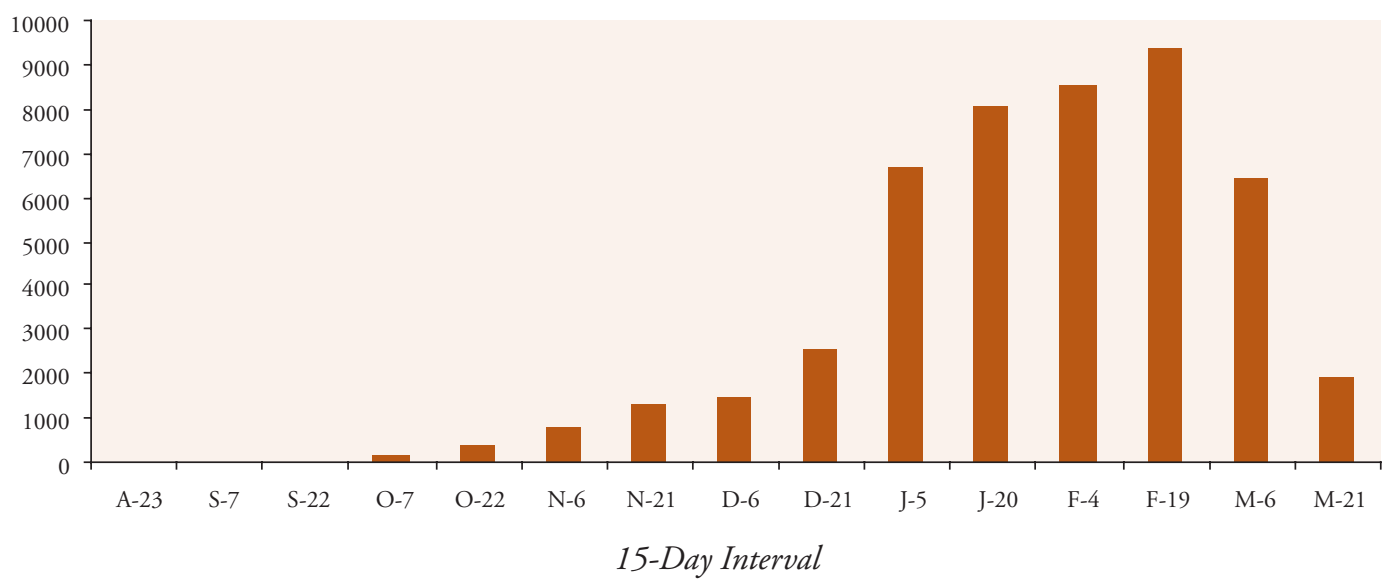

Figure 4-56. Population objectives by 15-day intervals for dark geese in San Joaquin Basin.

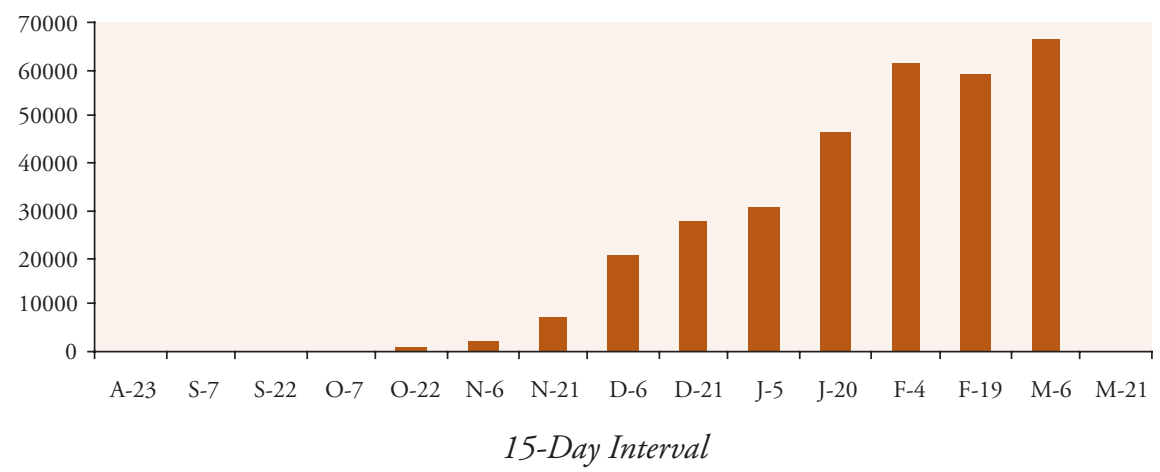

Figure 4-57. Population objectives by 15-day intervals for white geese in San Joaquin Basin.

\section{Agricultural Enhancement}

There is no agricultural enhancement objective for San Joaquin Basin, because wetlands provide the overwhelming majority of food sources.

\section{Agricultural Easements for Maintaining Waterfowl Foods (Type I)}

No easement areas of this type are proposed for San Joaquin Basin, because wetlands provide the overwhelming majority of food sources.

\section{Agricultural Easements to Buffer Residential and Urban Growth (Type II)}

Human population projections for San Joaquin Basin are the second highest in the Central Valley (Figure 3-15). Growth is projected from several directions towards public and private wetlands in the Grasslands, but is especially prevalent along the Interstate 5 corridor and State Highways 165, 152, and 33 (Figure 4-60). Easements that buffer wetlands from this growth should be considered.
Table 4-29. Annual wetland enhancement objectives for San Joaquin Basin.

\begin{tabular}{|cc|} 
Wetland Acres & $\begin{array}{r}\text { Annual Enhancement } \\
\text { Objective }^{(\text {Acres })^{c}}\end{array}$ \\
\hline $61,013^{a}$ & 5,084 \\
63,013 & 5,251 \\
65,013 & 5,418 \\
67,013 & 5,584 \\
69,013 & 5,751 \\
71,013 & 5,918 \\
73,013 & 6,084 \\
75,013 & 6,251 \\
77,013 & 6,418 \\
79,013 & 6,584 \\
$81,013^{b}$ & 6,751 \\
\hline
\end{tabular}

${ }^{a}$ Current acres of wetlands in San Joaquin Basin. ${ }^{b}$ Acres of wetlands in San Joaquin Basin when wetland restoration objectives are met. 'Annual enhancement objectives reflect progress in meeting wetland restoration objectives for San Joaquin Basin. 


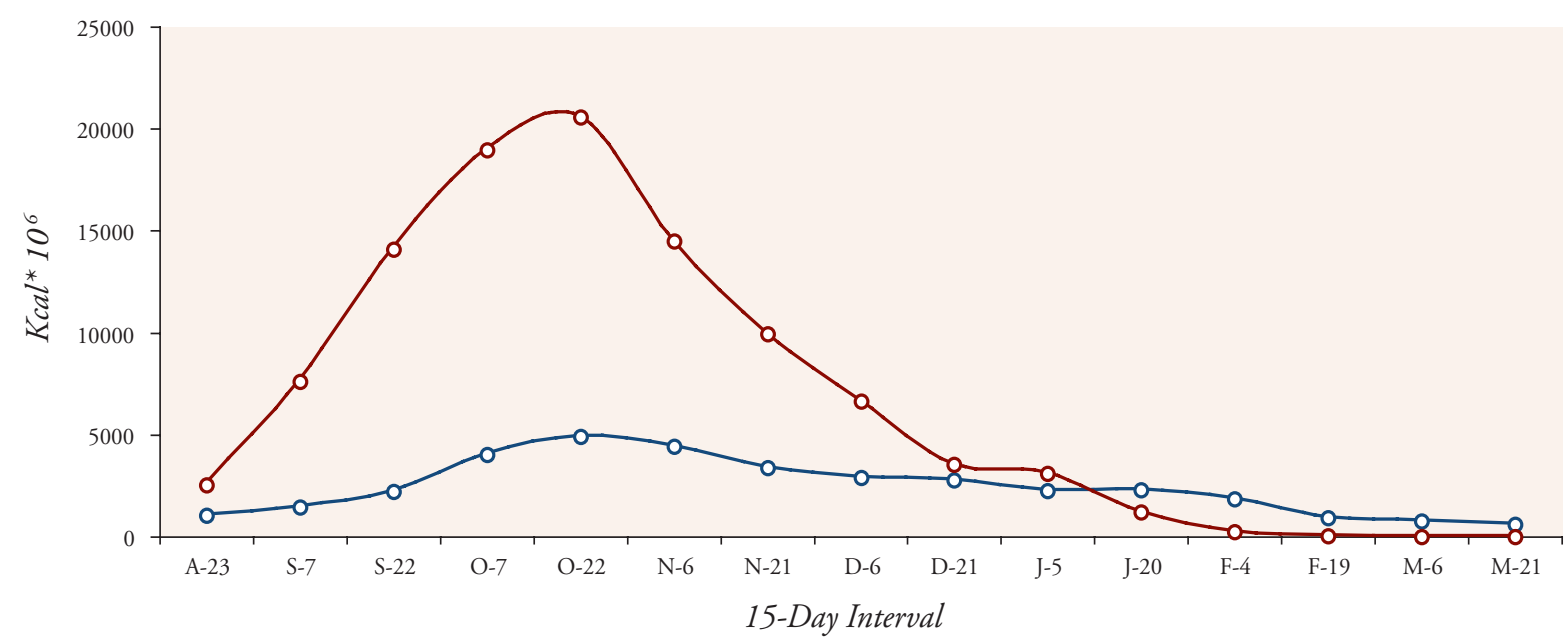

Figure 4-58. Population energy demand (blue) vs. food energy supplies (red) for ducks in San Joaquin Basin when duck populations are at NAWMP goals.

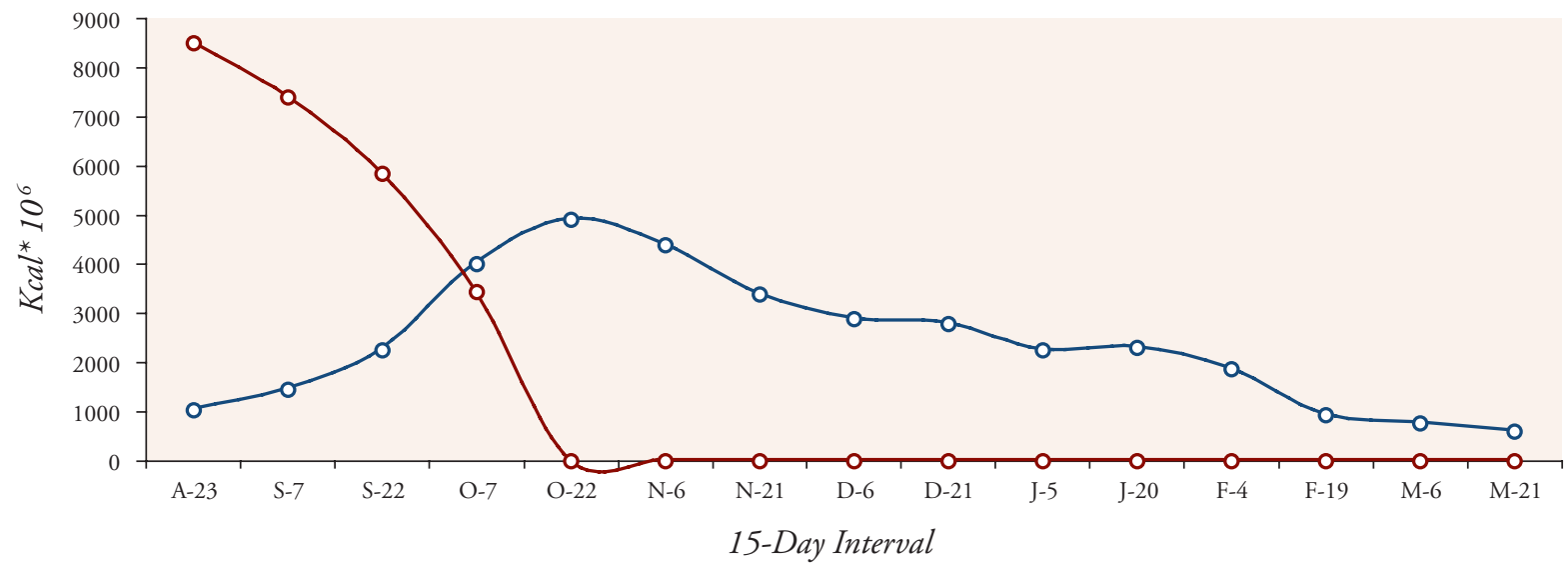

Figure 4-59. Population energy demand (blue) vs. food energy supply (red) for ducks in San Joaquin Basin if ducks are restricted to foraging on public lands.

\section{Conservation Objective Priorities}

Conservation objectives for San Joaquin Basin are summarized in Table 4-31. The information used to prioritize these objectives is provided in Figure 4-61. Current food supplies are moderate because only $75 \%$ of duck needs are met by existing food resources when duck populations are at NAWMP goals. Habitat protection was also rated moderate at $75 \%$ (high ratings begin at $76 \%$ ), as was progress in meeting wetland needs ( 61,013 present vs. 81,013 needed or $75 \%$ of need). High ratings in this category begin at $76 \%$. Population growth and loss of irrigated farmland are both moderate for the basin.

Wetland restoration is a priority for San Joaquin Basin, because only $75 \%$ of the wetlands needed by ducks exist. However progress in meeting wetland needs is high which may allow increased emphasis on wetland enhancement. Finally, agricultural easement programs that buffer wetlands from growth should be considered.
Table 4-30. Water needs for seasonal wetlands in San Joaquin Basin when wetland restoration objective is met.

\begin{tabular}{|cc|} 
Month & $\begin{array}{c}\text { Water Need } \\
(\text { Acre-Feet })\end{array}$ \\
\hline JANUARY & 16,203 \\
FEBRUARY & 16,203 \\
MARCH & 16,203 \\
APRIL & 0 \\
MAY & 64,810 \\
JUNE & 20,253 \\
JULY & 0 \\
\hline AUGUST & 64,810 \\
SEPTEMBER & 162,026 \\
OCTOBER & 32,405 \\
NOVEMBER & 32,405 \\
DECEMBER & 16,203 \\
\hline ANNUAL NeED & 441,521 \\
\hline
\end{tabular}




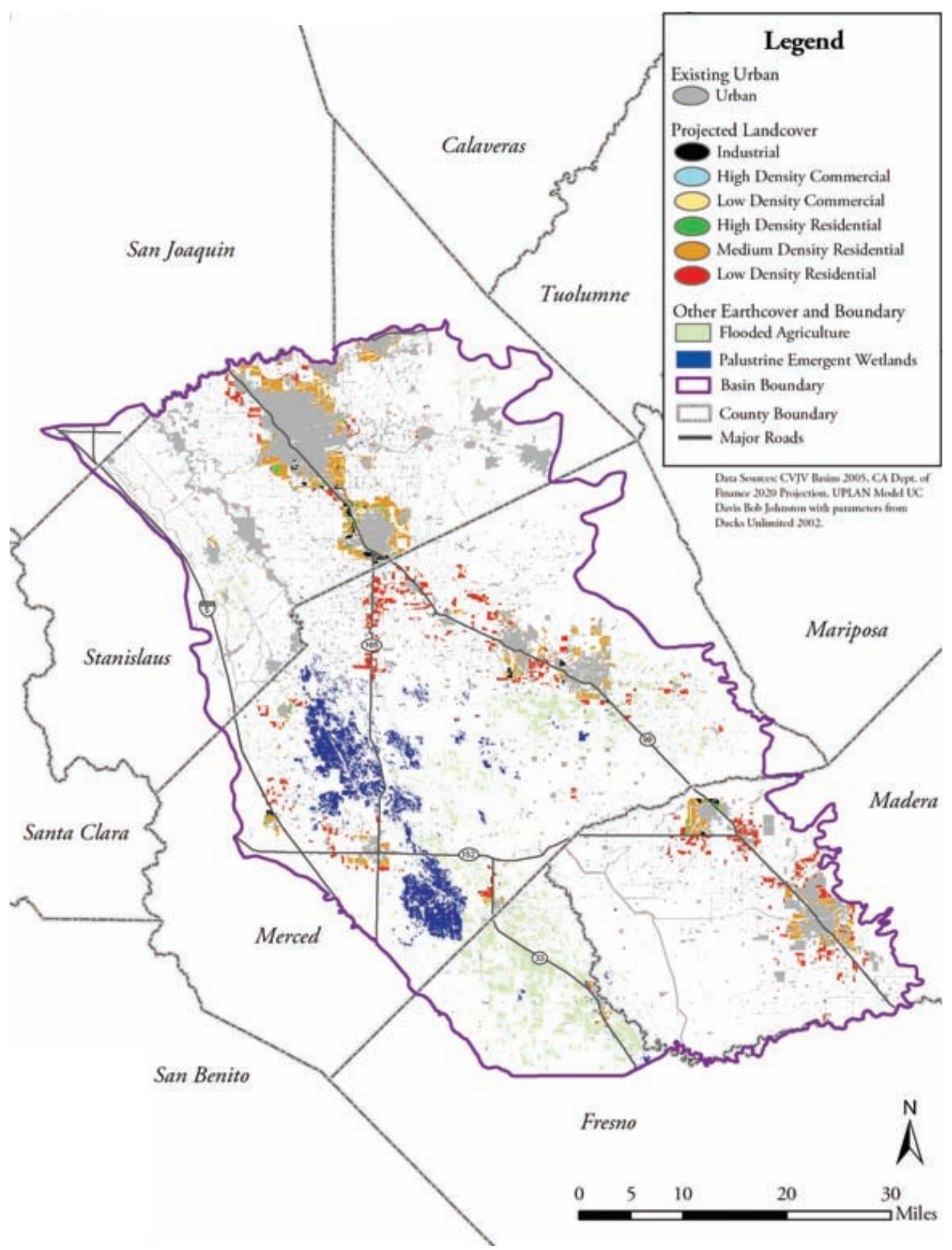

Figure 4-60. Projected growth in San Joaquin Basin to 2020. 
Table 4-31. Conservation objectives for wintering waterfowl in San Joaquin Basin

\begin{tabular}{cccccc|}
$\begin{array}{c}\text { Wetland } \\
\text { Restoration } \\
\text { (Acres) }\end{array}$ & $\begin{array}{c}\text { Wetland } \\
\text { Enhancement } \\
\text { (Acres) }\end{array}$ & $\begin{array}{c}\text { WaterSupplies } \\
\text { (Acre-Feet) }\end{array}$ & $\begin{array}{c}\text { Agricultural } \\
\text { Enhancement } \\
\text { (Acres) }\end{array}$ & $\begin{array}{c}\text { TypeI } \\
\text { Agricultural } \\
\text { Easements }\end{array}$ & $\begin{array}{c}\text { Type II } \\
\text { Agricultural } \\
\text { Easements }\end{array}$ \\
\hline 20,000 & $6,751^{a}$ & $441,521^{b}$ & NoNE & NoNE & NEEDED \\
\hline
\end{tabular}

aAnnual enhancement objective when the wetland restoration objective is met.

${ }^{b}$ Annual water supply need when the wetland restoration objective is met.

\begin{tabular}{|c|c|c|c|c|c|}
\hline $\begin{array}{l}\text { Current Food } \\
\text { Supplies }\end{array}$ & $\begin{array}{l}\text { Habitat } \\
\text { Protection }\end{array}$ & $\begin{array}{c}\text { Progress } \\
\text { in Meeting } \\
\text { Wetland Need }\end{array}$ & $\begin{array}{l}\text { Population } \\
\text { Growth }\end{array}$ & $\begin{array}{c}\text { Loss of } \\
\text { Irrigated } \\
\text { Farmland }\end{array}$ & $\begin{array}{c}\text { Conservation Objective } \\
\text { Priorities }\end{array}$ \\
\hline High & High & High & High & HIGH & WETLAND RESTORATION \\
\hline Moderate & Moderate & Moderate & Moderate & Moderate & WeTLAND ENHANCEMENT \\
\hline \multirow[t]{2}{*}{ Low } & Low & Low & Low & Low & $\begin{array}{c}\text { Type II AgRICUltural } \\
\text { EASEMENTS }\end{array}$ \\
\hline & VERY LOW & VERY LOW & VERY LOW & & \\
\hline
\end{tabular}

Figure 4-61. Information used to identify conservation objective priorities for San Joaquin Basin.

\section{Sutter Basin}

\section{Population Energy Demand vs. Food Energy Supplies: Current Conditions}

Population objectives for migrating and wintering waterfowl in Sutter Basin are presented in Figures 4-62 through 4-64. Duck population objectives are highest in December, while population objectives for dark and white geese peak during January and February respectively. Rice provides the majority of foraging habitat in the basin, while seasonal wetlands total less than 2,000 acres (Table 4-32).

Food supplies for ducks in Sutter Basin are adequate in all time periods with peak supplies occurring in December (Figure 4-65). Food supplies for dark and white geese also peak in December and are well above population needs from fall through spring (Figure 4-66). Agriculture provides $92 \%$ percent of the food energy available for ducks in the basin. Loss of these agricultural habitats foods would significantly reduce duck carrying capacity, as food supplies are exhausted by mid-November, if ducks are restricted to foraging in wetlands (Figure 4-67). Public wetlands alone can only meet duck energy needs through the end of October (Figure 4-68).

\section{Conservation Objectives}

\section{Wetland Restoration}

The amount of seasonal wetlands required to meet 50\% of duck energy needs in Sutter Basin is estimated at 5,951 acres. There are currently 1,951 acres of seasonal wetlands in the basin, leaving a wetland restoration goal of 4,000 acres.

\section{Wetland Enhancement}

The annual enhancement objective for existing wetlands in Sutter Basin is 163 acres/year. Wetland enhancement objectives increase to 496 acres/year when wetland restoration objectives are met for the basin (Table 4-33). 


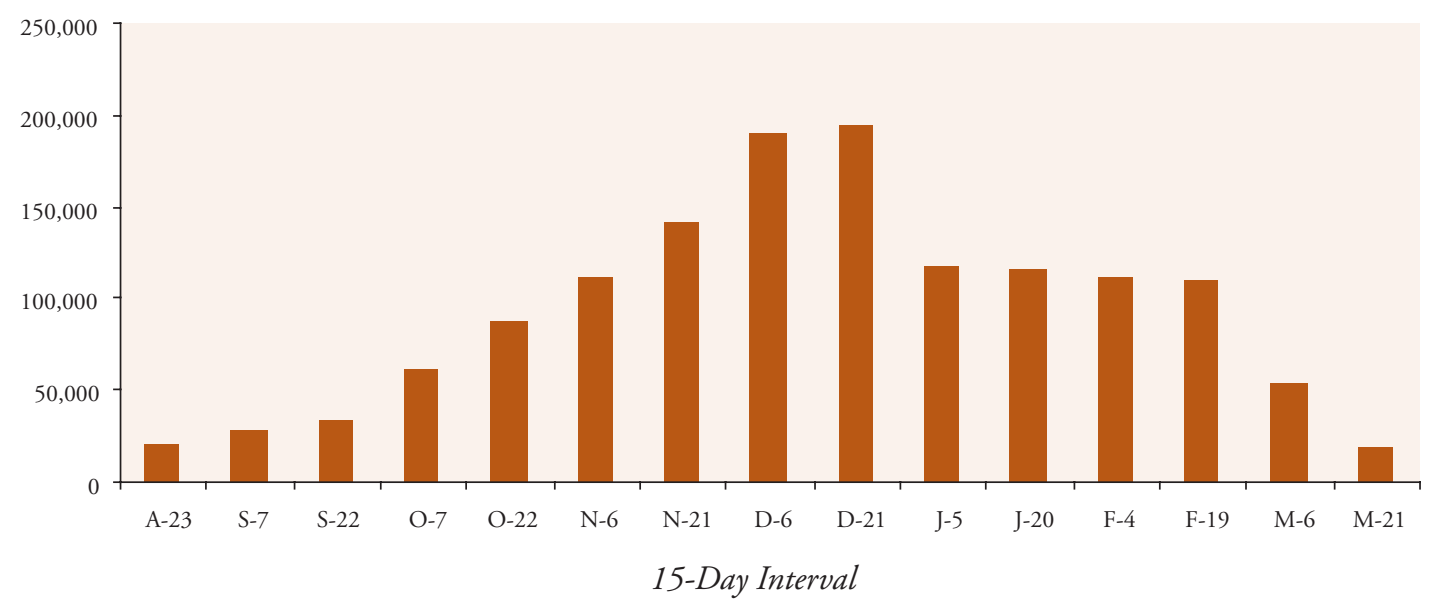

Figure 4-62. Population objectives by 15-day intervals for ducks in Sutter Basin.

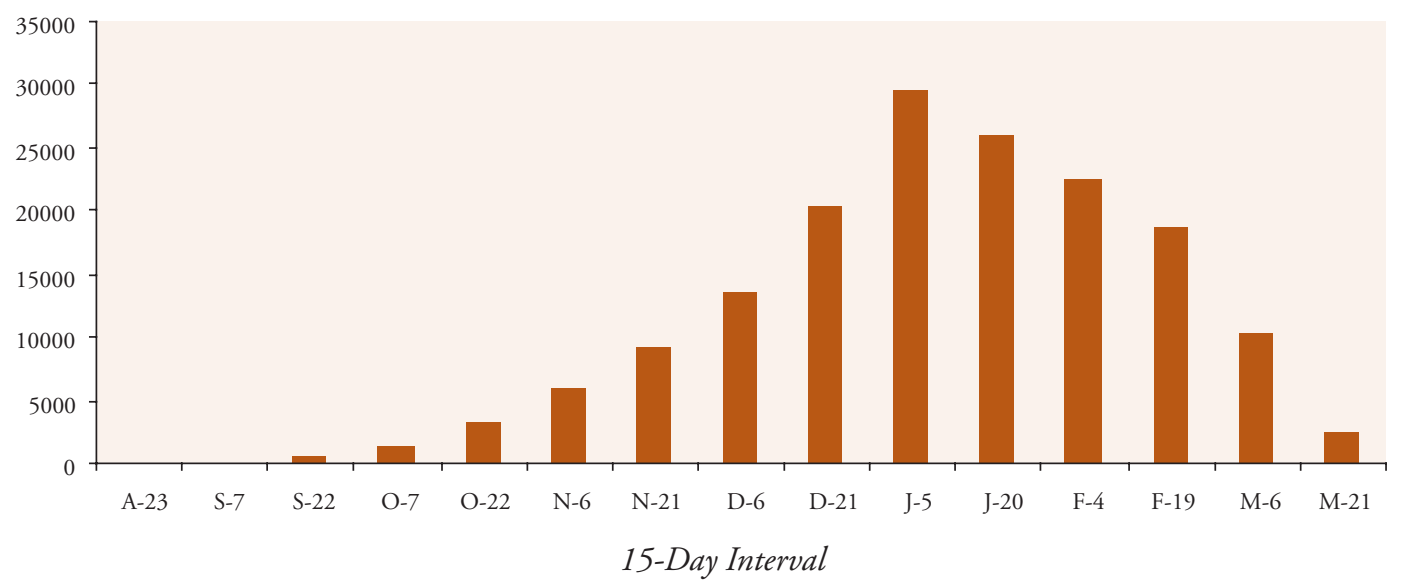

Figure 4-63. Population objectives by 15-day intervals for dark geese in Sutter Basin.

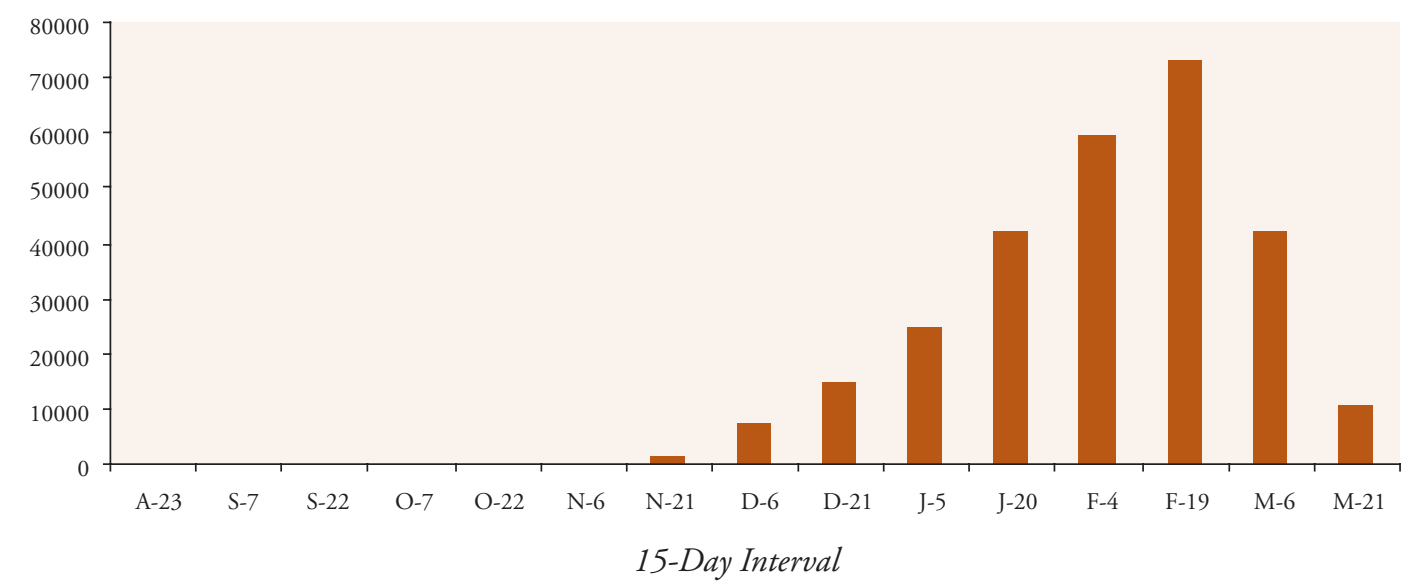

Figure 4-64. Population objectives by 15-day intervals for white geese in Sutter Basin. 
Water Supplies for Wetland Management

Annual management of seasonal wetlands in Sutter Basin will require 29,755 acre-feet of water when wetland restoration objectives for the basin are met. These annual water requirements are further broken down by time period to reflect flooding schedules and summer irrigation needs (Table 4-34).

\section{Agricultural Enhancement}

The agricultural enhancement objective for Sutter Basin is 18,000 acres, all of which is assumed to be rice. This objective represents the amount of rice habitat that must be maintained in a waterfowl-friendly state when wetland restoration objectives have been met for the basin. Ten thousand of these acres must be winter-flooded to meet duck energy needs. Waterfowl-friendly rice habitat in the basin is currently estimated at nearly 43,000 acres. Over 33,000 of these acres are winter-flooded (Table 4-35). Agricultural enhancement objectives are currently exceeded the basin.

\section{Agricultural Easements for Maintaining Waterfowl Foods}

Agricultural habitats are extremely important to waterfowl in Sutter Basin and provide $92 \%$ of the food energy available to ducks (Figure 4-68). The loss of irrigated farmland in Sutter Basin by 2040 is estimated at 8,700 acres or $3.6 \%$ of existing lands (Figure 3-15). Approximately 1,700 of these acres are predicted to be rice (Table 3-4). Most wetland restoration occurs on rice ground, and meeting wetland restoration goals for the basin could reduce rice acreage by an additional 4,000 acres. Planted rice in the basin is now estimated at 46,000 acres. This acre base would be reduced by 5,700 acres if growth projections are accurate and wetland restorations are met.

Reducing Sutter Basin's rice acreage by 5,700 acres would not appear to prevent the JV's agricultural enhancement goal from being met, because over 40,000 acres of rice would remain to meet the 18,000 acre objective for waterfowl-friendly rice (Figure 4-69). However, some resource professionals believe that growth projections for the basin underestimate the future impacts on riceland, especially for the area between Yuba City and Sutter NWR (Figure 4-70). This rice currently buffers wetlands in the Sutter Bypass, the only major wetland complex in the basin. Thus, the JV may need to consider establishing agricultural easements in this portion of the basin.

\section{Agricultural Easements to Buffer Urban Growth (Type II)}

Growth west of Yuba City may ultimately reduce the quality of wetlands in Sutter NWR (Figure 4-70), and a Type II easement program could divert development away from this important wetland complex.

\section{Conservation Objective Priorities}

Conservation objectives for Sutter Basin are summarized in Table 4-36. The information used to prioritize these objectives is presented in Figure 4-71. Food supplies exceed $100 \%$ of duck needs and were rated high. The overall level of habitat protection is very low at $16 \%$, while progress in meeting wetland needs is low (1,951 acres present (vs. 5,951 acres needed or 33\% of need). Population growth and loss of irrigated farmland were both considered low. Wetland restoration is a conservation priority for the basin as only $33 \%$ of wetland needs have been met for ducks. Although projected losses of irrigated farmland are low, agricultural easements that specifically buffer Sutter NWR are needed.
Table 4-32. Foraging habitats available to wintering waterfowl in Sutter Basin.

\begin{tabular}{|cc|}
\hline Habitat Type & Acres \\
\hline SEASONAL WETLANDS & 1,951 \\
FLOODED RICE & 33,168 \\
UNFLOODED RICE & 9,674 \\
CORN & 2,875 \\
\hline
\end{tabular}

Table 4-33. Annual wetland enhancement objectives for Sutter Basin.

\begin{tabular}{|cc|}
$\begin{array}{c}\text { Wetland } \\
\text { Acres }\end{array}$ & $\begin{array}{c}\text { Annual Enhancement } \\
\text { Objective (Acres) }\end{array}$ \\
\hline $1,951^{a}$ & 163 \\
3,951 & 329 \\
$5,951^{b}$ & 496 \\
\hline
\end{tabular}

${ }^{a}$ Current acres of wetlands in Sutter Basin. ${ }^{b}$ Acres of wetlands in Sutter Basin when wetland restoration objectives are met. 'Annual enhancement objectives reflect progress in meeting wetland restoration objectives for Sutter Basin.

Table 4-34. Water needs for seasonal wetlands in Sutter Basin when wetland restoration objective is met.

\begin{tabular}{|cc|} 
Month & $\begin{array}{c}\text { Water Need } \\
\text { (Acre-Feet })\end{array}$ \\
\hline JANUARY & 1,190 \\
FEBRUARY & 1,190 \\
MARCH & 1,190 \\
APRIL & 0 \\
MAY & 4,166 \\
JUNE & 0 \\
JULY & 0 \\
AUGUST & 5,356 \\
SEPTEMBER & 10,712 \\
OCTOBER & 2,308 \\
\hline NOVEMBER & 2,308 \\
DECEMBER & 1,190 \\
ANNUAL NEED & 29,755 \\
\hline
\end{tabular}

Table 4-35. Agricultural enhancement objectives for Sutter Basin.

\begin{tabular}{|ccc|}
\hline & $\begin{array}{c}\text { Waterfowl- } \\
\text { friendly } \text { Rice }^{a}\end{array}$ & $\begin{array}{c}\text { Flooded } \\
\text { Rice }\end{array}$ \\
\hline OBJECTIVE & 18,000 & 10,000 \\
CURRENT & $42,842^{b}$ & 33,168 \\
\hline
\end{tabular}

${ }^{a}$ Waterfowl-friendly rice includes rice that is flooded and rice that is not deep plowed following harvest but which remains dry. ${ }^{b}$ Planted rice acreage in Sutter Basin is estimated at 46,066 acres (Table 3-6). The JV assumes that 42,842 of these acres provide waterfowl-friendly habitat.

Chapter 4: Wintering Waterfowl 


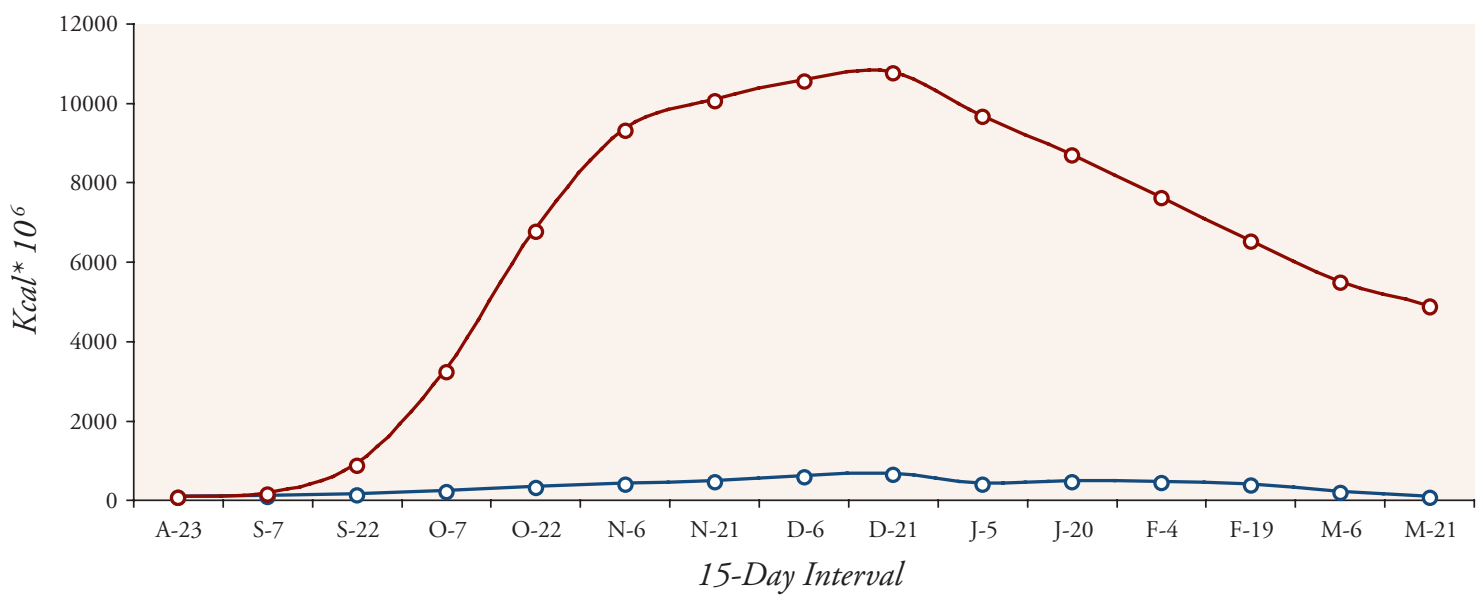

Figure 4-65. Population energy demand (blue) vs. food energy supply (red) for ducks in Sutter Basin when duck populations are at NAWMP goals.

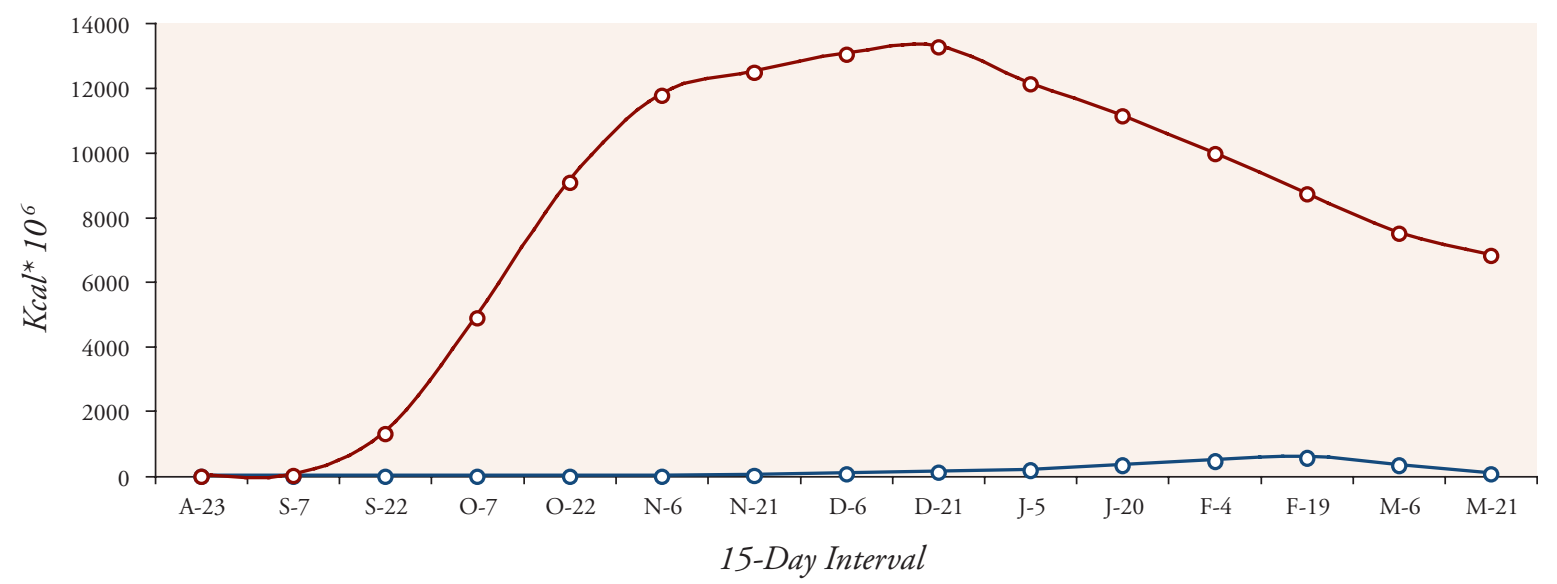

Figure 4-66 (a). Dark goose population energy demand (blue) vs. food energy supplies (red) in Sutter Basin.

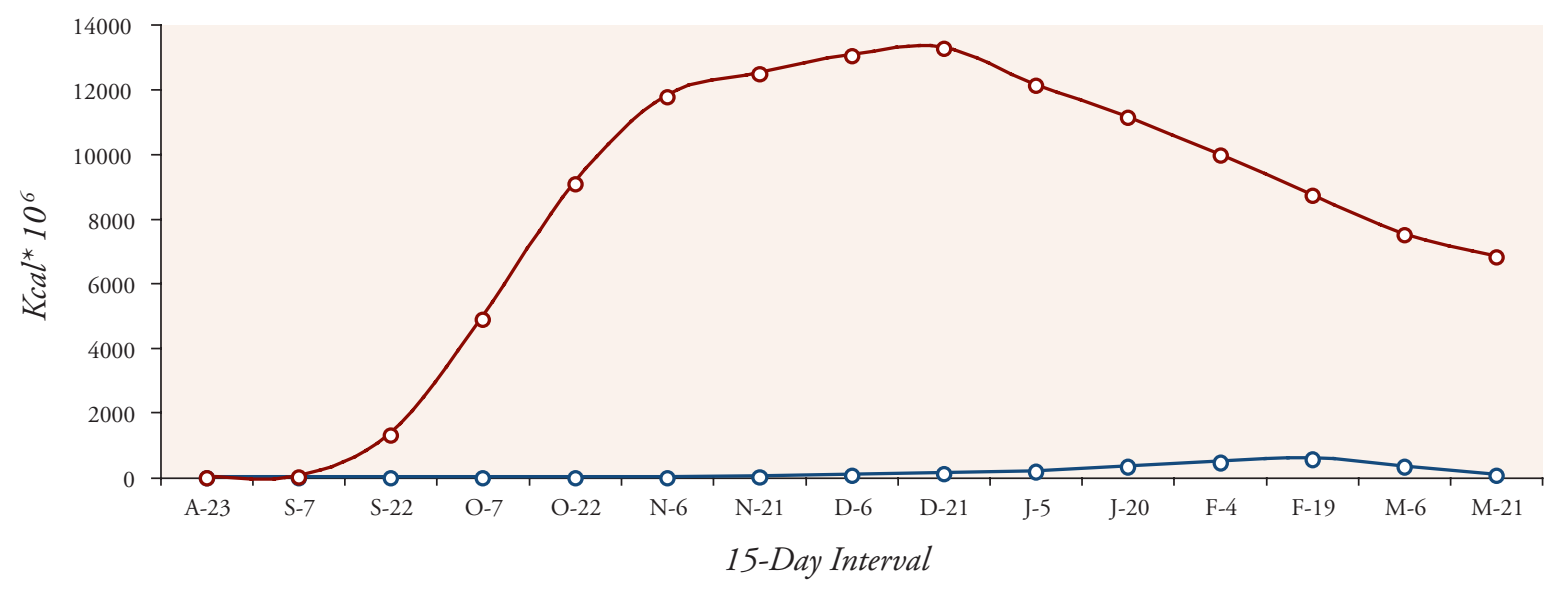

Figure 4-66 (b). White goose population energy demand (blue) vs. food energy supplies (red) in Sutter Basin. 


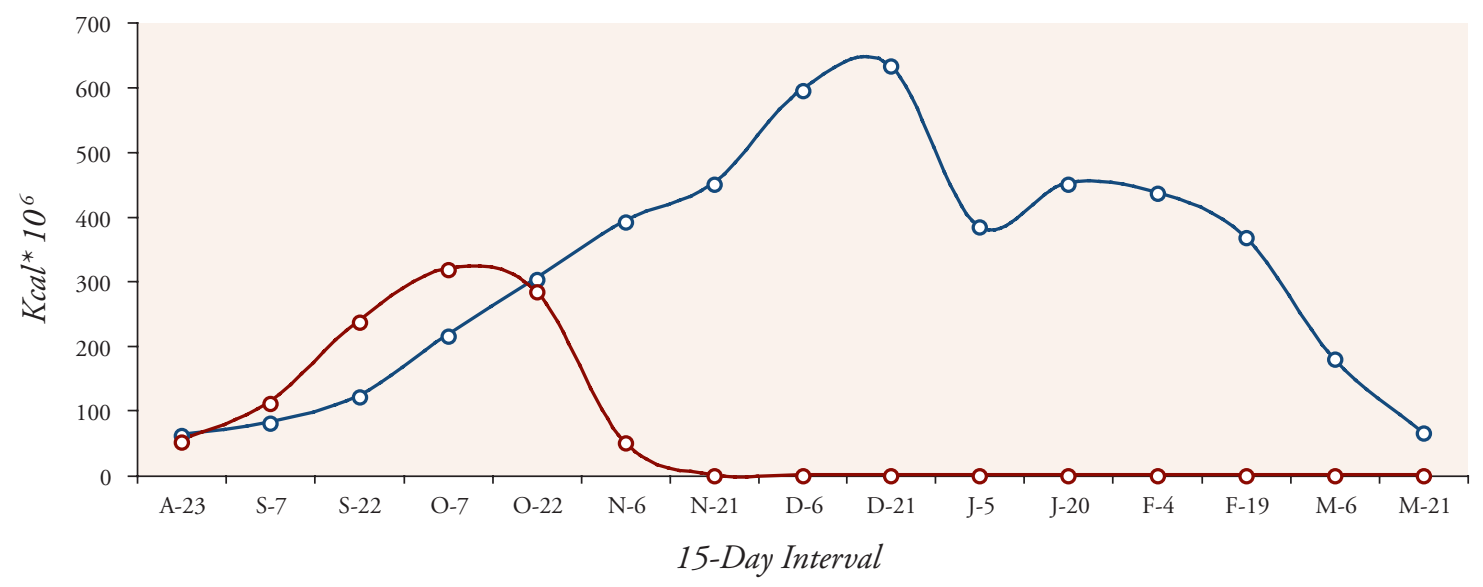

Figure 4-67. Population energy demand (blue) vs. food energy supply (red) for ducks in Sutter Basin when no agricultural food sources are available.

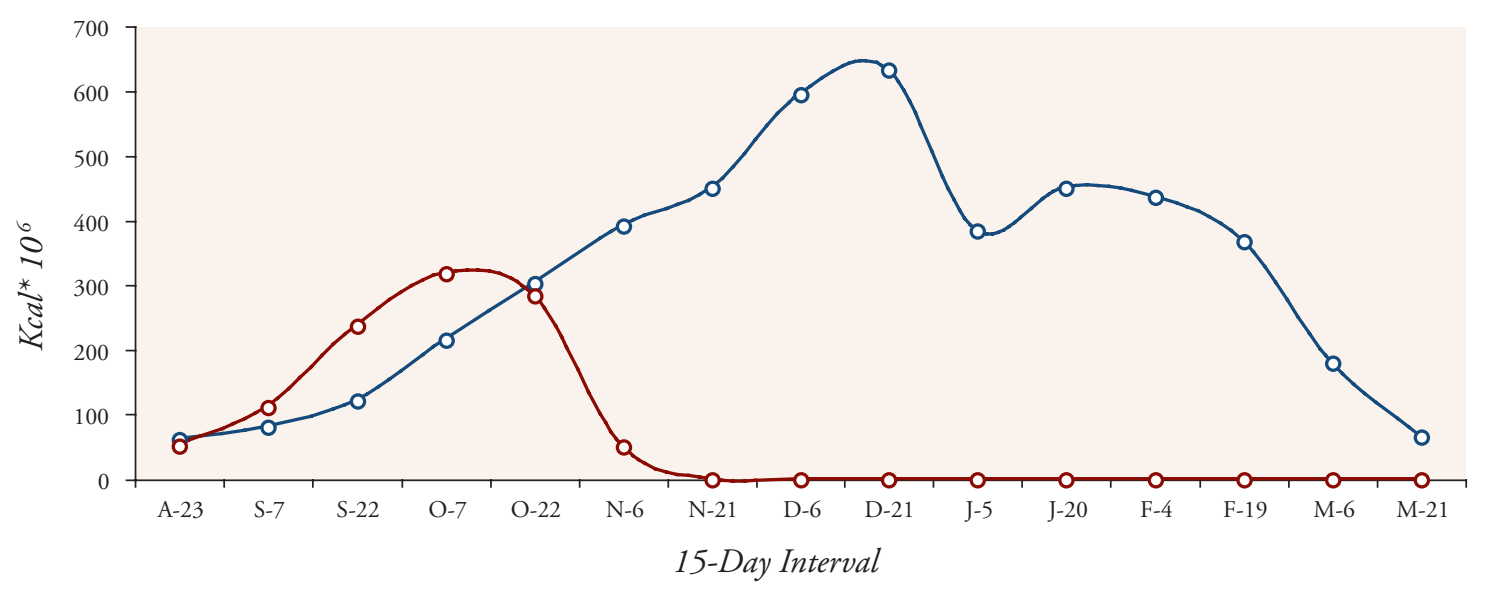

Figure 4-68. Population energy demand (blue) vs. food energy supply (red) for ducks in Sutter Basin if ducks are restricted to foraging on public lands.

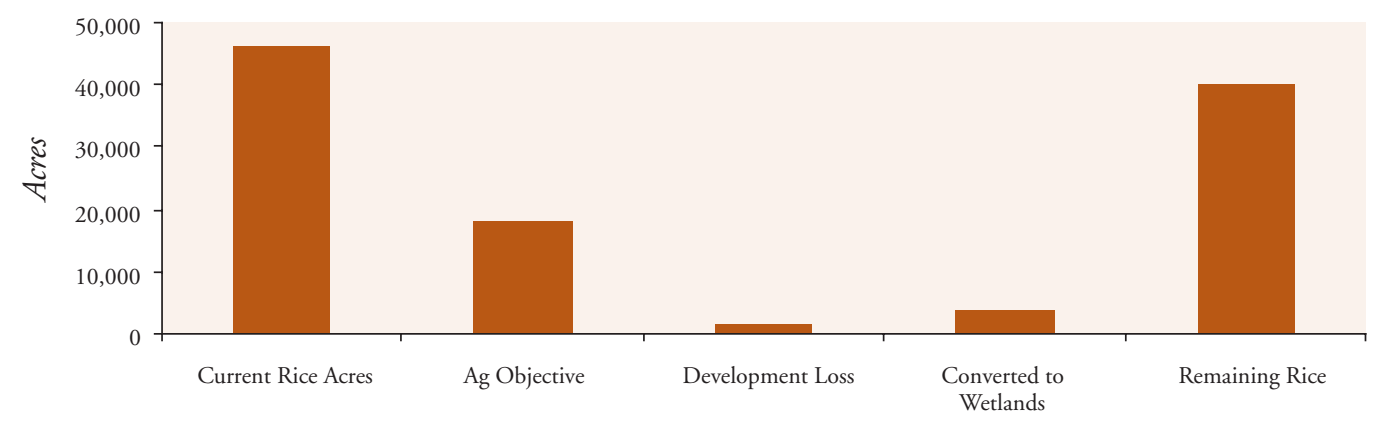

Figure 4-69. Forecasted changes in rice acreage for the Sutter Basin compared to the basin's agricultural enhancement objective. 


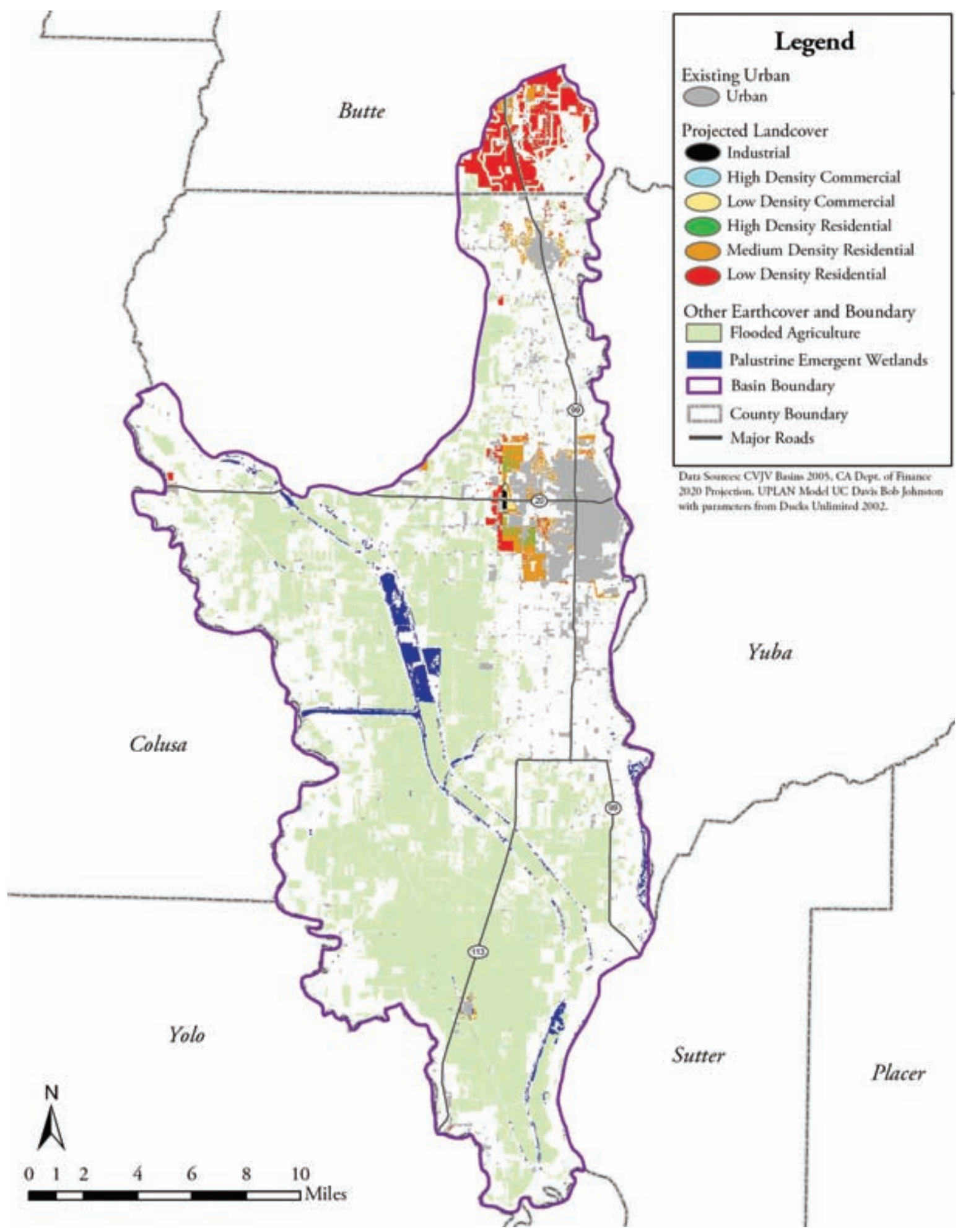

Figure 4-70. Projected growth in Sutter Basin to 2020. 
Table 4-36. Conservation objectives for wintering waterfowl in Sutter Basin.

\begin{tabular}{|c|c|c|c|c|c|}
\hline $\begin{array}{l}\text { Wetland Restoration } \\
\text { (Acres) }\end{array}$ & $\begin{array}{c}\text { Wetland Enhancement } \\
\text { (Acres) }\end{array}$ & $\begin{array}{l}\text { Water Supplies } \\
\text { (Acre-Feet) }\end{array}$ & $\begin{array}{c}\text { Agricultural } \\
\text { Enhancement (Acres) }\end{array}$ & $\begin{array}{c}\text { Type I Agricultural } \\
\text { Easements }\end{array}$ & $\begin{array}{c}\text { Type II Agricultural } \\
\text { Easements }\end{array}$ \\
\hline 4,000 & $496^{a}$ & $29,755^{b}$ & $\begin{array}{l}18,000^{c} \\
10,000^{d}\end{array}$ & NEEDED & NeEded \\
\hline
\end{tabular}

"Annual enhancement objective when the wetland restoration objective is met.

${ }^{b}$ Annual water supply need when the wetland restoration objective is met.

'Total acres of rice that must be maintained in a waterfowl-friendly state (includes 10,000 acres that must be flooded).

Objective has been met.

${ }^{d}$ Total acres of rice that must be flooded out of the total enhancement objective of 18,000 acres.

Objective has been met.

\begin{tabular}{|c|c|c|c|c|c|}
\hline $\begin{array}{l}\text { Current Food } \\
\text { Supplies }\end{array}$ & $\begin{array}{l}\text { Level of Habitat } \\
\quad \text { Protection }\end{array}$ & $\begin{array}{l}\text { Progress in Meeting } \\
\text { Wetland Needs }\end{array}$ & Population Growth & $\begin{array}{l}\text { Loss of Irrigated } \\
\text { Farmland }\end{array}$ & $\begin{array}{c}\text { Conservation Objective } \\
\text { Priorities }\end{array}$ \\
\hline $\mathrm{HIGH}$ & HigH & HIGH & HigH & HigH & WETLAND REstoration \\
\hline Moderate & Moderate & Moderate & Moderate & Moderate & $\begin{array}{l}\text { Type I Agricultural } \\
\text { EASEMENTS }\end{array}$ \\
\hline \multirow[t]{2}{*}{ Low } & Low & Low & Low & Low & $\begin{array}{l}\text { Type II Agricultural } \\
\text { EASEMENTS }\end{array}$ \\
\hline & VERY LOW & VERY LOW & VERY LOW & & \\
\hline
\end{tabular}

Figure 4-71. Information used to identify conservation objective priorities for Sutter Basin.

\section{Suisun Basin}

\section{Population Energy Demand vs. Food Energy Supplies: Current Conditions}

Population objectives for migrating and wintering waterfowl in Suisun Marsh are presented in Figures 4-72 through 4-74. Duck population objectives are highest for December, while population objectives for dark and white geese peak during January. However, dark and white goose populations in Suisun Marsh are very small relative to most other basins and no further results are presented for these birds. Wetlands provide all the food resources in Suisun Marsh, as there are no agricultural habitats in the basin (Table 4-37).

Table 4-37. Foraging habitats available to wintering waterfowl in Suisun Marsh.

\begin{tabular}{|c|c|}
\hline Habitat Type & Acres \\
\hline Seasonal Wetlands & 32,232 \\
\hline
\end{tabular}

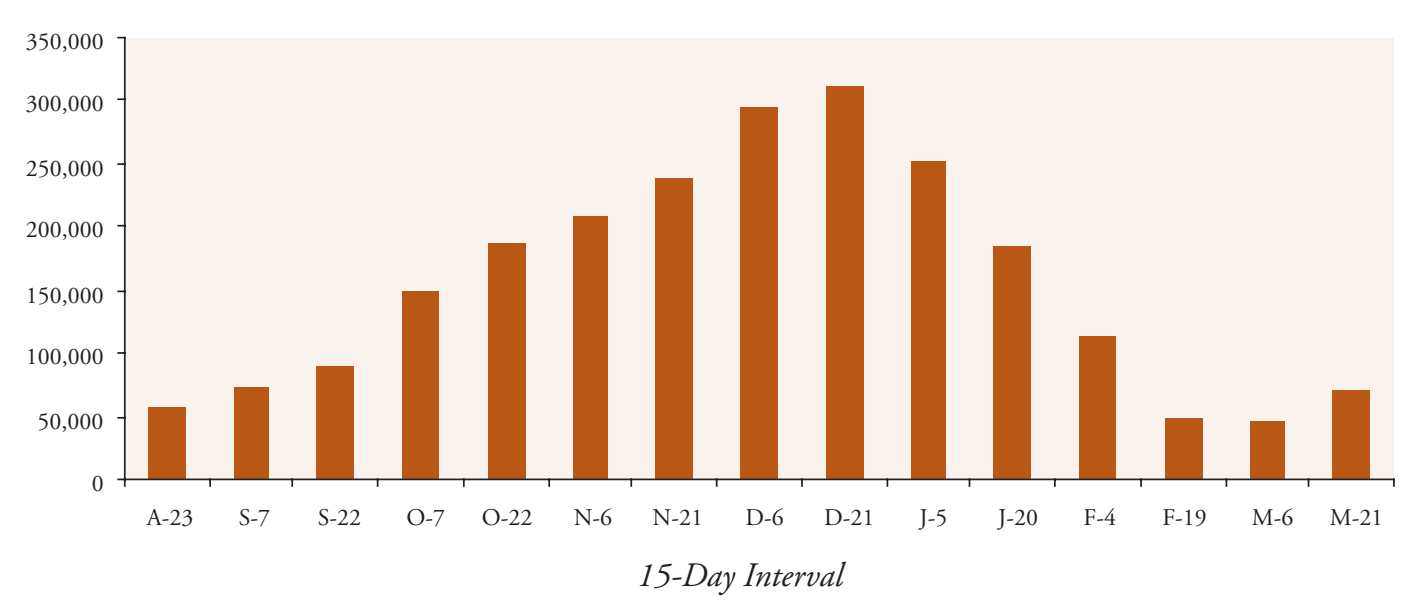

Figure 4-72. Population objectives by 15-day intervals for ducks in Suisun Basin. 
Recent proposals to restore 5,000 acres of Suisun Marsh to tidal flow have raised some concern that carrying capacity will be reduced because food production in saline habitats may be lower than in freshwater environments. Duck food supplies are adequate in all time periods if seed production in Suisun wetlands is similar to other basins (566 lbs/acre) (Figure 4-75). Food supplies remain adequate from fall through spring, even if 5,000 acres of wetlands are restored to tidal flow and no food production is assumed for these tidally restored habitats (Figure 4-76).

Although much of the Suisun Marsh is isolated from tidal flows, wetland habitats are more saline than elsewhere in the Central Valley. Plant communities that are associated with high salinities often produce less seed than plants adapted to freshwater environments. As a result, the JV has assumed that seed production in Suisun Marsh is $50 \%$ of other Basins ( $283 \mathrm{lbs} / \mathrm{acre})$. Food supplies for ducks are adequate even when seed production is assumed to be $283 \mathrm{lbs} /$ acre (Figure 4-77). However, restoring tidal flow to 5,000 acres of existing habitat could result in food supplies being exhausted by early February, if few food resources are provided in these tidal areas and the remaining wetlands provide only $283 \mathrm{lbs}$ of seed/acre (Figure 4-78).

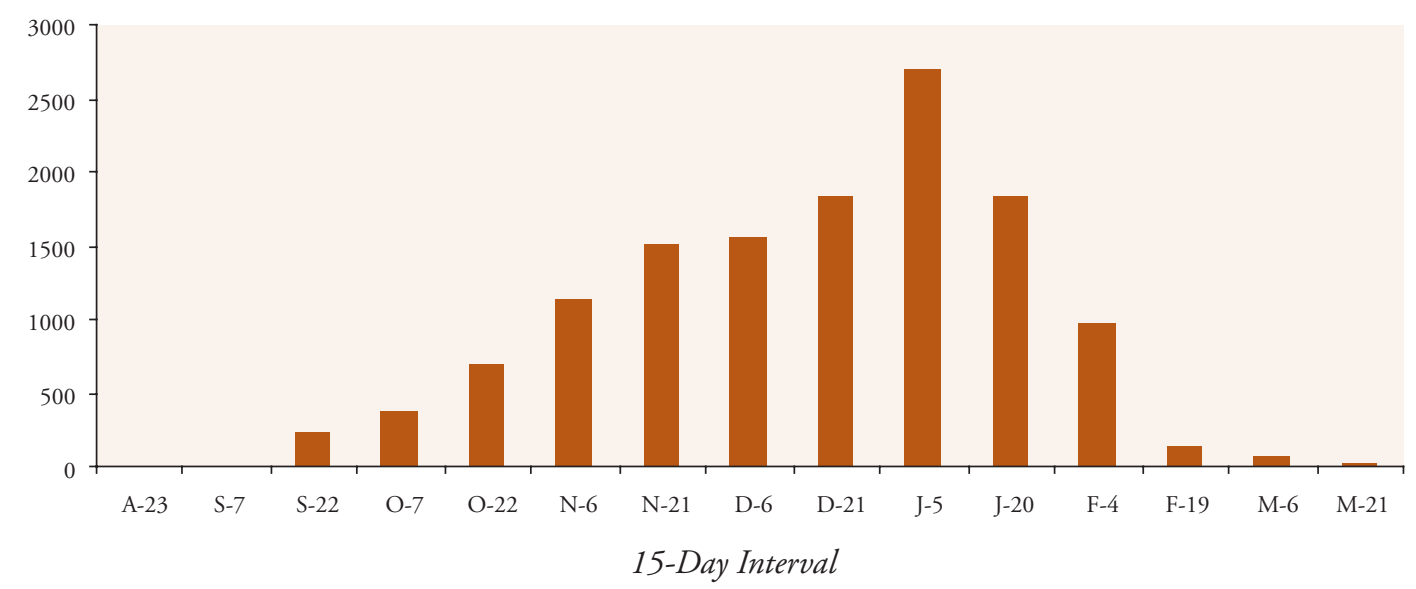

Figure 4-73. Population objectives by 15-day intervals for dark geese in Suisun Marsh.

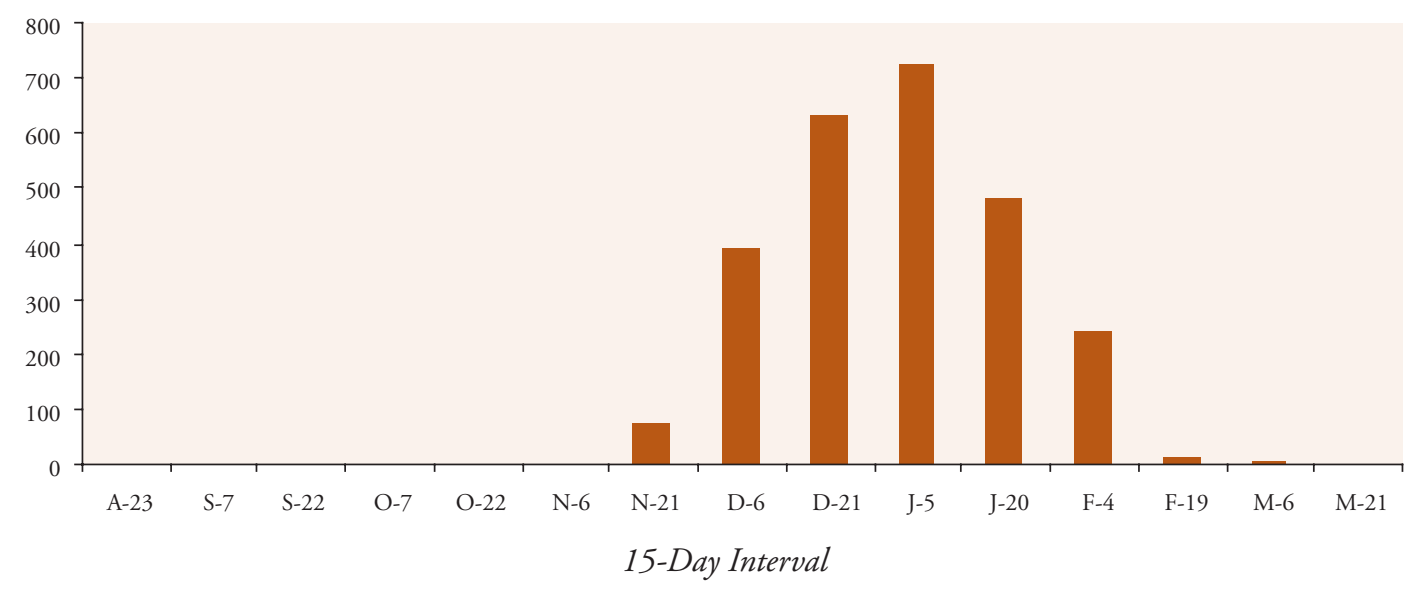

Figure 4-74. Population objectives by 15-day intervals for white geese in Suisun Marsh.

Uncertainty over the food resources provided by Suisun wetlands, and the possible effect of tidal restoration, make any assessment of food supplies difficult. Future studies to estimate food production in existing habitats and in tidally influenced areas would greatly improve the JV's ability to estimate duck carrying capacity in this basin. 


\section{Conservation Objectives}

\section{Wetland Restoration}

There is no wetland restoration objective for Suisun Marsh. Wetlands currently meet $100 \%$ of duck energy needs even when seed production is assumed to be half that of other basins.

\section{Wetland Enhancement}

The annual enhancement objective for existing wetlands in Suisun Marsh is 2,686 acres/year.

\section{Water Supplies for Wetland Management}

Annual management of seasonal wetlands in Suisun Marsh requires 153,102 acre-feet of water. These annual water requirements are further broken down by time period to reflect flooding schedules and summer irrigation needs (Table 4-38).

\section{Agricultural Enhancement}

There is no agricultural enhancement objective for Suisun Marsh, as no crops are grown in the basin.

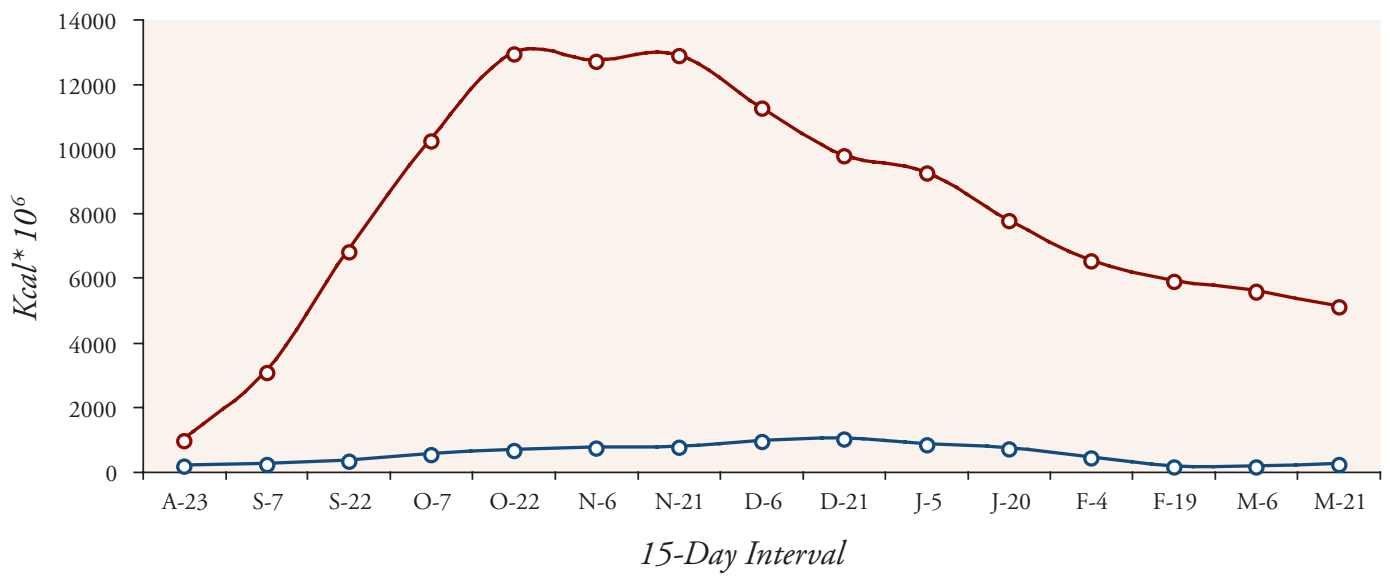

Figure 4-75. Population energy demand (blue) vs. food energy supply (red) for ducks in Suisun Marsh if wetland seed production is similar to other areas of the Central Valley (566 lbs/acre).

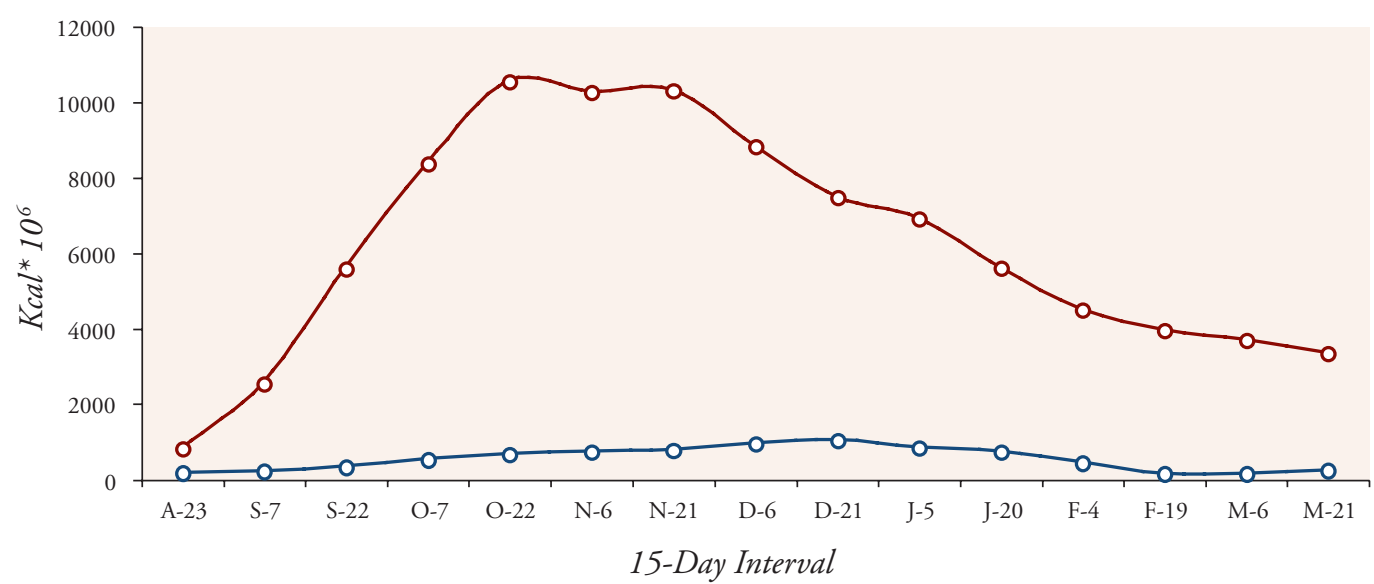

Figure 4-76. Population energy demand (blue) vs. food energy supply (red) for ducks in Suisun Marsh, if wetland seed production is similar to other areas of the Central Valley (566 lbs/acre), and tidal flow is restored to 5,000 acres of existing wetlands. 


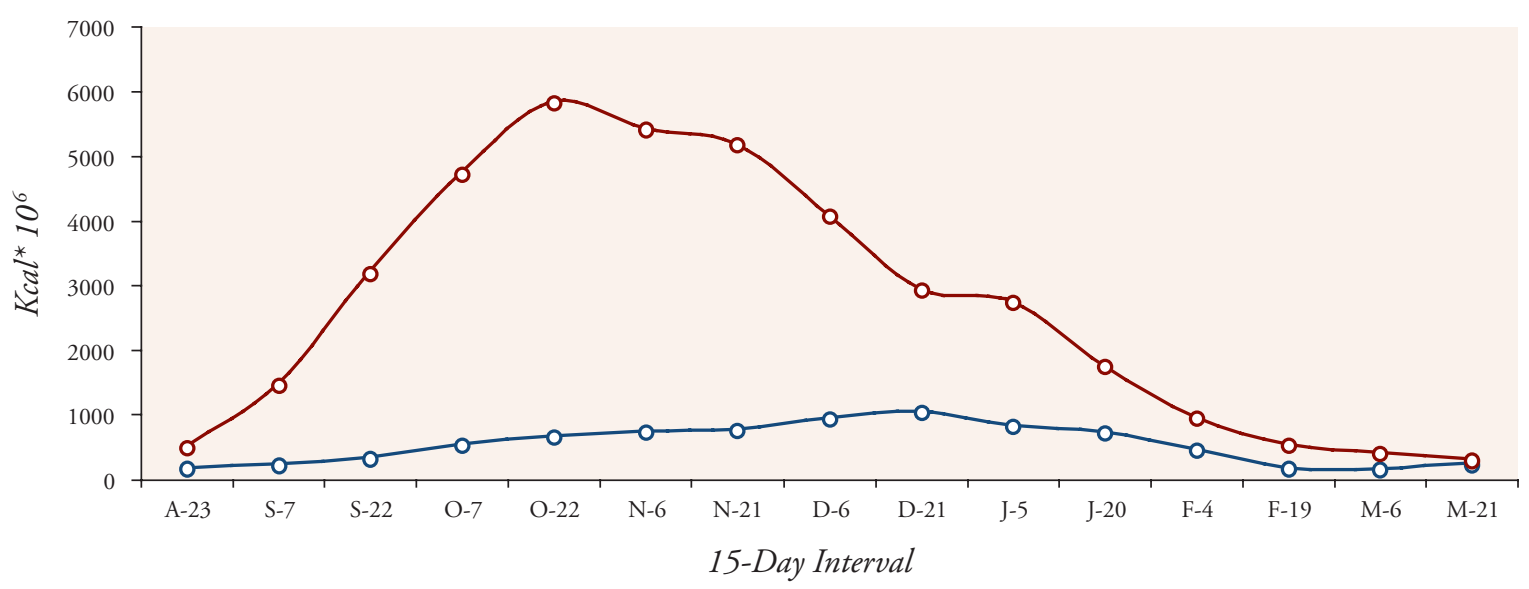

Figure 4-77. Population energy demand (blue) vs. food energy supply (red) for ducks in Suisun Marsh if wetland seed production is assumed to be $50 \%$ of other areas of the Central Valley ( $283 \mathrm{lbs} / \mathrm{acre})$.

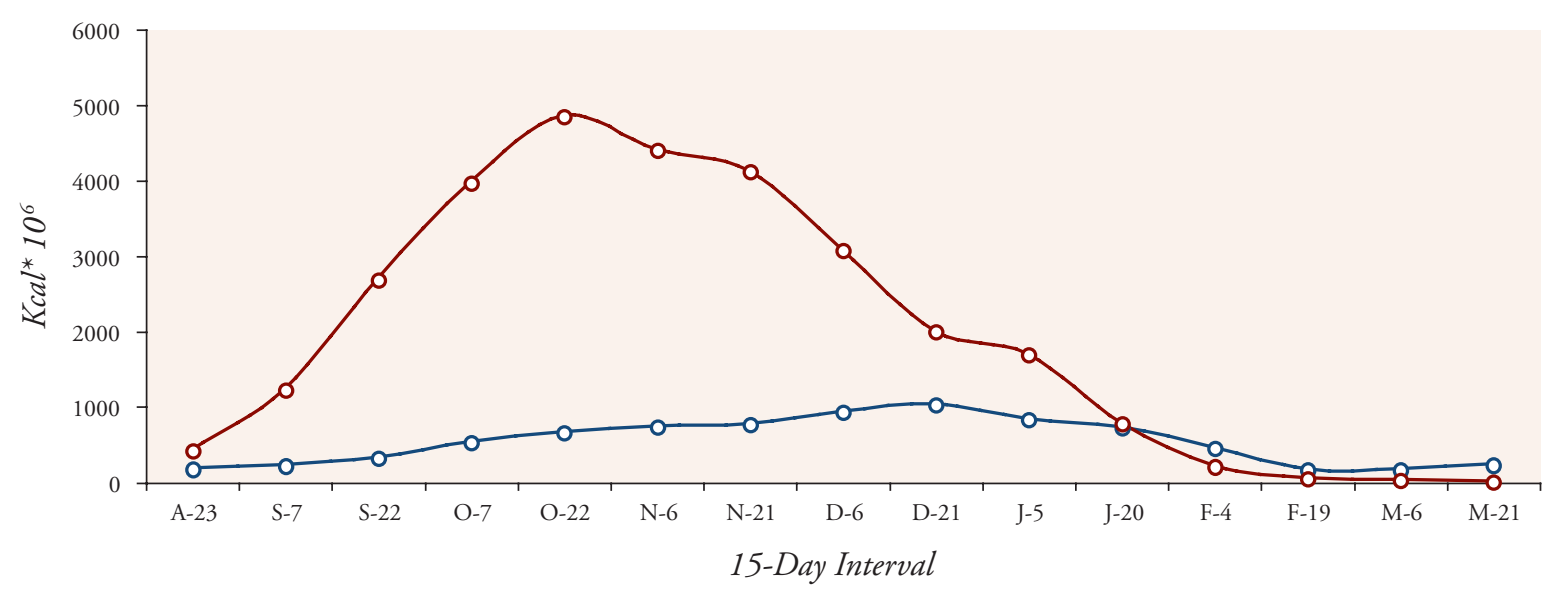

Figure 4-78. Population energy demand (blue) vs. food energy supply (red) for ducks in Suisun Marsh if wetland seed production is assumed to be $50 \%$ of other areas of the Central Valley ( $283 \mathrm{lbs} / \mathrm{acre}$ ), and tidal flow is restored to 5,000 acres of existing wetlands.

\section{Agricultural Easements for Maintaining Waterfowl Foods}

No easements of this type are proposed, as there are no crops grown in the basin.

\section{Agricultural Easements to Buffer Residential and Urban Growth}

No easements of this type are proposed, as there are no crops grown in the basin and no projected residential or urban growth.

\section{Conservation Objective Priorities}

Conservation objectives for Suisun Marsh are summarized in Table 4-39. Information used to prioritize these conservation objectives is presented in Figure 4-79. Food supplies exceed $100 \%$ of duck needs and were rated high. The level of habitat protection is high $(100 \%)$ as is progress in meeting wetland needs (no future wetland restoration proposed). No population growth or loss of irrigated farmland is anticipated for the basin. As a result, wetland enhancement is the only conservation priority identified for Suisun Marsh. 
Table 4-39. Conservation objectives for wintering waterfowl in Suisun Marsh.

\begin{tabular}{|c|c|c|c|c|c|}
\hline $\begin{array}{l}\text { Wetland Restoration } \\
\text { (Acres) }\end{array}$ & $\begin{array}{c}\text { Wetland } \\
\text { Enhancement (Acres) }\end{array}$ & $\begin{array}{l}\text { Water Supplies } \\
\text { (Acre-Feet) }\end{array}$ & $\begin{array}{c}\text { Agricultural } \\
\text { Enhancement (Acres) }\end{array}$ & $\begin{array}{c}\text { Type I Agricultural } \\
\text { Easements }\end{array}$ & $\begin{array}{c}\text { Type II Agricultural } \\
\text { Easements }\end{array}$ \\
\hline 0 & $2,686^{a}$ & $153,102^{b}$ & 0 & None & None \\
\hline
\end{tabular}

aAnnual enhancement objective for existing wetlands.

${ }^{b}$ Annual water supply need for existing wetlands.

\begin{tabular}{|c|c|c|c|c|c|}
$\begin{array}{c}\text { Current Food } \\
\text { Supplies }\end{array}$ & $\begin{array}{c}\text { Level of Habitat } \\
\text { Protection }\end{array}$ & $\begin{array}{c}\text { Progress in Meeting } \\
\text { Wetland Needs }\end{array}$ & $\begin{array}{c}\text { Population } \\
\text { Growth }\end{array}$ & HigH & Loss of Irrigated \\
Farmland & Conservation Objective \\
Priorities
\end{tabular}

Figure 4-79. Information used to prioritize conservation objectives for Suisun Marsh.

\section{Yolo Basin}

\section{Population Energy Demand vs. Food Energy Supplies: Current Conditions}

Population objectives for wintering waterfowl in Yolo Basin are presented in Figures 480 through 4-82. Duck and white geese population objectives are highest in February, while population objectives for dark geese peak during January. Agriculture provides the majority of foraging habitat in the basin, although significant amounts seasonal wetlands are also present (Table 4-40).
Table 4-40. Foraging habitats available to wintering waterfowl in Yolo Basin.

\begin{tabular}{|cc|}
\hline Habitat Type & Acres \\
\hline SEASONAL WETLANDS & 8,558 \\
\hline FLOODED RICE & 7,020 \\
\hline UNFLOODED RICE & 2,048 \\
\hline CORN & 20,640 \\
\hline
\end{tabular}

Food supplies for Yolo Basin ducks are adequate in all time periods, although supplies peak six to eight weeks before bird numbers reach their maximum (Figure 4-83). Food supplies for dark and white geese are also well above population needs and large food surpluses occur from fall through spring (Figure 4-84). Agriculture provides $79 \%$ of the food energy available for ducks in the basin. Loss of these agricultural foods would decrease duck carrying capacity, as food supplies are exhausted by early February if ducks are restricted to foraging in wetlands (Figure 4-85). Public wetlands are capable of meeting duck needs through mid-December (Figure 4-86).

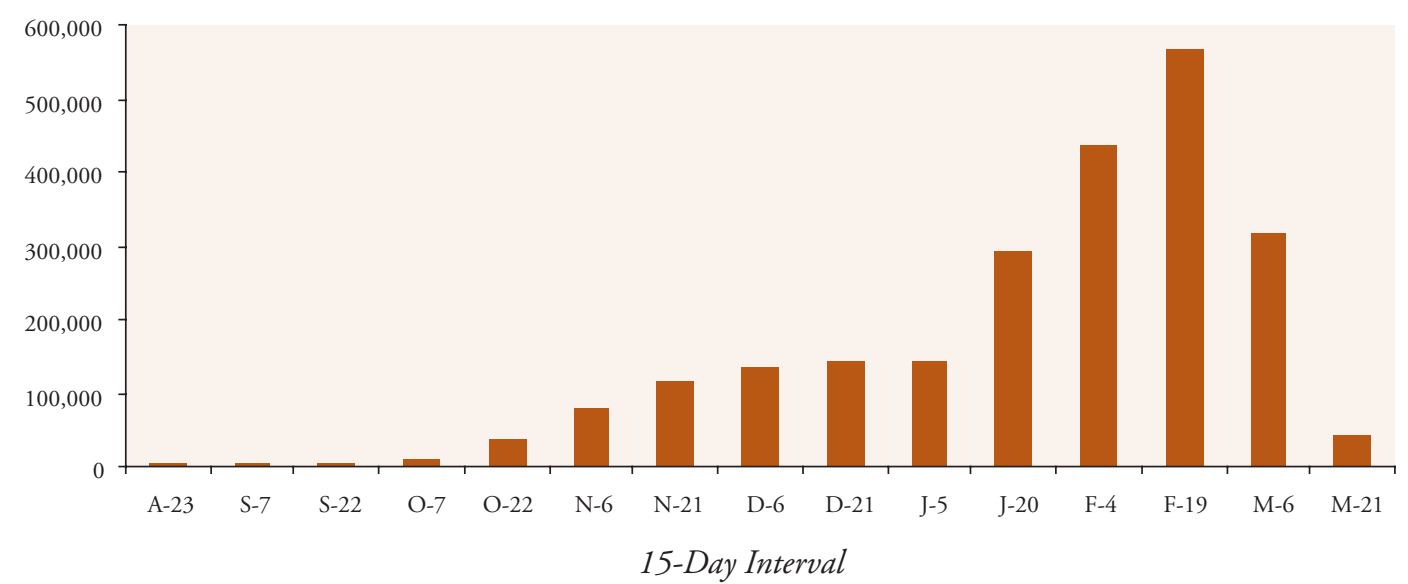

Figure 4-80. Population objectives by 15-day intervals for ducks in Yolo Basin. 


\section{Conservation Objectives}

\section{Wetland Restoration}

The amount of seasonal wetlands required to meet $50 \%$ of duck energy needs in Yolo Basin is estimated at 11,558 acres. There are currently 8,558 acres of seasonal wetlands in the basin, leaving a wetland restoration goal of 3,000 acres.

\section{Seasonal Wetland Enhancement}

The annual enhancement objective for existing seasonal wetlands in Yolo Basin is 713 acres/year. Wetland enhancement objectives will increase to 963 acres/year when wetland restoration objectives are met for the basin (Table 4-41).

\section{Water Supplies for Wetland Management}

Annual management of seasonal wetlands in Yolo Basin will require 57,790 acre-feet of water when wetland restoration objectives in the basin have been met. These annual water requirements are further broken down by time period to reflect flooding schedules and summer irrigation needs (Table 4-42).

\section{Agricultural Enhancement}

The Yolo Basin contains significant amounts of both corn and rice, and agricultural enhancement objectives for the basin reflect the relative abundance of these two crop types. The enhancement objective for the basin is 11,000 acres, of which 8,000 is assumed to be corn. The remaining 3,000 acres is assumed to be flooded rice. This objective represents the amount of corn and rice that must be maintained in a waterfowlfriendly state when wetland restoration objectives have been met for the basin. Corn acreage is currently estimated at 20,640, while flooded rice totals 7,020 acres (Table 4-43). Agricultural enhancement objectives are currently exceeded for the basin.

\section{Agricultural Easements for Maintaining Waterfowl Foods}

Agricultural habitats are extremely important to waterfowl in Yolo Basin and provide $79 \%$ of the food energy now available to ducks (Figure 4-85). The loss of irrigated farmland in the basin by 2040 is estimated at nearly 50,000 acres or $8.3 \%$ of existing lands (Figure 3-15). Approximately 800 of these acres are predicted to be rice, while 3,400 acres of corn will be lost ( $8.3 \%$ loss rate applied to existing acres of corn). Most wetland restoration occurs on rice ground, and an additional 3,000 acres of rice may be converted to wetlands if wetland restoration objectives are met for the basin.

Forty-one thousand acres of corn and nearly 10,000 acres of rice are planted annually in Yolo Basin (Table 3-6). The loss of 3,400 acres of corn to development will not prevent agricultural enhancement objectives for corn being met, especially since objectives for corn are now exceeded by over 100\% (Table 4-43). However, reducing the basin's 10,000 acre rice base by nearly 4,000 acres is a significant loss. While this loss may not prevent agricultural enhancement objectives being met for rice (Figure 4-87), changes in the rice base should be closely monitored to determine if a Type I easement program is needed in the future.

\section{Agricultural Easements to Buffer Urban Growth}

Growth projections for Yolo Basin indicate that little residential or urban development will occur near existing wetlands (Figure 4-88). As a result, no agricultural easements to buffer growth are proposed for the basin.
Table 4-41. Annual wetland enhancement objectives for Yolo Basin.

\begin{tabular}{|cc|} 
Wetland Acres & $\begin{array}{c}\text { Annual Enhancement } \\
\text { Objective (Acres) }\end{array}$ \\
\hline $8,558^{a}$ & 713 \\
10,558 & 880 \\
$11,558^{b}$ & 963 \\
\hline
\end{tabular}

${ }^{a}$ Current acres of wetlands in Yolo Basin. ${ }^{b}$ Acres of wetlands in Yolo Basin when wetland restoration objectives are met.

'Annual enhancement objectives reflect progress in meeting wetland restoration objectives for Yolo Basin.

Table 4-42. Water needs for seasonal wetlands in Yolo Basin when wetland restoration objective is met.

\begin{tabular}{|cc|} 
Month & $\begin{array}{c}\text { Water Need } \\
(\text { Acre-Feet })\end{array}$ \\
\hline JANUARY & 2,312 \\
FEBRUARY & 2,312 \\
MARCH & 2,312 \\
APRIL & 0 \\
MAY & 8,091 \\
JUNE & 0 \\
JULY & 0 \\
AUGUST & 10,402 \\
SEPTEMBER & 20,804 \\
OCTOBER & 4,623 \\
NOVEMBER & 4,623 \\
DECEMBER & 2,312 \\
ANNUAL NeED & 57,790 \\
\hline
\end{tabular}

Table 4-43. Agricultural enhancement objectives for Yolo Basin.

\begin{tabular}{|ccc|}
\multicolumn{1}{c}{} & $\begin{array}{c}\text { Waterfowl } \\
\text { Friendly }\end{array}$ & $\begin{array}{c}\text { Flooded } \\
\text { Rice }\end{array}$ \\
\hline OBJeCtive & 8,000 & 3,000 \\
CURRENT & $20,640^{b}$ & 7,020 \\
\hline
\end{tabular}

${ }^{a}$ Waterfowl-friendly corn includes corn that is flooded and corn that is not deep plowed following harvest but which remains dry. ${ }^{b}$ Planted corn in Yolo Basin is estimated at 41,280 acres (Table 3-6). The JV assumes that 20,640 or $50 \%$ of these acres provide waterfowlfriendly habitat, most of which is dry.

Table 4-45. Foraging habitats available to wintering waterfowl in Tulare Basin.

\begin{tabular}{|cc|}
\hline Habitat Type & Acres \\
\hline SEASONAL WETLANDS & 20,212 \\
\hline
\end{tabular}


Table 4-44. Conservation Objectives for wintering waterfowl in Yolo Basin.

\begin{tabular}{cccccc|}
$\begin{array}{c}\text { Wetland } \\
\text { Restoration (Acres) }\end{array}$ & $\begin{array}{c}\text { Wetland } \\
\text { Enhancement (Acres) }\end{array}$ & $\begin{array}{c}\text { Water Supplies } \\
\text { (Acre-Feet) }\end{array}$ & $\begin{array}{c}\text { Agricultural } \\
\text { Enhancement (Acres) }\end{array}$ & $\begin{array}{c}\text { Type I Agricultural } \\
\text { Easements }\end{array}$ & $\begin{array}{c}\text { Type II Agricultural } \\
\text { Easements }\end{array}$ \\
\hline 3,000 & $963^{a}$ & $57,790^{b}$ & $\begin{array}{l}8,000^{c} \\
3,000^{d}\end{array}$ & NONE & NONE \\
\hline
\end{tabular}

annual enhancement objective when the wetland restoration objective is met.

${ }^{b}$ Annual water supply need when the wetland restoration objective is met.

'Total acres of corn that must be enhanced. Objective has been met.

${ }^{d}$ Total acres of rice that must be flooded. Objective has been met.

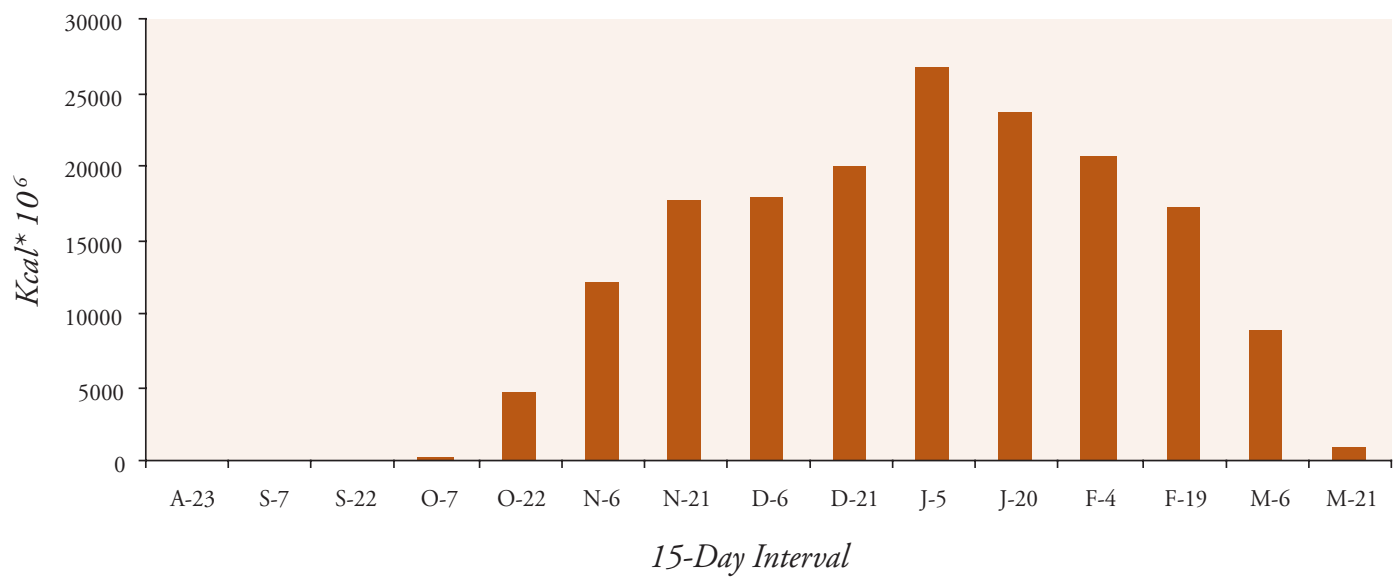

Figure 4-81. Population objectives by 15-day intervals for dark geese in Yolo Basin.

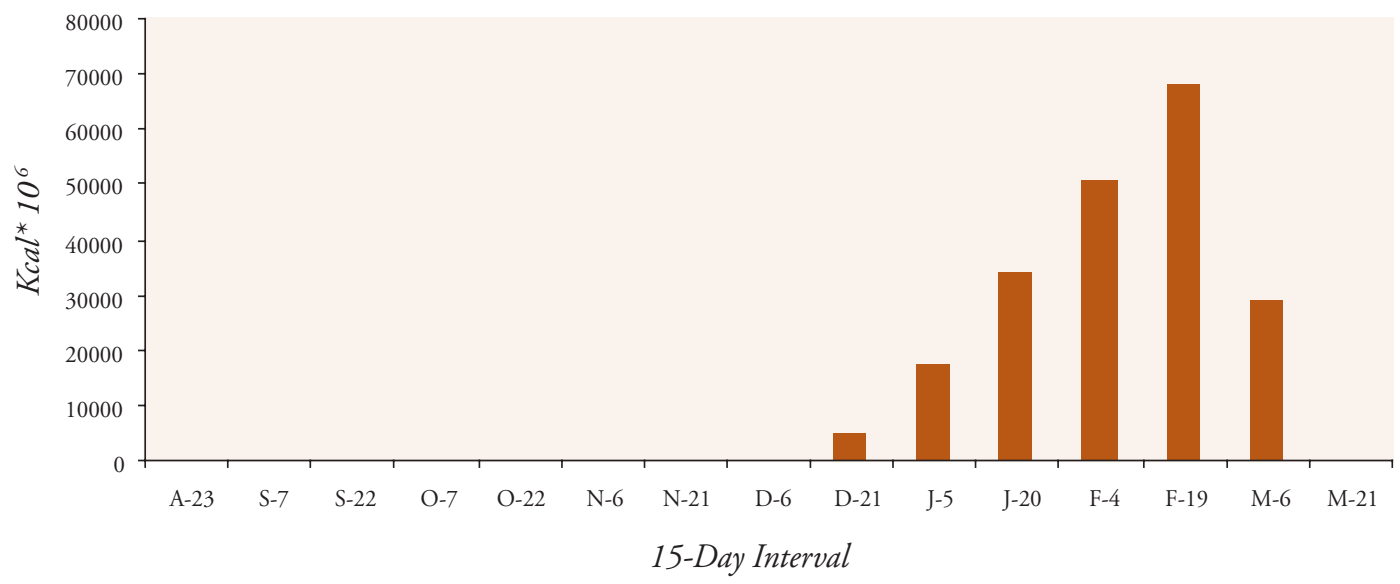

Figure 4-82. Population objectives by 15-day intervals for white geese in Yolo Basin.

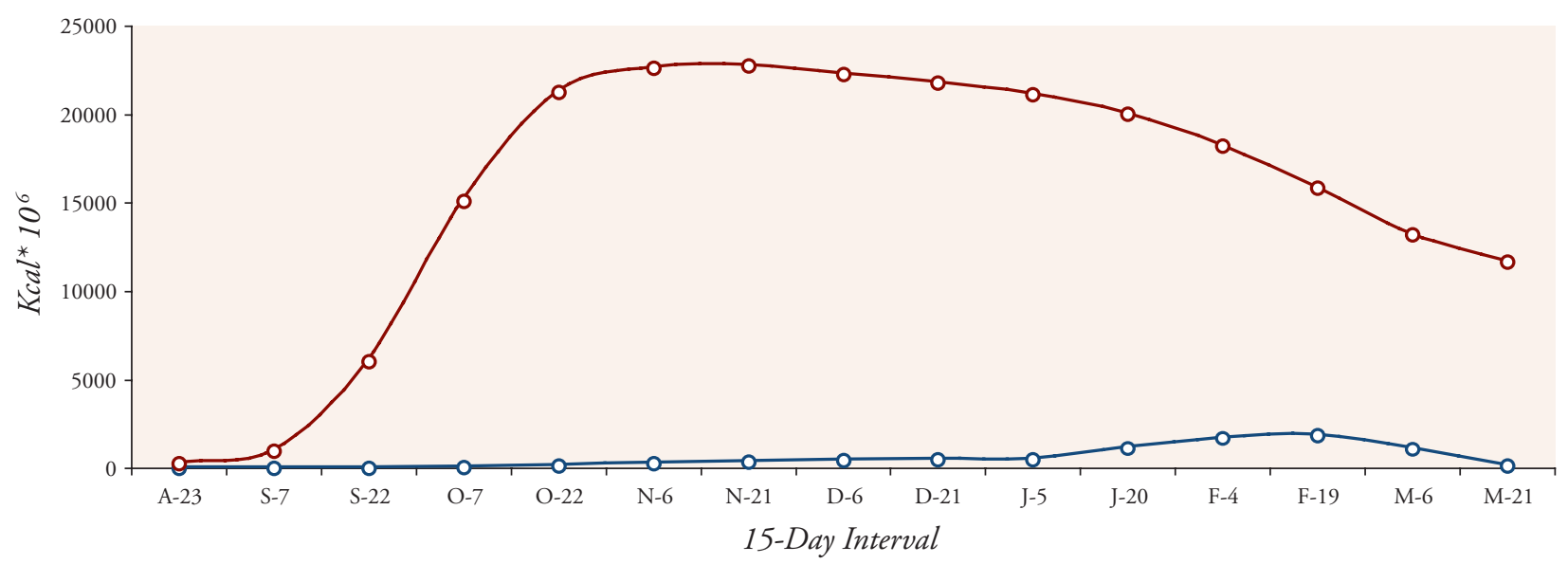

Figure 4-83. Population energy demand (blue) vs. food energy supply (red) for ducks in Yolo Basin when duck populations are at NAWMP goals. 


\section{Conservation Objective Priorities}

Conservation objectives for Yolo Basin are summarized in Table 4-44. The information used to identify conservation objective priorities for the basin is presented in Figure 4-89. Food supplies exceed 100\% of duck needs and were rated high. Habitat protection in the basin is low at $36 \%$, while progress in meeting wetland needs is moderate $(8,000$ acres present vs. 11,000 acres needed or $72 \%$ of need). Human population growth for the basin was categorized as low, while the projected loss of irrigated farmland is moderate. Wetland restoration is a priority for the basin.

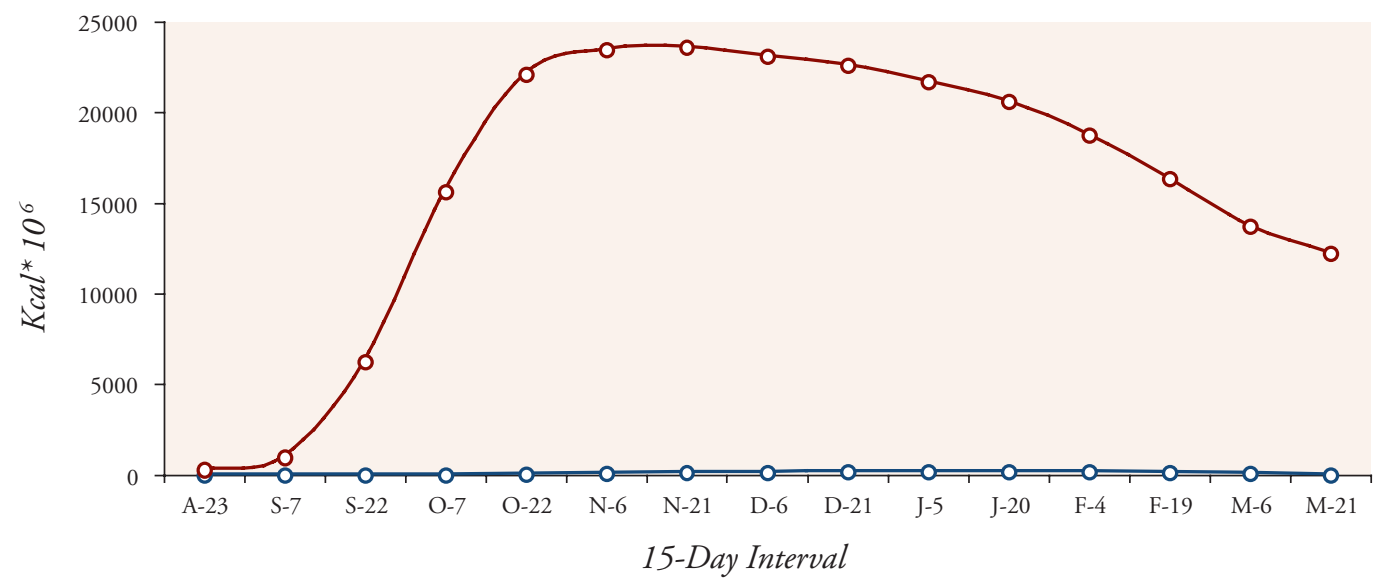

Figure 4-84 (a). Dark goose population energy demand (blue) vs. food energy supply (red) in Yolo Basin.

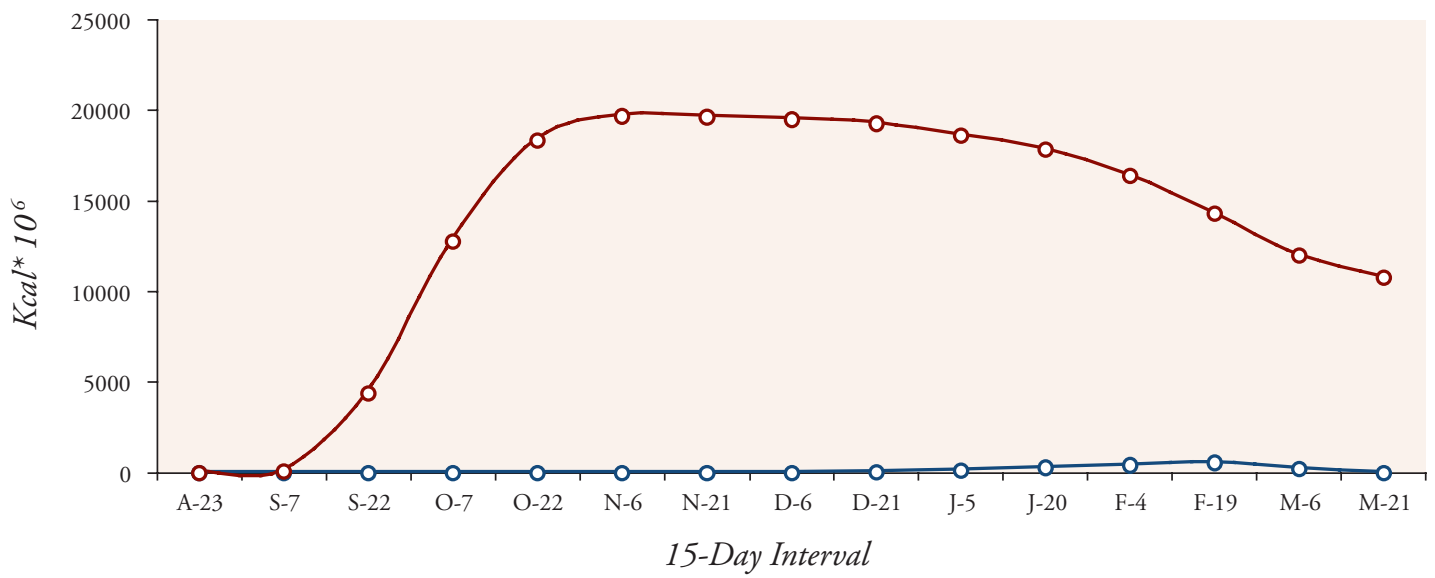

Figure 4-84 (b). White goose population energy demand (blue) vs. food energy supply (red) in Yolo Basin.

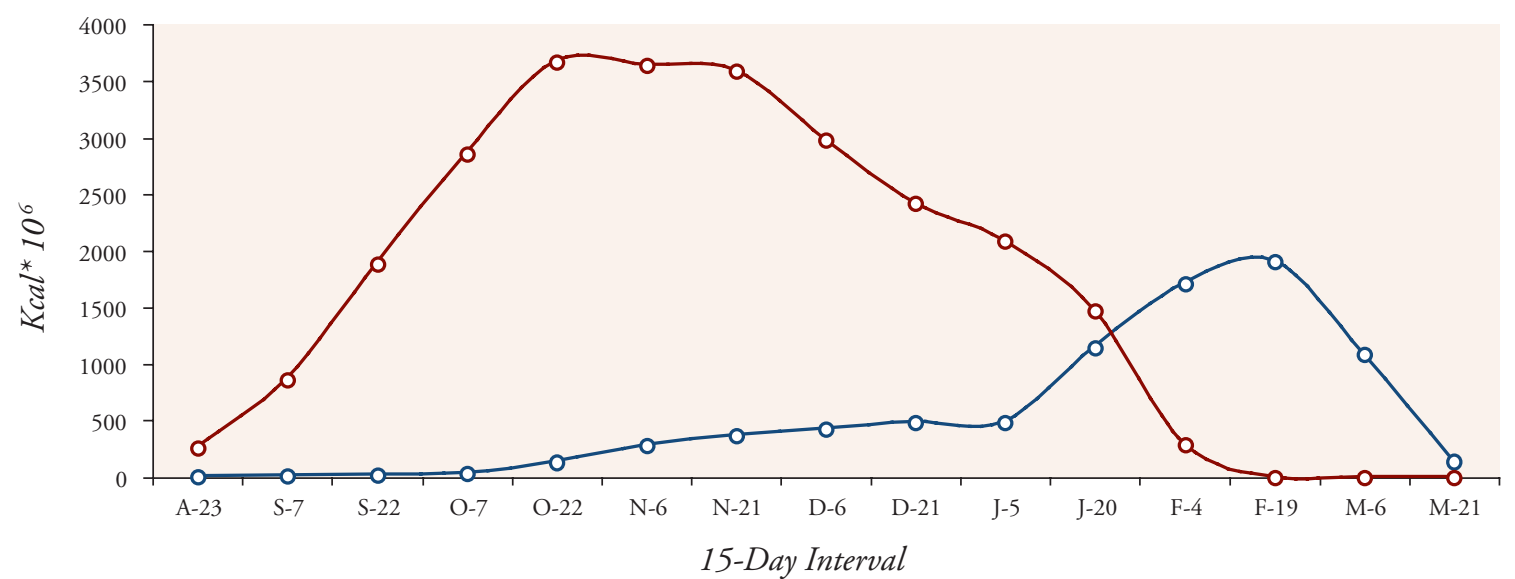

Figure 4-85. Population energy demand (blue) vs. food energy supply (red) for ducks in Yolo Basin when no agricultural food sources are available. 


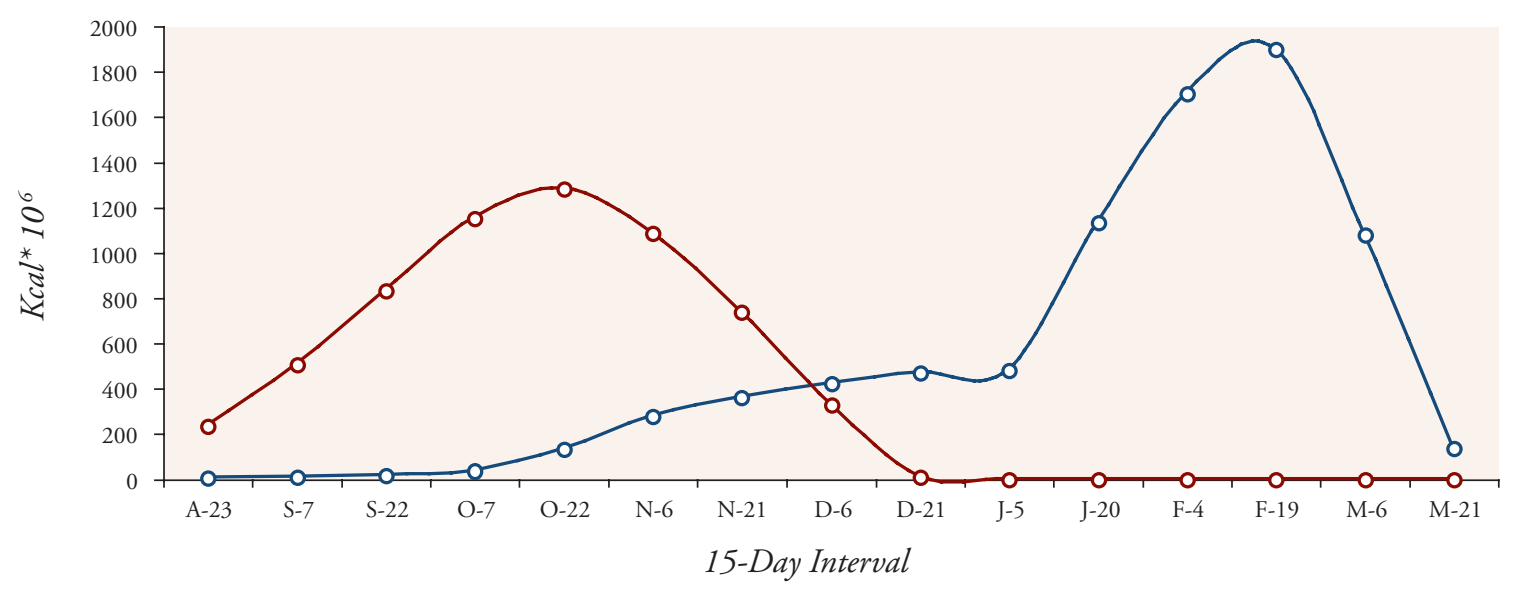

Figure 4-86. Population energy demand (blue) vs. food energy supply (red) for ducks in Yolo Basin when ducks are restricted to foraging on public lands.

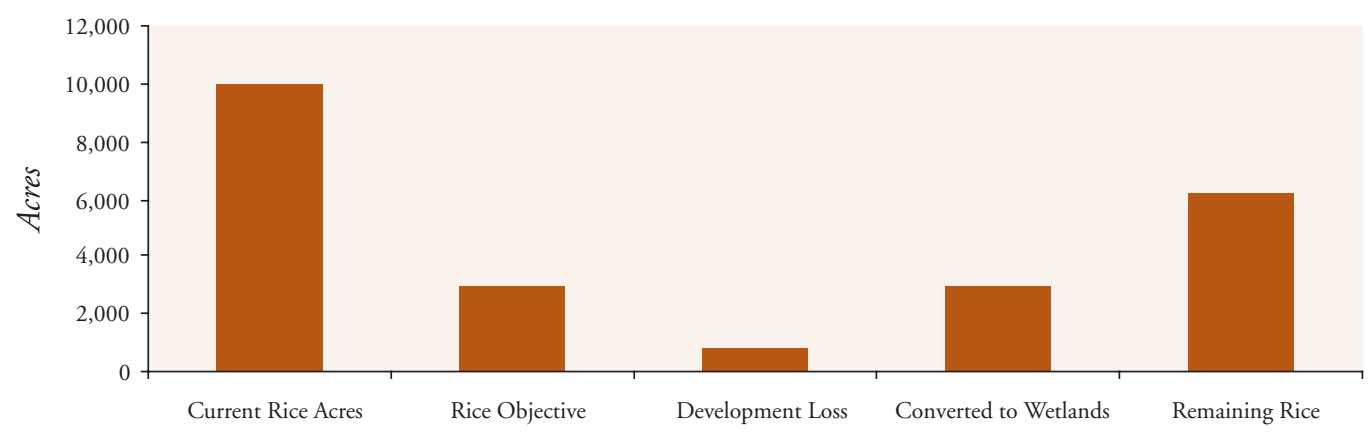

Figure 4-87. Forecasted changes in rice acreage for the Yolo Basin compared to the basin's rice habitat objective.

\begin{tabular}{|c|c|c|c|c|c|}
\hline $\begin{array}{l}\text { Current Food } \\
\text { Supplies }\end{array}$ & $\begin{array}{l}\text { Level of Habitat } \\
\quad \text { Protection }\end{array}$ & $\begin{array}{l}\text { Progress in Meeting } \\
\text { Wetland Needs }\end{array}$ & Population Growth & $\begin{array}{l}\text { Loss of Irrigated } \\
\text { Farmland }\end{array}$ & $\begin{array}{c}\text { Conservation Objective } \\
\text { Priorities }\end{array}$ \\
\hline $\mathrm{HIGH}$ & $\mathrm{HIGH}$ & $\mathrm{HIGH}$ & $\mathrm{HigH}$ & $\mathrm{HIGH}$ & WETLAND REstoration \\
\hline Moderate & Moderate & Moderate & Moderate & Moderate & \\
\hline \multirow[t]{2}{*}{ Low } & Low & Low & Low & Low & \\
\hline & VERY LOW & VERY LOW & VERY LOW & & \\
\hline
\end{tabular}

Figure 4-89. Information used to prioritize conservation objectives for Yolo Basin. 


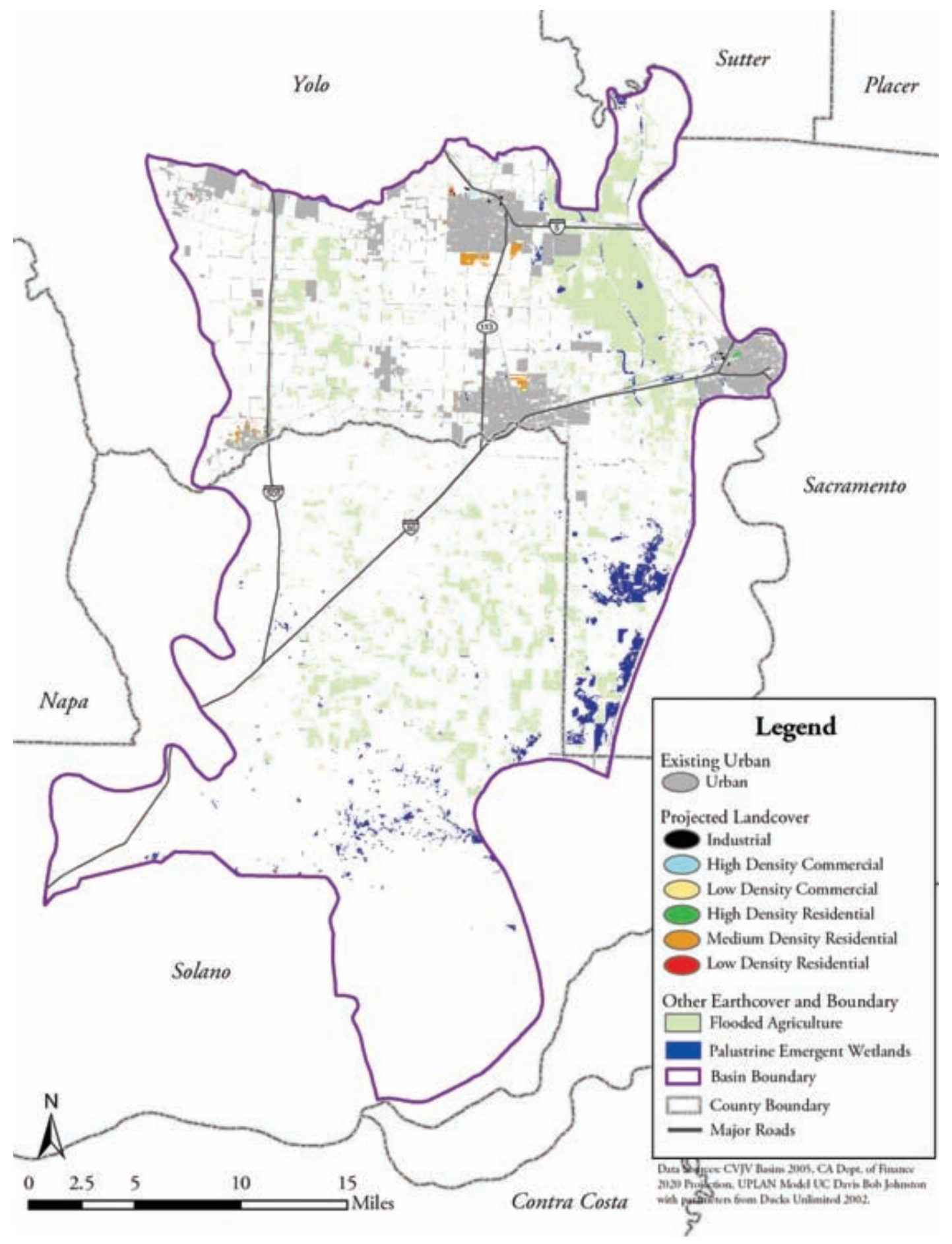

Figure 4-88. Projected growth in Yolo Basin to 2020. 


\section{Population Energy Demand vs. Food Energy Supplies: Current Conditions}

Although most basins have lost the majority of their wetlands habitat, changes in the Tulare Basin have been especially detrimental for waterfowl. As a result, additional information was considered when evaluating current conditions for waterfowl in the basin and when establishing conservation objectives and priorities.

Tulare Basin once contained a series of shallow lake beds that provided 260,000 acres of seasonal wetlands and over 250,000 acres of permanent and semi-permanent Tule marshes (Wershkull 1984). Prior to being converted to agriculture, these marshes provided much of the late summer/early fall habitat available to waterfowl in the Central Valley. Most wetlands in other basins in the valley resulted from over-bank flooding that historically occurred well after fall migration had begun.

It is assumed that early migrants flew directly to Tulare Basin because the lake beds provided reliable habitat. In contrast, most wetlands north of the basin remained dry until late fall or early winter. When over-bank flooding and precipitation made these habitats available, waterfowl moved north out of the basin. In essence, birds were over-flying much of the Central Valley and then undergoing a south to north migration as winter progressed. This type of reverse migration has been documented for pintails in both the Central Valley (Fleskes et al. 2002) and Mississippi Flyway (Cox and Afton 1992).

The loss of late summer-early fall habitat in Tulare Basin has substantially altered waterfowl use of the basin. Recent surveys indicate that duck migration is similar to other basins, with peak numbers occurring in late December and early January (Fleskes et al 2002; Figure 4-90a). In contrast, surveys conducted in the early 1970's indicate that duck numbers in the basin were highest in late September and early October (Figure 4-90b). These earlier surveys are consistent with how ducks historically used the basin, while recent surveys are not. Moreover, duck populations in the early and mid-1970's had averaged 350,000 birds during September. By the 1980s that number had shrunk to 51,000 (Jones and Stokes 1988). Early season bird use of the basin has significantly declined over the past three decades.

Declines in early season use do not appear related to any recent loss of permanent wetlands. By 1945 the vast majority of the basin's lake beds had been converted to agriculture, yet early season use of the basin remained high until the 1970s (Jones and Stokes 1988). Instead, reduced duck numbers during September and October may be related to declines in pre-irrigation of agricultural crops.

Pre-irrigation is the application of water on agricultural lands outside of the growing season. Prior to the mid-1970s, much of the land farmed for wheat and other grain crops in Tulare Basin was pre-irrigated during early fall and winter to store soil moisture and to flush salts from the soil (Houghton et al. 1985). Waterfowl relied heavily on these pre-irrigated fields in early fall when few managed wetlands were flooded. However, the amount of pre-irrigated farmland began to decline in the mid-1970s, especially land that was pre-irrigated in August and September (Houghton 1985). This decline continued into the 1980s, though more recent work in the basin indicates that the amount of pre-irrigated habitat has stabilized (Fleskes 1999).

Recent research indicates that waterfowl continue to rely heavily on the pre-irrigated fields in Tulare Basin and that these habitats provide both waste grain and invertebrate food resources (Moss et al. 2005). These agricultural habitats are available from mid-August through mid-October and have the potential to meet the bulk of waterfowl needs during this early period. Early season flooding of seasonal wetlands in the basin is increasingly difficult due to both the rising cost of water and the general lack of available water. Pre-irrrigation flooding may substantially reduce the need for early season wetland habitat in the basin. Efforts are now ongoing to determine how much pre-irrigation habitat is needed from mid-August through mid-October to meet waterfowl needs. Although a pre-irrigation program to benefit waterfowl may not substantially reduce wetland objectives for the basin, it may reduce the need for costly early season flooding of seasonal wetland habitat. 
Although pre-irrigated fields once supported large numbers of birds, it is not clear how much of this habitat remains or what food resources it provides. As a result, only existing seasonal wetlands were considered when evaluating food supplies for ducks in the basin. However, research to quantify the foraging quality of pre-irrigated fields is expected in the near future. If pre-irrigated fields still have the potential to support large numbers of early season birds, future conservation objectives for the basin will be modified to include this habitat type.

Tulare Basin presents difficult choices from both a planning and habitat delivery standpoint. Restoring early season waterfowl use of the basin will require a substantial increase in the amount of habitat available in August and September. Providing these early season habitats may be especially difficult because of the basin's chronic water shortages. Finally, the need to provide early season habitat in the basin has been questioned. Management efforts in the Central Valley now provide a substantial amount of early fall habitat, which may compensate for the loss of early season wetlands in Tulare Basin.

Table 4-46. Annual wetland enhancement objectives for Tulare Basin.

\begin{tabular}{|cc|} 
Wetlands Acres & $\begin{array}{c}\text { Annual Enhancement } \\
\text { Objective (acres) }\end{array}$ \\
\hline $20,212^{a}$ & 1,684 \\
22,212 & 1,851 \\
\hline 24,212 & 2,018 \\
26,212 & 2,185 \\
28,212 & 2,352 \\
30,212 & 2,519 \\
32,212 & 2,686 \\
34,212 & 2,853 \\
36,212 & 3,020 \\
38,212 & 3,187 \\
$39,212^{b}$ & 3,268 \\
\hline
\end{tabular}

${ }^{a}$ Current acres of wetlands in Tulare Basin. ${ }^{b}$ Acres of wetlands in Tulare Basin when wetland restoration objectives are met.

Table 4-47. Water needs for seasonal wetlands in Tulare Basin when wetland restoration objectives have been met.

\begin{tabular}{|cc|}
\hline Month & $\begin{array}{c}\text { Water Need } \\
\text { (Acre-Feet })\end{array}$ \\
\hline JANUARY & 7,842 \\
\hline FEBRUARY & 7,842 \\
\hline MARCH & 0 \\
\hline APRIL & 31,370 \\
\hline MAY & 0 \\
\hline JUNE & 21,567 \\
\hline JULY & 0 \\
\hline AUGUST & 19,606 \\
\hline SEPTEMBER & 78,424 \\
\hline OCTOBER & 15,684 \\
\hline NOVEMBER & 15,684 \\
\hline DECEMBER & 7,842 \\
\hline ANNUAL NEED & $\mathbf{2 0 5 , 8 6 1}$ \\
\hline
\end{tabular}

The JV's Tulare Basin Working Group (Working Group) considered these challenges as well as the need to maintain and improve hunting opportunities in the basin. Private landowners incur considerable costs to maintain wetland habitat in the basin and the number of duck clubs in the region has declined significantly over the past four decades (Jones and Stokes 1988). The Working Group concluded that increasing early season use of the basin was important, as was maintaining and improving hunting opportunities.

Increasing early season habitat and concerns over hunting opportunities were considered when assuming a migration pattern for Tulare Basin ducks. Migration chronology for other basins was based on recent waterfowl surveys in the Central Valley (Fleskes et al. 2000). However, those surveys do not reflect the basin's historical pattern of early season use (Figure 4-90a). In contrast, waterfowl surveys from the early 1970's indicate that most bird use occurred prior to November (Figure 4-90b). The Working Group decided to integrate these migration data from different time periods for use in the 2006 Plan. Although this "integrated" curve assumes high early season use of Tulare Basin, it also recognizes the need to support large numbers of waterfowl during the hunting season (Figure 4-90c). This integrated migration curve was used to establish duck population objectives by time period for the basin.

Population objectives for wintering waterfowl are presented in Figures 4-91 and 4-92. Duck population objectives are highest for late September and late December based on the integrated migration curve (Figure 4-90c). Dark goose population objectives peak during February, while there are no population objectives for white geese. No further results are presented for dark geese, because relatively few of these birds use the basin. Seasonal wetlands are assumed to provide all or most of the foraging habitat in Tulare Basin (Table 4-45; but see below). The JV assumes that food production in the basin is only $75 \%$ of other basins because a lack of water for summer irrigation of seasonal wetlands may reduce seed production.

The energetic model predicts that food supplies for ducks in Tulare Basin would be depleted by late January if duck populations are at NAWMP goals and duck use of the basin follows the integrated migration curve (Figure 4-93). Duck populations are not currently at NAWMP goals nor do ducks currently use the basin in a way consistent with the integrated curve of Figure 4-90c. However, the model indicates that habitat conditions in the basin are inadequate for achieving the seasonal pattern of bird use that the Working Group recommends, when duck populations are at NAWMP goals (i.e., traditional early season use and large numbers of birds during winter to maintain good hunting opportunities). Finally, the model result depicted in Figure 4-93 assumes that water is available to flood all 20,212 acres of seasonal wetlands that currently exist in the basin, and that flooding schedules follow that of Figure 4-9c. 

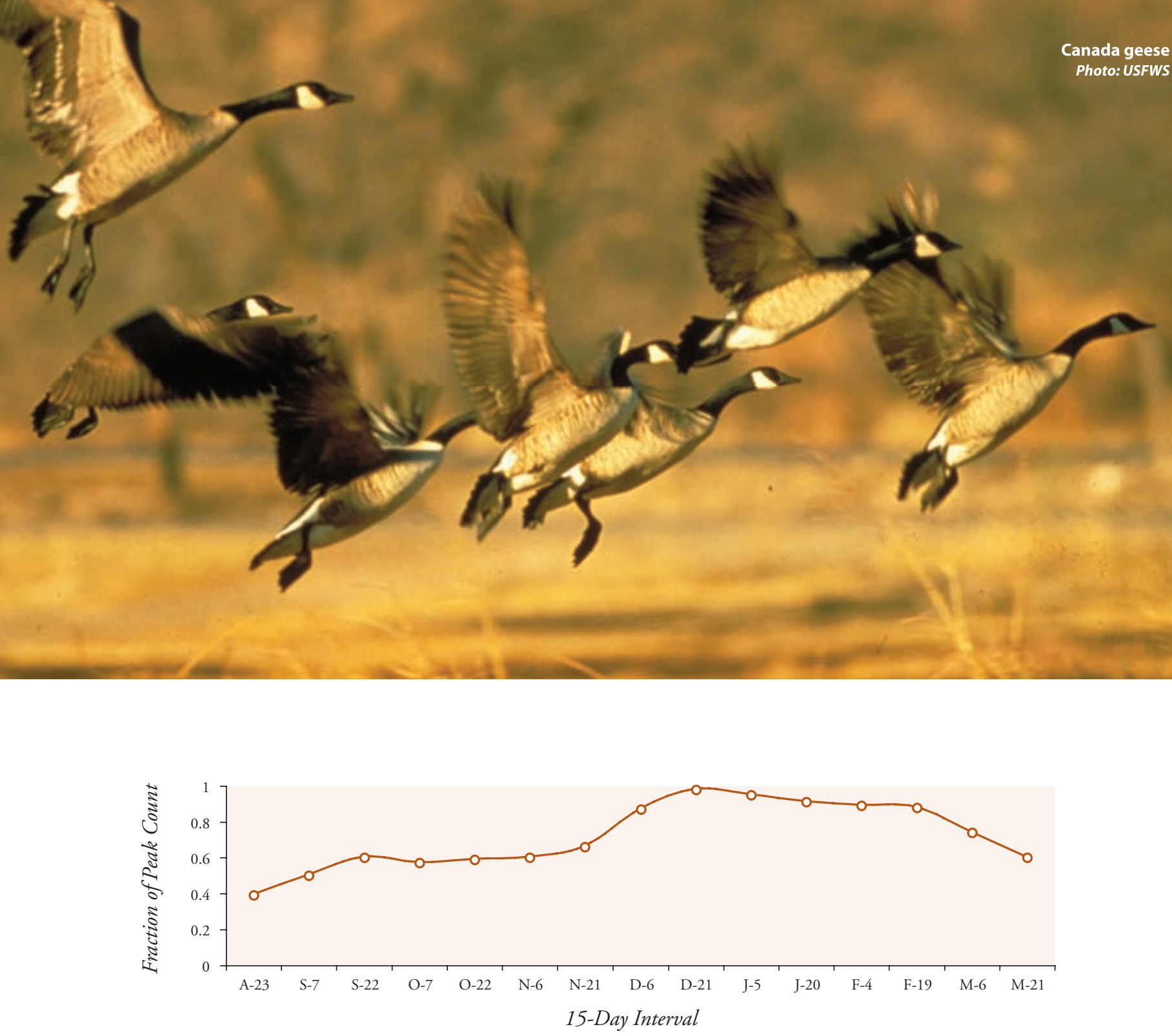

Figure 4-90 (a). Migration chronology of ducks in Tulare Basin as determined from waterfowl surveys conducted in 1998 and 1999.

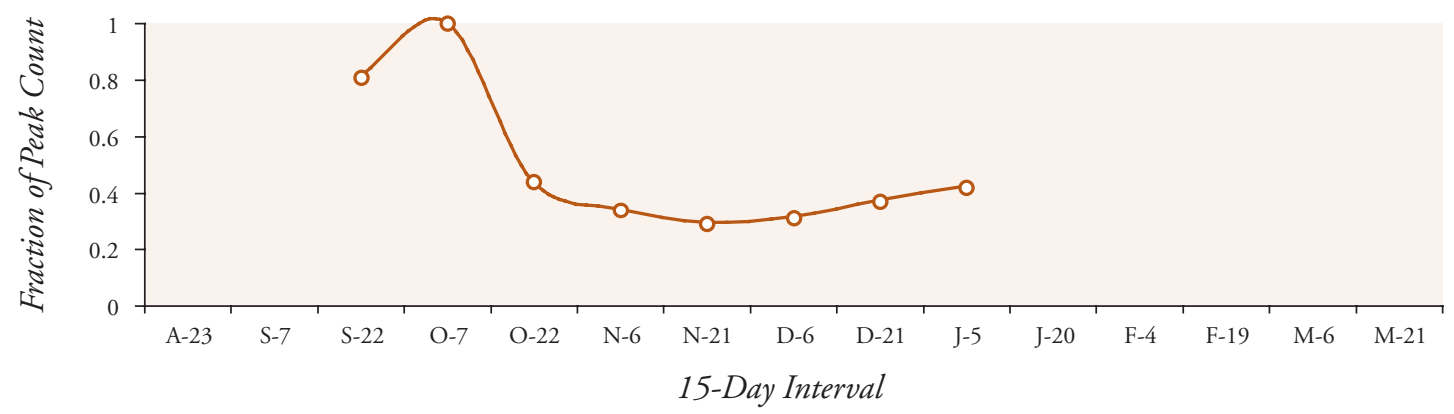

Figure 4-90 (b). Migration chronology of ducks in Tulare Basin as determined from waterfowl surveys conducted in 1973. 


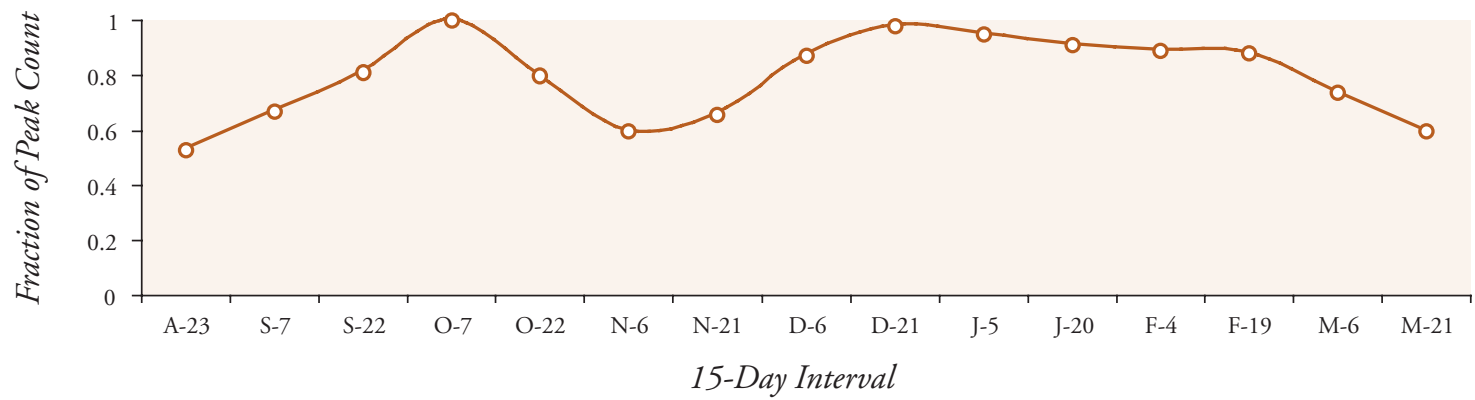

Figure 4-90c. Migration chronology of ducks in Tulare Basin that results from combining waterfowl surveys from 1998-1999 with surveys conducted in 1973.

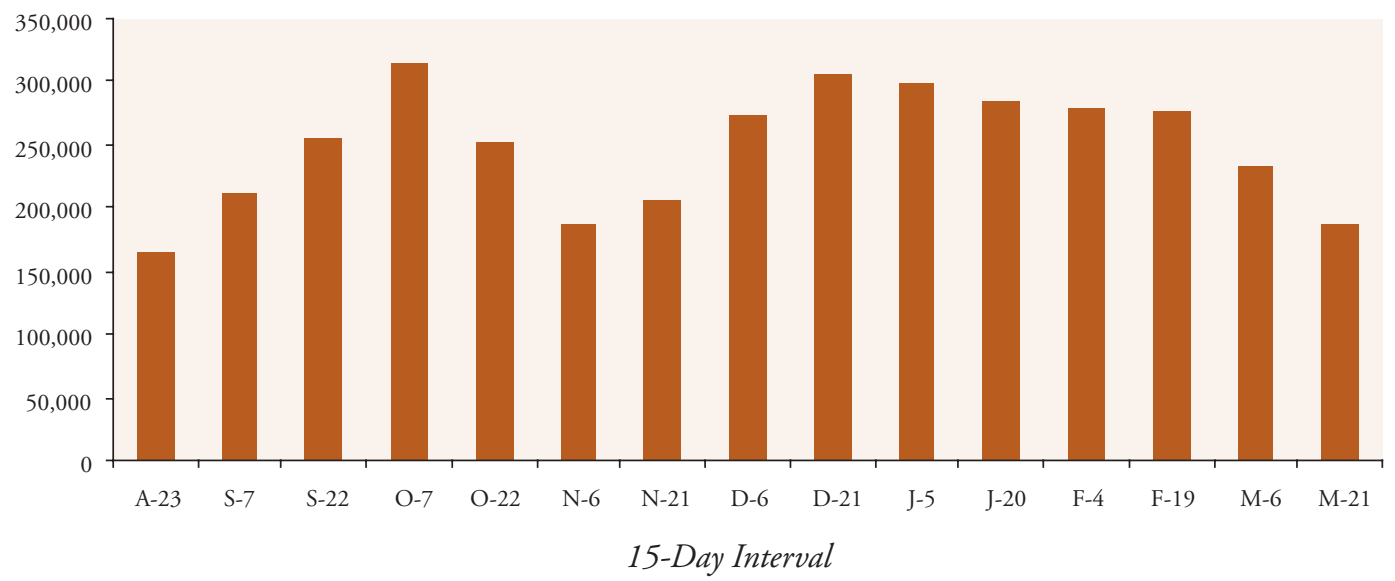

Figure 4-91. Population objectives by 15-day intervals for ducks in Tulare Basin.

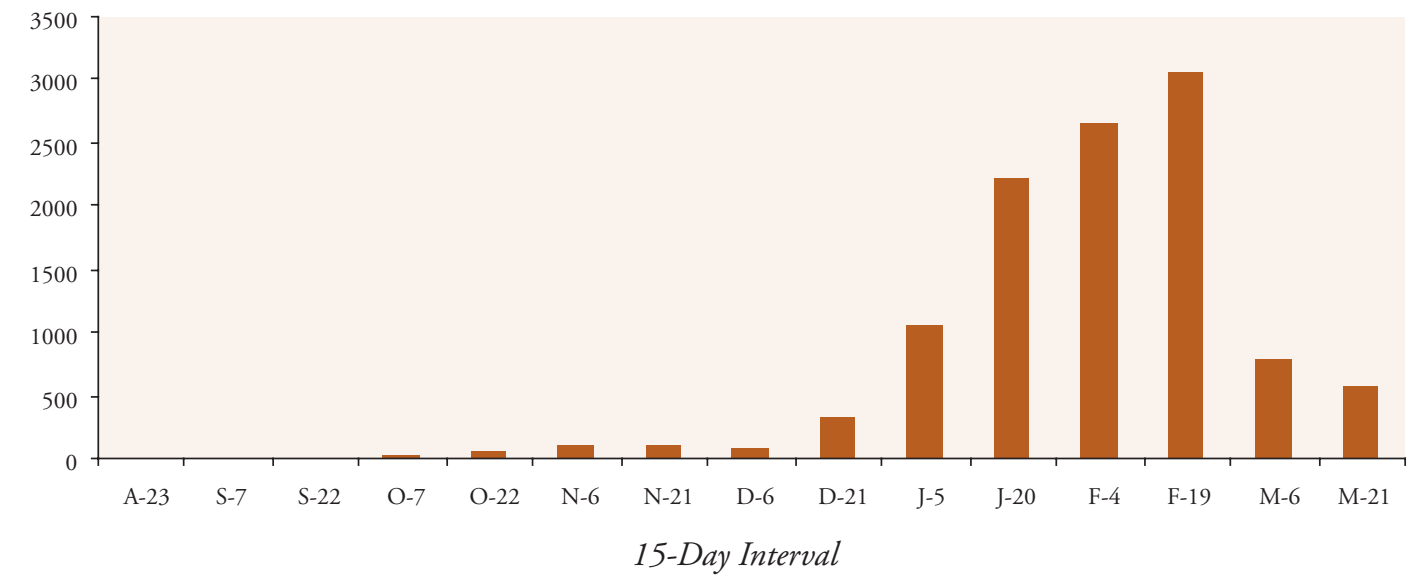

Figure 4-92. Population objectives by 15-day intervals for dark geese in Tulare Basin. 


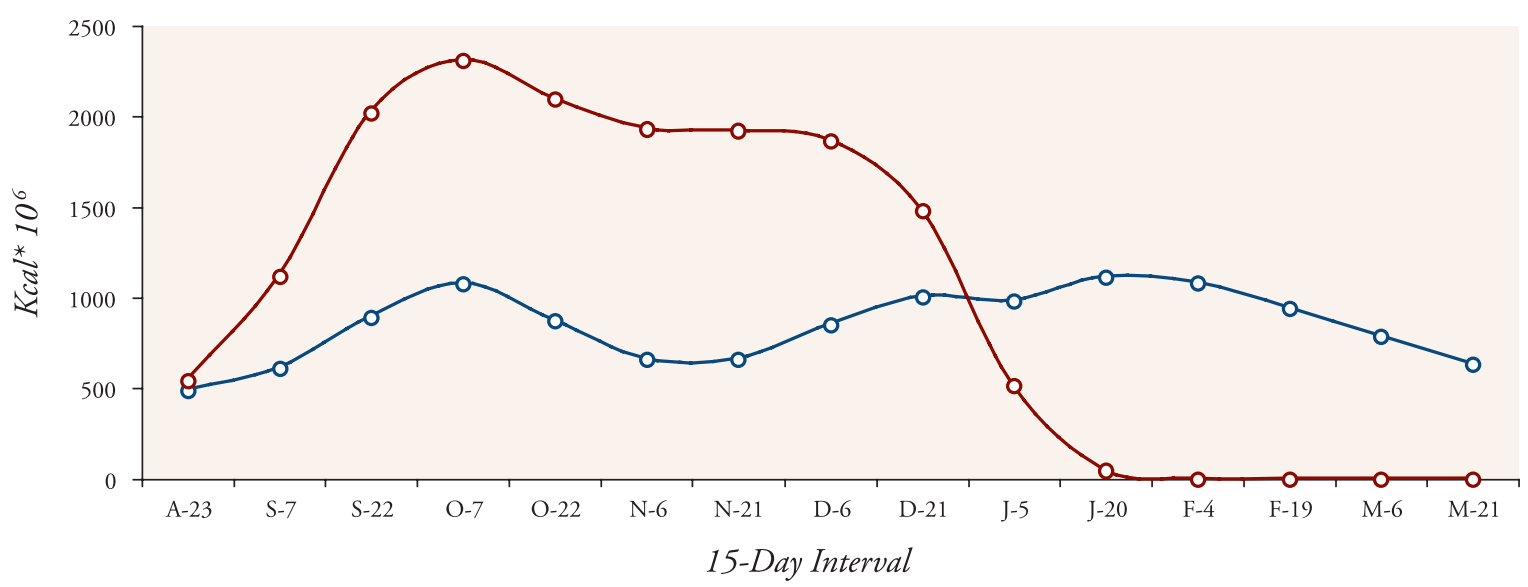

Figure 4-93. Population energy demand (blue) vs. food energy supply (red) for ducks in Tulare Basin when duck populations are at NAWMP goals.

\section{Conservation Objectives}

\section{Wetland Restoration}

The amount of seasonal wetlands required to meet duck energy needs in Tulare Basin is estimated at 39,212 acres. This estimate assumes that duck populations are at NAWMP goals, and that Figure 4-90c represents seasonal bird use of the basin. There are currently 20,212 acres of seasonal wetlands in the basin leaving a wetland restoration goal of 19,000 acres.

\section{Seasonal Wetland Enhancement}

The annual enhancement objective for existing seasonal wetlands in Tulare Basin is 1,684 acres/year. Wetland enhancement objectives will increase to 3,268 acres/year when seasonal wetland restoration objectives are met for the basin (Table 4-46).

\section{Water Supplies for Seasonal Wetland Management}

Annual management of seasonal wetlands in Tulare Basin will require 205,861 acre-feet of water when seasonal wetland restoration objectives in the basin have been met. These annual water requirements are further broken down by time period to reflect flooding schedules and summer irrigation needs (Table 4-47).

\section{Agricultural Enhancement}

No agricultural enhancement objective currently exists for Tulare Basin. An agricultural enhancement objective may be developed, pending an assessment of the foraging value of pre-irrigated fields in the basin and an assessment of landowner interest in developing pre-irrigation practices that are beneficial to waterfowl.

\section{Agricultural Easements for Maintaining Waterfowl Foods}

No agricultural easements of this type are currently proposed for Tulare Basin.

\section{Agricultural Easements to Buffer Urban Growth}

Growth projections for Tulare Basin indicate that little residential and urban development will occur near existing wetlands (Figure 4-94). As a result, no agricultural easements to buffer growth are proposed for the basin. 


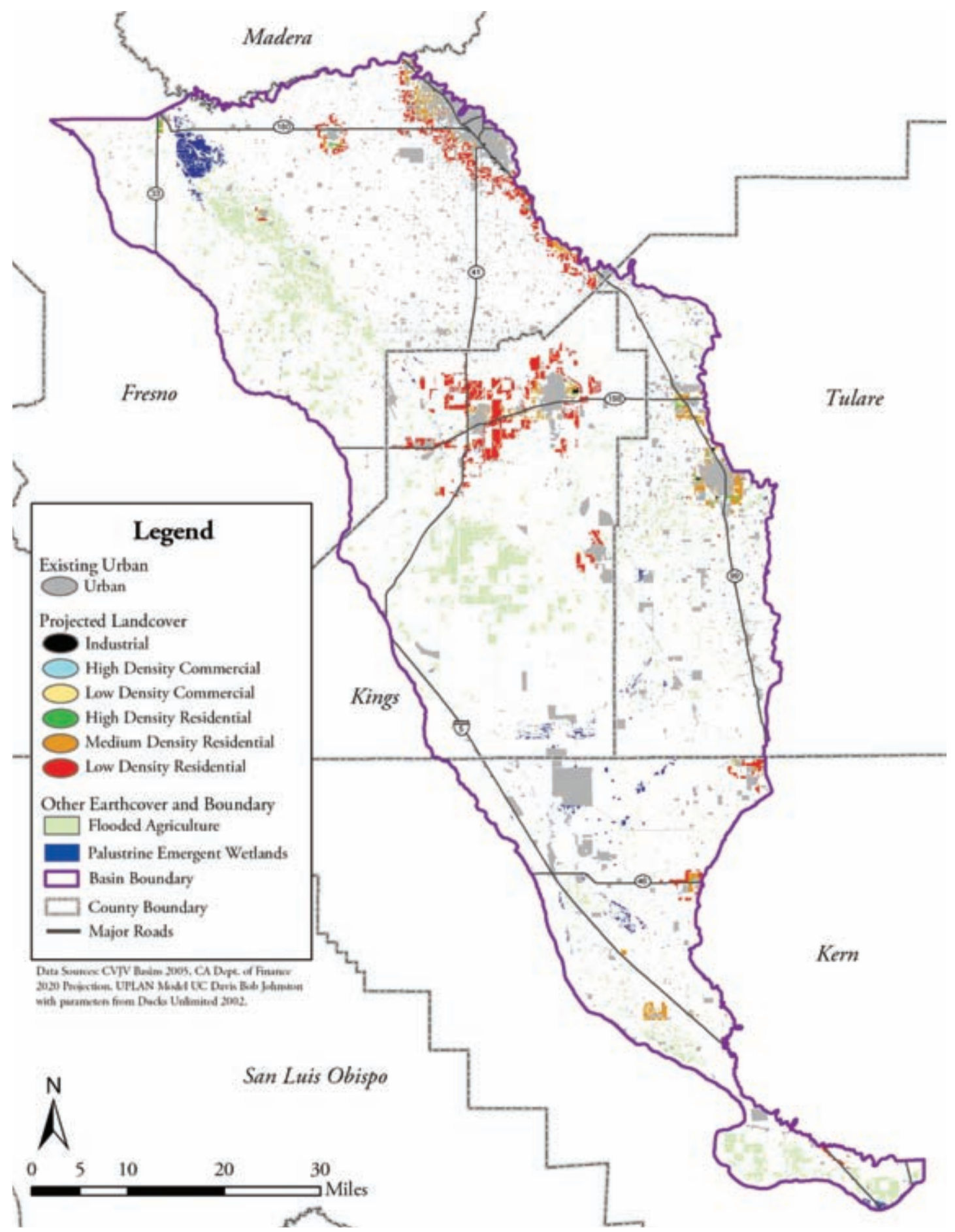

Figure 4-94. Projected growth in Tulare Basin to 2020. 


\section{Conservation Objective Priorities}

Conservation objectives for Tulare Basin are summarized in Table 4-48. The information used to prioritize conservation objectives is presented in Figure 4-95. Food supplies are less than 75\% of duck needs and were therefore rated low. Habitat protection in the basin is moderate, as is progress in meeting wetland needs (20,212 acres present vs. 39,212 acres needed or 52\%). Human population growth is categorized as high for the basin and is expected to exceed two million people. However, most of this growth will occur some distance from existing wetland habitats. Loss of irrigated farmland is rated as high; however a further assessment of the role of agriculture for ducks in the basin is needed before the effects of farmland loss can be evaluated.

Wetland restoration is a priority for Tulare Basin. The assessment of food energy supplies vs. food energy demands for ducks in the basin assumes that all wetlands, both existing and those to be restored, receive adequate water supplies. However, members of the Working Group currently believe that many existing wetlands are not flooded during fall and winter because of a lack of reliable and affordable water supplies. It is critical to recognize that the total seasonal wetland acreage need for the basin $(39,212$ acres) assumes that all these wetlands receive adequate water consistent with the flooding schedules for seasonal wetlands in the basin (Figure 4-9c). If wetland restoration objectives are met for the basin, but water is not available for these habitats, then duck population objectives for the basin will not be realized.

Table 4-48. Conservation objectives for wintering waterfowl in Tulare Basin.

\begin{tabular}{|c|c|c|c|c|c|}
\hline $\begin{array}{l}\text { Wetland Restoration } \\
\text { (Acres) }\end{array}$ & $\begin{array}{l}\text { Wetland Enhancement } \\
\text { (Acres) }\end{array}$ & $\begin{array}{l}\text { Water Supplies } \\
\text { (Acre-Feet) }\end{array}$ & $\begin{array}{c}\text { Agricultural } \\
\text { Enhancement (Acres) }\end{array}$ & $\begin{array}{l}\text { Type I Agricultural } \\
\text { Easements }\end{array}$ & $\begin{array}{c}\text { Type II Agricultural } \\
\text { Easements }\end{array}$ \\
\hline 19,000 & $3,2698^{a}$ & $205,861^{b}$ & None & None & None \\
\hline
\end{tabular}

"Annual enhancement objective when the wetland restoration objective is met.

${ }^{b}$ Annual water supply need when the wetland restoration objective is met.

\begin{tabular}{|c|c|c|c|c|c|}
\hline $\begin{array}{l}\text { Current Food } \\
\text { Supplies }\end{array}$ & $\begin{array}{l}\text { Level of Habitat } \\
\quad \text { Protection }\end{array}$ & $\begin{array}{l}\text { Progress in Meeting } \\
\text { Wetland Needs }\end{array}$ & $\begin{array}{l}\text { Population } \\
\text { Growth }\end{array}$ & $\begin{array}{l}\text { Loss of Irrigated } \\
\quad \text { Farmland }\end{array}$ & $\begin{array}{c}\text { Conservation Objective } \\
\text { Priorities }\end{array}$ \\
\hline HigH & HigH & HigH & HigH & HigH & WETLAND REstoration \\
\hline Moderate & Moderate & Moderate & Moderate & Moderate & \\
\hline \multirow[t]{2}{*}{ Low } & Low & Low & Low & Low & \\
\hline & VERY LOW & VERY LOW & VERY LOW & & \\
\hline
\end{tabular}

Figure 4-95. Information used to prioritize conservation objectives for Tulare Basin.

\section{Summary}

Conservation objectives are summarized for each basin and for the entire Central Valley in Table 4-49. Wetland restoration remains a key conservation objective for most basins, with a total wetland restoration need of 104,000 acres. Figure 4-96 shows progress in meeting seasonal wetland restoration objectives in the Central Valley. Annual wetland enhancement objectives will exceed 23,000 acres when wetland restoration objectives are met for the Central Valley. Annual water needs for managing seasonal wetlands in the Central Valley will exceed 1.4 million acre-feet when wetland restoration objectives are met. Although some of this water is now guaranteed under the Central Valley Project Improvement Act of 1992, the JV will face significant challenges in helping secure reliable and affordable sources of water as human populations continue to increase in the Central Valley (Chapter 10). Agricultural enhancement objectives are currently exceeded for all basins, as most rice producers now use winter flooding to decompose straw. However, agricultural easements to maintain waterfowl food supplies and buffer existing wetlands from urban development may become increasingly important in basins where large increases in human populations are predicted. 


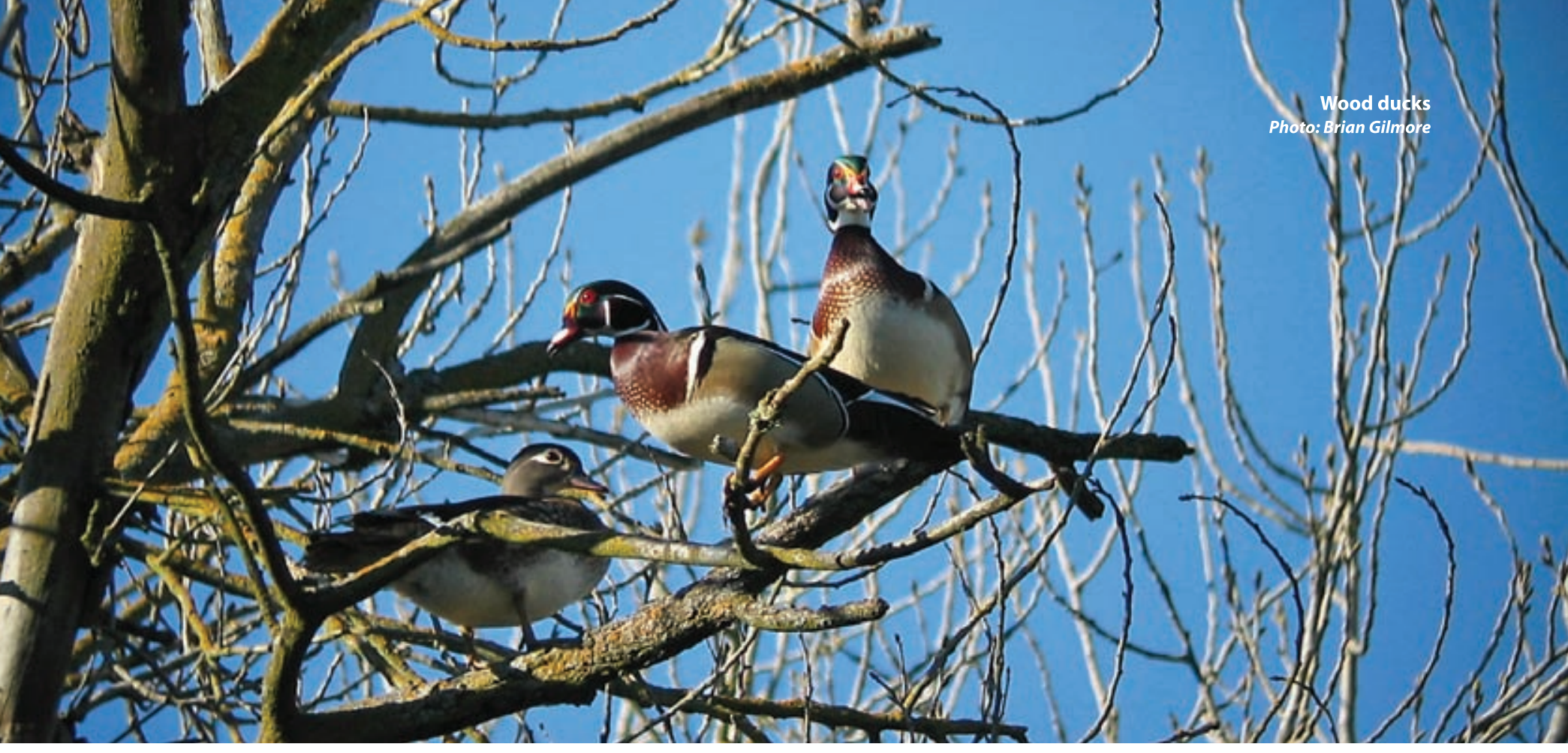

Table 4-49. Conservation objectives for wintering waterfowl in the Central Valley of California.

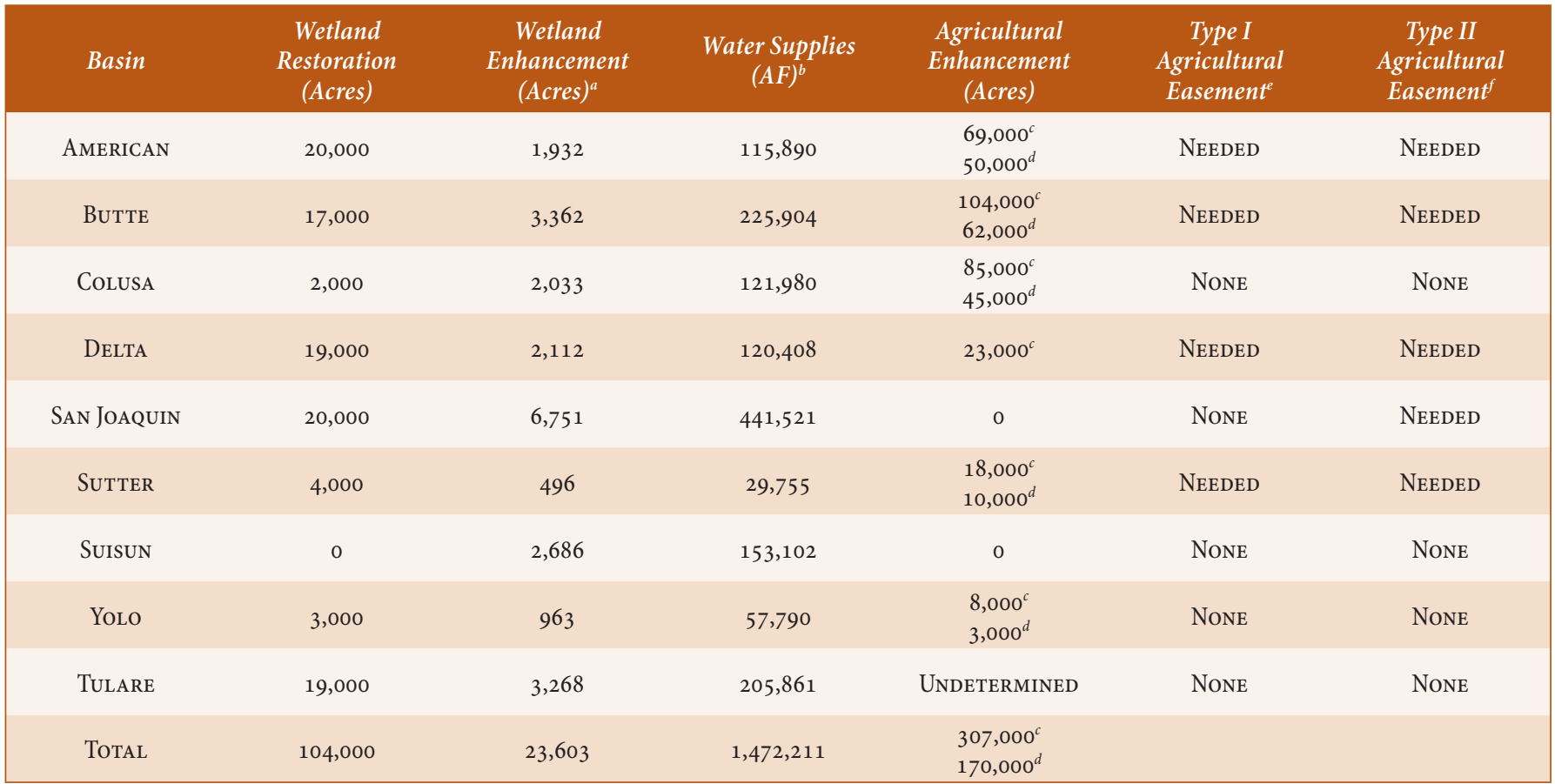

"Annual wetland enhancement objective when wetland restoration objectives are met for a basin. The wetland enhancement objective assumes that wetlands undergo some maintenance or enhancement an average of every 12 years.

${ }^{b}$ Annual acre-feet of water needed to manage seasonal wetlands when wetland restoration objectives are met for a basin.

'Agricultural enhancement objectives represent the amount of agricultural habitat needed to meet the needs of ducks and geese when wetland restoration objectives are met for a basin. Enhancement includes fields (rice or corn) that are not deep plowed following harvest or are winterflooded. Agricultural enhancement in most basins include only rice, however, corn is an important habitat type in the Delta and Yolo Basins. Agricultural enhancement objectives are currently met for all basins.

${ }^{d}$ Acres of the agricultural objective that must be flooded to meet duck needs (e.g., a minimum of 50,000 acres of the American Basin's total agricultural enhancement objective of 69,000 acres must be flooded).

'Agricultural easements to maintain waterfowl food sources on agricultural lands.

${ }^{f}$ Agricultural easements to buffer wetlands from the impacts of residential and urban growth. 


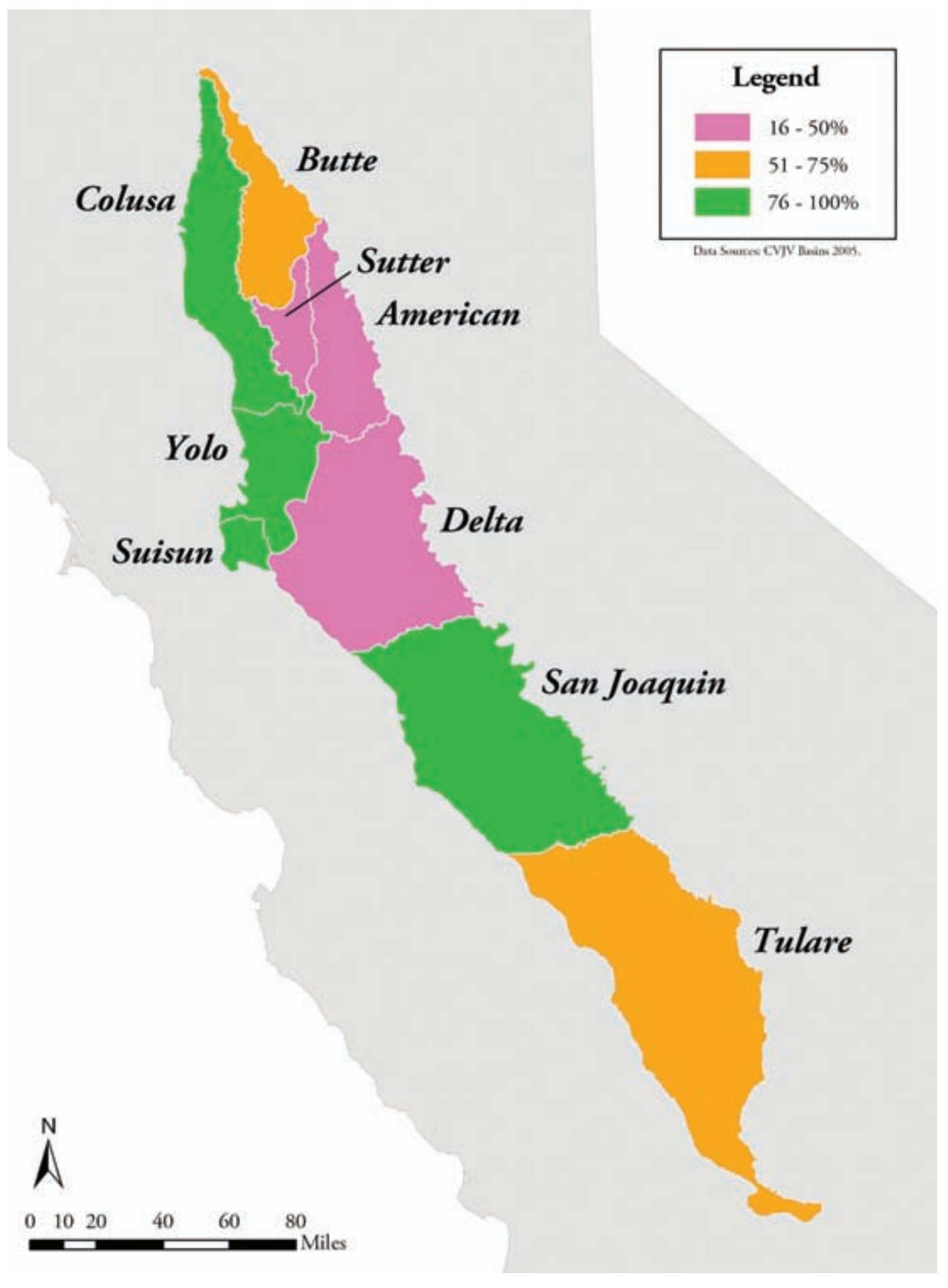

Figure 4-96. Progress in meeting seasonal wetland restoration objectives in the Central Valley. 
112 Chapter 4: Wintering Waterfowl 


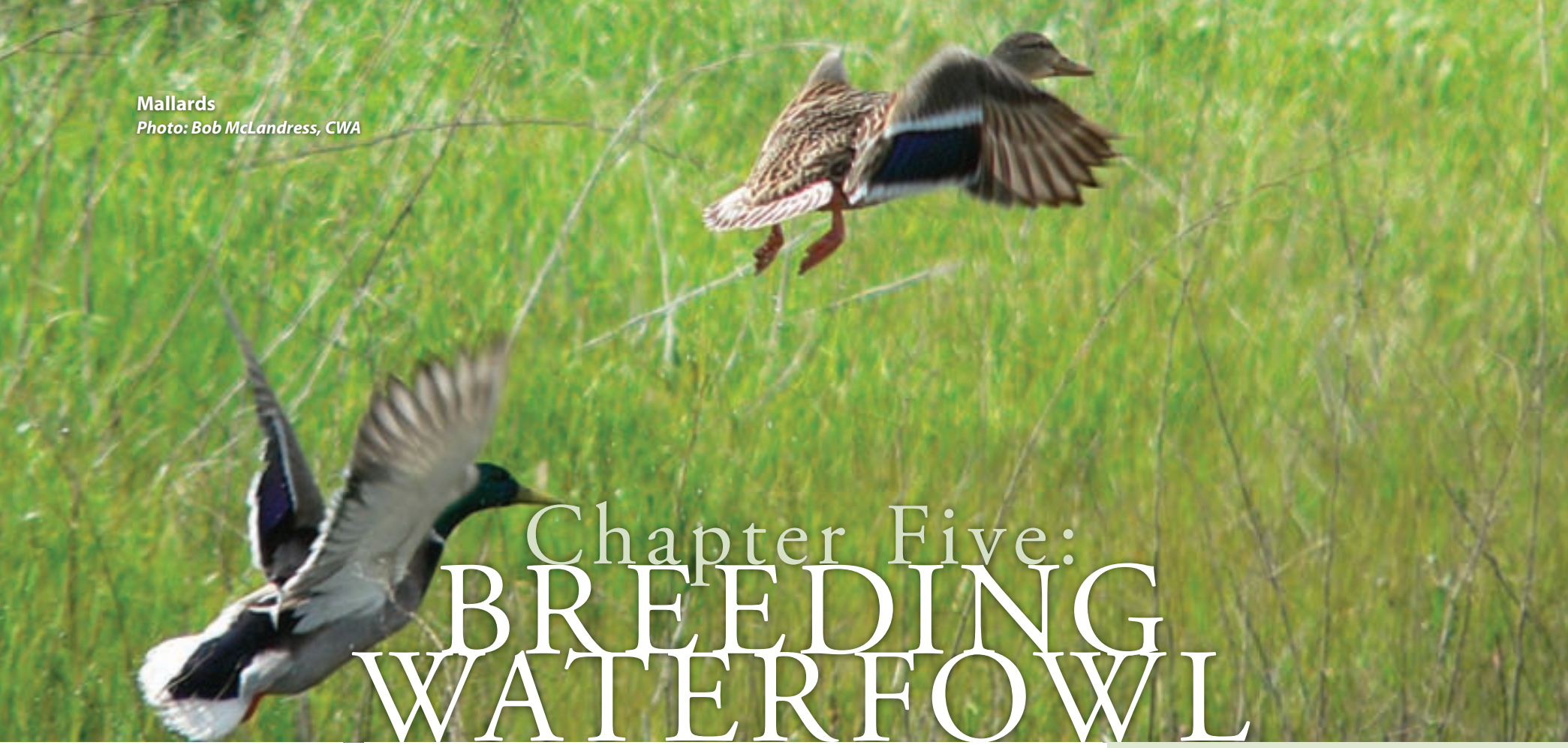

This chapter discusses the habitat needs and associated conservation efforts for breeding waterfowl in the Central Valley. Mallards (Anas platyrhynchos) comprise $80 \%$ of the breeding waterfowl in the valley and a significant amount of biological information is available for this species. As a result, recommendations for breeding waterfowl are largely based on the JV's understanding of mallard breeding ecology.

\section{Introduction}

Although conservation planning for waterfowl in the Central Valley has largely focused on meeting the needs of wintering birds, significant numbers of ducks also breed in the valley. Habitat needs of breeding ducks differ substantially from that of wintering ducks and include the use of different wetland types and the need for upland nesting cover. As a result, the 2006 Plan has developed distinct conservation strategies for breeding waterfowl.

Locally produced ducks now comprise up to $20 \%$ of the total duck harvest in California with most of those birds being mallards. As a result, local mallard production has become increasingly important to hunter success. Most private wetland owners in the Central Valley manage their land with the purpose of hunting waterfowl. These private wetland owners provide nearly seventy percent of all wetland habitats and incur substantial costs in doing so. Providing a reasonable level of hunter success is critical to this continued private investment in wetlands. The JV's efforts to increase the size and success of breeding waterfowl populations can contribute to this goal.

The 1990 Plan identified a breeding population objective of 490,000 ducks, of which 300,000 were mallards. These objectives were based on a goal of producing a local fall flight of one million birds. However, breeding populations of waterfowl can vary considerably from one year to the next in response to environmental factors (i.e., rainfall) that effect

"California's Central Valley is unique among waterfowl wintering grounds in North America in that it also provides habitat for healthy breeding populations of several duck species. The challenges of providing for the life requisites of local nesting as well as wintering waterfowl require innovative approaches and a variety of wetland and upland habitat management techniques unlike anywhere else."

Robert McLandress, Ph.D. President

California Waterfowl Association 
breeding habitat conditions. Population objectives for breeding waterfowl in the 2006 Plan have been modified to accommodate annual variation in breeding habitat conditions. Specifically, the JV's breeding waterfowl objective is to "maintain, enhance, and restore sufficient habitats to increase mallard populations by $25 \%$ over the range of variation observed from 1992-2002." During this period, the Central Valley estimate of breeding mallards ranged from 186,000 to 389,000 (D. Yparraguirre, California Department of Fish and Game, personal communication). Meeting the 2006 objective would result in mallard populations ranging between 232,000 and 486,000 birds. Population objectives for wintering waterfowl are usually translated into quantifiable estimates of habitat need, as was the case in Chapter 4 (e.g., acres of foraging habitat). However, there is no clear link between population objectives for breeding waterfowl and the amount of habitat needed to support some range of breeding birds. One alternative for establishing habitat programs for breeding waterfowl in the Central Valley is the approach used in the U.S. Prairie Pothole Region (PPR). See Appendix 5-1. Breeding waterfowl objectives were established for the PPR in the 1986 North American Waterfowl Management Plan. However, planning efforts in the PPR have largely focused on identifying what vital rates limit breeding duck numbers and developing habitat programs to address these limitations. The JV defines vital rates as population parameters that potentially limit the growth of duck populations (Table 5-1). For example, nest success is believed to limit duck populations across much of the PPR and conservation efforts have focused on restoring and protecting upland cover. This approach assumes that population objectives for breeding waterfowl in the PPR will be met if the biological factors that limit duck numbers are identified and addressed.

Conservation planning for breeding waterfowl in the 2006 Plan is conceptually based on planning efforts for waterfowl in the PPR, and is further described in Appendix 5-1. Although planning efforts in the 2006 Plan focus on mallards, several species of ducks breed in the Central Valley including gadwall (Anas strepera), cinnamon teal (A. cyanoptera), ruddy duck (Oxyura jamaicensis), redhead (Aythya Americana), and wood duck (Aix sponsa). Habitat needs of these species during the breeding season differ from mallards and may be addressed in future planning efforts. The remainder of this chapter is divided into 2 sections: (1) a review of planning information available for breeding mallards in the Central Valley; and (2) conservation objectives for breeding mallards in the Central Valley.

\section{A Review of Planning Information Available for Breeding Mallards in the Central Valley}

Habitat programs in the PPR address the biological factors that most limit duck numbers. Moreover, it is recognized that different conservation strategies are needed for different landscapes, and that habitat programs for breeding waterfowl should not be pursued in all areas.

Table 5-1. Vital rates that may limit the growth of duck populations including mallards that breed in the Central Valley of California.

\begin{tabular}{|c|c|}
\hline Vital Rate & Definition \\
\hline BREEDING INCIDENCE & Percent OF FEMALES THAT INITIATE AT LEAST ONE NEST ATTEMPT \\
\hline Mean Clutch Size & AVERAGE NUMBER OF EGGS LAID PER NEST \\
\hline Nest Success & PERCENT OF NEST HATCHING ONE OR MORE EGGS \\
\hline EgG Success & PERCENT OF EGGS THAT HATCH IN SUCCESSFUL NESTS \\
\hline RE-NESTING INTENSITY & $\begin{array}{l}\text { PROBABILITY THAT FEMALES WILL RE-NEST AFTER THE LOSS OF A NEST, AND } \\
\text { HOW THIS PROBABILITY CHANGES WITH SUCCESSIVE NEST ATTEMPTS }\end{array}$ \\
\hline Duckling SuRvival & PERCENT OF HATCHED DUCKLINGS THAT SUCCESSFULLY FLEDGE \\
\hline BreEding Survival & SURVIVAL OF FEMALES DURING THE BREEDING SEASON \\
\hline Non-BreEding Survival & SURVIVAL OF FEMALES DURING THE NON-BREEDING SEASON \\
\hline ANNUAL SURVIVAL $^{a}$ & ANNUAL SURVIVAL OF FEMALES \\
\hline
\end{tabular}

"Annual survival is the product of survival during the breeding season and survival outside of the breeding season.

Implementing targeted habitat programs to efficiently increase duck populations is also a goal of the JV. However, all the information needed to duplicate the PPR planning effort is not yet available for the Central Valley. As a result, the JV reviewed: (1) vital rate information that is available for Central Valley breeding mallards; (2) habitat programs that address specific vital rates; and (3) available information that can be used to develop spatial planning tools for the Central Valley. 


\section{Vital Rate Information for Central Valley Mallards}

Vital rate information is available for breeding mallards in the Central Valley from several published and unpublished sources (Table 5-2). Results of these studies are briefly summarized below.

Table 5-2. Vital rates estimates available for mallards breeding in the Central Valley of California.

\begin{tabular}{|c|c|c|c|c|}
\hline \multicolumn{5}{|c|}{ Breeding Incidence } \\
\hline EsTIMATE & $\mathrm{AGE}^{b}$ & YeAR & BASIN(s) & Source \\
\hline $0.692^{a}$ & SY & 2004 & Colusa & OLDENBURGER 2005 \\
\hline $0.755^{a}$ & ASY & 2004 & Colusa & OLdenbuRger 2005 \\
\hline $0.932^{a}$ & SY & 2005 & Colusa & OLDENBURGER 2005 \\
\hline $0.948^{a}$ & ASY & 2005 & Colusa & OLdENBURGER 2005 \\
\hline \multicolumn{5}{|c|}{ Clutch Size } \\
\hline Estimate & AgE & YEAR(s) & BASIN & SOURCE \\
\hline 7.828 & SY & $1985-2003$ & SuIsun & CWA, UNPUBLISHED DATA \\
\hline 8.974 & ASY & $1985-2003$ & SuIsun & CWA, UNPUBLISHED DATA \\
\hline \multicolumn{5}{|c|}{ Egg Survival } \\
\hline Estimate & & YeAR(s) & $\operatorname{BAsin}(s)$ & SOURCE \\
\hline 0.82 & & $1985-2003$ & SuISUn MARSH & CWA, UNPUBLISHED DATA \\
\hline 0.68 & & $1995-2001$ & Yolo & CWA, UNPUBLISHED DATA \\
\hline 0.69 & & $2002-2004$ & Colusa \& Yolo & CWA, UNPUBLISHED DATA \\
\hline \multicolumn{5}{|c|}{ Re-nesting Intensity } \\
\hline Estimate & AGE & YEAR & BASIN & SOURCE \\
\hline \multicolumn{5}{|c|}{ Note: None estmated, but $M A X=3$ based on radioed females (Oldenburger, unpublished data) } \\
\hline \multicolumn{5}{|c|}{ Duckling Survival } \\
\hline Estimate & AGE & YEAR & BASIN & SOURCE \\
\hline 0.38 & & 1993 & Butte & YARRIS 1995 \\
\hline 0.35 & & 1994 & Butte & YARRIS 1995 \\
\hline 0.36 & & 1996 & SAN JOAQUIN & 2000-CHOUINARD \\
\hline 0.18 & & 1997 & SAN JOAQUIN & 2000-CHOUINARD \\
\hline \multicolumn{5}{|c|}{ Breeding Survival } \\
\hline Estimate & AgE & YEAR & BASIN & SOURCE \\
\hline $0.840^{a}$ & SY & 2004-2005 & Colusa & OLDENBURGER 2005 \\
\hline $0.909^{a}$ & ASY & 2004-2005 & Colusa & OldENBURGER 2005 \\
\hline \multicolumn{5}{|c|}{ Annual Survival } \\
\hline Estimate & AgE & YEAR & BASIN & SOURCE \\
\hline 0.48 & $\mathrm{HY}$ & $1948-1982$ & * & REINECKER 1990 \\
\hline 0.58 & AHY & $1948-1982$ & * & REINECKER 1990 \\
\hline 0.612 & HY & $1970-2002$ & * & HERZOG (UNPUBLISHED DATA) \\
\hline 0.607 & AHY & $1970-2002$ & * & HERZOG (UNPUBLISHED DATA) \\
\hline
\end{tabular}

Continued... 


\begin{tabular}{|c|c|c|c|}
\hline \multicolumn{4}{|c|}{ Nest Success } \\
\hline Estimate & YeAR & $\operatorname{BASIN}(s)$ & SOURCE \\
\hline 0.617 & 1985 & SuISUn MARSH & CWA, UNPUBLISHED DATA \\
\hline 0.453 & 1986 & SUISUN MARSH & CWA, UNPUBLISHED DATA \\
\hline 0.329 & & Butte \& Colusa & MCLANDRESS ET AL. 1996 \\
\hline 0.490 & 1987 & SUISUN MARSH & CWA, UNPUBLISHED DATA \\
\hline 0.228 & & SAN JOAQUIN & MCLANDRESS ET AL. 1996 \\
\hline 0.227 & & Butte \& Colusa & MCLANDRESS ET AL. 1996 \\
\hline 0.257 & 1988 & SUISUN MARSH & CWA, UNPUBLISHED DATA \\
\hline 0.504 & & SAN JOAQUIN & MCLANDRESS ET AL. 1996 \\
\hline 0.365 & & Butte \& Colusa & MCLANDRESS ET AL. 1996 \\
\hline 0.098 & 1989 & SUISUN MARSH & CWA, UNPUBLISHED DATA \\
\hline 0.373 & & SAN JOAQUIN & MCLANDRESS ET AL. 1996 \\
\hline 0.630 & 1990 & Butte \& Colusa & CWA, UNPUBLISHED DATA \\
\hline 0.426 & & SUISUN MARSH & CWA, UNPUBLISHED DATA \\
\hline 0.372 & & SAN JOAQUIN & MCLANDRESS ET AL. 1996 \\
\hline 0.250 & 1991 & Butte \& Colusa & CWA, UNPUBLISHED DATA \\
\hline 0.513 & & SUISUN MARSH & CWA, UNPUBLISHED DATA \\
\hline 0.212 & & SAN JOAQUIN & CWA, UNPUBLISHED DATA \\
\hline 0.463 & 1992 & SUISUN MARSH & CWA, UNPUBLISHED DATA \\
\hline 0.285 & 1993 & SUISUN MARSH & CWA, UNPUBLISHED DATA \\
\hline 0.273 & 1994 & SUISUN MARSH & CWA, UNPUBLISHED DATA \\
\hline 0.377 & 1995 & SUISUN MARSH & CWA, UNPUBLISHED DATA \\
\hline 0.570 & & Yolo & CWA, UNPUBLISHED DATA \\
\hline 0.174 & 1996 & SAN JOAQUIN & DESZALAY ET AL. 2003 \\
\hline 0.225 & & SUISUn MARSH & CWA, UNPUBLISHED DATA \\
\hline 0.082 & 1997 & SAN JOAQUIN & DESZALAY ET AL. 2003 \\
\hline 0.054 & & SUISUn MARSH & CWA, UNPUBLISHED DATA \\
\hline 0.068 & 1998 & SUISUN MARSH & ACKERMAN, UNPUBLISHED DATA \\
\hline 0.560 & & Yolo & CWA, UNPUBLISHED DATA \\
\hline 0.091 & 1999 & SUISUN MARSH & ACKERMAN, UNPUBLISHED DATA \\
\hline 0.333 & 2000 & SUISUN MARSH & ACKERMAN, UNPUBLISHED DATA \\
\hline 0.138 & 2001 & SUISUn MaRSH & CWA, UNPUBLISHED DATA \\
\hline 0.220 & 2002 & Colusa \& Yolo & CWA, UNPUBLISHED DATA \\
\hline 0.145 & & SUISUN MARSH & CWA, UNPUBLISHED DATA \\
\hline 0.368 & 2003 & Colusa \& Yolo & CWA, UNPUBLISHED DATA \\
\hline 0.139 & & SUISUN MARSH & CWA, UNPUBLISHED DATA \\
\hline 0.271 & 2004 & COLUSA \& Yolo & CWA, UNPUBLISHED DATA \\
\hline 0.068 & & Delta & CWA, UNPUBLISHED DATA \\
\hline 0.031 & & Colusa & CWA, UNPUBLISHED DATA \\
\hline 0.426 & 2005 & Colusa \& Yolo & CWA, UNPUBLISHED DATA \\
\hline
\end{tabular}

aPreliminary analysis

${ }^{b}$ Age: HY (hatch year); AHY (after hatch year); SY (second year); ASY (after second year)

\section{Breeding Incidence}

Estimates of breeding incidence are limited to a single study in the Colusa basin (Table 5-2). While less than 80\% of all females initiated nests in the first year of the study, over $90 \%$ of all marked females were known to nest in the study's second year (Table 5-2). Similar studies in the prairies and elsewhere have reported breeding incidence $>90 \%$ (Hoekman 1992). Lower breeding incidence is 
plausible for mallards in the Central Valley as most seasonal wetlands are drained prior to the breeding season, which greatly reduces wetland availability for breeding pairs. Density dependant factors (e.g., spacing behavior of breeding pairs) may prevent some females from breeding in areas where bird densities are high and wetlands are few. Additional spring wetland habitat in these areas may result in increased breeding incidence.

\section{Nest Success}

Nest success in the Central Valley appears to be high relative to other populations of mallards in North American. Twenty-nine of thirty-nine studies have reported nest success $>15 \%$ (Table 5-2). Some nest success estimates for the Central Valley are site-specific (e.g., winter wheat, rice-set aside lands, or refuges and wildlife areas). These site-specific estimates may not reflect nest success at the population level if birds using these habitats experience abnormally high success. However, a recent study of mallards that were marked prior to the breeding season estimated 35\% nest success (S. Oldenburger, unpublished data). This study does provide an unbiased estimate of nest success, and suggests that nest success estimates from earlier site-specific studies may be representative of nest success at the population level.

\section{Duckling Survival}

Duckling survival estimates that are available for mallards in North American typically range between 35\% and 45\% (Hoekman et al. 2002) though estimates from the Central Valley generally fall within the low end of this range. There is some indication that earlyhatched ducklings in portions of the Central Valley may experience low survival rates (G. Yarris, California Waterfowl Association, personal communication). Ducklings that are hatched later in the breeding season often have access to actively growing rice fields that provide an abundance of emergent cover. However, early-hatched ducklings may have to rely solely on a limited numbers of wetlands. Although it is difficult to generalize the importance of duckling survival to overall mallard population growth, low duckling survival could be limiting mallard numbers in some areas of the valley.

\section{Female Survival Rates}

Breeding survival rates for female mallards in the Central Valley have varied between 0.84 and 0.909 (Table 5-2), which is generally higher than that reported for prairie breeding birds (Devries et al. 2003). Annual survival rates of adult and juvenile female mallards banded in the Central Valley are similar to those reported for the prairies (Table 5-2). Although female survival rates are not believed to limit mallard numbers on the prairies, it is not possible at this time to reach any conclusion about the role of female survival in limiting mallard populations in the valley. On-going research indicates that female survival during molt may be low in some Klamath Basin habitats, where a large portion ( $>60 \%$; Yarris et al. 1994) of the valley population goes to molt, but data from other molting areas are lacking and population impacts have not been determined.

\section{Demographic Modeling}

Research efforts over the past two decades have provided valuable information on mallard vital rates in the Central Valley. However, it would be inappropriate to use this information in demographic models designed to identify what factors limit population growth. The vital rate estimates available for Central Valley mallards were obtained over different time periods, and from different regions (e.g., Sacramento vs. San Joaquin Valley). An ongoing study of breeding mallards in the Colusa Basin is providing vital rate estimates that are needed for demographic modeling (Oldenburger et al. 2005). This research is an important step in identifying factors that limit mallard populations in the Valley.

\section{Habitat Programs That Address Specific Vital Rates}

The use of targeted habitat prescriptions has been successful in addressing limiting factors for breeding waterfowl in a variety of areas across North America. Although the vital rate(s) that limit mallard populations in the Central Valley are relatively unknown, we do have some understanding of what habitat programs can be used to improve them. The following information can be used to develop preliminary conservation programs for mallards breeding in the Central Valley. 
Studies of nesting waterfowl in the Central Valley indicate that set-aside agricultural fields planted with a cover crop can support large numbers of mallards and promote high nest success (Loughman et al. 1991). If nest success does limit mallard populations, then programs that provide landowner incentives to set aside agricultural land (e.g., Conservation Reserve Enhancement Program [CREP]) may be effective in addressing this limiting factor.

\section{Duckling Survival}

Duckling survival may be heavily dependent on food availability, especially in the period immediately after hatch (Sedinger 1992). Reverse-cycle wetlands (i.e., wetlands flooded from spring through late summer) provide greater densities of invertebrates in May than do seasonal or permanent wetlands in the Central Valley (deSzalay et al. 2003). Most mallard ducklings hatch in May when they rely heavily on aquatic invertebrates. If duckling survival does limit mallard populations in the Central Valley, increasing the acres of reversecycle wetlands may be an effective tool for increasing duckling food supplies and ultimately survival.

\section{Spatial Planning Tools for Breeding Mallards in the Central Valley}

At a minimum, spatial planning tools developed for the Central Valley should include: (1) the spatial distribution of breeding mallards throughout the Central Valley; (2) the spatial distribution of wetland and rice habitats used by breeding mallards; and (3) the spatial distribution of potential nesting cover. In some cases (e.g., the PPR), the spatial distribution of wetlands and breeding waterfowl may be highly correlated. Information on the distribution of breeding mallards, wetlands, and nesting cover is available for the entire Central Valley and is summarized below.

\section{Distribution of Breeding Mallards}

Biologists with the California Department of Fish and Game (CDFG) annually conduct surveys of breeding waterfowl in the Central Valley. These surveys were initiated in 1992, and include 43 transects that are orientated northeast to southwest. Transects are included in all nine of the valley's drainage basins. To better understand the distribution of breeding mallards throughout the Central Valley, mallard counts were averaged for each transect between 1992 and 2002. A comparison of these transects revealed substantial differences in mallard densities among basins. For example, mallard densities in the Colusa and Suisun Marsh Basins are high relative to densities in the Tulare Basin (Figure 5-1). Information on mallard densities between 1992 and 2002 was used to categorize mallard breeding densities in each basin as high, medium, or low (Figure 5-2).

\section{Distribution of Wetlands for Breeding Waterfowl}

Managed wetlands in the Central Valley are categorized as seasonal or semi-permanent. Most wetlands used by breeding mallards in the valley are assumed to be semi-permanent because seasonal wetlands are typically drained prior to the breeding season. Semi-permanent wetlands are defined as wetlands that are flooded from early fall through late July or August. Total managed wetlands in the valley are estimated at 205,554 acres (see Chapter 3), and the distribution of these wetlands is depicted in Figure 5-3. Although 85\%-90\% of these wetlands are seasonal, it is assumed that the distribution of total managed wetlands in Figure 5-3 reflects the distribution of semipermanent wetlands as well. Differences in the distribution of semi-permanent wetland acres among basins are depicted in Figure 5-4.

Surveys of breeding waterfowl in 2003 used GPS technology to plot mallard distribution along transect routes. As a result, it is possible to associate mallard densities with landscape characteristics and to sub-divide transects that cross drainage basin boundaries. For example, mallard densities within and among transects may differ in response to differences in wetland acres along transect routes. A very preliminary analysis of mallard pair locations during the 2003 survey indicates that pair densities were higher in basins having greater amounts of semi-permanent wetlands.

${ }^{1}$ Regression of mallard pair densities and acres of semi-permanent wetland habitat within a basin suggests a linear relationship with an $r 2$ value of 0.85 (K. Petrik, Ducks Unlimited, Inc., personal communication). This relationship is only based on results from five drainage basins because 2003 mallard locations are still being processed. However, mallard breeding densities do appear to be positively associated with wetland densities, as is the case in the PPR. 


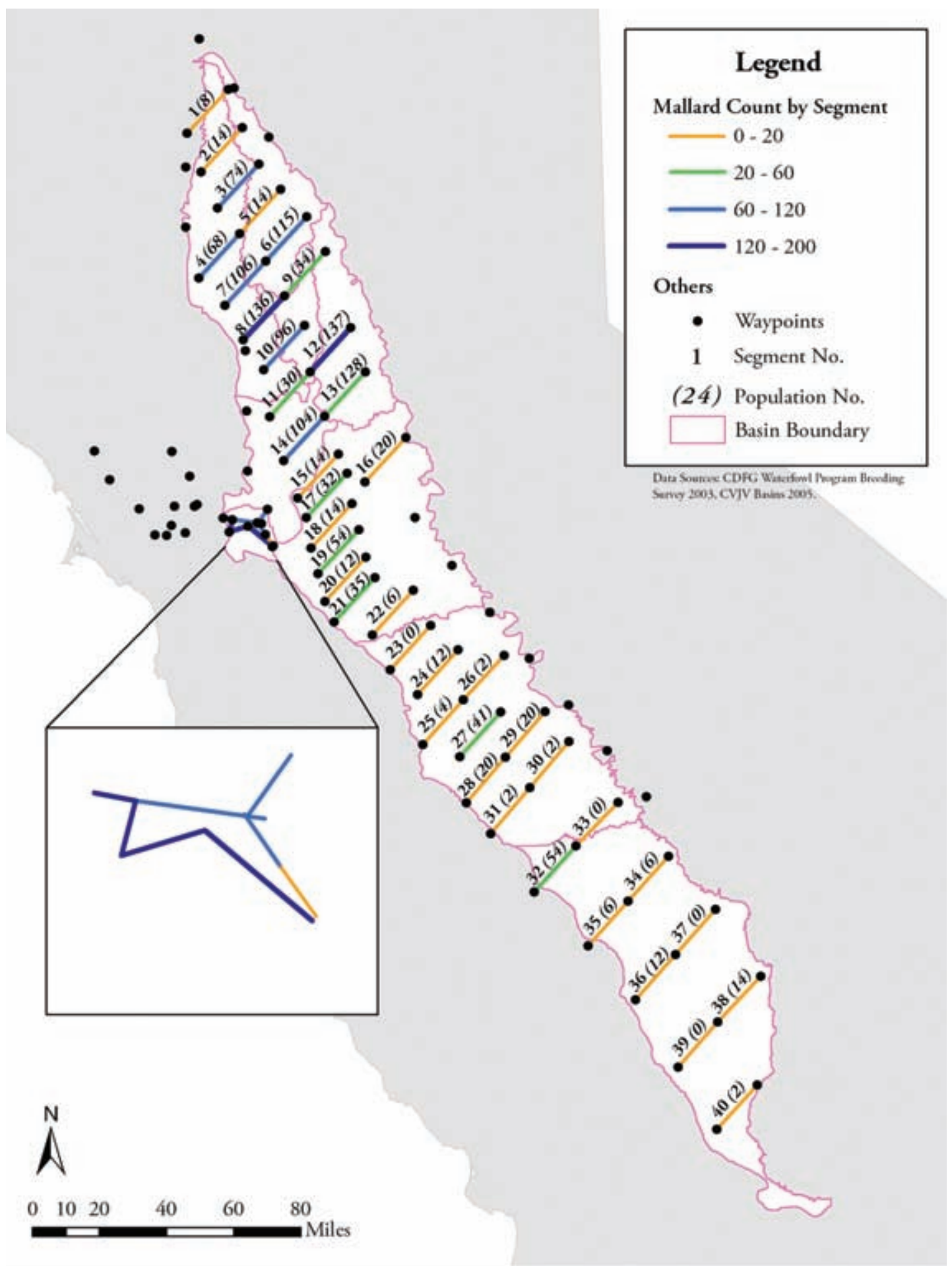

Figure 5-1. Aerial survey transects for breeding waterfowl in the Central Valley. 


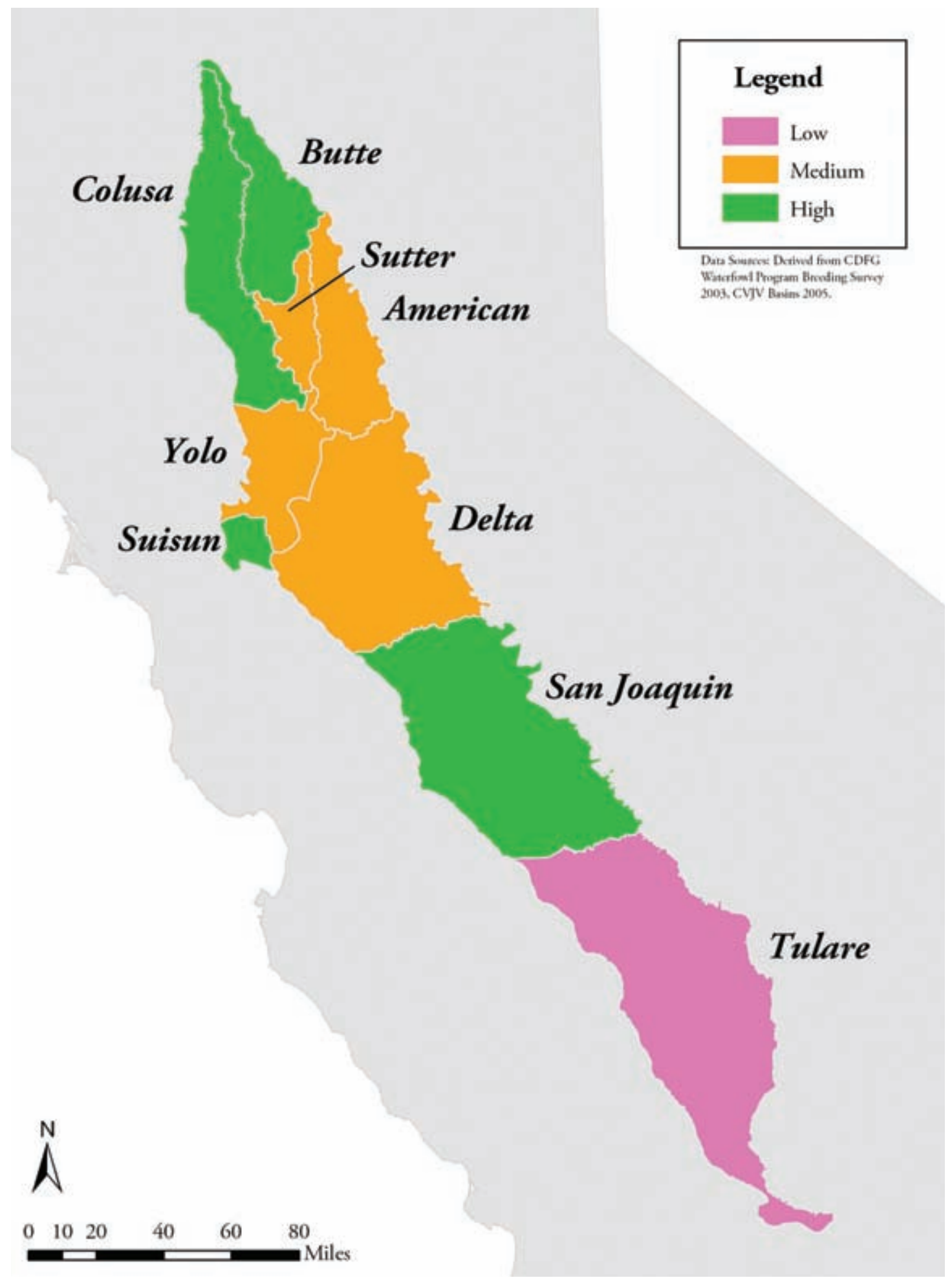

Figure 5-2. Relative densities of breeding mallards among basins. 


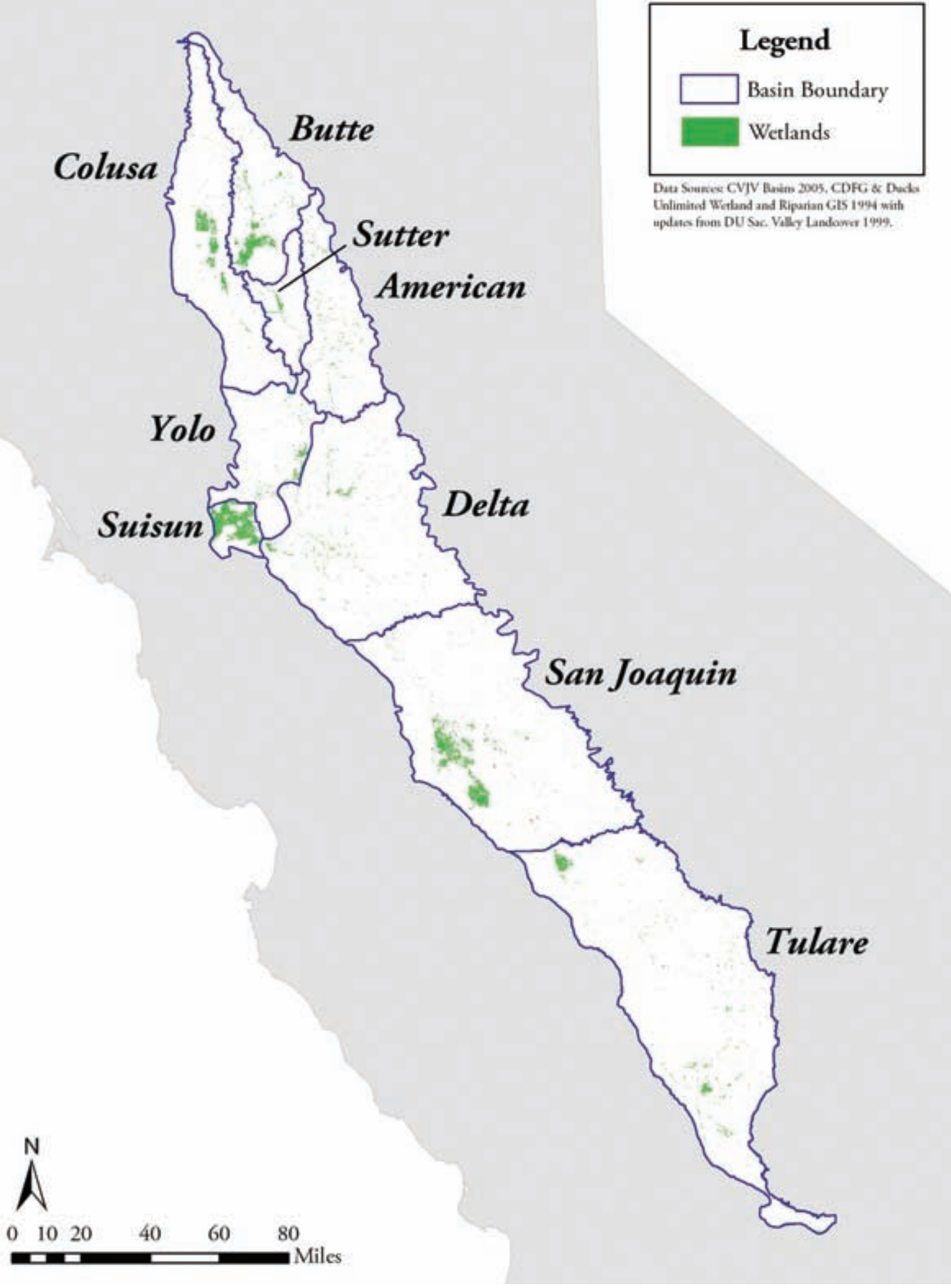

Figure 5-3. Wetland distribution in the Central Valley. 


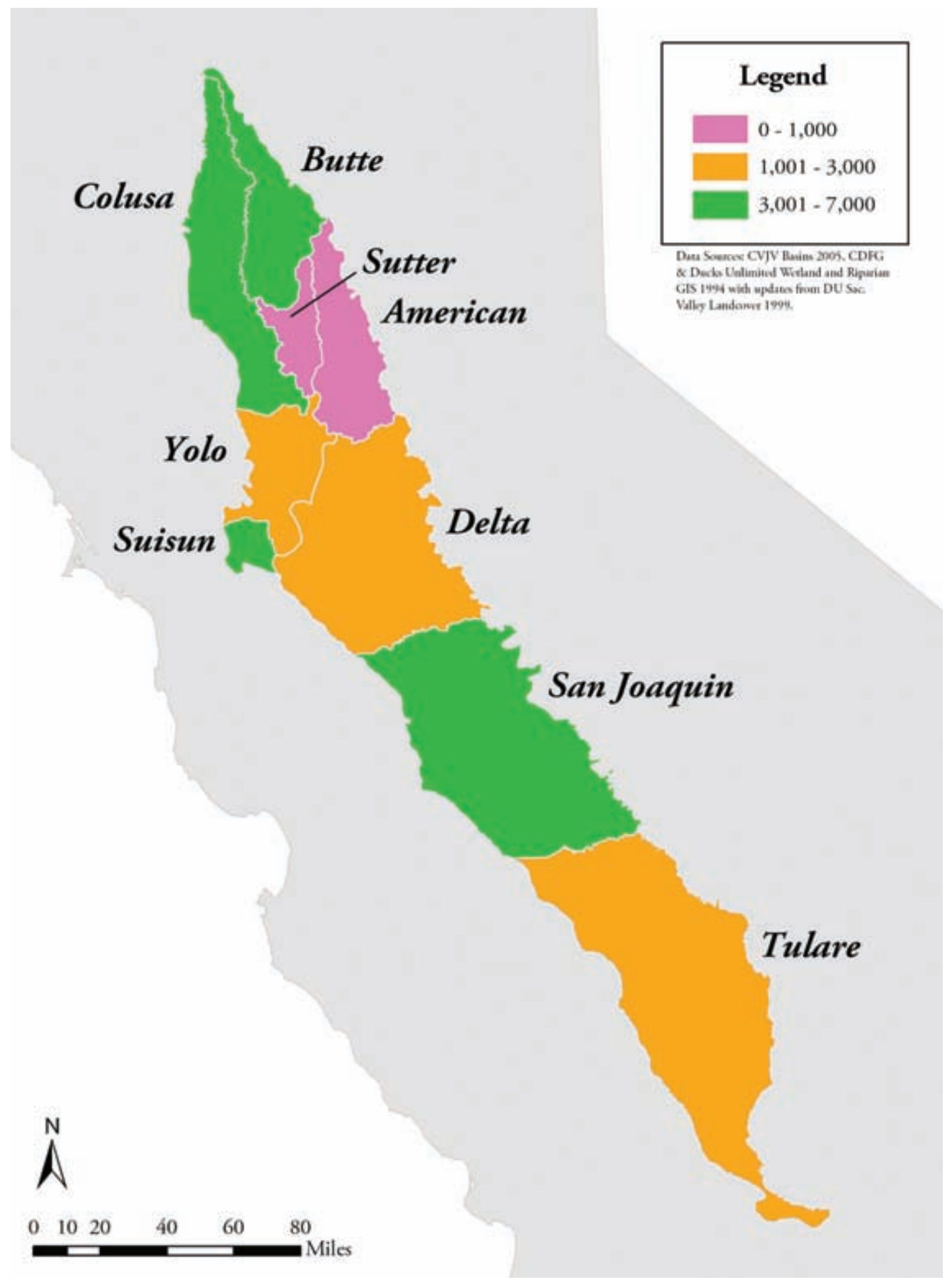

Figure 5-4. Acres of semi-permanent wetlands (breeding wetlands) by basin. 


\section{Distribution of Rice}

Rice fields provide habitat for both breeding mallard pairs and ducklings during the brood rearing period (April through August). The distribution of existing rice land is depicted in Figure 5-5.

\section{Distribution of Potential Nesting Cover}

Potential waterfowl nesting cover in the Central Valley includes grain and hay crops, native vegetation, and pasture (Loughman et al. 1991). The distribution of these three cover types was mapped using data from the California Department of Water Resources for areas of the valley with less than four degrees of slope (Figure 5-6). This slope constraint was applied to potential nesting habitat to exclude areas of the valley that are unlikely to be used by breeding mallards. Grain and hay crops, native vegetation, and pasture were then combined to depict the total amount of available nesting cover (Figure 5-7).

\section{Combining Data Layers}

Figure 5-8 reflects the spatial distribution of managed wetlands and upland nesting cover throughout the Central Valley. These layers were subsequently combined with the distribution of planted rice to depict all the major habitats used by breeding mallards in the Central Valley (Figure 5-9). Although these spatial data provide a first step in developing conservation objectives for breeding mallards, it remains unclear how well these data depict the habitat resources that are available to breeding birds (e.g., To what extent do nesting birds make use of pasture in the Central Valley?). Understanding the spatial data that are needed for breeding waterfowl would contribute significantly to future conservation planning efforts.

\section{Conservation Objectives for Breeding Mallards in the Central Valley}

Possible conservation objectives for breeding waterfowl in the Central Valley may include: (1) increasing the acreage of semi-permanent wetlands (wetlands used by breeding waterfowl) by restoring semi-permanent wetlands or managing existing seasonal wetlands as semipermanent habitats; (2) protection of existing semi-permanent wetlands; (3) restoration of upland nesting cover; and (4) protection of existing nesting cover. Conservation programs to restore or protect semi-permanent wetlands increase the amount of habitat for breeding mallard pairs, and for brood-rearing females. This may result in higher densities of breeding birds and in greater duckling survival. Similarly, conservation programs to restore or protect upland nesting cover may lead to increases in nest success.

Protecting existing unprotected wetlands will be a minor conservation objective for breeding mallards, because most wetlands are already under easement or are publicly owned (Chapter 2). However, restoring semi-permanent wetlands and providing incentives for landowners to maintain restored and existing wetlands in a semi-permanent condition may be an important conservation objective in some basins. Water costs for these wetlands are high and management of emergent vegetation is expensive. As a result, many landowners are reluctant to maintain semi-permanent wetlands. Private lands programs that have traditionally paid landowners to maintain wetland habitats (e.g., CDFG's California Waterfowl Habitat Program and the USDA Waterbank Program) would be crucial to this conservation objective. 


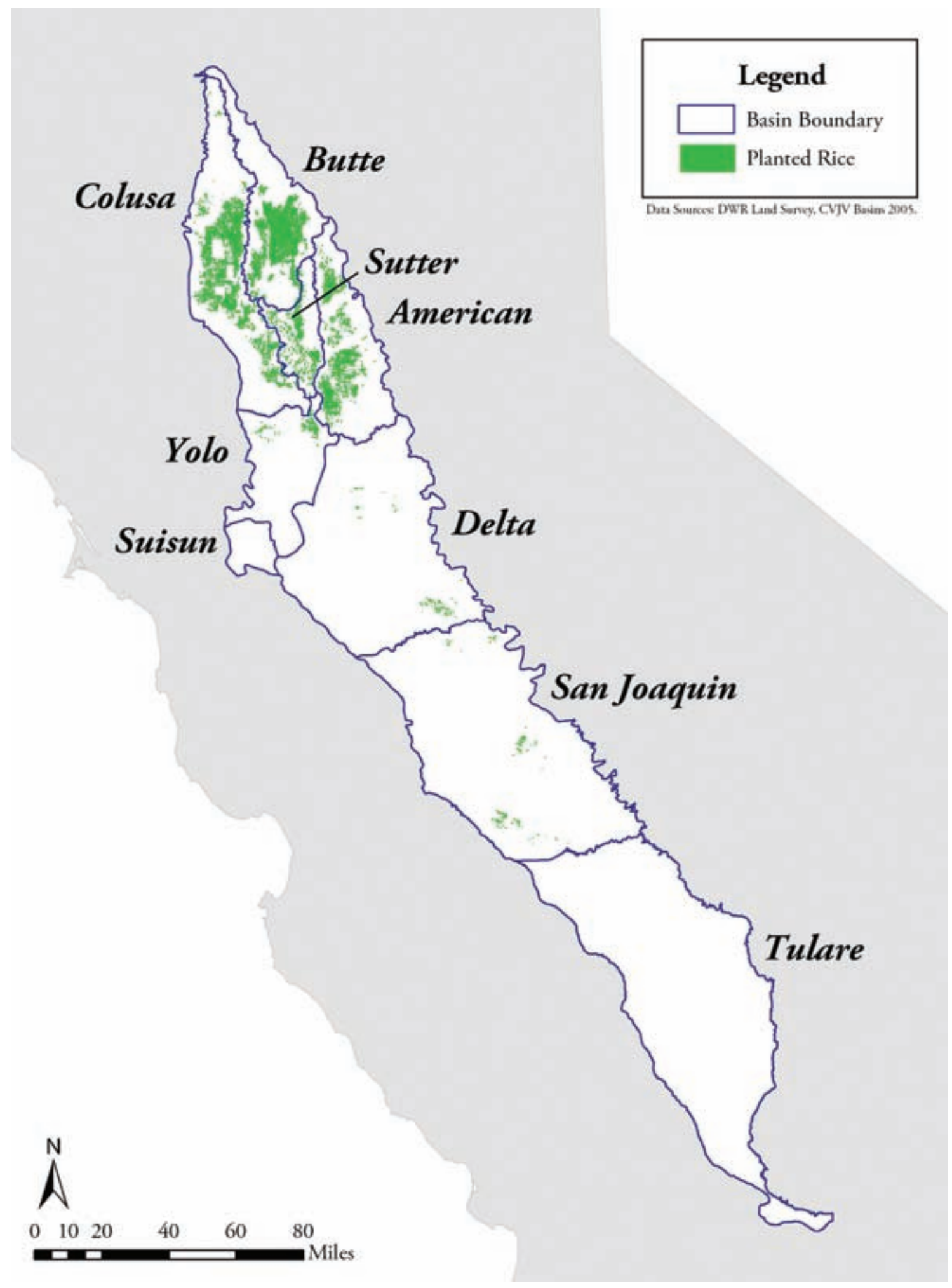

Figure 5-5. Distribution of planted rice in the Central Valley. 


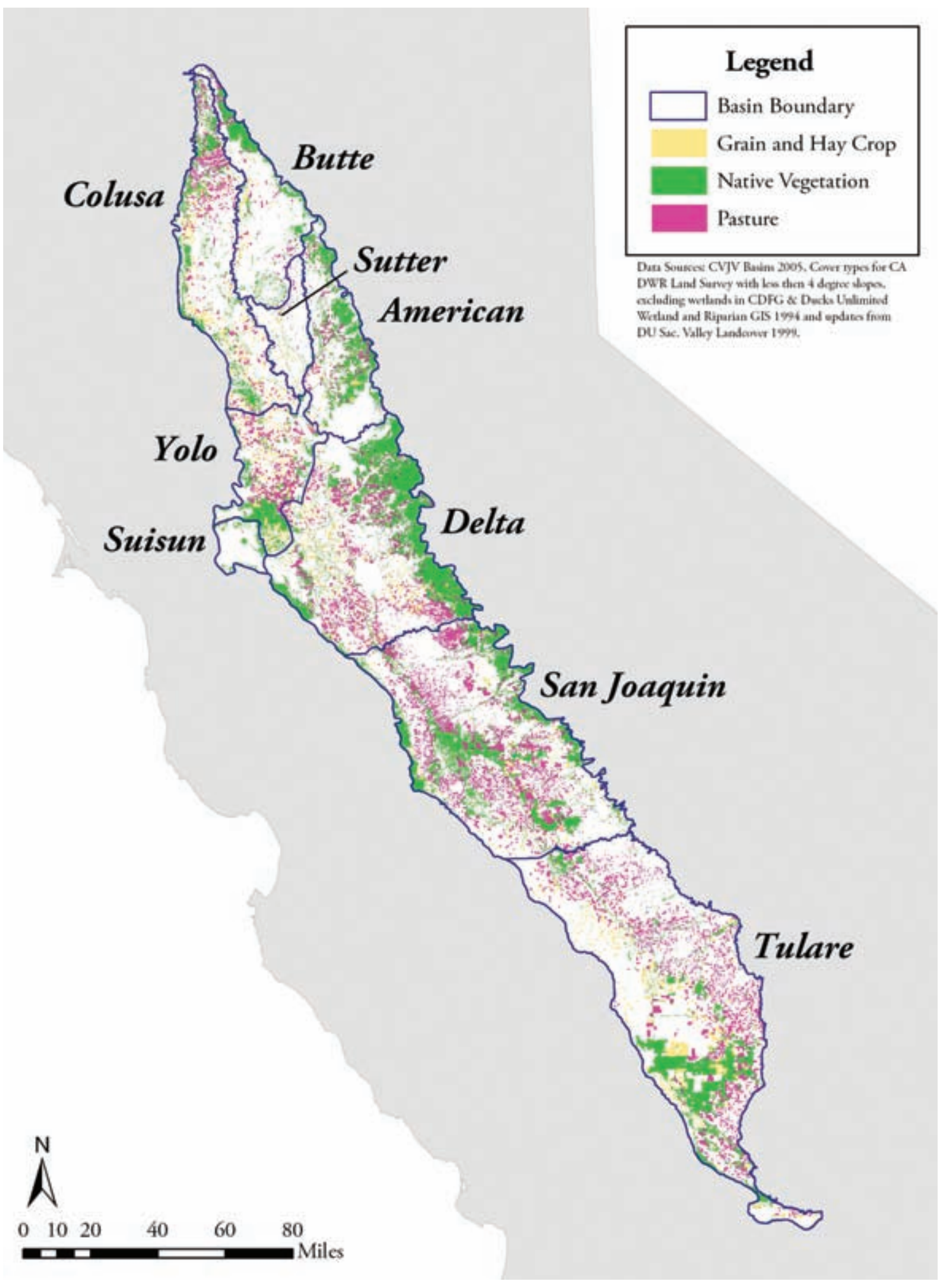

Figure 5-6. Distribution of potential nesting cover types in the Central Valley. 


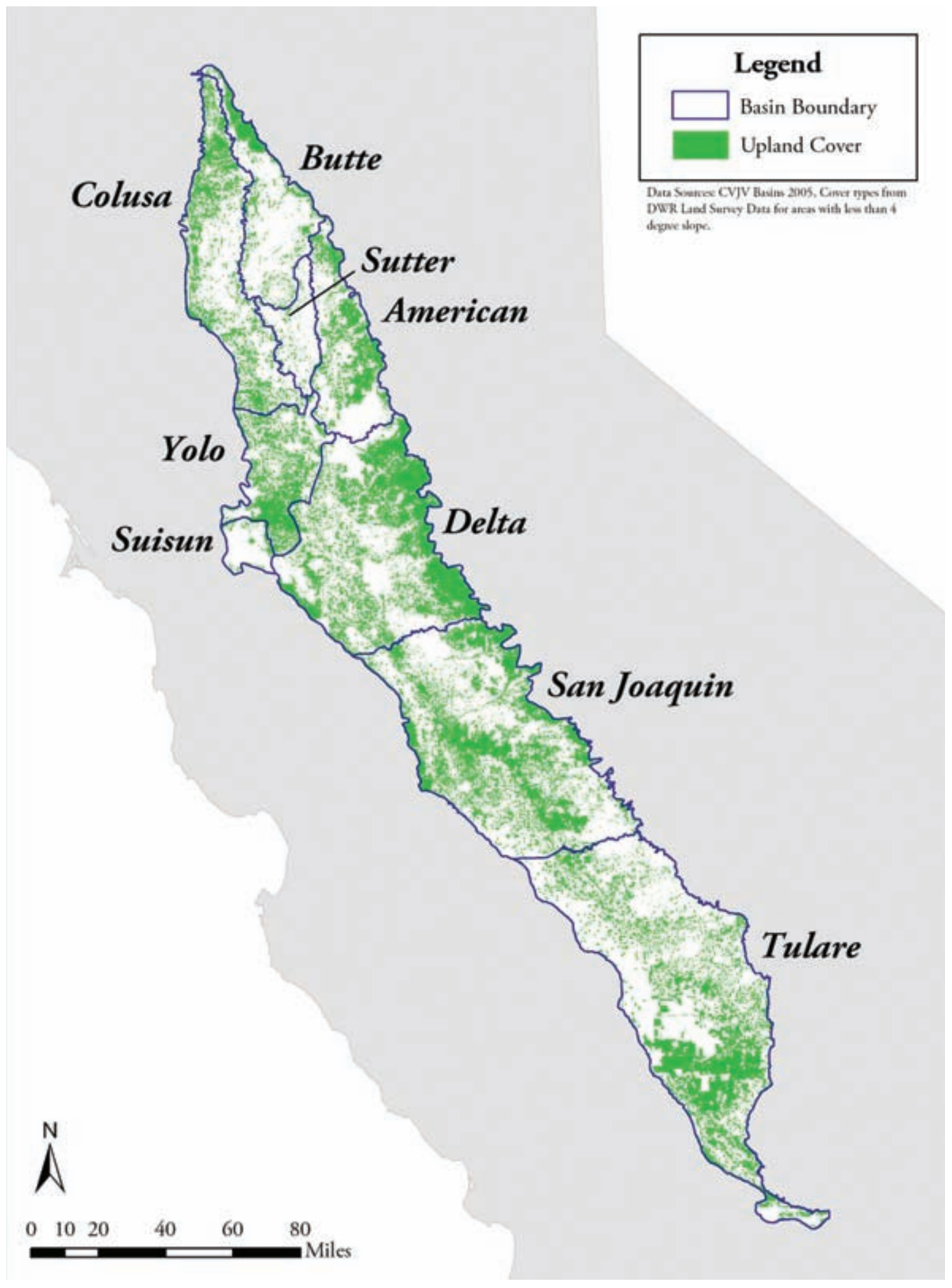

Figure 5-7. Distribution of potential nesting cover in the Central Valley. 


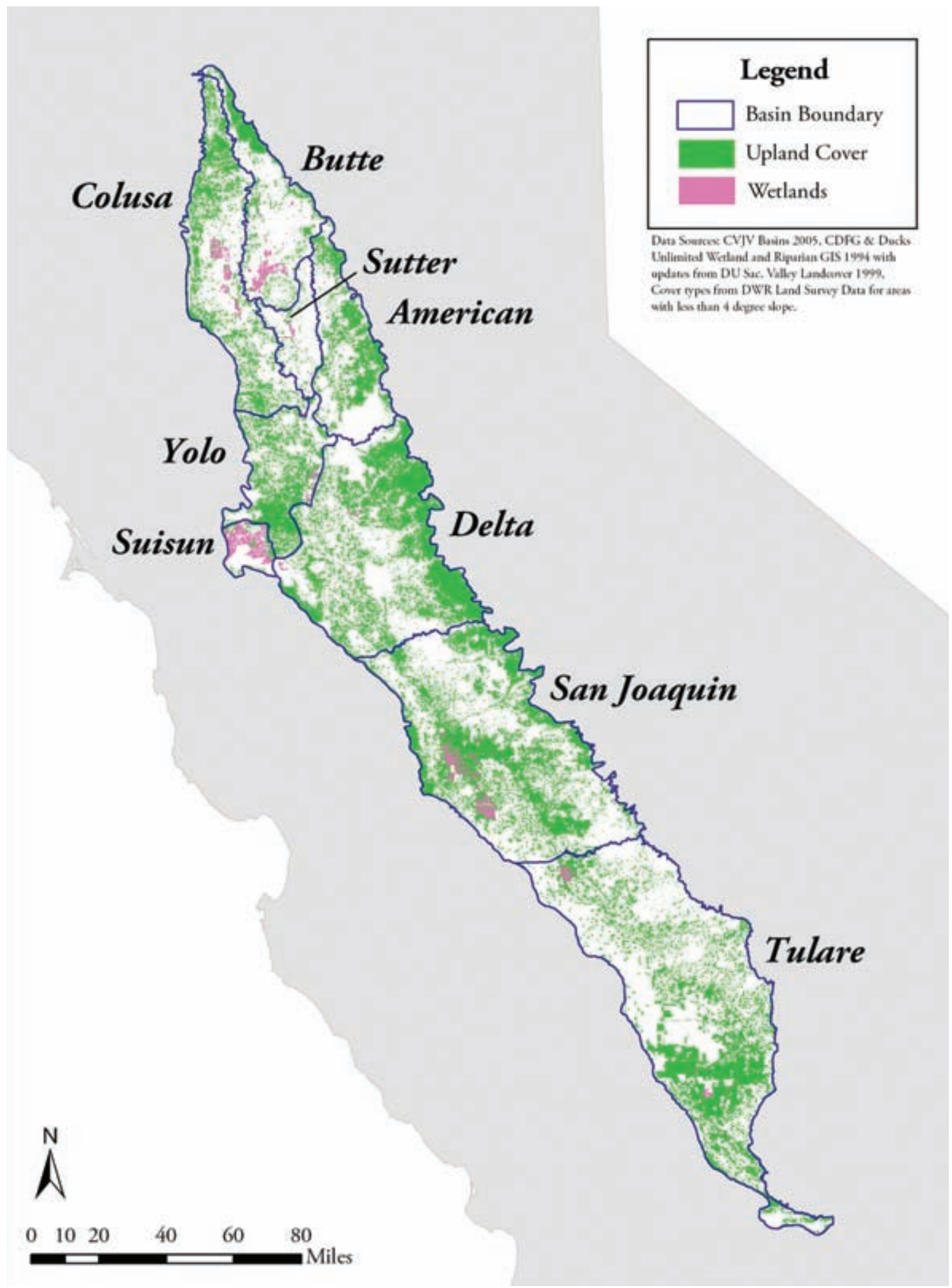

Figure 5-8. Distribution of wetlands and upland cover in the Central Valley. 


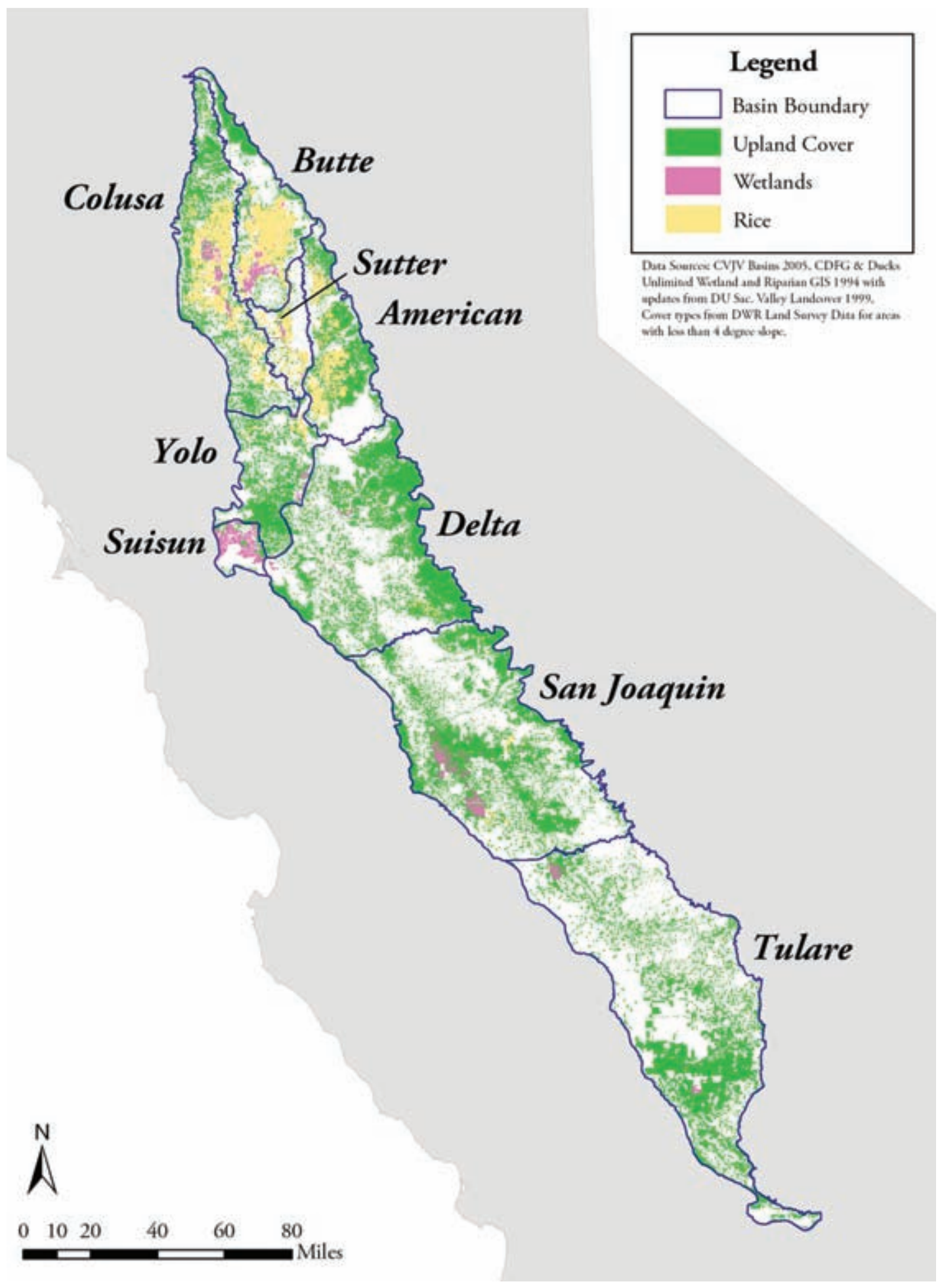

Figure 5-9. Distribution of potential upland cover, rice, and wetlands. 
Protecting nesting cover is unlikely to be a conservation objective for breeding mallards. Conservation programs to protect nesting habitat in the Central Valley would rely on farmland easements to protect existing cover, especially in areas where grains, hay land, and pasture provide the majority of nesting habitat. In the PPR, agricultural easements are inexpensive and nesting densities on these protected uplands are typically high. As a result, large numbers of birds are benefited at low costs. However, easement costs in the Central Valley would likely be too high, while nesting densities on these properties may be too low to justify the expense of a permanent easement. Accordingly, upland programs for nesting mallards are likely to focus on restoring upland cover in areas where breeding densities are high but the availability of nesting cover is low. These restoration programs will have to offer economic incentives that are competitive with commodity markets and Farm Bill Programs. In addition, they are likely to be short term in nature (e.g., 3-5 years) with farmers having an option to leave the program after the contract expires. The Sacramento Valley CREP pilot project, for example, provides landowners with an economic incentive to convert agricultural lands back to native cover for ten-year periods. If the CREP is delivered in areas where breeding densities are high it may benefit large numbers of birds at reasonable costs. The USDA Conservation Security Program is another new and well-funded program that could provide similar benefits for nesting waterfowl.

Based on available information, increasing and maintaining the amount of semi-permanent wetland habitat and expanding nesting cover in key areas appears to be the most appropriate conservation objectives for breeding mallards in the Central Valley. Moreover, the spatial distribution of existing wetland and upland resources can identify where these conservation objectives are best applied on the landscape.

Although the JV does not yet know what vital rates limit mallard populations in the Central Valley, it can make informed decisions about the types of programs to deliver for breeding mallards. In order to do so, the JV identified landscape types that may require different management prescriptions for breeding mallards. These landscapes were differentiated using three characteristics: (1) existing semi-permanent wetlands; (2) existing upland cover; and (3) existing planted rice. Within a landscape, each of these habitat components is categorized as high or low, where high and low categories reflect relative differences among landscapes. These categories result in eight classes of landscapes that may be encountered by breeding mallards (e.g., high availability of wetlands, high availability of upland cover, low availability of rice). The JV then developed a decision matrix that identified the appropriate conservation objective(s) for each landscape class (Figure 5-10). These eight conservation objectives - landscape class associations are described below.

\section{Conservation Objective-Landscape Class Associations}

\section{Low Wetlands, Low Rice, Low Upland Cover}

Increases in semi-permanent wetlands and upland cover are recommended for these landscapes. The lack of rice, wetlands, and nesting cover in these landscapes makes them a low priority for breeding habitat programs, at least in the short term. Existing mallard densities are likely to be low in these areas, as is reproductive success. Increasing the size and success of breeding mallard populations in these landscapes is not likely to be cost effective compared to landscapes where at least some habitat components are in place.

\section{Low Wetlands, High Rice, Low Uplands}

Increases in upland cover and semi-permanent wetlands are recommended for these landscapes. Increases in upland cover within rice growing areas may increase the nest success of mallards that rely on rice fields for pair habitat. Increases in semi-permanent wetlands may increase early season duckling survival, as they provide brood habitat at a time when rice does not yet provide adequate cover.

\section{Low Wetlands, Low Rice, High Uplands}

Increasing semi-permanent wetlands should be a conservation objective priority for these landscapes. Increases in wetland habitat should attract more birds to these landscapes and allow the birds to exploit large tracts of upland cover. This recommendation is dependant on these landscapes having areas that are suitable for wetland restoration.

\section{Low Wetlands, High Rice, High Uplands}

Increasing semi-permanent wetlands should be a conservation objective priority for these landscapes, as they may support large numbers of breeding mallards that experience high nest success. However, the absence of semi-permanent wetlands may result in low early-season brood survival. 


\section{High Wetlands, Low Rice, Low Uplands}

Increases in upland cover are recommended for these landscapes, as this habitat may support high densities of breeding mallards that are limited by low nest success.

\section{High Wetlands, High Rice, Low Uplands}

Increasing upland cover in these landscapes should be a priority conservation objective. These landscapes likely support high densities of breeding mallards that may benefit significantly from additional nesting cover. Increasing semipermanent wetlands could represent a secondary conservation objective as it may increase breeding incidence and duckling survival.

\section{High Wetlands, High Rice, High Uplands}

Increasing semi-permanent wetlands within these landscapes should be a conservation objective priority. These areas may support large numbers of breeding mallards that enjoy high reproductive success. Providing more wetland habitat in these landscapes may increase mallard densities, and allow additional birds to exploit existing upland and brood rearing resources.

\section{High Wetlands, Low Rice, High Uplands}

Increasing semi-permanent wetlands within these landscapes should be a conservation objective priority. These areas may support large numbers of breeding mallards that enjoy high reproductive success. Providing more wetland

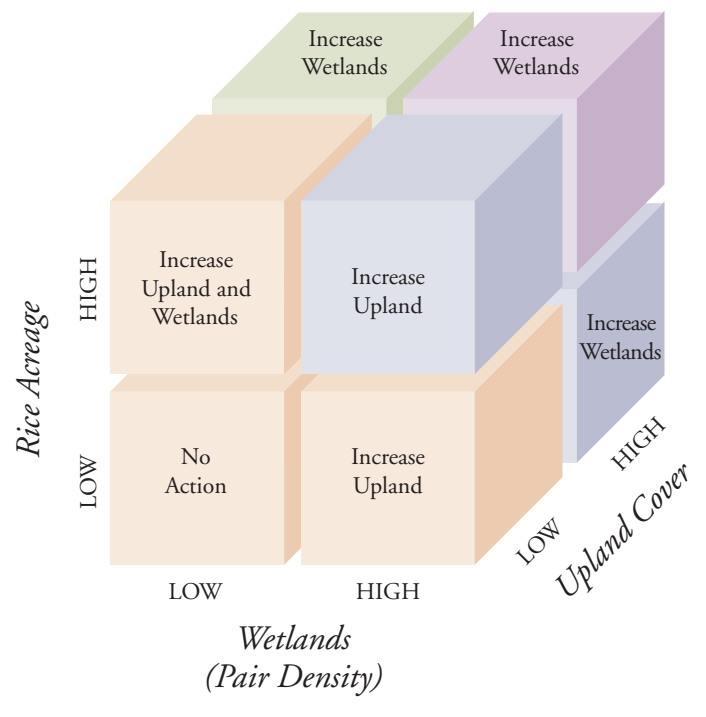

Figure 5-10. Decision matrix for breeding mallards in the Central Valley. habitat in these landscapes may increase mallard densities, and allow additional birds to exploit existing upland and brood rearing resources.

The remainder of this chapter reviews the spatial distribution of wetland, rice, and upland habitat in each basin. Although these data help distinguish the different landscape types in a basin, they are not sufficiently developed to allow site specific recommendations on what habitat programs to pursue for breeding mallards. For example, the Geographic Information System data in the PPR are sufficiently developed to identify habitat prescriptions at the four square mile scale. In the short term, decisions on what programs to deliver for breeding mallards in the Central Valley will require site by site assessment of existing habitat conditions using on the ground information and/or improved spatial data.

\section{Basin Conservation Objectives}

Although existing spatial data is inappropriate for identifying site specific management prescriptions, it can be used to broadly distinguish different landscape types and to suggest what habitat programs are suited to those landscapes. Figures 5-11 through 5-17 depict areas of each basin where habitat programs may be most beneficial to breeding waterfowl. 


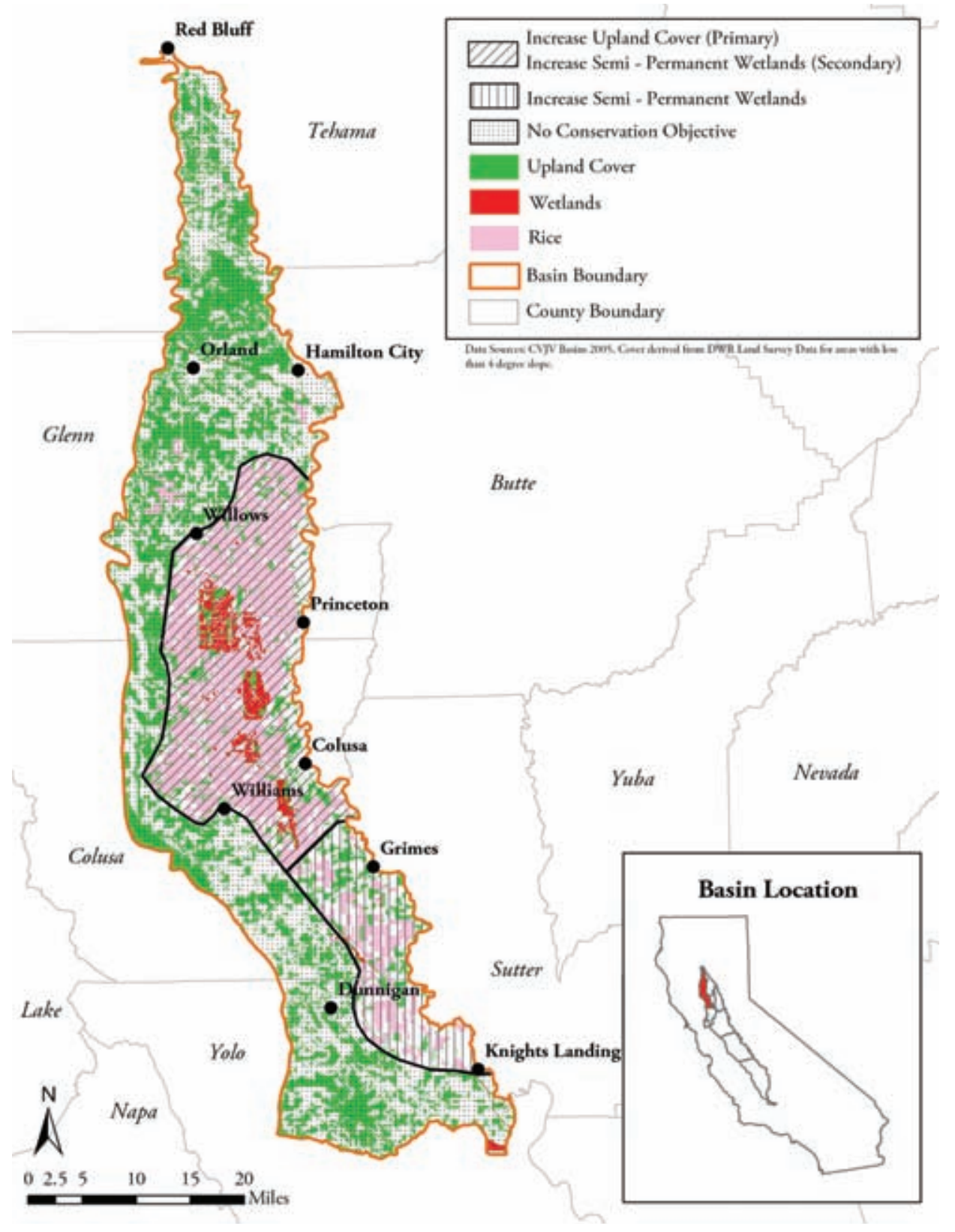

Figure 5-11. Conservation objectives for breeding mallards in Colusa Basin.

\section{Colusa Basin}

The distribution of upland, wetland, and rice habitats in the Colusa Basin is depicted in Figure 5-11. The portion of the basin that lies north of Willows is characterized by an abundance of potential upland cover, as is the entire western edge of the basin. Increasing semipermanent wetlands may be appropriate for at least portions of this landscape. Most wetland and rice habitat in the basin lies between Willows and Williams. However, upland habitat is generally lacking in this landscape. The restoration of upland cover may benefit breeding waterfowl in areas adjacent to these rice-wetland complexes. Increasing semi-permanent wetlands may also benefit breeding waterfowl as bird densities may already be high in this landscape, and increases in wetland habitat could increase breeding incidence and duckling survival. 


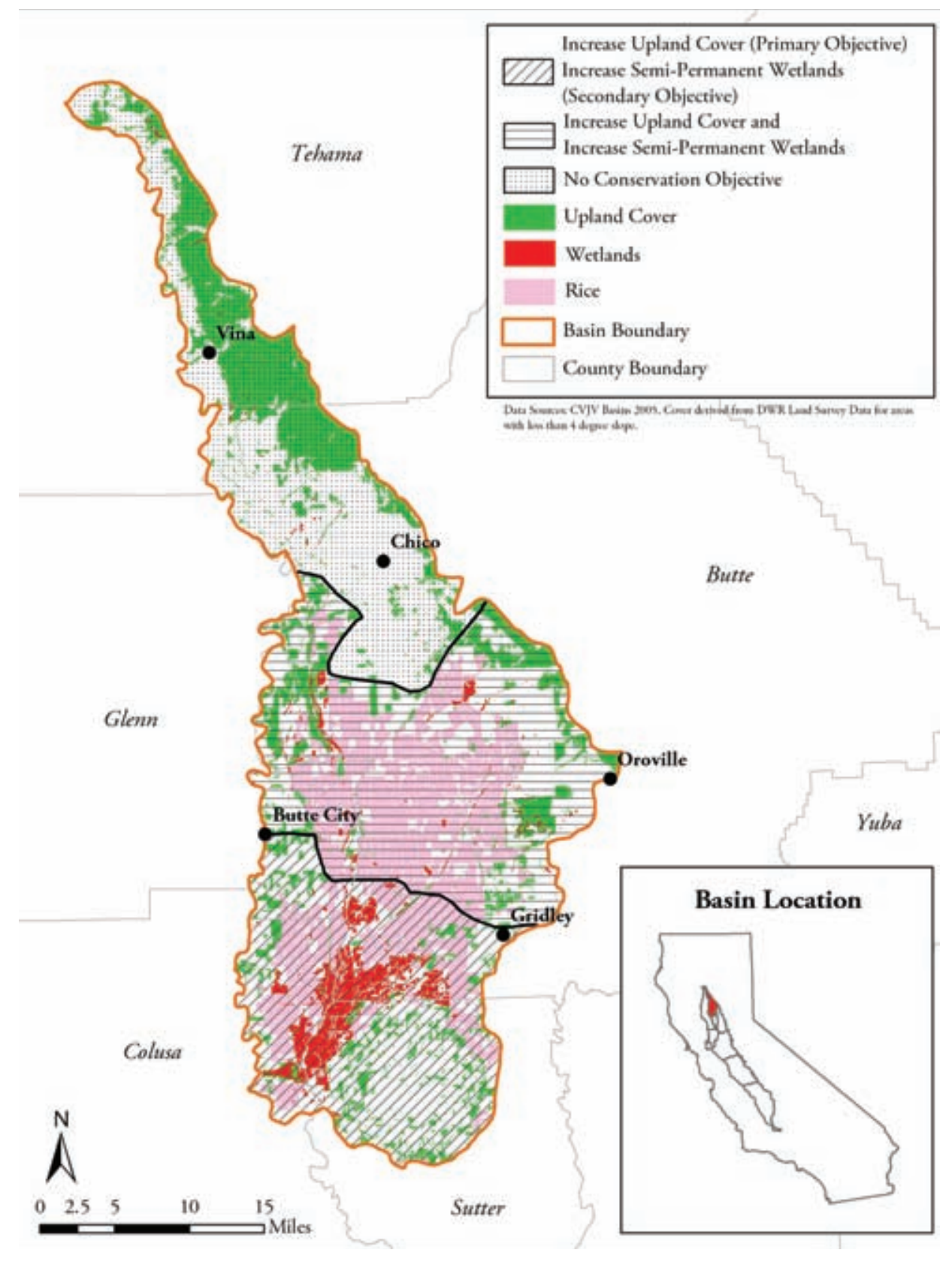

Figure 5-12. Conservation objectives for breeding mallards in Butte Basin.

\section{Butte Basin}

The distribution of upland, wetland, and rice habitats in the Butte Basin is presented in Figure 5-12. The portion of the basin that lies north of Chico is characterized by an abundance of upland cover. Increasing semi-permanent wetlands may be appropriate for at least portions of this landscape. South of Butte City and north of the Sutter Buttes is a landscape characterized by high amounts of wetlands and rice. However, upland habitat is lacking in this landscape and restoration of upland cover may benefit breeding waterfowl. Increasing semi-permanent wetlands may also benefit breeding waterfowl as bird densities may already be high in this landscape, and increases in wetland habitat could increase breeding incidence and duckling survival. North of the Butte City-Gridley line is a landscape with high amounts of rice, but low amounts of both wetlands and uplands. Conservation objectives for this landscape could include an increase in both semi-permanent wetlands and upland habitat. 


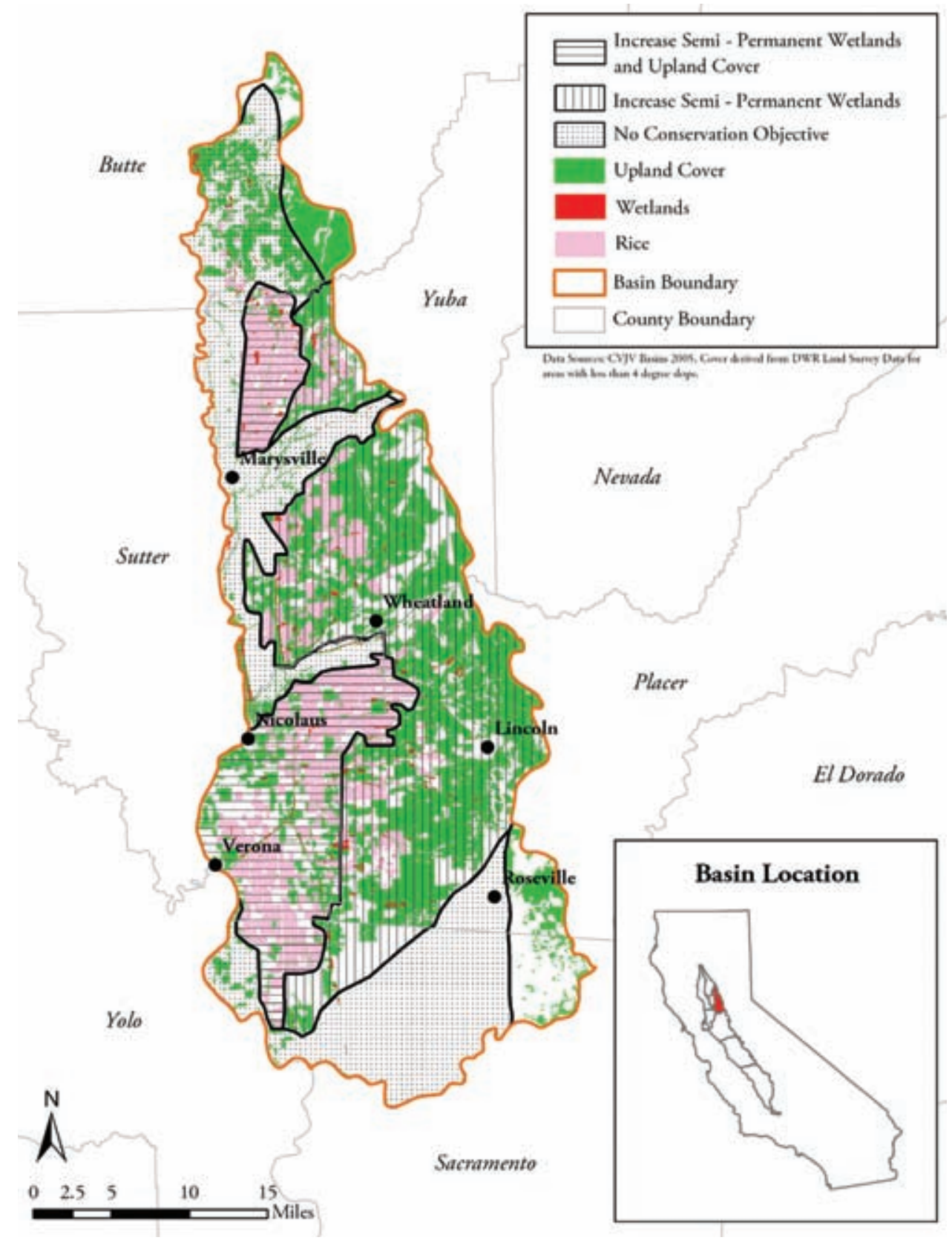

Figure 5-13. Conservation objectives for breeding mallards in American Basin.

\section{American Basin}

The distribution of upland, wetland, and rice habitats in the American Basin is presented in Figure 5-13. Large acreages of rice and upland habitat, but few wetlands characterize much of the eastern and central landscapes of the basin. Increases in semi-permanent wetlands may benefit breeding waterfowl in these areas. High amounts of rice occur in the north and southwest portions of the basin. However, these landscapes contain low amounts of both wetland and upland habitat. Increases in semi-permanent wetlands and upland cover may provide the greatest benefits to breeding waterfowl in these areas. 


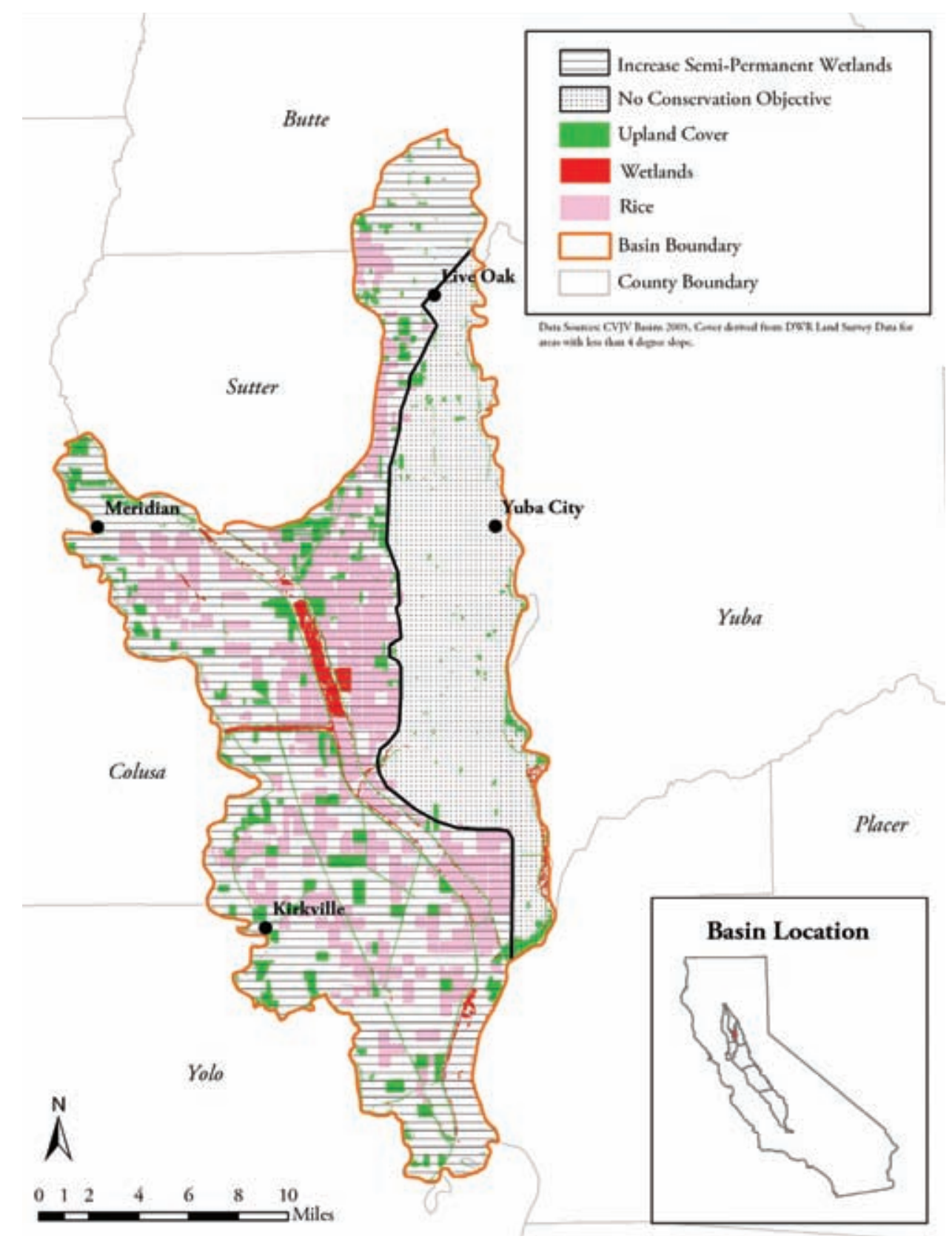

Figure 5-14. Conservation objectives for breeding mallards in Sutter Basin.

\section{Sutter Basin}

The distribution of upland, wetland, and rice habitats in the Sutter Basin is presented in Figure 5-14. Rice occurs in large amounts throughout the western half of the basin, though wetlands are limited and largely restricted to the Sutter Bypass. Although some upland cover occurs throughout western parts of the basin, it is scattered and present in small amounts. Increases in semi-permanent wetlands and upland cover may benefit breeding waterfowl throughout the western half of the basin. 


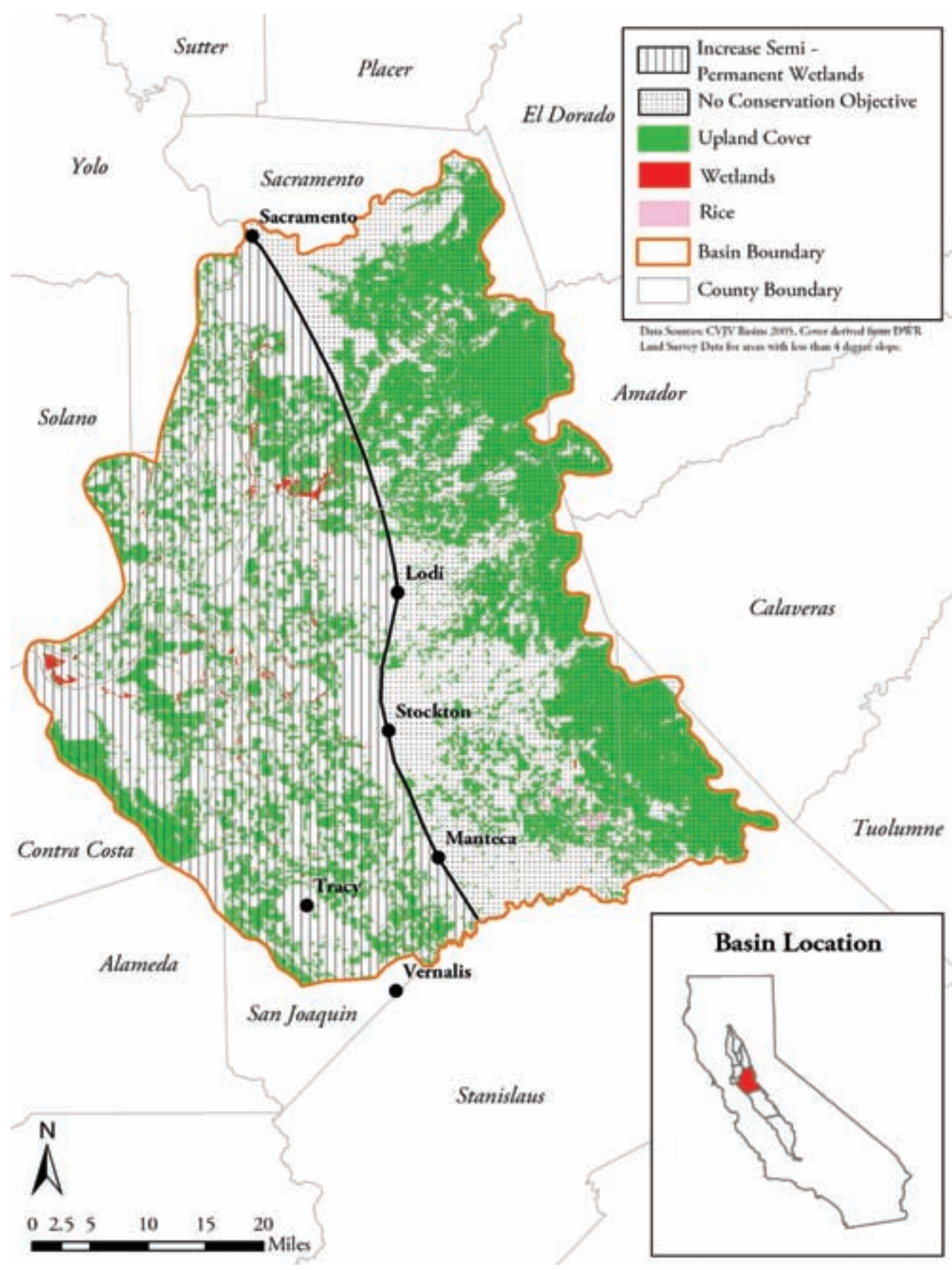

Figure 5-15. Conservation objectives for breeding mallards in Delta Basin.

\section{Delta Basin}

The distribution of upland and wetland habitats in the Delta Basin is presented in Figure 5-15. Rice acreage in the basin totals less than 1,500 acres. Upland cover is high throughout the eastern half of the basin. Increases in semi-permanent wetlands may be appropriate for at least portions of this landscape. Upland cover is also high in the western half of the basin, though wetland abundance is generally low. Increases in semi-permanent wetlands may benefit breeding mallards in this landscape as well. 


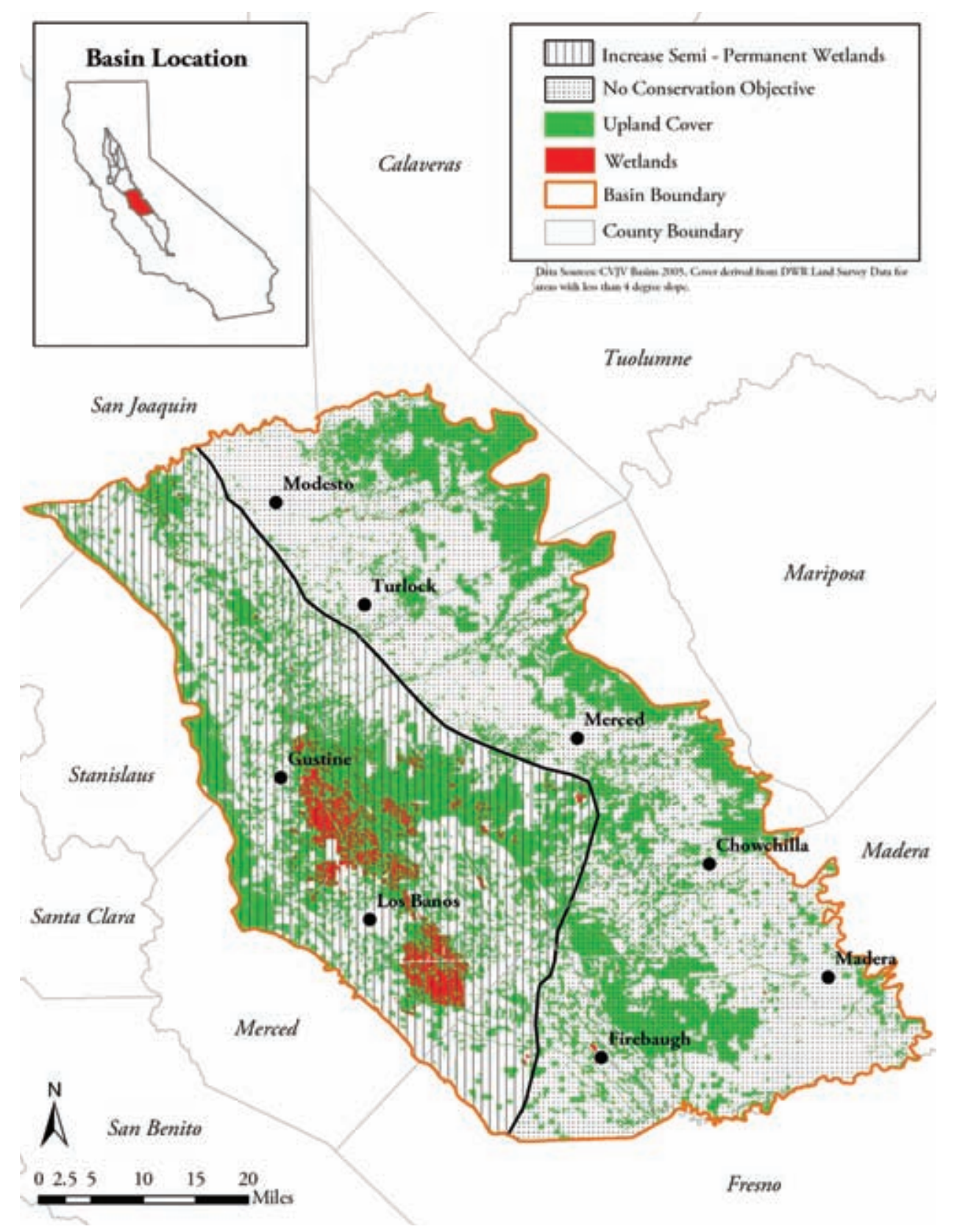

Figure 5-16. Conservation objectives for breeding mallards in San Joaquin Basin.

\section{San Joaquin Basin}

The distribution of upland and wetland habitat in the San Joaquin Basin is presented in Figure 5-16. Although there is some rice grown in the basin it occurs in low amounts. Upland cover is high west of Modesto, Merced, Chowchilla, and Firebaugh. Increases in semipermanent wetlands may be appropriate for at least portions of this landscape.

The remainder of the basin is characterized by high amounts of upland cover and large wetland complexes (i.e., West Grasslands). Increases in semi-permanent wetlands in these wetland-upland complexes may benefit breeding mallards (Figure 5-21). 

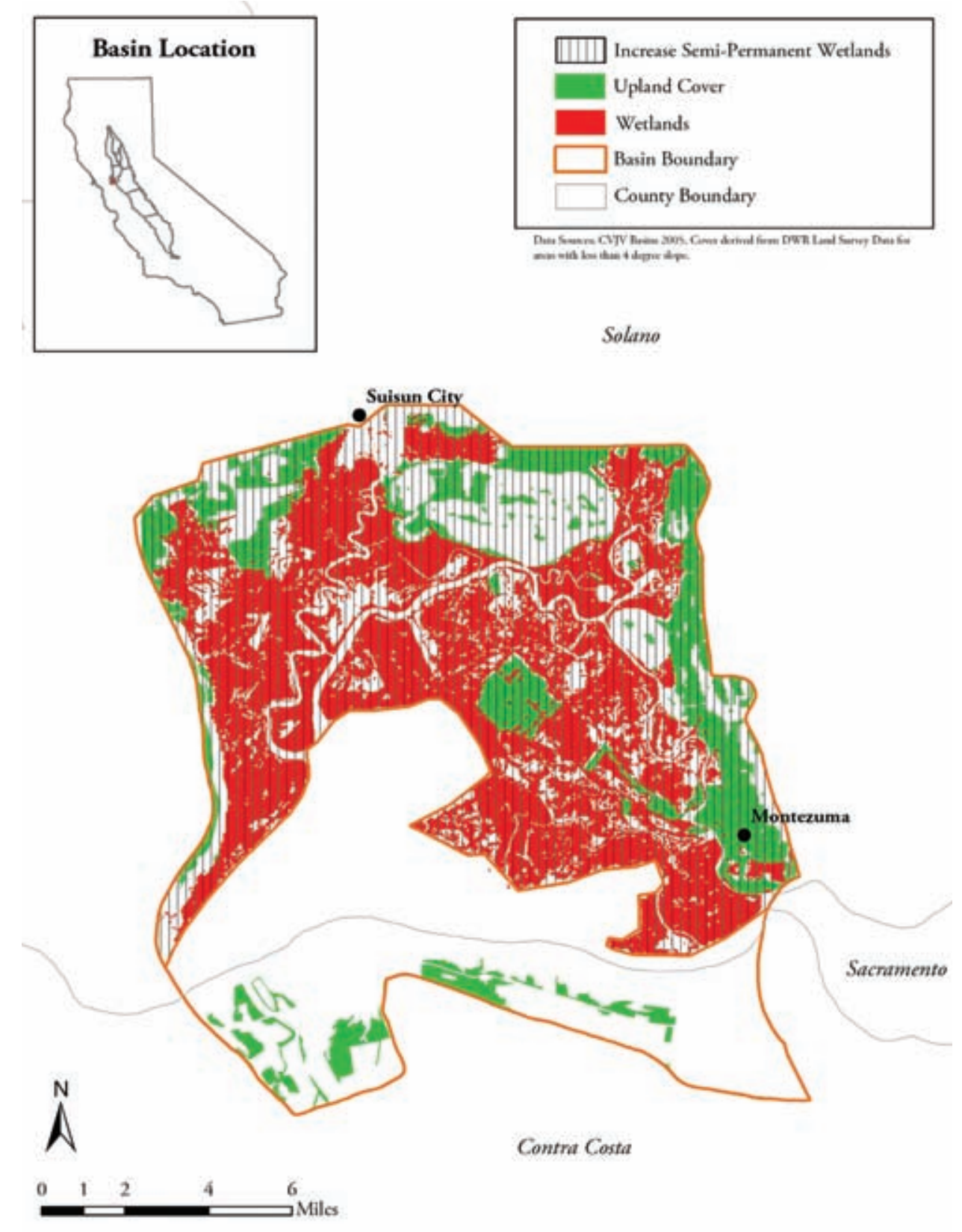

Figure 5-17. Conservation objectives for breeding mallards in Suisun Marsh Basin.

\section{Suisun Marsh Basin}

The distribution of upland and wetland habitats in the Suisun Marsh Basin is presented in Figure 5-17. No rice is grown in this basin. The entire landscape of the Suisun Marsh is characterized by high amounts of upland cover and wetland habitat. As a result, increasing the amount of semi-permanent wetlands within the basin is likely to provide the greatest benefits to breeding mallards. 


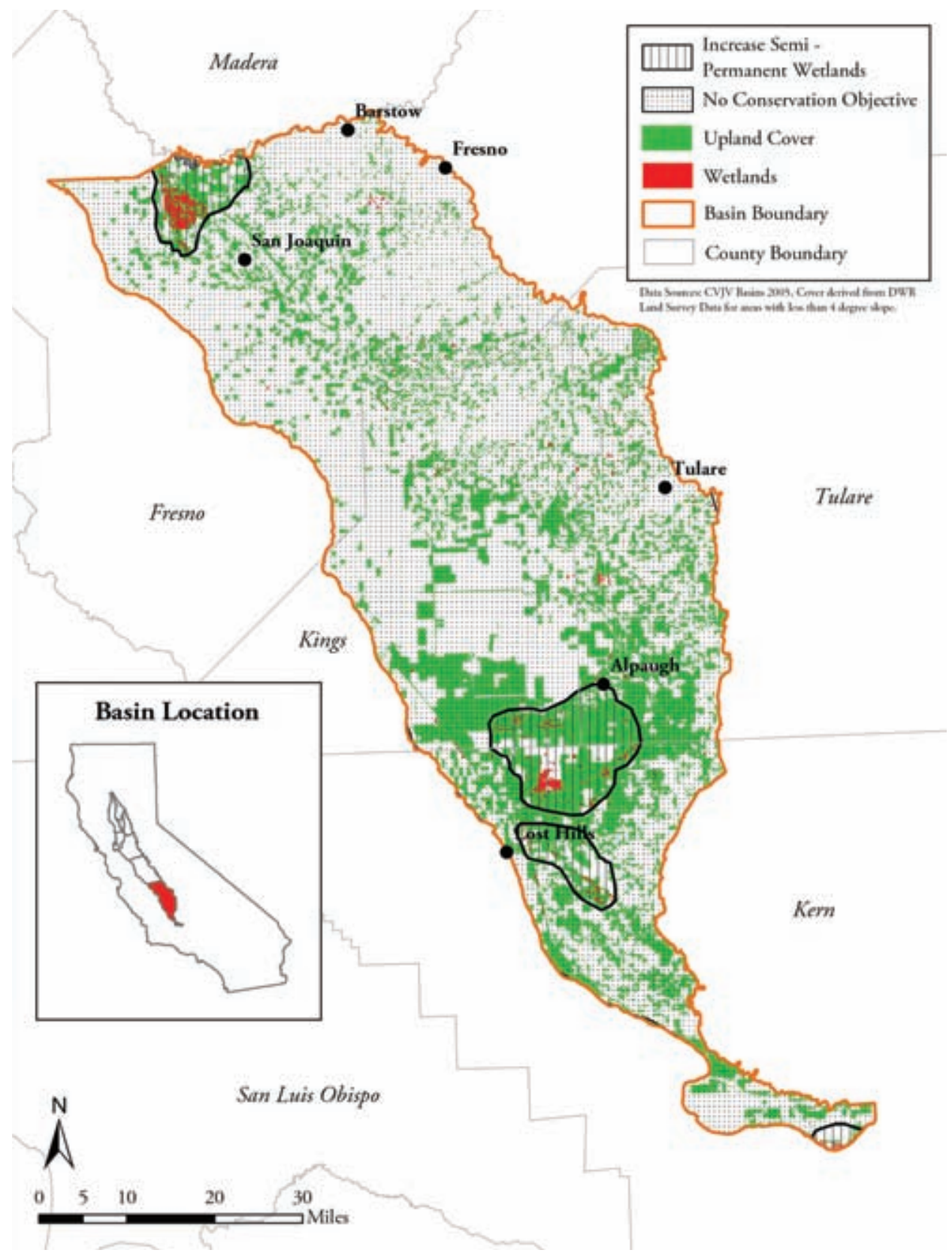

Figure 5-18. Conservation objectives for breeding mallards in Tulare Basin.

\section{Tulare Basin}

The distribution of upland and wetland habitats in the Tulare Basin is presented in Figure 5-18. No rice is grown in this basin. Significant amounts of cover occur in the north-central and southeastern parts of the basin, and increasing semi-permanent wetlands in these areas may benefit breeding mallards. 


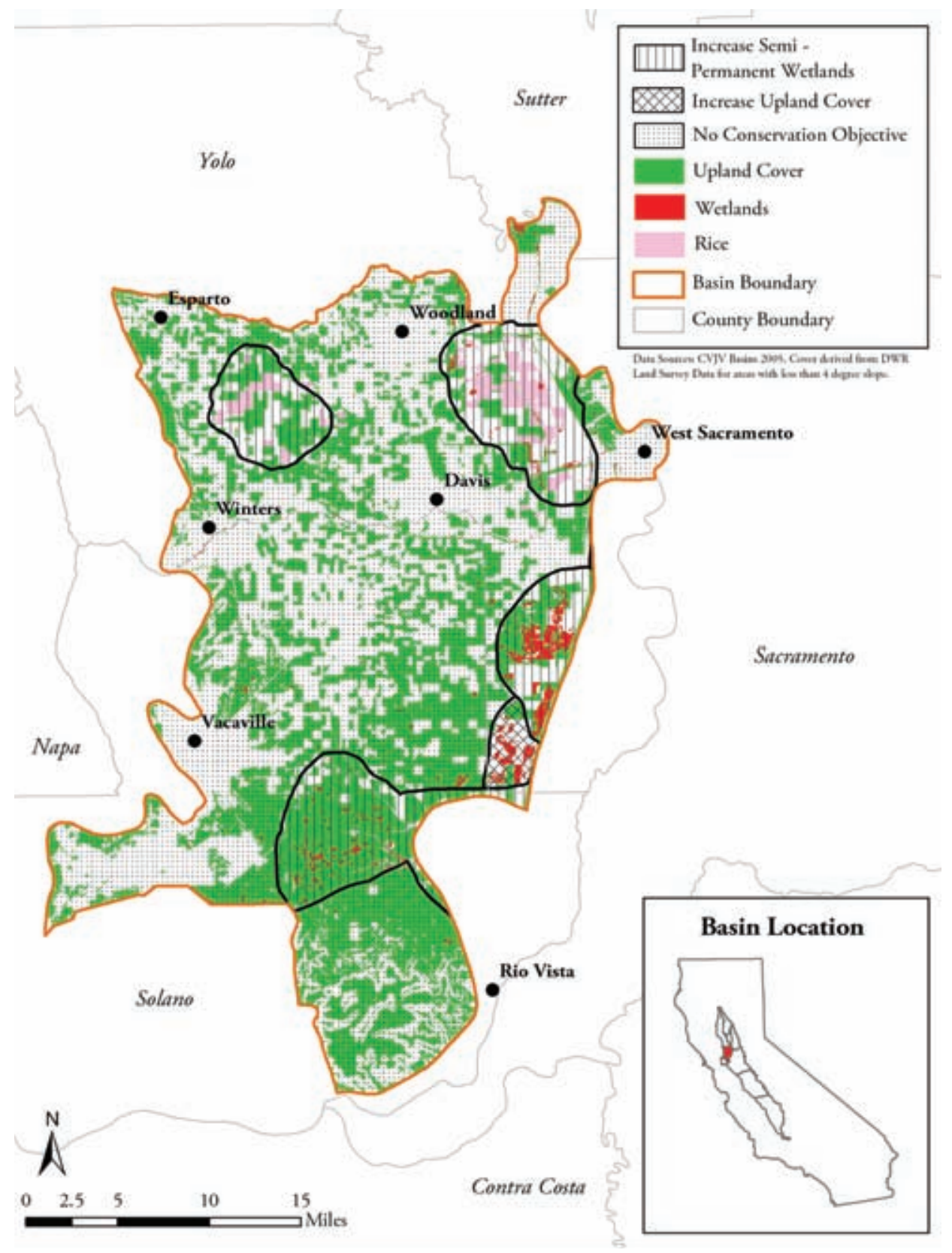

Figure 5-19. Conservation objectives for breeding mallards in Yolo Basin.

\section{Yolo Basin}

The distribution of upland, wetland, and rice habitats in Yolo Basin is presented in Figure 5-19. Most wetlands occur in one of three distinct blocks on the eastern edge of the Basin, and south of the Davis - West Sacramento line. The two most northern of these wetland blocks are interspersed with large areas of upland cover. Increasing semi-permanent wetlands within this landscape may benefit breeding mallards. The wetland complex south of this landscape is not interspersed with large amounts of upland cover, and restoring upland habitat, in conjunction with efforts to increase semi-permanent wetlands, may be appropriate (Figure 5-19).

Southeast of Vacaville is a series of small wetlands that are adjacent to large amounts of upland cover. Increasing semi-permanent habitat within this wetland complex could benefit breeding mallards by allowing larger number of birds to exploit this existing upland cover. Rice is grown in the northeast and northwest corners of the basin. Although some upland cover is associated with both of these rice complexes, wetland habitats are generally lacking. Increasing semi-permanent wetlands in each of these areas may increase mallard breeding densities, and may increase early season duckling survival. 


\section{Summary}

The 2006 Plan represents a further step in developing conservation objectives for breeding waterfowl in the Central Valley. Future efforts would benefit from a better understanding of what limits population growth of breeding mallards, and how these limiting factors vary geographically within the Valley. Finally, improved spatial data that depicts the habitat resources available to breeding ducks should permit JV partners to refine the delivery of conservation programs for breeding waterfowl beyond that presented here.

\section{Appendix 5-1}

\section{A Review of Conservation Planning for Breeding Waterfowl in the U.S. Prairie Pothole Region}

Conservation planning for breeding mallards in the Central Valley should result in habitat programs that increase the size and success of breeding duck populations in a cost effective manner. One option is to develop demographic models that identify the vital rates that limit population growth (e.g., Hoekman et al. 2002). These models require vital rate estimates that are representative of mallard populations breeding in the Central Valley (Table 5-1). In some cases, mallard populations may vary in terms of what vital rates limit population growth. For example, nest success might limit populations in the Suisun Marsh but not the Tulare Basin.

Demographic models alone cannot be used to target site-specific habitat efforts. Spatial planning tools that include information on breeding waterfowl densities and the distribution of wetland and upland habitats can be combined with demographic modeling to identify specific areas for acquisition, restoration, or enhancement of breeding habitat.

Conservation planning for breeding waterfowl in the U.S. portion of the Prairie Pothole Region (PPR) provides one example where demographic models are combined with spatial planning tools to develop site-specific habitat prescriptions for breeding waterfowl. Demographic modeling indicates that prairie waterfowl are most limited by nest success (Hoekman et al. 2002). As a result, habitat efforts to restore or protect upland nesting habitat are given priority in the PPR. To help guide these programs, perennial nesting cover was mapped for much of the PPR (Figure 5-20). The distribution of perennial cover was combined with information on breeding waterfowl densities (Figure 5-21) to develop a spatial planning tool that helped address the problem of low nest success (Figure 5-22). The red areas depicted in Figure 5-22 are regions where duck densities are high, and greater than $40 \%$ of the landscape is grassland. Conservation programs in these areas focus on protecting existing habitats because waterfowl numbers are high and upland cover is already sufficient to grow duck populations. Areas that have low bird densities and low amounts of grassland are designated in beige and include much of the eastern portion of the PPR. These areas are a low conservation priority because the resources needed to restore these areas for breeding waterfowl are currently too great. In between the extremes of red and beige are landscapes that require different conservation strategies. For example, areas that are depicted in green have high wetland densities but only moderate amounts of grassland (i.e., < 40\% cover). Within these landscapes, grassland restoration is an important conservation objective, as increases in upland cover should result in increased nest success.

The planning approach described for the PPR is only one example of how habitat programs could be targeted for breeding waterfowl in the Central Valley. There are an ever increasing number of sophisticated species-habitat modeling approaches that could be used to develop spatially explicit species-habitat models for identifying priority areas and conservation needs. 


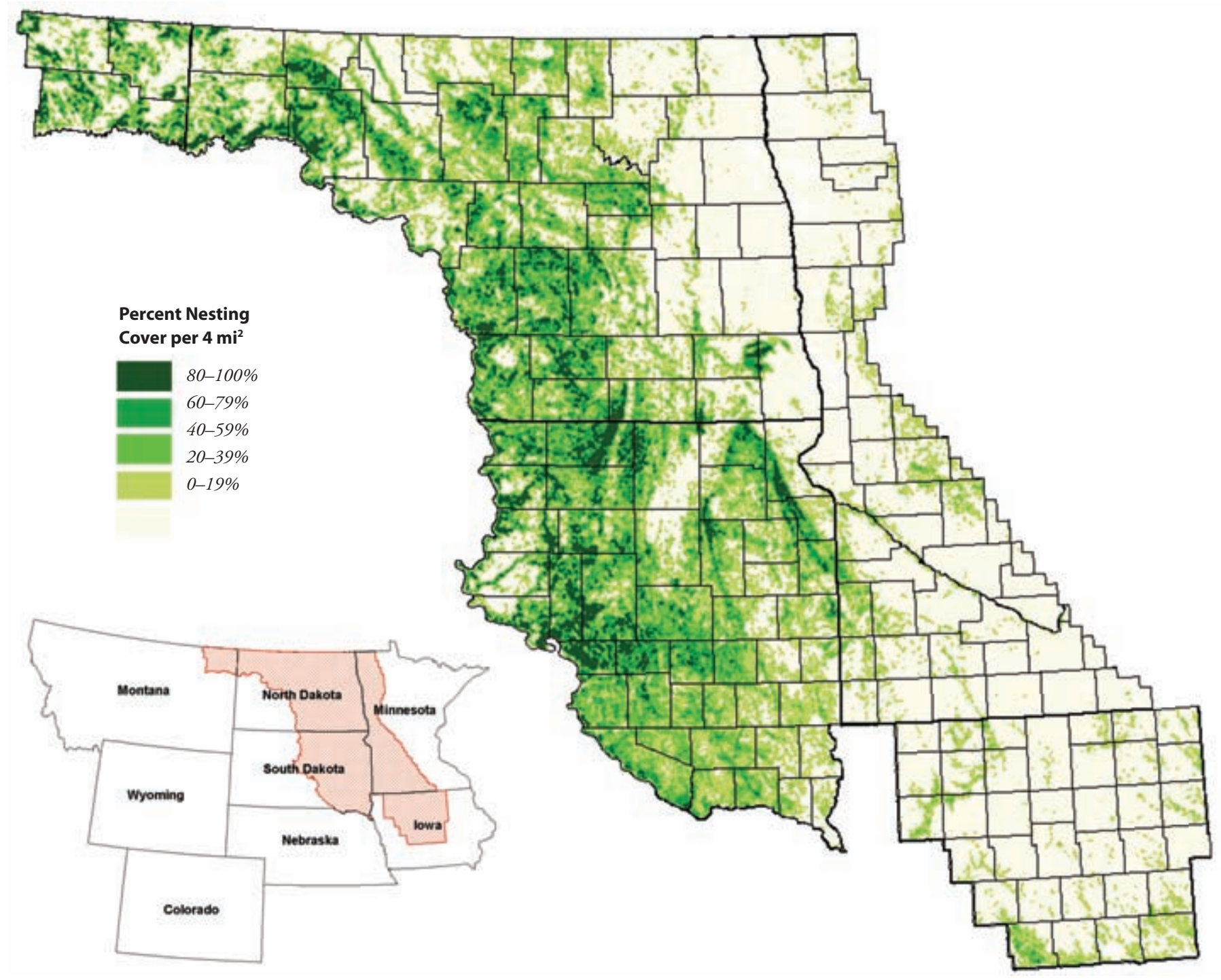

Data source: U.S. Fish and Wildlife Service/Ducks Unlimited, Inc.

Figure 5-20. Perennial nesting cover in the U.S. Prairie Pothole Region. 


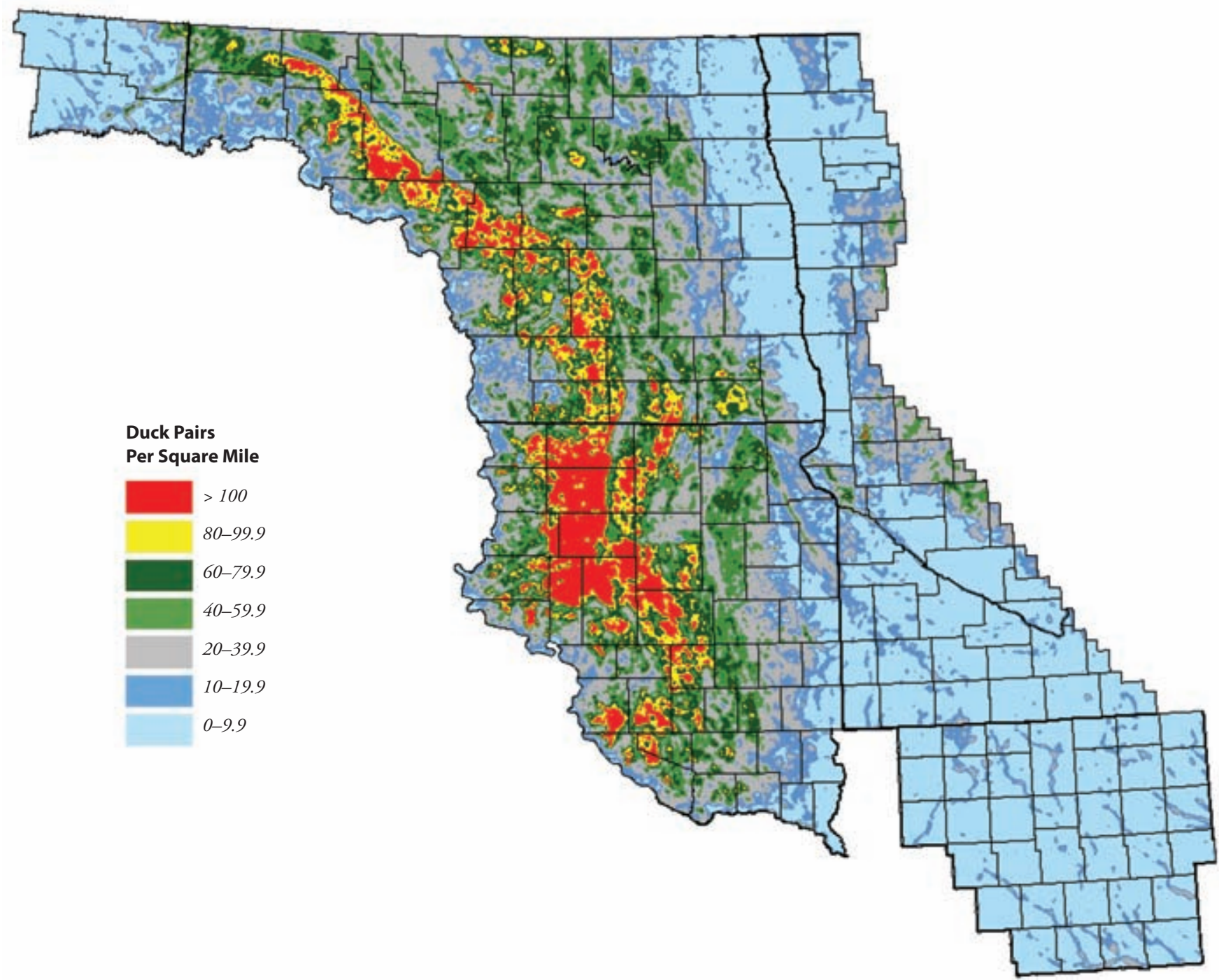

Data source: U.S. Fish and Wildlife Service/Ducks Unlimited, Inc.

Figure 5-21. Breeding waterfowl densities in the U.S. Prairie Pothole Region. 


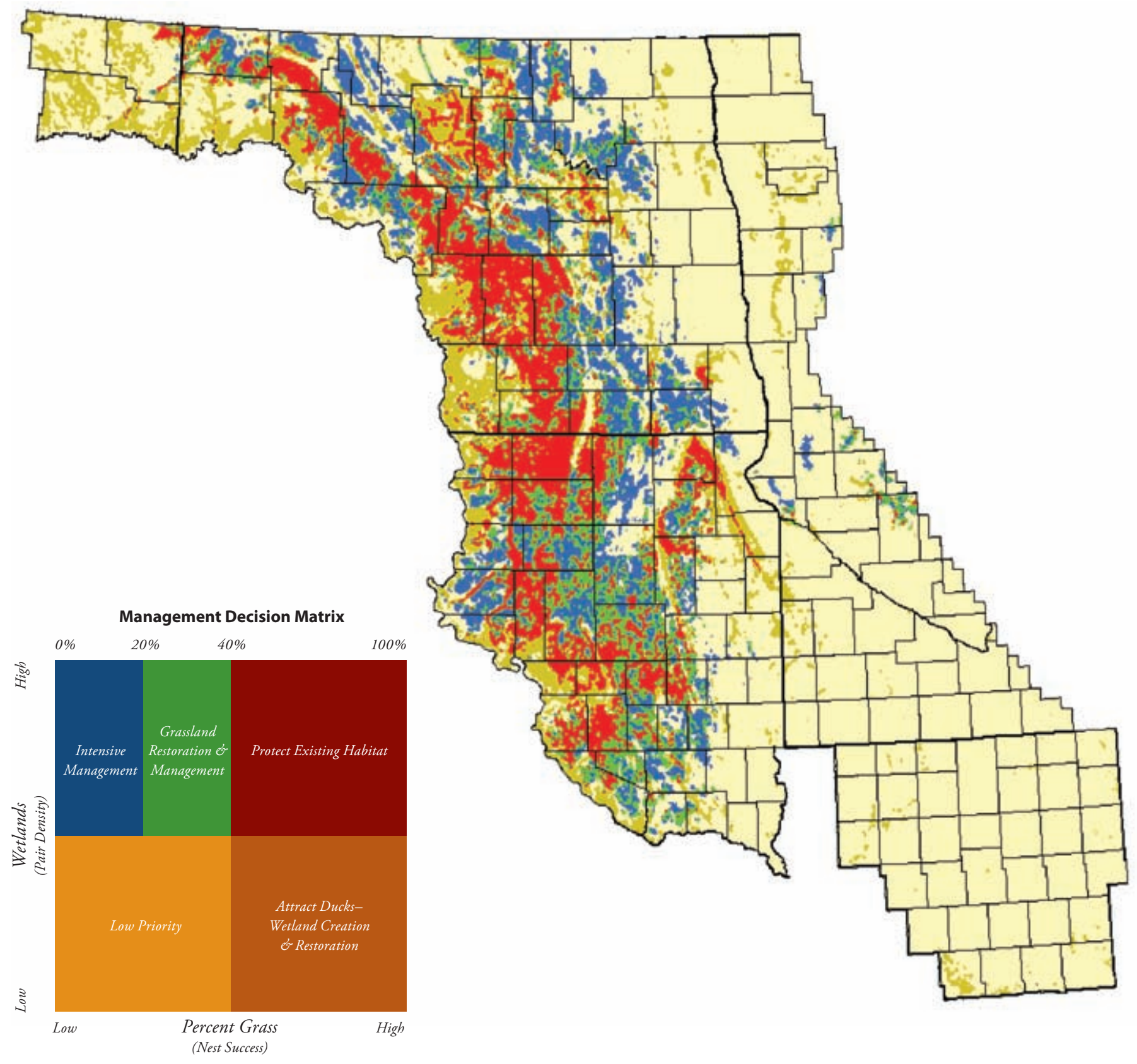

Data source: U.S. Fish and Wildlife Service/Ducks Unlimited, Inc.

Figure 5-22. Spatial planning tool for breeding waterfowl in the Prairie Pothole Region. 
144 Chapter 5: Breeding Waterfowl 
and the daily energy requirement of an individual shorebird, while food supplies are a product of habitat acres and the amount of food provided by each acre. Foraging habitat is assumed to be adequate when food supplies equal shorebird energy needs.

The food energy approach adopted for shorebirds in the 2006 Plan is based on the TRUEMET model. The model calculates population energy demand and population energy supplies for specific time periods, and can incorporate effects like flooding and de-watering (drawdown) schedules to account for temporal variation in habitat availability. The model was used to estimate shorebird habitat needs and to develop conservation objectives for wintering shorebirds for each Shorebird Planning Region. Additional information on the TRUEMET model is provided in Chapter 4.

\section{Biological Inputs Used in the TRUEMET Model}

Four categories of biological inputs were used in the TRUEMET model: (1) population objectives; (2) daily energy requirements; (3) habitat acreage; and (4) habitat foraging values. This section describes how these inputs were derived, and it details many of the assumptions made for wintering shorebirds in the 2006 Plan.

\section{Population Objectives}

Unlike waterfowl, no process of stepping down continental population goals for wintering shorebirds has been established under the U.S. Shorebird Conservation Plan. Instead, population objectives were developed from Central Valley-wide surveys of wintering shorebirds that were conducted between April and August 1992 to 1994 (Shuford et al. 1998).

Average shorebird counts between 1992 and 1994 were available for August, November, January, and April (Table 6-1). However, wintering shorebirds rely on Central Valley habitats from July through early May. In addition, shorebird survey results do not equate to population objectives because of missed birds and/or depressed shorebird numbers during the years that surveys were conducted. The JV's Shorebird Working Group adjusted survey results upward when establishing population objectives and developed objectives for months outside the survey periods, based on their understanding of shorebird migration. Shorebird population objectives by 15 -day intervals between July 1 and May 10 are presented for the entire Central Valley in Table 6-2. 


\section{Planning Regions}

Where possible, conservation objectives for bird groups included in the 2006 Plan were established at the basin scale. However, several basins were combined into two planning regions: (1) Sacramento Valley (SV) consisting of Colusa, Butte, American, and Sutter Basins; and (2) Delta, consisting of Yolo and Delta Basins. The Suisun Marsh was not included, as counts do not exist for this region. However, the Suisun Marsh does provide valuable habitat for wintering shorebirds, and the following conservation actions identified in the Southern Pacific Shorebird Conservation Plan may benefit this bird group: (1) incorporate shorebird habitat components in tidal marsh restorations; (2) increase tidal circulation and water quality in marshes to enhance invertebrate productivity and shorebird foraging areas; (3) manage vegetation in some ponds to provide expanses of open habitat; and (4) create one to six inch water depths in some ponds. (Hickey et al. 2003). The San Joaquin and Tulare Basins were maintained as separate planning regions (Figure 6-2). These planning regions reflect the scale at which shorebird population information is available.

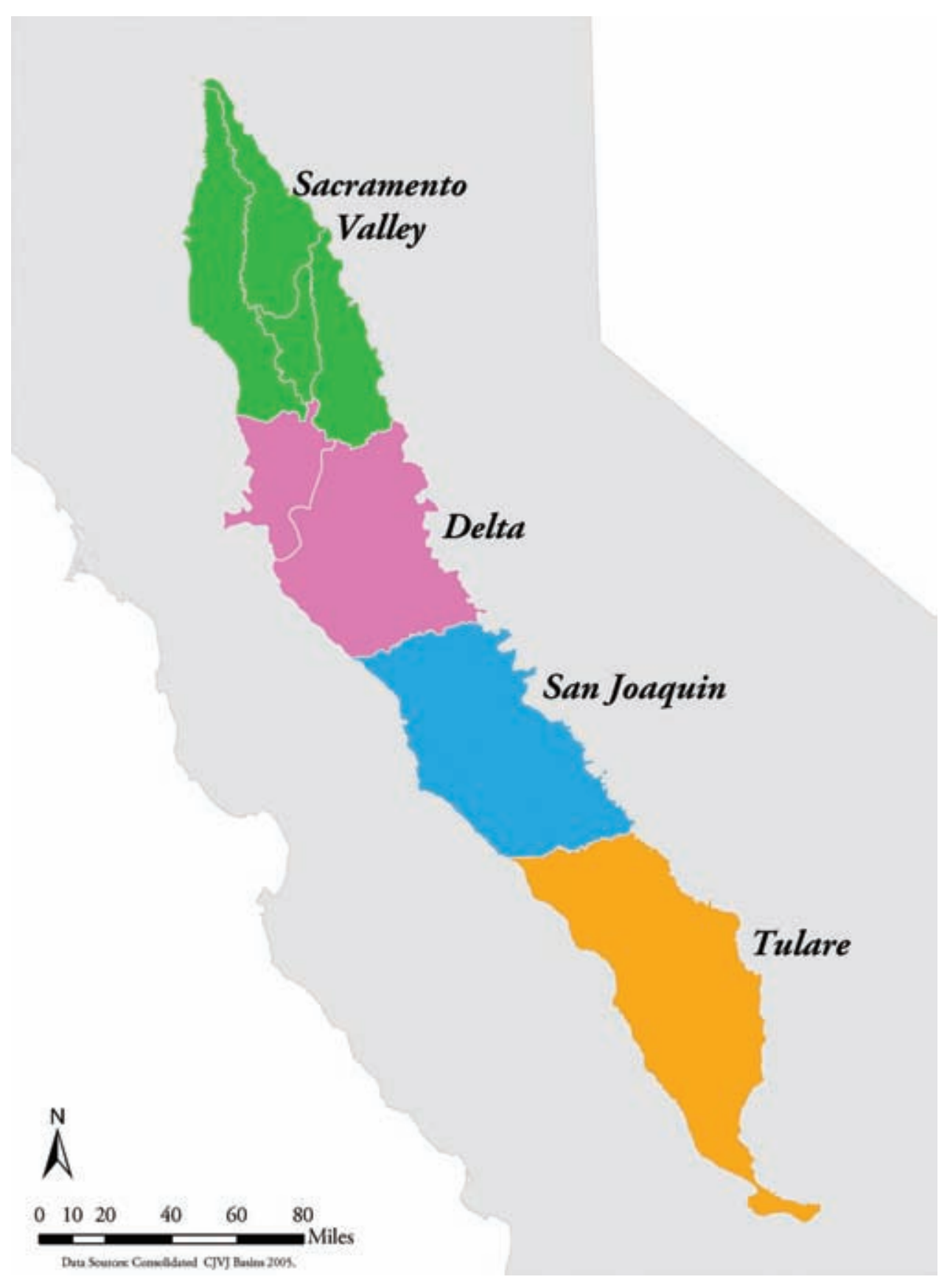

Figure 6-2. Planning regions for wintering shorebirds in the Central Valley. 
It was necessary to distribute shorebird population objectives for the entire Central Valley among the four planning regions in Figure 6-2. However, shorebird surveys conducted in August, November, January, and April 1992 to 1994 indicate that shorebird distribution in the Central Valley varies seasonally. For example, $50 \%$ of all shorebirds counted in August were observed in the Tulare Basin, while only $10 \%$ of all shorebirds were seen in Tulare Basin during January surveys (Table 6-3).
Table 6-3. Distribution of wintering shorebirds in the Central Valley by region and time period (from Shuford et al. 1998).

\begin{tabular}{|c|c|c|c|c|}
\hline Region & August $t^{a}$ & November ${ }^{a}$ & January ${ }^{a}$ & April ${ }^{a}$ \\
\hline SV Planning Region & 0.35 & 0.38 & 0.45 & 0.39 \\
\hline Delta Planning Region & 0.075 & 0.12 & 0.17 & 0.03 \\
\hline SAN JOAQUIN BASIN & 0.075 & 0.32 & 0.28 & 0.41 \\
\hline Tulare Basin & 0.50 & 0.18 & 0.10 & 0.17 \\
\hline
\end{tabular}

${ }^{a}$ Fraction of all shorebirds present in the Central Valley.

To develop population objectives for each of the four planning regions by 15-day periods, the JV assumed that shorebird surveys conducted in August, November, January, and April corresponded to 15-day intervals as follows: (1) shorebird surveys conducted in August correspond to the distribution of shorebirds between July 1 and October 31; (2) shorebird surveys conducted in November correspond to the distribution of shorebirds between November 1 and December 31; (3) shorebird surveys conducted in January correspond to the distribution of shorebirds between January 1 and March 31; and (4) shorebird surveys conducted in April correspond to the distribution of shorebirds between April 1 and May 12.

This information on temporal changes in shorebird distribution was combined with population objectives for the entire Central Valley to generate population objectives by 15 -day periods for each of the four planning regions. These population objectives are presented later when establishing conservation objectives for each region.

\section{Daily Energy Requirements for Individual Birds}

Shorebird energy needs are assumed to be dependant on body mass, and equations exist to calculate food energy needs using body mass estimates. Shorebird populations in the Central Valley include several species. Because species composition of these populations varies seasonally, a weighted body mass was calculated for each of the four survey periods (August, November, January, April 1992-1994; Table 6-4). These weighted body mass estimates were then applied to the appropriate 15-day period. The following equation was used to estimate the daily energy requirements (DER) of an individual shorebird in each 15 -day period (kj/day):

$\operatorname{DER}(\mathrm{kj})=912$ (Body Mass $(\mathrm{kg})) 0.704$ where kj's were converted to kcal's by dividing by 4.18. Finally, the DER estimated for shorebirds from this equation was increased by $33 \%$ for all 15 -day intervals between March 1 and May 12 to account for increased energy needs associated with fat deposition prior to spring migration.

Table 6-4. Weighted body mass for shorebirds in the Central Valley in each of the four survey periods.

\begin{tabular}{|cc|} 
SurveyPeriod & Weighted Body Mass $(g)$ \\
\hline AUGUST & 126 \\
NOVEMBER & 102 \\
JANUARY & 96 \\
APRIL & 82 \\
\hline
\end{tabular}

Table 6-5. Acres of managed wetlands and intentionally flooded rice in the Central Valley.

\begin{tabular}{|cc|}
\hline Habitat Type & Acres \\
\hline SeAsonal WetLAND & 179,232 \\
SeMi-PERMANENT WetLAND & 26,322 \\
\hline FloOded Rice & 354,633 \\
\hline
\end{tabular}

Shorebirds in the Central Valley currently rely on a variety of habitats to meet their food energy needs, including evaporation and sewage ponds (Shuford et al. 1998). However, the use of evaporation and sewage ponds may expose shorebirds to concentrated contaminants like selenium, or increase the probability of disease transmission (Hickey et al. 2003). As a result, only "desirable" habitat types were considered in the 2006 Plan when establishing habitat objectives for shorebirds. These include: (1) managed seasonal wetlands; (2) managed semipermanent wetlands; and (3) harvested rice fields that are intentionally flooded to provide wildlife benefits and/or promote straw decomposition.

Table 6-5 provides a summary of wetland and agricultural habitats in the Central Valley (information on how these estimates were derived was presented in Chapter 3). Foraging ecology studies indicate that shorebirds require water depths $<10 \mathrm{~cm}(-4$ inches) deep (Safran et al. 1997). However, wetland and agricultural habitat estimates for the Central Valley are not stratified by depth. Consequently, Table 6-5 only represents the amount of habitat that is potentially available to shorebirds if all these acres were managed at depths $<10 \mathrm{~cm}$. In reality, only a small fraction of these acres may meet these depth requirements, as management efforts 
for waterfowl usually result in depths greater than $10 \mathrm{~cm}$. Within the 2006 Plan, habitat objectives for wintering shorebirds assume that $100 \%$ of these habitats are maintained $<10 \mathrm{~cm}$ deep.

Comparing shorebird habitat objectives to estimates of existing wetland and agricultural acres may provide some insight into whether shorebird needs are being met. For example, shorebird food needs are more likely to be met where shorebird habitat objectives are small compared to the acres of existing wetland or rice habitat. This issue is explored further in this chapter when assessing current conditions for wintering shorebirds throughout the Central Valley.

In addition to water depth, temporal variation in habitat availability can strongly influence available food supplies. To better understand the availability of shorebird foraging habitat. Flooding and drawdown schedules were developed for public and privately managed wetlands in the Central Valley (Figure 6-3), as well as for flooding of rice habitat during the post harvest season (Figure 6-4). Flooding and drawdown schedules were also developed for each of the four shorebird planning regions.

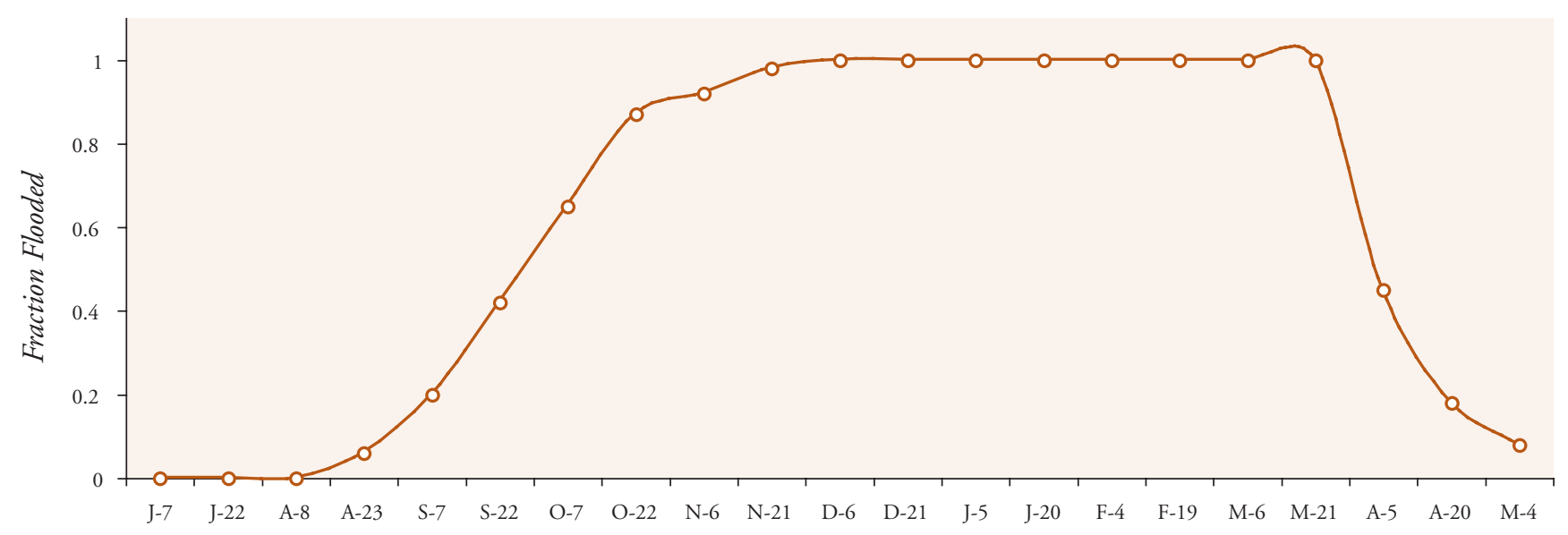

Figure 6-3. Flooding and draw down schedules for managed seasonal wetlands in the Central Valley (private and public wetlands combined).

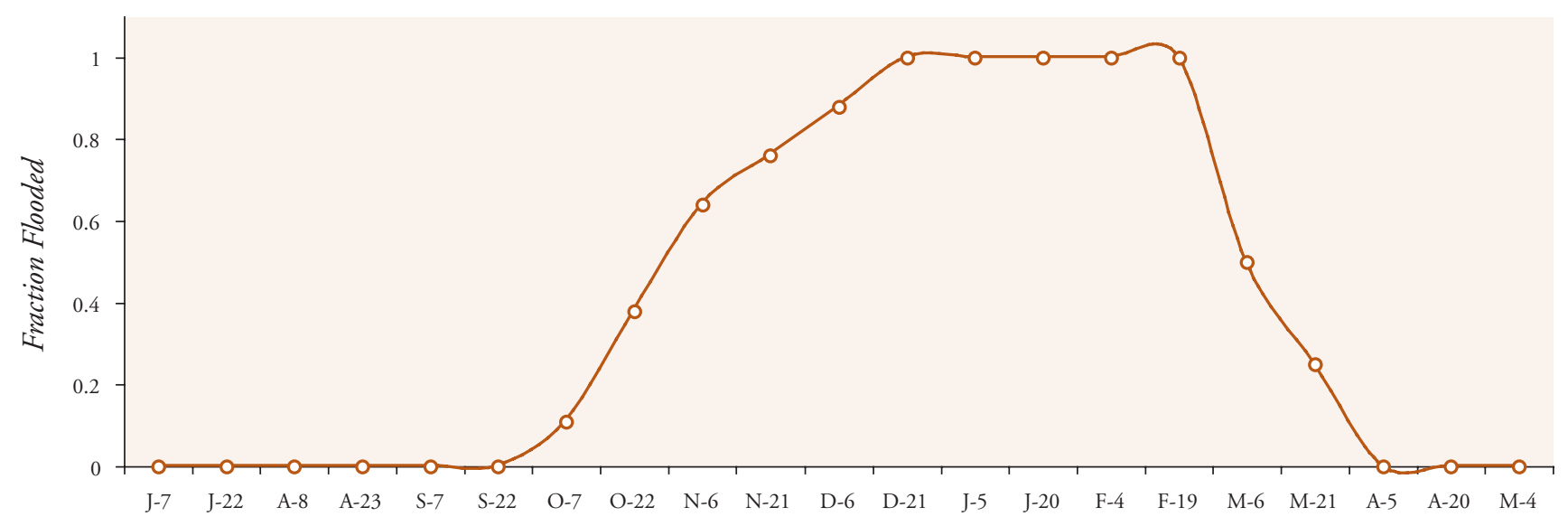

Figure 6-4. Flooding and draw down schedules for winter flooded rice in the Central Valley.

\section{Habitat Foraging Values}

The food energy approach used to estimate shorebird habitat needs in the 2006 Plan requires estimates of invertebrate biomass on a per area basis (e.g., lbs. per acre). Although numerous studies have characterized invertebrate communities in Central Valley wetlands and flooded rice fields, no estimates of invertebrate biomass exist for these habitats. Shorebird habitat in the Mississippi Alluvial Valley (MAV) is assumed to provide $20 \mathrm{~kg} / \mathrm{ha} \mathrm{(}-18 \mathrm{lbs}$./acre) of invertebrate biomass (Loesch et al. 2000). This estimate was adopted for planning purposes in the Central Valley, and was applied to managed wetlands and to rice fields that are winter flooded. 
Using measures of invertebrate biomass from outside the Central Valley adds another level of uncertainty to the JVs estimates of shorebird habitat needs. The assumption that managed wetlands and rice habitat provide $20 \mathrm{~kg} / \mathrm{ha}$ of invertebrate biomass also assumes that invertebrate food resources are non-renewable in response to shorebird foraging. In reality, invertebrate biomass is likely influenced by seasonal changes in invertebrate growth rates, reproduction, and the effects of shorebird foraging. For example, invertebrate biomass may increase through time, though this increase may be partially constrained by the effects of shorebird foraging. Assuming a static value of $20 \mathrm{~kg} /$ ha does not reflect the complexity of invertebrate food resources. Therefore, future efforts to understand temporal changes in invertebrate biomass would add greatly to the JV's understanding of shorebird habitat needs.

\section{Overall Assessment of Current Habitat Conditions in the Central Valley}

Habitat conditions for wintering shorebirds were first evaluated for the entire Central Valley. Flooding schedules and flooding depths strongly influence shorebird food supplies, and the JV began its assessment of habitat conditions by comparing shorebird population objectives and water management practices in key habitats.

\section{Seasonal Wetlands}

Figure 6-5 depicts the relationship between overall shorebird population objectives for the Central Valley, and the availability of managed seasonal wetlands. Although significant numbers of shorebirds are present in July and early August, flooding of seasonal wetlands does not begin until mid-August. Flooding of seasonal wetlands is complete by late November, with water maintained in these habitats generally through the end of March. Shorebird populations are highest in March and April, when most seasonal wetlands are being drawn down (Figure 6-6). Although peak populations of shorebirds correspond to drawdown of seasonal wetlands in March and April, these drawdowns may result in increased foraging habitat. Drawdowns typically increase the area of shallow water habitat available to shorebirds, at least in the short term. Drawdowns of seasonal wetlands in spring (e.g., April) in the Grasslands did not result in higher shorebird use of these habitats (Taft et al. 2002). However, drawdown of seasonal wetlands in winter (e.g., December) resulted in significant increases in shorebird use (Taft et al. 2002). The lack of shorebird response to spring drawdowns may reflect an overall abundance of shallow water habitat, as seasonal wetlands are being dewatered throughout the Central Valley. In contrast, shorebird response to experimental winter drawdowns indicates that shallow water habitat is limited during this period because most seasonal wetlands are fully flooded (Taft et al. 2002).

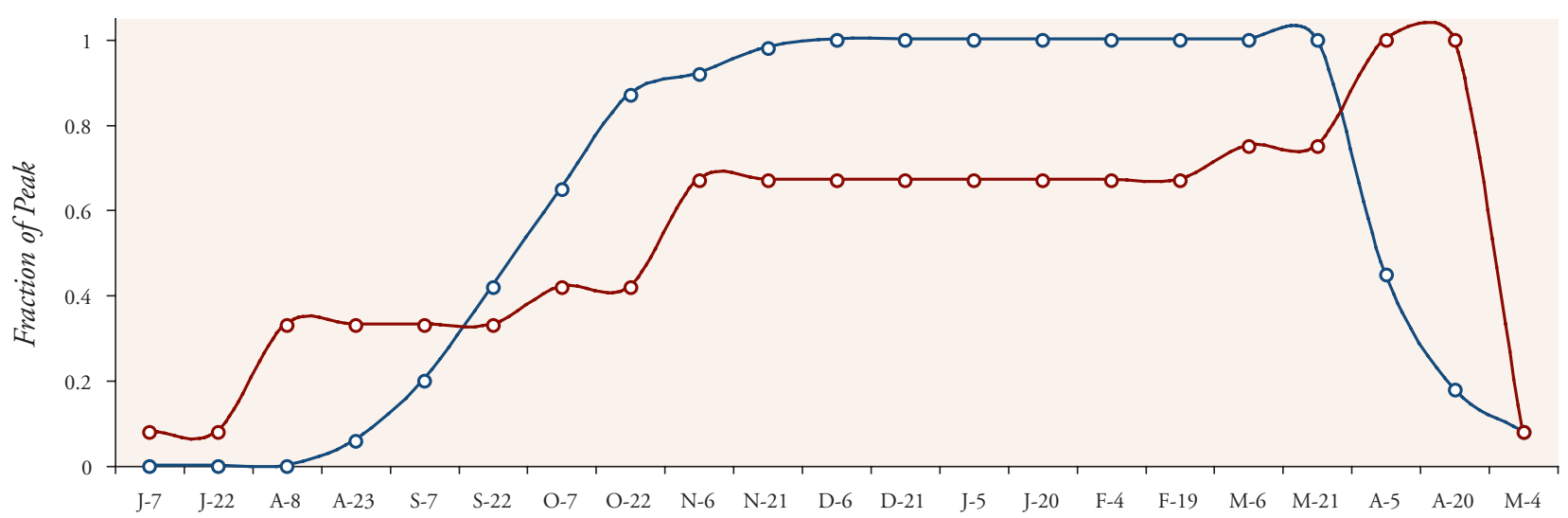

Figure 6-5. Shorebird population objectives (red) vs. flooding schedules for managed seasonal wetlands (blue) for the Central Valley. Shorebird population objectives are expressed as the fraction of peak population; wetlands are expressed as the fraction of seasonal wetlands that are flooded.

\section{Semi-Permanent Wetlands}

Although most wetlands in the Central Valley are managed on a seasonal basis, over 26,000 acres of semi-permanent wetlands also exist (Table 6-5). Semi-permanent wetlands are typically flooded in early fall, with drawdowns occurring during the first half of July. Although semi-permanent wetlands may provide little shorebird habitat for much of the year because of deep flooding, these habitats may be critical to shorebirds during July. Drawdown of semi-permanent wetlands in July could provide shallow water habitat that helps meet shorebird needs at a time when few alternative habitats exist.

150 Chapter 6: Wintering Shorebirds 


\section{Winter Flooded Rice}

Figure 6-6 depicts the relationship between shorebird population objectives and the availability of winter flooded rice fields. Flooding schedules for harvest rice indicate that this habitat provides few shorebird food resources prior to mid-October. Winter flooding of rice fields peaks in mid-winter with most fields drained by late March or early April (Figure 6-7). Mean water depths in flooded rice fields range between 15-20 cm from November through January, but decline thereafter to less than $10 \mathrm{~cm}$ in February and March (Elphick 1998). Although winter flooded rice fields provide little shorebird habitat during peak populations in April, declining water depths from January to March may provide an abundance of foraging habitat during the late winter period (Shuford et al. 1998).

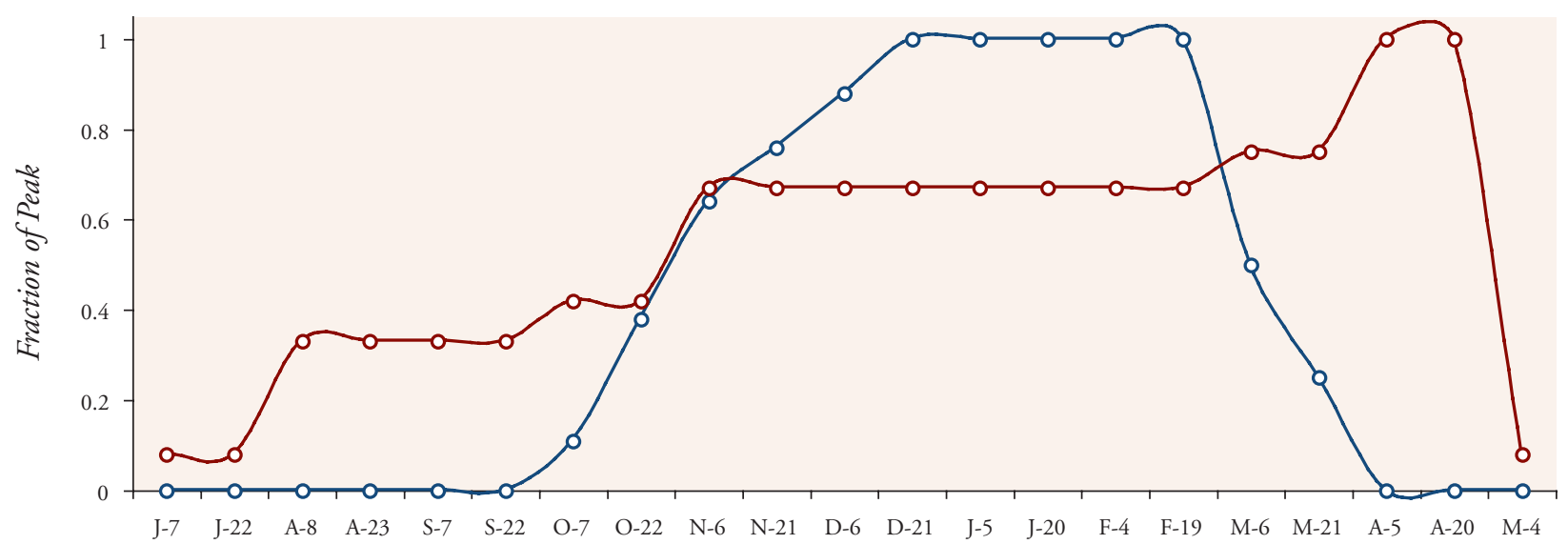

Figure 6-6. Shorebird population objectives for the Central Valley (red) vs. flooding schedules for winter flooded rice (blue).

In general, flooding schedules for managed wetlands and for winter flooded rice are more consistent with the needs of waterfowl than shorebirds in the Central Valley. Migration chronology of wintering waterfowl in the Central Valley corresponds well with flooding schedules for seasonal wetlands and with the availability of winter flooded rice (Figure 6-7). In contrast, shorebirds occur in significant numbers during July and August when important wetland and agricultural habitats have yet to be flooded.

Although shorebird planning efforts in the Central Valley benefit from reliable estimates of habitat acres and flooding schedules, no effort was made to evaluate the current relationship between food energy needs and food energy supplies using TRUEMET, as was done for wintering waterfowl. This supply-demand analysis would be meaningless without a better understanding of how habitats are stratified by foraging depth. To provide some insight into current habitat conditions, the JV determined the fraction of existing wetland and agricultural resources that must be $<10 \mathrm{~cm}$ deep to meet shorebird needs. This measure is called the required depth ratio and is described later in Chapter 6.

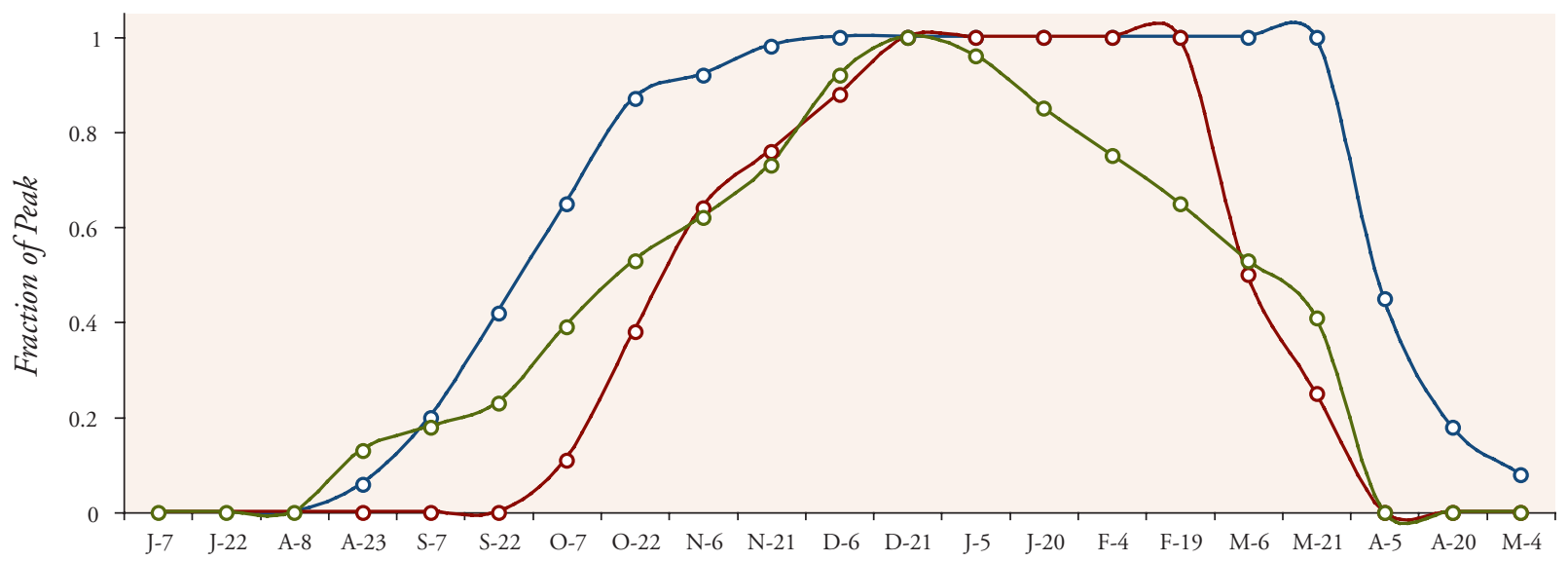

Figure 6-7. Shorebird population objectives (red) vs. flooding schedules for managed seasonal wetlands (blue) and rice (green). Shorebird population objectives are expressed as the fraction of peak population; wetlands and rice are expressed as the fraction of these habitats that are flooded. 


\section{Methods for Establishing Conservation Objectives for Wintering Shorebirds}

The JV's assessment of habitat conditions in the Central Valley suggests that shorebird needs may be met by: (1) managing wetlands and agricultural habitats to provide foraging depths $<10 \mathrm{~cm}$; and (2) adjusting flooding and draw down schedules of wetlands to meet the needs of wintering shorebirds, especially during July and August. These conclusions are important because they provide the types of conservation objectives that should be established for shorebirds in each of the four planning regions.

Three conservation objectives were identified for wintering shorebirds: 1) Management of existing seasonal and semi-permanent wetlands to provide foraging depths $<10 \mathrm{~cm}$. This includes changes in traditional flooding schedules. Existing wetlands are defined as wetlands that may be restored to meet habitat objectives for non-breeding waterfowl; 2) Securing additional water supplies that may be needed for changes in seasonal wetland flooding schedules; and 3) Management of agricultural habitats to provide foraging depths $<10 \mathrm{~cm}$.

Prior to the 2006 Plan, the JV Technical Committee imposed a constraint that at least 50\% of shorebird energy needs must be met from wetlands in each planning region. This decision was made because changing agricultural markets are beyond the control of the $\mathrm{JV}$, and seeking a balance between agricultural and wetland habitat is warranted. However, Central Valley agriculture provides little or no shorebird benefits prior to early October (Figure 6-6). Drawdown of winter flooded rice fields in March also requires shorebirds to rely exclusively on wetland habitats during April and early May. As a result, the wetland constraint was modified so that wetlands are required to meet $100 \%$ of shorebird needs in all 15-day intervals between July 1 and October 1 , and all 15 -day intervals between March 30 and May 10.

The same approach was used to establish conservation objectives for shorebirds in each planning region. Shorebird population objectives between July and May were first compared to seasonal changes in habitat availability. Seasonal changes in shorebird foraging habitat are largely dependent on water management practices in wetlands and winter flooded agricultural lands. Understanding how these practices meet or do not meet shorebird needs is essential to developing effective conservation objectives for this bird group.

Next, shorebird food energy needs in each 15-day interval were estimated using the TRUEMET model. Food energy needs were a function of population objectives for that 15-day interval, and the daily energy requirement of a single bird. TRUEMET was then used to convert these food energy needs into an equivalent amount of foraging habitat for each 15 -day interval. This overall foraging habitat need was then stepped down to the appropriate conservation objective(s). The methods for establishing shorebird conservation objectives are described below.

\section{Management of Existing Seasonal and Semi-permanent Wetlands}

To determine how much seasonal and semi-permanent wetland habitat must be managed at depths $<10 \mathrm{~cm}$ in depth, the JV recognized four distinct flooding periods; summer, fall, spring, and winter. Conservation objectives for these managed wetlands were broken down by flooding period because water management practices within these flooding periods differ. These differences are likely to influence the availability of habitat $<10 \mathrm{~cm}$ in depth. The four flooding periods are described as follows:

\section{Description of Flooding Periods}

\section{Summer Flooding Period (July 1-August 16)}

Historically, snow runoff provided huge lacustrine wetlands in the Tulare Basin, and evaporation of wetlands in the Delta Planning Region and the Butte Sink and Colusa Trough areas of the Sacramento Valley Planning Region provided shorebird habitat during July and August. Today, this period is characterized by an absence of seasonal wetlands, as flooding of these habitats does not begin until after mid-August. Semi-permanent wetlands are typically drawn down during July, with most assumed to be dry by mid-July. However, some wetlands may contain water through July if drawdowns are delayed until mid-month. Semi-permanent wetlands can provide shorebird habitat during these July drawdowns because water depths decline at this time. The JV assumes that semipermanent wetlands provide no shorebird habitat outside of this July drawdown period, as water depths generally exceed $10 \mathrm{~cm}$. 


\section{Fall Flooding Period (August 17-November 29)}

Historically, this was the driest period in the Central Valley, resulting in fewer wetlands available to shorebirds. Exposure of shallow habitats would have occurred in Tulare Basin, and flooding of seasonal wetlands could have occurred in October and November. This period is characterized by flooding of seasonal wetlands. Beginning in mid-August, seasonal wetlands on public and private wetlands are flooded throughout the Central Valley. This flooding is mostly complete by late November, though there is some variation among shorebird planning regions. The availability of shorebird habitat during this period is likely characterized by large temporal and spatial variation. For example, water depths $<10 \mathrm{~cm}$ may be abundant during the initial phases of flooding. This would be true for both individual wetlands, and for the entire shorebird-planning region. As fall progresses and many of these seasonal wetlands are fully flooded, the availability of foraging habitat $<10 \mathrm{~cm}$ deep may decline.

Although the JV assumes that seasonal wetlands provide $20 \mathrm{~kg} /$ ha of invertebrates, it is unclear how invertebrate availability changes through the Fall Flooding Period. For example, there may be a significant lag between when water is applied to seasonal wetlands and when invertebrate populations reach levels that are beneficial to shorebirds. Future efforts to understand how invertebrate communities and biomass change, relative to the date of flooding, will help refine the JV's estimates of shorebird needs during the Fall Flooding Period.

\section{Winter Flooding Period (November 30-March 29)}

Historically, this period would have provided the greatest abundance of shallow habitat throughout the Central Valley. Today, this period is characterized by maximum availability of seasonal wetlands as most habitats are flooded by mid-November with water levels maintained through late March (Figure 6-3). Although water levels fluctuate during this period, the temporal and spatial variation in water levels that characterized the Fall Flooding Period may be diminished. Shorebirds during the Winter Flooding Period period may face a more stable wetland environment, as changing water levels are less likely compared to the Fall Flooding Period. However, this may ultimately result in fewer acres flooded to $<10 \mathrm{~cm}$ in depth, especially during the early portion of this period.

\section{Spring Flooding Period (April 1-May 12)}

Historically, many floodplain wetlands would be drying during this period. Today, this period is characterized by the drawdown of seasonal wetlands (Figure 6-3). These drawdowns likely increase the area of shallow water habitat for shorebirds, especially if most seasonal wetlands were managed at depths greater than $10 \mathrm{~cm}$. Many of the public and private seasonal wetlands are managed for April and early May drawdowns to maximize moist soil plant germination.

\section{Hypothetical Shorebird Planning Region}

The method for determining how much seasonal and semi-permanent wetland habitat must be managed at depths $<10$ $\mathrm{cm}$ is described using a hypothetical shorebird-planning region. Habitat resources and water management schedules for this planning region are presented in Table 6-6, while shorebird foraging habitat needs are presented for each 15-day interval in Table 6-7.
Table 6-6. Habitat resources and associated flooding schedules for a hypothetical shorebird planning region.

\begin{tabular}{|c|c|c|c|}
\hline Interval & $\begin{array}{c}\text { Seasonal } \\
\text { Wetlands (Acres) }\end{array}$ & $\begin{array}{c}\text { Semi-Perm. } \\
\text { Wetlands (Acres) }\end{array}$ & $\begin{array}{c}\text { Winter Flooded } \\
\text { Rice (Acres) }\end{array}$ \\
\hline J-7 (JuLY 1-July 15) & 0 & 2000 & 0 \\
\hline J-22 (July 16-JuLY 31) & 0 & 0 & 0 \\
\hline A-8 (Aug 1-Aug 16) & 0 & 0 & 0 \\
\hline A-23 (Aug 17-Aug 23) & 600 & 0 & 0 \\
\hline S-7 (SEPT 1-SEPT 15) & 2,000 & 120 & 0 \\
\hline S-22 (SEPT 16-SEPt 30) & 4,200 & 400 & 0 \\
\hline O-7 (Ост 1-Ост 15) & 6,500 & 840 & 2,200 \\
\hline O-22 (ОСт 16-Ост 30) & 8,700 & 1,300 & 7,600 \\
\hline N-6 (Oct 31-Nov 14) & 9,200 & 1,740 & 12,800 \\
\hline N-21 (Nov 15-Nov 29) & 10,000 & 1,840 & 15,200 \\
\hline D-6 (Nov 30-Dec 14) & 10,000 & 2,000 & 17,600 \\
\hline D-21 (DEC 15-Dec 29) & 10,000 & 2,000 & 20,000 \\
\hline J-5 (DEC 30-JAN 13) & 10,000 & 2,000 & 20,000 \\
\hline J-20 (JAN 14-JAN 28) & 10,000 & 2,000 & 20,000 \\
\hline F-4 (JAN 29-FeB 12) & 10,000 & 2,000 & 20,000 \\
\hline F-19 (FeB 13-Feb 27) & 10,000 & 2,000 & 20,000 \\
\hline M-6 (FEB 28-MAR 14) & 10,000 & 2,000 & 10,000 \\
\hline M-21 (MAR 15-MAR 29) & 10,000 & 2,000 & 5,000 \\
\hline A-5 (MAR 30-APR 13) & 10,000 & 2,000 & 0 \\
\hline A-20 (APR 14-APR 28) & 3,150 & 2,000 & 0 \\
\hline M-4 (APR 29-MAY 10) & 1,300 & 2,000 & 0 \\
\hline
\end{tabular}




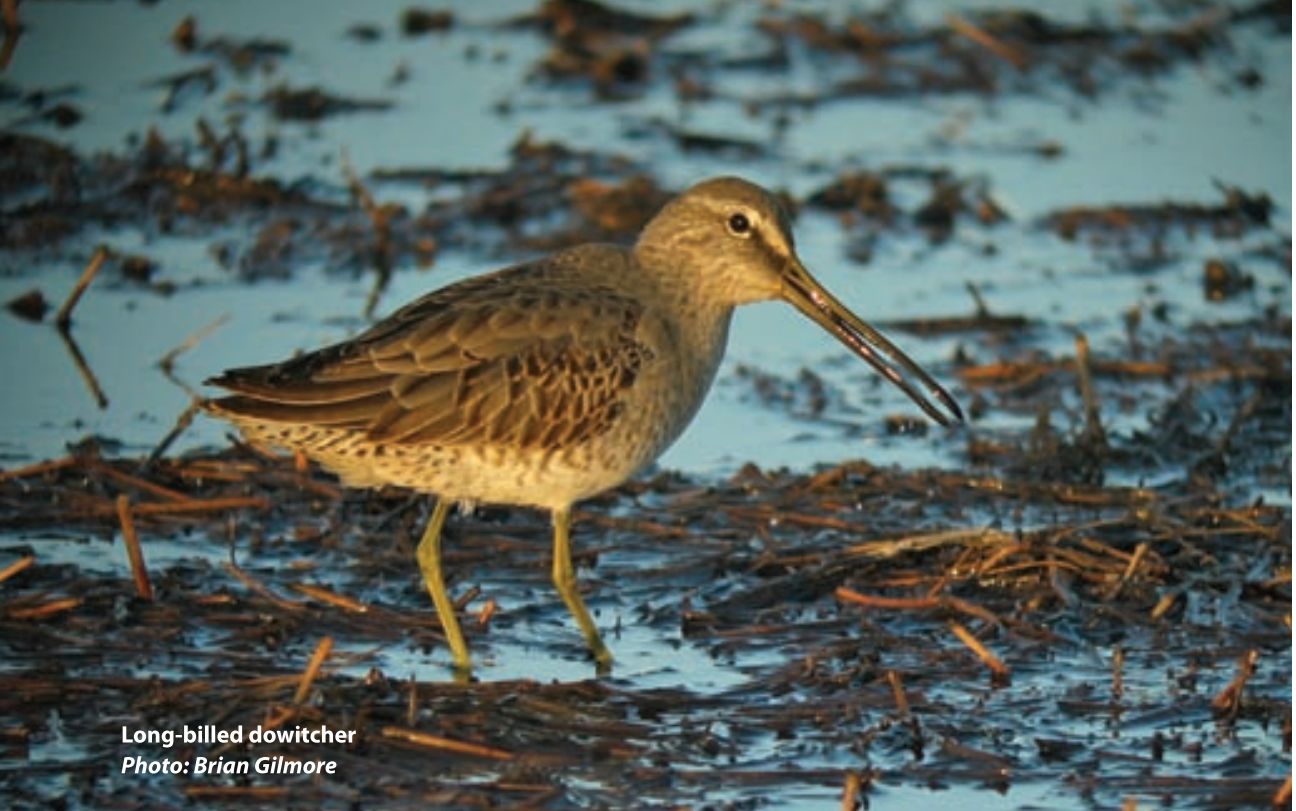

To provide some insight into whether wetlands currently satisfy shorebird energy requirements, the JV estimated a "required depth ratio" for all time intervals in all flooding periods. This ratio reflects the fraction of existing seasonal or semi-permanent wetlands that must be $<10 \mathrm{~cm}$ in depth to meet shorebird needs. These depth ratios may provide some basis for future monitoring and evaluation. For example, water depths periodically measured in seasonal wetlands can be compared to these depth ratios to determine if adequate shallow water habitat is being provided.

\section{Summer Flooding Period for the Hypothetical Planning Region}

Shorebirds require 100 acres of wetland habitat $<10 \mathrm{~cm}$ deep in both the July 7 and July 22 intervals, with habitat needs increasing to 150 acres during the August 8 interval (Table 6-7). All habitat requirements during the Summer Flooding Period must be met from managed wetlands, as no winter flooded rice is available.

Providing 100 acres of shallowly flooded habitat would meet shorebird needs in the July 7 interval. However, simply maintaining the same 100 acres would not meet shorebirds needs in the July 22 interval, because food resources in these 100 acres are depleted by July 15 (the 2006 Plan assumes that invertebrate populations are not self-renewing). Meeting shorebird needs for the entire month of July requires that 100 acres of wetlands be provided on July 1, with an additional 100 acres to be provided on or before July 16. In theory, the 100 acres of wetland habitat needed in the July 22 interval can be provided at any date between July 1 and July 16. For example, 200 acres flooded on July 1 would meet shorebird needs for the entire month.

Semi-permanent wetlands may provide the best opportunity to meet shorebird needs during July. Most semi-permanent wetlands are drawn down during the first part of July, which may result in significant habitat $<10 \mathrm{~cm}$ deep. The planning region contains 2,000 acres of semi-permanent wetlands (Table 6-6). If all wetlands are drawn down by mid-July, the required depth ratio for these semi-permanent habitats is $5 \%$ (i.e., 100 of the 2,000 acres must provide water depths $<10 \mathrm{~cm}$ ). If all 2,000 acres of semi-permanent wetlands are dry by mid-July, no opportunity exists to meet shorebird needs in the July 22 interval using these wetlands. Seasonal wetlands could be flooded to meet habitat needs during the second half of July. However, it may be better to delay the drawdown of some semi-permanent wetlands to meet shorebird needs in the July 22 interval.

Although habitat needs of shorebirds in the July 22 interval may be met through delayed drawdown of semi-permanent wetlands, it is assumed that habitat needs in the August 8 interval $(150$ acres) must be met by flooding seasonal wetlands. Flooding of seasonal wetlands in this hypothetical shorebird region has not occurred prior to mid-August; so providing 150 acres of seasonal wetlands in the August 8 interval represents a management effort directed solely at shorebird needs. However, this involves early flooding of only $1.5 \%$ of the existing seasonal wetland base $(150 / 10,000)$. 


\section{Fall Flooding Period for the Hypothetical Planning Region}

Habitat needs for shorebirds in the Fall Flooding Period (August 17-November 29) range from 300 acres in August and September, to 600 acres for the November 21 interval (Table 6-7). Although this hypothetical shorebird region contains 20,000 acres of winter flooded rice, none of this agricultural habitat is available prior to the October 7 interval (October 1-15). As a result, shorebird needs must be met entirely from seasonal wetland habitats in the August and September intervals.

Seasonal wetland habitat objectives for shorebirds in the Fall Flooding Period are provided in Table 6-8. Seasonal wetland objectives prior to October are equivalent to the overall habitat needs of shorebirds, as most winter flooding of rice has yet to begin. Beginning in October, seasonal wetland objectives decline to $50 \%$ of overall habitat needs (Table 6-7), as rice becomes available and is assumed to meet half of shorebird energy requirements.

Although the summed seasonal wetland objective of 2,000 acres is staggered over seven 15-day intervals, it is possible to meet this overall habitat objective in a shorter period of time. For example, seasonal wetland objectives for shorebirds could be met in the Fall Flooding Period by providing 2,000 acres during the August 23 interval and maintaining these acres at a depth $<10 \mathrm{~cm}$ through the end of November (Figure 6-8).

Seasonal wetlands become increasingly available from August through November, as these habitats are flooded prior to the hunting season. This increase in seasonal wetlands is reflected in the required depth ratio of shorebird habitat. Two thirds of all seasonal wetland acres that are flooded by the August 23 interval must be $<10$ $\mathrm{cm}$ deep if shorebird habitat needs are to be met in this 15-day interval. However, the depth ratio declines in later intervals as seasonal wetlands become increasingly abundant and fewer of these acres must be $<10 \mathrm{~cm}$ to meet shorebird needs (Figure 6-9). The required depth ratio for
Table 6-8. Seasonal wetland objectives (acres) for shorebirds in the Fall Flooding Period of a hypothetical planning region.

\begin{tabular}{|ccccc|} 
Interval & $\begin{array}{c}\text { SW Interval } \\
\text { Objective }\end{array}$ & $\begin{array}{c}\text { Cumulative }^{a} \\
\text { SW Objective }\end{array}$ & $\begin{array}{c}\text { Flooded }^{b} \\
\text { SWs }\end{array}$ & $\begin{array}{c}\text { Required Depth }^{c} \\
\text { Ratio (\%) }^{\text {Sh }}\end{array}$ \\
\hline A-23 (AUG 17-AUg 23) & 300 & 450 & 600 & 67 \\
S-7 (SEPT 1-SEPT 15) & 300 & 750 & 2,000 & 38 \\
S-22 (SEPT 16-SEPT 30) & 300 & 1,050 & 4,200 & 25 \\
O-7 (OCT 1-OCT 15) & 250 & 1,300 & 6,500 & 20 \\
O-22 (OCT 16-OCT 30) & 250 & 1,550 & 8,700 & 18 \\
N-6 (OCT 31-Nov 14) & 300 & 1,850 & 9,200 & 20 \\
N-21 (Nov 15-Nov 29) & 300 & 2,150 & 10,000 & 22 \\
TotAL & 2,000 & 2,150 & & \\
\hline
\end{tabular}

SW-Seasonal Wetland.

"Includes SW objectives from previous flooding periods.

${ }^{b}$ Flooded SWs reflect flooding schedules within a shorebird planning region.

${ }^{c}$ Cumulative SW Objective/Flooded SWs.

Table 6-9. Seasonal wetland objectives (acres) for shorebirds in the Winter Flooding Period of a hypothetical planning region.

\begin{tabular}{|ccccc|}
\hline Interval & $\begin{array}{c}\text { SW Interval } \\
\text { Objective }\end{array}$ & $\begin{array}{c}\text { Cumulative }^{a} \\
\text { SW Objective }^{\text {Flooded }}\end{array}$ & $\begin{array}{c}\text { SWs }^{b} \\
\text { D-6 (Nov 30-DEC 14) }\end{array}$ & $\begin{array}{c}\text { Required Depth }^{c} \\
\text { Ratio (\%) }^{c}\end{array}$ \\
\hline D-21 (DEC 15-DEC 29) & 50 & 2,200 & 10,000 & 22 \\
J-5 (DEC 30-JAN 13) & 50 & 2,300 & 10,000 & 23 \\
J-20 (JAN 14-JAN28) & 50 & 2,350 & 10,000 & 24 \\
F-4 (JAN 29-FEB 12) & 100 & 2,400 & 10,000 & 24 \\
F-19 (FEB 13-FEB 27) & 100 & 2,500 & 10,000 & 25 \\
M-6 (FEB 28-MAR 14) & 100 & 2,700 & 10,000 & 26 \\
M-21 (MAR 15-MAR 29) & 100 & 2,800 & 10,000 & 27 \\
TotAL & 600 & 2,800 & & 28 \\
\hline
\end{tabular}

SW-Seasonal Wetland.

"Includes SW objectives from previous flooding periods.

${ }^{b}$ Flooded SWs reflect flooding schedules within a shorebird planning region.

${ }^{c}$ Cumulative SW Objective/Flooded SWs.

intervals in the Fall Flooding Period is calculated as the cumulative objective for seasonal wetlands, divided by the acres of seasonal wetlands that are flooded. The cumulative seasonal wetland objective includes any objectives from previous flooding periods. In Table 6-8, 4,200 acres of seasonal wetlands are flooded by the September 22 interval. Twenty five percent of these acres must have provided water depths $<10 \mathrm{~cm}$ through this interval. This is equivalent to about 1,050 acres of shallow water habitat. Note that this 1050 -acre objective must be appropriately staggered between the August 23 and September 22 intervals if shorebirds needs are to be met for all intervals (i.e., the required depth ratios must be met for the earlier intervals as well). 


\section{Winter Flooding Period for the Hypothetical Planning Region}

Overall habitat needs for shorebirds in the Winter Flooding Period (November 30-March 29) range from 100 acres in December and January, to 200 acres in February and March (Table 6-7). Seasonal wetland objectives for shorebird populations in the Winter Flooding Period are provided in Table 6-9. These wetland objectives are equivalent to $50 \%$ of the interval habitat needs, as winter flooded rice is assumed to meet half of all shorebird energy requirements. Seasonal wetland objectives are also summed from one interval to the next to provide a total seasonal wetland objective between December and March. Although the summed seasonal wetland objective is staggered over several 15-day intervals, it is possible to front-end this overall habitat objective. For example, seasonal wetland objectives for shorebirds could be met in the Winter Flooding Period by providing 600 acres during the December 6 interval and maintaining these acres at a depth $<10 \mathrm{~cm}$ through the end of March (Figure 6-10).

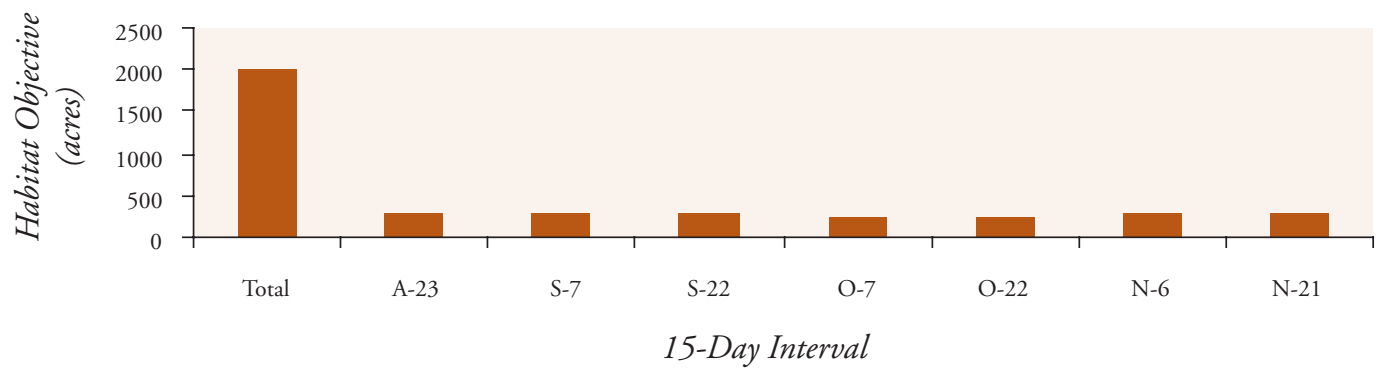

Figure 6-8. Seasonal wetland objectives for shorebirds in the Fall Flooding Period by 15 -day intervals for a hypothetical planning region.

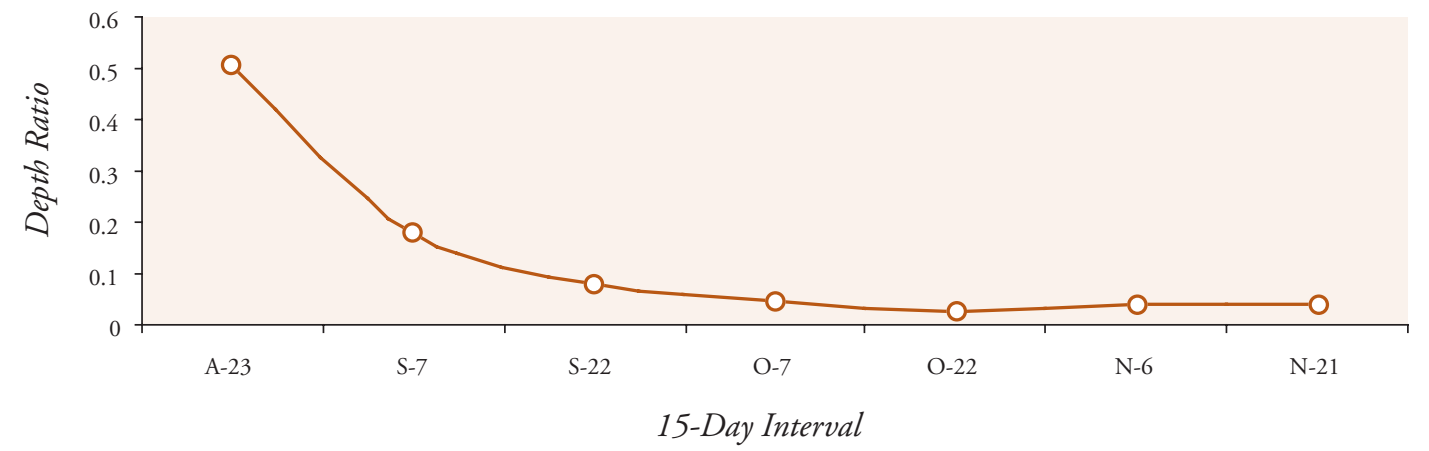

Figure 6-9. Changes in the depth ratio for shorebirds in the Fall Flooding Period. The fraction of potential shorebird habitat (seasonal wetlands) that must be $<10 \mathrm{~cm}$ deep declines from August through November.

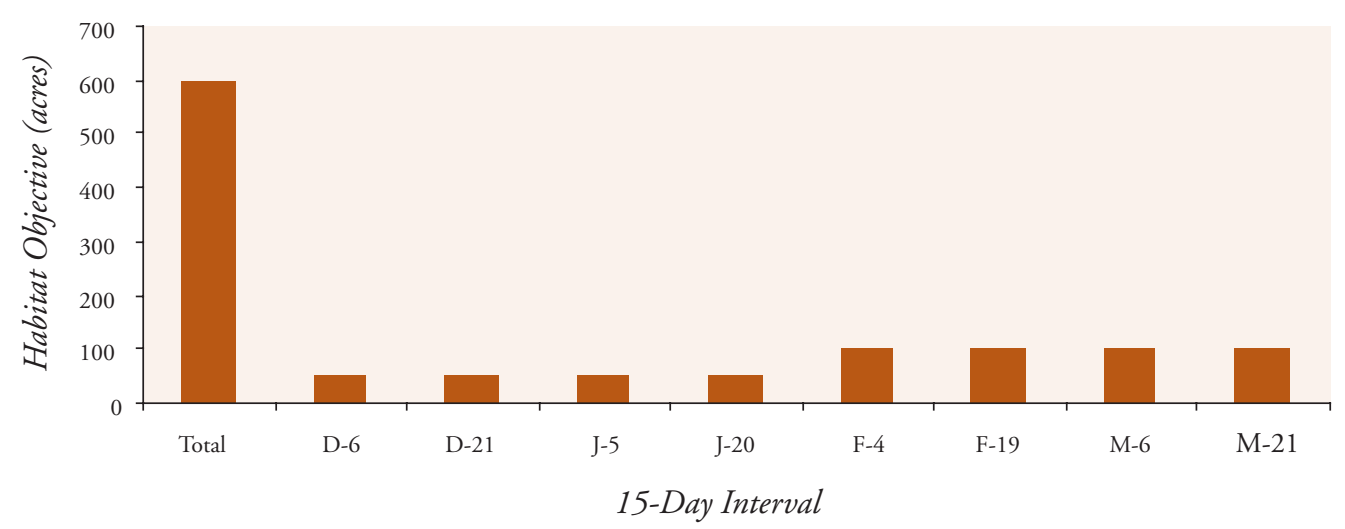

Figure 6-10. Seasonal wetland objectives for shorebirds in the Winter Flooding Period by 15-day intervals for a hypothetical planning region. 
The required depth ratio increases from December through March (Table 6-9). For the Winter Flooding Period, the depth ratio is calculated as the summed seasonal wetland objective for a given interval divided by the potential seasonal wetland habitat at the beginning of the Winter Flooding Period (i.e., the December 6 interval). The required depth ratio increases through winter, as no new wetlands are being flooded and shorebirds deplete food resources on seasonal wetland acres that are managed below $10 \mathrm{~cm}$ in depth (Figure 6-11). Wetland managers could respond to this increase in required depth ratios by reducing water depths in some wetlands that are traditionally managed for waterfowl.

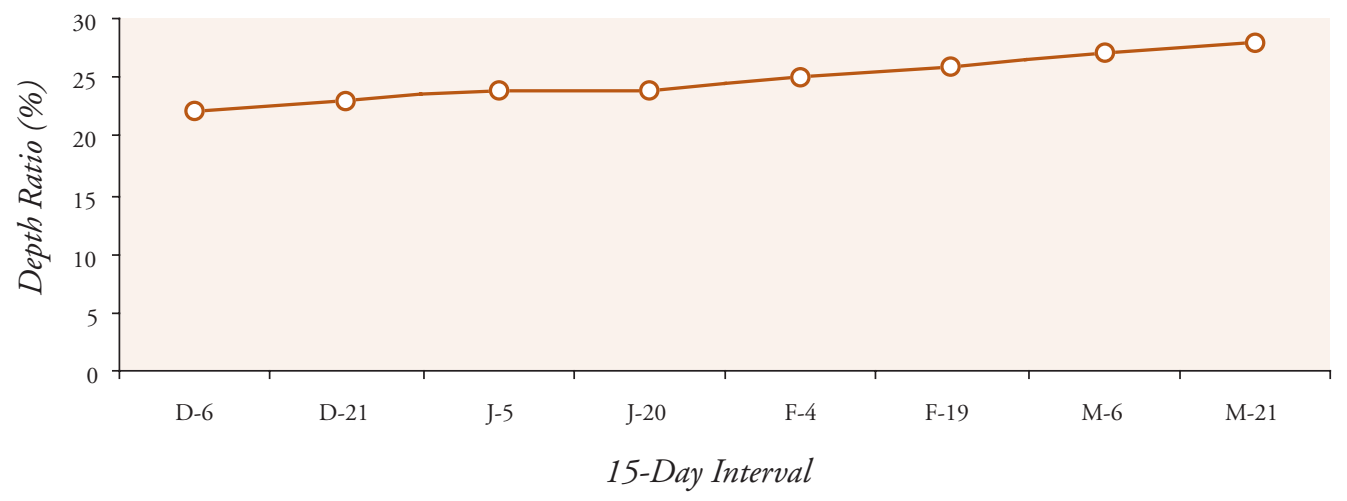

Figure 6-11. Changes in the required depth ratio for seasonal wetlands in the Winter Flooding Period for a hypothetical planning region.

\section{Spring Flooding Period for the Hypothetical Planning Region}

Overall, habitat needs for shorebirds in the Spring Flooding Period (March 30-May 12) range from 500 acres in each of the April intervals, to 300 acres in the May 4 interval (Table 6-7). Seasonal wetland objectives for shorebirds in each 15-day interval of the Spring Flooding Period are provided in Table 6-10. These wetland objectives are equivalent to the overall habitat needs of shorebirds, as winter flooded rice has been drained prior to the growing season. Seasonal wetland objectives are also summed from one interval to the next to provide a total seasonal wetland objective for April and May. Although the summed seasonal wetland objective is staggered over three 15-day intervals, it is possible to front-end this overall habitat objective. For example, seasonal wetland objectives could be met in the spring period by providing 1,300 acres at the beginning of the April 5 interval and maintaining these acres at a depth $<10$ cm until mid-May (Figure 6-12). Required depth ratios were not calculated for intervals in the Spring Flooding Period because of the uncertainty introduced by drawdowns of wetlands during this time. The drawdown of seasonal wetlands may result in an abundance of shorebird habitat during the Spring Flooding Period (Taft et al. 2002). Finally, the ending cumulative objective of 4,100 acres suggests that forty one percent $(4,100 / 10,000)$ of all seasonal wetlands in this hypothetical planning region must be managed for shorebirds for at least some time during the wintering period. Estimating what fraction of wetlands must be managed for shorebirds may be a useful exercise (i.e., depth ratios). However, it bears repeating that such estimates are compromised by a lack of knowledge on invertebrate communities within these habitats, and how these communities respond to shorebird foraging.

Table 6-10. Seasonal wetland objectives (acres) for shorebirds in the Spring Flooding Period of a hypothetical planning region.

\begin{tabular}{|cccc|} 
Interval & $\begin{array}{c}\text { SW Interval } \\
\text { Objective }\end{array}$ & $\begin{array}{c}\text { Cumulative SW } \\
\text { Objective }\end{array}$ & Flooded SWs $^{b}$ \\
\hline A-5 (MAR 30-APR 13) & 500 & 3,300 & 10,000 \\
\hline A-20 (APR 14-APR 28) & 500 & 3,800 & 3,150 \\
M-4 (APR 29-MAY 10) & 300 & 4,100 & 1,300 \\
TotAL & $\mathbf{1 , 3 0 0}$ & 4,100 & \\
\hline
\end{tabular}

SW-Seasonal Wetland.

ancludes SW objectives from previous flooding periods.

${ }^{b}$ Flooded SWs reflect flooding schedules within a shorebird planning region. 


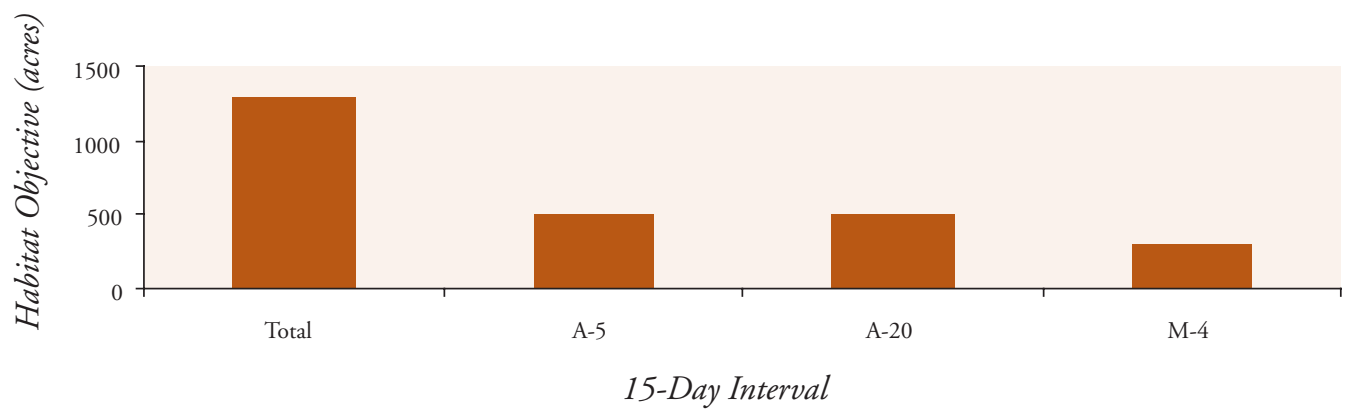

Figure 6-12. Seasonal wetland objectives for shorebirds in the Spring Flooding Period by 15-day intervals for a hypothetical planning region.

\section{Water Supplies for Wetland Management for the Hypothetical Planning Region}

Water supplies needed to manage seasonal wetlands for wintering waterfowl were estimated in Chapter 4 . The assumption here is that shorebird needs can be met in the context of meeting waterfowl needs provided that adequate amounts of wetland habitat are managed at depths $<10 \mathrm{~cm}$. As a result, water supply estimates that are specific to shorebirds are not needed for the period when seasonal wetlands are traditionally flooded in the Central Valley (i.e., beginning in mid-August). However, shorebirds rely on the Central Valley prior to when seasonal wetlands are traditionally flooded (i.e., July and early August), and flooding of wetlands in this period may be needed to meet shorebird needs. As a result, the water needs (acre-feet) associated with providing seasonal wetlands prior to conventional flooding dates was estimated. These estimates were based on wetland acre needs of shorebirds outside of conventional flooding dates (e.g., July and early August). The acre-feet estimate of water needed to flood these wetlands was based on annual wetland water requirements from the 2000 Central Valley Wetland Water Supply Investigations, CVPIA 3406 (d) (6) (A,B), A Report to Congress (U.S. Fish \& Wildlife Service 2000).

Meeting shorebird needs in the hypothetical planning region required flooding 150 acres of seasonal wetlands in the August 8 interval. Conventional flooding schedules indicate that seasonal wetlands receive about 1 acre-foot of water during the second half of August and 2-acre feet of water in September (Figure 6-13). However, these water requirements are geared towards waterfowl and may provide water depths that are less than optimal for shorebirds. The JV tentatively assumes that providing shorebird habitat outside of the conventional flooding schedules requires 2 acre-feet per acre. For example, providing 150 acres of seasonal wetlands in the August 8 interval would require 300 acre-feet of water. This water requirement is above and beyond the water needed to manage seasonal wetlands in a conventional manner (i.e., where flooding does not begin before mid to late August).

\section{Agricultural Enhancement}

Harvested rice fields that are winter flooded in the Central Valley can provide important shorebird habitat during the wintering period. Similar to wintering waterfowl, winter flooded rice may provide up to $50 \%$ of the food energy needs of shorebirds. However, winter flooded rice is only available from early October through late March (Figure $6-4)$. As a result, wetlands must meet $100 \%$ of shorebird needs in all 15 -day intervals

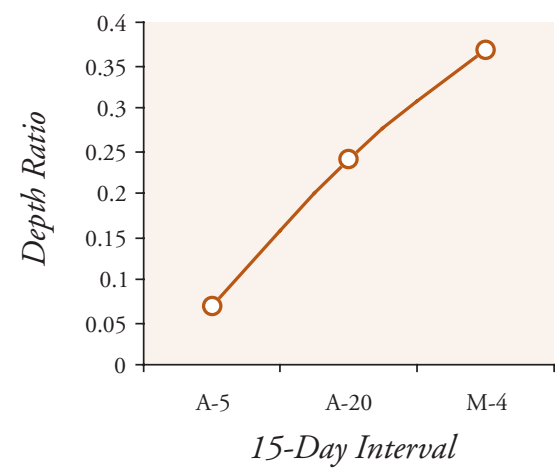

Figure 6-13. Changes in the seasonal wetland depth ratio for shorebirds during the Spring Flooding Period. between July 1 and October 1, and March 30 and May 10.

The methods for determining how much winter flooded rice must be managed at depths $<10 \mathrm{~cm}$ is described using the hypothetical shorebird region in Table 6-6. The planning region contains 20,000 acres of winter flooded rice. Flooding of this rice begins in early October, with drawdown complete by the end of March (Figure 6-4).

Overall, habitat needs for shorebirds between October 1 and March 29 range from a high of 600 acres in November, to a low of 100 acres in the December and January intervals (Table 6-7). Agricultural enhancement objectives (i.e., flooded rice) for shorebirds between October and March are presented in Table 6-11. The agricultural objectives are equivalent to $50 \%$ of the interval habitat needs, as seasonal wetlands are assumed to meet half of all shorebird energy requirements. Agricultural enhancement objectives are also summed from one interval to the next to provide a total rice objective between early October and the end of March. Although the 
summed agricultural objective of 1,700 acres is staggered over several 15-day intervals, it is possible to front-end this overall habitat objective. For example, the agricultural enhancement objective could be met by providing 1,700 acres of winter flooded rice in early October and maintaining these acres at a depth $<10$ $\mathrm{cm}$ through the end of March (Figure 6-14). The required depth ratio remains relatively steady for winter flooded rice between October and March (Figure 615). This is largely the result of interval rice objectives being small relative to the amount of flooded rice that is available.
Table 6-11. Rice habitat objectives (acres) for shorebirds between early October and the end of March in a hypothetical planning region.

\begin{tabular}{|c|c|c|c|c|}
\hline Interval & $\begin{array}{c}\text { Rice Interval } \\
\text { Objective }\end{array}$ & $\begin{array}{l}\text { Cumulative } \\
\text { Rice Objective }\end{array}$ & $\begin{array}{l}\text { Flooded }^{a} \\
\text { Rice }\end{array}$ & $\begin{array}{c}\text { Required }^{b} \\
\text { Depth Ratio (\%) }\end{array}$ \\
\hline О-7 (Ост 1-Ост 15) & 250 & 250 & 2,200 & 11 \\
\hline О-22 (Ост 16-Ост 30) & 250 & 500 & 7,600 & 7 \\
\hline N-6 (Ост 31-Nov 14) & 300 & 800 & 12,800 & 6 \\
\hline N-21 (Nov 15-Nov 29) & 300 & 1,100 & 15,200 & 7 \\
\hline D-6 (Nov 30-DeC 14) & 50 & 1,150 & 1,7600 & 7 \\
\hline D-21 (DeC 15-Dec 29) & 50 & 1,200 & 20,000 & 6 \\
\hline J-5 (DEC 30-JAN 13) & 50 & 1,250 & 20,000 & 6 \\
\hline J-20 (JAN 14-JAN 28) & 50 & 1,300 & 20,000 & 7 \\
\hline F-4 (JAN 29-FEB 12) & 100 & 1,400 & 20,000 & 7 \\
\hline F-19 (FeB 13-FeB 27) & 100 & 1,500 & 20,000 & 8 \\
\hline M-6 (FEB 28-MAR 14) & 100 & 1,600 & 10,000 & \\
\hline M-21 (MAR 15-MAR 29) & 100 & 1,700 & 5,000 & \\
\hline TotaL & 1,700 & 1,700 & & \\
\hline
\end{tabular}

a Flooded Rice reflects post-harvest flooding schedules for rice.

${ }^{b}$ Cumulative Rice Objective/Flooded Rice.

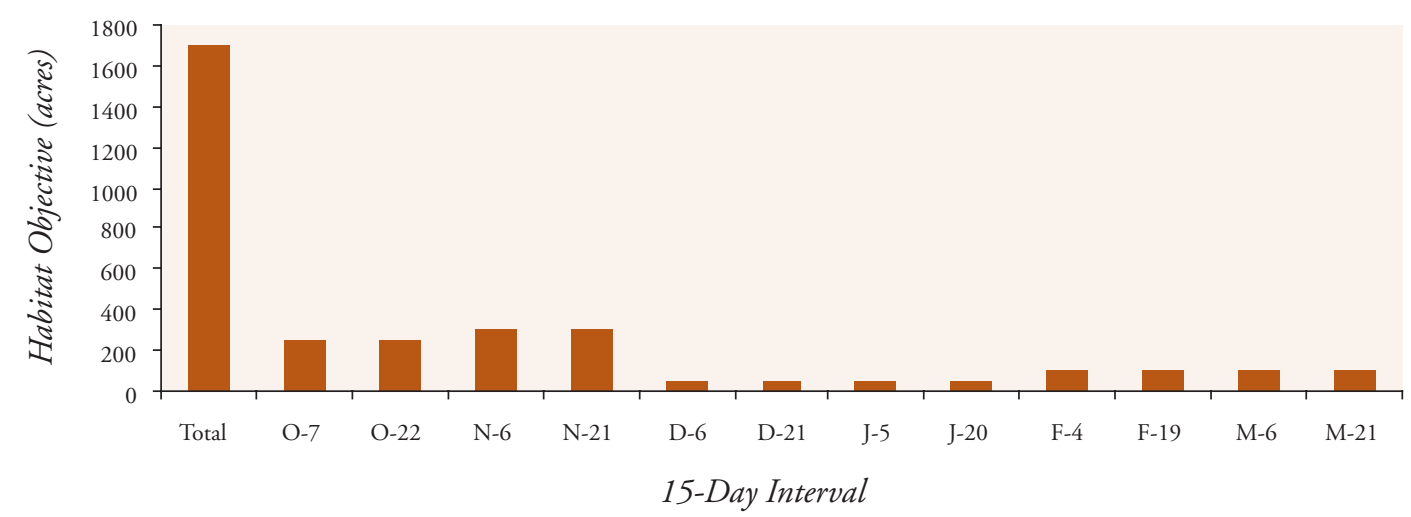

Figure 6-14. Rice habitat objectives for shorebirds by 15 -day intervals for a hypothetical planning region.

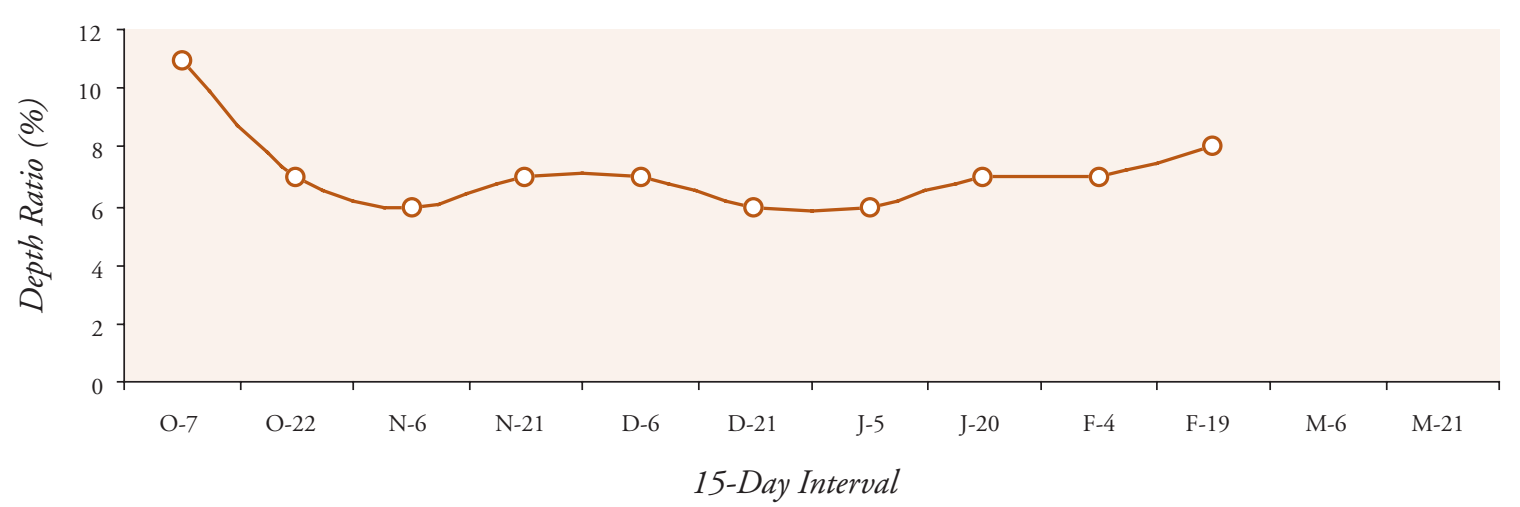

Figure 6-15. Changes in the required depth ratio for rice habitat between October and March. 


\section{Summary}

Conservation objectives for managed seasonal and semi-permanent wetlands, water supplies, and agricultural enhancement are summarized for the hypothetical shorebird-planning region in Table 6-12.

Table 6-12. Conservation objectives for non-breeding shorebirds in a hypothetical planning region.

\begin{tabular}{|c|c|c|c|c|}
\hline Interval & $\begin{array}{c}\text { Seasonal } \\
\text { Wetlands (Acres) }\end{array}$ & $\begin{array}{c}\text { Semi-Perm. } \\
\text { Wetlands (Acres) }\end{array}$ & $\begin{array}{c}\text { Water } \\
\text { (Acre-Feet) }\end{array}$ & $\begin{array}{l}\text { Winter Flooded } \\
\text { Rice (Acres) }\end{array}$ \\
\hline J-7 (JuLY 1-JulY 15) & 0 & 100 & 0 & 0 \\
\hline J-22 (JuLY 16-JuLY 31) & 0 & 100 & 0 & 0 \\
\hline A-8 (Aug 1-Aug 16) & 150 & 0 & 300 & 0 \\
\hline A-23 (Aug 17-Aug 23) & 300 & 0 & 0 & 0 \\
\hline S-7 (SEPT 1-SEPT 15) & 300 & 0 & 0 & 0 \\
\hline S-22 (SEPT 16-SEPt 30) & 300 & 0 & 0 & 0 \\
\hline O-7 (Ост 1-Ост 15) & 250 & 0 & 0 & 250 \\
\hline О-22 (Ост 16-Ост 30) & 250 & 0 & 0 & 250 \\
\hline N-6 (Ост 31-Nov 14) & 300 & 0 & 0 & 300 \\
\hline N-21 (Nov 15-Nov 29) & 300 & 0 & 0 & 300 \\
\hline D-6 (Nov 30-DeC 14) & 50 & 0 & 0 & 50 \\
\hline D-21 (DEC 15-DeC 29) & 50 & 0 & 0 & 50 \\
\hline J-5 (DEC 30-JAN 13) & 50 & 0 & 0 & 50 \\
\hline J-20 (JAN 14-JAN 28) & 50 & 0 & 0 & 50 \\
\hline F-4 (JAN 29-FeB 12) & 100 & 0 & 0 & 100 \\
\hline F-19 (FeB 13-FeB 27) & 100 & 0 & 0 & 100 \\
\hline M-6 (FEB 28-MAR 14) & 100 & 0 & 0 & 100 \\
\hline M-21 (MAR 15-MAR 29) & 100 & 0 & 0 & 100 \\
\hline A-5 (MAR 30-APr 13) & 500 & 0 & 0 & 0 \\
\hline A-20 (APR 14-APr 28) & 500 & 0 & 0 & 0 \\
\hline M-4 (APR 29-MAY 10) & 300 & 0 & 0 & 0 \\
\hline TotaL & 4,050 & 200 & 300 & 1,700 \\
\hline
\end{tabular}




\section{Conservation Objectives for Wintering Shorebirds Within Planning Regions}

\section{Sacramento Valley Planning Region}

\section{Current Conditions}

Population objectives for migrating and wintering shorebirds in the Sacramento Valley Planning Region (Colusa, Butte, American, and Sutter Basins) are presented in Figure 6-16. Population objectives are the highest for April, with shorebird numbers reaching a minimum in July. Winter flooded rice provides the majority of foraging habitat potentially available to shorebirds, though seasonal wetlands exceed 50,000 acres (Table 6-13).

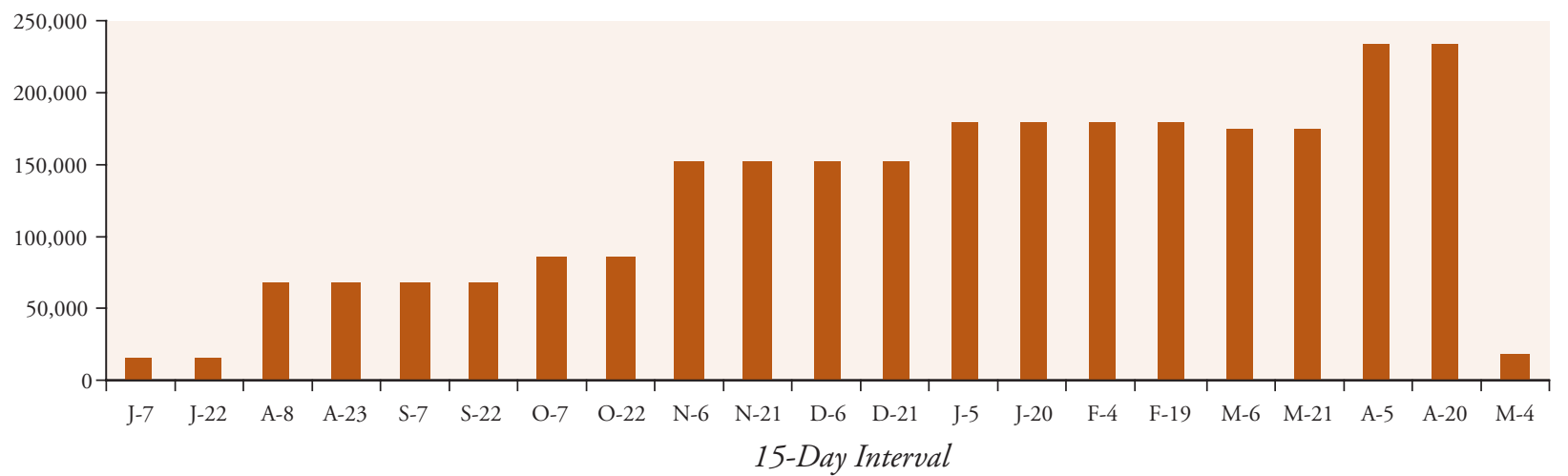

\begin{tabular}{|c|c|c|c|c|c|c|c|c|c|c|c|c|c|c|c|c|c|c|c|c|}
\hline $\begin{array}{c}\text { G } \\
\text { v }\end{array}$ & 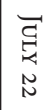 & $\begin{array}{l}\vec{D} \\
\stackrel{D}{\infty} \\
\infty\end{array}$ & $\begin{array}{l}\text { 空 } \\
\text { in } \\
\text { }\end{array}$ & 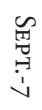 & $\begin{array}{l}\text { 思 } \\
\stackrel{n}{N} \\
N\end{array}$ & 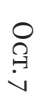 & 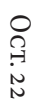 & 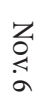 & 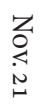 & $\begin{array}{l}\text { 菻 } \\
\stackrel{2}{2}\end{array}$ & $\begin{array}{l}\text { 罚 } \\
\stackrel{i}{N}\end{array}$ & 㞼 & 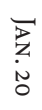 & 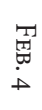 & \begin{tabular}{l} 
勇 \\
\multirow{5}{5}{}
\end{tabular} & $\begin{array}{l}3 \\
\text { 恿 }\end{array}$ & 党 & 宽 & $\begin{array}{l}\text { 党 } \\
\tilde{N}\end{array}$ & $\begin{array}{l}3 \\
+ \\
+\end{array}$ \\
\hline 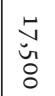 & $\begin{array}{l}\overrightarrow{5} \\
\text { जू } \\
\text { वे }\end{array}$ & $\begin{array}{l}\text { वे } \\
\text { ¿े }\end{array}$ & $\begin{array}{l}\text { ปे } \\
\text { ¿े }\end{array}$ & 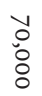 & $\begin{array}{l}\text { ปे } \\
\text { ¿े }\end{array}$ & $\begin{array}{l}\infty \\
\text { जu } \\
\text { I }\end{array}$ & 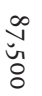 & $\begin{array}{l}\vec{W} \\
\\
\text { o } \\
\vdots\end{array}$ & $\begin{array}{l}\vec{W} \\
\\
\text { o } \\
\vdots\end{array}$ & 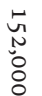 & 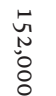 & $\begin{array}{l}\infty \\
\stackrel{\infty}{\circ} \\
\vdots \\
0\end{array}$ & $\begin{array}{l}\infty \\
0 \\
0 \\
\vdots \\
\vdots\end{array}$ & $\begin{array}{l}\infty \\
0 \\
0 \\
\vdots \\
\vdots\end{array}$ & $\begin{array}{l}\infty \\
0 \\
0 \\
0 \\
\vdots\end{array}$ & 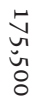 & 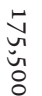 & 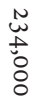 & 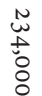 & 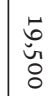 \\
\hline
\end{tabular}

Figure 6-16. Shorebird population objectives (acres) for the Sacramento Valley Planning Region.

Figure 6-17 depicts the relationship between shorebird population objectives and the availability of seasonally flooded wetlands and winter flooded rice. Semi-permanent wetlands are assumed to provide shorebird habitat from July 1 to July 15 when they are typically drawn down and more likely to provide foraging habitat $<10 \mathrm{~cm}$ in depth.

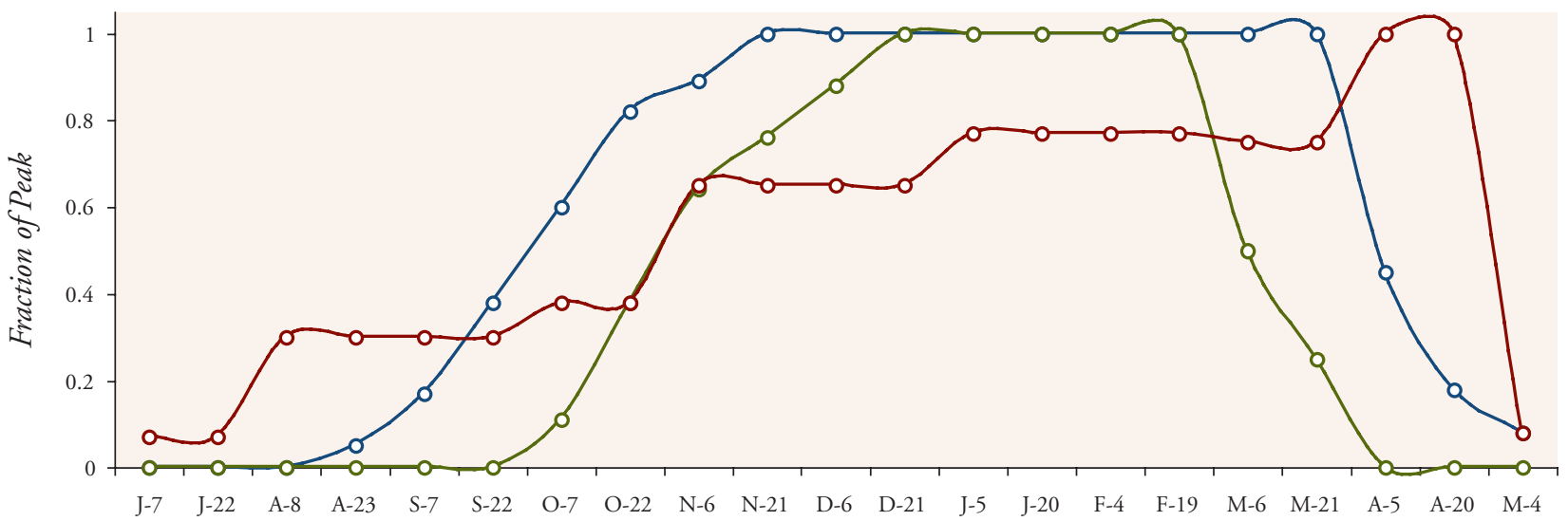

Figure 6-17. Shorebird population objectives (red) vs. flooding schedules for managed seasonal wetlands (blue) and rice (green) for the Sacramento Valley Planning Region. Shorebird population objectives are expressed as the fraction of peak population; wetlands and rice are expressed as the fraction of these habitats that are flooded. 
Seasonal wetlands provide no habitat prior to the August 23 interval when flooding of these wetlands in the SV Planning Region typically begins. However, drawdown of semi-permanent wetlands in early July provides some foraging habitat between July 1 and July 15. Increases in the amount of seasonal wetlands track increases in shorebird numbers from late August to early December. Shorebird numbers increase during April when seasonal wetlands are being drawn down and the amount of foraging habitat $<10$ $\mathrm{cm}$ deep is likely increasing.

Winter flooded rice provides no foraging habitat prior to the October 7 interval. Although rice provides large amounts of potential habitat from late October through late March, these habitats are largely dry by the time shorebird numbers peak in April.

\section{Management of Existing Seasonal and Semi-Permanent Wetlands}

\section{Summer Flooding Period (July 1-August 16)}

Shorebirds require 396 acres of foraging habitat $<10 \mathrm{~cm}$ deep in the July 7 interval, with habitat needs increasing to 423 acres and 1,584 acres in the July 22 and August 8 intervals respectively (Table 6-14). All habitat requirements during the Summer Flooding Period must be met from managed wetlands, as no winter flooded rice is available.

Semi-permanent wetlands may provide the best opportunity to meet shorebird needs in July. The SV Planning Region contains nearly 9,000 acres of semi-permanent wetlands (Table 6-13). If all these wetlands are drawn down between July 1 and July 15 , the required depth ratio for these semi-permanent habitats is $4 \%$ (i.e., 396 of the 8,968 acres must provide water depths $<10 \mathrm{~cm}$ to meet shorebird needs in the July 7 interval). Semi-permanent public wetlands alone (3,562 acres) can meet shorebird needs in the July 7 interval if only $11 \%$ of these habitats provide suitable water depths during drawdown. If all 8,968 acres of semi-permanent wetlands are drawn down by mid-July, no opportunity exists to meet shorebird needs in the July 22 interval using these habitats. Delaying the drawn down of some semi-permanent wetlands until late July could help provide the 423 acres of habitat needed by shorebirds in the July 22 interval.
Table 6-13. Acres of managed wetlands and intentionally flooded rice in the Sacramento Valley Planning Region.

\begin{tabular}{ccc}
$\begin{array}{c}\text { Seasonal } \\
\text { Wetland }\end{array}$ & $\begin{array}{c}\text { Semi-Perm. } \\
\text { Wetland }\end{array}$ & $\begin{array}{c}\text { Winter } \\
\text { Flooded Rice }\end{array}$ \\
\hline 50,868 & 8,968 & 346,606 \\
\hline
\end{tabular}

Table 6-14. Habitat objectives for shorebirds in the Sacramento Valley Planning Region during the Summer Flooding Period.

\begin{tabular}{|cc|}
\hline Interval & $\begin{array}{c}\text { Habitat Objective } \\
\text { (Acres) }\end{array}$ \\
\hline J-7 (JUlY 1-July 15) & 396 \\
J-22 (JULY 16-July 31) & 423 \\
\hline A-8 (AUg 1-AUg 16) & 1,584 \\
\hline
\end{tabular}

Table 6-15. Overall habitat needs for shorebirds in the Sacramento Planning Region during the Fall Flooding Period.

\begin{tabular}{|cc|} 
Interval & $\begin{array}{c}\text { Habitat } \\
\text { Objective (Acres) }\end{array}$ \\
\hline A-23 (AUG 17-AUG 31) & 1,584 \\
S-7 (SEPT 1-SEPT 15) & 1,584 \\
S-22 (SEPT 16-SEPT 30) & 1,584 \\
O-7 (OCT 1-OCT 15) & 1,980 \\
O-22 (OCT 16-OCT 30) & 1,980 \\
N-6 (OCT 31-Nov 14) & 2,965 \\
N-21 (Nov 15-Nov 29) & 2,965 \\
\hline TotAL & $\mathbf{1 4 , 6 4 2}$ \\
\hline
\end{tabular}

Population energy demand estimates for shorebirds indicate that 1,584 acres of wetland habitat are required during the August 8 interval. There are currently no seasonal wetlands flooded in the SV Planning Region during the first two weeks of August, and all semi-permanent wetlands are assumed to be dry by this time. The 1,584 acres of wetlands needed by shorebirds during this interval could be met through early flooding of seasonal wetlands. These 1,584 acres represent 3\% of existing seasonal wetlands in the SV Planning Region, and 13\% of all public seasonal wetlands.

\section{Fall Flooding Period (August 17-November 29)}

Habitat needs for shorebirds in the Fall Flooding Period range from 1,584 acres in each of the August and September intervals, to nearly 3,000 acres in each of the November intervals (Table 6-15). Although the SV Planning Region has over 350,000 acres of winter flooded rice, none of this agricultural habitat is available prior to the October 7 interval. As a result, shorebird needs must be met entirely from seasonal wetland habitats in the August and September intervals. Beginning in October, seasonal wetland objectives decline to $50 \%$ of interval habitat needs as rice is assumed to meet half of all shorebird needs (Table 6-16). 
Table 6-16. Seasonal wetland objectives (acres) for shorebirds in the Sacramento Valley Planning Region during the Fall Flooding Period.

\begin{tabular}{|c|c|c|c|c|}
\hline Interval & $\begin{array}{c}\text { SW Interval } \\
\text { Objective }\end{array}$ & $\begin{array}{c}\text { Cumulative SWa } \\
\text { Objective }\end{array}$ & Flooded SWs ${ }^{b}$ & $\begin{array}{l}\text { Required Depth } \\
\text { Ratio (\%) }\end{array}$ \\
\hline A-23 (Aug 17-Aug 31) & 1,584 & 3,168 & 2,543 & $>100$ \\
\hline S-7 (SEPT 1-SEPT 15) & 1,584 & 4,752 & 8,648 & 55 \\
\hline S-22 (SEPT 16-SEPT 30) & 1,584 & 6,336 & 19,330 & 33 \\
\hline O-7 (Ост 1-Ост 15) & 990 & 7,326 & 30,521 & 24 \\
\hline О-22 (Ост 16-Ост 30) & 990 & 8,316 & 41,712 & 20 \\
\hline N-6 (Oct 31-Nov 14) & 1,483 & 9,799 & 45,273 & 22 \\
\hline N-21 (Nov 15-Nov 29) & 1,483 & 11,282 & 50,868 & 22 \\
\hline TотAL & 9,698 & & & \\
\hline
\end{tabular}

SW-Seasonal Wetland.

"Includes SW objectives from previous flooding periods.

${ }^{b}$ Flooded SWs reflect flooding schedules within a shorebird planning region.

${ }^{c}$ Cumulative SW Objective/Flooded SWs.

Although the total seasonal wetland objective of 9,698 acres is staggered over seven 15-day intervals, it is possible to meet this overall habitat objective in a shorter period of time. For example, seasonal wetland objectives for shorebirds could be met in the Fall Flooding Period by providing 9,698 acres during the August 23 interval and maintaining these acres at a depth $<10 \mathrm{~cm}$ through the end of November (Figure 6-18).

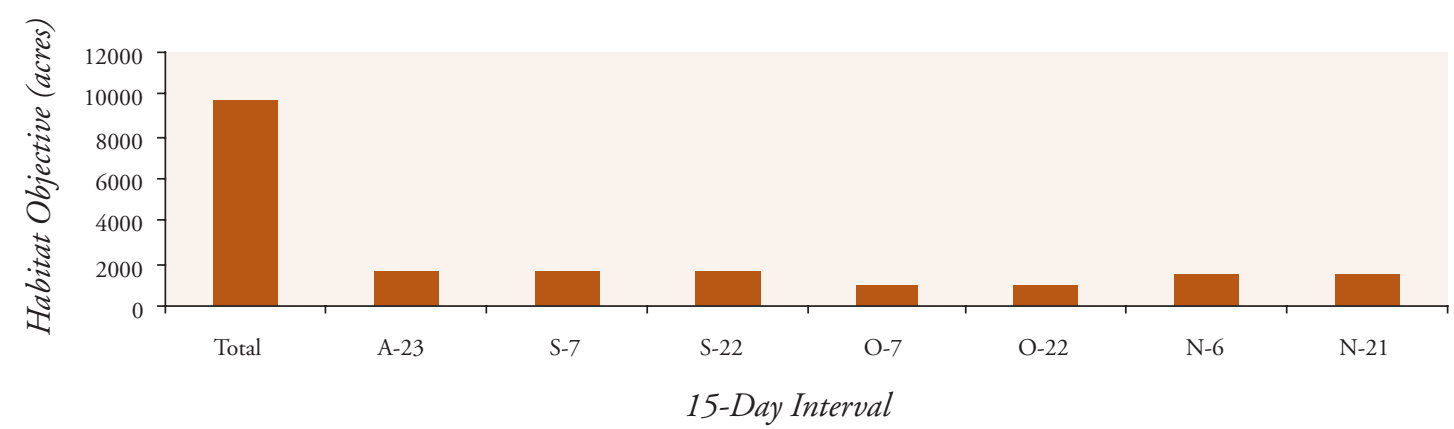

Figure 6-18. Seasonal wetland objectives for shorebirds in the Fall Flooding Period by 15-day intervals for the Sacramento Valley Planning Region.

Seasonal wetlands become increasingly available from August through November as these habitats are flooded prior to the hunting season. This increase in seasonal wetlands is reflected in the required depth ratio, which declines from August through October (Figure 6-19).

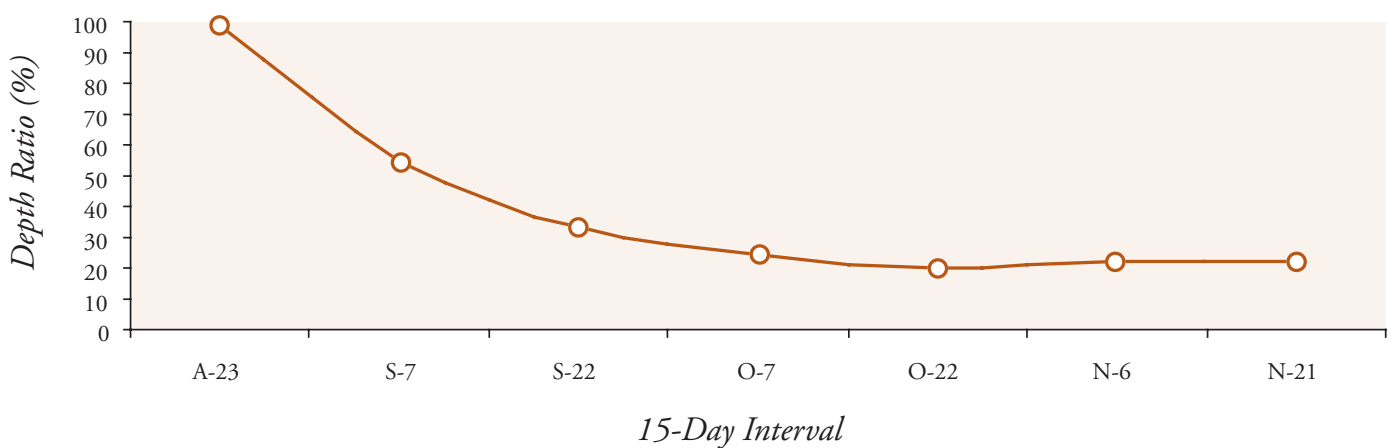

Figure 6-19. Changes in the required depth ratio for seasonal wetlands in the Fall Flooding Period for the Sacramento Valley Planning Region. 


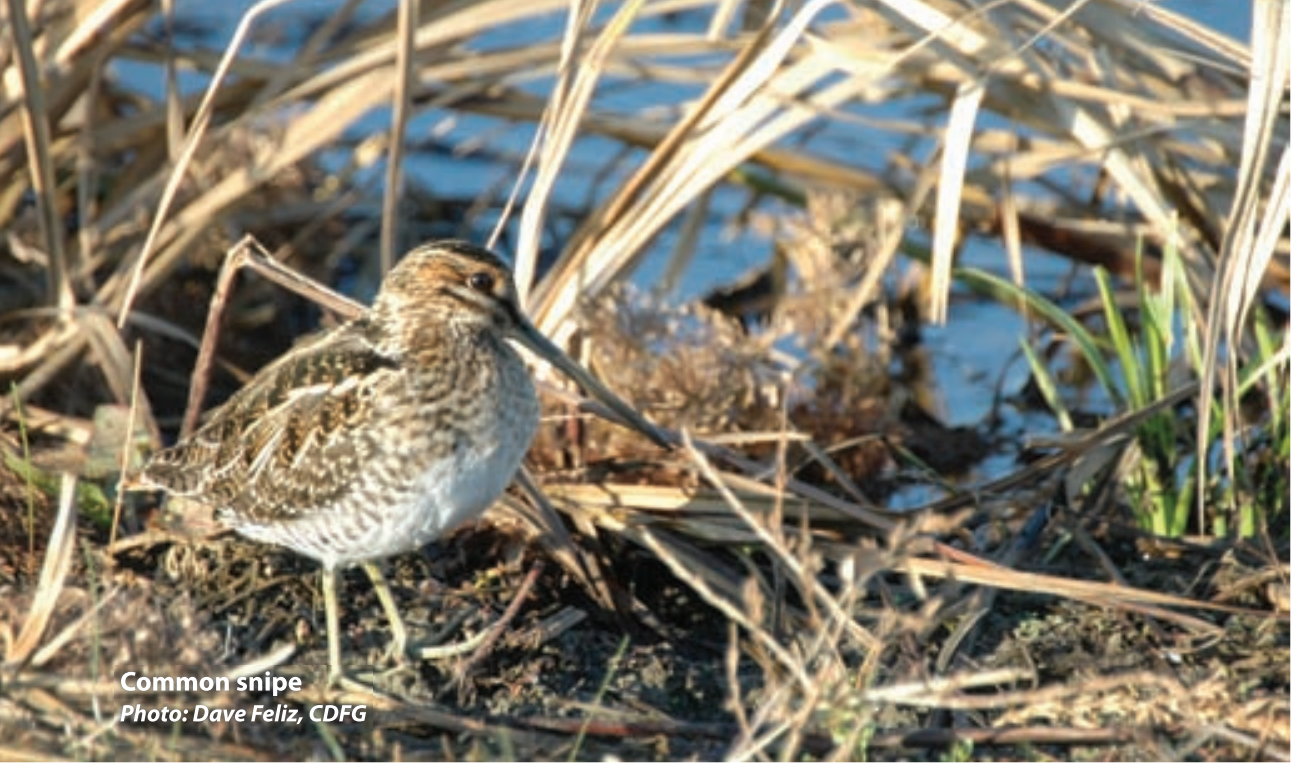

Table 6-17. Overall habitat needs for shorebirds during the Winter Flooding Period.

\begin{tabular}{|cc|} 
Interval & $\begin{array}{c}\text { Habitat Objective } \\
\text { (Acres) }\end{array}$ \\
\hline D-6 (Nov 30-DEC 14) & 2,965 \\
D-21 (DEC 15-DEC 29) & 2,965 \\
J-5 (DEC 30-JAN 13) & 3,367 \\
J-20 (JAN 14-JAN 28) & 3,367 \\
F-4 (JAN 29-FEB 12) & 3,367 \\
F-19 (FeB 13-FEB 27) & 3,367 \\
M-6 (FeB 28-MAR 14) & 3,918 \\
M-21 (MAR 15-MAR 29) & 3,918 \\
TotAL & $\mathbf{2 7 , 2 3 4}$ \\
\hline
\end{tabular}

\section{Winter Flooding Period (November 30-March 29)}

Habitat needs for shorebirds in the Winter Flooding Period range from nearly 3,000 acres in the December intervals, to over 3,900 acres in March intervals (Table 6-17). Fifty percent of these habitat needs must be met from seasonal wetlands, with the balance being provided by winter flooded rice (Table 6-18). The overall seasonal wetland objective for the Winter Flooding Period is 13,260 acres. Although this wetland objective is staggered over several 15-day intervals, it is possible to meet this conservation objective in ashorter period of time. For example, seasonal wetland objectives for shorebirds could be met in the Winter Flooding Period by providing 13,620 acres during the December 6 interval and maintaining these acres at a depth $<10 \mathrm{~cm}$ through the end of March (Figure 620). As expected, the required depth ratio increases through the Winter Flooding Period, as no new wetlands are being flooded and shorebirds deplete food resources on seasonal wetland acres that are managed $<10 \mathrm{~cm}$ in depth (Figure 6-21).

Table 6-18. Seasonal wetland objectives (acres) for shorebirds in the Sacramento Valley Planning Region during the Winter Flooding Period.

\begin{tabular}{|c|c|c|c|c|}
\hline Interval & $\begin{array}{c}\text { SW Interval } \\
\text { Objective }\end{array}$ & $\begin{array}{c}\text { Cumulative SW } \\
\text { Objective }\end{array}$ & Flooded $^{b}$ SWs & $\begin{array}{c}\text { Required Depth } \\
\text { Ratio (\%) }\end{array}$ \\
\hline D-6 (Nov 30-DeC 14) & 1,483 & 12,765 & 50,868 & 25 \\
\hline D-21 (DeC 15-Dec 29) & 1,483 & 14,248 & 50,868 & 28 \\
\hline J-5 (DEC 30-JAN 13) & 1,684 & 15,932 & 50,868 & 31 \\
\hline J-20 (JAN 14-JAN 28) & 1,684 & 17,616 & 50,868 & 35 \\
\hline F-4 (JAN 29-FEB 12) & 1,684 & 19,300 & 50,868 & 38 \\
\hline F-19 (Fев 13-Feв 27) & 1,684 & 20,984 & 50,868 & 41 \\
\hline M-6 (FeB 28-Mar 14) & 1,959 & 22,943 & 50,868 & 45 \\
\hline M-21 (MAR 15-MAR 29) & 1,959 & 24,902 & 50,868 & 49 \\
\hline TotaL & 13,620 & 24,902 & & \\
\hline
\end{tabular}

SW-Seasonal Wetland.

ancludes SW objectives from previous flooding periods.

${ }^{b}$ Flooded SWs reflect flooding schedules within a shorebird planning region.

${ }^{c}$ Cumulative SW Objective/Flooded SWs. 


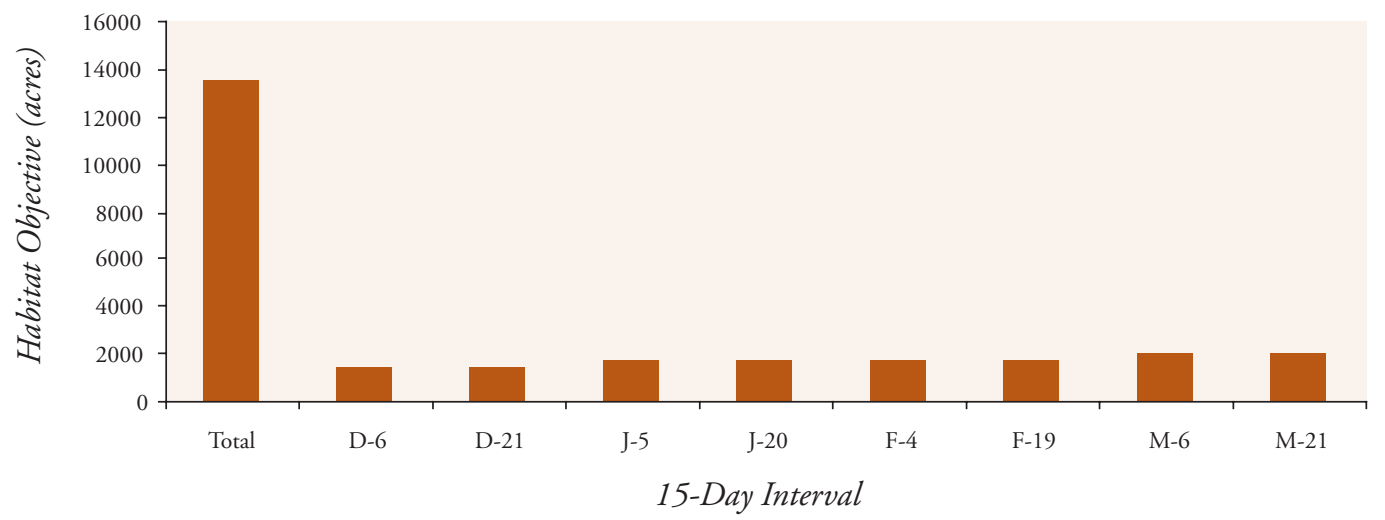

Figure 6-20. Seasonal wetland objectives for shorebirds in the Winter Flooding Period by 15-day intervals for the Sacramento Valley Planning Region.

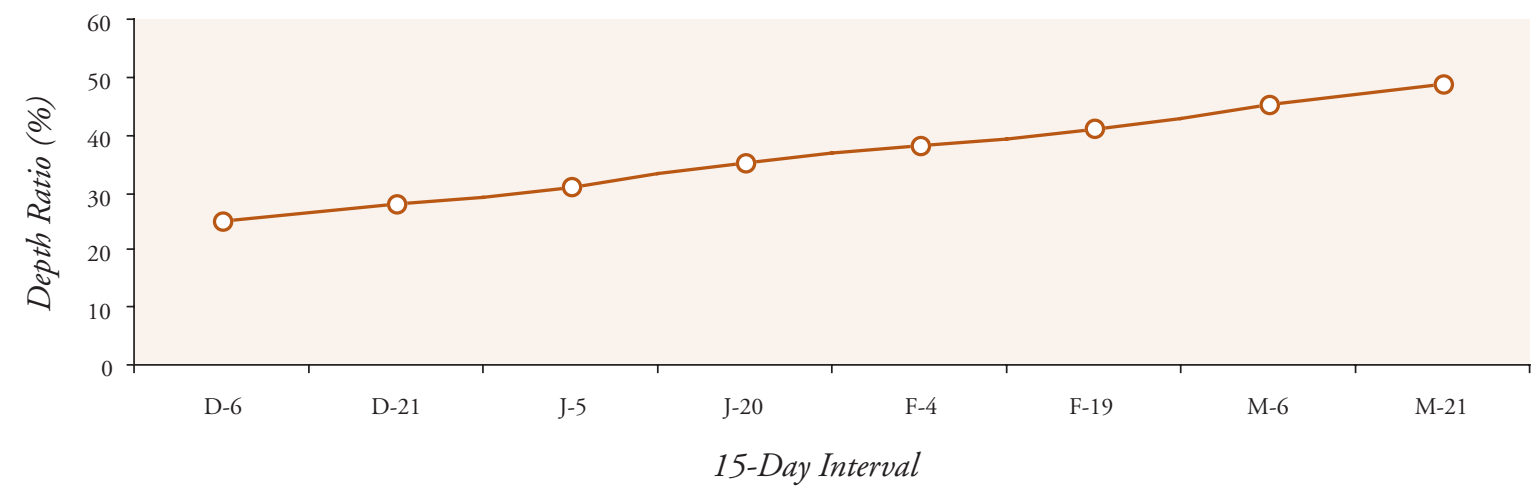

Figure 6-21. Changes in the required depth ratio for seasonal wetlands in the Winter Flooding Period for the Sacramento Valley Planning Region.

\section{Spring Flooding Period (March 30-May 12)}

Habitat needs for shorebirds in the Spring Flooding Period range from over 5,000 acres in each of the April intervals to less than 400 acres in May. Shorebird needs must be met exclusively by seasonal wetlands as rice fields are assumed to be dry by this time (Table 6-19). The summed seasonal wetland objective for the Spring Flooding Period is nearly 11,000 acres, with most of these acres needed in the April intervals (Figure 6-22).

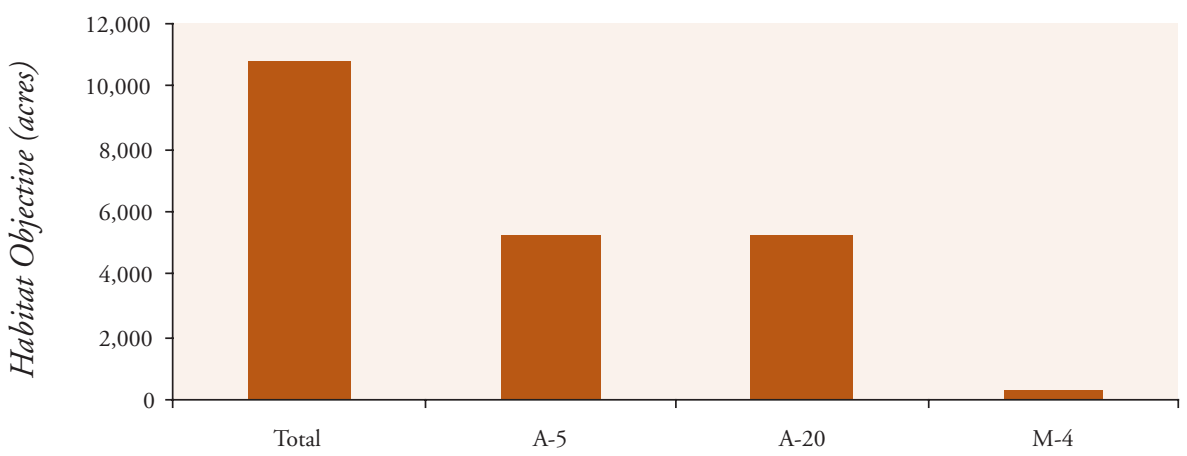

Figure 6-22. Seasonal wetland objectives for shorebirds in the Spring Flooding Period by 15-day intervals for the Sacramento Valley Planning Region. 
Table 6-19. Seasonal wetland objectives (acres) for shorebirds in the Sacramento Valley Planning Region during the Spring Flooding Period.

\begin{tabular}{|cccc|} 
Interval & SW Interval Objective & $\begin{array}{c}\text { Cumulative SW } \\
\text { Objective }\end{array}$ & Flooded SW $^{b}$ Habitat $^{a}$ \\
\hline A-5 (MAR 30-APR 13) & 5,223 & 30,125 & 50,868 \\
\hline A-20 (APR 14-APR 28) & 5,223 & 35,348 & 16,023 \\
M-4 (APR 29-MAY 10) & 348 & 35,696 & 6,612 \\
\hline TotAL & $\mathbf{1 0 , 7 9 4}$ & 35,696 & \\
\hline
\end{tabular}

SW-Seasonal Wetland.

"Includes SW objectives from previous flooding periods.

${ }^{b}$ Flooded SWs reflect flooding schedules within a shorebird planning region.

\section{Water Supplies for Wetland Management}

Additional water supplies that are needed for shorebirds are based on seasonal wetland needs in the August 8 interval (see earlier description for establishing water supply objectives). Seasonal wetland objectives for shorebirds in the SV Planning Region during the August 8 interval are estimated at 1,584 acres. This equates to a water supply need of 3,168 acre-feet.

\section{Agricultural Enhancement}

Habitat objectives for flooded rice in the SV Planning Region range from just under 1,000 acres in the October intervals, to nearly 2,000 acres throughout March (Table 6-20). Although the summed agricultural enhancement objective is staggered over several 15day intervals, it is possible to front-end this objective. For example, rice habitat objectives could be met by providing 18,566 acres during the October 7 interval and maintaining these acres at a depth $<10 \mathrm{~cm}$ through the end of March (Figure 6-23). The required depth ratio for rice habitat is low for all time intervals, which reflects the large amount of rice acreage that is available relative to shorebird needs in the SV Planning Region (Figure 6-24).

Table 6-20. Rice habitat objectives (acres) for shorebirds between early October and the end of March in the Sacramento Valley Planning Region.

\begin{tabular}{|c|c|c|c|c|}
\hline Interval & $\begin{array}{c}\text { Rice Interval } \\
\text { Objective }\end{array}$ & $\begin{array}{c}\text { Cumulative Rice } \\
\text { Objective }\end{array}$ & Flooded Rice ${ }^{a}$ & $\begin{array}{l}\text { Required Depth } \\
\text { Ratio (\%) }\end{array}$ \\
\hline О-7 (Ост 1-Ост 15) & 990 & 990 & 38,123 & 3 \\
\hline О-22 (Ост 16-Ост 30) & 990 & 1,980 & 131,171 & 2 \\
\hline N-6 (Oct 31-Nov 14) & 1,483 & 3,463 & 221,828 & 2 \\
\hline N-21 (Nov 15-Nov 29) & 1,483 & 4,946 & 263,421 & 2 \\
\hline D-6 (Nov 30-DeC 14) & 1,483 & 6,429 & 305,013 & 2 \\
\hline D-21 (DEC 15-Dec 29) & 1,483 & 7,912 & 346,606 & 2 \\
\hline J-5 (DEC 30-JAN 13) & 1,684 & 9,596 & 346,606 & 3 \\
\hline J-20 (JAN 14-JAN 28) & 1,684 & 11,280 & 346,606 & 3 \\
\hline F-4 (JAN 29-FEB 12) & 1,684 & 12,964 & 346,606 & 4 \\
\hline F-19 (FEB 13-FEB 27) & 1,684 & 14,648 & 346,606 & 4 \\
\hline M-6 (FEB 28-MAR 14) & 1,959 & 16,607 & 346,606 & 5 \\
\hline M-21 (MAR 15-MAR 29) & 1,959 & 18,566 & 346,606 & 5 \\
\hline ToTAL & 18,566 & 18,566 & 346,606 & \\
\hline
\end{tabular}

${ }^{a}$ Flooded Rice reflects post-harvest flooding schedules of rice.

${ }^{b}$ Cumulative Rice Objective/Flooded Rice. 
Table 6-21. Conservation Objectives for non-breeding shorebirds in the Sacramento Valley Planning Region.

\begin{tabular}{|c|c|c|c|c|}
\hline Interval & $\begin{array}{c}\text { Seasonal } \\
\text { Wetlands (Acres) }\end{array}$ & $\begin{array}{c}\text { Semi-Perm. } \\
\text { Wetlands (Acres) }\end{array}$ & $\begin{array}{c}\text { Water } \\
\text { (Acre-Feet) }\end{array}$ & $\begin{array}{l}\text { Winter Flooded } \\
\text { Rice (Acres) }\end{array}$ \\
\hline J-7 (JuLY 1-JulY 15) & 0 & 396 & 0 & 0 \\
\hline J-22 (JuLY 16-JuLY 31) & 0 & 423 & 0 & 0 \\
\hline A-8 (AUg 1-AUg 16) & 1,584 & 0 & 1,584 & 0 \\
\hline A-23 (Aug 17-Aug 31) & 1,584 & 0 & 0 & 0 \\
\hline S-7 (SEPT 1-SEPT 15) & 1,584 & 0 & 0 & 0 \\
\hline S-22 (SEPt 16-SePt 30) & 1,584 & 0 & 0 & 0 \\
\hline O-7 (Ост 1-Ост 15) & 990 & 0 & 0 & 990 \\
\hline O-22 (Ост 16-Ост 30) & 990 & 0 & 0 & 990 \\
\hline N-6 (Oct 31-Nov 14) & 1,483 & 0 & 0 & 1,483 \\
\hline N-21 (Nov 15-Nov 29) & 1,483 & 0 & 0 & 1,483 \\
\hline D-6 (Nov 30-DeC 14) & 1,483 & 0 & 0 & 1,483 \\
\hline D-21 (DEC 15-DeC 29) & 1,483 & 0 & 0 & 1,483 \\
\hline J-5 (DEC 30-JAN 13) & 1,684 & 0 & 0 & 1,684 \\
\hline J-20 (JAN 14-JAN 28) & 1,684 & 0 & 0 & 1,684 \\
\hline F-4 (JAN 29-FEB 12) & 1,684 & 0 & 0 & 1,684 \\
\hline F-19 (FeB 13-FeB 27) & 1,684 & 0 & 0 & 1,684 \\
\hline M-6 (FEB 28-MAR 14) & 1,959 & 0 & 0 & 1,959 \\
\hline M-21 (MAR 15-MAR 29) & 1,959 & 0 & 0 & 1,959 \\
\hline A-5 (MAR 30-APR 13) & 5,223 & 0 & 0 & 0 \\
\hline A-20 (APR 14-APR 28) & 5,223 & 0 & 0 & 0 \\
\hline M-4 (APR 29-MAY 10) & 348 & 0 & 0 & 0 \\
\hline ToTAL & 35,696 & 819 & 1584 & 18,566 \\
\hline
\end{tabular}




\section{Delta Planning Region}

\section{Current Conditions}

Population objectives for migrating and wintering shorebirds in the Delta Planning Region are presented in Figure 6-25. Population objectives are highest for January and February, with shorebird numbers reaching a minimum in July. Seasonal wetlands provide the majority of foraging habitat available to shorebirds (Table 6-22).

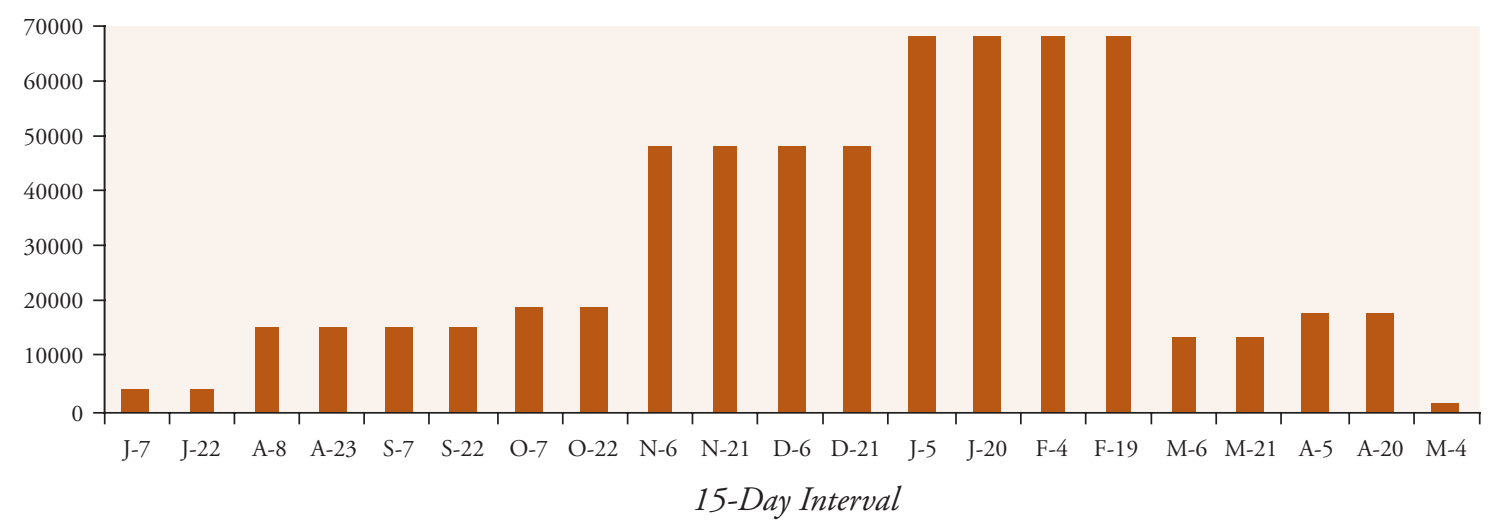

\begin{tabular}{|c|c|c|c|c|c|c|c|c|c|c|c|c|c|c|c|c|c|c|c|c|}
\hline$\underset{\mathrm{V}}{\mathrm{Z}}$ & $\begin{array}{l}\vec{E} \\
\stackrel{2}{N} \\
\stackrel{N}{N}\end{array}$ & $\begin{array}{l}\vec{C} \\
\text { C) } \\
\infty\end{array}$ & $\begin{array}{l}\text { 岂 } \\
\text { Q⿱ } \\
\text { 心 }\end{array}$ & 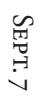 & 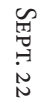 & $\begin{array}{l}\stackrel{0}{\rho} \\
\stackrel{+}{v}\end{array}$ & 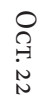 & $\begin{array}{l}z \\
\text { a } \\
: 4 \\
a\end{array}$ & $\begin{array}{l}Z \\
0 \\
0 \\
\stackrel{4}{n} \\
\text { N }\end{array}$ & 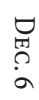 & 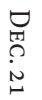 & $\begin{array}{l}\vec{s} \\
\text { 学 } \\
\dot{v}\end{array}$ & $\begin{array}{l}\vec{s} \\
\underset{2}{2} \\
\text { N } \\
0\end{array}$ & 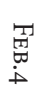 & 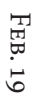 & 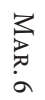 & 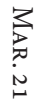 & $\begin{array}{l}\overrightarrow{0} \\
\text { v } \\
ن\end{array}$ & $\begin{array}{l}\overrightarrow{0} \\
\text { d } \\
\dot{\tilde{O}}\end{array}$ & $\begin{array}{l}3 \\
+2 \\
\end{array}$ \\
\hline$\breve{J ్ ~}_{\tilde{J}}^{w}$ & $\breve{J ̆}^{w}$ & \begin{tabular}{l}
\multirow{I}{*}{} \\
$\stackrel{8}{8}$
\end{tabular} & \begin{tabular}{l}
\multirow{1}{*}{} \\
ठ \\
8
\end{tabular} & \begin{tabular}{l}
\multirow{1}{*}{} \\
$\stackrel{0}{8}$
\end{tabular} & \begin{tabular}{l}
\multirow{H}{\circ}{} \\
$\stackrel{8}{ }$
\end{tabular} & 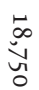 & 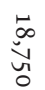 & $\begin{array}{l}\vec{\infty} \\
8 \\
8\end{array}$ & $\begin{array}{l}+\infty \\
0 \\
8 \\
0\end{array}$ & $\begin{array}{l}+\infty \\
\infty \\
8 \\
8\end{array}$ & $\begin{array}{l}+\infty \\
\infty \\
\&\end{array}$ & $\begin{array}{l}\infty \\
\circ \\
\circ\end{array}$ & $\begin{array}{l}\infty \\
\infty \\
\circ \\
\&\end{array}$ & $\begin{array}{l}\infty \\
\circ \\
\circ\end{array}$ & $\begin{array}{l}\infty \\
\infty \\
\circ \\
8\end{array}$ & 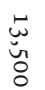 & 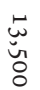 & $\begin{array}{l}\sigma_{0} \\
\stackrel{8}{\circ}\end{array}$ & $\begin{array}{l}\infty \\
\infty \\
\vdots\end{array}$ & $\begin{array}{l}\text { ज్ } \\
\text { ᄋ }\end{array}$ \\
\hline
\end{tabular}

Figure 6-25. Shorebird population objectives (acres) for the Delta Planning Region.

Table 6-22. Foraging habitats (acres) available to wintering shorebirds in the Delta Planning Region.

\begin{tabular}{|ccc|}
\hline $\begin{array}{c}\text { Seasonal } \\
\text { Wetland }\end{array}$ & $\begin{array}{c}\text { Semi-Permanent } \\
\text { Wetland }\end{array}$ & $\begin{array}{c}\text { Winter Flooded } \\
\text { Rice }\end{array}$ \\
\hline 14,907 & 2,633 & 8,027 \\
\hline
\end{tabular}

Figure 6-26 depicts the relationship between shorebird population objectives and the availability of seasonally flooded wetlands and winter flooded rice. Semi-permanent wetlands are assumed to provide shorebird habitat from July 1 to July 15 when they are typically drawn down and likely to provide foraging habitat $<10 \mathrm{~cm}$ in depth. Seasonal wetlands provide no habitat prior to the August 23 interval when flooding of these wetlands in the Delta Planning Region typically begins. However, drawdown of semipermanent wetlands in early July likely provides some foraging habitat between July 1 and July 15 . Increases in the amount of seasonal wetlands generally track increases in shorebird numbers in this region from late August through February. Although declines in shorebird numbers correspond to a decline in seasonal wetland acres between late March and May, the amount of foraging habitat is likely increasing during this period as drawdowns increase the numbers of acres $<10 \mathrm{~cm}$ in depth. (Figure 6-26). Winter flooded rice provides no foraging habitat prior to the October 7 interval. However, rice provides large amounts of potential habitat from November through March when shorebird populations in this region reach their peak. 


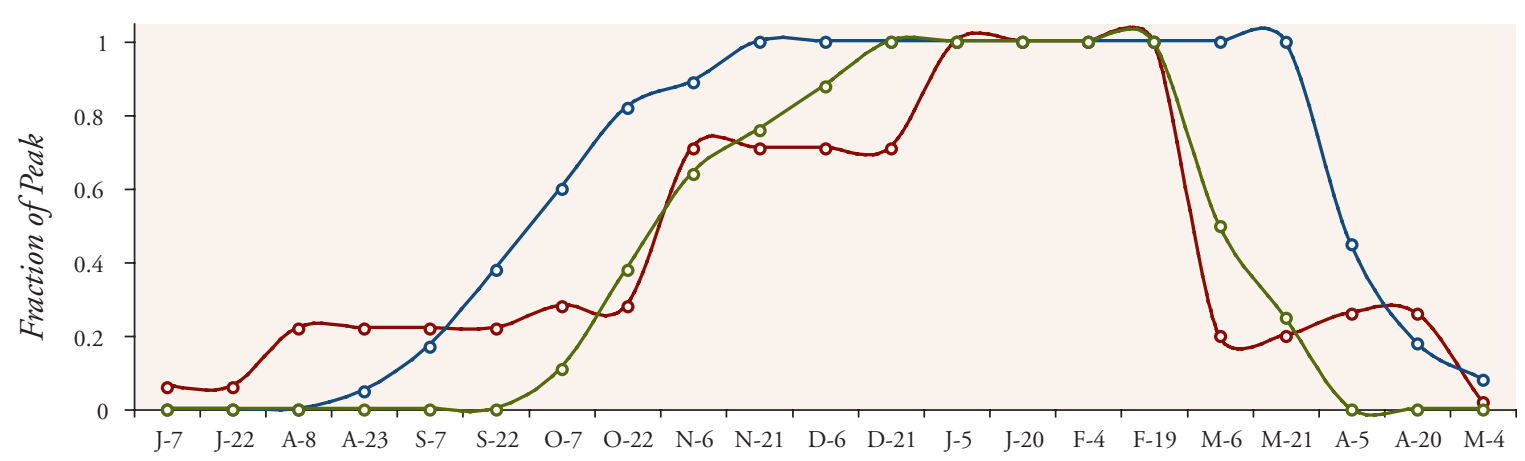

Figure 6-26. Shorebird population objectives (red) vs. flooding schedules for managed seasonal wetlands (blue) and rice (green) for the Delta Planning Region. Shorebird population objectives are expressed as the fraction of peak population; wetlands and rice are expressed as the fraction of these habitats that are flooded.

\section{Management of Existing Seasonal and Semi-Permanent Wetlands}

\section{Summer Flooding Period (July 1-August 15)}

Shorebirds require 85 acres of foraging habitat in both the July 7 and July 22 intervals, with habitat needs increasing to 340 acres in the August 8 interval (Table 6-23). All habitat requirements during the Summer Flooding Period must be met from managed wetlands, as no winter flooded rice is available.

Table 6-23. Habitat objectives for shorebirds in the Delta Planning Region during the Summer Flooding Period.

\begin{tabular}{|cc|} 
Interval & $\begin{array}{c}\text { Habitat Objective } \\
\text { (Acres) }\end{array}$ \\
\hline J-7 (JulY 1-JulY 15) & 85 \\
J-22 (JULY 16-JULY 31) & 85 \\
\hline A-8 (AUg 1-AUg 16) & 340 \\
\hline TotaL & 510 \\
\hline
\end{tabular}

Semi-permanent wetlands may provide the best opportunity to meet shorebird needs in July. The Delta Planning Region contains over 2,600 acres of semi-permanent wetlands. If all these wetlands are drawn down between July 1 and July 15, the required depth ratio for these semi-permanent habitats is $3 \%$ (i.e., 85 of the 2,633 acres must provide water depths $<10 \mathrm{~cm}$ to meet shorebird needs in the July 7 interval). Semi-permanent public wetlands alone $(945$ acres) can meet shorebird needs in the July 7 interval if $9 \%$ of these habitats provide suitable water depths during drawdown. If all 8,968 acres of semi-permanent wetlands are drawn down by mid-July, no opportunity exists to meet shorebird needs in the July 22 interval using these habitats. Delaying the drawn down of some semipermanent wetlands until late July could help meet the 85 acres of habitat needed by shorebirds in the July 22 interval.

Population energy demand estimates for shorebirds indicate that 340 acres of wetland habitat are required during the August 8 interval. There are currently no seasonal wetlands flooded in the region during the first two weeks of August, and all semi-permanent wetlands are assumed to be dry by this time. The 340 acres of wetlands needed by shorebirds during this interval could be met through early flooding of seasonal wetlands. These 340 acres represent $2 \%$ of existing seasonal wetlands in the region, and $6 \%$ of all public seasonal wetlands.

\section{Fall Flooding Period (August 17-November 29)}

Habitat needs of shorebirds in the Fall Flooding Period range from 340 acres in the August and September intervals, to nearly 1,300 acres in the January and February intervals (Table 6-24). 
Table 6-24. Overall habitat needs for shorebirds in the Delta Planning Region during the Fall Flooding Period.

\begin{tabular}{|cc|} 
Interval & $\begin{array}{c}\text { Habitat } \\
\text { Objective (Acres) }\end{array}$ \\
\hline A-23 (AUG 17-AUG 31) & 340 \\
S-7 (SEPT 1-SEPT 15) & 340 \\
S-22 (SEPT 16-SEPT 30) & 340 \\
O-7 (OCT 1-OCT 15) & 424 \\
O-22 (OCT 16-OCT 30) & 424 \\
N-6 (OCT 31-NOV 14) & 936 \\
N-21 (Nov 15-Nov 29) & 936 \\
TotAL & 3,740 \\
\hline
\end{tabular}

Because winter flooded rice is unavailable prior to October, shorebird needs must be met entirely from seasonal wetland habitats in the August and September intervals. Beginning in October, seasonal wetland objectives decline to $50 \%$ of interval habitat needs, as rice is assumed to meet half of all shorebird needs (Table 6-25).

Table 6-25. Seasonal wetland objectives (acres) for shorebirds in the Delta Planning Region during the Fall Flooding Period.

\begin{tabular}{|c|c|c|c|c|}
\hline Interval & $\begin{array}{l}\text { SW Interval } \\
\text { Objective }\end{array}$ & $\begin{array}{c}\text { Cumulative SW } \\
\text { Objective }\end{array}$ & Flooded SWs ${ }^{b}$ & $\begin{array}{c}\text { Required Depth } \\
\text { Ratio }\end{array}$ \\
\hline A-23 (AUg 17-AUg 31) & 340 & 680 & 745 & 91 \\
\hline S-7 (SEPT 1-SEPT 15) & 340 & 1,020 & 2,534 & 40 \\
\hline S-22 (SEPT 16-SEPT 30) & 340 & 1,360 & 5,665 & 24 \\
\hline О-7 (Ост 1-Ост 15) & 212 & 1,572 & 8,944 & 18 \\
\hline О-22 (Ост 16-Ост 30) & 212 & 1,784 & 12,224 & 15 \\
\hline N-6 (Ост 31-Nov 14) & 468 & 2,252 & 13,268 & 17 \\
\hline N-21 (Nov 15-Nov 29) & 468 & 2,720 & 14,907 & 18 \\
\hline Total & 2,380 & & & \\
\hline
\end{tabular}

SW-Seasonal Wetland.

"Includes SW objectives from previous flooding periods.

${ }^{b}$ Flooded SWs reflect flooding schedules within a shorebird planning region.

${ }^{c}$ Cumulative SW Objective/Flooded SWs.

Although the total seasonal wetland objective of 2,380 acres is staggered over seven 15-day intervals, it is possible to front-end this overall habitat objective. For example, seasonal wetland objectives for shorebirds could be met in the Fall Flooding Period by providing 2,380 acres during the August 23 interval and maintaining these acres at a depth $<10 \mathrm{~cm}$ through the end of November (Figure 6-27).

Seasonal wetlands become increasingly available from August through November, as these habitats are flooded prior to the hunting season. This increase in seasonal wetlands is reflected in the required depth ratio, which declines from August through October (Figure 6-28).

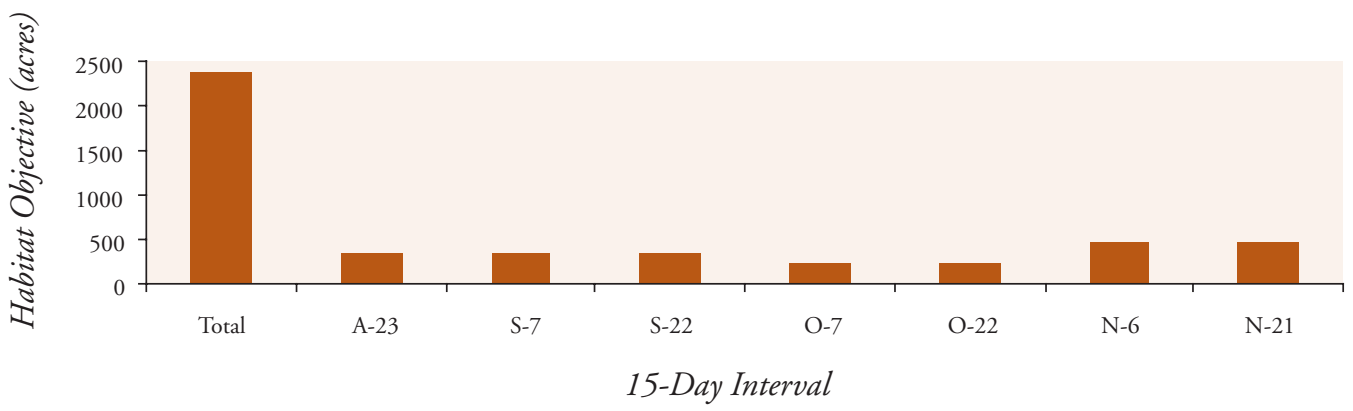

Figure 6-27. Seasonal wetland objectives for shorebirds in the Fall Flooding Period by 15-day intervals for the Delta Planning Region. 


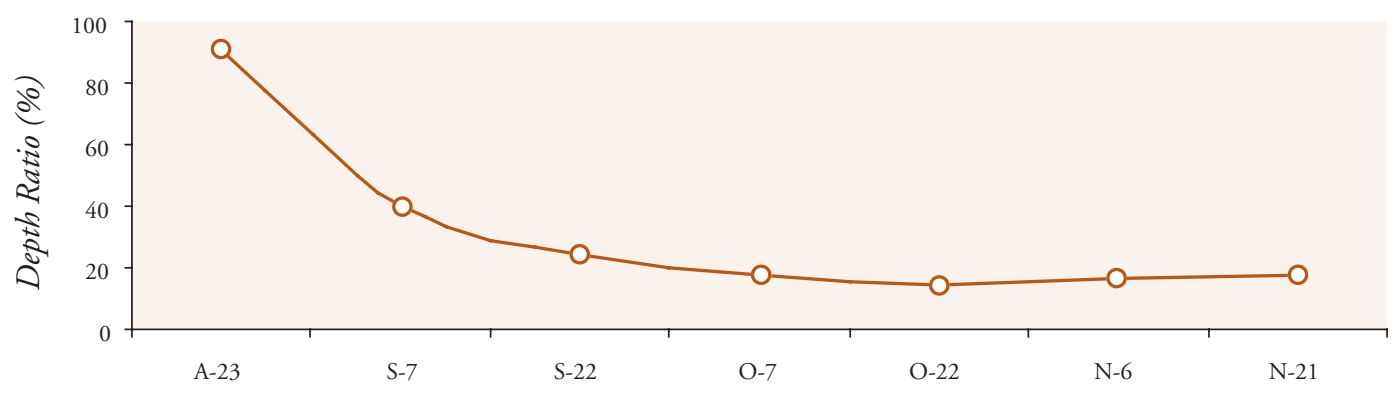

15-Day Interval

Figure 6-28. Changes in the required depth ratio for seasonal wetlands in the Fall Flooding Period for the Delta Planning Region.

\section{Winter Flooding Period (November 30-March 29)}

Habitat needs for shorebirds in the Winter Flooding Period range from nearly 1,300 acres in the December intervals, to 300 acres in March intervals (Table 6-26). Fifty percent of these habitat needs must be met from seasonal wetlands, with the balance being provided by winter flooded rice (Table 6-27). The overall seasonal wetland objective for the Winter Flooding Period is 3,782 acres. Although this wetland objective is staggered over several 15 -day intervals, it is possible to front-end this conservation objective. For example, seasonal wetland objectives for shorebirds could be met in the Winter Flooding Period by providing 3,782 acres during the December 6 interval and maintaining these acres at a depth $<10 \mathrm{~cm}$ through the end of March (Figure 6-29).

As expected, the required depth ratio increases through the Winter Flooding Period as no new wetlands are being flooded and shorebirds deplete food resources on seasonal wetland acres that are managed $<10 \mathrm{~cm}$ in depth (Figure 6-30).
Table 6-26. Overall habitat needs for shorebirds in the Delta Planning Region during the Winter Flooding Period.

\begin{tabular}{|cc|} 
Interval & $\begin{array}{c}\text { Habitat } \\
\text { Objective (Acres) }\end{array}$ \\
\hline D-6 (Nov 30-DEC 14) & 936 \\
D-21 (DEC 15-DEC 29) & 936 \\
J-5 (DEC 30-JAN 13) & 1,272 \\
J-20 (JAN 14-JAN 28) & 1,272 \\
F-4 (JAN 29-FEB 12) & 1,272 \\
F-19 (FEB 13-FEB 27) & 1,272 \\
M-6 (FEB 28-MAR 14) & 301 \\
M-21 (MAR 15-MAR 29) & 301 \\
TotAL & 7,562 \\
\hline
\end{tabular}

Table 6-27. Seasonal wetland objectives (acres) for shorebirds in the Delta Planning Region during the Winter Flooding Period.

\begin{tabular}{|c|c|c|c|c|}
\hline Interval & $\begin{array}{c}\text { SW Interval } \\
\text { Objective }\end{array}$ & $\begin{array}{c}\text { Cumulative SW } \\
\text { Objective }\end{array}$ & $\begin{array}{l}\text { Flooded }^{b} \\
\text { SWs }\end{array}$ & $\begin{array}{c}\text { Required Depth } \\
\text { Ratio }\end{array}$ \\
\hline D-6 (Nov 30-DeC 14) & 468 & 3,188 & 14,907 & 21 \\
\hline D-21 (Dec 15-Dec 29) & 468 & 3,656 & 14,907 & 25 \\
\hline J-5 (DEC 30-JAN 13) & 636 & 4,292 & 14,907 & 29 \\
\hline J-20 (JAN 14-JAN 28) & 636 & 4,928 & 14,907 & 33 \\
\hline F-4 (JAN 29-FEB 12) & 636 & 5,564 & 14,907 & 37 \\
\hline F-19 (FeB 13-FeB 27) & 636 & 6,200 & 14,907 & 42 \\
\hline M-6 (FeB 28-MAR 14) & 151 & 6,351 & 14,907 & 43 \\
\hline M-21 (MAR 15-MAR 29) & 151 & 6,502 & 14,907 & 44 \\
\hline TotaL & 3,782 & 6,502 & 14,907 & \\
\hline
\end{tabular}

SW-Seasonal Wetland.

"Includes SW objectives from previous flooding periods.

${ }^{b}$ Flooded SWs reflect flooding schedules within a shorebird planning region.

'Cumulative SW Objective/Flooded SWs. 


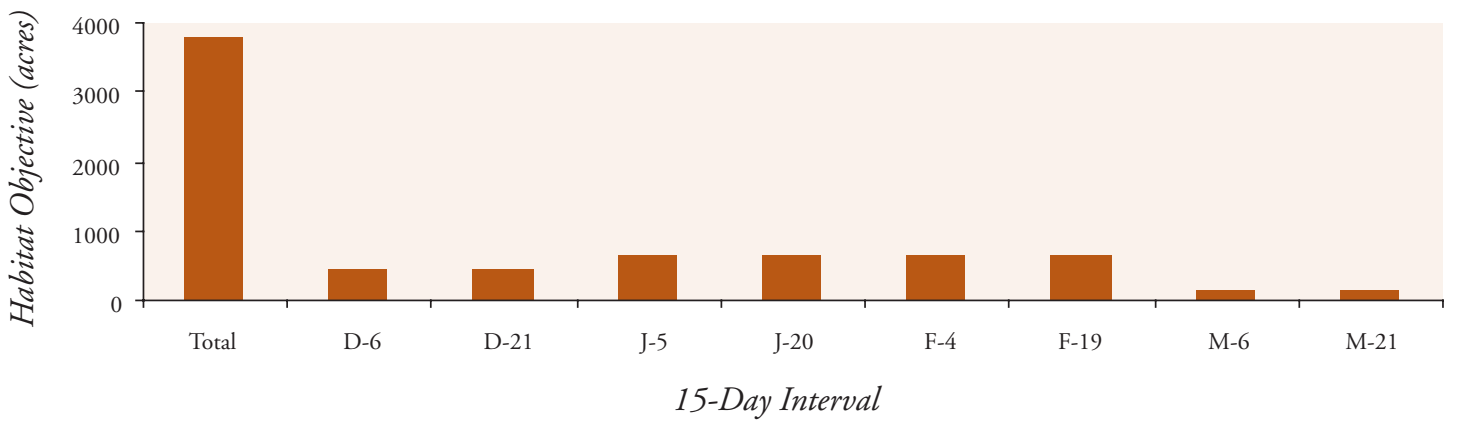

Figure 6-29. Seasonal wetland objectives for shorebirds in the Winter Flooding Period by 15-day intervals for the Delta Planning Region.

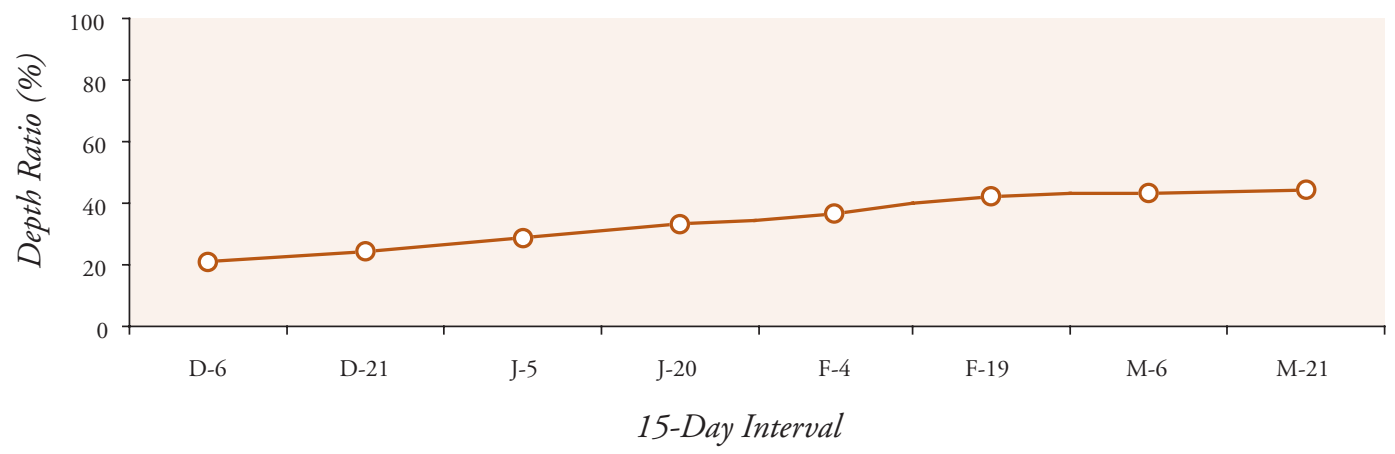

Figure 6-30. Changes in the required depth ratio for seasonal wetlands in the Winter Flooding Period for the Delta Planning Region.

\section{Spring Flooding Period (March 30-May 12)}

Habitat needs for shorebirds in the Spring Flooding Period range from 402 acres in each of the April intervals, to 28 acres in May. Shorebird needs must be met exclusively by seasonal wetlands as rice fields are assumed to be dry by this time (Table 6-28). The summed seasonal wetland objective for the Spring Flooding Period is nearly 832 acres, with most of these acres needed in the April intervals (Figure 6-31).

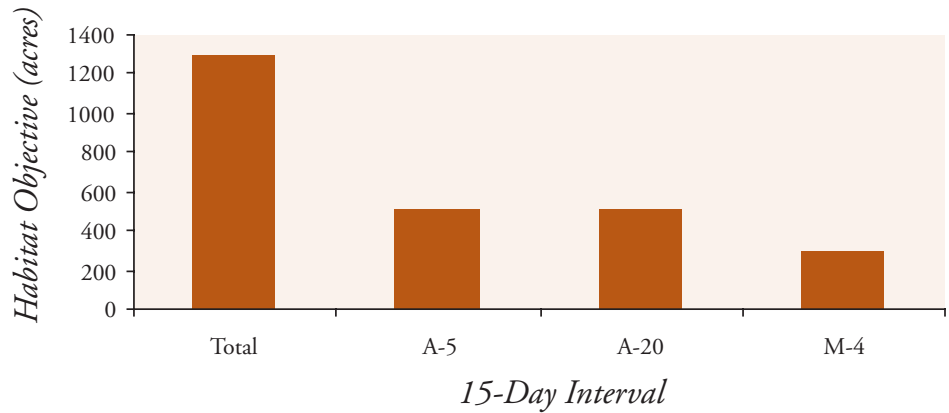

Figure 6-31. Seasonal wetland objectives for shorebirds in the Delta Planning Region during the Spring Flooding Period by 15-day intervals. 


\section{Water Supplies for Wetland Management}

Additional water supplies that are needed for shorebirds are based on seasonal wetland needs in the August 8 interval (see earlier description for establishing water supply objectives). Seasonal wetland objectives for shorebirds in the Delta Planning Region during the August 8 interval are estimated at 340 acres. This equates to a water supply need of 680 acre-feet.
Table 6-28. Seasonal wetland objectives (acres) for shorebirds in the Delta Planning Region during the Spring Flooding Period.

\begin{tabular}{|cccc|}
\hline Interval & $\begin{array}{c}\text { SW Interval } \\
\text { Objective }\end{array}$ & $\begin{array}{c}\text { Cumulative } \\
\text { SW Objective }\end{array}$ & Flooded SWs \\
\hline A-5 (MAR 30-APR 13) & 402 & 6,904 & 14,907 \\
\hline A-20 (APR 14-APR 28) & 402 & 7,306 & 4,696 \\
M-4 (APR 29-MAY 10) & 28 & 7,334 & 1,938 \\
\hline TotAL & $\mathbf{8 3 2}$ & 7,334 & \\
\hline
\end{tabular}

\section{Agricultural Enhancement}

Habitat objectives for flooded rice in the Delta Planning Region range from just under 1,000 acres in the October intervals, to nearly 2,000 acres throughout March (Table 6-29). Although the total agricultural enhancement objective is staggered over several 15-day intervals, it is possible to front-end this objective. For example, rice habitat objectives could be met by providing 5,142 acres during the October 7 interval and maintaining these acres at a depth $<10 \mathrm{~cm}$ through the end of March (Figure 6-32). The required depth ratio for rice habitat increases from October through March, and reflects the relatively small amount of rice grown in the region (Figure 6-33).

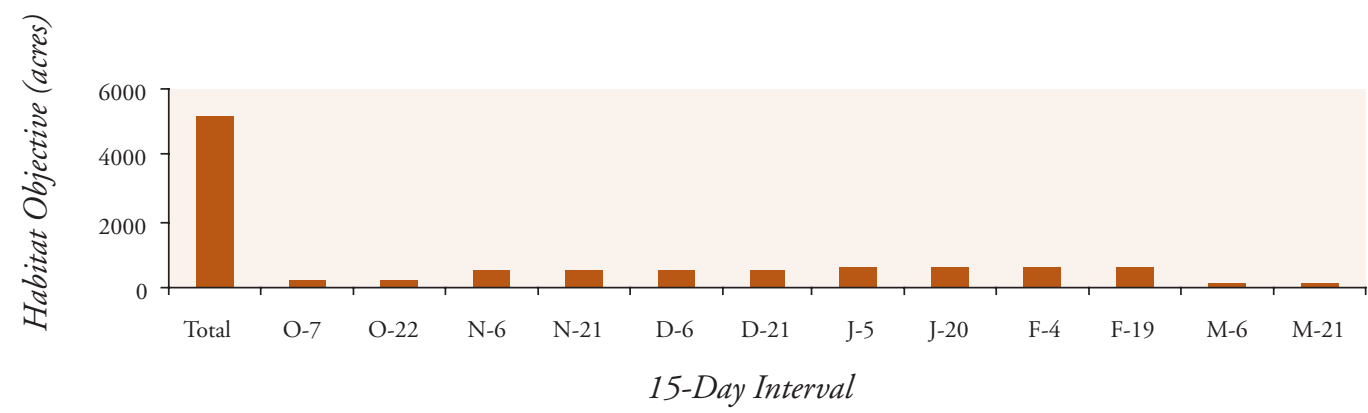

Figure 6-32. Rice habitat objectives for shorebirds by 15-day intervals in the Delta Planning Region.

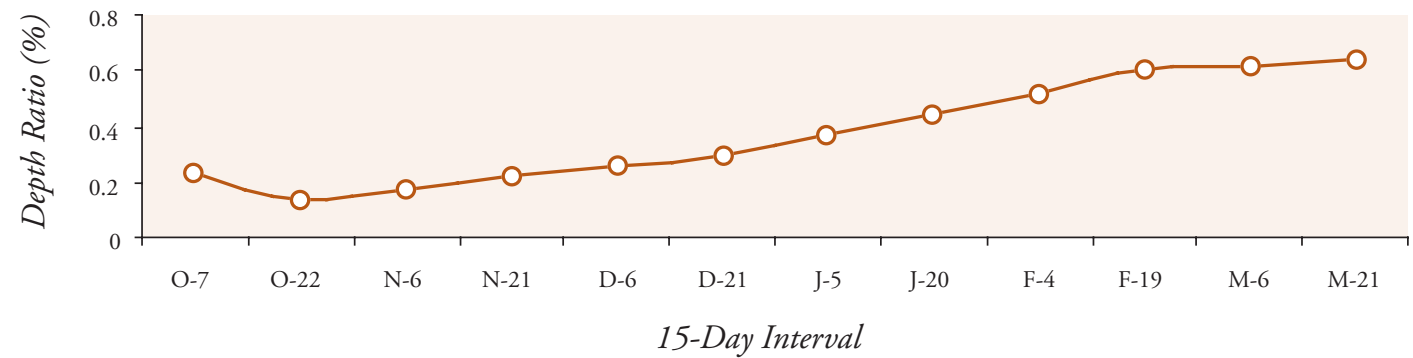

Figure 6-33. Changes in the required depth ratio for rice habitat in the Delta Planning Region. 


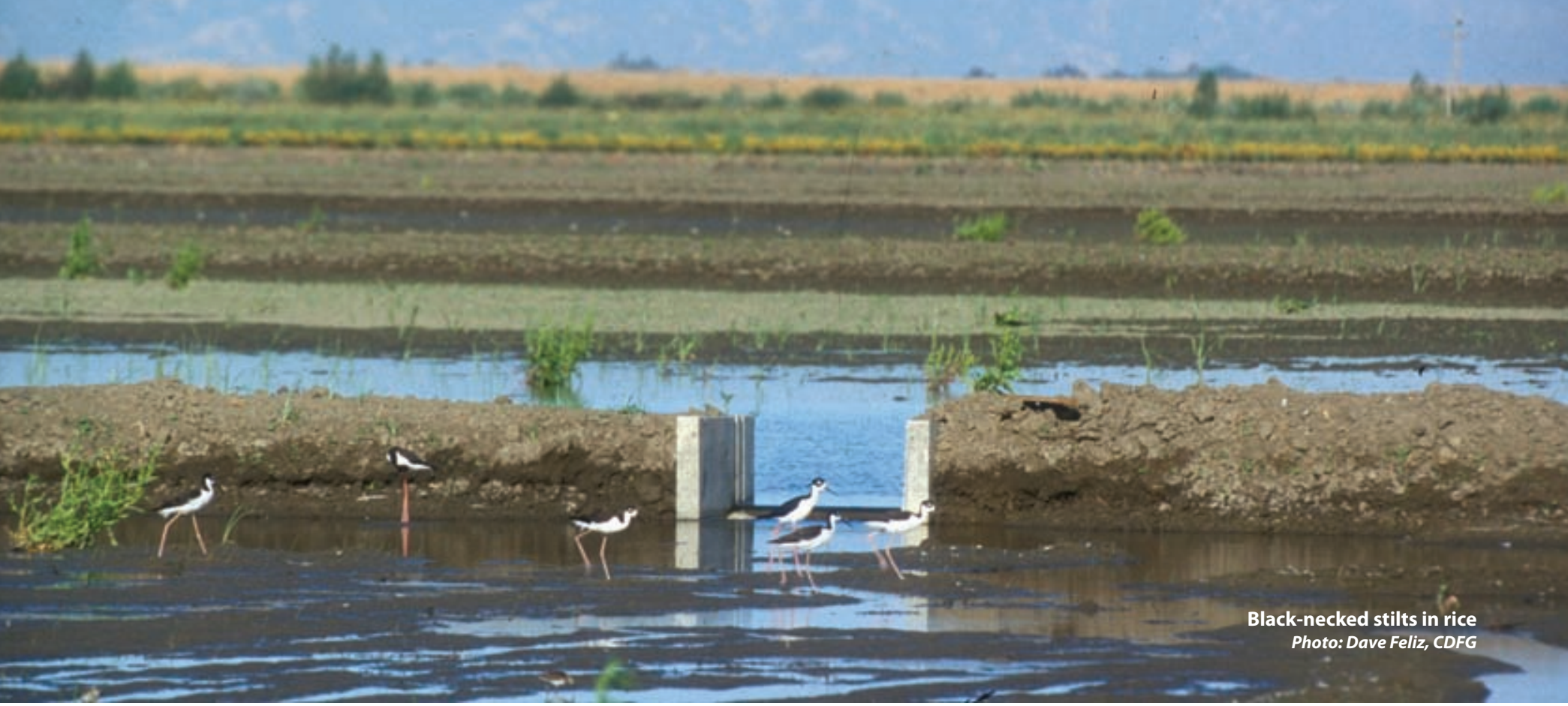

Table 6-29. Rice habitat objectives (acres) for shorebirds between early October and the end of March in the Delta Planning Region.

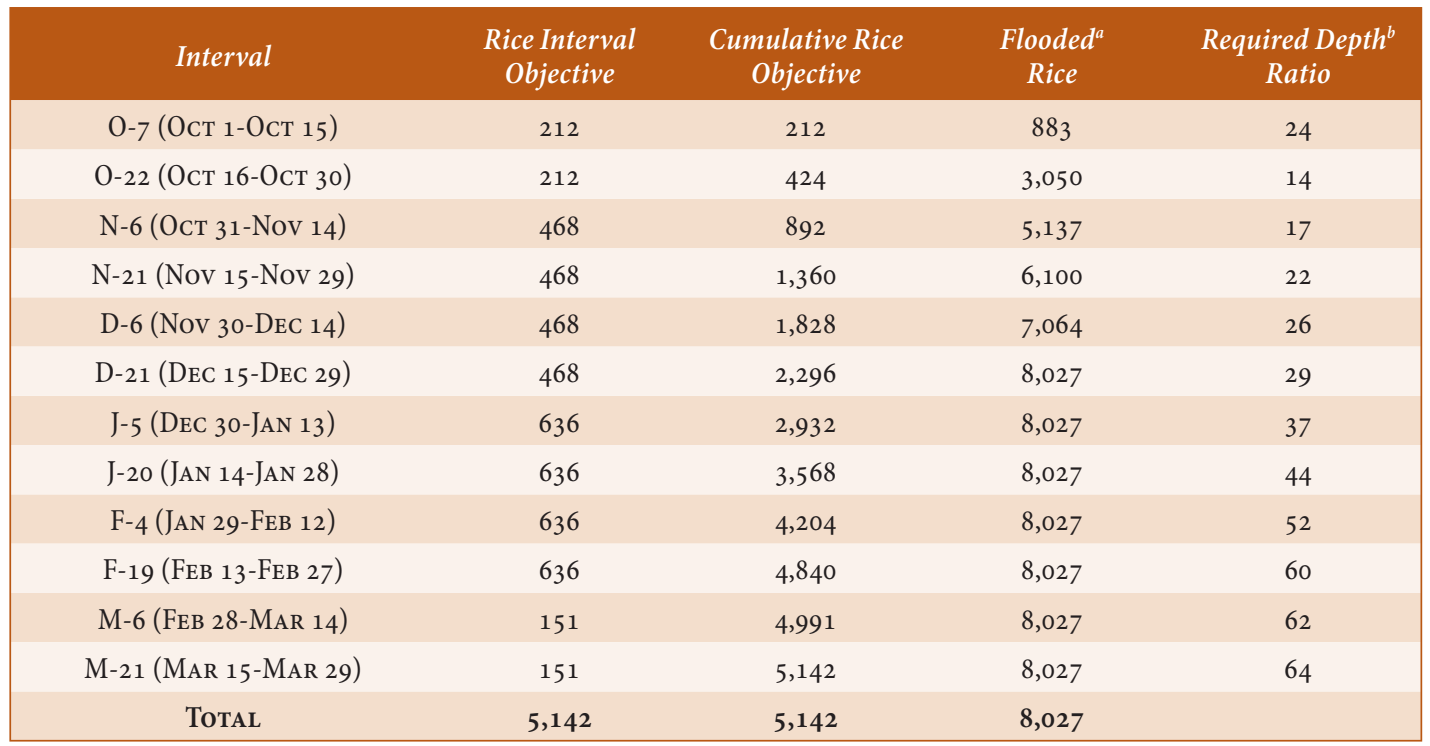

"Flooded Rice reflects post-harvest flooding schedules of rice.

${ }^{b}$ Cumulative Rice Objective/Flooded Rice.

\section{Summary}

Conservation objectives for managed seasonal and semi-permanent wetlands, water supplies, and agricultural enhancement are summarized for the Delta Planning Region in Table 6-30. Nearly 50\% of the seasonal wetlands present in this region (7,334/14,907 acres) must provide foraging depths $<10 \mathrm{~cm}$ during some portion of the wintering period if seasonal wetland objectives for shorebirds are to be met. This figure is even higher for rice, where $64 \%$ of all winter flooded rice $(5,142 / 8,027$ acres) must provide suitable foraging depths during some portion of the wintering period to meet agricultural enhancement objectives for this region. 
Table 6-30. Conservation Objectives for non-breeding shorebirds in the Delta Planning Region.

\begin{tabular}{|c|c|c|c|c|}
\hline Interval & $\begin{array}{c}\text { Seasonal } \\
\text { Wetlands (Acres) }\end{array}$ & $\begin{array}{c}\text { Semi-Perm. } \\
\text { Wetlands (Acres) }\end{array}$ & Water (Acre-Feet) & $\begin{array}{c}\text { Winter Flooded } \\
\text { Rice (Acres) }\end{array}$ \\
\hline J-7 (JULY 1-JULY 15) & 0 & 85 & 0 & 0 \\
\hline J-22 (July 16-July 31) & 0 & 85 & 0 & 0 \\
\hline A-8 (Aug 1-Aug 16) & 340 & 0 & 680 & 0 \\
\hline A-23 (Aug 17-Aug 31) & 340 & 0 & 0 & 0 \\
\hline S-7 (SEPT 1-SEPT 15) & 340 & 0 & 0 & 0 \\
\hline S-22 (SEPT 16-SEPT 30) & 340 & 0 & 0 & 0 \\
\hline O-7 (Ост 1-Ост 15) & 212 & 0 & 0 & 212 \\
\hline О-22 (Ост 16-Ост 30) & 212 & 0 & 0 & 212 \\
\hline N-6 (Oct 31-Nov 14) & 468 & 0 & 0 & 468 \\
\hline N-21 (Nov 15-Nov 29) & 468 & 0 & 0 & 468 \\
\hline D-6 (Nov 30-DeC 14) & 468 & 0 & 0 & 468 \\
\hline D-21 (DeC 15-Dec 29) & 468 & 0 & 0 & 468 \\
\hline J-5 (DEC 30-JAN 13) & 636 & 0 & 0 & 636 \\
\hline J-20 (JAN 14-JAN 28) & 636 & 0 & 0 & 636 \\
\hline F-4 (JAN 29-FEB 12) & 636 & 0 & 0 & 636 \\
\hline F-19 (FeB 13-FeB 27) & 636 & 0 & 0 & 636 \\
\hline M-6 (FEB 28-MAR 14) & 151 & 0 & 0 & 151 \\
\hline M-21 (MAR 15-MAR 29) & 151 & 0 & 0 & 151 \\
\hline A-5 (MAR 30-APR 13) & 402 & 0 & 0 & 0 \\
\hline A-20 (APR 14-APR 28) & 402 & & 0 & 0 \\
\hline M-4 (APR 29-MAY 10) & 28 & & 0 & 0 \\
\hline ToTAL & 7,334 & 170 & 680 & 5,142 \\
\hline
\end{tabular}

\section{San Joaquin Basin}

\section{Current Conditions}

Population objectives for migrating and wintering shorebirds in the San Joaquin Basin are presented in Figure 6-34. Population objectives are highest in April, with shorebird numbers reaching a minimum in July. Seasonal wetlands provide the majority of foraging habitat, as no winter flooded rice is available in the basin (Table 6-31). 


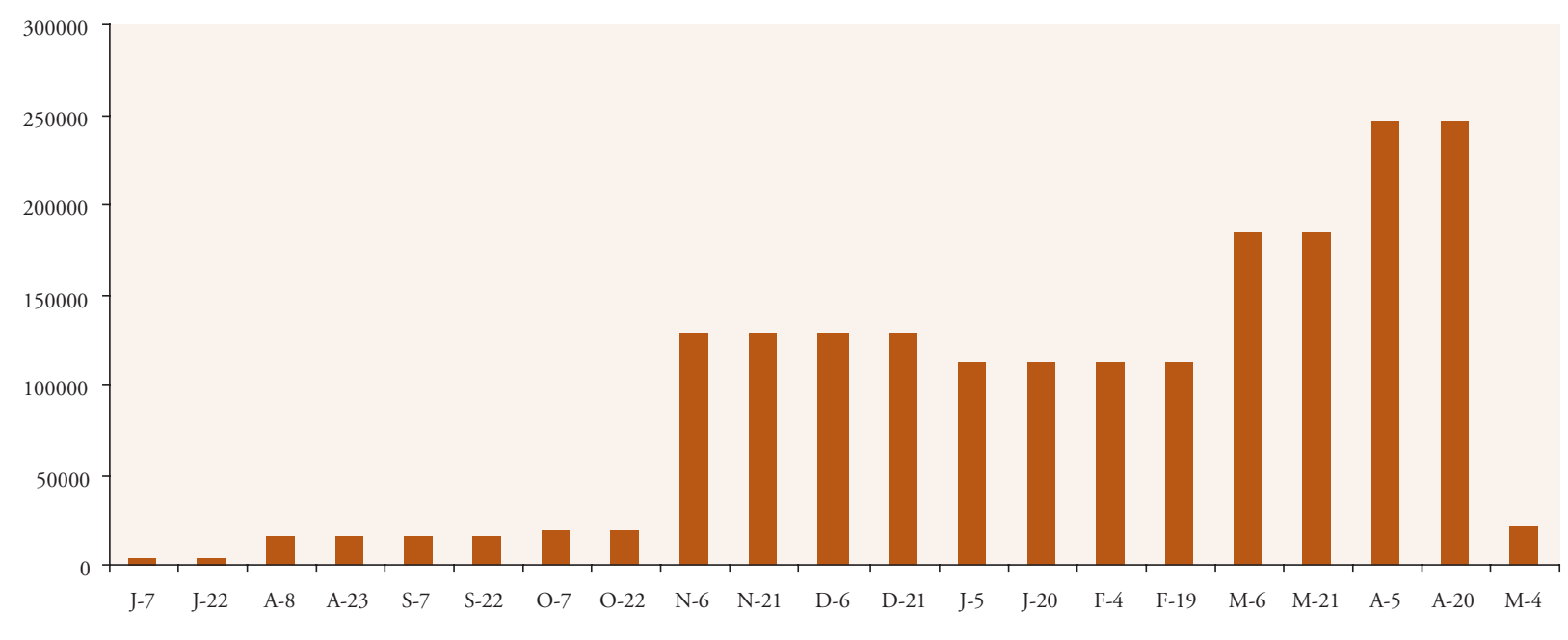

15-Day Interval

\begin{tabular}{|c|c|c|c|c|c|c|c|c|c|c|c|c|c|c|c|c|c|c|c|c|}
\hline $\bar{G}$ & $\underset{\substack{\vec{G} \\
\mathbb{N}}}{\vec{N}}$ & 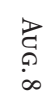 & $\begin{array}{l}\vec{c} \\
\stackrel{i}{i} \\
\text { d }\end{array}$ & 䍖 & 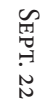 & 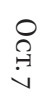 & 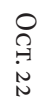 & 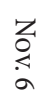 & 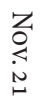 & 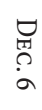 & $\begin{array}{l}\stackrel{g}{\mathrm{H}} \\
\stackrel{i}{\mathrm{~N}}\end{array}$ & 丞 & $\begin{array}{l}\overrightarrow{s_{2}} \\
\dot{\tilde{o}}\end{array}$ & 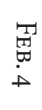 & 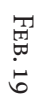 & 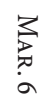 & 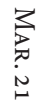 & 宽 & $\begin{array}{l}\text { 常 } \\
\text { N }\end{array}$ & $\underset{+}{3}$ \\
\hline$\underset{v}{\sim}$ & $\begin{array}{l}\breve{w}_{0} \\
\text { I }\end{array}$ & 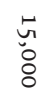 & $\begin{array}{l}\stackrel{5}{n} \\
\stackrel{2}{\circ}\end{array}$ & $\begin{array}{l}\breve{s} \\
\stackrel{\circ}{\circ}\end{array}$ & 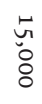 & $\begin{array}{c}\vec{D}_{0}^{\infty} \\
\vec{J}^{\prime}\end{array}$ & $\begin{array}{c}\vec{D}_{0}^{\infty} \\
\vec{J}^{\prime}\end{array}$ & $\begin{array}{l}\vec{N} \\
\infty \\
\& \\
\&\end{array}$ & $\begin{array}{l}\text { D } \\
\infty \\
\vdots \\
0\end{array}$ & $\begin{array}{l}\tilde{N} \\
\infty \\
0 \\
0\end{array}$ & $\begin{array}{l}\vec{N} \\
\infty \\
0 \\
0\end{array}$ & $\begin{array}{l}\vec{D} \\
\stackrel{0}{\circ}\end{array}$ & $\begin{array}{l}\vec{D} \\
\stackrel{0}{\circ} \\
8\end{array}$ & $\begin{array}{l}\vec{H} \\
\stackrel{N}{0} \\
\stackrel{0}{0}\end{array}$ & $\begin{array}{l}\vec{N} \\
\stackrel{N}{\circ} \\
\stackrel{8}{*}\end{array}$ & $\begin{array}{l}\vec{\infty} \\
\text { ثే } \\
\stackrel{8}{\circ}\end{array}$ & 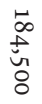 & $\begin{array}{l}\text { N } \\
\hat{a} \\
\stackrel{8}{8}\end{array}$ & $\begin{array}{l}\text { N } \\
\hat{a} \\
\stackrel{8}{8}\end{array}$ & $\begin{array}{l}\text { No } \\
\text { Un } \\
\text { \& }\end{array}$ \\
\hline
\end{tabular}

Figure 6-34. Shorebird population objectives for the San Joaquin Basin.

Table 6-31. Foraging habitats (acres) available to wintering shorebirds in San Joaquin Basin.

\begin{tabular}{|ccc|}
$\begin{array}{c}\text { Seasonal } \\
\text { Wetland }\end{array}$ & $\begin{array}{c}\text { Semi-Permanent } \\
\text { Wetland }\end{array}$ & $\begin{array}{c}\text { Winter } \\
\text { Flooded Rice }\end{array}$ \\
\hline 61,013 & 6,779 & 0 \\
\hline
\end{tabular}

Figure 6-35 depicts the relationship between shorebird population objectives and the availability of seasonally flooded wetlands. Semi-permanent wetlands are assumed to provide shorebird habitat from July 1 to July 15 when they are typically drawn down and likely to provide foraging habitat $<10 \mathrm{~cm}$ in depth. Seasonal wetlands provide no habitat prior to the August 23 interval when flooding of these wetlands in the San Joaquin Basin typically begins. However, drawdown of semi-permanent wetlands in early July likely provides some foraging habitat between July 1 and July 15. Increases in the amount of seasonal wetlands track increases in shorebird numbers from late August to early November. Shorebird numbers increase during April, when seasonal wetlands are being drawn down and the amount of foraging habitat $<10 \mathrm{~cm}$ deep is likely increasing.

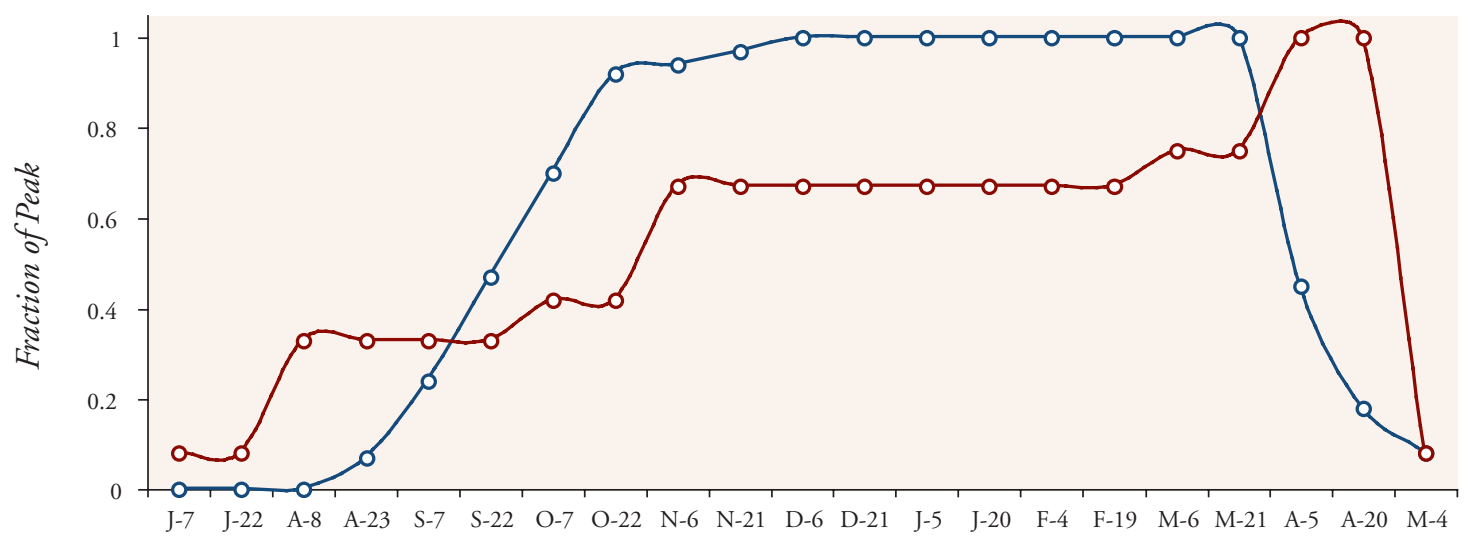

Figure 6-35. Shorebird population objectives (red) vs. flooding schedules for managed seasonal wetlands (blue) for the San Joaquin Basin. Shorebird population objectives are expressed as the fraction of peak population; wetlands are expressed as the fraction of seasonal wetlands that are flooded. 


\section{Management of Existing Seasonal and Semi-Permanent Wetlands}

\section{Summer Flooding Period (July 1-August 15)}

Shorebirds require less than 100 acres of foraging habitat in both the July intervals, with habitat needs increasing to 340 acres in the August 8 interval (Table 6-32). Semipermanent wetlands provide the best opportunity to meet shorebird needs in July. The San Joaquin Basin contains nearly 6,800 acres of semi-permanent wetlands, of which 1,573 acres are publicly owned (Table 6-31). If all semi-permanent wetlands are drawn down between July 1 and July 15, only $1 \%$ of these acres must provide water depths $<10$ $\mathrm{cm}$ deep to meet shorebird needs in the July 7 interval. Semi-permanent public wetlands alone can meet shorebird needs in the July 7 interval even if only $5 \%$ of these habitats provide suitable water depths during drawdown. If all semi-permanent wetlands are drawn down by mid-July, there is no opportunity for these habitats to meet shorebird needs in the July 22 interval. Delaying the drawdown of some of these habitats until late July could help meet shorebird needs in the July 22 interval.

Shorebirds require 340 acres of foraging habitat in the August 8 interval. There are currently no seasonal wetlands flooded in the San Joaquin Basin during the first two weeks of August, and all semi-permanent wetlands are assumed to be dry. The 340 acres needed by shorebirds could be met through early flooding of seasonal wetlands. These 340 acres represent less than $0.1 \%$ of existing seasonal wetlands in the basin.

\section{Fall Flooding Period (August 17-November 29)}

Habitat needs for shorebirds in the Fall Flooding Period range from 340 acres in the September intervals, to nearly 2,500 acres in November (Table 6-33). Shorebird needs in the Fall Flooding Period must be met exclusively from seasonal wetlands, as no winter flooded rice is available.

Table 6-33. Seasonal wetland objectives (acres) for shorebirds in San Joaquin Basin during the Fall Flooding Period.

\begin{tabular}{|c|c|c|c|c|}
\hline Interval & $\begin{array}{c}\text { SW Interval } \\
\text { Objective }\end{array}$ & $\begin{array}{c}\text { Cumulative SW } \\
\text { Objective }\end{array}$ & Flooded SWs ${ }^{b}$ & $\begin{array}{c}\text { Required }^{c} \text { Depth } \\
\text { Ratio }\end{array}$ \\
\hline A-23 (Aug 17-Aug 31) & 340 & 680 & 4,271 & 16 \\
\hline S-7 (SEPT 1-SEPT 15) & 340 & 1,020 & 14,643 & 7 \\
\hline S-22 (SEPT 16-SEPT 30) & 340 & 1,360 & 28,676 & 5 \\
\hline O-7 (Ост 1-Ост 15) & 424 & 1,784 & 42,709 & 4 \\
\hline О-22 (Ост 16-Ост 30) & 424 & 2,208 & 56,132 & 4 \\
\hline N-6 (Oст 31-Nov 14) & 2,497 & 4,705 & 56,132 & 8 \\
\hline N-21 (Nov 15-Nov 29) & 2,497 & 7,202 & 59,183 & 12 \\
\hline TотAL & 6,862 & 7,202 & & \\
\hline
\end{tabular}

SW-Seasonal Wetland.

ancludes SW objectives from previous flooding periods.

${ }^{b}$ Flooded SWs reflect flooding schedules within a shorebird planning region.

${ }^{c}$ Cumulative SW Objective/Flooded SWs.

Although the summed seasonal wetland objective of 6,862 acres is staggered over seven 15-day intervals, it is possible to front-end this overall habitat objective. For example, seasonal wetland objectives for shorebirds could be met in the Fall Flooding Period by providing 6,862 acres during the August 23 interval and maintaining these acres at a depth $<10 \mathrm{~cm}$ through the end of November (Figure 6-36).

Seasonal wetlands become increasingly available from August through November as these habitats are flooded prior to the hunting season. This increase in seasonal wetlands is reflected in the required depth ratio, which declines from August through October (Figure 6-37). 


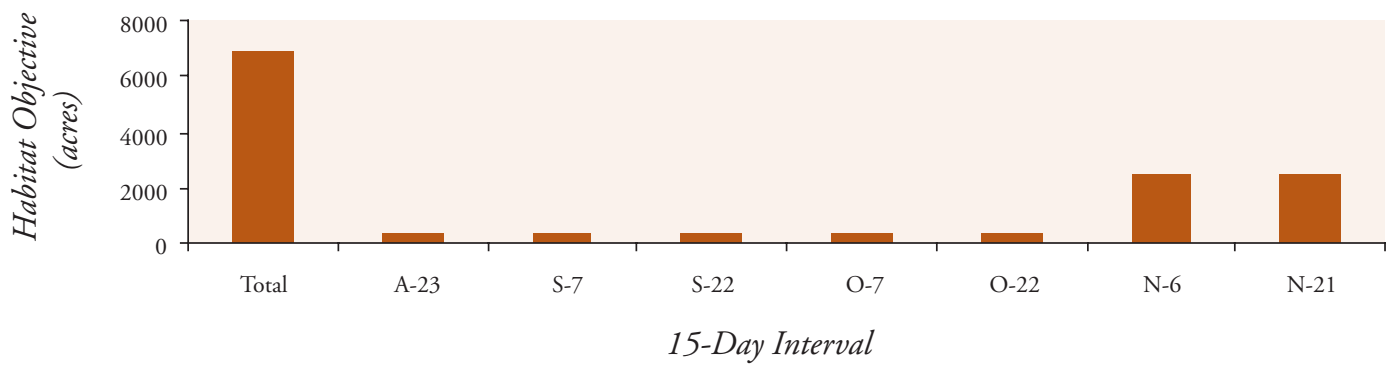

Figure 6-36. Seasonal wetland objectives for shorebirds in the Fall Flooding Period by 15-day intervals for the San Joaquin Basin.

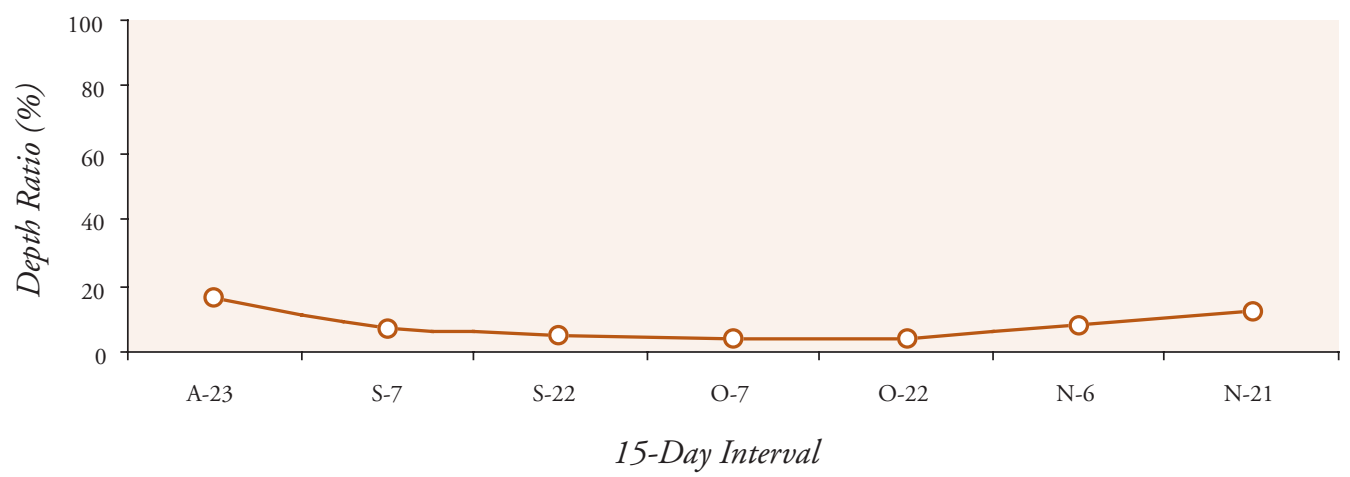

Figure 6-37. Changes in the required depth ratio for seasonal wetlands in the Fall Flooding Period for the San Joaquin Basin.

\section{Winter Flooding Period (November 30-March 29)}

Habitat needs for shorebirds in the Winter Flooding Period range from nearly 2,100 acres in the January and February intervals, to over 4,100 acres in both March intervals. All of these habitat needs must be met from seasonal wetlands, as no winter flooded rice is available (Table 6-34).

Table 6-34. Seasonal wetland objectives (acres) for shorebirds in San Joaquin Basin during the Winter Flooding Period.

\begin{tabular}{|c|c|c|c|c|}
\hline Interval & $\begin{array}{l}\text { SW Interval } \\
\text { Objective }\end{array}$ & $\begin{array}{c}\text { Cumulative SW } \\
\text { Objective }\end{array}$ & Flooded SWs ${ }^{b}$ & $\begin{array}{l}\text { Required Depth } \\
\text { Ratio (\%) }\end{array}$ \\
\hline D-6 (Nov 30-Dec 14) & 2,497 & 9,669 & 61,013 & 16 \\
\hline D-21 (DEC 15-DEC 29) & 2,497 & 12,166 & 61,013 & 20 \\
\hline J-5 (DEC 30-JAN 13) & 2,095 & 14,261 & 61,013 & 23 \\
\hline J-20 (JAN 14-JAN 28) & 2,095 & 16,356 & 61,013 & 27 \\
\hline F-4 (JAN 29-FEB 12) & 2,095 & 18,451 & 61,013 & 30 \\
\hline F-19 (FeB 13-FeB 27) & 2,095 & 20,546 & 61,013 & 33 \\
\hline M-6 (FeB 28-MAR 14) & 4,118 & 24,664 & 61,013 & 40 \\
\hline M-21 (MAR 15-MAR 29) & 4,118 & 28,782 & 61,013 & 47 \\
\hline TотAL & 21,610 & 28,782 & 61,013 & \\
\hline
\end{tabular}

SW-Seasonal Wetland.

"Includes SW objectives from previous flooding periods.

${ }^{b}$ Flooded SWs reflect flooding schedules within a shorebird planning region.

${ }^{c}$ Cumulative SW Objective/Flooded SWs.

The overall seasonal wetland objective for the Winter Flooding Period is 21,610 acres. Although this wetland objective is staggered over several 15-day intervals, it is possible to front-end this conservation objective. For example, seasonal wetland objectives for shorebirds could be met in the Winter Flooding Period by providing 21,610 acres during the December 6 interval and maintaining these acres at a depth $<10 \mathrm{~cm}$ through the end of March (Figure 6-38). 
As expected, the required depth ratio increases through the Winter Flooding Period as no new wetlands are being flooded and shorebirds deplete food resources on seasonal wetland acres that are managed $<10 \mathrm{~cm}$ in depth (Figure 6-39).

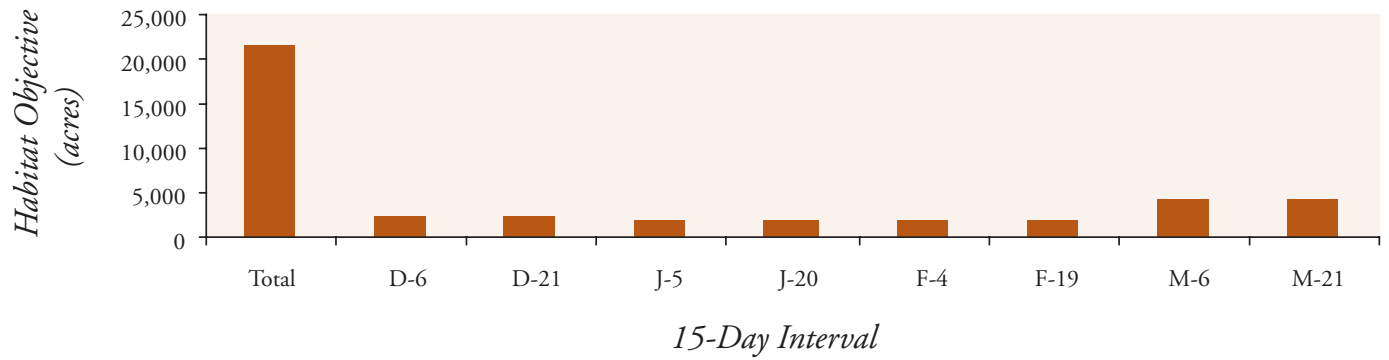

Figure 6-38. Seasonal wetland objectives for shorebirds in the Winter Flooding Period by 15-day intervals for the San Joaquin Basin.

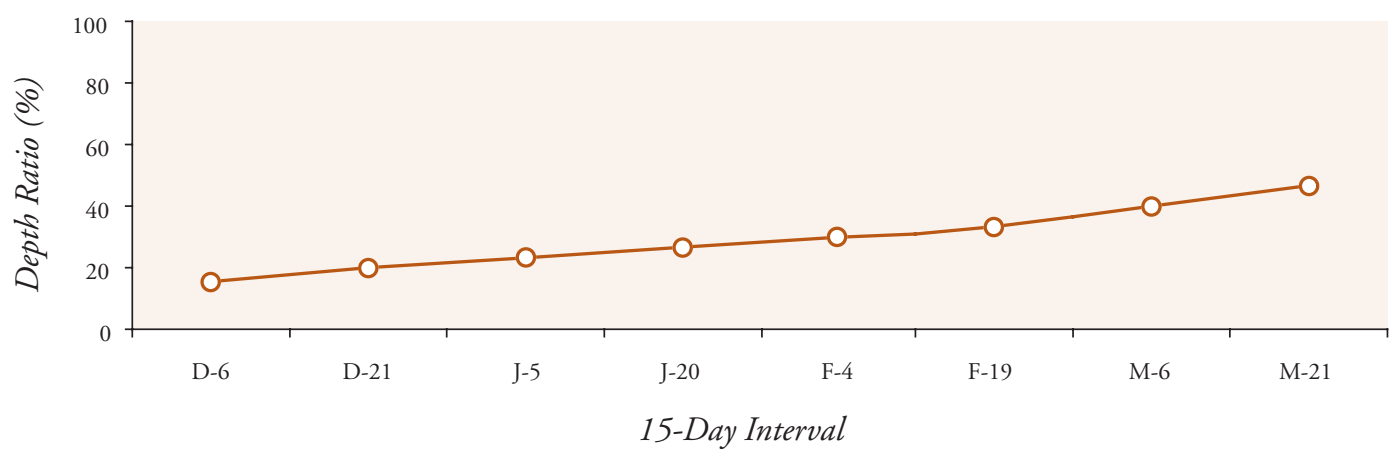

Figure 6-39. Changes in the required depth ratio for seasonal wetlands in the Winter Flooding Period for the San Joaquin Basin.

\section{Spring Flooding Period (March 30-May 12)}

Habitat needs for shorebirds in the Spring Flooding Period range from nearly 5,500 acres in each of the April intervals, to 366 acres in May (Table 6-35). The summed seasonal wetland objective for this period is 11,348 acres, with over $95 \%$ of these acres needed in the April intervals (Figure 6-40).

Table 6-35. Seasonal wetland objectives (acres) for shorebirds in San Joaquin Basin during the Spring Flooding Period.

\begin{tabular}{|cccc|}
\hline Interval & SW Interval Objective & $\begin{array}{c}\text { Cumulative SW } \\
\text { Objective }\end{array}$ & Flooded SW $W^{b}$ Habitat \\
\hline A-5 (MAR 30-APR 13) & 5,491 & 34,273 & 61,013 \\
\hline A-20 (APR 14-APR 28) & 5,491 & 39,764 & 19,219 \\
M-4 (APR 29-MAY 10) & 366 & 40,130 & 7,932 \\
\hline TotAL & $\mathbf{1 1 , 3 4 8}$ & 40,130 & \\
\hline
\end{tabular}

SW-Seasonal Wetland.

ancludes SW objectives from previous flooding periods.

${ }^{b}$ Flooded SWs reflect flooding schedules within a shorebird planning region. 


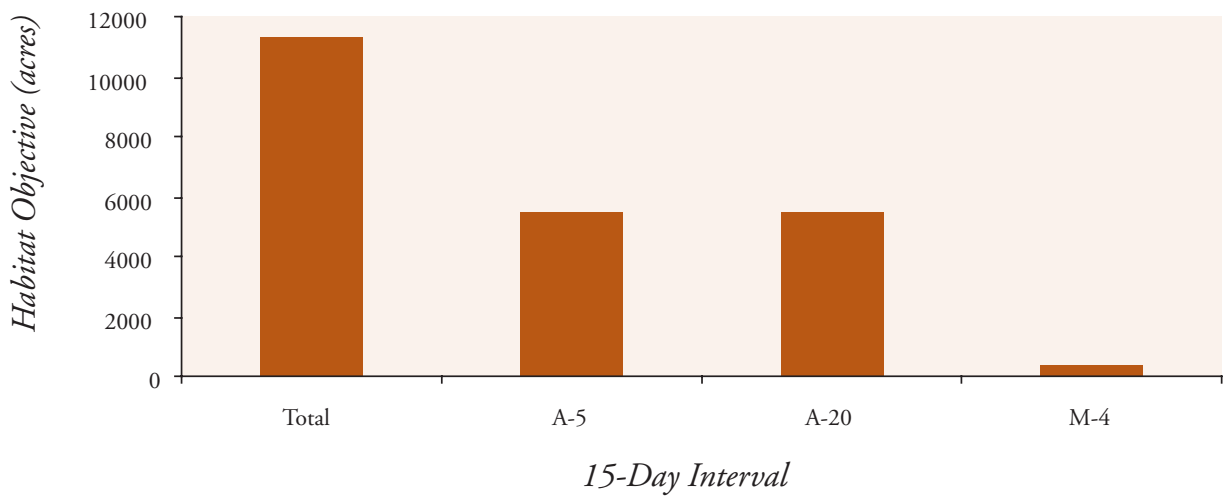

Figure 6-40. Seasonal wetland objectives for shorebirds in San Joaquin Basin during the Spring Flooding Period by 15-day intervals.

\section{Water Supplies for Wetland Management}

Additional water supplies that are needed for shorebirds are based on seasonal wetland needs in the August 8 interval (see earlier description for establishing water supply objectives). Seasonal wetland objectives for shorebirds in the San Joaquin Basin during the August 8 interval are estimated at 340 acres. This equates to a water supply need of 680 acre-feet.

\section{Summary}

Conservation objectives for managed seasonal and semi-permanent wetlands are summarized for the San Joaquin Basin in Table 636. Nearly $66 \%$ of the seasonal wetlands present in this planning region $(40,130 / 61,013$ acres) must provide foraging depths $<10 \mathrm{~cm}$ during some portion of the wintering period if seasonal wetland objectives for shorebirds are to be met.

Table 6-36. Conservation Objectives for non-breeding shorebirds in San Joaquin Basin.

\begin{tabular}{|c|c|c|c|}
\hline Interval & $\begin{array}{l}\text { Seasonal Wetlands } \\
\text { (Acres) }\end{array}$ & $\begin{array}{c}\text { Semi-Perm. } \\
\text { Wetlands (Acres) }\end{array}$ & $\begin{array}{c}\text { Water } \\
\text { (Acre-Feet) }\end{array}$ \\
\hline J-7 (JuLY 1-JuLY 15) & 0 & 85 & 0 \\
\hline J-22 (JuLY 16-JulY 31) & 0 & 90 & 0 \\
\hline A-8 (AUg 1-AUg 16) & 340 & 0 & 680 \\
\hline A-23 (AUg 17-AUg 31) & 340 & 0 & 0 \\
\hline S-7 (SEPT 1-SEPT 15) & 340 & 0 & 0 \\
\hline S-22 (SEPT 16-SEPT 30) & 340 & 0 & 0 \\
\hline О-7 (Ост 1-Ост 15) & 424 & 0 & 0 \\
\hline О-22 (Ост 16-ОСт 30) & 424 & 0 & 0 \\
\hline N-6 (Oct 31-Nov 14) & 2,497 & 0 & 0 \\
\hline N-21 (Nov 15-Nov 29) & 2,497 & 0 & 0 \\
\hline D-6 (Nov 30-DeC 14) & 2,497 & 0 & 0 \\
\hline D-21 (DEC 15-Dec 29) & 2,497 & 0 & 0 \\
\hline J-5 (DEC 30-JAN 13) & 2,095 & 0 & 0 \\
\hline J-20 (JAN 14-JAN 28) & 2,095 & 0 & 0 \\
\hline F-4 (JAN 29-FEB 12) & 2,095 & 0 & 0 \\
\hline F-19 (FeB 13-FeB 27) & 2,095 & 0 & 0 \\
\hline M-6 (FEB 28-MAR 14) & 4,118 & 0 & 0 \\
\hline M-21 (MAR 15-MAR 29) & 4,118 & 0 & 0 \\
\hline A-5 (MAR 30-APR 13) & 5,491 & 0 & 0 \\
\hline A-20 (APR 14-APR 28) & 5,491 & 0 & 0 \\
\hline M-4 (APR 29-MAY 10) & 366 & & 0 \\
\hline TотAL & 40,130 & 175 & 680 \\
\hline
\end{tabular}




\section{Tulare Basin}

\section{Current Conditions}

Table 6-37. Foraging habitats (acres) available to wintering shorebirds in the Tulare Basin.

Population objectives for migrating and wintering shorebirds in the Tulare Basin are presented in Figure 6-41. Population objectives are highest in April, with shorebird numbers reaching a minimum in July. Seasonal wetlands provide the majority of foraging habitat, as no winter flooded rice is available in this planning region (Table 6-37).

\begin{tabular}{|ccc|}
\hline $\begin{array}{c}\text { Seasonal } \\
\text { Wetland }\end{array}$ & $\begin{array}{c}\text { Semi-Permanent } \\
\text { Wetland }\end{array}$ & $\begin{array}{c}\text { Winter Flooded } \\
\text { Rice }\end{array}$ \\
\hline 20,212 & 2,245 & 0 \\
\hline
\end{tabular}

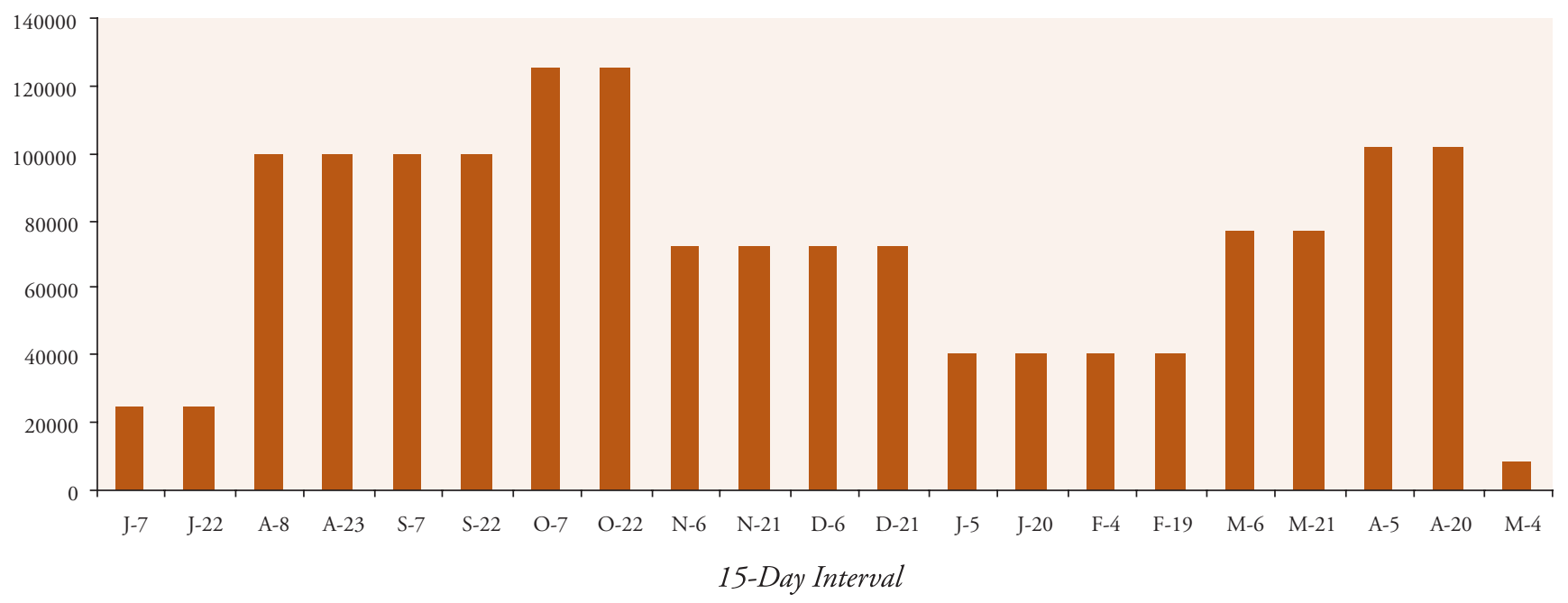

\begin{tabular}{|c|c|c|c|c|c|c|c|c|c|c|c|c|c|c|c|c|c|c|c|c|}
\hline 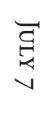 & $\begin{array}{l}\vec{\Xi} \\
\vec{Z} \\
\tilde{N}\end{array}$ & 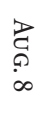 & 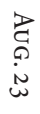 & 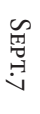 & 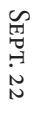 & $\stackrel{\overbrace{}}{\stackrel{\ominus}{\ominus}}$ & $\begin{array}{l}0 \\
\stackrel{9}{\rightarrow} \\
\stackrel{N}{N}\end{array}$ & 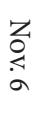 & 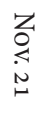 & 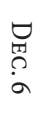 & $\begin{array}{l}\text { 节 } \\
\stackrel{\leftrightarrow}{\sim} \\
\stackrel{\sim}{\sim}\end{array}$ & 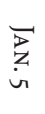 & $\begin{array}{l}\vec{s} \\
\underset{Z}{3} \\
\text { N }\end{array}$ & $\begin{array}{l}\text { Tit } \\
\stackrel{7}{0} \\
+\end{array}$ & 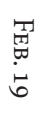 & 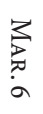 & 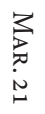 & $\begin{array}{l}\vec{D}_{0}^{0} \\
\text { ن }\end{array}$ & $\begin{array}{l}\overrightarrow{0} \\
\stackrel{0}{0} \\
\dot{0}\end{array}$ & $\begin{array}{l}3 \\
3 \\
+3 \\
+2\end{array}$ \\
\hline $\begin{array}{l}\text { N } \\
\stackrel{0}{\circ} \\
0\end{array}$ & $\begin{array}{l}N \\
\stackrel{N}{\circ} \\
\stackrel{8}{8}\end{array}$ & $\begin{array}{l}5 \\
: \\
\circ \\
\circ\end{array}$ & $\begin{array}{l}\text { s } \\
: \\
\circ\end{array}$ & $\begin{array}{l}\text { \& } \\
: \\
\circ\end{array}$ & $\begin{array}{l}\vec{\circ} \\
8 \\
8 \\
8\end{array}$ & $\begin{array}{l}\vec{N} \\
\text { ○ } \\
\stackrel{8}{0}\end{array}$ & $\begin{array}{l}\text { N } \\
\\
\stackrel{8}{\circ}\end{array}$ & $\begin{array}{l}\text { N } \\
\text { مे }\end{array}$ & $\begin{array}{l}\text { Na } \\
\stackrel{2}{\circ} \\
8\end{array}$ & $\begin{array}{l}\text { N } \\
\text { ¿ } \\
\text { O }\end{array}$ & $\begin{array}{l}n \\
\text { N } \\
0 \\
0\end{array}$ & $\begin{array}{l}\overrightarrow{0} \\
\dot{0} \\
8\end{array}$ & $\begin{array}{l}\overrightarrow{0} \\
: \\
:\end{array}$ & $\begin{array}{l}\overrightarrow{0} \\
\text { : } \\
8\end{array}$ & $\begin{array}{l}\overrightarrow{0} \\
\stackrel{0}{\circ} \\
8\end{array}$ & 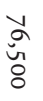 & 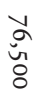 & $\begin{array}{l}\text { ○ } \\
\text { N } \\
\text { О } \\
\text { О }\end{array}$ & 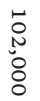 & $\begin{array}{l}\infty \\
\text { ஸे } \\
8\end{array}$ \\
\hline
\end{tabular}

Figure 6-41. Shorebird population objectives (acres) for the Tulare Basin.

Figure 6-42 depicts the relationship between shorebird population objectives and the availability of seasonally flooded wetlands. Semi-permanent wetlands are assumed to provide shorebird habitat from July 1 to July 15, when they are typically drawn down and likely to provide foraging habitat $<10 \mathrm{~cm}$ in depth. Seasonal wetlands provide no habitat prior to the August 23 interval, when flooding of these wetlands in the Tulare Basin typically begins. However, drawdown of semi-permanent wetlands in early July likely provides some foraging habitat between July 1 and July 15. Increases in the amount of seasonal wetlands track increases in shorebird numbers from late August through October. However, shorebird populations are high in early and mid-August when no seasonal wetlands are available. Shorebirds in the basin currently rely on sub-optimal habitats like evaporation ponds in August (Shuford et al. 1998), which probably reflects the lack of flooded seasonal wetlands. Shorebird numbers in the basin increase again during April when seasonal wetlands are being drawn down and the amount of foraging habitat $<10 \mathrm{~cm}$ deep is likely increasing. 


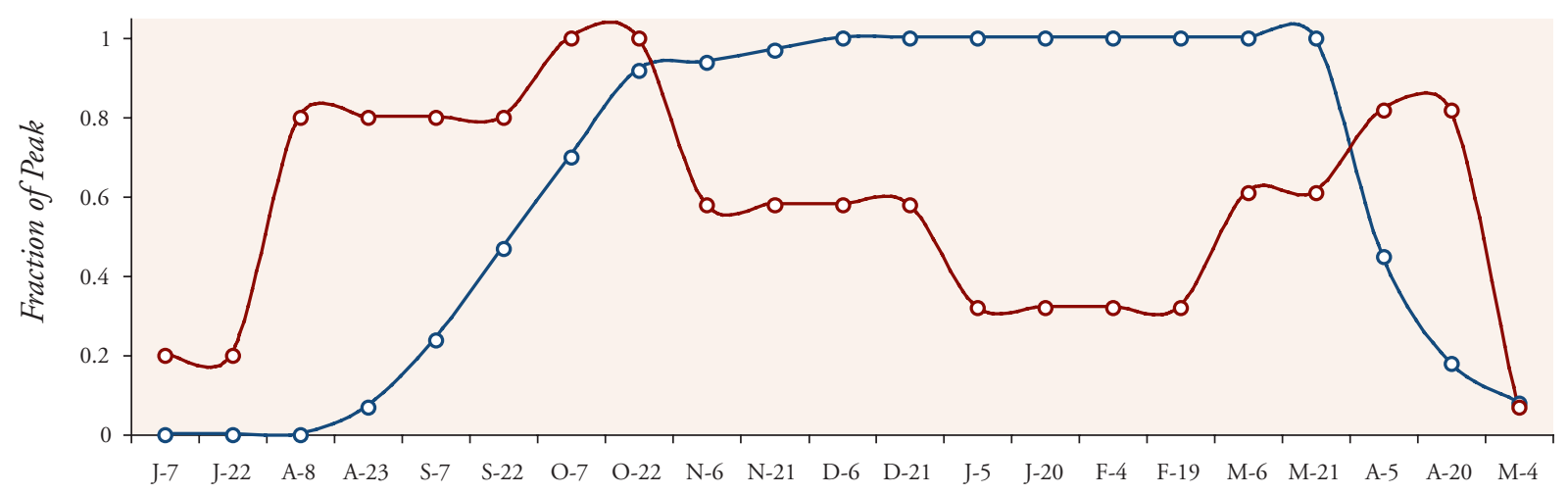

Figure 6-42. Shorebird population objectives (red) vs. flooding schedules for managed seasonal wetlands (blue) for the Tulare Basin. Shorebird population objectives are expressed as the fraction of peak population; wetlands are expressed as the fraction of seasonal wetlands that are flooded.

\section{Management of Existing Seasonal and Semi-Permanent Wetlands}

\section{Summer Flooding Period (July 1-August 16)}

Shorebirds require approximately 600 acres of foraging habitat in both the July intervals, with habitat needs increasing to nearly 2,300 acres in the August 8 interval (Table 6-38). Semi-permanent wetlands provide some opportunity to meet shorebird needs in July. The Tulare Basin contains nearly 2,250 acres of semi-permanent wetlands, of which 746 acres are publicly owned (Table 6-37). If all semi-permanent wetlands are drawn down between July 1 and July 15, twenty-five percent of these acres must maintain water depths $<10 \mathrm{~cm}$ deep to meet shorebird needs in the July 7 interval. Semi-permanent public wetlands alone can meet shorebird needs in the July 7 interval if $76 \%$ of these habitats provide suitable water depths during drawdown. If all semi-

Table 6-38. Habitat objectives for shorebirds in Tulare Basin during the Summer Flooding Period.

\begin{tabular}{|cc|} 
Interval & $\begin{array}{c}\text { Habitat Objective } \\
\text { (Acres) }\end{array}$ \\
\hline J-7 (July 1-July 15) & 566 \\
J-22 (July 16-July 31) & 604 \\
\hline A-8 (AUg 1-AUg 16) & 2,263 \\
\hline TotaL & 3,433 \\
\hline
\end{tabular}
permanent wetlands are drawn down by mid-July, there is no opportunity for these habitats to meet shorebird needs in the July 22 interval. Delaying the drawdown of some of these habitats until late July could help meet shorebird needs in the July 22 interval.

Shorebirds require 2,263 acres of foraging habitat in the August 8 interval. There are currently no seasonal wetlands flooded in the Tulare Basin during the first two weeks of August, and all semi-permanent wetlands are assumed to be dry. The 2,263 acres needed by shorebirds could be met through early flooding of seasonal wetlands. However these 2,263 acres represent over $10 \%$ of existing seasonal wetlands in the basin, and finding water supplies for this early flooding may be difficult.

\section{Fall Flooding Period} (August 17-November 29)

Habitat needs for shorebirds in the Fall Flooding Period range from over 2,800 acres in the October intervals, to 1,400 acres in November (Table 6-39). Shorebird needs in this period must be met exclusively from seasonal wetlands, as no winter flooded rice is available in basin.
Table 6-39. Seasonal wetland objectives (acres) for shorebirds in Tulare Basin during the Fall Flooding Period.

\begin{tabular}{|ccccc|}
\hline Interval & $\begin{array}{c}\text { SW Interval } \\
\text { Objective }\end{array}$ & $\begin{array}{c}\text { Cumulative }^{a} \\
\text { SW Objective }^{\text {SWlooded SWs }}{ }^{b}\end{array}$ & $\begin{array}{c}\text { Required }^{c} \\
\text { Depth Ratio }^{\text {Fio }}\end{array}$ \\
\hline A-23 (AUG 17-AUG 31) & 2,263 & 4,526 & 1,415 & $>100$ \\
S-7 (SEPT 1-SEPT 15) & 2,263 & 6,789 & 4,851 & $>100$ \\
S-22 (SEPT 16-SEPT 30) & 2,263 & 9,052 & 9,500 & 95 \\
O-7 (OCT 1-OCT 15) & 2,829 & 11,881 & 14,148 & 84 \\
O-22 (OCT 16-OCT 30) & 2,829 & 14,710 & 18,595 & 79 \\
N-6 (OCT 31-Nov 14) & 1,404 & 16,114 & 18,999 & 85 \\
N-21 (Nov 15-Nov 29) & 1,404 & 17,518 & 19,606 & 89 \\
TotAL & 15,255 & 17,518 & & \\
\hline
\end{tabular}

SW-Seasonal Wetland.

"Includes SW objectives from previous flooding periods.

${ }^{b}$ Flooded SWs reflect flooding schedules within a shorebird planning region.

${ }^{c}$ Cumulative SW Objective/Flooded SWs. 
The total seasonal wetland objective for Tulare Basin in the Fall Flooding Period is 15,255 acres (Figure 6-43). It is unlikely that this objective is currently met for shorebirds. Although the Tulare Basin contains over 20,000 acres of seasonal wetlands, almost all of these habitats would have to provide foraging depths $<10 \mathrm{~cm}$ to fully meet shorebird needs. This is reflected in the required depth ratio, which exceeds or approaches 1.0 in each 15-day interval of the Fall Flooding Period (Figure 6-44).

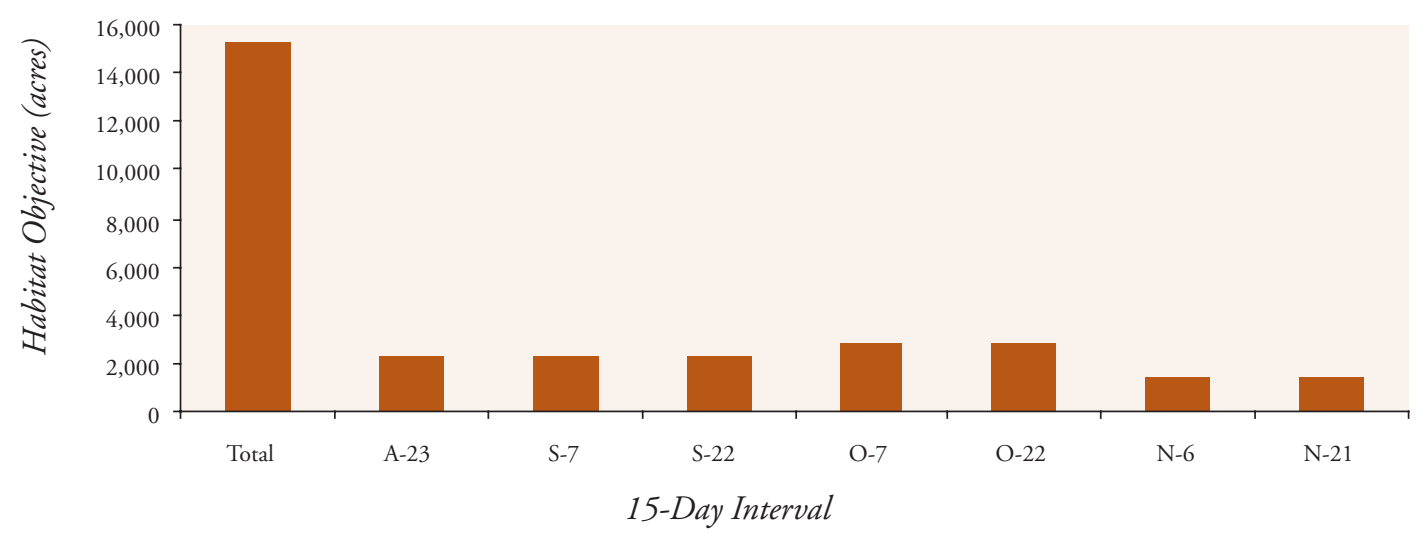

Figure 6-43. Seasonal wetland objectives for shorebirds in the Fall Flooding Period by 15-day intervals for the Tulare Basin.

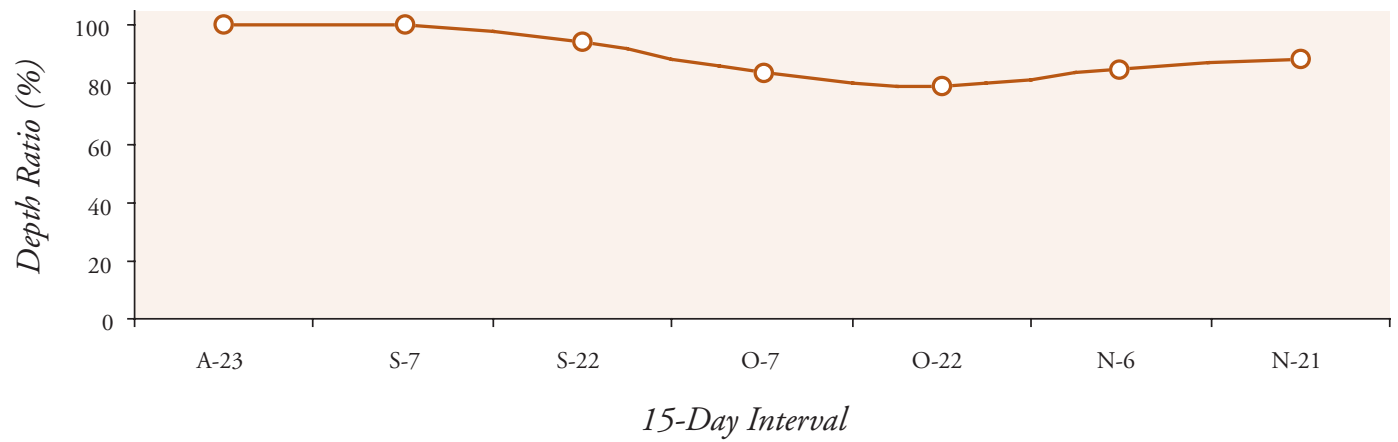

Figure 6-44. Changes in the required depth ratio for seasonal wetlands in the Fall Flooding Period for the Tulare Basin.

\section{Winter Flooding Period (November 30-March 29)}

Habitat needs for shorebirds in the Winter Flooding Period range from nearly 750 acres in the January and February intervals, to over 1,700 acres in both March intervals (Table 6-40). The overall seasonal wetland objective for the Winter Flooding Period is 9,216 acres (Figure 6-45). As expected, the required depth ratio remains high through the Winter Flooding Period, as no new wetlands are being flooded and shorebirds deplete food resources on seasonal wetland acres that are managed $<10 \mathrm{~cm}$ in depth (Figure 6-46). 
Table 6-40. Seasonal wetland objectives (acres) for shorebirds in Tulare Basin during the Winter Flooding Period.

\begin{tabular}{|c|c|c|c|c|}
\hline Interval & $\begin{array}{l}\text { SW Interval } \\
\text { Objective }\end{array}$ & $\begin{array}{c}\text { Cumulativea SW } \\
\text { Objective }\end{array}$ & Flooded SW's ${ }^{b}$ & $\begin{array}{l}\text { Required Depth } \\
\text { Ratio (\%) }\end{array}$ \\
\hline D-6 (Nov 30-DEC 14) & 1,404 & 18,922 & 20,212 & 94 \\
\hline D-21 (DeC 15-DeC 29) & 1,404 & 20,326 & 20,212 & $>100$ \\
\hline J-5 (DEC 30-JAN 13) & 748 & 21,074 & 20,212 & $>100$ \\
\hline J-20 (JAN 14-JAN 28) & 748 & 21,822 & 20,212 & $>100$ \\
\hline F-4 (JAN 29-FEB 12) & 748 & 22,570 & 20,212 & $>100$ \\
\hline F-19 (FeB 13-Feв 27) & 748 & 23,318 & 20,212 & $>100$ \\
\hline M-6 (FeB 28-MAR 14) & 1,708 & 25,026 & 20,212 & $>100$ \\
\hline M-21 (MAR 15-MAR 29) & 1,708 & 26,734 & 20,212 & $>100$ \\
\hline TотAL & 9,216 & 26,734 & 20,212 & \\
\hline
\end{tabular}

SW-Seasonal Wetland.

"Includes SW objectives from previous flooding periods.

${ }^{b}$ Flooded SW's reflect flooding schedules within a shorebird planning region.

${ }^{c}$ Cumulative SW Objective/Flooded SW's

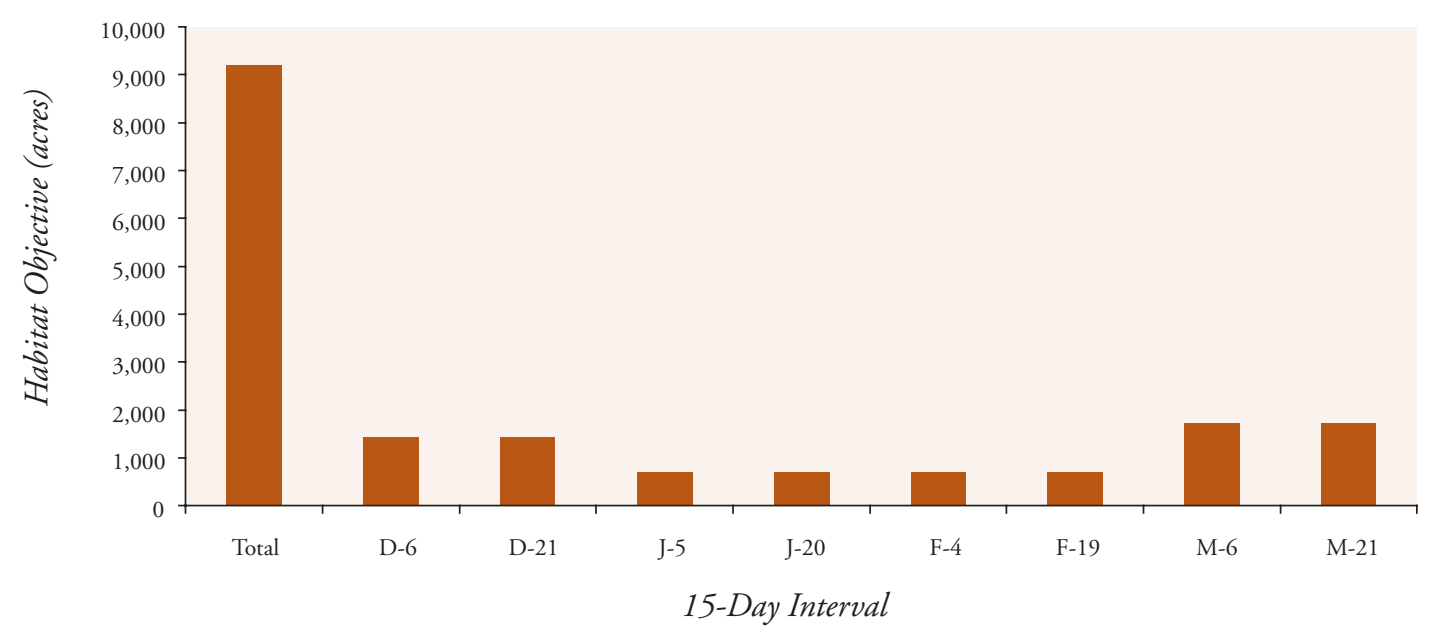

Figure 6-45. Seasonal wetland objectives for shorebirds in the Winter Flooding Period by 15-day intervals for the Tulare Basin.

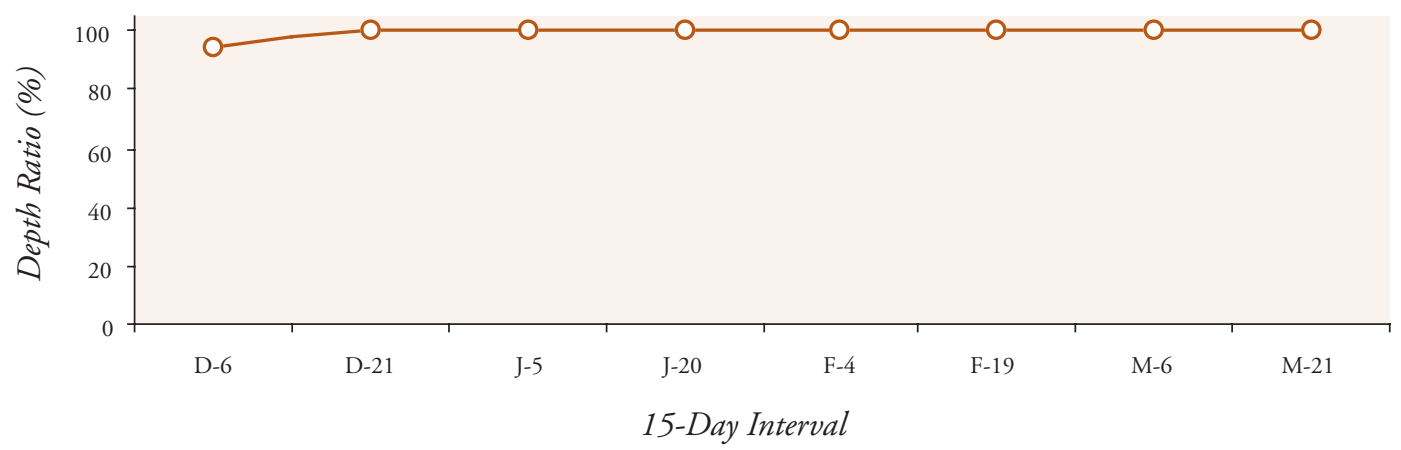

Figure 6-46. Changes in the required depth ratio for seasonal wetlands in the Winter Flooding Period for the Tulare Basin. 


\section{Spring Flooding Period (March 30-May 12)}

Habitat needs for shorebirds in the Spring Flooding Period range from nearly 2,300 acres in each of the April intervals, to 152 acres in May (Table 6-41). The summed seasonal wetland objective for the Spring Flooding Period is 4,706 acres, with over $95 \%$ of these acres needed in the April intervals (Figure 6-47).

Table 6-41. Seasonal wetland objectives (acres) for shorebirds in Tulare Basin during the Spring Flooding Period.

\begin{tabular}{|cccc|} 
Interval & $\begin{array}{c}\text { SW Interval } \\
\text { Objective }\end{array}$ & $\begin{array}{c}\text { Cumulative SW } \\
\text { Objective }\end{array}$ & $\begin{array}{c}\text { Flooded SW }^{b} \\
\text { Habitat }\end{array}$ \\
\hline A-5 (MAR 30-APR 13) & 2,277 & 29,011 & 20,212 \\
\hline A-20 (APR 14-APR 28) & 2,277 & 31,288 & 6,367 \\
M-4 (APR 29-MAY 10) & 152 & 31,440 & 2,628 \\
\hline ToTAL & 4,706 & 31,440 & \\
\hline
\end{tabular}

SW-Seasonal Wetland.

"Includes SW objectives from previous flooding periods.

${ }^{b}$ Flooded SW's reflect flooding schedules within a shorebird planning region.

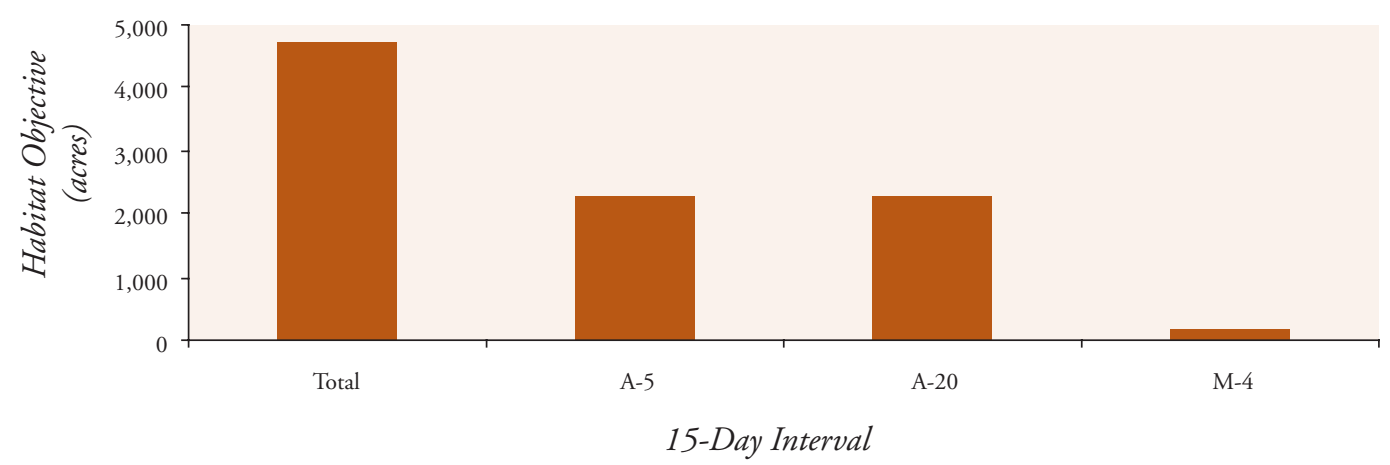

Figure 6-47. Seasonal wetland objectives for shorebirds in Tulare Basin during the Spring Flooding Period by 15-day intervals.

\section{Water Supplies for Wetland Management}

Additional water supplies that are needed for shorebirds are based on seasonal wetland needs in the August 8 interval (see earlier description for establishing water supply objectives). Seasonal wetland objectives for shorebirds in the Tulare Basin during the August 8 interval are estimated at 2,263 acres. This equates to a water supply need of 4,526 acre-feet.

\section{Summary}

Conservation objectives for managed seasonal and semi-permanent wetlands are summarized for the Tulare Basin in Table 6-42. Seasonal wetland objectives for shorebirds cannot be met even if all currently available habitat provides foraging depths $<10 \mathrm{~cm}$ during some portion of the wintering period. This obviously does not occur in the Tulare Basin, which may explain the reliance of shorebirds on sub-optimal habitats within this basin. 
Table 6-42. Conservation objectives for non-breeding shorebirds in Tulare Basin.

\begin{tabular}{|c|c|c|c|}
\hline Interval & $\begin{array}{c}\text { Seasonal } \\
\text { Wetlands (Acres) }\end{array}$ & $\begin{array}{c}\text { Semi-Perm. } \\
\text { Wetlands (Acres) }\end{array}$ & $\begin{array}{c}\text { Water } \\
\text { (Acre-Feet) }\end{array}$ \\
\hline J-7 (July 1-July 15) & 0 & 566 & 0 \\
\hline J-22 (JuLY 16-JulY 31) & 0 & 604 & 0 \\
\hline A-8 (Aug 1-Aug 16) & 2,263 & 0 & 4,526 \\
\hline A-23 (AUg 17-Aug 31) & 2,263 & 0 & 0 \\
\hline S-7 (SEPT 1-SePt 15) & 2,263 & 0 & 0 \\
\hline S-22 (SEPT 16-SEPT 30) & 2,263 & 0 & 0 \\
\hline O-7 (Ост 1-Ост 15) & 2,829 & 0 & 0 \\
\hline О-22 (Ост 16-Ост 30) & $2,, 829$ & 0 & 0 \\
\hline N-6 (Ост 31-Nov 14) & 1,404 & 0 & 0 \\
\hline N-21 (Nov 15-Nov 29) & 1,404 & 0 & 0 \\
\hline D-6 (Nov 30-DeC 14) & 1,404 & 0 & 0 \\
\hline D-21 (DeC 15-Dec 29) & 1,404 & 0 & 0 \\
\hline J-5 (DEC 30-JAN 13) & 748 & 0 & 0 \\
\hline J-20 (JAN 14-JAN 28) & 748 & 0 & 0 \\
\hline F-4 (JAN 29-FEB 12) & 748 & 0 & 0 \\
\hline F-19 (FeB 13-Fев 27) & 748 & 0 & 0 \\
\hline M-6 (Feb 28-Mar 14) & 1,708 & 0 & 0 \\
\hline M-21 (MAR 15-MAR 29) & 1,708 & 0 & 0 \\
\hline A-5 (MAR 30-APR 13) & 2,277 & 0 & 0 \\
\hline A-20 (APR 14-APR 28) & 2,277 & 0 & 0 \\
\hline M-4 (APR 29-MAY 10) & 152 & & 0 \\
\hline Total & 31,440 & 1,170 & 4,526 \\
\hline
\end{tabular}

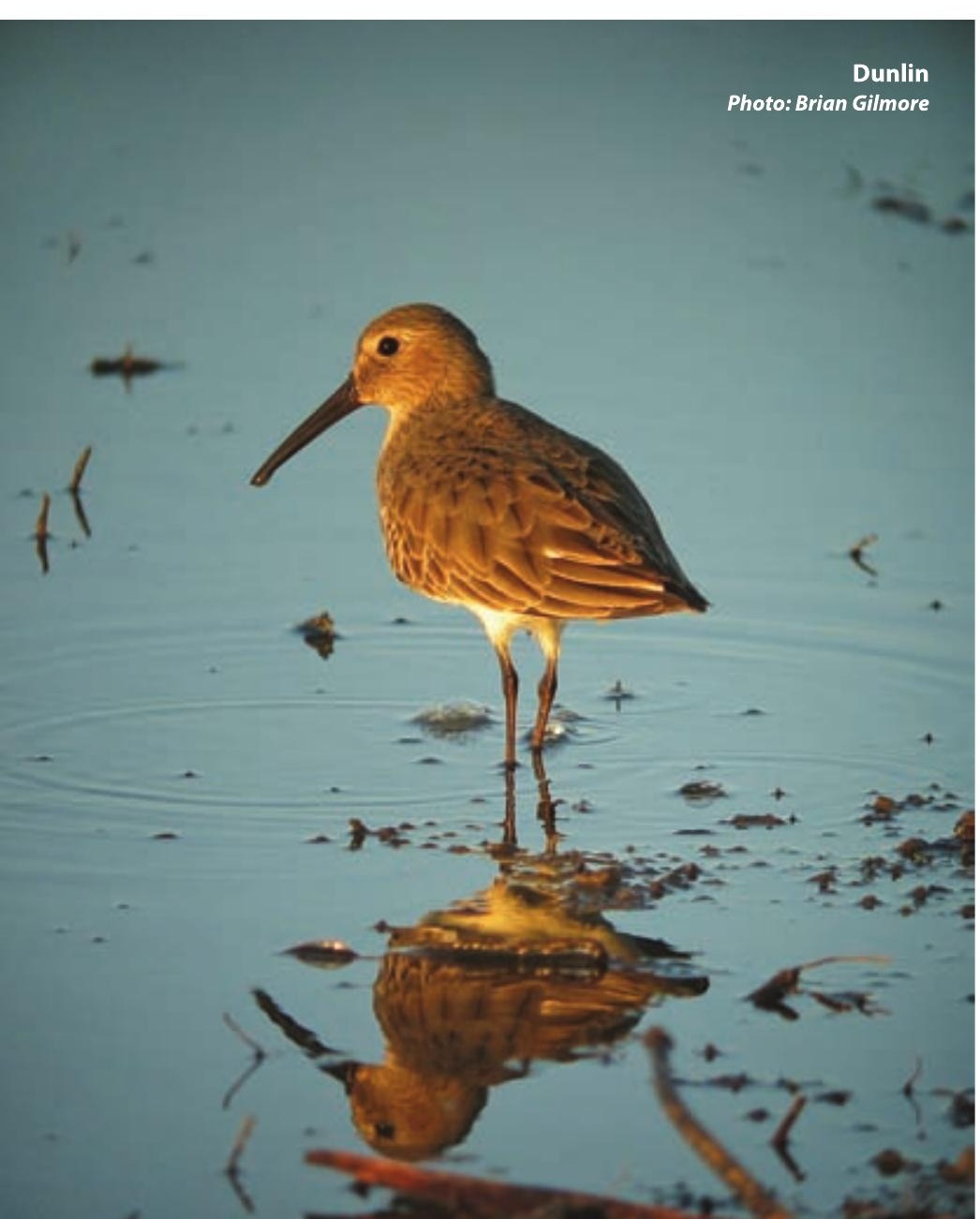

\section{Summary}

Acre objectives for seasonal wetlands, semi-permanent wetlands, and winter flooded rice are summarized for the entire Central Valley in Tables 6-43 through 6-45. Habitat objectives for shorebirds are strongly dependant on the estimates of invertebrate biomass adopted for wetland and agricultural habitats. Unfortunately, invertebrate biomass estimates do not exist for Central Valley habitats. As a result, the JV had to rely on biomass estimates obtained from other regions of the United States. More importantly, the JV assumed that invertebrate food sources are not renewable in the face of shorebird foraging. In reality, invertebrate populations and biomass may grow or remain stable despite the effects of shorebird foraging (i.e., invertebrate food resources are not depleted in the way seed resources are). If invertebrate populations are wholly or partially renewable, then shorebird habitat objectives may be overestimated. Future efforts to document seasonal changes in invertebrate biomass within the Central Valley should allow the JV to refine these habitat objectives. 


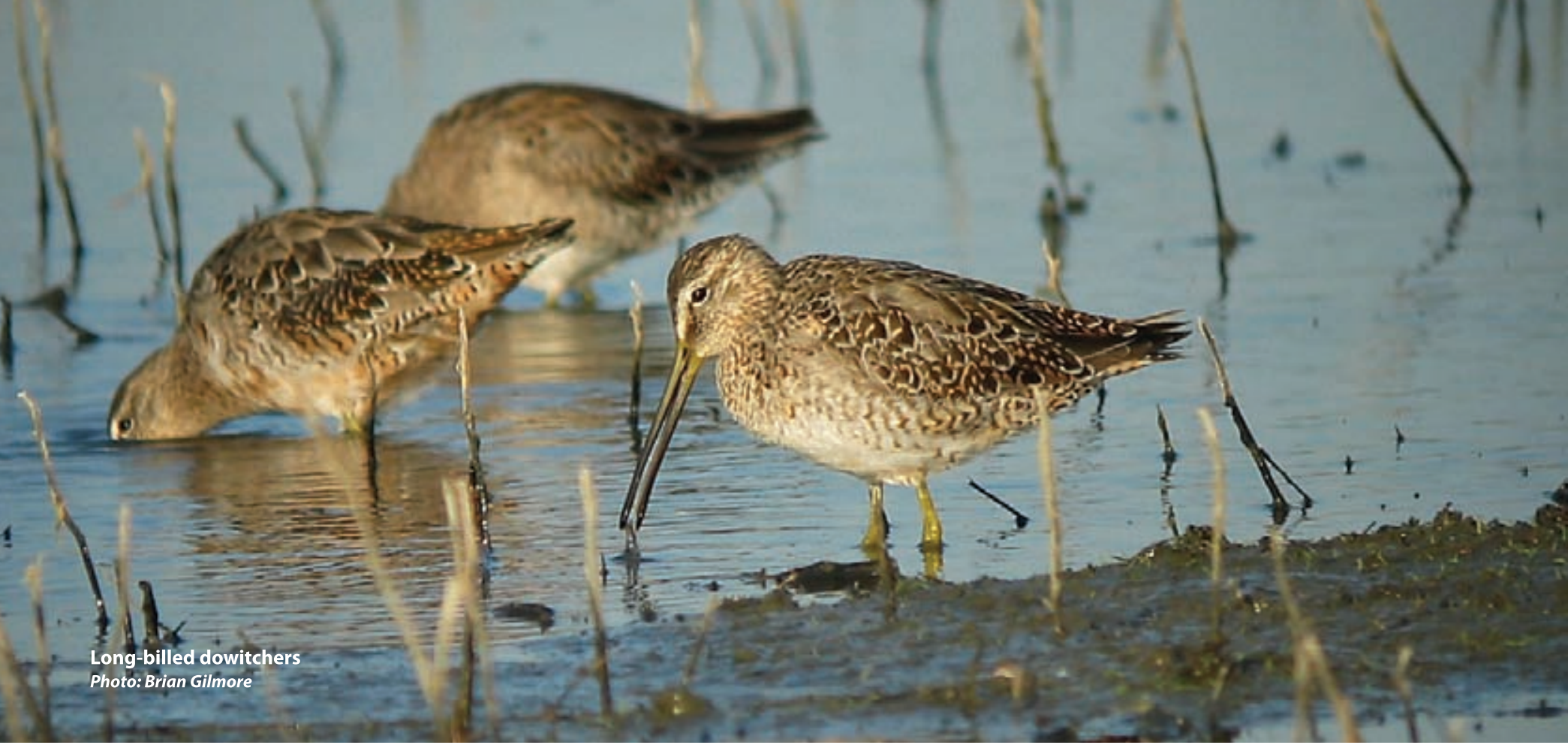

Table 6-43. Seasonal wetlands objectives (acres) for shorebirds in the Central Valley.

\begin{tabular}{|c|c|c|c|c|c|}
\hline Interval & NSV & Delta Planning Region & San Joaquin Basin & Tulare Basin & Total \\
\hline J-7 (July 1-July 15) & 0 & 0 & 0 & 0 & 0 \\
\hline J-22 (JULY 16-JULY 31) & 0 & 0 & 0 & 0 & 0 \\
\hline A-8 (Aug 1-Aug 16) & 1,584 & 340 & 340 & 2,263 & 4,527 \\
\hline A-23 (AUg 17-AUg 31) & 1,584 & 340 & 340 & 2,263 & 4,527 \\
\hline S-7 (SEPT 1-SEPT 15) & 1,584 & 340 & 340 & 2,263 & 4,527 \\
\hline S-22 (SEPT 16-SEPT 30) & 1,584 & 340 & 340 & 2,263 & 4,527 \\
\hline О-7 (Ост 1-Ост 15) & 990 & 212 & 424 & 2,829 & 4,455 \\
\hline О-22 (Ост 16-Ост 30) & 990 & 212 & 424 & 2,829 & 4,455 \\
\hline N-6 (Oct 31-Nov 14) & 1,483 & 468 & 2,497 & 1,404 & 5,852 \\
\hline N-21 (Nov 15-Nov 29) & 1,483 & 468 & 2,497 & 1,404 & 5,852 \\
\hline D-6 (Nov 30-Dec 14) & 1,483 & 468 & 2,497 & 1,404 & 5,852 \\
\hline D-21 (DEC 15-DeC 29) & 1,483 & 468 & 2,497 & 1,404 & 5,852 \\
\hline J-5 (DEC 30-JAN 13) & 1,684 & 636 & 2,095 & 748 & 5,163 \\
\hline J-20 (JAN 14-JAN 28) & 1,684 & 636 & 2,095 & 748 & 5,163 \\
\hline F-4 (JAN 29-FEB 12) & 1,684 & 636 & 2,095 & 748 & 5,163 \\
\hline F-19 (FeB 13-FeB 27) & 1,684 & 636 & 2,095 & 748 & 5,163 \\
\hline M-6 (FEB 28-MAR 14) & 1,959 & 151 & 4118 & 1,708 & 7,936 \\
\hline M-21 (MAR 15-MAR 29) & 1,959 & 151 & 4,118 & 1,708 & 7,936 \\
\hline A-5 (MAR 30-APR 13) & 5,223 & 402 & 5,491 & 2,277 & 13,393 \\
\hline A-20 (APR 14-APR 28) & 5,223 & 402 & 5,491 & 2,277 & 13,393 \\
\hline M-4 (APR 29-MAY 10) & 348 & 28 & 366 & 152 & 894 \\
\hline ToтAL & 35,696 & 7,334 & 40,130 & 31,440 & 114,600 \\
\hline
\end{tabular}


Table 6-44. Semi-permanent wetland objectives (acres) for shorebirds in the Central Valley.

\begin{tabular}{|cccccc|} 
Interval & NSV & Delta Planning Region & San Joaquin Basin & Tulare Basin \\
\hline J-7 (July 1-July 15) & 396 & 85 & 85 & 566 & 1,132 \\
J-22 (July 16-July 31) & 423 & 85 & 90 & 604 & 1,202 \\
Total & $\mathbf{8 1 9}$ & $\mathbf{1 7 0}$ & $\mathbf{1 7 5}$ & $\mathbf{1 , 1 7 0}$ \\
\hline
\end{tabular}

Table 6-45. Winter Flooded Rice objectives (acres) for shorebirds in the Central Valley.

\begin{tabular}{|c|c|c|c|c|c|}
\hline Interval & $N S V$ & Delta Planning Region & San Joaquin Basin & Tulare Basin & Total \\
\hline J-7 (July 1-July 15) & 0 & 0 & 0 & 0 & 0 \\
\hline J-22 (July 16-JuLY 31) & 0 & 0 & 0 & 0 & 0 \\
\hline A-8 (AUg 1-Aug 16) & 0 & 0 & 0 & 0 & 0 \\
\hline A-23 (Aug 17-Aug 31) & 0 & 0 & 0 & 0 & 0 \\
\hline S-7 (SEPT 1-SEPT 15) & 0 & 0 & 0 & 0 & 0 \\
\hline S-22 (SEPT 16-SEPT 30) & 0 & 0 & 0 & 0 & 0 \\
\hline O-7 (Ост 1-Ост 15) & 990 & 212 & 0 & 0 & 2,192 \\
\hline О-22 (Ост 16-Ост 30) & 990 & 212 & 0 & 0 & 1,202 \\
\hline N-6 (OCт 31-Nov 14) & 1,483 & 468 & 0 & 0 & 1,951 \\
\hline N-21 (Nov 15-Nov 29) & 1,483 & 468 & 0 & 0 & 1,951 \\
\hline D-6 (Nov 30-DEC 14) & 1,483 & 468 & 0 & 0 & 1,951 \\
\hline D-21 (DeC 15-Dec 29) & 1,483 & 468 & 0 & 0 & 1,951 \\
\hline J-5 (DeC 30-JAN 13) & 1,684 & 636 & 0 & 0 & 2,320 \\
\hline J-20 (JAN 14-JAN 28) & 1,684 & 636 & 0 & 0 & 2,320 \\
\hline F-4 (JAN 29-FEB 12) & 1,684 & 636 & 0 & 0 & 2,320 \\
\hline F-19 (Feв 13-Feв 27) & 1,684 & 636 & 0 & 0 & 2,320 \\
\hline M-6 (FEB 28-MAR 14) & 1,959 & 151 & 0 & 0 & 2,110 \\
\hline M-21 (MAR 15-MAR 29) & 1,959 & 151 & 0 & 0 & 2,110 \\
\hline A-5 (MAR 30-APR 13) & 0 & 0 & 0 & 0 & 0 \\
\hline A-20 (APR 14-APR 28) & 0 & 0 & 0 & 0 & 0 \\
\hline M-4 (APR 29-MAY 10) & 0 & 0 & 0 & 0 & 0 \\
\hline ToTAL & 18,566 & 5,142 & 0 & 0 & 23,708 \\
\hline
\end{tabular}

Although shorebird habitat objectives may be conservative, regional differences in habitat objectives and required depth ratios help suggest where the JV should focus its efforts for shorebirds both temporally and spatially. During the Summer Flooding Period (July 1-August 16), shorebird habitat needs in the July intervals may be met through staggered drawdowns of semi-permanent wetlands. Within the SV, Delta, and San Joaquin Basin Planning Regions, only a small percent of existing semi-permanent wetlands must provide habitat $<10 \mathrm{~cm}$ in depth. It seems likely that shorebird needs are either being met in these regions, or can be met with minor management adjustments. In contrast, a much higher percent of semi-permanent wetlands in the Tulare Basin must provide foraging depths $<10 \mathrm{~cm}$ during the July drawdowns to meet shorebird needs. Tulare Basin also differs from the other three planning regions during the first half of August (August 8 interval). Over 10\% of the existing seasonal wetlands would need to be flooded early to meet shorebird needs during this period. This objective may be especially challenging given the high cost of water in the basin. In contrast, less than 3\% of the seasonal wetlands in the SV, Delta, and San Joaquin Basin Planning Regions need to be flooded during the first half of August. The Tulare Basin contains 50\% of all shorebirds in the Central Valley during the Summer Flooding Period, and faces unique conservation challenges. As a result, it represents the JVs highest regional priority during this period. 
Although shorebird populations in the Tulare Basin decline in the second half of the Fall Flooding Period, the region remains a priority during this time. Required depth ratios in the SV, Delta, and San Joaquin Basin Planning Regions remain relatively low during the Fall Flooding Period. The lower the required depth ratio, the more likely that shorebird habitat needs are being met. In contrast, required depth ratios in the Tulare Basin during the Fall Flooding Period were near or at 100\% for all 2-week time intervals.

Required depth ratios increased in the SV, Delta, and San Joaquin Basin Planning Regions during the Winter Flooding Period, and remained near or at $100 \%$ for the Tulare Basin. It seems likely that shorebirds may have increasing difficulty in meeting their food energy needs during the Winter Flooding Period as wetlands become fully flooded and the availability of shallow water habitat declines. Drawdown of seasonal wetlands during winter resulted in significant increases in shorebird use, which supports this assumption (Taft et al. 2002).

The Delta Planning Region, San Joaquin Basin, and Tulare Basin are considered priority regions for additional habitat conservation to meet shorebird needs during the Winter Flooding Period. Although required depth ratios in the SV Planning Region were similar to other regions, the abundance of rice habitat in the SV Planning Region makes it more likely that shorebird needs are being met in this region.

Finally, no priority regions were identified for the Spring Flooding Period. Most seasonal wetlands are being drawn down during this period, which may create an abundance of shallow water habitat that exceeds shorebird needs (Taft et al. 2002). 


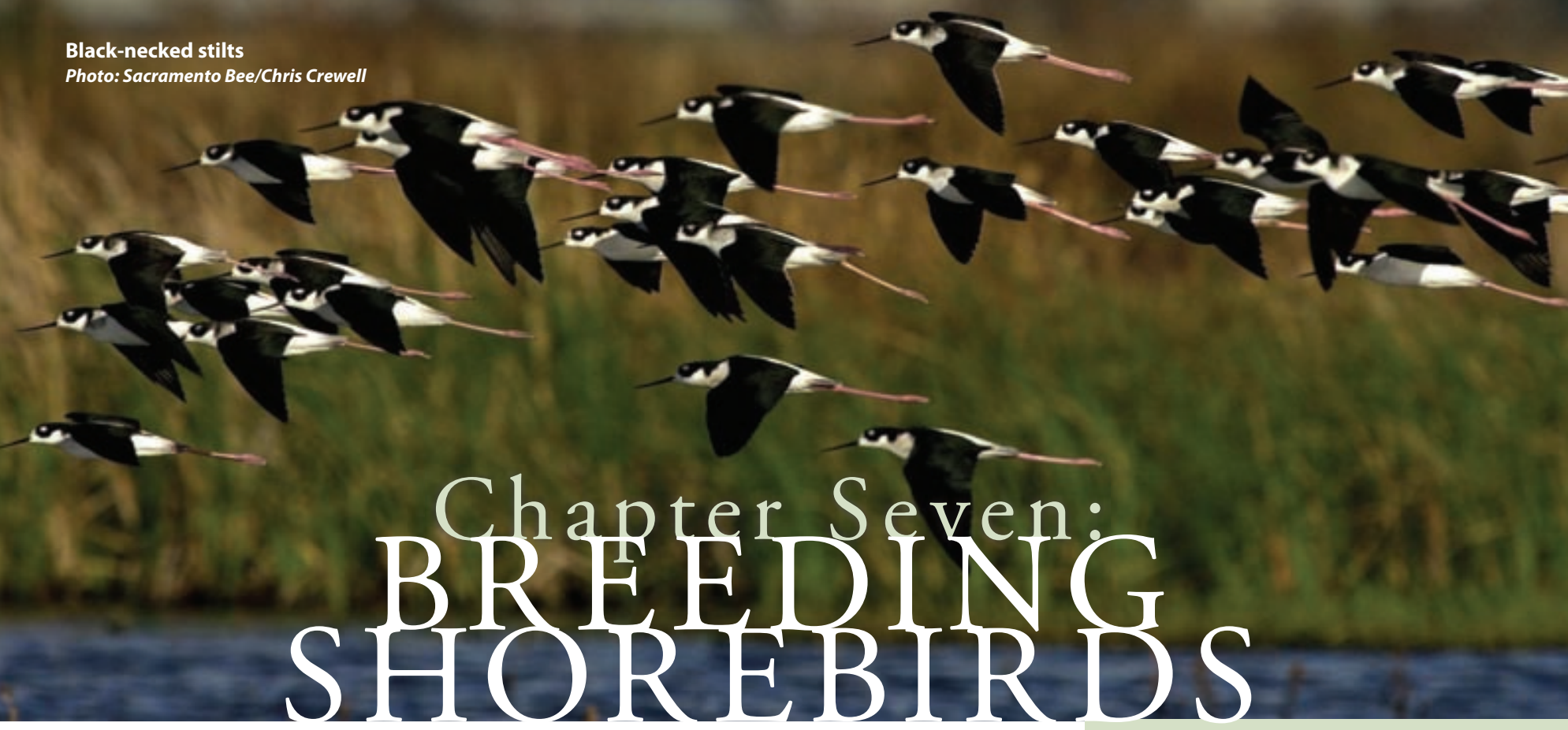

This chapter addresses the needs of seven species of shorebirds that breed within the Central Valley.

\section{Introduction}

Among the shorebirds breeding within the Central Valley, only the killdeer (Charadrius vociferous), the black-necked stilt (Himantopus mexicanus), and the American avocet (Recurvirostra americana) are widespread, numerous, and nest in a variety of wetland, agricultural, and water treatment or storage habitats. Because of their widespread distribution and available survey information, black-necked stilts (stilts) and American avocets (avocets) form the basis for breeding shorebird habitat objectives in the 2005 Plan. Four other shorebird species also breed in the Central Valley including snowy plover (Charadrius alexandrinus), spotted sandpiper (Actitis macularia), Wilson's snipe (Gallinago delicata), and Wilson's phalarope (Phalaropus tricolor). Although there are no breeding population estimates for these species, future surveys could lay the foundation for additional habitat objectives specific to these shorebird species.

\section{Historical Overview of Central Valley Breeding Shorebird Habitat}

Prior to European settlement, the Central Valley contained extensive shallow-water wetland habitat that varied both seasonally and annually depending on the amount of flooding from winter rains and spring runoff. These shallow-water wetlands were highly productive, and when they persisted into spring and summer, provided important habitat for many species of breeding waterbirds, and shorebirds (Shuford et al. 2001). By the mid-1900s, breeding populations of stilts and avocets in California had been reduced commensurate with the loss of interior marshlands (Grinnell and Miller 1944). The loss of breeding habitat for stilts and avocets in the Central Valley was partially offset by the creation of salt ponds in the San Francisco Bay estuary, where nesting populations of both species increased early in the 1900s (Gill 1977).

"The Central Valley supports thousands of nesting shorebird species such as black-necked stilt, American avocet, and killdeer, as well as populations of snowy plover. These populations are important on both a statewide and regional scale."

Glenn Olson

Executive Director

Audubon California 


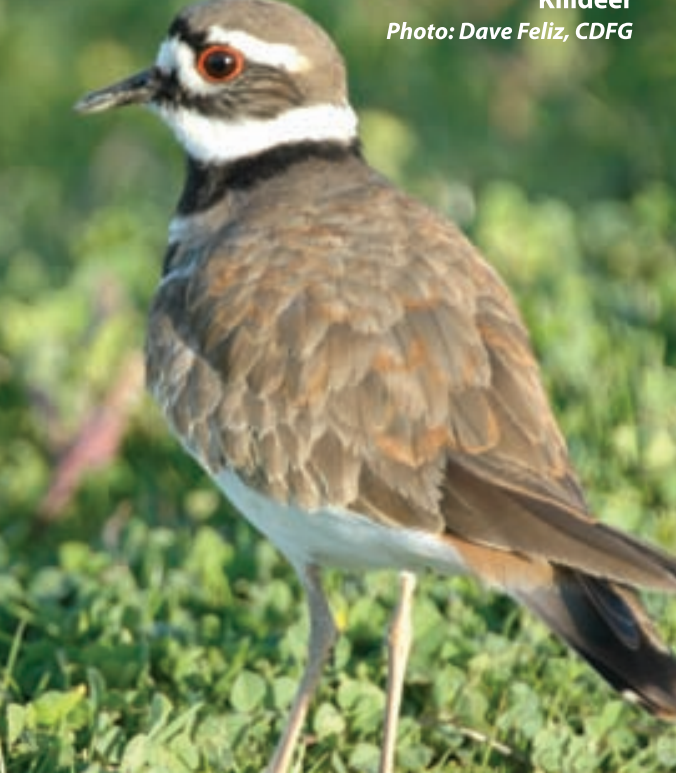

In addition to habitat loss, breeding shorebirds in the Central Valley are often exposed to poor or toxic water conditions, because they frequently rely on evaporation and sewage ponds for breeding habitat. In the 1980s, agricultural drain water in the San Joaquin Valley containing high levels of salts and trace elements was delivered to wetlands to provide wildlife habitat and to agricultural evaporation ponds for disposal. This contamination resulted in bioaccumulation of selenium sufficient to harm reproduction of shorebirds, including stilts and avocets (Ohlendorf et al. 1987, 1993; Skorupa and Ohlendorf 1991.

In wetlands, exposure to selenium has been reduced by filling over areas which contained highest concentrations of this element or by providing uncontaminated water for wetland management. Evaporation ponds are now managed to reduce contamination risk to wildlife by: (1) filling some ponds; (2) hazing birds or physically altering ponds to make them less attractive; and (3) creating nearby uncontaminated wetlands as alternative habitat (Moore et al. 1990, Steele and Bradford 1991, Bradford 1992). Despite steady declines in selenium levels, concentrations in some species still exceed those known to impair reproduction (Paveglio et al. 1992, 1997; Hothem and Welsh 1994a,b). Monitoring is ongoing to determine shorebird and other bird response to these management actions. (R. Hansen, Hansen's Biological Consulting, unpublished data).

Habitat needs for wintering shorebirds were established using a forage-based model that directly linked population objectives to habitat goals (Chapter 6). However, there is no clear link between population objectives for breeding shorebirds and the amount of habitat needed to support breeding birds. The approach used here establishes five-year habitat objectives that reflect the pace of JV accomplishments in recent years. Five years is the amount of time expected between the 2006 Plan and the next Implementation Plan update. It is important that JV partners recognize that this is a short-term objective that reflects the practical realities of habitat delivery in the Central Valley. Habitat objectives for breeding shorebirds may increase in future plan updates, as a better understanding of the link between population objectives and habitat needs of breeding shorebirds is gained. The remainder of this chapter is divided into two sections: (1) a short review of planning information available for breeding shorebirds in the Central Valley; and (2) conservation objectives for breeding shorebirds in the Central Valley.

\section{A Review of Planning Information Available for Breeding Shorebirds in the Central Valley}

The JV used four planning regions within the Central Valley to evaluate breeding shorebird needs and to establish conservation objectives for this bird group: (1) Sacramento Valley, consisting of Colusa, Butte, American, and Sutter Basins; (2) Delta, consisting of Yolo and Delta Basins; (3) San Joaquin Basin; and (4) Tulare Basin. The Suisun Basin was not included, as counts do not exist for this region. However, the Suisun Marsh does provide valuable habitat for breeding shorebirds, and the following conservation actions identified in the Southern Pacific Shorebird Conservation Plan may benefit this bird group: (1) maintain or increase current breeding populations of killdeer, black-necked stilt, and American avocet by restoring, enhancing or creating nesting habitat; (2) incorporate shorebird habitat components in tidal marsh restorations; (3) increase tidal circulation and water quality in marshes to enhance invertebrate productivity and shorebird foraging areas; (4) time water drawdowns in managed marshes to correspond with the peak of spring shorebird migration from mid-April to mid-May; (5) manage vegetation in some ponds to provide expanses of open habitat; and (6) increase nesting habitat for black-necked stilt and American avocet in managed marshes through the strategic placement of islands. (PRBO 2003).

Four factors were considered when establishing conservation objectives for breeding shorebirds in the Central Valley: (1) historic patterns of habitat loss; (2) current distribution of breeding shorebirds among planning regions; (3) an estimate of the habitat resources currently available to breeding shorebirds in each planning region; and (4) annual rates of wetland restoration in the Central Valley. Annual wetland restoration rates provide a basis for identifying how much conservation work might be accomplished on behalf of breeding shorebirds in the next five years, while factors one through three provide the basis for distributing this objective in a biologically meaningful way. 


\section{Historic Habitat Loss}

Although 95\% of the Central Valley's wetlands are now gone, loss of shorebird habitat has been particularly high in the Tulare Basin. Prior to European settlement, Tulare Lake represented the largest freshwater body west of the Mississippi River (Johnson et al. 1993, Thelander and Crabtree 1994). Tulare Basin also contained several smaller lakes (Buena Vista, Goose, Kern), that together provided 260,000 acres of seasonal wetlands and over 250,000 acres of semi-permanent marshes (Griggs et al. 1992).

In 2001, the California State University, Chico began to develop a set of historic natural vegetation maps for the Central Valley of California that identify major changes in the valley due in part to hydrologic alterations associated with the Central Valley Project (1945) and the California State Water Project (1973). Preliminary analysis from the Central Valley Historic Mapping Project indicates that $96 \%$ of the historic wetland and aquatic habitats of the Tulare Basin were lost prior to 1995, and that the loss of these habitat types in the other planning regions of the Central Valley, has ranged between 55\% and 87\% (http://www.gic.csuchico.edu/historic).

Hydrologic factors varied significantly among basins of the Central Valley, resulting in regional differences in the amount of summer wetland habitat. Despite suffering disproportionately high rates of wetland loss, the Tulare Basin likely contained an abundance of summer wetland habitat relative to other areas of the valley. Because Tulare Basin was a terminal basin, it retained water well into summer, since most water moved slowly out of the basin via evaporation. The timing of flood events was another important factor in producing regional differences in summer wetland habitat. Rainfall induced floods (Dec-Mar) predominated in the Sacramento Valley Planning Region, whereas prolonged snowmelt floods (Apr-June) were the norm in the San Joaquin Valley, particularly in the Tulare Basin (The Bay Institute 1998). Various accounts indicate that Tulare Basin wetland habitats supported large numbers of breeding birds, including pelicans, cormorants, waterfowl, shorebirds, and terns.

\section{Current Shorebird Distribution}

Surveys were conducted throughout the Central Valley in 2003 to determine distribution, abundance, and habitat use of breeding stilts and avocets. These two species form the basis for breeding shorebird habitat objectives in the 2006 Plan. The 2003 survey estimated 29,600 stilts and 10,550 avocets in the entire Central Valley, exclusive of Suisun Marsh (Shuford et al. 2004). The distribution of these two species among habitat types and planning regions of the Central Valley is presented in Tables 7-1 and 7-2.

Sixty-four percent of all breeding shorebirds (stilts and avocets combined) were observed in the Sacramento Valley Planning Region, with $32 \%$ of all birds counted in the Tulare Basin. Less than 5\% were observed in the Delta Planning Region and the San Joaquin Basin. Seventy-four percent of all stilts were observed in the Sacramento Valley Planning Region, with most others (23\%) observed in the Tulare Basin. The Delta Planning Region and the San Joaquin Basin each contained less than 3\% of all breeding stilts (Table 7-1). Unlike stilts, most avocets (57\%) were counted in the Tulare Basin. The Sacramento Valley Planning Region contained 36\% of all breeding avocets, while the combined counts from the San Joaquin and Tulare Basins made up less than $8 \%$ of all birds (Table 7-2).

The distribution of breeding shorebirds among habitat types also differed by planning region. Ninety-eight percent of all stilts in the Sacramento Valley Planning Region were observed in rice fields and only one percent in managed wetlands. In contrast, thirty-five percent of all stilts in the Tulare Basin were counted in managed wetlands (Table 7-1). Avocets displayed similar geographic variation in their use of habitat types. Nearly $93 \%$ of all avocets in the Sacramento Valley Planning Region were observed in rice fields, with less than $4 \%$ occurring in managed wetlands. In contrast, nearly half of all avocets in the Tulare Basin were observed in managed wetlands (Table 7-2).

Table 7-1. Numbers (\%) of breeding black-necked stilts in various habitat types by planning regions of the Central Valley in 2003 (from Shuford et al. 2004 ).

\begin{tabular}{|c|c|c|c|c|c|}
\hline & Sacramento Valley & Delta & San Joaquin Basin & Tulare Basin & Central Valley Total \\
\hline MANAGED WETLANDS & $219(1.0)$ & $4(2.5)$ & $307(44.2)$ & $2,441(35.3)$ & $2,971(10.0)$ \\
\hline SEWAGE PONDS & $133(0.6)$ & $33(20.6)$ & $274(39.4)$ & $1,329(19.2)$ & $1,769(6.0)$ \\
\hline RICE FIELDS & $21,412(98.1)$ & $72(45.0)$ & $26(3.7)$ & $0(0.0)$ & $21,510(72.7)$ \\
\hline WATER STORAGE FACILITIES & $42(0.2)$ & $0(0.0)$ & $2(0.3)$ & $820(11.8)$ & $864(2.9)$ \\
\hline Miscellaneous & $21(0.1)$ & $51(31.9)$ & $86(12.4)$ & $202(2.9)$ & $360(1.2)$ \\
\hline EVAPORATION PONDS & $0(0.0)$ & $0(0.0)$ & $0(0.0)$ & $1,170(16.9)$ & $1,170(4.0)$ \\
\hline Agricultural canals & $0(0.0)$ & $0(0.0)$ & $0(0.0)$ & $958(13.8)$ & $958(3.2)$ \\
\hline TOTAL OF ALL HABITAT TYPES & 21,827 & 160 & 695 & 6,920 & 29,602 \\
\hline
\end{tabular}


Table 7-2. Numbers (\%) of breeding American avocets in various habitat types by planning regions of the Central Valley in 2003 (From Shuford et al. 2004$).$

\begin{tabular}{|c|c|c|c|c|c|}
\hline & Sacramento Valley & Delta & San Joaquin Basin & Tulare Basin & Central Valley Total \\
\hline SEWAGE PONDS & $121(3.2)$ & $12(13.8)$ & $217(29.6)$ & $614(10.3)$ & $964(9.1)$ \\
\hline RICE FIELDS & $3,469(92.6)$ & $27(31.0)$ & $15(2.0)$ & $0(0.0)$ & $3,511(33 \cdot 3)$ \\
\hline WATER STORAGE FACILITIES & $11(0.3)$ & $0(0.0)$ & $1(0.1)$ & $192(3.2)$ & $204(1.9)$ \\
\hline MisCELLANEOUS & $6(0.2)$ & $45(51.7)$ & $104(14.2)$ & $55(0.9)$ & $210(2.0)$ \\
\hline EVAPORATION PONDS & $0(0.0)$ & $0(0.0)$ & $0(0.0)$ & $1,538(25.7)$ & $1,538(14.6)$ \\
\hline Agricultural CANALS & $0(0.0)$ & $0(0.0)$ & $0(0.0)$ & $694(11.6)$ & $694(6.6)$ \\
\hline TOTAL OF ALL HABITAT TYPES & 3744 & 87 & 732 & 5,983 & 10,546 \\
\hline
\end{tabular}

Stilts and avocets were more evenly distributed among habitat types in the Tulare Basin than in any other planning region of the Central Valley. Five habitats in the Tulare Basin held $>10 \%$ of all stilts or avocets. The Tulare Basin was the only planning region where agricultural evaporation ponds, canals ditches, and water storage facilities (water recharge ponds, storm water storage ponds, and reservoirs) supported large numbers of stilts and avocets. The proportion of shorebirds in managed wetlands in the Tulare Basin, and to a lesser degree in the Central Valley as a whole, was weighted heavily by large numbers of stilts and avocets counted in a single compensation wetland in the Tulare Basin that was supplied by saline water from an adjacent agricultural evaporation basin.

Overall, shorebirds in some parts of the Central Valley (e.g., Tulare Basin) rely heavily on habitats that serve the production, water conveyance, storage, treatment, or disposal needs of agriculture, municipalities, or industry. The use of some of these habitats may expose shorebirds to toxic substances. Therefore, reliance on some of these artificial environments is risky as future management practices may serve human efficiencies and economies, but reduce benefits to wildlife. This highlights the need to restore and enhance sufficient summer wetland habitat to meet the needs of breeding shorebirds, and other migratory and resident wildlife.

\section{Existing Habitats}

Acres of managed semi-permanent wetlands and planted rice are presented for each of the four planning regions in Table 7-3. These acre estimates are intended to provide an index to the amount of habitat now available to breeding shorebirds in each of these four planning regions. However, the JV recognizes that Table 7-3 does not include all habitat types (e.g., water storage habitats), nor does it distinguish between semi-permanent wetlands that are managed consistent with shorebird needs vs. semi-permanent habitats that are not managed with shorebird needs in mind. Still, the habitat estimates presented in Table 7-3 provide some insight to regional

Table 7-3. Existing breeding shorebird habitats (acres) in the Central Valley.

\begin{tabular}{|ccc|}
\hline Planning region & $\begin{array}{c}\text { Semi-permanent } \\
\text { wetlands }\end{array}$ & Planted rice \\
\hline SACRAMENTO VALLEY & 10,488 & 491,146 \\
\hline DELTA & 1,121 & 1,399 \\
SAN JOAQUIN BASIN & 6,779 & 10,000 \\
TULARE BASIN & 2,245 & 0 \\
\hline
\end{tabular}

differences in the resources available to breeding shorebirds.

Half of all semi-permanent wetlands in the four shorebird planning regions occur in the Sacramento Valley Planning Region, with most of the remaining wetlands located in the San Joaquin Basin. Only about ten percent of all semi-permanent wetlands occur in the Tulare Basin, despite this region's importance to breeding shorebirds. Finally, about $5 \%$ of all managed wetlands are located in the Delta Planning Region, where breeding shorebird numbers are low relative to other areas of the Central Valley (Table 7-3).

\section{Annual Rates of Wetland Restoration in the Central Valley}

Annual tracking of JV accomplishments indicates that wetland restoration in the Central Valley averages about 6,000 acres per year. Between $10 \%$ and $15 \%$ of these wetlands are managed as semi-permanent wetlands, depending on the basin (U.S. Fish and Wildlife Service 2000). Assuming an average value of $12.5 \%$, approximately 750 acres of semi-permanent wetlands are annually restored in the Central Valley. 


\section{Conservation}

Objectives for Breeding Shorebirds

Although Central Valley shorebirds breed in a variety of habitats (Shuford et al. 2004), there is general agreement that conservation efforts should focus on providing summer wetland habitat (semipermanent wetlands) that is managed to prevent widespread establishment of robust emergent plant communities. As a result, conservation objectives for breeding shorebirds in the 2006 Plan are limited to: (1) the establishment of semipermanent wetland objectives (acres) in each of the four planning regions; and (2) the annual water needs of these wetlands. It is assumed that these wetlands will be managed consistent with the needs of breeding shorebirds, including control of robust emergent vegetation, provision of unvegetated nesting islands, provision of shallow foraging habitat for adults and young, and, where appropriate, employing methods to control predation of nests and young (see Shuford et al. 2004 for more specific management recommendations).

Recent surveys of breeding shorebirds in the Central Valley indicate that most birds breed in the Sacramento Valley Planning Region and the Tulare Basin. Of the 40,000 stilts and avocets observed in the 2003 breeding survey, nearly $64 \%$ occurred in the Sacramento Valley Planning Region. Tulare Basin accounted for 32\% of this total (Tables 7-1 and 7-2). Although both these planning regions are important to breeding shorebirds, they differ in terms of historic habitat loss and existing habitat resources. Loss of historic shorebird breeding habitat appears to be especially high in the Tulare Basin with the loss of terminal lake systems to agriculture. Moreover, Tulare Basin has considerably less summer wetland habitat than occurs in the Sacramento Valley Planning Region. These differences in existing habitat resources are compounded by the difficulty in acquiring water for summer wetland habitat in Tulare Basin because of high costs and low availability.

\section{Wetland Restoration}

The conservation objective is to restore 7,500 acres of semi-permanent wetlands over the next five years (Table 7-4). Restoration of semi-permanent wetlands in the Central Valley has averaged about 750 acres per year in recent years. This objective is a two-fold increase over current rates of restoration, and was apportioned among the four planning regions based on the current distribution of breeding shorebirds, historic patterns of wetland loss, and existing wetland resources. While believed to be realistic, this objective will require a substantial effort on the part of JV partners to deliver over the next five years.

\section{Wetland Water Requirements}

Annual water needs for semi-permanent wetlands are estimated to average 6.5 acre-feet per acre (U.S. Fish and Wildlife Service 2000). Table 7-5 identifies the annual wetland water needs to meet breeding shorebird requirements based on five year habitat objectives for each planning region. 


\section{Summary}

Overall, meeting the five-year habitat objectives for breeding shorebirds in the Central Valley requires an additional 7,500 acres of semi-permanent habitat to be distributed as described in Table 7-4. Longer-term habitat objectives for breeding shorebird populations will be developed over the next several years by the $\mathrm{JV}$, and will be reflected in future revisions of the 2006 Plan. It is assumed that these acres will be managed in a way that is consistent with breeding shorebird needs (see Shuford et al. 2004 for specific habitat management recommendations). The forthcoming JV monitoring and evaluation plan should outline an approach to monitor the suitability of semi-permanent wetland habitat for breeding shorebirds and population response to habitat increases. In addition, it may suggest monitoring needs for breeding shorebird species not included in this chapter, and an approach to produce additional habitat objectives for those species.
Table 7-4. Five-year wetland restoration objectives for breeding shorebirds in the Central Valley.

\begin{tabular}{|cc|}
\hline Planning region & 5-year acre objective \\
\hline SACRAMENTO VALLEY & 875 \\
\hline DELTA & 875 \\
\hline SAN JOAQUIN BASIN & 1,315 \\
TULARE BASIN & 4,435 \\
TOTAL & 7,500 \\
\hline
\end{tabular}

Table 7-5. Annual wetland water needs (acre-feet) to meet 5-year breeding shorebird habitat objectives.

\begin{tabular}{|cc|}
\hline Planning region & $\begin{array}{c}\text { Annual acre-feet } \\
\text { Need }\end{array}$ \\
\hline SACRAMENTO VALLEY & 5,688 \\
DELTA & 5,688 \\
SAN JOAQUIN BASIN & 8,548 \\
TULARE BASIN & 28,828 \\
TotAL & $\mathbf{4 8 , 7 5 2}$ \\
\hline
\end{tabular}




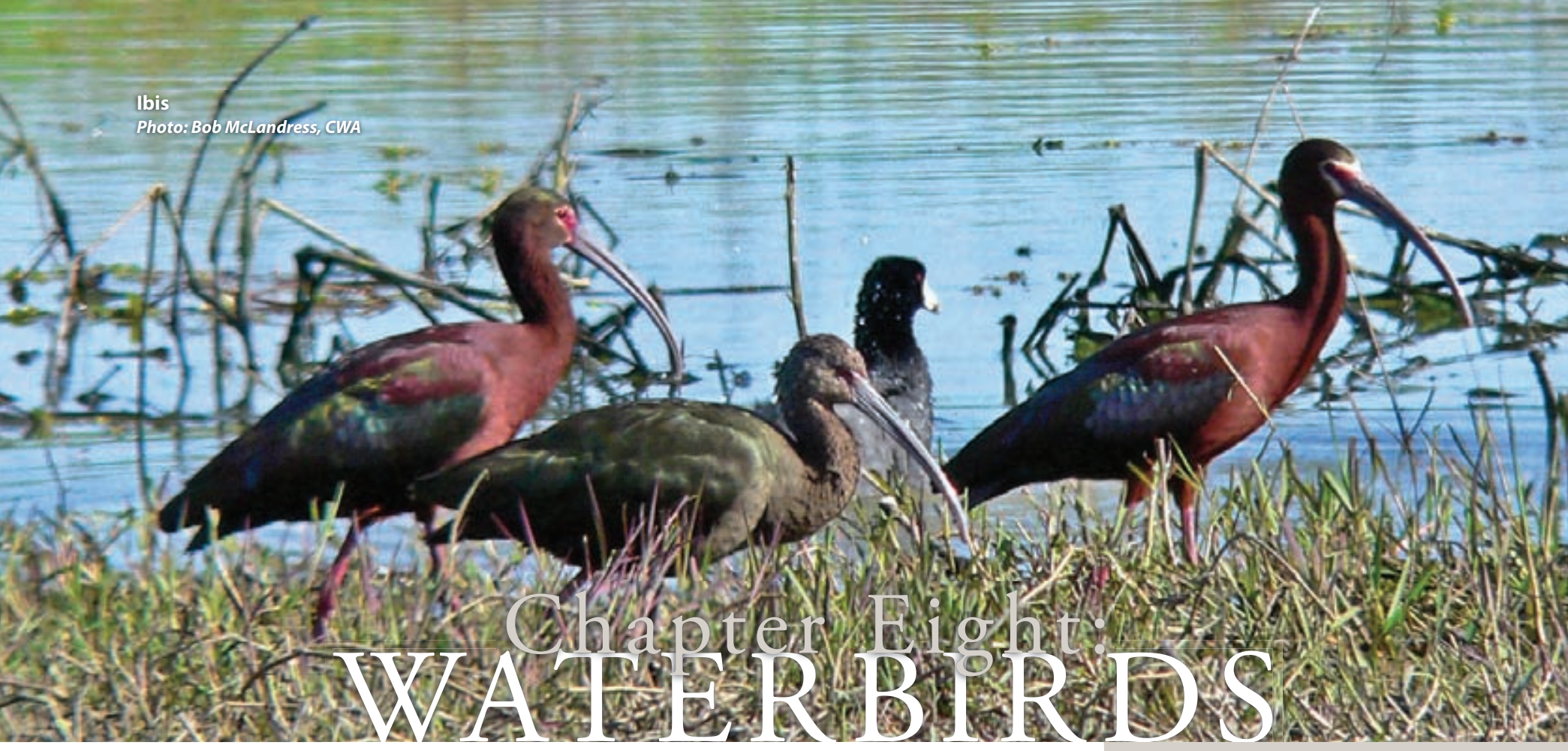

This chapter addresses conservation needs within the Central Valley for waterbirds, a large and diverse group that includes seabirds, coastal waterbirds, wading birds and marshbirds that rely on aquatic habitats.

\section{Introduction}

The Central Valley provides habitat for thirty-eight species of waterbirds. The North American Waterbird Conservation Plan (NAWCP; Kushlan et al. 2002) provides a continental framework for the conservation and management of 23 families of North American waterbirds. Version 1 of the NAWCP concentrates on colonial nesting species with future versions of the plan to address solitary-nesting waterbirds. The NAWCP outlines four goals with associated strategies and desired results for waterbirds: (1) species and population; (2) habitat; (3) education and information; and (4) coordination and information. The NAWCP also relegates responsibility to regional step-down conservation plans for the development of specific conservation goals at regional scales. In the absence of a completed regional bird conservation plan, this 2005 Plan incorporates appropriate recommendations from the NAWCP Species and Population and Habitat Goals into the JV planning process. This is the first organized effort to explicitly link goals and strategies outlined in the NAWCP with the goals and objectives of the JV. The remainder of this chapter is divided into three sections: (1) approach used to develop conservation objectives for waterbirds; (2) selecting focal species; and (3) conservation objectives for waterbirds.
"Degradation of Central Valley wetlands undoubtedly collapsed waterbird populations. Recent seasonal wetland and riparian restoration efforts have resulted in an expansion of breeding colonial waterbird nesting. Among species that have made dramatic recoveries are breeding white-faced ibis and wintering great blue heron. However, several other species (least bittern, black tern, and black rail) remain at low levels, and demand further habitat conservation efforts."

Frederic Reid, Ph.D.

Director of Conservation Planning Ducks Unlimited, Inc. 


\section{Approach Used to Develop Conservation Objectives for Waterbirds}

Version 1 of the NAWCP provides quantitative information for colonial nesting species, the majority of which are long-legged waders and seabirds. The lack of continental and regional population goals and population baseline data on size and distribution is the greatest obstacle to developing population-based habitat goals and objectives. The U.S. Fish and Wildlife Service (USFWS) is currently developing a waterbird conservation plan for Bird Conservation Region (BCR) 32, Coastal California, which wholly encompasses the Central Valley (U.S. NABCI Committee 2000). This plan will establish long term conservation goals and objectives for waterbirds and will provide a basis for establishing long term goals for the next JV implementation plan update. This chapter develops short term (5-year) conservation objectives that include a combination of quantitative habitat objectives and qualitative habitat conservation recommendations to benefit a range of waterbird species that breed and/or winter within the Central Valley. Specifically, this chapter: (1) identifies focal species that serve as an "umbrella" for similar species; (2) identifies factors believed to be limiting their populations; and (3) develops conservation strategies to counter these limiting factors.

\section{Selecting Focal Species}

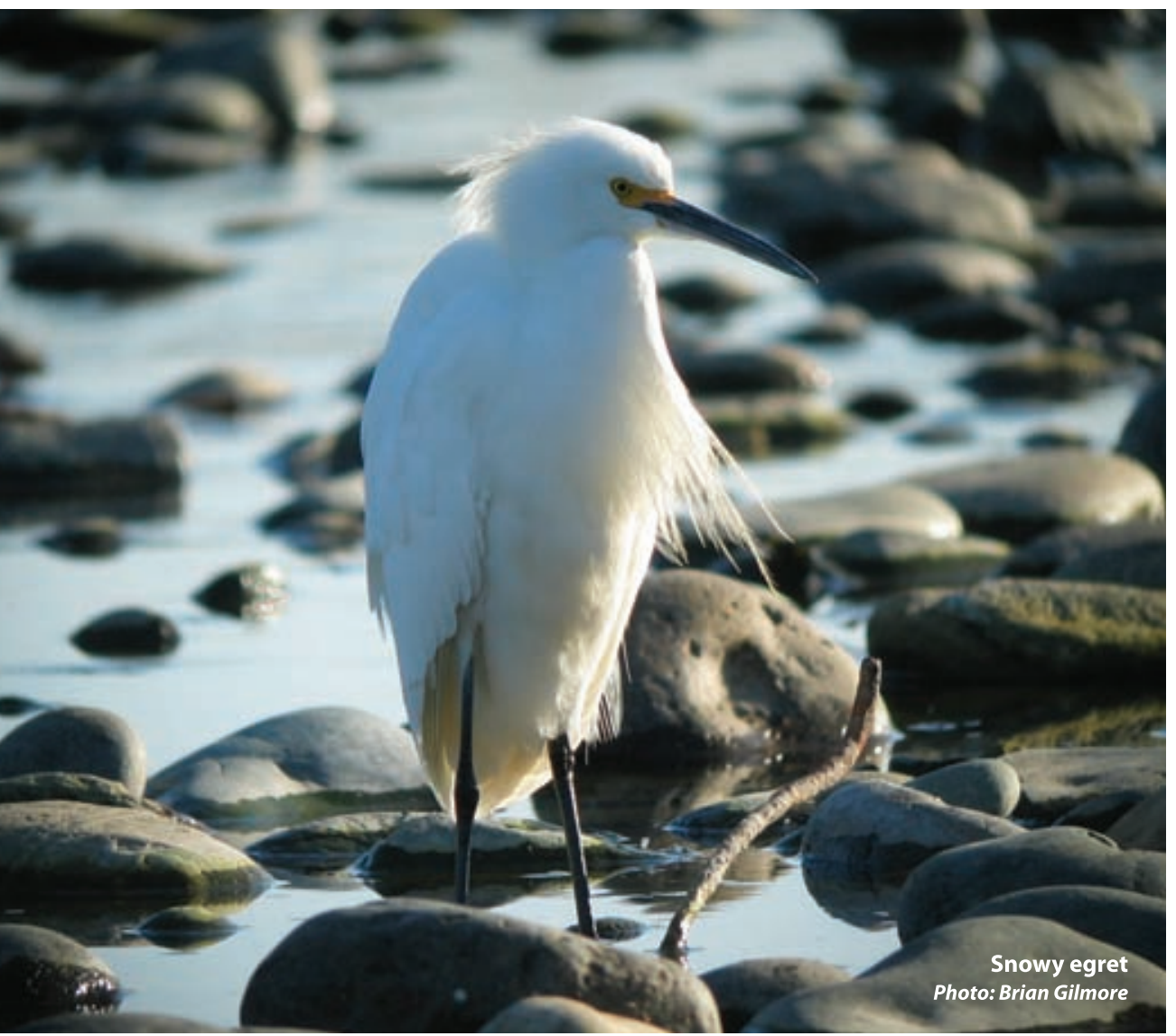

The JV selected focal species by reviewing the NAWCP and other documents to determine the distribution of all waterbird species within the JV and subsequently evaluated the current level of conservation concern for these species. Focal species that best serve as "umbrella" species for the family or group of waterbirds that they represent, and that would most likely benefit from JV conservation actions, were selected from this list. This chapter includes a brief overview of the habitat needs and associations of each focal species.

\section{Distribution of Waterbirds in the JV}

The NAWCP summarizes available population data for 210 species of North American waterbirds. It also lists the distribution and classification of waterbirds (breeding, wintering, migratory, pelagic) for $52 \mathrm{BCRs}$ and Pelagic Bird Conservation Regions. The JV used range maps from Zeiner et al. (1990) to determine which species found in BCR 32 occur within the boundaries of the JV during summer and/or winter. Because information on waterbirds is lacking at the basin level, the JV combined some basins to form four waterbird planning regions similar to the shorebird planning region units described in chapters 6 and 7 (Figure 8-1). The Sacramento Valley Planning Region includes the Butte, Colusa, Sutter, and American Basins. The Delta Planning Region includes the Yolo and Delta Basins and the Suisun Marsh. The San Joaquin and Tulare basins stand alone as their own planning regions. Thirty-eight species representing eight families of waterbirds occur within the JV (Table 8-1). Twenty-seven of those species winter within one or more planning regions, and 25 occur in one or more planning regions during the breeding season. 


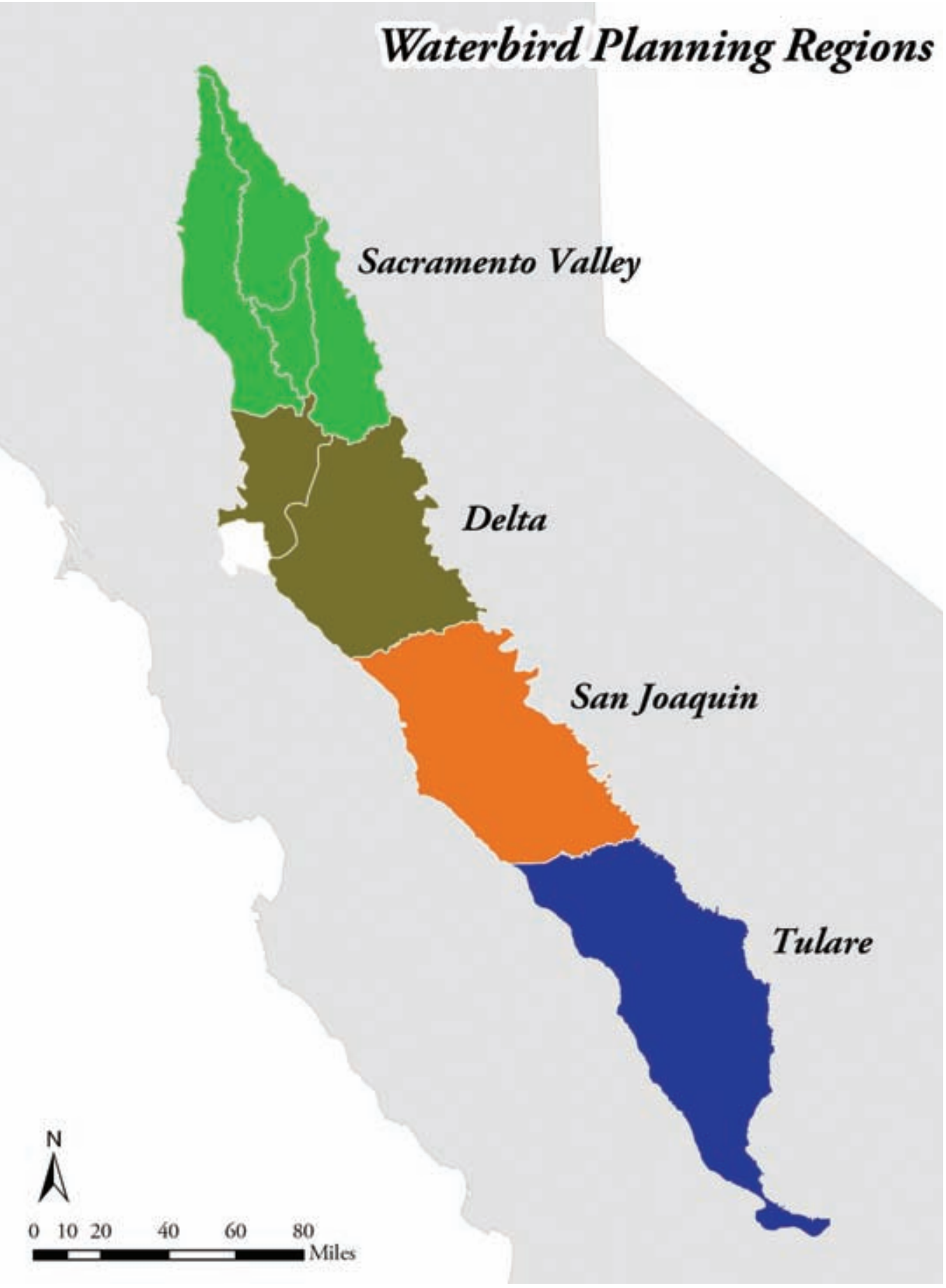

Figure 8-1. Waterbird planning regions of the Central Valley Joint Venture. 
Table 8-1. Breeding ${ }^{1}$ and wintering ${ }^{2}$ distribution of waterbirds among waterbird planning regions.

\begin{tabular}{|c|c|c|c|c|}
\hline & $\begin{array}{c}\text { Sacramento } \\
\text { Valley }\end{array}$ & Delta & San Joaquin & Tulare \\
\hline EARED GREBE & $\mathrm{w}$ & $\mathrm{B}, \mathrm{W}$ & $\mathrm{w}$ & $\mathrm{B}, \mathrm{w}$ \\
\hline WESTERN GREBE & $\mathrm{B}, \mathrm{w}$ & $\mathrm{w}$ & $\mathrm{B}, \mathrm{w}$ & $\mathrm{B}, \mathrm{w}$ \\
\hline ClaAk's GREBE & B, $\mathrm{W}$ & $\mathrm{w}$ & B, $\mathrm{W}$ & B, $\mathrm{W}$ \\
\hline Pied-BILled GREBE & $\mathrm{B}, \mathrm{W}$ & $\mathrm{B}, \mathrm{W}$ & $\mathrm{B}, \mathrm{W}$ & $\mathrm{B}, \mathrm{W}$ \\
\hline AMERICAN WHITE PELICAN & $\mathrm{w}$ & $\mathrm{w}$ & $\mathrm{w}$ & $\mathrm{w}$ \\
\hline DOUBLE-CRESTED CORMORANT & $\mathrm{B}, \mathrm{W}$ & $\mathrm{w}$ & $\mathrm{w}$ & $\mathrm{B}, \mathrm{W}$ \\
\hline SNOWY EGRET & $\mathrm{B}, \mathrm{W}$ & $\mathrm{B}, \mathrm{W}$ & $\mathrm{B}, \mathrm{W}$ & $\mathrm{w}$ \\
\hline BLACK-CROWNED NIGHT HERON & $\mathrm{B}, \mathrm{W}$ & $\mathrm{B}, \mathrm{W}$ & $\mathrm{B}, \mathrm{W}$ & $\mathrm{B}, \mathrm{W}$ \\
\hline GREEN-BACKED HERON & B, $w$ & $\mathrm{~B}, \mathrm{~W}$ & $\mathrm{~B}, \mathrm{w}$ & $\mathrm{B}, \mathrm{W}$ \\
\hline GREAT BLUE HERON & $\mathrm{B}, \mathrm{W}$ & $\mathrm{B}, \mathrm{W}$ & $\mathrm{B}, \mathrm{W}$ & $\mathrm{B}, \mathrm{W}$ \\
\hline GREAT EGRET & $\mathrm{B}, \mathrm{W}$ & $\mathrm{B}, \mathrm{W}$ & $\mathrm{B}, \mathrm{w}$ & $\mathrm{B}, \mathrm{W}$ \\
\hline CATTLE EGRET & $\mathrm{B}, \mathrm{W}$ & & & \\
\hline LEAST BITTERN & в & B & B & \\
\hline AMERICAN BITTERN & $\mathrm{B}, \mathrm{W}$ & $\mathrm{B}, \mathrm{W}$ & $\mathrm{B}, \mathrm{W}$ & $\mathrm{B}, \mathrm{W}$ \\
\hline WHITE-FACED IBIS & $\mathrm{B}, \mathrm{W}$ & & $\mathrm{B}, \mathrm{W}$ & $\mathrm{B}, \mathrm{W}$ \\
\hline CALIFORNIA GULL & $\mathrm{w}$ & $\mathrm{B}, \mathrm{W}$ & B, $\mathrm{W}$ & B, $\mathrm{W}$ \\
\hline FORSTER’s TERN & в & в & в & в \\
\hline BLACK TERN & в & в & в & в \\
\hline BONAPARTE'S GULL & & $\mathrm{w}$ & & \\
\hline THAYER's GULL & $\mathrm{w}$ & $\mathrm{B}, \mathrm{W}$ & $\mathrm{B}, \mathrm{W}$ & \\
\hline HERRING GULL & $\mathrm{w}$ & w & w & $\mathrm{w}$ \\
\hline GLAUCOUS-WINGED GULL & $\mathrm{w}$ & $\mathrm{w}$ & w & \\
\hline RING-BILLED GULL & $\mathrm{w}$ & $\mathrm{B}, \mathrm{W}$ & $\mathrm{B}, \mathrm{W}$ & $\mathrm{B}, \mathrm{W}$ \\
\hline MeW GULL & $\mathrm{w}$ & $\mathrm{w}$ & & \\
\hline BLACK RAIL & в & $\mathrm{B}, \mathrm{W}$ & & \\
\hline VIRGINIA RAIL & B, $W$ & $\mathrm{~B}, \mathrm{~W}$ & $\mathrm{~B}, \mathrm{~W}$ & $\mathrm{~B}, \mathrm{~W}$ \\
\hline SORA RAIL & $\mathrm{B}, \mathrm{W}$ & $\mathrm{B}, \mathrm{W}$ & $\mathrm{B}, \mathrm{W}$ & $\mathrm{B}, \mathrm{W}$ \\
\hline COMMON MOORHEN & $\mathrm{B}, \mathrm{W}$ & $\mathrm{B}, \mathrm{W}$ & $\mathrm{B}, \mathrm{W}$ & $\mathrm{B}, \mathrm{W}$ \\
\hline AMERICAN COOT & $\mathrm{B}, \mathrm{W}$ & $\mathrm{B}, \mathrm{W}$ & $\mathrm{B}, \mathrm{W}$ & $\mathrm{B}, \mathrm{W}$ \\
\hline SANDHILl CRANE & $\mathrm{w}$ & $\mathrm{w}$ & $\mathrm{w}$ & $\mathrm{w}$ \\
\hline
\end{tabular}

1. $B=$ breeding $2 . W=$ wintering

\section{Conservation Status of Waterbirds}

The status of waterbird species is tracked in a variety of ways. The NAWCP lists categories of conservation concern for each species as highly imperiled, high concern, moderate concern, low concern, or not currently at risk. The California Department of Fish and Game maintains a list of California Bird Species of Special Concern, and the USFWS periodically publishes a list of Birds of Conservation Concern. The most recent edition of this publication highlights birds of conservation priority at three geographic scales, including the BCR level (U.S. Fish and Wildlife Service 2002). The JV reviewed the status of waterbird species from each of these lists to determine their continental and regional conservation status (Table 8-2).
Table 8-2. Conservation status of selected waterbirds among various bird conservation plans.

\begin{tabular}{|cccc|}
\hline Focal Species & NAWCP & BSSC & BCC \\
\hline WESTERN GREBE & MODERATE & & \\
SNOWY EGRET & HIGH & & \\
LEAST BITTERN & N/A & $\mathrm{X}$ & \\
WHITE-FACED IBIS & LOW & & \\
BLACK TERN & MODERATE & $\mathrm{X}$ & \\
BLACK RAIL & N/A & & $\mathrm{X}$ \\
SANDHILL CRANE & N/A & $\mathrm{x}$ & \\
\hline
\end{tabular}

NAWCP $=$ North American Waterbird Conservation Plan $B S S C=$ California bird species of special concern. $B C C=$ USFWS Birds of Conservation Concern (USFWS 2002). 


\section{Identifying Focal Species}

To facilitate planning and implementation of conservation programs, the JV used a modification of Lamback's (1997) technique to identify focal species that are representative of groups of species found in the Central Valley. Species were selected from each family, if they met the following criteria: (1) listed as Highly Imperiled or of High Concern in the NAWCP; or (2) listed as of Moderate Concern in the NAWCP and California Bird Species of Special Concern; and/or listed as a USFWS Bird of Conservation Concern. Using this process, the JV identified seven focal species representing six families spanning a range of wetland or riparian conditions: Western grebe (Aechmophorus occidentalis); snowy egret (Egretta thula); least bittern (Ixobrychus exilis); white-faced ibis (Plegadis chihi); black tern (Chlidonias niger); black rail (Laterallus jamaicensis); and Sandhill crane (Grus Canadensis). White-faced ibis was included because of the species' visibility as important wetland wildlife to land managers, biologists, and the general public. Western grebes are ranked as "moderate" by the NAWCP, but have few secure breeding opportunities in California. However, they were identified as a focal species because of the recent attention to their conservation needs (Ivey 2004).

\section{Limiting Factors for Waterbird Focal Species}

Recognizing the extent of wetland habitat loss in the Central Valley, habitat quantity and quality are assumed to be limiting factors during key life cycle events. Thus, the protection, restoration and/or enhancement of wintering and/or breeding habitat will benefit waterbird populations. The NAWCP evaluated the conservation status of waterbirds based on six factors: (1) population trend; (2) population size; (3) threats to breeding; (4) threats to non-breeding; (5) breeding distribution; and (6) non-breeding distribution. Each of these factors received a score from 1 to 5 , in increasing order of severity. The JV examined these factors to help determine those that are potentially limiting to focal species. The term "threats" includes actual threats to populations, as well as declining population status or other vulnerabilities such as small population size and limited distribution. Factors receiving a score of " 4 " or higher were considered significant threats (Table 8-3). Principal threats were categorized as breeding, non-breeding or both in order to make assumptions concerning the best conservation strategies. For example, western grebes and snowy egrets face significant threats in both breeding and wintering seasons. Black terns face threats during the breeding season.

Table 8-3. North American Waterbird Conservation Plan level of conservation threats to focal waterbird species.

\begin{tabular}{|c|c|c|c|c|c|c|}
\hline Focal Species & Population Trend & Population Size & $\begin{array}{l}\text { Threats To } \\
\text { Breeding }\end{array}$ & $\begin{array}{l}\text { Threats To Non- } \\
\text { Breeding }\end{array}$ & $\begin{array}{c}\text { Breeding } \\
\text { Distribution }\end{array}$ & $\begin{array}{c}\text { Non-Breeding } \\
\text { Distribution }\end{array}$ \\
\hline WESTERN GREBE & 3 & 2 & 4 & 4 & 3 & 3 \\
\hline SNOWY EGRET & 4 & 2 & 4 & 3 & 3 & 4 \\
\hline LEAST BITTERN & $\mathrm{N} / \mathrm{A}$ & $\mathrm{N} / \mathrm{A}$ & $\mathrm{N} / \mathrm{A}$ & $\mathrm{N} / \mathrm{A}$ & $\mathrm{N} / \mathrm{A}$ & $\mathrm{N} / \mathrm{A}$ \\
\hline WHITE-FACED IBIS & 2 & 2 & 4 & 3 & 3 & 4 \\
\hline BLACK TERN & 3 & 2 & 4 & 3 & 2 & 2 \\
\hline BLACK RAIL & $\mathrm{N} / \mathrm{A}$ & $\mathrm{N} / \mathrm{A}$ & $\mathrm{N} / \mathrm{A}$ & $\mathrm{N} / \mathrm{A}$ & $\mathrm{N} / \mathrm{A}$ & $\mathrm{N} / \mathrm{A}$ \\
\hline SANDHILl CRANE & $\mathrm{N} / \mathrm{A}$ & $\mathrm{N} / \mathrm{A}$ & $\mathrm{N} / \mathrm{A}$ & $\mathrm{N} / \mathrm{A}$ & $\mathrm{N} / \mathrm{A}$ & $\mathrm{N} / \mathrm{A}$ \\
\hline
\end{tabular}

Population size, breeding distribution, and non-breeding distribution are based on quantitative information. Population trend, threats to breeding population, and threats to non-breeding population are based on qualitative information. All factors are scaled from 1-5, with 5 indicating the greatest vulnerability. Least bitterns, black rails, and Sandhill cranes are not covered in Version 1 of the NAWCP. Others sources (cited in text) are used to determine conservation threats.

\section{Conservation Objectives for Waterbirds}

Without population goals on which to base habitat objectives, the JV's approach was to identify factors believed to be limiting populations, and to target conservation strategies that counter these limiting factors. The JV used a two-step process to develop conservation objectives. First, biologists developed quantitative (i.e., acre) habitat objectives for each of five principal waterbird habitats and distributed them among each waterbird planning region. Secondly, they provided qualitative focal species conservation recommendations. 


\section{Habitat Objectives and Distribution}

Principal waterbird habitats in the Central Valley include both "natural" habitats like seasonal wetlands, semi-permanent and permanent wetlands, and riparian habitat as well as agricultural habitats like rice, other cropland and irrigated pasture. Table 8-6 details the recommended distribution of habitats and associated focal species among waterbird planning basins. Conservation objectives are general in nature (i.e., acres of semi-permanent wetlands) and do not account for micro-habitat needs or specific best management practices for focal species. The JV's approach for establishing conservation varies by habitat as described below. For some habitats, acreage objectives were developed based on a $25-33 \%$ increase over current rates of restoration. These objectives are believed to be realistic, but will

require a substantial effort on the part of JV partners to deliver over the next five years. In general, objectives for natural habitats (i.e., wetlands, riparian) are for new habitat while agricultural habitat objectives seek to maintain current conditions. Table 8-4 provides a quick reference to habitat associations, and Table 8-5 summarizes conservation objectives for waterbirds.

\section{Seasonal Wetlands}

Seasonal wetlands provide important habitat for non-breeding snowy egrets, white-faced ibis, and associated waterbirds. Habitat objectives for wintering waterfowl include restoration of 104,000 acres of seasonal wetlands. The JV assumes that these seasonal wetlands will provide the range of micro-habitats needed by a range of waterbirds and that resource competition between waterbirds and waterfowl using seasonal wetlands is negligible. Therefore, no additional habitat objectives for seasonal wetlands are proposed.

\section{Semi-permanent Wetlands}

The objective of 5,000 acres of restored semi-permanent wetlands was established to benefit breeding black rails, black terns, whitefaced ibis, western grebe, and least bittern; and non-breeding snowy egrets and white-faced ibis. For habitat tracking purposes, semipermanent and permanent wetlands have been combined, and are hereafter referred to as semi-permanent wetlands. Collectively, these wetlands currently comprise $15 \%$ of the total wetland base in the Sacramento Valley and Delta Planning Regions, and 10\% of the wetland base in the San Joaquin and Tulare Basins. Waterbird habitat objectives have been adjusted to increase the apparent relative shortfall in semi-permanent wetlands in the two southernmost regions. The objective of 5,000 acres represents a $33 \%$ increase over current rates of restoration for semi-permanent wetlands, to include 1,000 acres in both the Sacramento Valley and Delta Planning Regions and 1,500 acres in both the San Joaquin and Tulare Basins. 
Rice fields provide important habitat for breeding black terns and white-faced ibis and for wintering white-faced ibis and Sandhill cranes. Habitat objectives for wintering waterfowl include enhancement of 170,000 acres of rice by winter flooding. Similar to seasonal wetlands, negligible resource competition is assumed between these waterbirds and wintering waterfowl. Therefore, no additional habitat objectives for rice are proposed.

\section{Cropland and Irrigated Pasture}

Irrigated cereal grains, alfalfa, and pasture provide the primary foraging habitat for wintering Sandhill cranes in the Central Valley. Foraging habitat is threatened by a number of factors including urbanization, conversion to orchards and vineyards, and other changing agricultural practices. These habitats are especially at risk in the Delta Planning Region, an area of traditionally high use by wintering Sandhill cranes, and the region where estimates of irrigated cropland loss (18.3\% by 2040) and human population growth (> 2 million by 2040) are highest. Sandhill cranes show high site fidelity to roost sites and are slow to colonize new roosting areas. Therefore, conservation objectives for cropland and irrigated pasture include the acquisition of agricultural easements on suitable foraging sites within three miles of nocturnal roost sites (Littlefield and Ivey 2000).

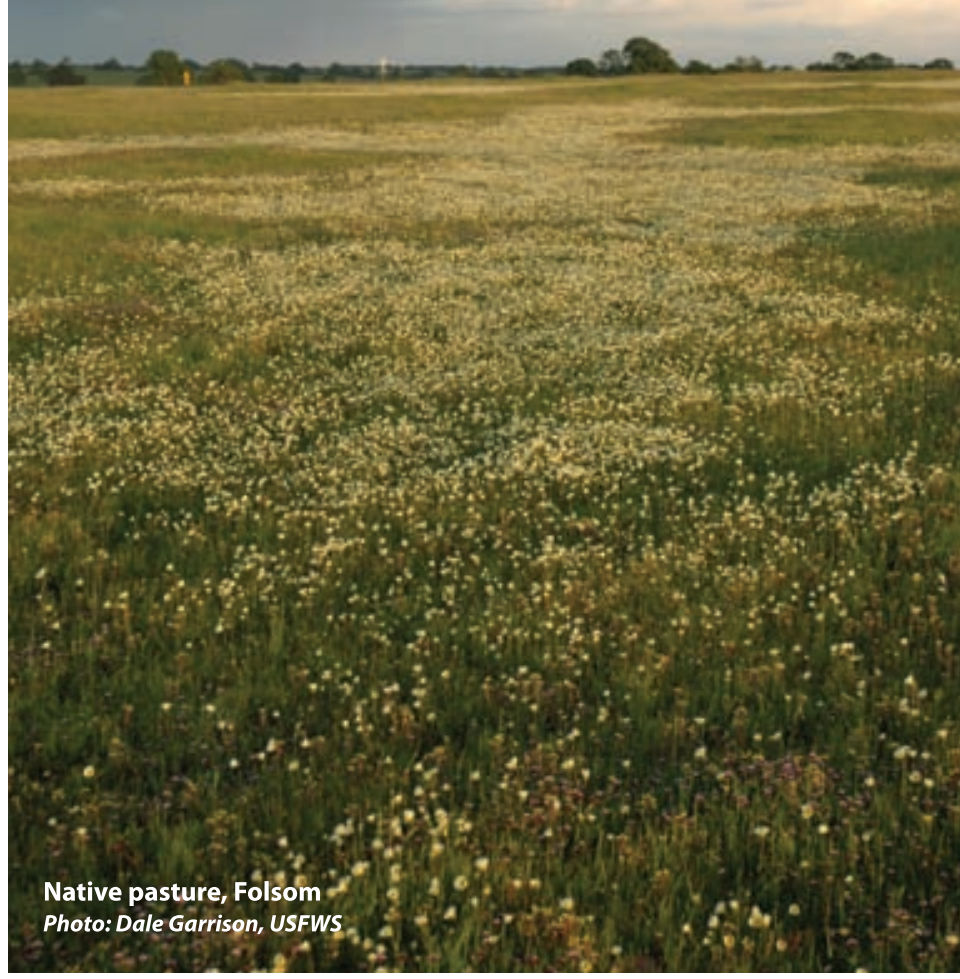

\section{Riparian}

Restoration of riparian habitat, especially in proximity to foraging areas is a high priority need for breeding and non-breeding snowy egrets and associated species. The objective of restoring 5,000 acres of riparian habitat represents a $25 \%$ increase over current rates of restoration. Most of the remaining riparian habitat and a large percentage of restored riparian habitat occur in the Sacramento Valley and Delta Planning Regions. Because the San Joaquin and Tulare Basins collectively comprise about 18\% of the existing riparian habitat in the Central Valley, the JV adjusted habitat objectives to attempt to make up for the apparent shortfall in the southern Central Valley by allotting acreage objectives as follows: Sacramento Valley-1,000 acres, Delta-1,000 acres, San Joaquin-1,500 acres, Tulare-1,500 acres.

\section{Focal Species Conservation Recommendations}

Some conservation practices are applicable to many focal species. For example, favorable water management regimes are critical for successful breeding of most waterbirds. Waterbird survival and productivity can be increased by stabilizing water levels during the nesting season to protect nests from flooding, and by implementing the appropriate timing of drawdown in semi-permanent wetlands. Information below provides conservation recommendations specific to individual focal species. Project managers are considered best equipped to make decisions regarding site-specific application of practices geared towards specific focal species. An overview of habitat requirements and conservation actions for each focal species is provided to assist planners and managers in their efforts to integrate waterbirds with other conservation programs. Table 8-6 summarizes conservation needs of focal species. Many other species receive benefits from conservation actions undertaken for focal species, though no attempt was made to compile a list of all such species. When appropriate, specific birds of conservation interest [i.e., tricolored blackbird (Agelaius tricolor)] or species that are taxonomically similar (i.e., Clark's grebe, western grebe) that may receive benefits are mentioned. 
Table 8-6. Summary of conservation needs of focal waterbird species of the Central Valley Joint Venture.

\begin{tabular}{|c|c|c|}
\hline Focal Species & Conservation Need & Planning Regions \\
\hline WESTERN GREBE & $\begin{array}{l}\text { STABILIZE WATER LEVELS DURING BREEDING; PROTECT NESTING AREAS } \\
\text { FROM DISTURBANCE. }\end{array}$ & Sacramento Valley \\
\hline SNOWY EGRET & $\begin{array}{l}\text { RESTORATION AND ENHANCEMENT OF RIPARIAN HABITAT IN PROXIMITY TO RICELAND } \\
\text { AND WETLAND COMPLEXES. }\end{array}$ & AlL \\
\hline LEAST BITTERN & $\begin{array}{l}\text { ENHANCEMENT AND RESTORATION OF DENSE EMERGENT (PRIMARILY CATTAIL) } \\
\text { PERMANENT AND SEMI-PERMANENT WETLANDS. }\end{array}$ & $\begin{array}{l}\text { SaCRamento Valley, Delta, } \\
\text { SAN JOAQUiN }\end{array}$ \\
\hline WHITE-FACED IBIS & $\begin{array}{c}\text { ENHANCEMENT AND RESTORATION OF PERMANENT AND } \\
\text { SEMI-PERMANENT WETLANDS AND SECURING WATER FOR } \\
\text { ESTABLISHED NEST COLONY SITES. }\end{array}$ & Sacramento Valley, Tulare \\
\hline BLACK TERN & $\begin{array}{l}\text { PROTECTION, RESTORATION AND ENHANCEMENT OF LARGE PERMANENT/SEMI- } \\
\text { PERMANENT WETLANDS OR WETLAND COMPLEXES WITH SHORT TO MEDIUM HEIGHT } \\
\text { VEGETATION [12-20 HA. }(\sim 30-50 \text { ACRES }) \text { Min. }] \text {. }\end{array}$ & ALL \\
\hline BLACK RAIL & $\begin{array}{l}\text { PROTECTION, RESTORATION AND ENHANCEMENT OF PERMANENT/SEMI-PERMANENT } \\
\text { WETLANDS AND SIMILAR PROTECTION AND RESTORATION OF UPLAND HABITATS FOR } \\
\text { ESCAPE COVER DURING FLOOD EVENTS. }\end{array}$ & Delta, Sacramento Valley \\
\hline SANDHILl CRANE & $\begin{array}{l}\text { PROTECTION, RESTORATION AND ENHANCEMENT OF SEASONAL WETLANDS IN } \\
\text { PROXIMITY TO FORAGING HABITAT, ESP. RICE, CEREAL GRAINS, IRRIGATED PASTURE } \\
\text { AND ALFALFA. PROTECTION OF ROOSTS AND NEARBY FORAGING HABITAT. }\end{array}$ & AlL \\
\hline
\end{tabular}

\section{Western grebe}

Western grebes nest colonially on floating vegetation in or near sparse emergent habitat, usually hardstem bulrush, adjacent to open water. During winter, open water in the Central Valley serves as resting and foraging habitat for these birds. Recommended conservation activities for breeding birds include reducing water fluctuations and protecting nesting areas from disturbance. Specific conservation actions for this species at the Thermolito Afterbay, below Lake Oroville, (and for other sites in California) are described in Ivey (2004). Clark's grebes will also benefit from conservation activities implemented for western grebes.

\section{Snowy egret}

Snowy egrets nest colonially in riparian habitats with dense woody vegetation, as well as in permanent and semi-permanent wetlands with dense emergent vegetation (Zeiner et al. 1990, Parsons and Master 2000). Ideal nesting sites offer nearby foraging habitat, therefore restoration and enhancement of riparian habitat in proximity to riceland and wetland complexes is the primary conservation need. Snowy egrets associate with other colonial wading bird species during breeding and foraging activities (Parsons and Master 2000). Specific objectives include the restoration of 5,000 acres of riparian habitat distributed among the following waterbird planning regions: Sacramento Valley-2,800 acres; Delta-1,100 acres; San Joaquin-1,000 acres, Tulare-100 acres. These regional goals are based on the proportion of potential restorable riparian habitat among the four planning regions.

\section{Least bittern}

Least bitterns differ from other members of the heron family found in the Central Valley as they rarely nest or perch in trees (Zeiner et al. 1990), preferring instead to breed in dense emergent cattail marsh. Conservation of this habitat type is the primary conservation need for least bitterns in the in the Central Valley. Both least and American bitterns are generally solitary nesters and interaction between the two species while feeding or nesting is rare. American bitterns generally prefer slightly less densely vegetated and somewhat shallower wetlands for breeding and foraging (Gibbs et al. 1992) but will also nest in uplands (M. Wolder, United States Fish \& Wildlife Service, personal communication). Though each species prefers different microhabitats, both are commonly found within the same wetlands, and actions benefiting least bitterns should also benefit American bitterns. 


\section{White-faced ibis}

White-faced ibis breed colonially in shallow permanent and semi-permanent wetlands in the Central Valley, often nesting in "islands" of emergent vegetation (Ryder and Manry 1994). They forage in flooded rice fields, flooded or partially flooded pastures, and cropland, especially alfalfa at all times of the year (Ryder and Manry 1994). During winter, white-faced ibis forage in seasonal wetlands and roost in both semi-permanent and seasonal wetlands. Enhancement and restoration of permanent and semi-permanent wetlands is a priority conservation action for white-faced ibis. Obtaining reliable water for established colonial nesting sites is an important conservation strategy for this species (Ryder and Manry 1994). Enhancing emergent growth in permanent or semi-permanent wetlands adjacent to rice or irrigated alfalfa may benefit tricolored blackbirds as well. ${ }^{1}$

\section{Black tern}

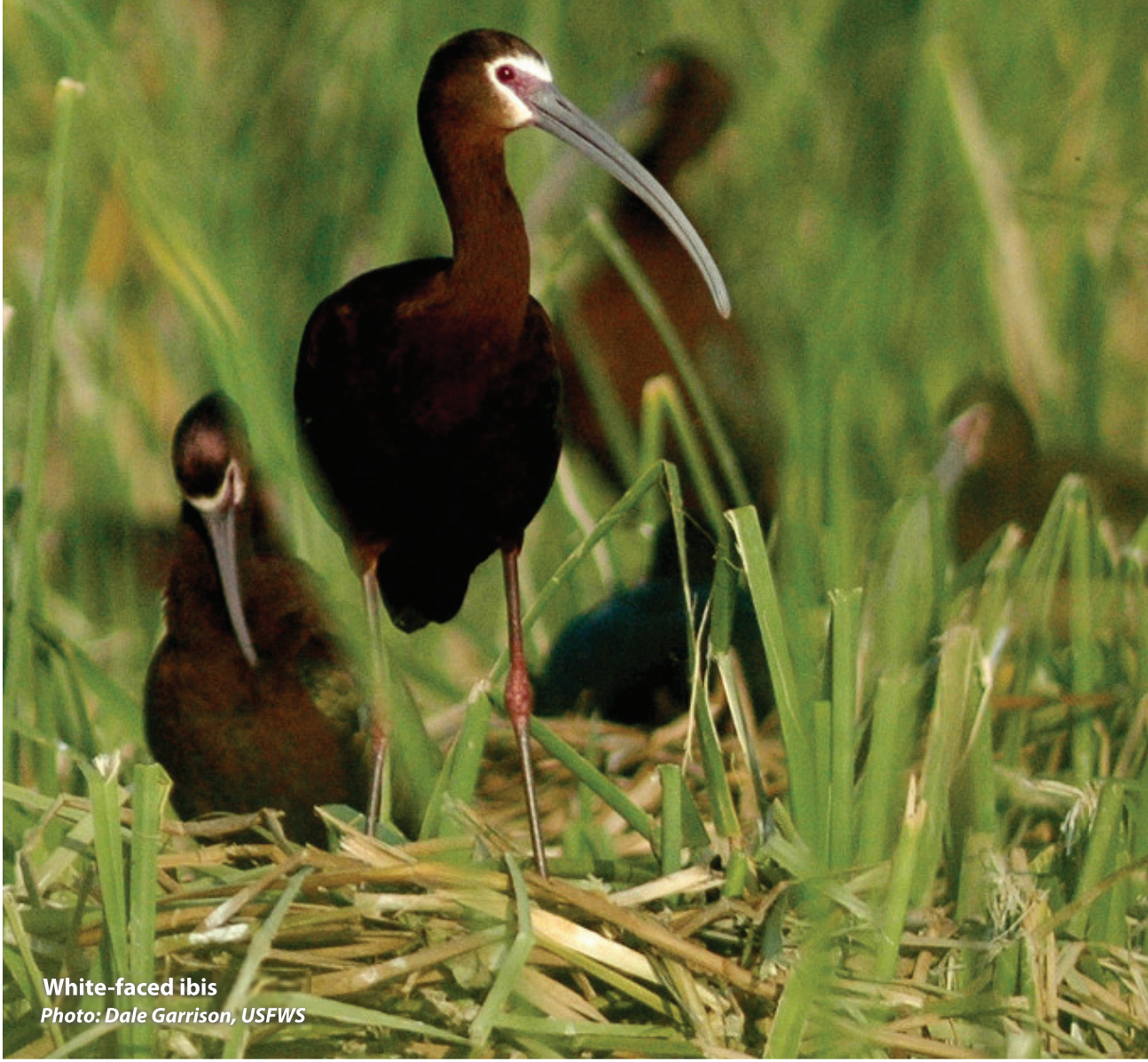

Black terns breed widely in the Sacramento Valley almost exclusively in rice fields, and locally in rice fields in Merced and northern Fresno counties within the San Joaquin Basin. They rarely breed elsewhere and if so, mainly in ephemeral habitat (D. Shuford, personal communication). Breeding habitat use is different in the Central Valley than in much of the range, where they nest in permanent and semi-permanent wetlands (Shuford et al. 2001). Black terns are somewhat area sensitive during the breeding season, selecting wetlands or wetland complexes with a minimum size of 12-20 ha ( $-30-50$ acres). Top conservation actions for black terns include protecting and restoring wetland habitat, and adapting wetland management practices to integrate optimal black tern habitat with the needs of other wetland dependent birds (Shuford 1999).

\section{Black rail}

Black rails breed and winter in higher parts of tidal marshes, freshwater marshes, and wet meadows within portions of the Delta Planning Region. Recent discoveries of black rails in Butte, Yuba, and Nevada counties may provide conservation opportunities in small wetland areas along the base of the foothills in the Butte and American Basins. Black rails will utilize habitats with shallower water regimes than other rails, and will tolerate some degree of flooding, provided that suitable upland escape cover is available during flood events (Eddleman et al. 1994). Conservation needs include protection, restoration, and enhancement of wetlands in the Delta Planning Region, and similar protection and restoration of upland habitats that serve as vital escape cover during flood events.

${ }^{1}$ Tricolored blackbirds are a high profile, priority species at state and federal levels, and are the focus of conservation efforts supported by many JV partners. The white-faced ibis is considered a suitable umbrella species for this species in wetland habitats, as they overlap in their nesting requirements, and to some extent in foraging habitat as well. Tricolored blackbirds nest in the same emergent marshes as white-faced ibis, and forage in adjacent rice fields and irrigated alfalfa. Although tricolored blackbirds are not a focal species in this plan, the JV is a partner in the conservation of this species and will work to implement conservation measures on public and private lands as they are more fully developed. 
This chapter provides quantified population and habitat objectives for riparian songbirds in the Central Valley, and is based on a suite of focal bird species that breed primarily in riparian habitat.

\section{Introduction}

Over 225 species of birds, mammals, reptiles, and amphibians depend on California's riparian habitats. The Central Valley provides essential breeding and wintering habitat, migration stopover areas, and corridors of dispersal for riparian-associated songbirds (Cogswell 1962, Gaines 1977, Humple and Geupel 2002, Flannery et al. 2004, Fleskes et al. 2005). Sixty-two species of songbirds have regularly bred in Central Valley riparian areas over the last 13 years (PRBO Conservation Science unpublished; see Ballard et al. 2003 for criteria used). Riparian vegetation is vital to the quality of in-stream habitat. It significantly promotes the aquatic food chain by providing shade, food, and nutrients, (Jensen et al. 1993) thus providing food resources for migratory songbirds as well.

While riparian habitat makes up less than $0.5 \%$ of California's total land area (approximately 360,000 acres; CDF 2002), decades of research indicate that riparian habitat supports ecosystem integrity and function across landscapes (Sands 1977, Katibah 1984, Faber 2004, RHJV 2004). Over $98 \%$ of riparian habitat in the Central Valley has been lost or severely degraded in the past 150 years (Smith 1977, Katibah 1984). Riparian habitat loss may be the most important cause of population declines among songbird species in western North America (DeSante and George 1994), including the decline and extirpation of many riparian species formerly common in the Central Valley.
"California's semi-arid Central Valley harbors the largest rivers in the state, areas that are vitally important to riparian birds and a multitude of other species. These rivers are to the health of the larger watershed what arteries are to the human body. When degraded, the entire system is put at risk, but when rehabilitated, a richness of life is conserved."

Gregory Golet, Ph.D. Senior Ecologist

The Nature Conservancy
Riparian habitats are transitional areas between terrestrial and aquatic ecosystems. In the Central Valley and lower foothills of the Cascade, Sierra Nevada, and Coast ranges, these habitats occur along streams, ranging from swift rapids and waterfalls of steep canyons to slow moving water in floodplains of the Central Valley floor. Riparian vegetation is structurally complex and may contain a canopy, subcanopy, and understory layers. Dominant trees include valley oak, cottonwood, California sycamore, box elder, and Oregon ash. Shrub layer plants include willows, wild grape, wild rose, California blackberry, blue elderberry, poison oak, and buttonbush. The herbaceous layer is diverse. 
Broad-scale interest in songbird conservation began in December of 1990 with the advent of Partners in Flight (PIF). PIF is a voluntary international coalition formed in response to growing concerns about declining populations of neotropical migrants across North America. Its expanded mission now includes all songbirds and seeks to help species at risk, keep common birds common, and promote voluntary partnerships on behalf of birds, habitat, and the public. Recently, PIF synthesized a continental perspective on conservation priorities with The North American Land Bird Conservation Plan (Rich et al. 2004). Species, habitat, geographic priorities and global population estimates for all songbirds in North America north of Mexico are included in the plan. Population size estimates are important conservation tools and innovative approaches to population estimates for songbirds have been developed by Rosenberg and Blancher (in press); a similar approach is used here. Survey data from the North American Breeding Bird Survey (Robbins et al. 1986) were used to derive estimated global populations (Rich et al. 2004) and regional population estimates (Rosenberg and Blancher in press, Bart in press). The use of this approach will allow future investigations to compare how population estimates presented in this chapter contribute to continental objectives presented by Rich et al. (2004) and future regional objectives [e.g., by Bird Conservation Region (BCR); U.S. NABCI Committee 2000].

This chapter presents populations objectives based on a suite of focal bird species that primarily breed in riparian habitat. The suite of species presented here is unique among many multi-specie planning efforts, in that it does not focus only on species with threatened and endangered status. Instead species were chosen whose requirements define different spatial attributes, habitat characteristics (e.g., young willows vs. old cottonwoods) and management regimes believed to be representative of a healthy riparian system (Chase and Geupel 2005). Furthermore, thanks to coordinated efforts of many individuals and agencies under the auspices of Partners in Flight, highly standardize methods for collecting data on landbirds (Ralph et al. 1993) have resulted in a wealth of current and comparable information across the Central Valley and the state. (http://www.prbo.org/calpif/htmldocs/riparian.html [Ballard et al. 2003]). This current and repeatable information provides the scientific foundation for the development of biological objectives that guide effective conservation efforts (Pashley and Geupel 2003, Elliot et al. 2003).

The remainder of this chapter is divided into three sections: (1) Use of focal species to establish conservation objectives for breeding riparian songbirds; (2) Methods for setting conservation objectives for breeding riparian songbirds; and (3) Conservation objectives for breeding riparian songbirds in the Central Valley.

\section{Use of Focal Species to Establish Conservation Objectives for Breeding Riparian Songbirds}

Basic biological data are not available for all species of riparian-dependent songbirds. Therefore, conservation planners frequently develop management and planning objectives using a single or subset of species, commonly called "focal species," for which biologists have better information, and that represent critical ecosystem and habitat elements. Biological knowledge about these species then guides habitat restoration, enhancement, protection, and evaluation. Biologists assume that the implementation of these recommendations should maintain overall biodiversity (Chase and Geupel 2005). This approach is considered by many conservation biologists as valuable, providing assumptions underlying the choice of focal species that are stated explicitly and subjected to scientific testing (Soulé 1995, Caro and O’Doherty 1999, Poiani et al. 2001, Lindenmayer et al. 2002).

Focal species may be used to guide several components of conservation planning: (1) the selection and design of protected areas or a reserve system; (2) habitat restoration and management; and (3) population monitoring, both of population trends over time and effects of management actions. Planning areas for protection involves selecting which sites should be considered and determining their configuration on the landscape. Thus, the distribution and ecological needs of one or more focal species may be useful in site selection and reserve configuration (Margules and Pressey 2000). However, to ensure the persistence of species, conservation planners must also identify effective forms of habitat restoration and active habitat management to maintain desired conditions. One way to accomplish this is to design restoration and management to benefit multiple focal species. Monitoring is also an essential component of conservation planning, especially when management takes place in an adaptive manner.

Focal species are frequently selected on the basis of their regulatory status (e.g., threatened or endangered), largely because these species have the strongest legal protection. However, species at risk are not necessarily the most effective focal species, due in part to the inability to collect sufficient data to statistically measure population response (Franklin 1994). Several relatively common species (i.e., abundant and widely distributed) are also included as focal species in order to promote greater scientific rigor in statistical design and analysis and to allow conservation actions to be evaluated. 
The Riparian Bird Conservation Plan (RBCP; RHJV 2004), a collaborative effort of the Riparian Habitat Joint Venture and California Partners in Flight, was developed to guide riparian conservation in California and provides a critical link between science and habitat management (Golet 2001). It relies on the biological needs of seventeen species that were selected by a consensus of ornithologists based on criteria described below. These species collectively depend on various stages of vegetative succession and/or critical ecosystem elements found in riparian systems (Geupel and Elliott 2001, Golet 2001, RHJV 2004; Figure 9-1). Each species has a detailed, species account summarizing information on conservation needs and management recommendations on the California Partners in Flight web site (http://www.prbo.org/calpif/htmldocs/riparian.html). To produce the Riparian Bird Conservation Plan (RBCP; RHJV 2004), species account authors and other resource managers synthesized the recommendations made in the individual species accounts to develop habitat-based recommendations that will influence multiple species. An example is the recommendation to restore and manage riparian forests to increase the volume and diversity of understory. These recommendations may reduce brownheaded cowbird parasitism rates, and provide nest substrate for declining species.

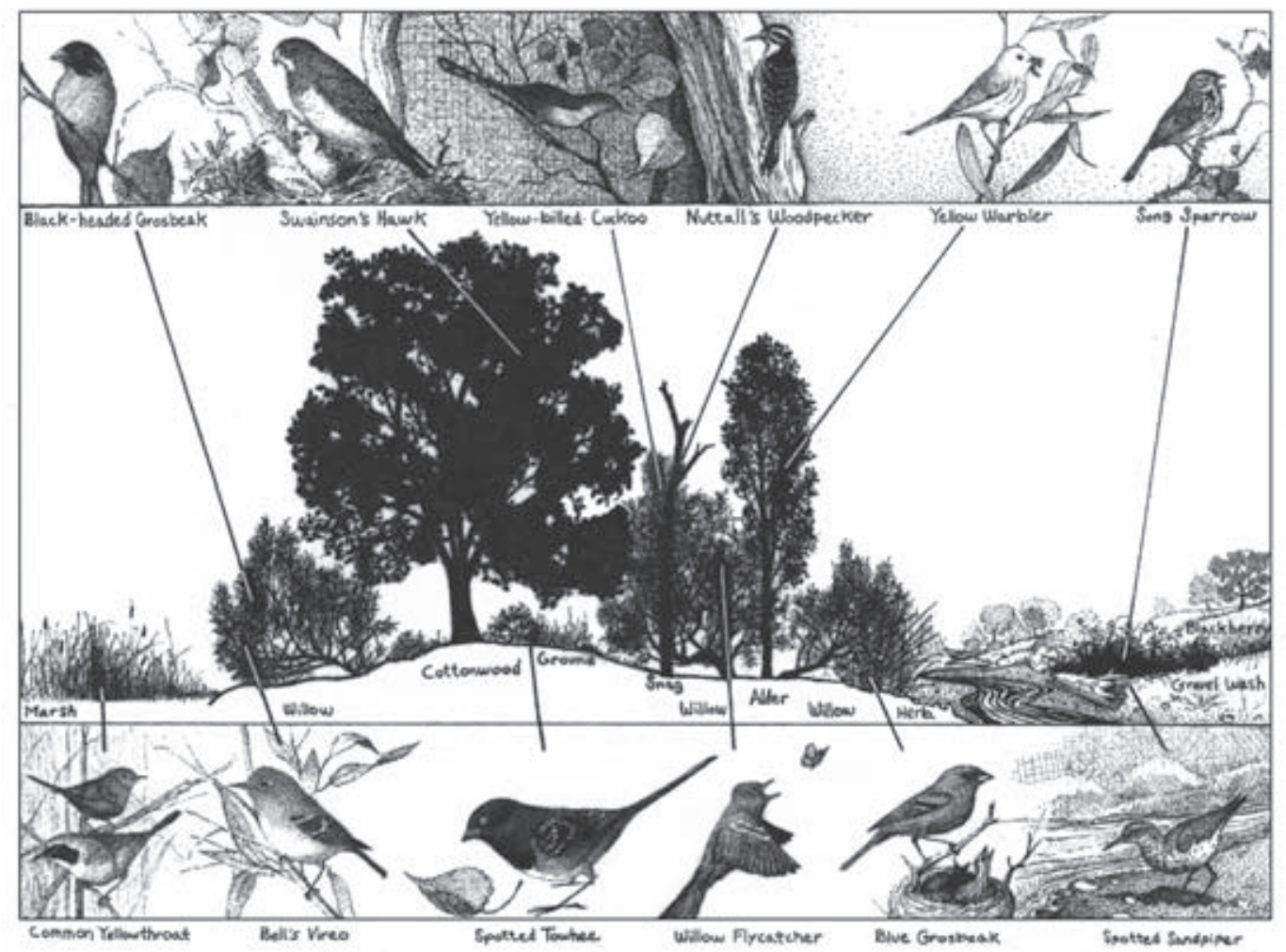

Figure 9-1. Preferred nesting substrates of selected songbird species breeding in California riparian habitat illustrating the diversity of vegetation and structure utilized (RHJV 2004).

Of the seventeen species presented in the RBCP, the JV selected seven focal species to develop its riparian conservation objectives. Six of the seven species (song sparrow [Melospiza melodia], yellow-breasted chat [Icteria virens], black-headed grosbeak [Pheucticus melanocephalus], common yellowthroat [Geothlypis trichas], yellow warbler [Dendroica petechia], and western yellow-billed cuckoo [Coccyzus americanus]) were selected based on the approach used by Chase and Geupel (2005). The seventh species, spotted towhee (Pipilo maculatus) was included for a variety of reasons that are discussed in the text below.

Suitable focal species meet at least one of the following criteria:

- Use riparian habitat as a principal breeding habitat in most basins throughout the Central Valley.

- Warrant special management status, or have experienced reduction in breeding range or populations in the Central Valley.

- Are useful for monitoring effects of management actions because they are:

Abundant in riparian habitats throughout the Central Valley or basin (i.e., provide adequate sample sizes for statistically valid analyses).

Amenable to monitoring (e.g., nests can be found and adults are tolerant of researcher disturbance).

Indicate quick, strong and/or consistent responses to habitat management or restoration. 
The following species descriptions are based upon RBCP species accounts (http://www.prbo.org/calpif/htmldocs/riparian.html) and new information presented later in this chapter.

\section{Song sparrow}

The estimated current populations of song sparrows in riparian habitat of the American, Butte, Sutter, Colusa, and Yolo Basins are exceptionally low (< 1000 pairs per basin). Creating suitable habitat (emergent dense understory) within and adjacent to riparian zones for this species should be a high priority in these basins. Populations of song sparrows in the Delta, San Joaquin, and Tulare Basins are much more abundant. In these basins song sparrows are generally found in newly restored riparian sites within two years of restoration.

\section{Yellow-breasted chat}

Although once common throughout the Central Valley, the yellow-breasted chat (a California Species of Special Concern) has declined considerably in recent years. Central Valley populations appear highest in American, Butte, Colusa, Sutter and Yolo Basins. Only the Butte Basin has a current population estimate of more than 1,000 individuals. This species prefers low, extremely dense riparian thickets. Thus, projects that focus on restoring woody shrubs-especially large patches of native blackberry-in the riparian forest understory should facilitate recovery of this species in these basins and possibly in the Delta Basin along the Cosumnes and Mokelumne rivers.

\section{Black-headed grosbeak}

Black-headed grosbeaks are relatively common throughout the American, Butte, Colusa, Sutter and Yolo Basins. Highest densities of existing populations occur in the Butte and Colusa basins, where appropriate conservation actions may significantly increase populations. In contrast, populations within Delta, San Joaquin, and Tulare Basins occur in much lower densities and are not likely to respond as well to conservation actions. Black-headed Grosbeaks are excellent indicators of a healthy riparian forest sub-canopy and will respond significantly to restoration within 5 years (Figure 9-2, Gardali et al. in press).

\section{Common yellowthroat}

Although this species may be locally common, its overall population size remains low throughout the year in the Central Valley. Common yellowthroats prefer the ecotone between wetland habitats and riparian forest edges. This species may respond rapidly to restoration (normally within 2 years) and may increase with conservation efforts targeted near existing populations in the Colusa, Delta, and San Joaquin Basins.

\section{Yellow warbler}

Yellow warbler (a California Species of Special Concern) populations are exceedingly low and have been extirpated in most basins of the Central Valley. Recent re-colonization of a few pairs along the main stem of the Sacramento River (in Butte Basin) and a new and increasing population (14 pairs in 2004) within the San Joaquin River National Wildlife Refuge (in San Joaquin Basin; Wood et al. 2005) suggest that the species may be returning to historical breeding sites in the Central Valley. A short-term goal should be to establish a minimum of 100 pairs each in the American, Butte, Colusa, Sutter, Delta, and San Joaquin Basins. They have been known to respond quickly to restoration in riparian forest understory through fencing or planting, and in areas managed for dense willow cover near water (Wood et al. 2001, Krueper et al. 2003).

\section{Western yellow-billed cuckoo}

The current western yellow-billed cuckoo population is about 60 to 100 pairs statewide (Halterman et al. 2001), with the only increase recorded in the western United States occurring in the Sacramento Valley (Halterman et al. 2003). This increase is likely an artifact of new sampling methodologies and the recent discovery that the species will nest in restored riparian habitat as young as 


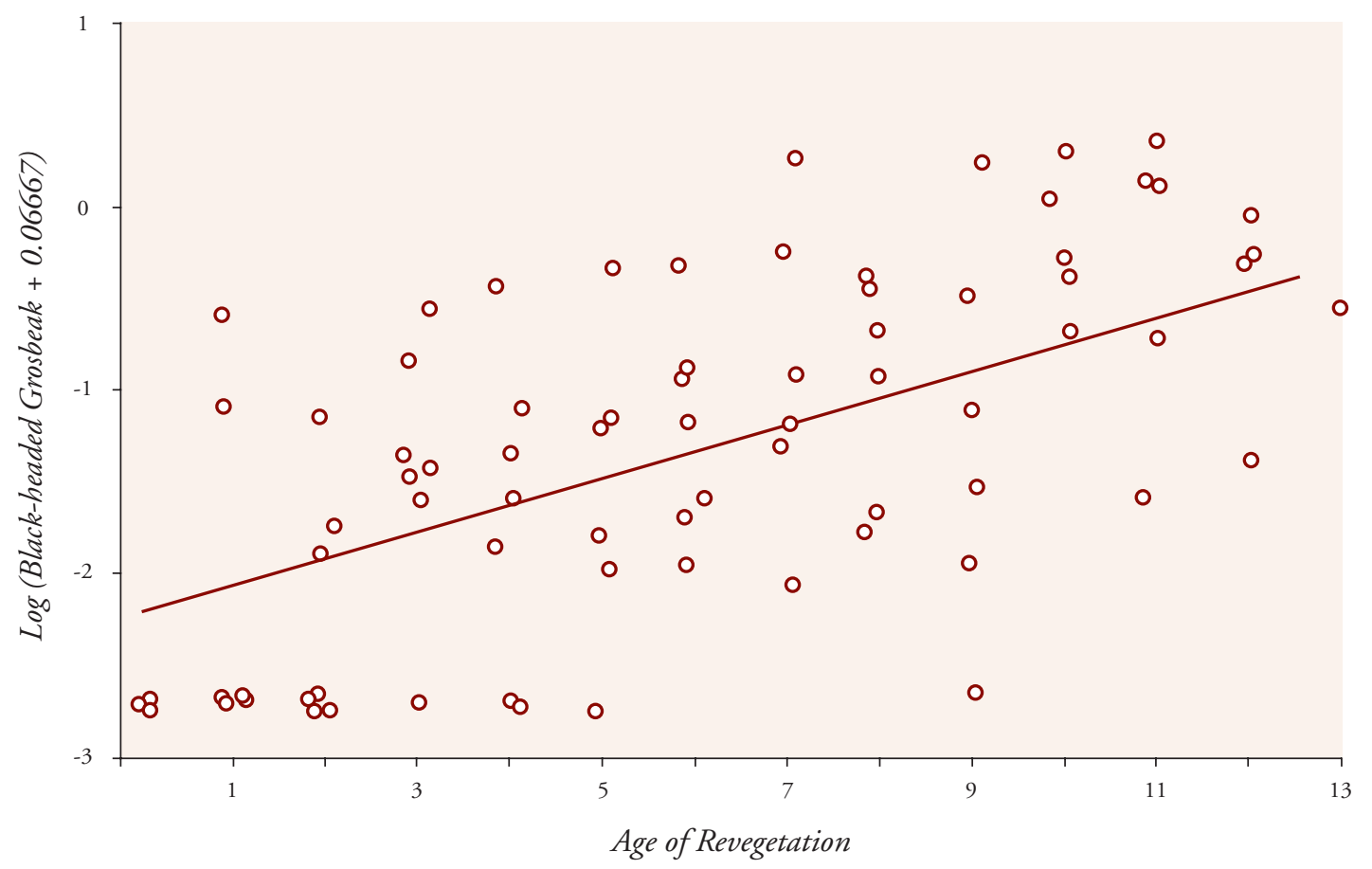

Figure 9-2. Black-headed grosbeak trend in response to age of restoration on the Sacramento River. Trend $(\%)=15.72,95 \% \mathrm{Cl}=9.12-22.73 . P<0.0001, \mathrm{R} 2=0.65$. (from Gardali et al. 2006).

eight years old (Small et al. 1999). Considering the number of acres that have been restored in the Butte and Colusa Basins (including the Sacramento River), populations may continue to increase. The RBCP recommends restoring habitat in 25 locations to support 625 pairs (25 pairs per location). Simulation modeling indicates that populations of less than 10 pairs have a high probability of being ephemeral (RHJV 2004). At least 25 pairs in a subpopulation and corridors to other subpopulations may prevent local extirpations. Since territory size for a pair averages 20 to 25 hectares $^{1}$ (a minimum of 10 hectares), the optimal goal for each population is to protect and restore habitat in minimum 20-hectare patches that collectively total 500 hectares within a watershed or stream section. Yellow-billed cuckoos have used willow-cottonwood habitat of any age with high humidity and a habitat breadth of 325 feet (100 m) (Gaines and Laymon 1984). Nesting groves at the South Fork Kern River are characterized by higher canopy closure, higher foliage volume, intermediate basal area, and intermediate tree height when compared to random sites with less than 40\% canopy closure are unsuitable, those with 40\%-65\% are marginal to suitable, and those with greater than 65\% are optimal (Laymon 1998).

${ }^{1}$ Hectares are used as a unit of area measurement in this chapter, since most riparian research is reported in metric units. One hectare equals 2.47 acres.

\section{Spotted towhee}

Although regularly found in habitats other than riparian, the spotted towhee (Pipilo maculatus) was included due to its common and wide spread occurrence in the Central Valley riparian habitats and its usefulness for monitoring the effects of management actions (Nur 2004). The spotted towhee occurs in relatively high densities in all basins and is an indicator of vigorous ground cover, which is associated with regular flooding events.

Quantifiable population objectives for other riparian species that are known to have (or have had) significant breeding populations in the Central Valley (for example, spotted sandpiper, bank swallow, tree swallow, and blue grosbeak) are lacking because current information on population size is not available or surveys are limited. However current management recommendations for these species are described thoroughly in the RBCP species accounts (http://www.prbo.org/calpif/htmldocs/riparian.html). 


\section{Methods for Setting Conservation Objectives for Breeding Riparian Songbirds}

Acreage objectives should be derived from estimates of habitat needed to achieve population goals. However, simply achieving acreage objectives does not guarantee that population goals will be met. Surrounding landscape factors also determine whether bird populations respond. Seemingly "suitable" habitat for many riparian species (e.g., yellow-billed cuckoo, yellow warbler and song sparrow) remains unoccupied in many areas of the Central Valley. Thus, the use of numerical population targets provides a useful index of potential change in habitat quality within a dynamic environment where natural and human-mediated disturbances can alter habitat quality quickly (Donovan et al. 2000).

Most songbirds are territorial during their breeding seasons. Thus, data collected from the breeding season are more reliable than data collected during other times of the year. Standardized methods for monitoring abundance (point counts), population size, and density (spot-maps), are established across California (Ralph et al. 1993, Ballard et al. 2003). Thus simple population estimates can be derived by multiplying appropriate estimates (birds per acre) by the area of current available habitat, as mapped by the best available GIS vegetation layers. Population targets may be derived by multiplying an appropriate target density by the area of potentially restorable habitat, also based on GIS-based historic habitat layers.

There are several potential sources of variation associated with this method. The density estimate is influenced by observer bias during surveys, detection probability, differences in habitat quality across sites, annual variation, intrinsic variation in bird habitat selection, and other factors. Therefore a sample variance around each density estimate was calculated.

Population objectives based on monitoring data were developed for six species that commonly breed in the riparian areas of the Central Valley (see above). The method to develop population objectives for the state threatened yellow-billed cuckoo differed from other species due to its small population size and low rate of survey detections. For this species, minimum management goals for populations in each basin were developed using population simulation models (Halterman et al. 2001; RHJV 2004).

These population objectives helped to develop and prioritize riparian habitat objectives for eight of the nine basins in the Central Valley: American, Butte, Colusa, Sutter, Yolo, Delta, San Joaquin, and Tulare. Sufficient data to develop population objectives for riparian species in the Suisun Marsh are lacking.

\section{Inputs Used for Setting Conservation Objectives}

Several sources of information serve as inputs for setting habitat objectives for riparian songbirds: (1) existing and restorable riparian habitat; (2) population estimates and targets; (3) recommended values of nest success; (4) species distribution and richness; and (5) annual rates of riparian restoration.

Information on existing and restorable riparian habitat identifies on a regional scale where future restoration projects can have the greatest impact. This information is also the basis for developing population targets and quantifying conservation objectives by basin.

Recommended values of nest success, and species distribution and richness provide a measure of relative habitat quality, and help to determine which conservation actions will have the most impact.

Estimated annual rates of riparian restoration help to develop realistic habitat objectives. A combination of these inputs provides each basin with an importance rank for riparian birds (Table 9-1). This section describes how these factors and rankings were derived and outlines the assumptions made for riparian songbirds in the Central Valley. 
Table 9-1. Current and potentially restorable riparian habitat and number of bird point count stations per basin.

\begin{tabular}{|c|c|c|c|c|c|c|}
\hline Basin & Valley & $\begin{array}{c}\text { Current } \\
\text { Riparian Acres }\end{array}$ & $\begin{array}{c}\text { Potentially } \\
\text { Restorable } \\
\text { Riparian Acres }\end{array}$ & $\begin{array}{l}\text { Total Riparian } \\
\text { Acres }\end{array}$ & $\begin{array}{l}\text { Proportion of Restorable } \\
\text { Riparian Area Currently } \\
\text { with Riparian habitat }\end{array}$ & $\begin{array}{c}\text { Number of } \\
\text { Riparian Point } \\
\text { Count Stations }\end{array}$ \\
\hline AMERICAN BASIN & SACRAMENTo & 16,364 & 82,757 & 99,121 & 0.20 & 191 \\
\hline Butte Basin & SACRAMENTo & 32,535 & 143,230 & 175,765 & 0.23 & 146 \\
\hline Colusa Basin & SACRAMENTo & 19,708 & 207,149 & 226,857 & 0.10 & 202 \\
\hline Sutter Basin & SACRAMENTo & 3,641 & 79,378 & 83,019 & 0.05 & 51 \\
\hline Yolo BASIN & SACRAMENTO & 3,569 & 68,394 & 71,963 & 0.05 & 121 \\
\hline Delta Basin & SAN JOAQUIN & 14,840 & 132,548 & 147,388 & 0.11 & 97 \\
\hline SAN JOAQUIN BASIN & SAN JOAQUIN & 12,249 & 188,394 & 200,643 & 0.07 & 175 \\
\hline Tulare Lake Basin & SAN JOAQUIN & 7,195 & 15,835 & 23,030 & 0.45 & 42 \\
\hline $\begin{array}{c}\text { Central Valley } \\
\text { Totals } \\
\end{array}$ & & 110,100 & 917,687 & $1,027,786$ & 0.12 & 662 \\
\hline
\end{tabular}

${ }^{1} J V$ derived species density estimates in basins with fewer than 30 stations using point count data from the entire respective valley (Sacramento or San Joaquin). These point count sample sizes are 365 and 314, respectively.

\section{Existing and Potentially Restorable Riparian Habitat}

Several GIS data sources were combined to produce a single representation of Central Valley riparian habitat (Figure 9-3). The 31-meter grid layer was derived by combining the areas mapped as riparian habitat by one of the following five partially overlapping data sources:

a. California Department of Fish and Game's (CDFG) Central Valley Wetlands layer (from Landsat and Spot images taken from 1986 to 1993$)$

b. California Department of Water Resources' (DWR) land use layers (developed from 1986 to 1999);

c. California State University's (Chico campus), riparian mapping for the Sacramento River, prepared for the California Bay-Delta Authority, DWR, U.S. Bureau of Reclamation, and CDFG (from aerial photos of varying scale, taken between 1991 and 1998);

d. DWR's riparian vegetation of the San Joaquin River for the San Joaquin River Riparian Habitat Restoration Program (from 1998 aerial photos); and

e. Jones \& Stokes' riparian vegetation mapping for Placer County (based on 2002 aerial photos).

Merging all areas classified as riparian habitat by at least one of these layers likely represents a liberal estimate of current riparian forest and shrub habitat.

The amount of potentially restorable riparian habitat possible in each basin was estimated using historic vegetation map layers compiled by the Bay Institute's Sierra to the Sea mapping project (TBI 1998). This GIS layer, derived from multiple sources represents the historical extent of Central Valley riparian forests and the extent of soil types that likely supported riparian forest before 1800. All habitat types with potential for restoration, including agricultural fields, were totaled as potential riparian habitat. Areas that have been developed and/or urbanized were assumed to be permanently lost as riparian habitat and were excluded from acreage calculations.

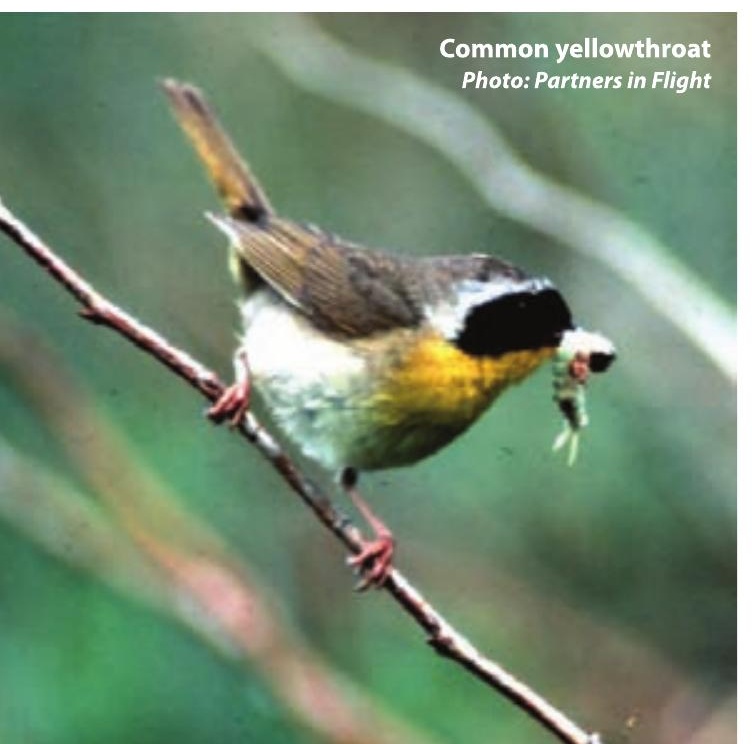

For planning purposes, the JV assumed that 110,010 acres of riparian habitat remains in the Central Valley (Table 9-1) based on the GIS data described above. Sutter, Yolo and San Joaquin basins have the least, while American, Butte, and Colusa Basins have the most riparian habitat remaining. These results should be interpreted with caution, as most of this habitat is highly degraded and disconnected from the floodplain. Low species richness (Figure 9-4), poor vital rates, and low abundance of songbirds at many remnant sites reflect the loss of riparian habitat integrity. 


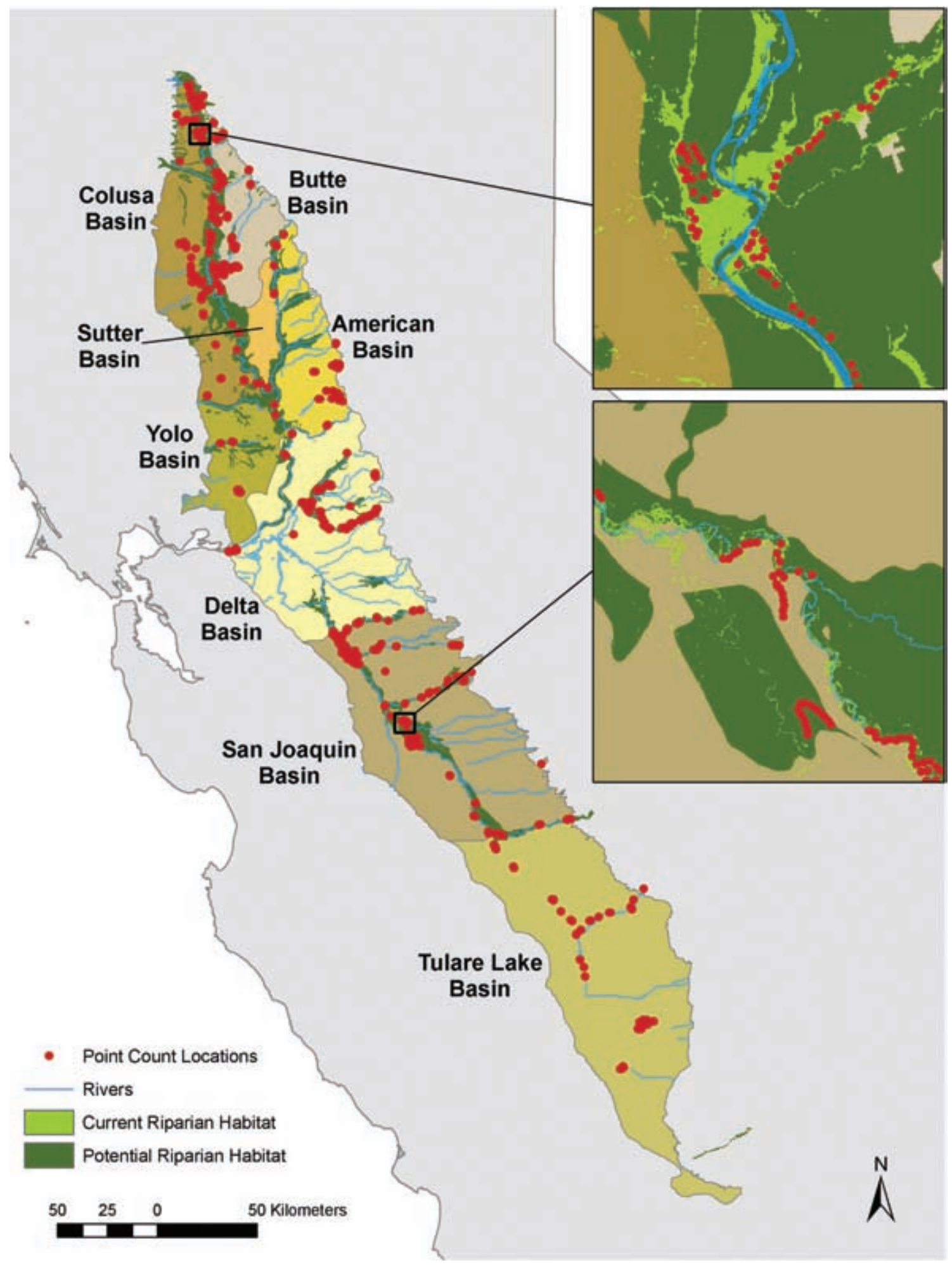

Figure 9-3. Existing and potentially restorable riparian habitat within the Central Valley. 


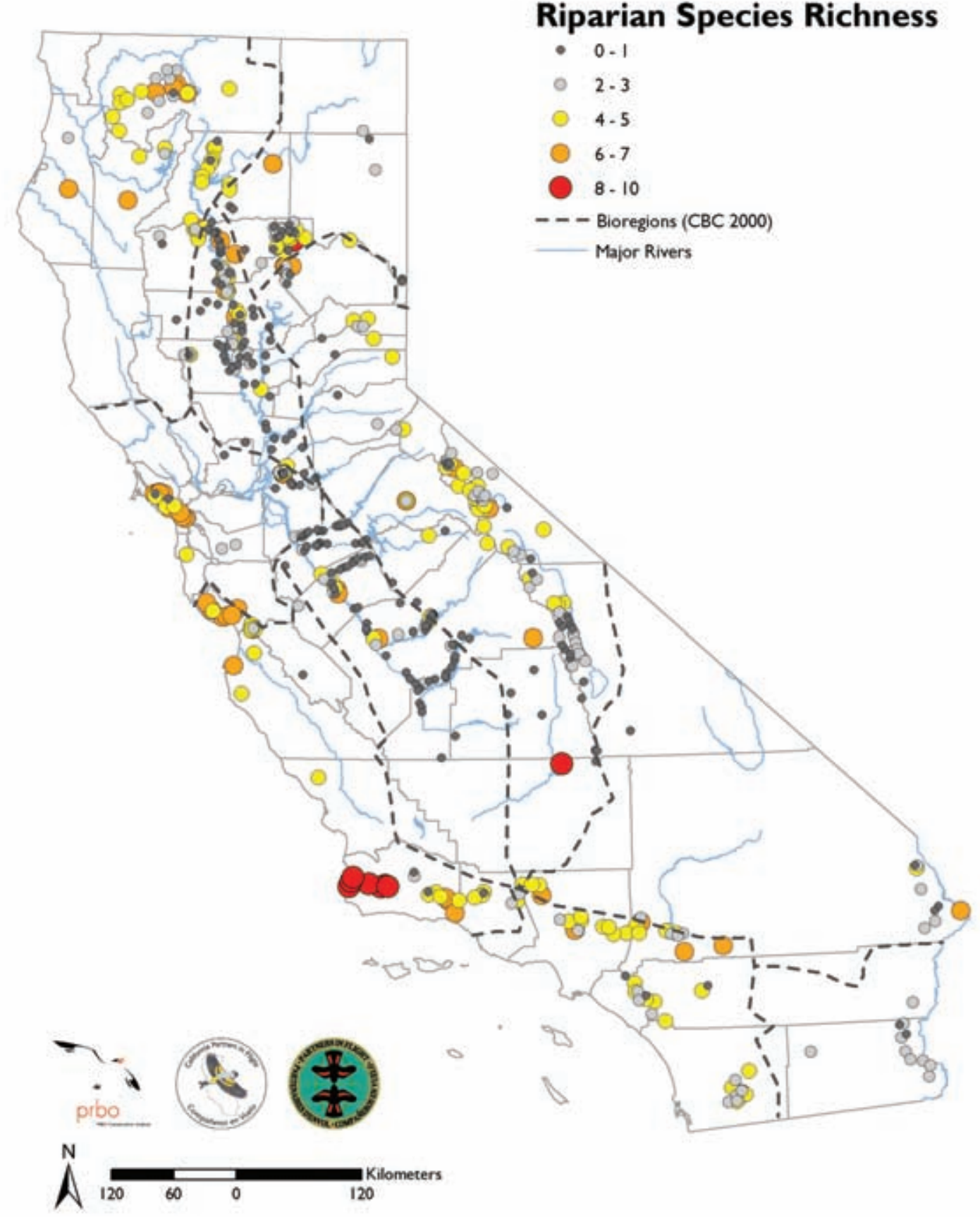

Figure 9-4. Species richness indices for riparian songbirds at sites with standardized bird monitoring in California (from RHJV 2004). 


\section{Population Estimates and Targets}

Population objectives are an estimate of potential population size or "targets." Methods used to develop objectives for each focal species are described below.

The current population size of each focal species ("population estimates") was estimated by multiplying basin-specific estimates of bird density by basin-specific estimates of current riparian habitat acres. Density estimates were based on point count surveys conducted between 1994 and 2003 (Small et al. 1999, Gardali et al. 2004). Initial point count-level densities were calculated by dividing the number of detections within 50 meters by the area of the 50 -meter radius circle ( 0.785 hectares). To account for detectability differences across species, these point-count level estimates were then multiplied by species-specific detectability coefficients derived by comparing more accurate, but spatially limited, spot-map data with overlapping point count data (Table 9-2). Mean adjusted densities ( \pm standard error) were calculated for each the five basins with sufficient point count stations $(n>30)$; overall means for the entire Sacramento and San Joaquin valleys were used to estimate densities in basins with fewer than 30 point count stations.

The potential population size of each focal species ("population target") was estimated using a similar approach as for current populations, but using historic vegetation layers rather than current vegetation layers. Estimates of potentially restorable habitat in each basin were based on historic vegetation map layers corrected for habitat permanently lost to urban development (Table 9-1).

If sufficient, data from basin-specific or valley-specific point count surveys were used to estimate potential densities; otherwise (for song sparrows and yellow warblers), spot-map densities from a reference study site with good quality habitat (Cosumnes and Clear Creek, respectively) were used instead. To develop population targets, potential density estimates were based on the 75 th percentile of the survey data instead of the mean (used for current density estimates). Use of the 75th percentile assumed that future densities would more appropriately be based on high quality, rather than currently degraded, riparian habitat, and assumed that high densities equate to high quality habitat (Bock and Jones 2004). As with current density estimates, detectability coefficients (Table 9-2) provided target populations, as in the following formula:

Target population $=$ (potential habitat $\mathrm{x}$ potential density), where potential habitat is current habitat plus restorable habitat and density is corrected by an appropriate detectability coefficient.

Figures 9-5 to 9-8 represent potential population change in each basin if all potential habitat was restored. Certain basins have higher potential for specific species (e.g., black-headed grosbeaks in the Colusa Basin).

The process to develop population objectives for the state threatened yellow-billed cuckoo differed from other species due to its exceptionally low current population size and difficult sampling methodology. Instead, a minimum management goal for populations in each basin was established (Table 9-3).

Table 9-3. Minimum management goals for subpopulations, pairs, and reforestation of suitable habitat, based on 40 hectares per pair, for western yellow-billed cuckoos. (from RHJV 2004).

\begin{tabular}{|ccccc|} 
Locality & Subpopulations & Number of Pairs & $\begin{array}{c}\text { Current Suitable } \\
\text { (hectares) }\end{array}$ & $\begin{array}{c}\text { Reforestation Suitable } \\
\text { (hectares) }\end{array}$ \\
\hline SACRAMENTO RIVER & 6 & 150 & 2,370 & 3,700 \\
FEATHER RIVER & 1 & 25 & 240 & 770 \\
STANISLAUS RIVER & 1 & 25 & 240 & 770 \\
COSUMNES RIVER & 1 & 25 & 0 & 1,010 \\
MERCED RIVER & 1 & 25 & 0 & 1,010 \\
KINGS RIVER & 1 & 25 & 0 & 1,010 \\
MENDOTA & 1 & 25 & 0 & 1,010 \\
Total & $\mathbf{1 2}$ & 300 & $\mathbf{2 8 5 0}$ & $\mathbf{9 , 2 8 0}$ \\
\hline
\end{tabular}




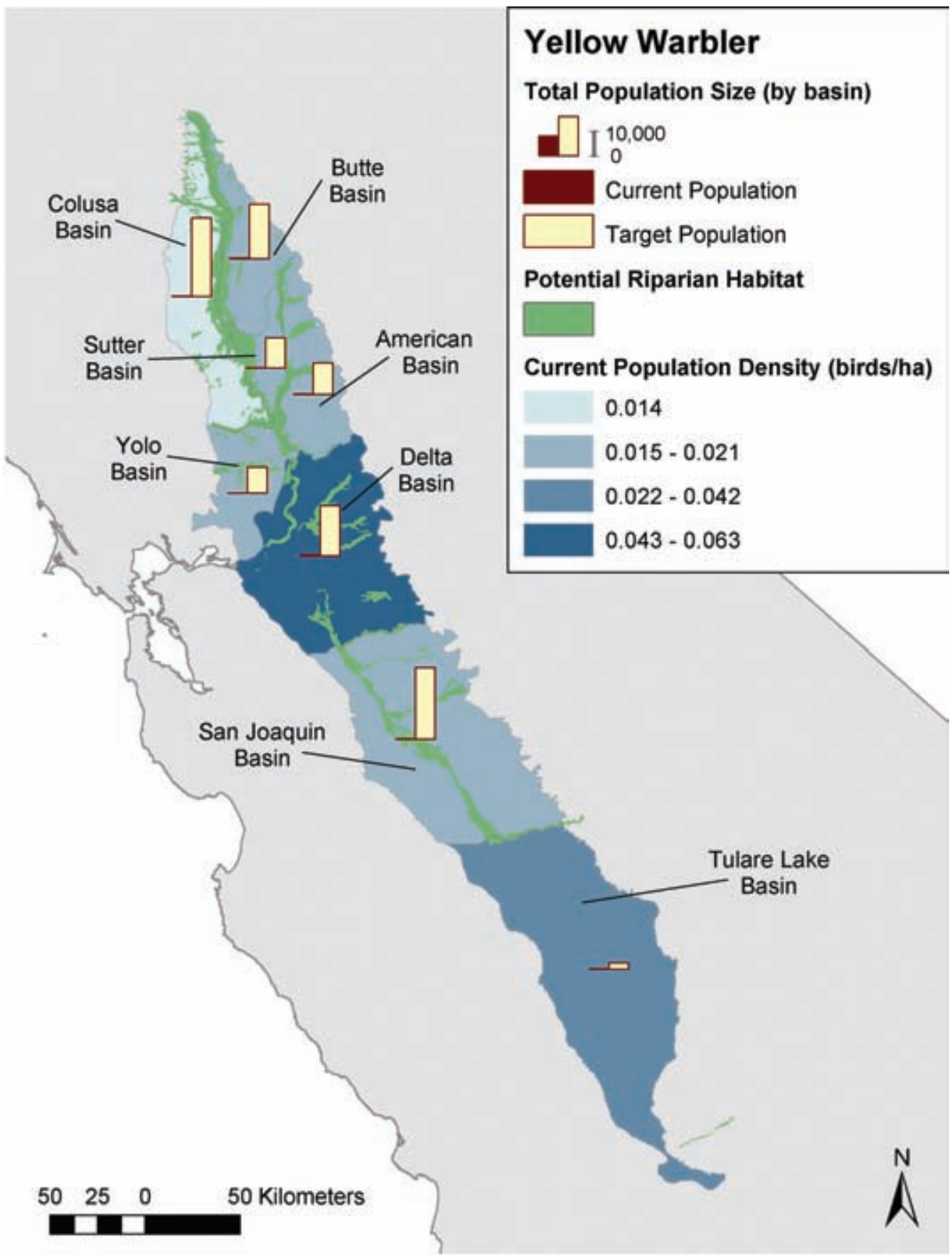

Figure 9-5. Yellow warbler current populations and targets.

\section{Recommended Values of Nest Success}

Population growth models require measures of survival and productivity as inputs. These are often referred to as vital rates. A critical vital rate in modeling population growth (lambda) is nest success. By including a nest success objective, the persistence of a population can be gauged, thereby providing a link between population size and habitat condition (Martin 1995, Sherry and Holmes 2000). Bird density may be a misleading indicator of habitat quality (Van Horne 1983 but see Bock and Jones 2004). Thus, setting target values for specific demographic parameters (primarily nest success and adult survivorship) will provide a more meaningful biological objective and thereby ensure better habitat quality and a higher probability of conservation success. Reproductive success and adult survival are key parameters used in population models (Pulliam 1988, Faaborg 2002). 
To determine whether a population is growing or declining, the value of population change (lambda) generated from the following equation needs to be greater than one:

Lambda $=$ Adult survival + $([$ number of nestlings/successful nest $] \mathrm{x}$ nest success $\mathrm{x}$ number of nest attempts $\mathrm{x}$ juvenile survival $) / 2 .{ }^{1}$

Estimates for nest success and adult survivorship for the spotted towhee and black-headed grosbeak are based on data from the Sacramento Valley (Geupel et al. 1997, Small et al. 1999, Gardali and Nur 2006). Nest success estimates for song sparrows are based on Central Valley data and over 20 years of data from coastal California (Chase and Geupel 2005). Other values for nest success are presented in Table 9-4.

For song sparrows in the Central Valley, nest success has ranged from 5\% to 28\%, with an average of $16 \%$. This suggests that at most locations in the Central Valley, song sparrows are not producing enough young to keep up with annual mortality and will likely continue to decline in the absence of immigration. To achieve lambda of over 1.0 , nest success would need to be at least $27 \%$, thus $25-30 \%$ is the recommended value of nest success for song sparrows (Table 9-4). Recommended values for black-headed grosbeaks and spotted towhees are also presented in Table 9-4. With more ongoing demographic monitoring throughout the Central Valley (in the form of nest monitoring and constant-effort mist netting), data for more species will likely be available in the near future (Gardali et al. 2004).

Table 9-4. Observed Mayfield (1975) estimates of survival by planning regions and recommend values of nest success and adult survivorship as determined by source-sink (lambda) models.

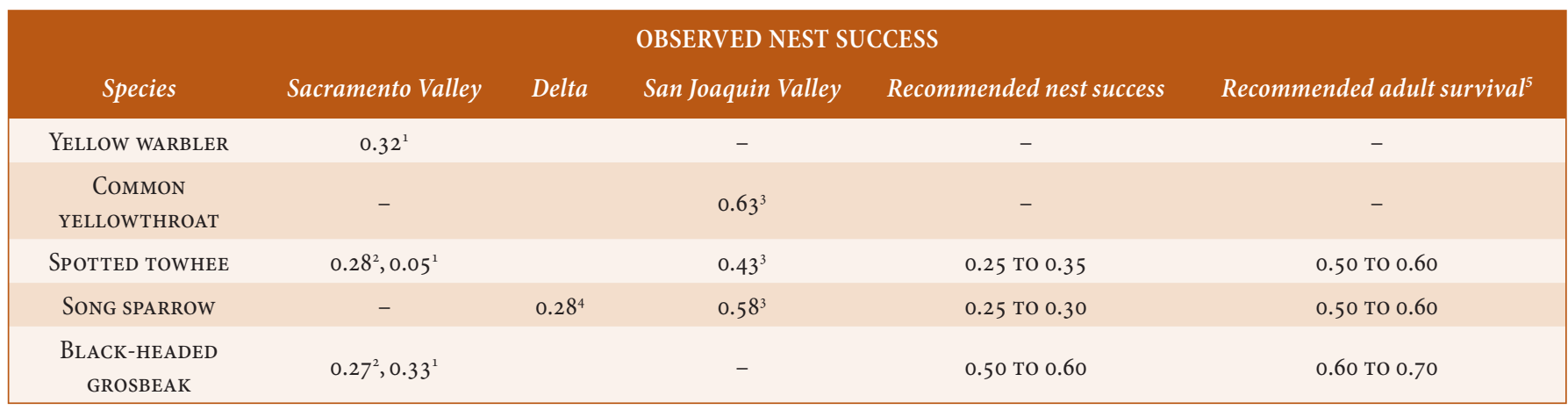

${ }^{1}$ Wood et al. 2001 (Clear Creek), ${ }^{2}$ Small et al. 1999 (lower Sacramento River), ${ }^{3}$ Haff et al. 2001 (Consumes River)

${ }^{4}$ Hammond and Geupel 2000 (Cosumnes River), ${ }^{5}$ Gardali and Nur 2006.

\section{Species Distribution and Richness}

The occurrence and persistence of a high diversity of focal species provides an indication of high quality habitat and restoration success (Chase and Geupel 2005, Gardali et al. in press, Dobkin et al. 1998). Restoring riparian habitat near existing sites of high species richness should increase the potential for species recolonization. Data on the number of sites with relatively high focal species richness for each basin were examined to help prioritize conservation efforts among basins.

\section{Annual Rates of Riparian Restoration and Enhancement in the Central Valley}

Riparian habitat restoration in the Central Valley generally involves planting trees and shrubs in areas where riparian forests have been cleared for agricultural production. The modification of the Central Valley's natural hydrology makes riparian re-establishment very difficult in many areas because natural flooding has been reduced substantially by flood control dams, bank stabilization riprap projects, and diversion of natural stream flows for irrigated agriculture. Irrigation, weed control, and maintenance of irrigation infrastructure usually are required for up to three years after initial plantings in order for restoration efforts to be successful. This can be viewed as a form of enhancement. While the JV has not developed separate enhancement goals for riparian habitat, restoration objectives and associated costs presented here include three years of post planting enhancement.

In order to develop habitat objectives that are challenging but realistic, current costs and annual rates of riparian restoration for the Central Valley were examined. Estimates range from $\$ 500$ to $\$ 5,000$ per acre for restoring riparian habitat on the valley floor, which commonly entails vegetative plantings and/or restoration by reconnecting the flood plain. Current estimates from groups actively engaged in restoration and enhancement indicate 1,500 to 2,000 acres could be restored and enhanced annually for the next 5 years (7,500-10,000 acres total).

${ }^{1}$ If the other values are held constant based on actual observed values (from monitoring data in the Central Valley and coast) the value lambda is less than 1; 0.60 (adult survival) + (2.82 (number of nestlings) $\times 16 \%$ (mean of observed estimates of nest success) $\times 2.20$ (number of nest attempts) $\times 0.40$ (juvenile survival)) $/ 2=0.79$ (Lambda). 


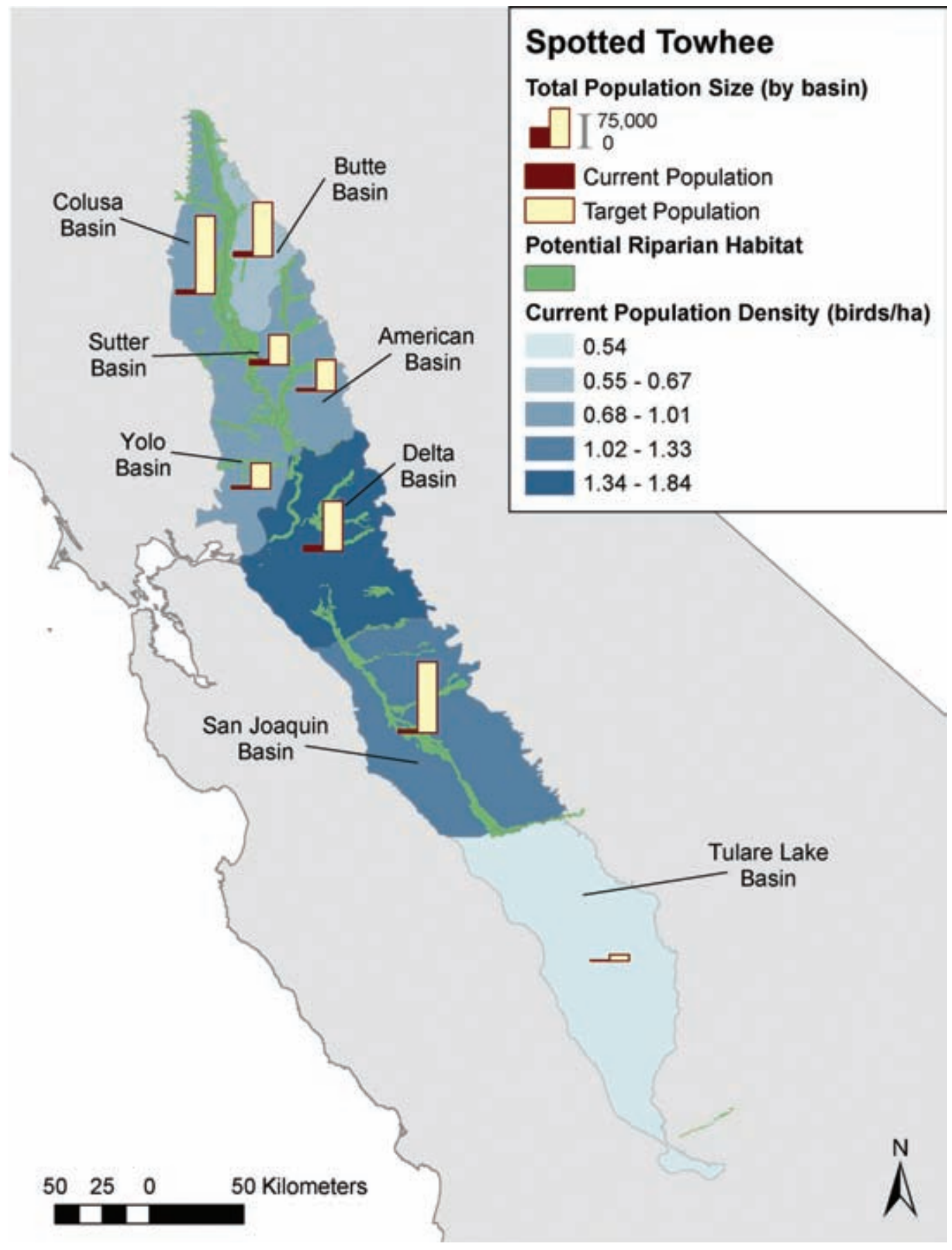

Figure 9-6. Spotted towhee current populations and targets.

\section{Conservation Objectives for Breeding Riparian Songbirds in the Central Valley}

\section{Riparian Habitat Objectives}

Population targets are based upon total potential habitat, and are considered long term targets. It is unrealistic to expect these targets to be reached in the short term, therefore 5 -year objectives for restoration of riparian habitat were developed. 


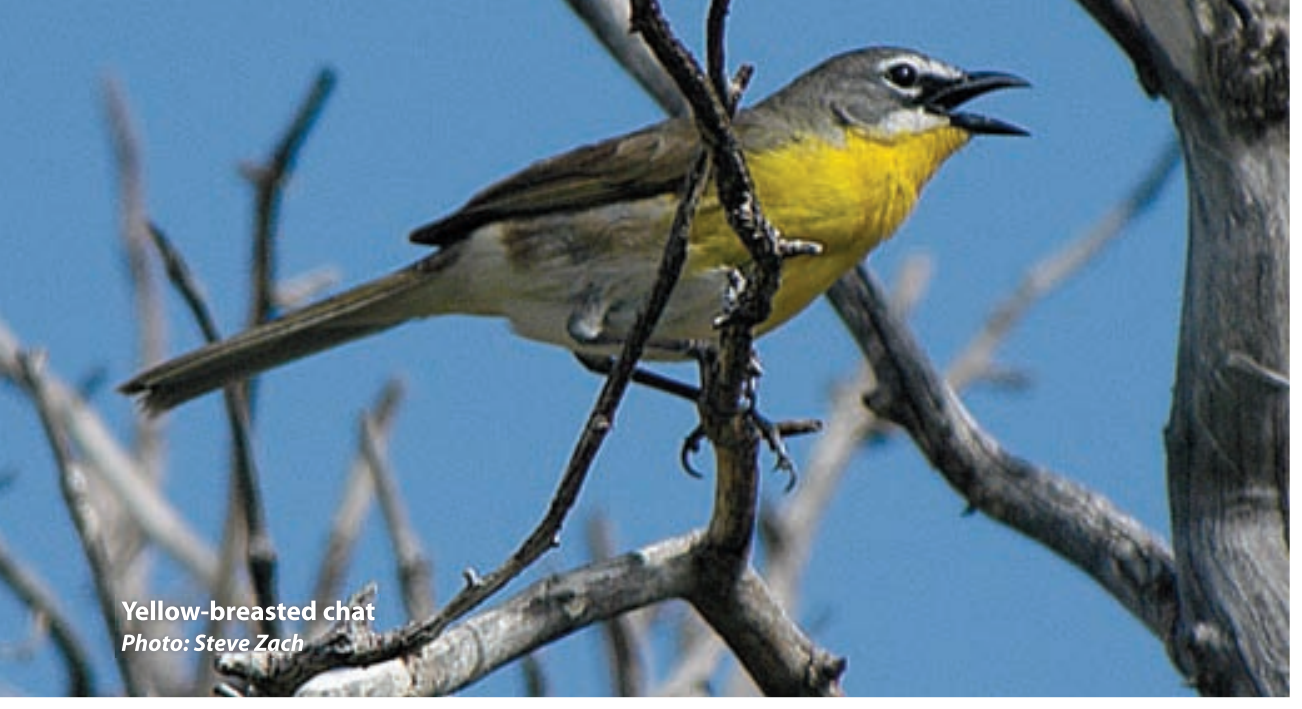

This plan calls for restoring 8,700 acres of riparian habitat for breeding riparian songbirds in the Central Valley over the next 5 years, which is within the 7,500-10,000 acre range of what could be restored and enhanced annually. Conservation objectives for breeding riparian songbirds are listed in Table 9-5. The Delta Basin is further broken down into objectives for the Mokulumne and Consumnes Rivers. The Sacramento Valley has an objective of 4,500 acres, which has been partitioned among its five basins based on the proportion of restorable habitat. Table 9-5 identifies conservation objectives for riparian songbirds by basin.

\section{Population Targets for Focal Species}

Tables 9-6 through 9-11 provide population targets for focal species by basin. The difference in bar heights in Figures 9-5 to 9-8 provides an indication of potential change in population in each basin, if all potentially restorable habitat was restored. Certain basins have higher potential for specific species (e.g., black-headed grosbeaks in Colusa Basin).

Table 9-6. Current and potential population densities and population targets for song sparrow.

\begin{tabular}{|c|c|c|c|c|}
\hline Basin & $\begin{array}{l}\text { Current Birds/Ha } \\
\quad( \pm S E)^{l}\end{array}$ & $\begin{array}{l}\text { Current Population Size } \\
\qquad( \pm S E)\end{array}$ & Target Birds/Acre ${ }^{2}$ & Target Population Size \\
\hline AMERICAN BASIN & $0.0493( \pm 0.0115)$ & $327( \pm 76)$ & 0.40 & 33,170 \\
\hline Butte BAsin & $0.0520( \pm 0.0216)$ & $685( \pm 285)$ & 0.40 & 57,408 \\
\hline Colusa Basin & $0.0299( \pm 0.0142)$ & $239( \pm 113)$ & 0.40 & 83,027 \\
\hline Sutter Basin & $0.0493( \pm 0.0115)$ & $73( \pm 17)$ & 0.40 & 31,816 \\
\hline YoLo BASIN & $0.0493( \pm 0.0115)$ & $71( \pm 17)$ & 0.40 & 27,413 \\
\hline Delta Basin & $0.7377( \pm 0.0764)$ & $4,432( \pm 459)$ & 0.68 & 90,690 \\
\hline SAN JOAQUIN BASIN & $1.161( \pm 0.088)$ & $5,757( \pm 438)$ & 0.68 & 128,901 \\
\hline Tulare Lake Basin & $1.166( \pm 0.196)$ & $3,396( \pm 572)$ & 0.68 & 10,835 \\
\hline
\end{tabular}

${ }^{I}$ Current density estimates were based on PRBO point count data. If a basin contained fewer than 30 point count stations, estimates were derived from all stations in the respective valley (Sacramento or San Joaquin).

${ }^{2}$ Target densities were based on the $75^{\text {th }}$ percentile value of all point counts in each valley, adjusted by a detectability coefficient. 


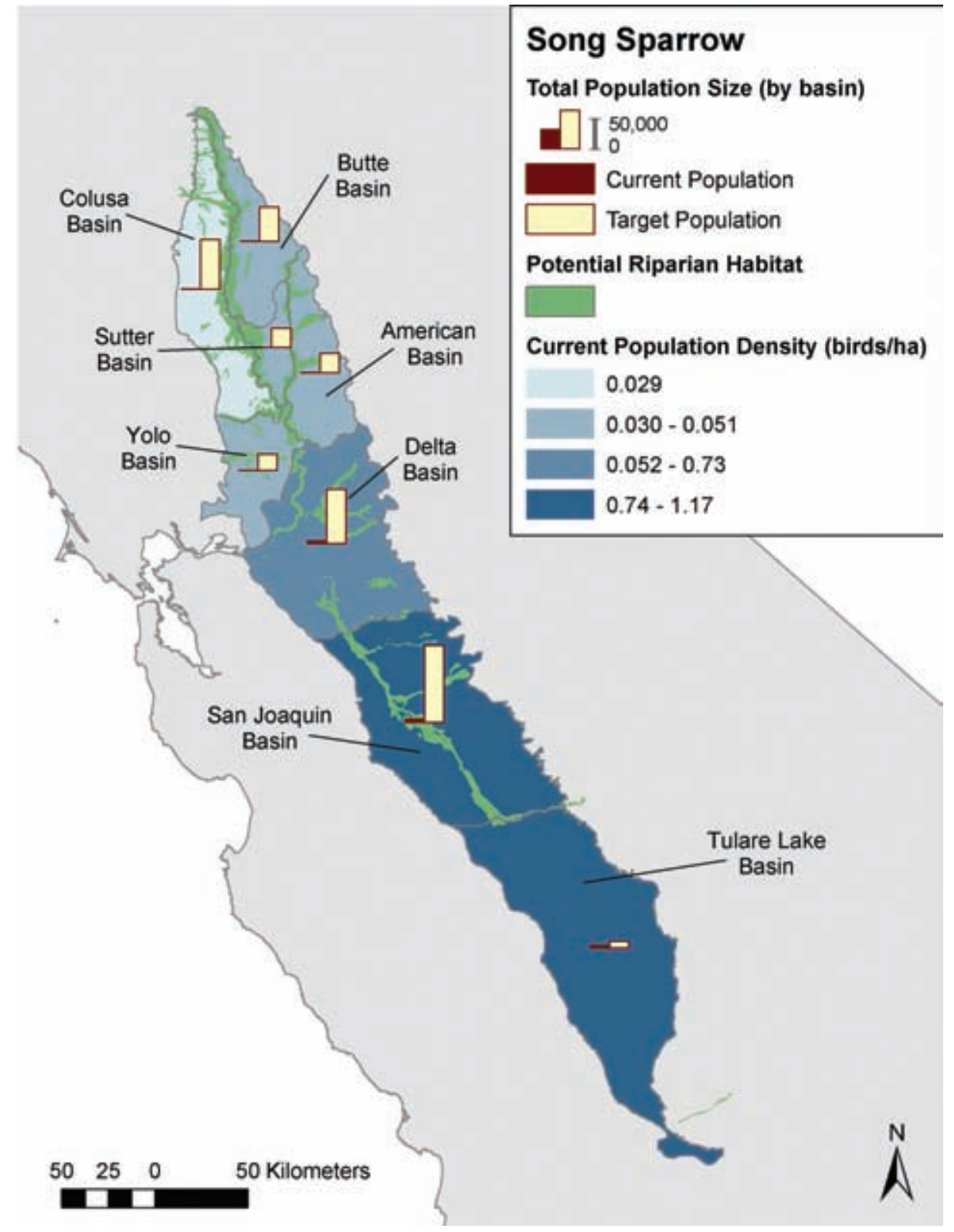

Figure 9-7. Song sparrow current populations and targets.

Table 9-7. Current and potential population densities and population targets for yellow-breasted chat.

\begin{tabular}{|c|c|c|c|c|c|c|}
\hline Basin & $\begin{array}{l}\text { Current Birds/Ha } \\
\qquad( \pm S E)^{1}\end{array}$ & $\begin{array}{c}\text { Current } \\
\text { Riparian Acres }\end{array}$ & $\begin{array}{c}\text { Current } \\
\text { Population Size } \\
( \pm S E)\end{array}$ & Target Birds/Acre ${ }^{2}$ & $\begin{array}{c}\text { Restorable } \\
\text { Riparian Acres }\end{array}$ & $\begin{array}{c}\text { Target } \\
\text { Population Size }\end{array}$ \\
\hline AMERICAN BASIN & $0.1377( \pm 0.0096)$ & 16,364 & $912( \pm 64)$ & 0.38 & 82,757 & 31,160 \\
\hline Butte Basin & $0.2104( \pm 0.0222)$ & 32,535 & $2,771( \pm 292)$ & 0.38 & 143,230 & 53,929 \\
\hline Colusa Basin & $0.0465( \pm 0.0054)$ & 19,708 & $371( \pm 43)$ & 0.38 & 207,149 & 77,995 \\
\hline SutTer BAsin & $0.1377( \pm 0.0096)$ & 3,641 & $203( \pm 14)$ & 0.38 & 79,378 & 29,887 \\
\hline Delta Basin & $0.0055( \pm 0.0019)$ & 14,840 & $33( \pm 11)$ & 0.21 & 132,548 & 28,441 \\
\hline SAN JOAQUIN BASIN & 0.00 & 12,249 & 0 & 0.21 & 188,394 & 40,425 \\
\hline Tulare Lake Basin & 0.00 & 7,195 & 0 & 0.21 & 15,835 & 3,398 \\
\hline
\end{tabular}

${ }^{1}$ Current density estimates were based on PRBO point count data. If a basin contained fewer than 30 point count stations, estimates were derived from all stations in the respective valley (Sacramento or San Joaquin).

${ }^{2}$ Target densities were based on the $75^{\text {th }}$ percentile value of all point counts in each valley, adjusted by a detectability coefficient. 
Table 9-8. Current and potential population densities and population targets for black-headed grosbeak.

\begin{tabular}{|ccccccc} 
Basin & $\begin{array}{c}\text { Current Birds/Ha } \\
( \pm \text { SE })^{1}\end{array}$ & $\begin{array}{c}\text { Current } \\
\text { Riparian Acres }\end{array}$ & $\begin{array}{c}\text { Current } \\
\text { Population Size } \\
( \pm \text { SE })\end{array}$ & $\begin{array}{c}\text { Target Birds/Acre }^{2} \\
\begin{array}{c}\text { Restorable } \\
\text { Riparian Acres }\end{array}\end{array}$ Target Population \\
Size
\end{tabular}

${ }^{I}$ Current density estimates were based on PRBO point count data. If a basin contained fewer than 30 point count stations, estimates were derived from all stations in the respective valley (Sacramento or San Joaquin).

${ }^{2}$ Target densities were based on the $75^{\text {th }}$ percentile value of all point counts in each valley, adjusted by a detectability coefficient.

Table 9-9. Current and potential population densities and population targets for common yellowthroat.

\begin{tabular}{|c|c|c|c|c|c|c|}
\hline Basin & $\begin{array}{l}\text { Current Birds/Ha } \\
\qquad( \pm S E)^{1}\end{array}$ & $\begin{array}{c}\text { Current } \\
\text { Riparian Acres }\end{array}$ & $\begin{array}{c}\text { Current } \\
\text { Population Size } \\
( \pm S E)\end{array}$ & Target Birds/Acre ${ }^{2}$ & $\begin{array}{c}\text { Restorable } \\
\text { Riparian Acres }\end{array}$ & $\begin{array}{c}\text { Target } \\
\text { Population Size }\end{array}$ \\
\hline AMERICAN BASIN & $0.1338( \pm 0.0173)$ & 16,364 & $866( \pm 115)$ & 0.10 & 82,757 & 8,376 \\
\hline Butte Basin & $0.1340( \pm 0.0316)$ & 32,535 & $1,765( \pm 416)$ & 0.10 & 143,230 & 14,497 \\
\hline Colusa Basin & $0.1766( \pm 0.0266)$ & 19,708 & $1,409( \pm 212)$ & 0.10 & 207,149 & 20,967 \\
\hline Sutter Basin & $0.1338( \pm 0.0173)$ & 3,641 & $197( \pm 25)$ & 0.10 & 79,378 & 8,034 \\
\hline YOLO BASIN & $0.1338( \pm 0.0173)$ & 3,569 & $193( \pm 25)$ & 0.10 & 68,394 & 6,923 \\
\hline Delta Basin & $0.1815( \pm 0.0300)$ & 14,840 & $1,090( \pm 181)$ & 0.20 & 132,548 & 26,832 \\
\hline SAN JOAQUIN BASIN & $0.0910( \pm 0.0201)$ & 12,249 & $451( \pm 100)$ & 0.20 & 188,394 & 38,137 \\
\hline Tulare Lake Basin & 0.00 & 7,195 & 0 & 0.20 & 15,835 & 3,206 \\
\hline
\end{tabular}

${ }^{1}$ Current density estimates were based on PRBO point count data. If a basin contained fewer than 30 point count stations, estimates were derived from all stations in the respective valley (Sacramento or San Joaquin).

${ }^{2}$ Target densities were based on the $75^{\text {th }}$ percentile value of all point counts in each valley, adjusted by a detectability coefficient.

Table 9-10. Current and potential population densities and population targets for yellow warbler.

\begin{tabular}{|c|c|c|c|c|c|c|}
\hline Basin & $\begin{array}{l}\text { Current Birds/Ha } \\
\qquad( \pm S E)^{1}\end{array}$ & $\begin{array}{c}\text { Current } \\
\text { Riparian Acres }\end{array}$ & $\begin{array}{c}\text { Current } \\
\text { Population Size } \\
( \pm S E)\end{array}$ & Target Birds/acre ${ }^{2}$ & $\begin{array}{c}\text { Restorable } \\
\text { Riparian Acres }\end{array}$ & $\begin{array}{c}\text { Target } \\
\text { Population Size }\end{array}$ \\
\hline AMERICAN BASIN & $0.0208( \pm 0.0103)$ & 16,364 & $138( \pm 68)$ & 0.13 & 82,757 & 10,758 \\
\hline Butte Basin & $0.0185( \pm 0.0176)$ & 32,535 & $244( \pm 231)$ & 0.13 & 143,230 & 18,620 \\
\hline Colusa Basin & $0.0147( \pm 0.0095)$ & 19,708 & $117( \pm 76)$ & 0.13 & 207,149 & 26,929 \\
\hline Sutter Basin & $0.0208( \pm 0.0103)$ & 3,641 & $31( \pm 15)$ & 0.13 & 79,378 & 10,319 \\
\hline Yolo BASIN & $0.0208( \pm 0.0103)$ & 3,569 & $31( \pm 15)$ & 0.13 & 68,394 & 8,891 \\
\hline Delta Basin & $0.0627( \pm 0.0693)$ & 14,840 & $377( \pm 417)$ & 0.13 & 132,548 & 17,231 \\
\hline SAN JOAQUIN BASIN & $0.0218( \pm 0.0163)$ & 12,249 & $108( \pm 81)$ & 0.13 & 188,394 & 24,491 \\
\hline Tulare Lake Basin & $0.042( \pm 0.0671)$ & 7,195 & $122( \pm 196)$ & 0.13 & 15,835 & 2,059 \\
\hline
\end{tabular}

${ }^{1}$ Current density estimates are derived from PRBO point count surveys, If a basin contained fewer than 30 point count stations, estimates were derived from all stations in the respective valley (Sacramento or San Joaquin).

${ }^{2}$ Target densities were based on spot-map densities from Clear Creek study plots, which are outside CVJV basins. 


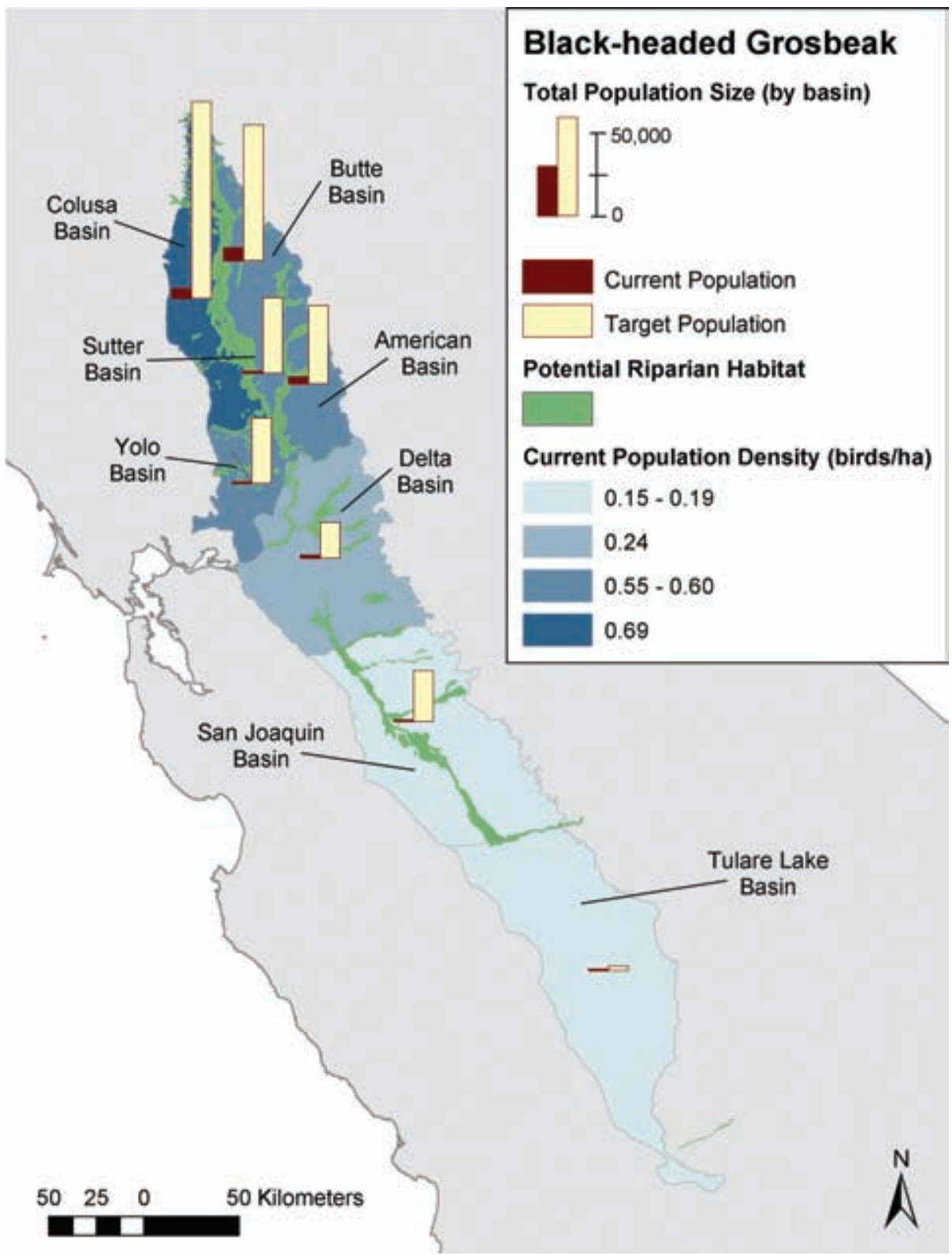

Figure 9-8. Black-headed grosbeak current populations and targets.

Table 9-11. Current and potential population densities and population targets for spotted towhee.

\begin{tabular}{|c|c|c|c|c|c|c|}
\hline Basin & $\begin{array}{l}\text { Current Birds/Ha } \\
\qquad( \pm S E)^{I}\end{array}$ & $\begin{array}{c}\text { Current } \\
\text { Riparian Acres }\end{array}$ & $\begin{array}{c}\text { Current } \\
\text { Population Size } \\
( \pm S E)\end{array}$ & Target Birds/Acre ${ }^{2}$ & $\begin{array}{c}\text { Restorable } \\
\text { Riparian Acres }\end{array}$ & $\begin{array}{c}\text { Target } \\
\text { Population Size }\end{array}$ \\
\hline AMERICAN BASIN & $0.7999( \pm 0.0342)$ & 16,364 & $5,299( \pm 227)$ & 0.78 & 82,757 & 64,330 \\
\hline Butte Basin & $0.6779( \pm 0.0552)$ & 32,535 & $8,929( \pm 727)$ & 0.78 & 143,230 & 111,337 \\
\hline Colusa Basin & $1.019( \pm 0.0509)$ & 19,708 & $8,129( \pm 406)$ & 0.78 & 207,149 & 161,023 \\
\hline Sutter BAsin & $0.7999( \pm 0.0342)$ & 3,641 & $10,536( \pm 451)$ & 0.78 & 79,378 & 61,703 \\
\hline Delta BAsin & $1.837( \pm 0.1038)$ & 14,840 & $11,037( \pm 624)$ & 0.78 & 132,548 & 103,033 \\
\hline SAN JOAQUIN BASIN & $1.337( \pm 0.0787)$ & 12,249 & $6,629( \pm 390)$ & 0.78 & 188,394 & 146,444 \\
\hline Tulare Basin & $0.5486( \pm 0.1088)$ & 7,195 & $1,598( \pm 317)$ & 0.78 & 15,835 & 12,309 \\
\hline
\end{tabular}

${ }^{1}$ Current density estimates were based on PRBO point count data. If a basin contained fewer than 30 point count stations, estimates were derived from all stations in the respective valley (Sacramento or San Joaquin).

${ }^{2}$ Target densities were based on the $75^{\text {th }}$ percentile value of all point counts in each valley, adjusted by a detectability coefficient. 


\section{Conservation Priorities for Breeding Riparian Songbirds}

Prioritization of habitat restoration work by basin is subjective and can vary depending on goals of the conservation action and opportunities on the ground. Basins were ranked according to six different criteria, with highest rank corresponding to the lowest score. Using this method, the Butte, Colusa, and San Joaquin Basins, ranked respectively are the most important basins in the conservation of riparian songbirds in the Central Valley. Table 9-12 ranks basins in order of importance to riparian birds based on a variety of factors.

By comparing amounts of acreage to be restored in specific projects and multiplying those acreages by current population densities, proposals may be evaluated and ranked on their contribution to overall basin population targets established for each species (or a suite of species). For example, Table 9-13 identifies a ranking system for North American Wetland Conservation Act grant proposals submitted in the spring 2003 grant cycle. This system provides a quantitative way to rank projects based on their potential to influence riparian songbird populations.

Table 9-12. Basins ranked in order of importance to riparian birds based on inputs for setting conservation objectives.

\begin{tabular}{|c|c|c|c|c|c|c|c|}
\hline Basin & $\begin{array}{c}\text { Current } \\
\text { Riparian Acres }\end{array}$ & $\begin{array}{c}\text { Restorable } \\
\text { Riparian } \\
\text { Acres }\end{array}$ & $\begin{array}{l}\text { Proportion } \\
\text { of current to } \\
\text { restorable }\end{array}$ & $\begin{array}{l}\text { Nest Success } \\
(4=\text { no data })\end{array}$ & $\begin{array}{l}\text { Number of Sites with } \\
\text { focal species richness } \\
>4-5 \text { (\# of sites) }\end{array}$ & $\begin{array}{c}\text { Current Focal } \\
\text { Species Distribution } \\
\text { (\# of species) }\end{array}$ & $\begin{array}{c}\text { Overall } \\
\text { Basin Rank } \\
\text { (total score) }\end{array}$ \\
\hline AMERICAN & 3 & 5 & 3 & 4 & $5(1)$ & $6(7)$ & $4(21)$ \\
\hline Butte & 1 & 3 & 2 & 4 & $3(4)$ & $1(12)$ & $1(14)$ \\
\hline Colusa & 2 & 1 & 5 & 3 & $2(8)$ & $2(11)$ & $2(15)$ \\
\hline DeLta & 4 & 4 & 4 & 2 & $4(4)$ & $4(9)$ & $5(22)$ \\
\hline SAN JOAQUIN & 5 & 2 & 6 & 1 & $1(9)$ & $3(10)$ & $3(18)$ \\
\hline Tulare & 6 & 8 & 1 & 4 & $6(0)$ & $7(6)$ & $6(32)$ \\
\hline
\end{tabular}

Table 9-13. Comparison of NAWCA proposals submitted spring 2003, based on contribution to riparian songbird targets.

\begin{tabular}{|c|c|c|c|c|c|c|c|}
\hline $\begin{array}{c}\text { CVJV } \\
\text { NAWCA } \\
\text { Proposals }\end{array}$ & Basin & $\begin{array}{c}\text { Riparian } \\
\text { Habitat Goal } \\
\text { (acres) }\end{array}$ & $\begin{array}{c}\text { Proposed amount } \\
\text { of riparian to } \\
\text { be restored/ } \\
\text { enhanced (acres) }\end{array}$ & $\begin{array}{l}\text { Projected Increase } \\
\text { of } 6 \text { focal species } \\
\text { (in total \# of } \\
\text { individuals) }\end{array}$ & $\begin{array}{l}\text { Contribution } \\
\text { to population } \\
\text { target for } 6 \text { focal } \\
\text { species (\%) }\end{array}$ & $\begin{array}{c}\text { Projected } \\
\text { increase in } \\
\text { total number of } \\
\text { Yellow Warbler }\end{array}$ & $\begin{array}{c}\text { Contribution to } \\
\text { Yellow Warbler } \\
\text { population } \\
\text { target (\%) }\end{array}$ \\
\hline Proposal \# 1 & Colusa & 207,149 & 5,000 & 19,711 & 1.8 & 615 & 1.7 \\
\hline PROPOSAL \# 2 & SAN JOAQUIN & 188,394 & 2,628 & 12,402 & 1.3 & 323 & 1.3 \\
\hline Proposal \# 3 & SAN JOAQUIN & 188,394 & 1,878 & 8,863 & 0.9 & 231 & 1.0 \\
\hline
\end{tabular}

\section{Summary of Conservation Objectives by Basin}

The RBCP contains specific information on factors (e.g., plant species) that positively influence the occurrence of focal riparian bird species. It provides multi-species management recommendations for protection, restoration, and enhancement. The RBCP provides a wealth of current information to guide songbird habitat conservation efforts and should be consulted as an authoritative reference for detailed restoration planning.

American Basin - The American Basin currently has 16,364 acres of riparian habitat and approximately 83,000 acres of restorable habitat. The five-year restoration objective for the American Basin is 675 acres. Current and target bird population and density data for focal species are provided in Tables 9-6 through 9-12.

Butte Basin - The Butte Basin currently has 132,535 acres of riparian habitat and approximately 143,000 acres of restorable habitat. The five-year restoration objective for the Butte Basin is 1,125 acres. Current and target bird population and density data for focal species are provided in Tables 9-9 through 9-14. 
Colusa Basin - The Colusa Basin currently has 19,708 acres of riparian habitat and approximately 207,000 acres of restorable habitat. The five-year restoration objective for the Colusa Basin is 1,350 acres. Current and target bird population and density data for focal species are provided in Tables 9-9 through 9-14.

Sutter Basin - The Sutter Basin currently has 3,641 acres of riparian habitat and approximately 79,000 acres of restorable habitat. The five-year restoration objective for the Sutter Basin is 675 acres. Current and target bird population and density data for focal species are provided in Tables 9-9 through 9-14.

Yolo Basin - The Yolo Basin currently has 3,569 acres of riparian habitat and approximately 68,000 acres of restorable habitat. The five-year restoration objective for the Yolo Basin is 675 acres. Current and target bird population and density data for focal species are provided in Tables 9-9 through 9-14.

Delta Basin - The Delta Basin currently has 14,840 acres of riparian habitat and approximately 132,548 acres of restorable habitat. The five-year restoration objective for the Delta Basin is 1,500 acres with 900 acres along the Mokulmne River and 600 acres along the Cosumnes River. Current and target bird population and density data for focal species are provided in Tables 9-9 through 9-14.

San Joaquin Basin - The San Joaquin Basin currently has 12,249 acres of riparian habitat and approximately 188,000 acres of restorable habitat. The five-year restoration objective for the San Joaquin Basin is 2,500 acres. Current and target bird population and density data for focal species are provided in Tables 9-9 through 9-14.

Tulare Basin - The Tulare Basin currently has 7,195 acres of riparian habitat and approximately 15,000 acres of restorable habitat. The five-year restoration objective for the Tulare Basin is 200 acres. Current and target bird population and density data for focal species are provided in Tables 9-9 through 9-14. 
226 Chapter 9: Breeding Riparian Songbirds 


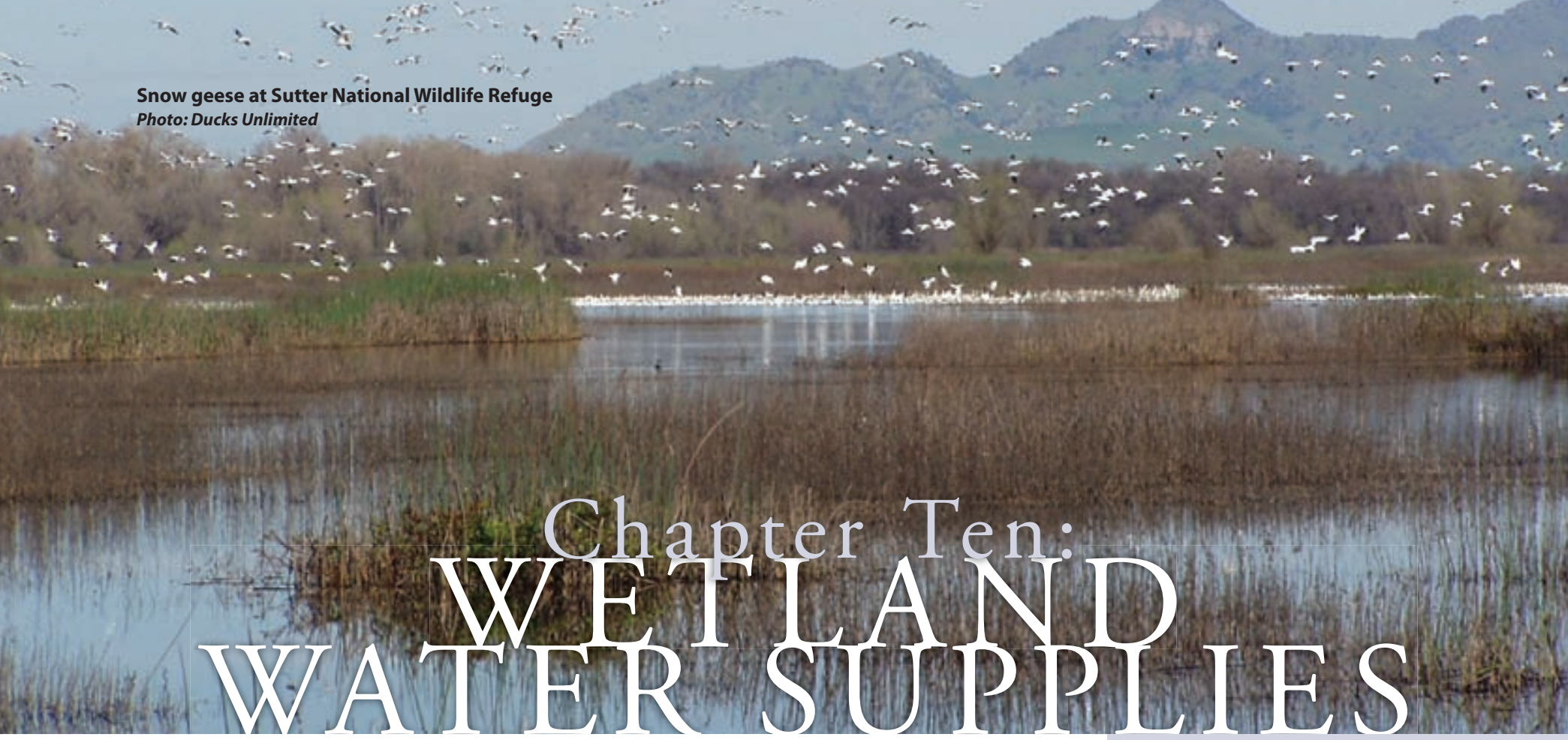

This chapter outlines the requirements for Central Valley managed wetland water supplies and the current conditions in the valley for obtaining water supplies to meet objectives stated in the 2006 Plan. The chapter also summarizes the history of wetland water supplies in the valley, the significant changes to supplies over time, and the most current and pressing water-related issues within each of the valley's nine basins.

\section{Introduction}

Ensuring reliable and affordable water supplies for wetland management may be the Central Valley Joint Venture's (JV) greatest challenge. Since publication of the 1990 Central Valley Habitat Joint Venture Implementation Plan (1990 Plan; Central Valley Habitat Joint Venture 1990), human demand for water in the Central Valley has increased at an alarming rate. At the same time, complex factors have caused the reduction of available water supplies for many wetlands. These include in-stream dedication for threatened and endangered fish species, human population growth, and urbanization. The economic and political competition for water has become intense, and the cost of water in some basins has risen 400\% since 1993 (D. Garrison, U.S. Fish and Wildlife Service, personal communication). Stakeholders with competing agricultural, urban, and environmental interests are lobbying on many fronts for reallocation of existing supplies.

Water shortages in California currently approach 1.6 million acre-feet in an average water year and 5.1 million acre-feet in drought years. This deficit is expected to increase to 2.4 million acre-feet in average years and to 6.2 million acre-feet in drought years by 2020 (California Department of Water Resources 1998).

The challenge facing both private and public wetland managers in the Central Valley is two-fold: (1) increasing the reliability of water sources for wetland management; and (2) ensuring that funds for water supplies cover the increasing costs of water in an increasingly 
competitive water market. Many private wetland managers rely on water supplies that are reduced in below-average water years, depend on return flows from agriculture, and/or are part of low-priority contracts with water purveyors. Increasing the reliability of these water sources is a priority for the JV, but water reliability does not guarantee long-term affordability. Wetland managers who continue to have access to reliable water supplies may ultimately be unable to afford water as prices increase. This chapter identifies JV efforts needed to secure reliable and accessible water supplies for Central Valley wetlands.

This chapter has three sections: (1) the history of Central Valley wetland water supplies; (2) water supplies needed to meet integrated bird habitat objectives; and (3) water issues and proposed actions.

\section{The History of Central Valley Wetland Water Supplies}

\section{Historical Overview}

The loss of wetlands in the Central Valley since the 1850s has been well documented by a variety of publications and reports. Surveys in the 1850s estimated there to be over four million acres of wetlands in the valley. The resulting influx of immigrants into California following the discovery of gold, initiated the changes that led to the conversion of over $90 \%$ of Central Valley wetlands. Human settlement increased the need to control annual flooding of the major valley river systems to protect developing cities, homesteads and associated infrastructure. As flood control levees were built to tame the rivers, agricultural lands expanded, and dams were constructed to provide additional flood control and water storage for expanding urban, industrial, and agricultural needs. As the population of California increased, so did this demand for agricultural products and other services. By the 1950s, expanding agricultural development had decreased Central Valley wetlands to an estimated 290,000 acres (Central Valley Habitat Joint Venture 1990).

The continued decline of Central Valley wetlands occurred between 1950 and 1970. Water supplies for managed wetlands during this period were not secure. Most managed wetlands depended upon agricultural irrigation return flows, low-priority water contracts, or non-binding agreements with water districts. Some of those historic agreements continue to this day. Examples include wetlands in the Butte Sink area that receive fall and winter water via a 1922 agreement with Western Canal Company and Pacific Gas \& Electric Company; the Sacramento, Delevan, and Colusa National Wildlife Refuges (NWR), which receive water through agreements with Glenn-Colusa Irrigation District; and the Gray Lodge Wildlife Area (WA), which receives a portion of its water needs from the BiggsWest Gridley Water District for lands allocated “Class 1" Feather River settlement water. Another example involves the Grassland Mutual Water Association, which filed suit against the Department of the Interior after losing San Joaquin River supplies when the Friant Dam Project began diverting flows from the San Joaquin River for agriculture and municipal and industrial uses in the Tulare Basin. A settlement provided 50,000 acre-feet of water (if and when available) for wetlands within the Grassland Water District (GWD) during the fall and winter months. The California Department of Fish and Game (CDFG) also negotiated agreements with the U.S. Bureau of Reclamation (USBR) and various local water districts for many of its wildlife areas. With few exceptions, these contracts and agreements provided water supplies on an "if and when available basis," with supplies being severely reduced, or eliminated, during drought years. This situation continued during the 1970s until a severe drought during the latter part of the decade greatly reduced wetland water supplies and, in some instances, eliminated all wetland water deliveries.

\section{Wetland Water Supply Studies}

The combination of drought and poor wetland water supply reliability resulted in significant impacts to wetland habitat and waterbird populations, and in particular, wintering waterfowl. By the end of the decade, political pressure from concerned landowners and wildlife agencies resulted in publication of the Total Water Management Study for the Central Valley Basin of California (U.S. Bureau of Reclamation unpublished report). This study included Working Document No. 12, "Fish and Wildlife Problems, Opportunities, and Solutions" (U.S. Bureau of Reclamation 1978), a survey of major fish and wildlife problems and improvement opportunities within the geographical area encompassed by the Central Valley Project (CVP) ${ }^{1}$. As a result of the study's findings, the USBR initiated the Central Valley Fish and Wildlife Management Study of 1979 (U.S. Bureau of Reclamation 1979). The goal of the study was the development of a comprehensive baseline of Central Valley fish and wildlife resources and to recommend specific solutions to water related issues.

\footnotetext{
${ }^{1}$ The Central Valley Project is a federal water project initially authorized in 1935 as a long-term plan to utilize water in California's Central Valley. The original goals of the project were flood control, improved transportation of water, and the development of water supplies for industrial, municipal, and agricultural use. Fish and wildlife needs were eventually added as goals, with the CVPIA furthering this objective through the allocation of CVP water supplies for specific fish and wildlife purposes.
} 
These studies continued into the early 1980s and resulted in a report that addressed waterfowl and wetland habitat, Central Valley Fish and Wildlife Management Study: Refuge Water Supply, Central Valley Hydrologic Basin, California 1986 (U.S. Bureau of Reclamation 1986). This study served as the basis for the Report on Refuge Water Supply Investigations, Central Valley Hydrologic Basin, California (1989 Report; U.S. Department of Interior 1989).

As these investigations progressed, other actions were underway that would significantly affect Central Valley wetlands. The North American Waterfowl Management Plan (U.S. Fish and Wildlife Service 1986), an international treaty between the United States and Canada, was signed in 1986 and identified the Central Valley as one of the six priority habitat areas for North American waterfowl. The JV was subsequently formed in 1988, and based upon the findings of the 1989 Report, one of the objectives stated in the 1990 Plan was to secure firm, reliable water supplies for publicly-owned Central Valley wetlands and the privately managed wetlands located within the Grassland Resource Conservation District (GRCD) and elsewhere in the valley.

\section{The Central Valley Project Improvement Act}

\section{CVPIA Mandates Water for Wetlands}

Efforts to secure reliable and accessible sources of water started with ecologically sound estimates of wetland water needs for optimal habitat management and were identified as Level 4 water supplies in the 1989 Report. Due to an investment in the legislative process by JV partners, provisions were made in the 1992 Central Valley Project Improvement Act (CVPIA) Title 34 of Public Law 103-575 Section 3406 (d)(1-5) to meet this need. This law authorized water supplies for those wetland areas covered by the 1989 Report and the San Joaquin Basin Action Plan (Action Plan; U.S. Bureau of Reclamation et a l. 1989), a plan developed to mitigate for the habitat losses resulting from the Kesterson NWR selenium contamination of the 1980s, and to implement the objectives of the JV.

Another specific provision of the CVPIA, 3406 (d)(6)(A,B), required the investigation of water and conveyance needs for private wetlands not covered by the provisions of CVPIA 3406 (d)(1-5) of the act. The Central Valley Wetlands Water Supply Investigations, CVPIA $3406(d)(6)(A, B)$, A Report to Congress (Water Report; U.S. Fish and Wildlife Service 2000) was produced as a result. Central Valley water suppliers were interviewed and their comments incorporated into the Water Report. Most expressed concern over the long-term shortages of water supplies resulting from a statewide lack of new water development (e.g., groundwater banking, new reservoirs, and new conveyance infrastructure); a reduction of Colorado River water supplies; and increasing urban and environmental demands that reduce supplies for agricultural and other uses. Although most suppliers face no legal obstructions to providing wetland water, many admitted that agriculture would have priority if water shortages develop.

To date, the CVPIA is one of the most important legislative actions taken to protect and restore Central Valley wetland habitat, and has laid the foundation for many significant and beneficial conservation activities in subsequent years. Since 1992, delivery of water supplies of adequate quality and quantity to certain NWRs, WAs, and the private wetlands of the GRCD through CVPIA has improved wetland habitat quality and benefited many wetland-dependent wildlife populations, including waterfowl, shorebirds, colonial waterbirds, and several threatened and endangered species. These benefits have been documented in annual reports to Congress and in a variety of studies and reports conducted by the U.S. Fish and Wildlife Service (USFWS) and CDFG, which are summarized here:

- A 300\% increase in waterfowl food production within the GRCD;

- An 89\% reduction in avian disease outbreaks on the Sacramento NWR Complex since 1992;

- A 49\% increase in fall shorebird use Central Valley-wide;

- An increase in bird use days on private lands in the San Joaquin Valley from 38,000 to 115,000; during the first year of CVPIA implementation, and today, the San Joaquin Valley hosts 500,000 to 1 million birds each year;

- A $50 \%$ increase in the number of heron and egret rookeries in the San Joaquin Valley;

- A 61\% increase in visitor use on the Sacramento NWR Complex between 1992 and 2006;

- Increases in threatened or endangered species (western pond turtles, tricolored blackbirds, and giant garter snakes); 
- Marked increases in white-faced ibis and Sandhill cranes (e.g., white-faced ibis populations increased from 100 birds in 1991 to 15,000 in 2002 at the Sutter NWR);

- The Agricultural Waterfowl Incentive Program, CVPIA 3406 (b)(22), funded the flooding of an average of 40,000 acres of agricultural lands each winter between 1997 and 2003, providing a substantial portion of the annual waterfowl energetic need within the Pacific Flyway during that time.

These habitat improvements have led to research studies by universities, government agencies, and non-governmental conservation organizations such as the California Waterfowl Association; Ducks Unlimited, Inc.; PRBO Conservation Science; University of California, Davis; United States Geological Survey’s Biological Research Division, Dixon Field Station; and others.

Several long-term water conveyance/supply contracts and agreements were negotiated during the 1990s that increase the reliability of CVPIA water supplies being delivered for the next 25 years. These contracts and agreements called for the establishment of an Interagency Refuge Water Management Team (Team). Comprised of USBR, USFWS, CDFG, and the GRCD, the Team meets regularly, collaborating on the acquisition and allocation of incremental water supplies necessary for wetlands to operate at full habitat development levels (Level 4) and other wetland water related issues.

\section{CVPIA Mandate Falls Short of Realization}

The CVPIA mandated delivery of historic water supplies (Level 2 supplies) and two-thirds of the full water supply requirements for lands identified in the Action Plan from the CVP. In addition, Level 4 water supplies were to be acquired through purchase from willing sellers and provided in $10 \%$ increments per year until 2002, when full water supply requirements were authorized. These full water levels have not been achieved, due in large part to state and federal budget shortages, inconsistency in the timing of water deliveries, and increases in the cost of blocks of water made available annually from willing sellers on the open market (also known as "spot market"). Budgetary constraints within USBR's annual CVPIA Restoration Fund and the state's inability to cover their 25\% cost-share mandate, required by CVPIA, have restricted the amount of Level 4 water supplies that can be acquired each year. These budget shortfalls also have inhibited the ability to complete the construction of conveyance facilities necessary to deliver water to refuge boundaries. In some cases, conveyance facilities to provide water delivery to the property boundary are still awaiting construction, and in the case of the Action Plan lands, wetland restoration has still not been completed. Some wetland areas still lack sufficient infrastructure to beneficially use their incremental Level 4 water supplies, even if delivered to the property boundary.

Water costs have escalated as water acquisitions to meet CVPIA, CALFED, urban, and agricultural needs have influenced sharp increases in spot market prices, further stressing limited budgets. USBR is currently studying the potential of increasing groundwater usage on CVPIA wetlands to offset both funding and supply limitations.

\section{Water Supplies Needed to Meet Integrated Bird Habitat Objectives}

The 2006 Plan addresses the habitat needs of six bird groups. To increase the efficiency of bird conservation in the Central Valley, the habitat needs of these bird groups were integrated at the basin scale where possible. Chapter 11 (Summary Chapter) provides a full description of these integrated habitat objectives and how they were obtained. The water needs associated with these integrated objectives are presented here.

Estimated annual water supplies needed to properly manage state, federal and GRCD seasonal and semi-permanent wetlands for each basin were identified in the 1989 Report and the Interagency Coordinated Program (ICP) task force report, An Interagency Coordinated Program for Wetland Water Use Planning: Central Valley, California (ICP Report; U.S. Bureau of Reclamation et al. 1998). These annual water needs, as well as the amount of water needed for winter-flooded agricultural habitat, are described in Table 10-1. 
The water needs that are associated with integrated bird objectives are a function of the amount of existing habitat, as well as the amount of additional habitat that must be restored to fully meet bird needs in the Central Valley. Table 10-2 presents the annual water needs that are associated with existing wetland habitats in the Central Valley, based on acre-feet per acre requirements identified in Table 10-1.

CVPIA Level II supplies currently total 422,252 acre-feet or $37 \%$ of annual water needs of existing wetlands. Full Level 4 supplies total 555, 515 acre-feet, or 49\% of existing wetland need (the reliability of Level 4 deliveries is directly related to annual spot market water costs, water availability, and Restoration Fund revenue levels for that year).

Beyond CVPIA Level 2 and 4 supplies, the reliability of water supplies needed to meet the full 1,129,151 acre-feet need of these wetlands remains largely unknown. Table 10-3 presents the annual water needs of additional seasonal and semi-permanent wetlands (new wetlands) that must be restored to achieve integrated habitat objectives for bird groups included in the 2006 Plan. These represent new water needs above and beyond the water being supplied to existing wetlands. Finally, Table 10-4 presents the combined water requirements of existing wetlands and wetlands that must be restored to fully meet integrated habitat objectives for the Central Valley. This overall estimate also includes the water needed for winter-flooding of agricultural habitats that must be maintained even when wetland objectives are fully met. Although this overall estimate of about 2.3 million acre-feet includes "new" water that is needed for wetlands yet to be restored, much of this water need is currently being met on existing wetland and agricultural habitats. However, the long-term reliability of these supplies remains uncertain.

Table 10-2. Total annual water needs for existing wetland habitats in the Central Valley.

\begin{tabular}{|c|c|c|c|c|c|}
\hline Basin & $\begin{array}{l}\text { Seasonal Wetlands } \\
\text { (acres) }\end{array}$ & $\begin{array}{l}\text { Seasonal Wetland Water } \\
\text { Needs (acre-feet) }\end{array}$ & $\begin{array}{l}\text { Semi-Permanent } \\
\text { Wetlands (acres) }\end{array}$ & $\begin{array}{l}\text { Semi-Permanent Wetland } \\
\text { Water Needs (acre-feet) }\end{array}$ & $\begin{array}{c}\text { Total Water Needs } \\
\text { (acre-feet) }\end{array}$ \\
\hline AMERICAN & 3,187 & 15,935 & 562 & 4,159 & 20,094 \\
\hline Butte & 23,340 & 130,704 & 4,119 & 30,481 & 161,185 \\
\hline Colusa & 22,390 & 111,950 & 3,951 & 29,237 & 141,187 \\
\hline Sutter & 1,951 & 9,755 & 344 & 2,546 & 12,301 \\
\hline YoLO & 8,558 & 42,790 & 1,512 & 11,189 & 53,979 \\
\hline Delta & 6,349 & 30,158 & 1,121 & 8,295 & 38,453 \\
\hline SuIsuN & 32,232 & 153,102 & 5,688 & 42,091 & 195,193 \\
\hline SAN JOAQUIN & 61,013 & 332,521 & 6,779 & 50,165 & 382,686 \\
\hline Tulare & 20,212 & 106,113 & 2,245 & 17,960 & 124,073 \\
\hline TotaL & 179,232 & 933,028 & 26,321 & 196,123 & $1,129,151$ \\
\hline
\end{tabular}


Table 10-3. Total annual water needs for additional wetland habitats that must be restored to fully meet integrated bird habitat objectives.

\begin{tabular}{|c|c|c|c|c|c|}
\hline Basin & $\begin{array}{c}\text { Seasonal Wetlands } \\
\text { (acres) }\end{array}$ & $\begin{array}{l}\text { Seasonal Wetland Water } \\
\text { Needs (acre-feet) }\end{array}$ & $\begin{array}{l}\text { Semi-Permanent } \\
\text { Wetlands (acres) }\end{array}$ & $\begin{array}{l}\text { Semi-Permanent Wetland } \\
\text { Water Needs (acre-feet) }\end{array}$ & $\begin{array}{c}\text { Total Water Needs } \\
\text { (acre-feet) }\end{array}$ \\
\hline AMERICAN & 20,396 & 101,980 & 425 & 3,145 & 105,125 \\
\hline Colusa & 2,396 & 11,980 & 425 & 3,145 & 15,125 \\
\hline Sutter & 4,396 & 21,980 & 425 & 3,145 & 25,125 \\
\hline SUISUN & 0 & 0 & 333 & 2,464 & 2,464 \\
\hline SAN JOAQUIN & 20,340 & 110,853 & 2,815 & 20,831 & 131,684 \\
\hline Tulare & 21,263 & 111,631 & 5,935 & 47,480 & 159,111 \\
\hline TotaL & 108,527 & 562,750 & 12,500 & 96,053 & 658,803 \\
\hline
\end{tabular}

Table 10-4. Total annual water needs for wetland and winter-flooded agricultural habitats in the Central Valley when integrated bird habitat objectives are met.

\begin{tabular}{|c|c|c|c|c|}
\hline Basin & $\begin{array}{l}\text { Seasonal Wetlands } \\
\quad(\text { acre-feet })^{a}\end{array}$ & $\begin{array}{l}\text { Semi-Permanent Wetlands } \\
(\text { acre-feet })^{b}\end{array}$ & $\begin{array}{l}\text { Agricultural Winter } \\
\text { Flooding (acre-feet) }\end{array}$ & Total Water (acre-feet) $)^{d}$ \\
\hline AMERICAN & 117,915 & 7,304 & 125,000 & 250,219 \\
\hline Butte & 228,122 & 33,626 & 155,000 & 416,748 \\
\hline Colusa & 123,930 & 32,382 & 112,500 & 268,812 \\
\hline Sutter & 31,735 & 5,691 & 25,000 & 62,426 \\
\hline YoLO & 58,640 & 14,948 & 7,500 & 81,088 \\
\hline Delta & 121,215 & 17,234 & $72,500^{e}$ & 210,949 \\
\hline SuISUN & 153,102 & 44,555 & 0 & 197,657 \\
\hline SAN JOAQUIN & 443,374 & 70,996 & 0 & 514,370 \\
\hline Tulare & 217,744 & 65,440 & 0 & 283,184 \\
\hline Total & $1,495,777$ & 292,176 & 497,500 & $2,285,453$ \\
\hline
\end{tabular}

"Annual water needs for managed seasonal wetlands (public and private) when seasonal wetland objectives are met for the Central Valley. ${ }^{b}$ Annual water needs for managed semi-permanent wetlands (public and private) when semi-permanent wetland objectives are met for the Central Valley.

'Annual water needs for winter-flooded agriculture (predominantly rice) when seasonal wetland objectives are met for the Central Valley.

${ }^{d}$ Sum of seasonal wetland, semi-permanent wetland, and winter-flooded agriculture water needs.

'Although there is not a winter-flooding objective for the Delta Basin, this figure represents current estimates of winter-flooded corn in the basin.

Although the 2006 Plan provides an estimate of the water needed to meet integrated bird habitat objectives, the current and future availability of wetland water supplies remains unclear. Site specific investigations are needed to evaluate wetland water supplies, both for existing wetlands and for wetlands that will be restored to meet bird habitat objectives. This is a key information need for all basins in the Central Valley, and will be critical as JV partners attempt to secure reliable and affordable water supplies for all of the region's wetlands. 


\section{Water Issues and Proposed Actions}

\section{Current Issues and Challenges}

\section{Water Supplies for New Wetlands}

Since the passage of CVPIA, additional wetlands have been added to NWRs and WAs that also need to be addressed, as well as the water supply needs of private wetlands within key basins. They include: Llano Seco Unit of the Sacramento River NWR, San Joaquin River NWR, Stone Lakes NWR, Butte Sink NWR, Upper Butte Basin WA, private wetlands within the Tulare Basin, and others. They contribute to the JV wetland restoration objective and utilize water supplies that were authorized when these properties were acquired. However, in many instances after the acquisition, the agencies lacked the funding to pay for the pumping, and/or conveyance of water supplies for these newly purchased wetlands.

Likewise, additions to San Joaquin Valley WAs such as North Grasslands and Volta WAs have varying reliability of supplies. For example, the Gadwall Unit addition to the North Grasslands WA falls within the GRCD and is entitled to CVPIA authorized water supplies, while recent additions to the Volta WA do not currently appear to have access to adequate water supplies.

\section{Spotlight on Tulare Basin Wetlands}

Interest in restoring historic wetland habitat conditions within the Tulare Basin has greatly increased since the passage of the CVPIA. While private wetlands within this area did not directly benefit from provisions of the CVPIA, the vast improvements that have resulted in other wetland basins that receive CVPIA water supplies has sparked renewed discussion at regional, state and federal levels in the Tulare Basin. A major initiative has resulted from these discussions, focusing on a combination of factors that could result in significant habitat restoration within the Tulare Basin.

These factors include:

- Historic wetland areas and soil types;

- Availability of water supplies, including cooperation from overlying agricultural water agencies and conjunctive use of available water resources for multiple purposes (including flood control);

- Cooperating private landowners who maintain interest in the re-establishment of wetlands on their property or willingness to protect the wildlife values of their property through state or federal ownership or conservation easements;

- Conjunctive use of existing and restored natural landscapes to provide endangered species benefits as well as wetland benefits;

- A high degree of cooperation among state and federal agencies, conservation organizations, and the agricultural community, with varying missions and authorizations.

High annual variation in runoff from the west slope of the Sierra Nevada into the southern San Joaquin Valley causes the Tulare Basin to experience the greatest fluctuation in water supplies in the Central Valley. For example, the annual runoff from the Kaweah River (a tributary to the Tulare Lake) over the past 100 years of record has ranged from approximately 93,000 acre-feet in 1977 to over 1.4 million acre-feet in 1983. Such vast fluctuations call for a strategy that takes into account this highly variable hydrology and establishes flexible wetland restoration goals within the region.

The Tulare Basin is the heart of some of the most intensively farmed and agriculturally productive lands in the world. It is also one of the fastest growing regions in California. There is no "silver bullet" strategy for finding more water for wetlands in Tulare Basin as may have been the case with implementation of the CVPIA elsewhere in the Central Valley. The basin suffers from chronic water shortages, and the impacts of having its imported water supplies significantly reduced, as a result of new laws or regulations, have not been resolved. It is facing significant new water demands for river and fishery habitat restoration and, due to its proximity to urban Southern California, has the potential to become a new source of water to meet the increasing water needs of that region. Only now are the existing and future wetlands needs of the Tulare Basin getting serious consideration in state and federal water and environmental forums. 


\section{Water Management Programs and Policies Affecting Wetland Water Supplies}

Along with increases in wetland acreage in the Central Valley during the past decade, various activities have occurred that have the serious potential to impact the quantity and quality of water supplies to many wetland areas throughout the valley.

\section{Federal Programs and Actions}

The U.S. Department of Agriculture, through the Natural Resources Conservation Service, has restored privately-owned wetlands throughout the Central Valley through the Wetlands Reserve Program. Most of these restored wetlands utilize water supplies that were available to the landowner prior to restoration. In many instances, reliability of these water supplies is unknown, yet must be clarified as part of an overall re-evaluation of wetland water supplies for the Central Valley.

The Department of the Interior's decision to decrease the amount of Colorado River supplies for Southern California has also affected water supplies in the Central Valley. This decision initiated the search for additional municipal and industrial water supplies by the Metropolitan Water District (MWD), which supplies water to the Los Angeles and San Diego metropolitan areas. MWD has become very active in locating and acquiring water supply options, both north and south of the Sacramento San Joaquin River Delta (Delta), to help meet anticipated future demands for its service area. Typically, urban water users can pay prices that are an order of magnitude greater than can be afforded by government agencies, conservation organizations, and private landowners, resulting in the unintended consequence of "out-bidding" wetland managers.

Endangered Species Act decisions have also affected agricultural water supplies that must be diverted and pumped south of the Delta. Reduced pumping from the Delta to protect listed fish species has decreased water supplies previously available to CVP and State Water Project districts. These decreased supplies have generated an energetic water transfer program between agricultural water districts in the San Joaquin Valley. These transfers have greatly increased the demand for surplus water supplies that become available in certain years. As the demand has increased, so has the cost of acquiring these limited water supplies. These increased costs have placed additional burdens on limited public funding available to acquire necessary water supplies for private and public wetlands.

\section{CALFED Program}

Approximately half of California's surface water flows through the Delta. Half of this water is diverted for urban, agricultural and environmental use. Remaining water is discharged into the Pacific Ocean through the San Francisco Bay (Bay). The Bay-Delta ecosystem is affected by these water diversions, and courts have intervened to assure that adequate freshwater supplies enter the system. State and federal agencies are working with local water districts and other stakeholders to improve conditions in the BayDelta, while continuing efforts to meet California's diverse water needs. These efforts are intended to be coordinated through the CALFED Program, which was initiated following the 1994 interagency Bay-Delta Accord. The program focuses on water quality standards, coordination of State Water Project and CVP operations; and long-term solutions to problems in the Bay-Delta Estuary.

CALFED, along with several CVPIA programs and various court decisions have brought about changes in water management programs throughout the Central Valley. CALFED includes water programs that could result in less water for wetlands in some areas, while potentially increasing wetland water supplies elsewhere in the Central Valley. A major CALFED program is the Environmental Water Account (EWA). The EWA was established to replenish water supplies required for management of federally threatened or endangered fish and to improve water quality in the Delta. The water needed for increasing water transfers, the EWA, and the Vernalis Adaptive Management Plan, a plan to meet flow objectives for migrating salmon within the San Joaquin River Basin (EA Engineering, Science, and Technology 1999) have all contributed to increased competition for limited environmental water supplies.

\section{Regional Water Quality Standards}

Wetland water quality issues are affected by various Regional Water Quality Control Board (RWQCB) programs and standards. Water quality supply issues are quickly becoming more important as regulations regarding outflow from agriculture and managed wetlands increase, and wetland managers are being held accountable for discharge from their properties, regardless of its source of origin. RWQCBs are developing and adopting programs which regulate managed wetland drainage through waivers to Waste Discharge Requirements, such as the Central Valley RWQCB's Irrigated Lands Conditional Waiver Program, and development of load restrictions, including total maximum daily loads (TMDLs) of mercury, salt and boron. As discharge restrictions increase, source water quality becomes more of a concern in order to meet new restrictions. 


\section{Water Use Planning Efforts}

State and federal agencies have responded to increasing concerns by wetland managers regarding water supplies. CDFG's Lands Committee examines water availability and potential use as part of its review of potential land acquisitions. The USFWS conducts a similar review prior to land acquisition that is more comprehensive than has been the case in the past. The ICP task force was established in 1998 and consists of the USFWS, USBR, GRCD, and CDFG, advised in the development of the ICP Report, a document examining water use and providing a process for the identification of effective water regimes for Central Valley wetlands.

Many agricultural and urban water districts have completed water conservation plans to comply with USBR contract requirements. The USFWS, CDFG, and GWD have completed water management plans for those NWRs, WAs, and GRCD lands with authorized CVPIA wetland water supplies. These planning efforts are designed to improve water use efficiency and conservation efforts to the benefit of all water users.

\section{Future Issues and Challenges}

Securing firm, reliable water supplies for managed wetlands in the Central Valley will become even more challenging in the future. Demand for limited water supplies will increase with continued population growth in California, and wetlands will compete for a legitimate allocation to meet wetland dependent resource needs. Wetland habitats cannot properly function without access to yearround water supplies to meet management objectives. Thus, issues and challenges that are faced today will continue and become more important as additional issues arise in future years.

Some of the most significant barriers to acquiring future water supplies for Central Valley wetlands include:

- Delta export and pumping constraints;

- Increasing competition to purchase limited water supplies;

- Increasing regulation of managed wetland water discharge;

- Capacity limitations of existing water delivery systems;

- Balance between supply and demand;

- Cost of acquiring annual and long-term water supplies;

- Current and future, state, federal, and private budget shortfalls that impact acquisition efforts;

- The State of California's ability to meet their $25 \%$ cost-share obligations under the CVPIA;

- Unreliable quality and quantity of groundwater supplies;

- Increased groundwater pumping costs;

- Annual and long-term water transfers that may adversely affect managed wetlands and fish and wildlife resources.

\section{Water Issues by Basin}

Current and future water issues affecting managed wetlands vary among basins in the Central Valley, and many of them are outlined here.

\section{Butte Basin}

- Reliance upon groundwater at Gray Lodge WA as part of Level 4 water supplies;

- A shift from optimal wetland management to the implementation of best management practices, in order to comply with vector control regulations;

- Insufficient infrastructure to deliver Level 2 and Level 4 water supplies to Gray Lodge WA;

- Ensuring that water supplies are attached to the property when protecting managed wetland habitat.

\section{Colusa Basin}

- Potential competition for water between post-harvested rice and managed wetlands, particularly during drought years;

- Timing of water use on shared conveyance systems;

- Quality issues related to surface water delivery and discharge at Sutter, Colusa, and Sacramento NWRs (e.g., boron and mercury);

- Equitable sharing of monitoring costs by those participating in water quality coalitions; 
- Potential increased groundwater use (e.g., Delevan NWR);

- A shift from optimal wetland management to the implementation of best management practices, in order to comply with vector control regulations;

- Management impacts resulting from re-route of the Colusa Drain;

- Transfer of permanent water rights to out of basin agricultural and urban users (potential adverse impact to wetlands and Level 4 water supplies associated with long-term out-of-basin water transfers);

- Ensuring that water supplies are attached to the property when protecting managed wetland habitat.

\section{Sutter Basin}

- Current conveyance system at Sutter NWR is insufficient to convey Level 4 water supplies;

- Timing of water on shared conveyance systems;

- Improving the facilitation of intra-basin and inter-basin water transfers among state and federally managed wetlands;

- A shift from optimal wetland management to the implementation of best management practices, in order to comply with vector control regulations;

- Ensuring that water supplies are attached to the property when protecting managed wetland habitat.

\section{Yolo Basin}

- Competing water use and loss of habitat due to urban growth in and around the city of Woodland;

- Increased regulatory requirements on managed wetland areas as a result of new mercury TMDL standards;

- Increasing competition for water between agricultural and habitat interests due to conveyance capacity limitations (e.g., Toe Drain and Putah Creek) at Yolo Bypass WA;

- Ensuring that water supplies are attached to the property when protecting managed wetland habitat.

\section{American Basin}

- Competing water use and loss of habitat (e.g., ricelands) due to urban growth in and around the cities of Yuba City and Marysville;

- Need for more protection of open space (e.g., agricultural easements);

- No current reliable supply of water for most managed wetlands within the basin;

- Ensuring that water supplies are attached to the property when protecting managed wetland habitat.

\section{Delta Basin}

- Balancing endangered species (e.g., Delta smelt) recovery needs with wetland water supply needs;

- Saltwater intrusion into fresh water wetland habitat;

- Challenges in maintaining existing levee system;

- Increased regulatory requirements on managed wetland areas within the basin as a result of new mercury TMDL standards;

- Competing water use and loss of habitat due to urban growth in and around the primary zone of the Delta.

\section{Suisun Basin}

- Maintenance of existing salinity standards established to sustain a brackish water marsh capable of producing high-quality forage and habitat conditions suitable for waterfowl and other wetland related wildlife;

- Negative impacts to wetland water quality and habitat conditions due to potential reduction of Delta outflows and increases in state and federal water project deliveries;

- Maintenance and improvement of 220 miles of exterior levee for the protection and enhancement of diked wetland habitats and the protection of Delta water quality;

- Lack of a maintenance program to protect and support publicly and privately managed wetland resources;

- Increased stress on the levee system and the threat to diked managed wetlands due to predicted rise in sea level;

- Potential localized salinity variations due to planned tidal restoration of diked areas, and associated negative impacts to adjacent waterfowl habitat management areas; 
- Increases in salinity resulting in a decrease in the life expectancy of existing water management infrastructure, and a reduction of diversity and productivity in diked wetlands;

- Concerns over water quality constituents in the marsh including, but not limited to, polychlorinated biphenyls, polycyclic aromatic hydrocarbons, organophosphate pesticides, methyl mercury, dissolved oxygen, organic matter, and heavy metals.

\section{San Joaquin Basin}

- Lack of sufficient above ground water storage dedicated to environmental purposes;

- Groundwater issues including access, poor water quality, overdraft, and subsidence.;

- Rapid urbanization in the region is likely to shift surface water use from agricultural to urban uses;

- Lack of pumping and conveyance capacity in the existing system to transport water south through the Delta to San Joaquin Basin wetlands;

- Low priority for conveyance of Level 4 water supplies through state and federal pumping facilities in the Delta;

- Lack of conveyance system to receive Level 2 or Level 4 water supplies at East Bear Creek unit of San Luis NWR;

- Stricter RWQCB standards for wetland discharges into the San Joaquin River. (e.g., boron, mercury, salinity, dissolved oxygen and selenium);

- Federal budget shortages for CVPIA water supplies due to increased competition for Restoration Fund dollars and increased costs of purchasing annual spot market water;

- Increasing water costs, especially during periods of drought;

- Lack of willing sellers of affordable long-term water rights;

- Timing of water use on shared conveyance systems;

- Degraded water quality from use of agricultural tail-water or poor quality groundwater;

- Inability of wetland managers to plan their yearly water use due to sporadic water purchases throughout any given year;

- Lack of year round conveyance affected by the current condition of Mendota Dam affects conveyance ability to deliver Level 4 water supplies to Mendota WA and reduces conveyance capacity for the GWD;

- Ensuring that water supplies are attached to the property when protecting managed wetland habitat.

\section{Tulare Basin}

- Groundwater issues including: lack of access, poor water quality, overdraft, and subsidence;

- Lack of a conveyance system to deliver Level 4 water supplies to Pixley NWR;

- Potential impacts to water quality, habitat, and wildlife from the introduction of municipal sludge onto agricultural lands adjacent to wetland habitat;

- Continued reliance upon purchasing spot market water;

- Increasing water costs, especially during periods of drought;

- Federal budget shortages for CVPIA water supplies due to increased competition for Restoration Fund dollars;

- Degraded water quality from using agricultural tail-water or poor quality groundwater;

- Dependence upon coordinating water management with adjacent landowners in order to effectively de-water Kern NWR;

- Inability of wetland managers to plan their yearly water use due to sporadic water purchases throughout any given year;

- Lack of reliable water supplies and inadequate conveyance systems to deliver water to the private wetlands within the basin;

- Ensuring that water supplies are attached to the property when protecting managed wetland habitat.

\section{Recommended Actions and Strategies to Secure Wetland Water Supplies}

Additional water supplies may be developed through expanded storage in existing reservoirs, groundwater banking, new water storage facilities, and coastal and Central Valley desalination plants. The JV partners can play a role in exploring these options and should consider implementation of the following strategies aimed at increasing future wetland water supplies and improving wetland water supply reliability.

- Establish and fund one or more positions that would be responsible for working with relevant agencies, NGO's and water entities, to collaborate and cooperate on realistically resolving wetland water supply needs (including matters involving wetland water quality), assuring that wetland needs are integrated into regional, state and federal water discussions. The position(s) would track water transfers that may have impacts on wetland water supplies, as well as monitor water quality issues that could effect JV wetland restoration and enhancement objectives; 
- Work closely with agencies and organizations conducting wetland restoration to ensure reliable water supplies are accessible to target properties;

- Seek additional state and federal funding to acquire and develop wetland water supplies, maintaining fulfillment of long-term CVPIA Level 4 water supplies as a top priority;

- Establish a public outreach program to educate the public and public officials of: (1) the benefits derived from CVPIA wetland water supplies; (2) the need to develop new sources of supply to meet the objectives of this Plan.

\section{Summary}

Since publication of the 1990 Plan, Central Valley water demands have dramatically increased. Competition for water has become intense, and the cost of obtaining wetland water supplies in some basins has risen by nearly $400 \%$. Agricultural, urban

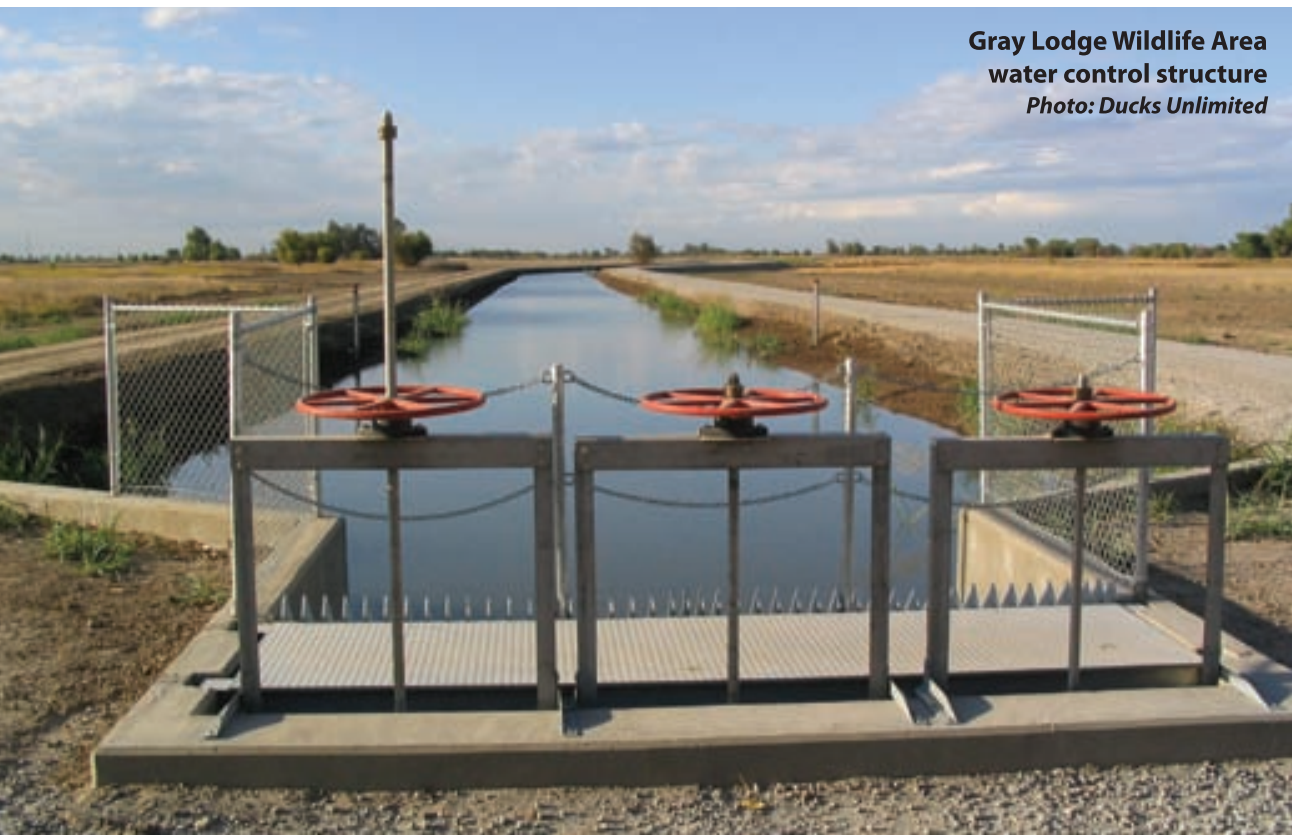
and environmental stakeholders are aggressively lobbying on many fronts for reallocation of existing water supplies. The 2006 Plan outlines a new strategy for the conservation of migratory birds and their habitats in a rapidly changing socio-political environment. Much of this strategy is dependent upon available and affordable water supplies. It is therefore essential for JV partners to participate in the many forums where water issues are being addressed to assure that wetland water needs are fully considered. Moreover, JV partners will need to carefully consider availability of water supplies when planning habitat acquisition, restoration and enhancement activities associated with the implementation of the 2006 Plan. 


\section{Introduction}

This Plan addresses the habitat needs of six bird groups including: (1) wintering waterfowl; (2) breeding waterfowl; (3) wintering shorebirds; (4) breeding shorebirds; (5) waterbirds; and (6) riparian songbirds. This chapter provides a summary of the conservation objectives associated with each of these bird groups. Where possible, conservation objectives for all bird groups are then integrated at the basin scale to improve the efficiency of all-bird conservation in the Central Valley. The cost of meeting these conservation objectives is also estimated. Finally the ability of existing conservation programs to meet integrated bird conservation objectives for the Central Valley is reviewed, and the need for additional programs is assessed. This chapter is divided into four sections: (1) conservation objectives by bird group; (2) integrating bird conservation objectives; (3) estimated costs of meeting integrated bird conservation objectives; and (4) conservation delivery options.

\section{Conservation Objectives by Bird Group}

Conservation objectives for wintering waterfowl, breeding waterfowl, and riparian songbirds were established for each of the nine Central Valley's basins. However, some basins were combined into larger planning regions when establishing conservation objectives for wintering shorebirds, breeding shorebirds, and waterbirds. The need to combine basins was largely driven by the lack of information available for these bird groups at the basin scale.

Two broad planning regions that contained multiple basins are recognized in this Plan: (1) the Sacramento Valley Planning Region; and (2) the Delta Planning Region. For wintering shorebirds and waterbirds, the Sacramento Valley Planning Region includes the American, Butte, Colusa, and Sutter Basins. For breeding shorebirds, the Sacramento Valley Planning Region includes these four basins and the Yolo Basin (Table 11-2). For wintering shorebirds, the Delta Planning Region includes the Yolo and Delta Basins, while the Delta Planning Region for waterbirds includes these two basins and Suisun Basin. Conservation objectives were established for all bird groups in the San Joaquin and Tulare Basins (Table 11-2).

Table 11-2. Scale at which conservation objectives were established for each bird group.

\begin{tabular}{|c|c|c|c|c|c|c|}
\hline Basin & $\begin{array}{l}\text { Wintering } \\
\text { Waterfowl }\end{array}$ & $\begin{array}{l}\text { Breeding } \\
\text { Waterfowl }\end{array}$ & $\begin{array}{l}\text { Wintering } \\
\text { Shorebirds }\end{array}$ & $\begin{array}{l}\text { Breeding } \\
\text { Shorebirds }\end{array}$ & Waterbirds & $\begin{array}{l}\text { Riparian } \\
\text { Songbirds }\end{array}$ \\
\hline AMERICAN $^{a b}$ & - & • & \multirow{4}{*}{ - } & \multirow{5}{*}{ • } & \multirow{4}{*}{ - } & - \\
\hline Butte $^{a b}$ & $\bullet$ & - & & & & $\bullet$ \\
\hline COLUSA $^{a b}$ & - & • & & & & • \\
\hline SUTteR $^{a b}$ & $\bullet$ & $\bullet$ & & & & • \\
\hline YoLO $^{b c d}$ & • & • & \multirow{2}{*}{ • } & & \multirow{3}{*}{ • } & • \\
\hline DeLta $^{c d}$ & $\bullet$ & $\bullet$ & & $\bullet$ & & $\bullet$ \\
\hline SUISUN $^{d}$ & - & - & $\mathrm{NC}$ & $\mathrm{NC}$ & & $\mathrm{NC}$ \\
\hline SAN JOAQUIN & • & • & • & • & $\bullet$ & • \\
\hline Tulare & - & - & - & • & - & - \\
\hline
\end{tabular}

${ }^{a}$ Basins included in the Sacramento Valley Planning Region for wintering shorebirds and waterbirds.

${ }^{b}$ Basins included in the Sacramento Planning Region for breeding shorebirds.

'Basins included in the Delta Planning Region for wintering shorebirds.

${ }^{d}$ Basins included in the Delta Planning Region for waterbirds.

$N C-N o$ conservation objectives. 


\section{Wintering Waterfowl}

Wintering waterfowl includes migrating and wintering ducks and geese that rely on Central Valley habitats between August and March. Seasonal wetland restoration objectives total 104,000 acres for the Central Valley and vary widely among basins (Table 11-3). Proper water management is critical to producing large amounts of food in seasonal wetlands. However, water control structures, levees, and ditch networks used to manage water levels must be periodically repaired or enhanced to maintain or improve food production. The JV assumes that managed seasonal wetlands need some form of enhancement on average every twelve years. As a result, wetland enhancement objectives are expressed perpetually as one-twelfth of the total wetland acres. Annual wetland enhancement objectives for the Central Valley total 23,603 acres when wetland restoration objectives have been met (Table 11-3).

The agricultural enhancement objective for wintering waterfowl is divided into two sub-objectives: (1) waterfowl-friendly agriculture, and (2) winter-flooded rice. Waterfowl-friendly agriculture includes: winter-flooded rice; rice that is not deep plowed following harvest and remains dry; corn that is winter-flooded; and corn that is not deep plowed following harvest and remains dry. Most waterfowl-friendly agriculture consists of rice habitat, except in the Delta Basin where corn is prevalent. Habitat objectives for waterfowl-friendly agriculture are 307,000 acres. Habitat objectives for winter flooded rice are 170,000 acres. (Table 11-3). The need for agriculture easements that protect waterfowl food sources (Type I) was identified for the American, Butte, and Sutter Basins. The need for agricultural easements that buffer existing wetlands from urban and residential development (Type II) was identified for the American, Butte, Sutter, Delta, and San Joaquin Basins (Table 11-3).

Table 11-3. Conservation objectives for wintering waterfowl in the Central Valley.

\begin{tabular}{|c|c|c|c|c|c|c|}
\hline Basin & $\begin{array}{l}\text { Seasonal Wetland } \\
\text { Restoration } \\
\text { (acres) }\end{array}$ & $\begin{array}{c}\text { Seasonal Wetland } \\
\text { Enhancement } \\
\text { (acres) }\end{array}$ & $\begin{array}{c}\text { Waterfowl-friendly } \\
\text { Agriculture } \\
\text { (acres) }^{a}\end{array}$ & $\begin{array}{c}\text { Winter } \\
\text { Flooded Rice } \\
\text { (acres) }^{b}\end{array}$ & $\begin{array}{c}\text { Type } I^{c} \\
\text { Easements }\end{array}$ & $\begin{array}{c}\text { Type II } \\
\text { Easements }\end{array}$ \\
\hline AMERICAN & 20,000 & 1,932 & 69,000 & 50,000 & NeEded & NeEded \\
\hline Butte & 17,000 & 3,362 & 104,000 & 62,000 & NeEded & NEEDED \\
\hline Colusa & 2,000 & 2,033 & 85,000 & 45,000 & & \\
\hline Sutter & 4,000 & 496 & 18,000 & 10,000 & NeEded & NeEDED \\
\hline YoLO & 3,000 & 963 & 8,000 & 3,000 & & \\
\hline Delta & 19,000 & 2,112 & 23,000 & 0 & & NeEded \\
\hline SuISUN & 0 & 2,686 & 0 & 0 & & \\
\hline SAN JOAQUIN & 20,000 & 6,751 & 0 & 0 & & NEEDED \\
\hline Tulare & 19,000 & 3,268 & 0 & 0 & & \\
\hline Total & 104,000 & 23,603 & 307,000 & 170,000 & & \\
\hline
\end{tabular}

${ }^{a}$ Waterfowl-friendly agriculture is defined as the amount of winter flooded rice plus rice and corn acres that are not flooded and are not deep plowed following harvest.

${ }^{b}$ The amount of harvested rice that must be flooded to meet wintering duck needs when wetland restoration objectives are met for the Central Valley. 'Agricultural easements that maintain waterfowl food resources on agricultural lands.

${ }^{d}$ Agricultural easements that buffer existing wetlands from urban and residential development.

\section{Breeding Waterfowl}

Most waterfowl that breed in the Central Valley are mallards, therefore, recommendations for breeding waterfowl in this Plan focus on this species. However, habitat acre objectives were not established for breeding waterfowl in this Plan, rather, general recommendations were made to increase semi-permanent wetlands and/or upland cover to improve the success of breeding waterfowl populations. These recommendations were based on an assessment of existing landscape conditions. In general, this Plan calls for increases in semi-permanent wetlands and upland cover in the northern basins of the Central Valley. Increases in semi-permanent wetlands are recommended for the remaining basins (Table 11-4). Specific areas of each basin where increases in semi-permanent wetlands and/or upland cover are suggested were identified in Chapter 5. 
Table 11-4. Conservation objectives for breeding waterfowl in the Central Valley.

\begin{tabular}{|ccc|}
\hline Basin & $\begin{array}{c}\text { Semi-Permanent } \\
\text { Wetlands }\end{array}$ & $\begin{array}{c}\text { Semi-Permanent } \\
\text { Wetland \& Upland Cover }\end{array}$ \\
\hline AMERICAN & & INCREASE \\
BUTtE & & INCREASE \\
COLUSA & & INCREASE \\
SUTTER & & INCREASE \\
Yolo & & INCREASE \\
SUISUN & INCREASE & \\
DELTA & INCREASE & \\
SAN JOAQUIN & INCREASE & \\
TULARE & INCREASE & \\
\hline
\end{tabular}

\section{Wintering Shorebirds}

Wintering shorebirds include migrating and wintering birds that rely on the Central Valley between July and May. Habitat objectives for wintering shorebirds were established for seasonal wetlands, semi-permanent wetlands, and winter-flooded rice (Table 11-5). Seasonal wetland restoration objectives are high throughout the Central Valley and represent the amount of seasonal wetland habitat that must be managed at depths $<10 \mathrm{~cm}(-4$ inches) to meet shorebird needs. Although seasonal wetlands are not available in July, most semi-permanent wetlands are being drawn down during this month. Draining these wetlands can create favorable foraging conditions for shorebirds as water levels are reduced. Acre objectives for semi-permanent wetlands represent the amount of shallow water habitat that must be provided by these habitats during the July drawn down period. Finally, winter-flooded rice is available to shorebirds between October and March in the Sacramento and Delta Planning Regions. Acre objectives for winter-flooded rice represent the amount of flooded agricultural habitat $<10 \mathrm{~cm}$ in depth that is needed for wintering shorebirds.

Table 11-5. Conservation objectives for wintering shorebirds in the Central Valley.

\begin{tabular}{|c|c|c|c|}
\hline Basin & Seasonal Wetlands & Semi-Permanent Wetlands & Winter-Flooded Rice \\
\hline AMERICAN $^{a}$ & \multirow{4}{*}{35,696} & \multirow{4}{*}{819} & \multirow{4}{*}{18,566} \\
\hline ButtE $^{a}$ & & & \\
\hline Colusa $^{a}$ & & & \\
\hline SUTteR $^{a}$ & & & \\
\hline YoLO $^{b}$ & \multirow{2}{*}{7,334} & \multirow{2}{*}{170} & \multirow{2}{*}{$5,142 \mathrm{C}$} \\
\hline $\operatorname{DELTA}^{b}$ & & & \\
\hline Suisun & $\mathrm{NC}$ & $\mathrm{NC}$ & $\mathrm{NC}$ \\
\hline SAN JOAQUIN & 40,130 & 175 & 0 \\
\hline Tulare & 31,440 & 1,170 & 0 \\
\hline TotaL & 114,600 & 2,334 & 23,708 \\
\hline
\end{tabular}

a Basins included in the Sacramento Planning Region for wintering shorebirds.

${ }^{b}$ Basins included in the Delta Planning Region for breeding shorebirds.

'Winter-flooded corn may substitute for winter-flooded rice in the Delta Planning Region.

$N C-N o$ conservation objective. 


\section{Breeding Shorebirds}

The 2006 Plan recommends a 7,500 acre increase in semi-permanent wetlands for breeding shorebirds over the next five years (Table 11-6). This is considered a short term objective that will be updated in future JV implementation plans, as more information on breeding shorebird habitat needs is developed. The need for increases in semi-permanent wetlands is highest in the San Joaquin and Tulare Basins, and reflects the optimum distribution of breeding shorebirds in the Central Valley.

\section{Waterbirds}

The 2006 Plan recommends a 5,000 acre increase in semi-permanent wetlands and riparian habitat for waterbirds over the next five years (Table 11-7). This is considered a short term objective that will be updated in future JV implementation plans, as more information on waterbird habitat needs is developed. Semipermanent wetland and riparian habitat objectives were distributed to increase the relative shortfall of these habitats in the two southernmost regions.

\section{Riparian Songbirds}

The 2006 Plan recommends an 8,700 acre increase in riparian habitat for songbirds over the next five years (Table 11-8). This is considered a short term objective that will be updated in future JV implementation plans, as more information on riparian songbird habitat needs is developed. Habitat objectives are distributed based generally on the potential for restoring riparian habitat within basins.
Table 11-6. Conservation objectives for breeding shorebirds in the Central Valley.

\begin{tabular}{|cc|}
\hline Basin & $\begin{array}{c}\text { Semi-Permanent } \\
\text { Wetlands }\end{array}$ \\
\hline AMERICAN $^{a}$ & \\
BUTTE $^{a}$ & \\
COLUSA $^{a}$ & 875 \\
SUTTER $^{a}$ & \\
YOLO $^{a}$ & \\
DELTA & 875 \\
SUISUN & 0 \\
SAN JOAQUIN & 1,315 \\
TULARE & 4,435 \\
TOTAL & 7,500 \\
\hline
\end{tabular}

${ }^{a}$ Basins included in the breeding shorebird Sacramento Valley Planning Region.

Table 11-7. Conservation objectives for waterbirds in the Central Valley.

\begin{tabular}{|c|c|c|}
\hline Basin & Semi-Permanent Wetlands & Riparian Habitat \\
\hline $\begin{array}{c}\text { AMERICAN }^{a} \\
\text { BUTtE }^{a} \\
\text { COLUSA }^{a} \\
\text { SUTTER }^{a}\end{array}$ & 1,000 & 1,000 \\
\hline $\begin{array}{c}\text { YoLo }^{b} \\
\text { DeLta }^{b} \\
\text { SUISUN }^{b}\end{array}$ & 1,000 & 1,000 \\
\hline SAN JOAQUIN & 1,500 & 1,500 \\
\hline Tulare & 1,500 & 1,500 \\
\hline TotaL & 5,000 & 5,000 \\
\hline
\end{tabular}

"Basins included in the Sacramento Planning Region for waterbirds.

${ }^{b}$ Basins included in the Delta Planning Region for waterbirds.

Table 11-8. Conservation objectives for riparian songbirds in the Central Valley.

\begin{tabular}{|cc|}
\hline Basin & Riparian Habitat \\
\hline AMERICAN & 675 \\
BUTTE & 1,125 \\
COLUSA & 1,350 \\
SUTTER & 675 \\
YOLO & 675 \\
DELTA & 1,500 \\
SUISUN & 0 \\
SAN JOAQUIN & 2,500 \\
TULARE & 200 \\
TOTAL & $\mathbf{8 , 7 0 0}$ \\
\hline
\end{tabular}




\section{Integrating Bird Conservation Objectives}

Conservation objectives for each bird group included in this Plan were developed separately (Chapters 4 through 9). However, the habitat needs of different bird groups frequently overlap. Meeting habitat objectives for one bird group may partially or wholly meet the needs of other bird species, and identifying these areas of overlap may increase the efficiency of all-bird conservation. The JV identified eight conservation objectives that collectively meet the needs of bird groups included in this Plan; (1) restoration of seasonal wetlands; (2) enhancement of seasonal wetlands; (3) restoration of semi-permanent wetlands: (4) restoration of riparian habitat; (5) winter flooding of harvested rice; (6) maintenance of waterfowl-friendly agriculture which includes winter-flooded rice, and nonflooded rice and corn fields that are not deep plowed following harvest; (7) acquisition of easements that maintain agricultural food sources; and 8) acquisition of agricultural easements that buffer existing wetlands from residential growth and development.

The JV used the following process to integrate bird needs for each of these eight conservation objectives. First, all bird groups associated with a conservation objective were identified. For example, objectives for winter-flooded rice were established for wintering waterfowl and wintering shorebirds, but not for the other four bird groups. Secondly, the bird group with the largest acre objective was identified in each basin or planning region as in the following example. The winter-flooded rice objective for wintering shorebirds in the Sacramento Planning Region is 18,566 acres (Table 11-5). Winter-flooded rice objectives for waterfowl in basins included in this shorebird planning region total 167,000 acres (Table 11-3). Finally, the JV assessed whether meeting the larger acre objective of one bird group would meet the needs of other bird groups. For example, within the 167,000 acre waterfowl objective are there enough acres managed at depths that are suitable for shorebirds? If the answer is yes, then flooded rice objectives for wintering waterfowl and wintering shorebirds may completely overlap in the Sacramento Valley Planning Region. If the answer is no, then flooded rice objectives for shorebirds may be partially or wholly additive to those for waterfowl. (Obtaining better information on water depths in rice fields prior to the next implementation plan update will allow the JV to better address this issue).

\section{Seasonal Wetland Restoration}

Acre objectives for seasonal wetlands were established for wintering waterfowl and wintering shorebirds. For waterfowl, acre objectives were established for all nine basins. For shorebirds, acre objectives were established for the Sacramento Valley and Delta Planning Regions and for the Suisun, San Joaquin, and Tulare Basins (Table 11-5). Wetland restoration objectives for waterfowl represent new wetland acres. Where possible, seasonal wetland objectives for shorebirds will be met through management of existing wetlands and management of seasonal wetlands that are restored for wintering waterfowl. However, seasonal wetland flooding schedules are not always consistent with shorebird needs (Chapter 6). Most or all seasonal wetlands in the Central Valley are flooded after mid-August (defined as conventional flooding). However, wetland objectives for wintering shorebirds include seasonal wetlands that are flooded prior to this mid-August date (defined as early flooding). Seasonal wetland objectives for shorebirds in this early flooding period are considered additive to those for waterfowl, while wetland objectives for waterfowl and shorebirds in the conventional flooding period are assumed to overlap.

\section{Sacramento Valley Planning Region}

Seasonal wetland objectives for wintering shorebirds in the Sacramento Valley Planning Region total nearly 36,000 acres during the conventional flooding period and nearly 1,600 acres during the early flooding period. Seasonal wetland restoration objectives for waterfowl in Sacramento Valley Planning Region basins total 43,000 acres (Table 11-9). There are currently 51,000 acres of seasonal wetlands in this region (Table 3-1). This figure increases to 94,000 acres if wetland objectives for waterfowl are met. However, shorebirds require 1,584 acres of seasonal wetlands prior to mid-August, when most or all of these habitats are dry (Table 11-9). Thus, 38\% of seasonal wetland acres in the Sacramento Valley Planning Region basins $(36,000 / 94,000)$ should be managed at depths consistent with shorebird needs, and nearly 1,600 of these acres should be provided in the early flooding period (Table 11-9). These early-flooded acres are considered additive to seasonal wetland objectives for waterfowl, while seasonal wetland objectives for waterfowl and shorebirds in the conventional flooding period are assumed to overlap. 


\section{Delta Planning Region}

Seasonal wetland objectives for wintering shorebirds in the Delta Planning Region total 6,994 acres in the conventional flooding period and 340 acres in the early flooding period. Seasonal wetland objectives for waterfowl in the Delta Planning Region basins total 22,000 acres (Table 11-9). There are currently 15,000 acres of seasonal wetlands in the Delta Planning Region basins (Table $3-1)$. This figure increases to 37,000 acres if wetland objectives for waterfowl are met. Thus, $20 \%$ of seasonal wetlands in these basins $(7,300 / 37,000)$ should be managed $<10 \mathrm{~cm}$ in depth and 340 of these acres should be provided in the early flooding period. These early-flooded acres are considered additive to seasonal wetland objectives for waterfowl, while wetland objectives for waterfowl and shorebirds in the conventional flooding period are assumed to overlap (Table 11-9).

\section{San Joaquin Basin}

Wintering shorebirds in the San Joaquin Basin require over 40,000 acres of seasonal wetland habitat as no winter-flooded rice is available. Three hundred and forty acres must be provided during the early flooding period. Seasonal wetland objectives for wintering waterfowl total 20,000 acres (Table 11-9). There are now 61,000 acres of seasonal wetlands in the San Joaquin Basin (Table 3-1). This figure would increase to 81,000 acres if seasonal wetland objectives are met for waterfowl. Overall nearly $50 \%$ of seasonal wetlands in the San Joaquin Basin should be managed at depths that meet shorebird needs, with 340 of these acres provided in the early flooding period (Table 11-9).

\section{Tulare Basin}

Wintering shorebirds in Tulare Basin require over 31,000 acres of seasonal wetland habitat. Nearly 2,300 acres must be provided in the early flooding period (Table 11-9). Seasonal wetland objectives for wintering waterfowl total 19,000 acres. Seasonal wetlands now total 20,212 in the Tulare Basin and meeting wetland restoration objectives for wintering waterfowl will increase this figure to nearly 40,000 acres. Over $75 \%$ of these acres would have to be managed $<10 \mathrm{~cm}$ deep to meet shorebird needs, with 2,300 of these acres provided in the early flooding period. These early-flooded acres are considered additive to seasonal wetland objectives for waterfowl, while wetland objectives for waterfowl and shorebirds in the conventional flooding period are assumed to overlap (Table 11-9).

Table 11-9. Integrated seasonal wetland objectives (acres) for wintering waterfowl and wintering shorebirds in the Central Valley.

\begin{tabular}{|c|c|c|c|c|}
\hline Basin & Wintering Waterfowl & $\begin{array}{l}\text { Wintering Shorebirds } \\
\text { Conventional Flooding }\end{array}$ & $\begin{array}{l}\text { Wintering Shorebirds } \\
\text { Early Flooding }\end{array}$ & $\begin{array}{l}\text { Basin } \\
\text { Totals }^{f}\end{array}$ \\
\hline AMERICAN $^{a}$ & 20,000 & \multirow{4}{*}{34,112} & \multirow{4}{*}{1,584} & 20,396 \\
\hline Butte $^{a}$ & 17,000 & & & 17,396 \\
\hline CoLusa $^{a}$ & 2,000 & & & 2,396 \\
\hline SutTeR $^{a}$ & 4,000 & & & 4,396 \\
\hline YoLo $^{b}$ & 3,000 & \multirow{2}{*}{6,994} & \multirow{2}{*}{340} & 3,170 \\
\hline Delta $^{b}$ & 19,000 & & & 19,170 \\
\hline SUISUN & 0 & $\mathrm{NC}$ & $\mathrm{NC}$ & 0 \\
\hline SAN JOAQUIN & 20,000 & 39,790 & 340 & 20,340 \\
\hline Tulare & 19,000 & 29,177 & 2,263 & 21,263 \\
\hline Total & 104,000 & 110,073 & 4,527 & 108,527 \\
\hline
\end{tabular}

a Basins included in the Sacramento Planning Region for wintering shorebirds.

${ }^{b}$ Basins included in the Delta Planning Region for breeding shorebirds.

'Seasonal wetland restoration objectives for wintering waterfowl. These represent new wetland acres to be added to the landscape.

${ }^{d}$ Seasonal wetland objectives for wintering shorebirds in the conventional flooding period (flooded after mid-August). The JV assumes that seasonal wetland objectives for shorebirds in this flooding period can be met through management of existing wetlands and wetlands that are restored for wintering waterfowl.

'Seasonal wetland objectives for wintering shorebirds in the early flooding period (flooded prior to mid-August). The JV assumes that seasonal wetland objectives for shorebirds in this flooding period are additive to that of waterfowl.

Integrated seasonal wetland objectives equal the sum of waterfowl objectives and shorebird objectives in the early flooding period. Seasonal wetland objectives for shorebirds in the early flooding period are distributed equally among basins included in a shorebird planning region when integrating objectives for the two bird groups. (e.g. the 1584 acre objective in the Sacramento Valley Planning Region is distributed equally among the four basins included in the region).

$N C-N o$ conservation objective. 


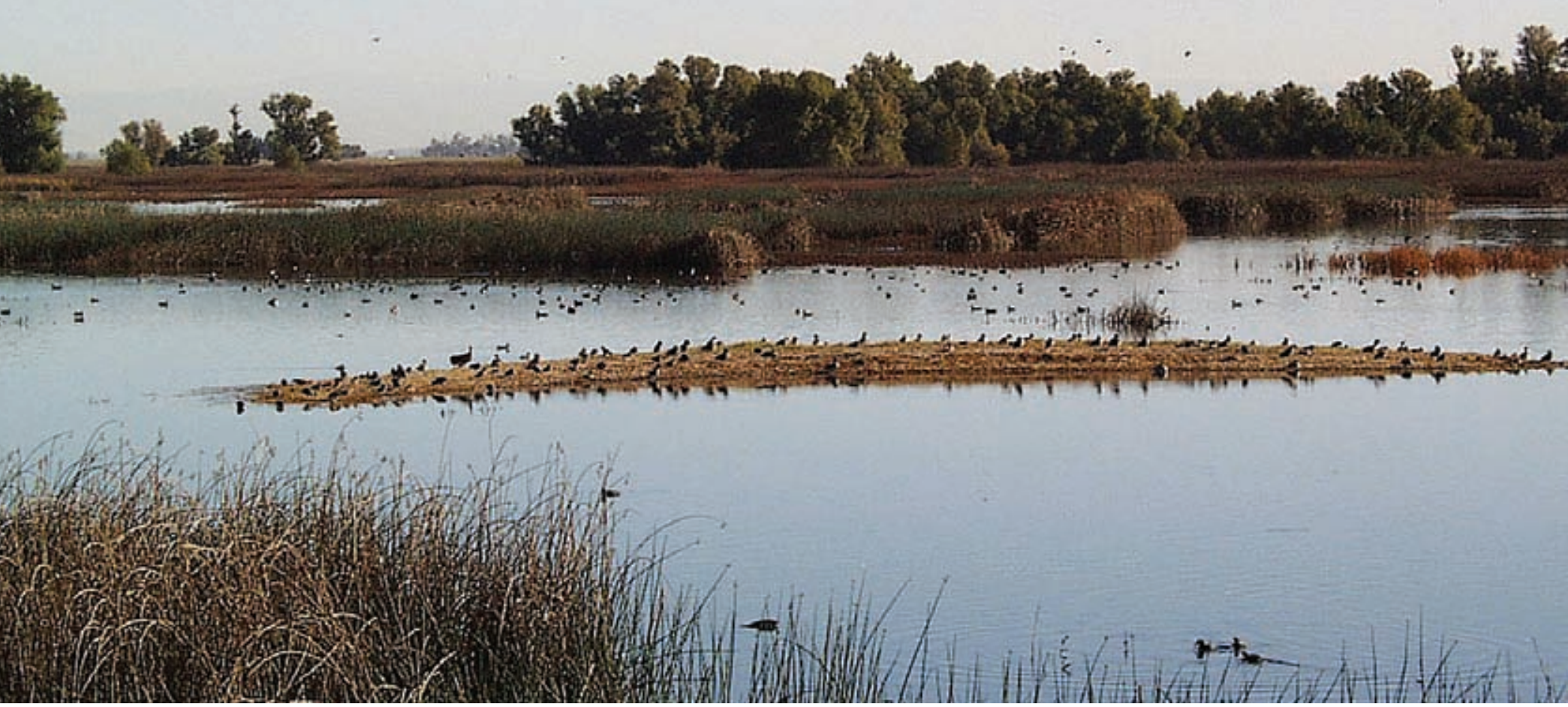

\section{Seasonal Wetland Enhancement}

Water control structures, levees, and ditch networks used to manage seasonal wetlands must be periodically repaired or enhanced to maintain the quality of these habitats. The JV assumes that managed seasonal wetlands need some form of enhancement on average every twelve years. As a result, wetland enhancement objectives are expressed perpetually as onetwelfth of the total wetland acres. Table 11-10 lists: (1) the amount of seasonal wetland habitat that will be present in the Central Valley when integrated seasonal wetland objectives are met for wintering waterfowl; and (2) wintering shorebirds, and the annual wetland enhancement objectives that are associated with this seasonal wetland base.
Table 11-10. Integrated seasonal wetland enhancement objectives for wintering waterfowl and wintering shorebirds in the Central Valley.

\begin{tabular}{|ccc|}
\hline Basin & $\begin{array}{c}\text { Seasonal Wetlands } \\
\text { (acres) }\end{array}$ & $\begin{array}{c}\text { Annual Seasonal Wetland }^{b} \\
\text { Enhancement Objectives (acres/year) }\end{array}$ \\
\hline AMERICAN & 23,583 & 1,957 \\
BUTTE & 40,736 & 3,381 \\
COLUSA & 24,786 & 2,057 \\
SUTTER & 6,347 & 527 \\
YOLO & 11,728 & 973 \\
DELTA & 25,519 & 2,118 \\
SUISUN & 32,232 & 2,675 \\
SAN JOAQUIN & 81,353 & 6,752 \\
TULARE & 41,475 & 3,442 \\
TotAL & $\mathbf{2 8 7 , 7 5 9}$ & $\mathbf{2 3 , 8 8 4}$ \\
\hline
\end{tabular}

a Seasonal wetlands that are present in a basin when integrated seasonal wetland objectives are met for wintering waterfowl and wintering shorebirds.

${ }^{b}$ Annual seasonal wetland enhancement objectives assume that all seasonal wetlands need some form of enhancement on average every twelve years. 


\section{Semi-Permanent Wetlands}

Acre objectives for semi-permanent wetlands were established for wintering shorebirds, breeding shorebirds, and waterbirds (Table 11-11). The JV assumes that semi-permanent wetland objectives for wintering shorebirds will be met through management of existing wetlands (Chapter 6). In contrast, semi-permanent wetland objectives for breeding shorebirds and waterbirds represent new wetland acres. Semi-permanent wetlands managed for breeding shorebirds are typically more open and contain less emergent vegetation that wetlands used by waterbirds (see Chapter 7 and Chapter 8). As a result, the JV assumes that semi-permanent wetland objectives for breeding shorebirds and waterbirds are additive (Table 11-11).

Although increases in semi-permanent wetlands were recommended for breeding waterfowl, these increases were not quantified (Table 11-4). Semi-permanent wetland objectives for breeding shorebirds and waterbirds total 12,500 acres. This represents a nearly fifty-percent increase in the 26,000 acres of semi-permanent wetlands now available in the Central Valley. Meeting this 12,500 acre objective would substantially improve habitat conditions for breeding waterfowl throughout the Central Valley, and is consistent with the general objective of increasing semi-permanent wetlands in each basin (Table 11-11).

Table 11-11. Integrated semi-permanent wetland objectives for breeding waterfowl, wintering shorebirds, breeding shorebirds, and waterbirds in the Central Valley.

\begin{tabular}{|c|c|c|c|c|c|}
\hline Basin & Breeding Waterfowl & $\begin{array}{c}\text { Winteringe } \\
\text { Shorebirds (acres) }\end{array}$ & $\begin{array}{l}\text { Breeding Shorebirds } f \\
\text { (acres) }\end{array}$ & $\begin{array}{l}\text { Waterbirds } \\
\text { (acres) }\end{array}$ & $\begin{array}{c}\text { Basin }^{h} \\
\text { Totals (acres) }\end{array}$ \\
\hline AMERICAN $^{a b}$ & INCREASE & \multirow{3}{*}{819} & \multirow{3}{*}{875} & \multirow{3}{*}{1,000} & 425 \\
\hline Colusa $^{a b}$ & INCREASE & & & & 425 \\
\hline SUTTER $^{a b}$ & INCREASE & & & & 425 \\
\hline SUISUN $^{d}$ & INCREASE & $\mathrm{NC}$ & $\mathrm{NC}$ & 1,000 & 333 \\
\hline SAN JOAQUIN & INCREASE & 175 & 1,315 & 1,500 & 2,815 \\
\hline Tulare & INCREASE & 1,170 & 4,435 & 1,500 & 5,935 \\
\hline Total & & 2,334 & 7,500 & 5,000 & 12,500 \\
\hline
\end{tabular}

${ }^{a}$ Basins included in the Sacramento Valley Planning Region for wintering shorebirds and waterbirds.

${ }^{b}$ Basins included in the Sacramento Valley Planning Region for breeding shorebirds.

'Basins included in the Delta Planning Region for wintering shorebirds.

${ }^{d B}$ asins included in the Delta Planning Region for waterbirds.

'JV assumes that semi-permanent wetland objectives for wintering shorebirds will be met through management of existing wetlands.

fSemi-permanent wetland objectives for breeding shorebirds represent new wetland acres to be added to the landscape.

sSemi-permanent wetland objectives for waterbirds represent new wetland acres to be added to the landscape.

${ }^{h}$ Sum of the semi-permanent wetland objectives for breeding shorebirds and waterbirds. Semi-permanent wetland objectives for a planning region are divided equally among the basins included in a planning region.

$N C-N o$ conservation objective.

\section{Riparian Habitat}

Acre objectives for riparian habitat were established for riparian songbirds and waterbirds. The JV assumed that these bird groups require similar types of riparian vegetation. For songbirds, acre objectives were established for all basins except Suisun Basin. For waterbirds, riparian habitat objectives were established for the Sacramento Valley, the Delta Planning Region, and the San Joaquin and Tulare Basins (Table 11-2). Riparian habitat objectives for waterbirds in the Sacramento Valley total 1,000 acres, while objectives for songbirds in Sacramento Valley basins total 3,825 acres (Table 11-12). Riparian objectives for waterbirds in the Delta Planning Region total 1,000 acres, while objectives for riparian songbirds in Delta Planning Region equal 2,175 acres (Table 11-12). The riparian habitat objective for waterbirds is 1,500 acres in the San Joaquin Basin and 1,500 acres in the Tulare Basin, while riparian objectives for songbirds in the San Joaquin and Tulare Basins equal 2500 acres and 200 acres respectively (Table 11-12).

Meeting riparian objectives for waterbirds will meet riparian objectives for songbirds in the Tulare Basin, whereas meeting riparian objectives for songbirds will meet riparian objectives for waterbirds in the remaining basins. As a result, the JV assumed that riparian habitat objectives for these two bird groups completely overlap. 
Winter Flooded Rice

Acre objectives for winter-flooded rice were established for wintering waterfowl and wintering shorebirds. For waterfowl, acre objectives were established for five basins: American, Butte, Colusa, Sutter, and Yolo (Table 11-13). For shorebirds, acre objectives were established for the Sacramento Valley and Delta Planning Regions (Table 11-13). Winter-flooded rice objectives for shorebirds in the Sacramento Valley Planning Region total 18,566 acres, while winter-flooded rice objectives for waterfowl in these basins total 167,000 acres (Table 11-13). The winter-flooded rice objective for shorebirds in the Delta Planning Region is 5,142 acres, while the flooded rice objective for waterfowl in these basins is 3,000 acres (Table 11-13).

Flooded rice objectives for waterfowl in Sacramento Valley basins exceed rice objectives for shorebirds by over 148,000 acres $(167,000-18,566)$. Approximately eleven percent of the 167,000 acre waterfowl objective must be managed at depths $<10 \mathrm{~cm}$ to meet shorebird needs $(167,000 / 18,566)$. Average water depths have been measured for rice fields in the Central Valley (Elphick 1998). Water depths averaged 20 to $25 \mathrm{~cm}(-8-10$ inches) in November and December, and $<10 \mathrm{~cm}$ from January through March (Elphick 1998). These depth estimates indicate that winter-flooded rice objectives for shorebirds in the Sacramento Valley Planning Region can be addressed by meeting the larger waterfowl objective. Most of the 167,000 acres of flooded rice needed by waterfowl would be available to shorebirds from January through March. Although average water depths are higher during November and December, many rice fields are still being flooded during this period (Figure 4-8). This early season flooding should provide enough shallow water habitat for shorebirds as only a small fraction of rice field habitat must be $<10 \mathrm{~cm}$. As a result, flooded rice objectives for wintering waterfowl and wintering shorebirds in the Sacramento Valley Planning Region and its associated basins are assumed to completely overlap in this Plan.

Flooded rice objectives for wintering shorebirds in the Delta Planning Region actually exceed flooded rice objectives for waterfowl in the Yolo and Delta Basins (5,142 acres vs. 3,000 acres; Table 11-13). However, winter flooding objectives for these two bird groups in the Delta Planning Region basins are still assumed to overlap. Although little rice is grown in the Delta Basin, private landowners flood over 29,000 acres of harvested corn (Table 3-5). The JV assumes that flooded corn and flooded rice are equally capable of meeting shorebird needs. Thus, winter flooding objectives for shorebirds in the Delta Planning Region can be partly or entirely met through shallow flooding of harvested cornfields. 


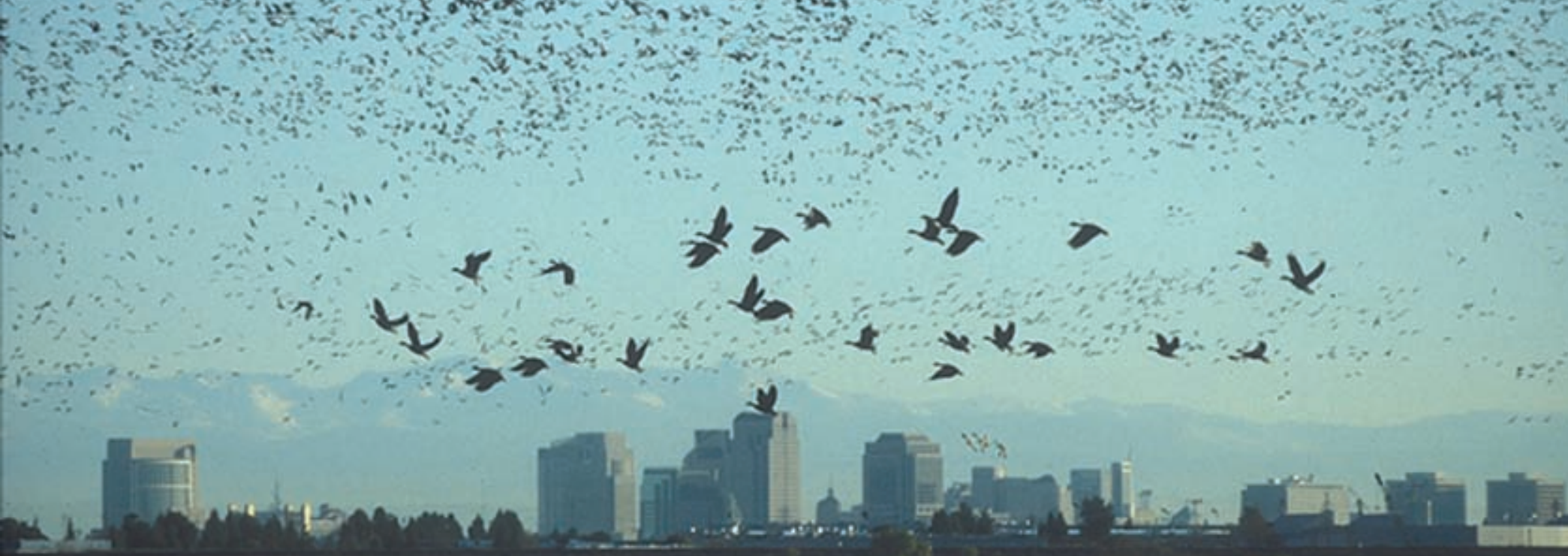

\section{Waterfowl-friendly Rice and Corn}

Waterfowl-friendly rice and corn includes rice fields that are intentionally flooded after harvest and rice and corn fields that are not deep plowed following harvest but which remain dry. Most of the acres associated with this objective are rice acres. Acre objectives for waterfowl-friendly rice and corn were only established for wintering waterfowl (Table 11-3). As a result, no integration of this conservation objective is necessary.

\section{Agricultural Easements}

The need for Type I and Type II agricultural easements was identified for wintering waterfowl and waterbirds (primarily sandhill cranes). For waterfowl, the need for Type I agricultural easements was identified for American, Butte, and Sutter Basins. For waterbirds, the need for Type I easements was identified for the Delta Basin (Table 11-14). As a result, the need for Type I easements is completely additive for these two bird groups. The need for Type II easements for waterfowl was identified for American, Butte, Sutter, Delta, and San Joaquin Basins, while waterbirds need Type II easements in the Delta Basin (Table 11-15). Thus, wintering waterfowl and waterbirds only overlap in their need for Type II agricultural easements in the Delta Basin.
Table 11-14. Integrated Type I agricultural easements for wintering waterfowl and waterbirds in the Central Valley.

\begin{tabular}{|c|c|c|c|}
\hline Basin & Wintering Waterfowl & $\begin{array}{c}\text { Waterbirds } \\
\text { (Sandhill cranes) }\end{array}$ & $\begin{array}{c}\text { Integrated Basin } \\
\text { Needs }\end{array}$ \\
\hline AMERICAN & Needed & & Needed \\
\hline Butte & Needed & & Needed \\
\hline \multicolumn{4}{|l|}{ Colusa } \\
\hline Sutter & NeEded & & NeEded \\
\hline \multicolumn{4}{|l|}{ YoLO } \\
\hline Delta & & NeEded & NeEded \\
\hline \multicolumn{4}{|l|}{ SUISUN } \\
\hline \multicolumn{4}{|l|}{ SAN JOAQUIN } \\
\hline Tulare & & & \\
\hline
\end{tabular}

Table 11-15. Integrated Type II agricultural easements for wintering waterfowl and waterbirds in the Central Valley.

\begin{tabular}{|c|c|c|c|}
\hline Basin & Wintering Waterfowl & $\begin{array}{c}\text { Waterbirds } \\
\text { (Sandhill cranes) }\end{array}$ & $\begin{array}{c}\text { Integrated Basin } \\
\text { Needs }\end{array}$ \\
\hline AMERICAN & NeEded & & NeEded \\
\hline Butte & Needed & & NeEded \\
\hline \multicolumn{4}{|l|}{ Colusa } \\
\hline Sutter & NeEded & & NeEded \\
\hline \multicolumn{4}{|l|}{ Yolo } \\
\hline Delta & Needed & NeEded & NeEded \\
\hline \multicolumn{4}{|l|}{ SuIsun } \\
\hline SAN JOAQUIN & Needed & & Needed \\
\hline Tulare & & & \\
\hline
\end{tabular}




\section{Summary of Integrated Conservation Objectives}

\section{Integrated Wetland Objectives}

Integrated bird conservation objectives for wetland habitats in the Central Valley are presented in Table 11-16.

Table 11-16. Integrated bird conservation objectives for wetland habitats in the Central Valley.

\begin{tabular}{|c|c|c|c|c|}
\hline Basin & $\begin{array}{l}\text { Seasonal Wetland } \\
\text { Restoration (acres) }\end{array}$ & $\begin{array}{c}\text { Seasonal Wetland } \\
\text { Enhancement (acres/year) }\end{array}$ & $\begin{array}{l}\text { Semi-Permanent Wetland } \\
\text { Restoration (acres) }\end{array}$ & $\begin{array}{c}\text { Riparian Restoration } \\
\text { (acres) }\end{array}$ \\
\hline AMERICAN & 20,396 & 1,957 & 425 & 675 \\
\hline Butte & 17,396 & 3,381 & 425 & 1,125 \\
\hline Colusa & 2,396 & 2,057 & 425 & 1,350 \\
\hline Sutter & 4,396 & 527 & 425 & 675 \\
\hline YoLO & 3,170 & 973 & 508 & 675 \\
\hline Delta & 19,170 & 2,118 & 1,208 & 1,500 \\
\hline SuIsun & 0 & 2,675 & 333 & 0 \\
\hline SAN JOAQUIN & 20,340 & 6,752 & 2,815 & 2,500 \\
\hline Tulare & 21,263 & 3,442 & 5,935 & 1,500 \\
\hline TOTAL & 108,527 & 23,884 & 12,500 & 10,000 \\
\hline
\end{tabular}

\section{Integrated Agricultural Objectives}

Integrated bird conservation objectives for agricultural habitats in the Central Valley are presented in Table 11-17.

Table 11-17. Integrated bird conservation objectives for agricultural habitats in the Central Valley

\begin{tabular}{|c|c|c|c|c|}
\hline Basin & $\begin{array}{l}\text { Winter-Flooded Rice } \\
\text { (acres) })^{a}\end{array}$ & $\begin{array}{c}\text { Waterfowl-friendly } \\
\text { Agriculture }^{b}\end{array}$ & $\begin{array}{c}\text { Type I Agricultural } \\
\text { Easements }^{c}\end{array}$ & $\begin{array}{c}\text { Type II Agricultural } \\
\text { Easements }^{d}\end{array}$ \\
\hline AMERICAN & 50,000 & 69,000 & NeEded & NeEded \\
\hline Butte & 62,000 & 104,000 & NeEded & NeEded \\
\hline Colusa & 45,000 & 85,000 & & \\
\hline Sutter & 10,000 & 18,000 & NeEded & NeEded \\
\hline Yolo & 3,000 & 8,000 & & \\
\hline Delta & 0 & 23,000 & & NeEded \\
\hline SuIsun & 0 & 0 & & \\
\hline SAN JOAQUIN & 0 & 0 & & NeEDED \\
\hline Tulare & 0 & 0 & & \\
\hline TотAL & 170,000 & 307,000 & & \\
\hline
\end{tabular}

aThe amount of harvested rice that must be flooded to meet wintering duck and wintering shorebird needs when wetland restoration objectives are met for the Central Valley.

${ }^{b}$ Waterfowl-friendly agriculture is defined as the amount of winter flooded rice plus rice and corn acres that are not flooded and are not deep plowed following harvest.

'Agricultural easements that maintain waterfowl food resources on agricultural lands.

${ }^{d}$ Agricultural easements that buffer existing wetlands from urban and residential development. 


\section{Integrated Annual Water Needs}

Table 11-18. Total annual water needs for wetland and winter-flooded agricultural habitats in the Central Valley when integrated bird habitat objectives are met.

\begin{tabular}{|c|c|c|c|c|}
\hline Basin & $\begin{array}{l}\text { Seasonal Wetland Water } \\
\text { Needs (acre-feet) }{ }^{a}\end{array}$ & $\begin{array}{l}\text { Semi-Permanent Wetland } \\
\text { Water Needs (acre-feet) }{ }^{b}\end{array}$ & $\begin{array}{l}\text { Agricultural Winter } \\
\text { FloodingcNeeds } \\
\text { (acre-feet })^{c}\end{array}$ & $\begin{array}{l}\text { Total Water Needs } \\
\quad{\text { (acre-feet })^{d}}^{d}\end{array}$ \\
\hline AMERICAN & 117,915 & 7,304 & 125,000 & 250,219 \\
\hline Butte & 228,122 & 33,626 & 155,000 & 416,748 \\
\hline Colusa & 123,930 & 32,382 & 112,500 & 268,812 \\
\hline SUTTER & 31,735 & 5,691 & 25,000 & 62,426 \\
\hline YoLO & 58,640 & 14,948 & 7,500 & 81,088 \\
\hline Delta & 121,215 & 17,234 & 72,500 & 210,949 \\
\hline SuIsun & 153,102 & 44,555 & 0 & 197,657 \\
\hline SAN JOAQUIN & 443,374 & 70,996 & 0 & 514,370 \\
\hline Tulare & 217,744 & 65,440 & 0 & 283,184 \\
\hline TotaL & $1,495,777$ & 292,176 & 497,500 & $2,285,453$ \\
\hline
\end{tabular}

aAnnual water needs for managed seasonal wetlands (public and private) when seasonal wetland objectives are met for the Central Valley. ${ }^{b}$ Annual water needs for managed semi-permanent wetlands (public and private) when semi-permanent wetland objectives are met for the Central Valley. 'Annual water needs for winter-flooded agriculture (predominantly rice) when seasonal wetland objectives are met for the Central Valley. ${ }^{d}$ Sum of seasonal wetland, semi-permanent wetland, and winter-flooded agriculture water needs.

Table 11-18 presents total annual water needs for seasonal wetlands, semipermanent wetlands, and winter-flooded agriculture, when integrated bird habitat objectives are met for the Central Valley. Annual water requirements used to estimate total water needs are presented by habitat type and basin in Table 1119. Total water for seasonal wetlands includes the water needs for existing wetlands, and the water needed when seasonal wetland restoration objectives are met. Total water needs for semipermanent wetlands also includes water needs of existing wetlands, and the water needed when semi-permanent wetland res

Securing long-term water supplies for managed wetlands in the valley will be a significant challenge for the JV. The CVPIA statutorily obligates the Secretary of Interior to consult with the JV in matters involving wetland water acquisition and delivery. Considering this obligation, the JV maintains a unique responsibility to consider CVPIA and other water supply issues related to the implementation of this 2006 Plan by participating in various forums where wetland water supplies can be affected.
Table 11-19. Annual water requirements (acre-feet per acre) by habitat type and basin.

\begin{tabular}{|cccc|}
\hline Basin & Seasonal Wetlands & $\begin{array}{c}\text { Semi-Permanent } \\
\text { Wetlands }\end{array}$ & $\begin{array}{c}\text { Winter Flooded }^{b} \\
\text { Agriculture }^{a}\end{array}$ \\
\hline AMERICAN & 5.0 & 7.4 & 2.5 \\
BUtTE & 5.6 & 7.4 & 2.5 \\
COLUSA & 5.0 & 7.4 & 2.5 \\
SUTtER & 5.0 & 7.4 & 2.5 \\
Yolo & 5.0 & 7.4 & 2.5 \\
DELTA & 4.75 & 7.4 & 2.5 \\
SUISUN & 4.75 & 7.4 & 0 \\
SAN JOAQUIN & 5.45 & 7.4 & 0 \\
TULARE & 5.25 & 8.0 & 0 \\
\hline
\end{tabular}

${ }^{a}$ Water requirements from Central Valley Wetlands Water Supply Investigations Final Report 2000. ${ }^{b}$ Dale Garrison, USFWS personal communication.

ration objectives are met. Finally, water needs for winter-flooded agriculture reflects the amount of winter flooding that must be maintained in the Central Valley even when wetland restoration objectives have been met.

\section{Estimated Costs of Meeting Integrated Bird Conservation Objectives}

The cost of delivering conservation programs in the Central Valley varies widely. As a result, dollar estimates for meeting integrated bird objectives are generalized in this Plan and are subject to change. The purpose in providing these costs is to broadly outline the challenges faced by JV partners in meeting the goals of this plan, and not provide rigorous cost projections.

Chapter 11: Summary 
Cost estimates used in the 2006 Plan were provided by public and private entities that deliver conservation programs in the Central Valley. Where possible, these costs are comprehensive. For example, costs associated with wetland restoration include the cost of the actual restoration (e.g. costs of levee construction), staff costs associated with a typical project (e.g. design and permitting), and easement costs paid to a landowner.

The costs of meeting wetland and riparian restoration objectives identified in the 2006 Plan are presented in Table 11-20. Seasonal wetland and semi-permanent wetland restoration objectives were combined as restoration costs were assumed to be similar. It is important to note that semi-permanent wetland objectives in this Plan are considered five year objectives that are likely to increase in future JV Plan updates.

The costs associated with wetland enhancement were not estimated in the 2006 Plan, as these expenses vary widely by project. Similarly, the cost of acquiring reliable water supplies to meet wetland and winter-flooded rice needs was not estimated as these costs can vary widely among years. Finally, the JV did not forecast the potential costs of Type I and Type II agricultural easements as acre targets have not been established for these conservation objectives.

Table 11-20. Estimated costs of meeting wetland and riparian restoration objectives for the Central Valley.

\begin{tabular}{|c|c|c|c|c|c|}
\hline Basin & $\begin{array}{l}\text { Wetland Restoration } \\
\text { Objectives (acres) }\end{array}$ & $\begin{array}{c}\text { Total Wetland } \\
\text { Restoration Costs }\end{array}$ & $\begin{array}{c}\text { Riparian Restoration } \\
\text { Objectives (acres) }\end{array}$ & $\begin{array}{c}\text { Total Riparian } \\
\text { Restoration Costs }\end{array}$ & Total Costs ${ }^{d}$ \\
\hline AMERICAN & 20,821 & $\$ 62,463,000$ & 675 & $\$ 3,375,000$ & $\$ 65,838,000$ \\
\hline Butte & 17,821 & $\$ 53,463,000$ & 1,125 & $\$ 5,625,000$ & $\$ 59,088,000$ \\
\hline Colusa & 2,821 & $\$ 8,463,000$ & 1,350 & $\$ 6,750,000$ & $\$ 15,213,000$ \\
\hline SutTer & 4,821 & $\$ 14,463,000$ & 675 & $\$ 3,375,000$ & $\$ 17,838,000$ \\
\hline YoLO & 3,678 & $\$ 11,034,000$ & 675 & $\$ 3,375,000$ & $\$ 14,409,000$ \\
\hline Delta & 20,378 & $\$ 61,134,000$ & 1,500 & $\$ 7,500,000$ & $\$ 68,634,000$ \\
\hline SUISUN & 333 & $\$ 999,000$ & 0 & $\$ 0$ & $\$ 999,000$ \\
\hline SAN JOAQUIN & 23,155 & $\$ 69,465,000$ & 2,500 & $\$ 12,500,000$ & $\$ 81,965,000$ \\
\hline Tulare & 27,198 & $\$ 81,594,000$ & 1,500 & $\$ 7,500,000$ & $\$ 89,094,000$ \\
\hline TotaL & 121,027 & $\$ 363,078,000$ & 10,000 & $\$ 50,000,000$ & $\$ 413,078,000$ \\
\hline
\end{tabular}

Includes seasonal and semi-permanent wetland restoration objectives.

${ }^{b}$ Wetland restoration costs estimated at $\$ 3,000 /$ acre.

'Riparian restoration costs estimated at $\$ 5,000 /$ acre

${ }^{d}$ Sum of wetland and riparian restoration costs.

\section{Conservation Delivery Options}

The JV has made great strides towards meeting conservation objectives set forth in the 1990 Plan. This success has been due to the efforts of many partners and a wide range of habitat programs. Some programs, such as California Wildlife Conservation Board's Inland Wetlands Conservation Program and California Department of Fish and Game's California Waterfowl Habitat Program, were developed in response to and for the purpose of implementing the stated objectives of the 1990 Plan. As the 2006 Plan has greatly expanded the JV's objectives to include multiple bird groups and habitat types, a comprehensive assessment of existing programs to deliver these objectives is needed. This assessment will evaluate the capability of current programs to deliver JV objectives, provide recommendations for adjusting existing programs, and identify new programs to deliver the 2006 Plan's objectives over the next 5 years. 


\section{LITERATURE CITED}

American Farmland Trust. 1997. Saving American Farmland: What Works. American Farmland Trust; AFT Publication, Northampton, MA. 334pp.

American Farmland Trust. 1995. Alternatives for Future Urban Growth in California's Central Valley: The Bottom Line for Agriculture and Taxpayers. AFT Publication, Davis, CA. 139pp.

Ballard, G., G. R. Geupel, D. Barton, and D. Moody. 2003. California Partners In Flight study areas database: an interactive geographic interface to California's landbird monitoring data: http:/cain.nbii.gov/prbo/calpifmap/livemaps/. Point Reyes Bird Observatory. Stinson Beach, CA.

BART, J. in press. Estimating total population size for songbirds. Bird Populations.

Batzer, D. P., M. McGee, V. H. Resh, and R. R. Smith. 1993. Characteristics of invertebrates consumed by mallards and prey response to wetland flooding schedules. Wetlands 13:41-49.

Bellrose, F.C. 1980. Ducks, geese, and swans of North America, 3rd ed. Stackpole Books, Harrisburg, Pennsylvania. 540pp.

Bock, C.E. And Z.F. Jones. 2004. Avian habitat evaluation: should counting birds count? Frontiers in Ecology and the Environment 2:403-410.

Bradford, D. F. 1992. Potential sites and mechanisms for creating wetland habitat in the southern San Joaquin Valley. Final report for California. Department of Water Resources, Sacramento, CA.

California Department of Water Resources. 1998. California Water Plan Update 1998. Bulletin 160-98.

California Department of Water Resources. 1993. California Water Plan Update 1993. Bulletin 160-93.

Caro, T. M. and G. O’Doherty. 1999. On the use of surrogate species in conservation biology. Conservation Biology 13:805-814.

CDF (California Department of Forestry and Fire Protection). 2002. Multi-source Land Cover Data (2002 v2).

Central Valley Habitat Joint Venture. 1990. Central Valley Habitat Joint Venture Implementation Plan - A Component of the North American Waterfowl Management Plan. U.S. Fish and Wildlife Service, Sacramento, CA. 122pp.

Chase, M. and G. R. Geupel. 2005. The use of avian focal species for conservation planning in California. Pp. 130-142. In Proceedings of the Third International Partners in Flight conference, C.J. Ralph and T.D. Rich eds. USDA Forest Service. PSW-GTR-191.

Checkett, J. M., R. D. Drobney, M. J. Petrie, and D. A. Graber. 2002. True metabolizable energy of moist soil seeds. Wildlife Society Bulletin 30:1113-1119.

Chouinard JR., M. P. 2000. Survival and habitat use of mallard broods in the San Joaquin Valley, California. Masters Thesis. Humboldt State University, Arcata, CA, USA.

Cogswell, H. L. 1962. Operation recovery begun in California’s Central Valley. Western Bird Bander 37:5254.

Conroy, M. J., G. R. Costanzo, and D. B. Stotts. 1989. Winter survival of female American black ducks on the Atlantic Coast. J. Wildl. Manage. 53:99-109.

Cox, R.R., JR. 1996. Movements, habitat use, and survival of female pintails in southwestern Louisiana. Ph.D. diss., Louisiana State Univ., Baton Rouge. 134pp. 
DeSante, D. F. and T. L. George. 1994. Population trends in the landbirds of western North America. Pp. 173-190 in J. R. Jehl, Jr. and N. K. Johnson (eds.). A century of avifaunal change in western North America. Studies in Avian Biology No. 15. The Cooper Ornithological Society, Lawrence, KS.

deSzalay, F.A., L. C Carroll, J. A. Beam, and V. H. Resh. 2003. Temporal overlap of nesting duck and aquatic invertebrate abundances in the Grasslands Ecological Area, California, USA. Wetlands 23(4):739-749.

DeVries, J. H., J. J. Citta, M. S. Lindberg, D. W. Howerter, and M. G. Anderson. 2003. Breeding-season survival of mallard females in the prairie pothole region in Canada. Journal of Wildlife Management 67:551-563.

Dobkin, D. S., A. C. Rich, And W. H. Pyle. I998. Habitat and avifaunal recovery from livestock grazing in a riparian meadow system of the northwest Great Basin. Conservation Biology 12:209-221.

Donovan, T. M., K. E. Freemark, B. A. Mauer, L.J. Petit, S.K. Robison, and V. SaAb. 2000. Pp. 53-59. In Strategies for Bird Conservation: The Partners in Flight Planning Process. (Proceedings of 3rd Partners in Flight Workshop; 1995 October 1-5; Cape May, NJ. ), R. Boney, D. Pashely, R. Cooper, L. Niles, Eds. USDA Forest Service Publication Proceedings RMRS-P16. Ogden UT.

Dunn, E.H., And D.J. Agro. 1995. Black Tern (Chlidonias niger). In The Birds of North America, No. 147 (A. Poole and F. Gill, eds.). The Birds of North America, Inc., Philadelphia, PA.

EA Engineering, Science, and Technology. 1999. Meeting Flow Objectives for the San Joaquin River Agreement 1999-2010. Environmental Impact Statement and Environmental Impact Report. Roseville, CA.

Eddleman, W.R., R.E. Flores, and M.L. Legare. 1994. Black Rail (Laterallus jamaicensis). In The Birds of North America, No. 123 (A. Poole and F. Gill, eds.). The Birds of North America, Inc., Philadelphia, PA.

Eцрніск, C. S. 1998. Waterbird conservation and ecology: the role of rice field management in habitat restoration. Ph.D. dissertation, University of Nevada, Reno.

Euliss, N. H., JR. 1984. The feeding ecology of pintail and green-winged teal wintering on Kern National Wildlife Refuge. M.S. thesis. Humboldt State Univ., Arcata, CA.

Euliss, N. H., Jr. and Harris, S.W. 1987. Feeding ecology of Northern pintails and green-winged teal wintering in California. J. Wildl. Manage. 51:724-732.

FAABORG, J. 2002. Saving migrant songbirds, developing strategies for the future. University of Texas Press Austin, TX.

Faber, P. 2004. Proceedings of the Riparian Habitat and Floodplains Conference. Riparian Habitat Joint Venture, Sacramento, CA.

Fleskes J.P., J.L. Yee, M.L. Casazza, M.R. Miller, J.Y. Takekawa, and D.L. Orthmeyer. 2005. "Waterfowl Distribution, Movements, and Habitat Use Relative to Recent Habitat Changes in the Central Valley of California. Final Report. U.S. Geological Survey - Western Ecological Research Center, Dixon Field Station, Dixon, California.

Fleskes, J. P., R. L. Jarvis, and D. S. Gilmer. 2003. Selection of flooded agricultural fields and other landscapes by female northern pintails wintering in Tulare Basin, California. Wildlife Society Bulletin 31: 793-803.

Fleskes, J.P., R.L. Jarvis, and D.S. Gilmer. 2002. Distribution and movements of female northern pintails radio tagged in the San Joaquin Valley, California. Journal of Wildlife Management 66:138-152.

Fleskes, J., J. Yee, M. Casazza, J. Daugherty and B. Perry. 2000. Waterfowl distribution, movements and habitat use relative to recent habitat changes in the Central Valley of California: A cooperative project to investigate impacts of the Central Valley Habitat Joint Venture and changing agricultural practices on the ecology of wintering waterfowl. Published Progress Report. U.S. Geological Survey, Dixon, California. 143 pp. 
Fleskes, J. P, M. L. Casazza, J. Yee, D. Orthmeyer, B. Perry, and J. Daughtery. 1999. Waterfowl distribution, movements, and habitat use relative to recent habitat changes in the Central Valley of California: A cooperative project to investigate impacts of the Central Valley Joint Venture and changing agricultural practices on the ecology of wintering waterfowl. Progress Report U.S. Geological Survey, Dixon, CA. 143pp.

Gaines, D.A. and S.A. Laymon. 1984. Decline, status and preservation of the Yellow-billed Cuckoo in California. Western Birds 15:49-80.

Gaines, D. F. 1977. The valley riparian forests of California: their importance to bird populations. In: Riparian forests in California: their ecology and conservation. A. Sands, ed. Institute of Ecology Publication 15. University of California. Davis, CA.

Gardali, T. and N. Nur. 2006. Site-specific survival of Black-headed Grosbeaks and Spotted Towhees at four sites within the Sacramento Valley, California. The Wilson Journal of Ornithology 118:178-186.

Gardali, T., A. Holmes, S. Small, N. Nur, G. Geupel, and G. Golet. 2006. Abundance Patterns of Landbirds in Restored and Remnant Riparian Forests on the Sacramento River, California, U.S.A. Restoration Ecology. 14:391-403.

Gardali, T., S.L. Small, N. Nur, G.R. Geupel, G. Ballard, and A.L. Holmes. 2004. Monitoring landbirds in the Sacramento Valley. PRBO report to The Nature Conservancy. Sacramento River, California, USA. PRBO report to The Nature Conservancy.

Geupel G.R. and G. Elliott. 20or. Wet and Wild. Using birds to conserve western riparian habitat. Bird Conservation 14:12-13.

Geupel, G. R., G. Ballard, N. Nur, And A. King. 1997. Population status and habitat associations of songbirds along riparian corridors of the lower Sacramento River: results from 1995 field season and summary of results 1993 to 1995. Point Reyes Bird Observatory report to the U.S. Fish and Wildlife Service and The Nature Conservancy. Stinson Beach, CA.

Gibbs, J.P., F.A. Reid, and S. M. Melvin. I992. Least Bittern. In The Birds of North America, No. 17 (A. Poole and F. Gill, eds.). The Birds of North America, Inc., Philadelphia, PA.

GiLL, R. E., JR. 1977. The breeding avifauna of the South San Francisco Bay estuary. Western Birds 8:1-12

Golet, G. H. 200I. The Riparian Bird Conservation Plan: Book Review. Western Birds 32:182.

Griggs, F. T., J. M. Zaninovich, and G. D Werschkull. I992. Historic native vegetation map of the Tulare Basin, California, in Endangered and sensitive species of the San Joaquin Valley: Their biology, management, and conservation (D. F. Williams, S. Byrne, and T. A. Rado, eds.), pp. 111-118. The California Energy Commission, 1516 Ninth St., Sacramento, CA 95814.

Grinnell, J., And Miller, A. H. 1944. The distribution of the birds of California. Pacific Coast Avifauna 27.

Halterman, M. D., D. S. Gilmer, S. A. Laymon, and G. A. FalXa. 200i. Status of the Yellow-billed Cuckoo in California: 1999-2000. Report to the USGS-BRD Dixon Field Station, 6924 Tremont Rd, Dixon, CA 95620.

Halterman. M.D., D.S. Gilmer, S.A. Layman and G.F. FalXa. 2003. Status of the Yellow-billed Cuckoo in California. Paper presented at the $75^{\text {th }}$ annual meeting of the Cooper Ornithological Society April 2003, Flagstaff, AZ.

Hammond, J. and G.R. Geupel. 2000. Songbird Monitoring on the San Joaquin River National Wildlife Refuge: A Progress Report for the 2000 Field Season.

Heitmeyer, M. E. 1989. Agriculture/wildlife enhancement in California: The Central Valley Habitat Joint Venture. Transactions of the North American Wildlife and Natural Resources Conference 54:391-402.

Heitmeyer, M. E., D.P. Connelly, and R.L. Pederson. 1989. The Central, Imperial, and Coachella valleys of California. Pages 475-505 in L.M. Smith, R.L. Pederson, and R.M. Kaminski, editors. Habitat management for migrating and wintering waterfowl in North America. Texas Tech University Press, Cambridge, United Kingdom. 
Heitmeyer, M.E. and D.G. Raveling. 1988. Winter resource use by three species of dabbling ducks in California. Unpubl. Final Rep. to Delta Waterfowl and Wetlands Research Station, Univ. Calif.-Davis. 201pp.

Heitmeyer, M.E. and L.H. Fredrickson. 198i. Do wetland conditions in the Mississippi Delta hardwoods influence mallard recruitment? Trans. 46th N.A. Wildl. \& Natur. Resour. Conf. 46:44-57.

Hickey, C., W. D. Shuford, G. W. Page, and S. Warnock. 2003. The Southern Pacific Shorebird Conservation Plan. A strategy for supporting California's Central Valley and coastal shorebird populations. Version 1.1. PRBO Conservation Science, 4990 Shoreline Highway, Stinson Beach, CA.

Hoekman, S. T., L. S. Mills, D. W. Howerter, J. H. Devries, and I. J. Ball. 2002. Sensitivity analyses of the life cycle of midcontinent mallards. Journal of Wildlife Management 66:883-900.

Hohman, W. L., T. M. Stark, And J. L. Moore. 1996. Food availability and feeding preferences of breeding fulvous whistlingducks in Louisiana ricefields. Wilson Bulletin 108:137-150.

Hothem, R. L., AND Welsh, D. 1994a. Duck and shorebird reproduction in the Grasslands of Central California. Calif. Fish Game 80:68-79.

Hothem, R. L., ANd Welsh, D. 1994b. Contaminants in eggs of aquatic birds from the Grasslands of Central California. Arch. Envir. Contam. Toxicol. 27:180-185.

Houghton, C. J., J. E. Houk, and T. J. Charmley. 1985. Waterfowl population objectives for the southern San Joaquin Valley and Kern National Wildlife Refuges: issues and strategies. Appendix E. to the Kern National Wildlife Refuge Master Plan. U. S. Fish and Wildlife Service, Region 1. Sacramento, CA.

Humple, D. L. and G. R. Geupel. 2002. Autumn populations of birds in riparian habitat of California’s Central Valley. Western Birds 33:34-50.

IveY, G. L. 2005. Sandhill crane objectives and conservation strategies. Unpublished. Report provided to the Central Valley Joint Venture. 8 pp.

IvEY, G. L. 2004. Conservation assessment and management plan for breeding western and Clark's grebes in California. Unpublished. Report provided to the American Trader Trustee Council. 80 pp.

Ivey G. L. and C. P. Herziger. 2003. Sandhill crane monitoring at Staten Island, San Joaquin County, California, 2002-03. Unpublished report. The Nature Conservancy, Galt, California. http://www.cosumnes.org/staten-cranes.pdf

Jensen, D., S. Torn, And J. Harte. 1993. In our hands: a strategy for conserving California’s biological diversity. University of California Press. Berkeley, CA.

Johnson, S., G. Haslam, and R. Dawson. 1993. The great Central Valley: California's heartland. Univ. Calif. Press, Berkeley, CA.

Jones and Stokes Associates, Inc. 1988. Private wetlands in the Kern-Tulare Basin, California: Their status, values, protection, and enhancement.

Kaminski, R. M., And E.A. Gluesing. 1987. Density and habitat related recruitment in mallards. Journal of Wildlife Management 51:141-148.

Katibah, E. F. 1984. A brief history of riparian forests in the Central Valley of California. In R. E. Warner and K. M. Hendrix (eds). California riparian systems: ecology, conservation, and productive management. University of California Press Ltd. London, England.

KonefF, M. 2003. Derivation of regional waterfowl planning objectives for NAWMP continental population objectives. Unpublished report. 
Krueper, D., J. Bart, and T.D. Rich. 2003. Response of Vegetation and Breeding Birds to the Removal of Cattle on the San Pedro River, Arizona (U.S.A.). The Journal of the Society for Conservation Biology 17 (2), 607-615.

Kushlan, J.A., M.J. Steinkamp, K.C. Parsons, J. Capp, M.A. Cruz, M. Coulter, I. Davidson, L. Dickson, N. Edelson, R. Elliot, R.M. Erwin, S. Hatch, S. Kress, R. Milko, S. Miller, K. Mills, R. Paul, R. Phillips, J.E. Saliva, B. Sydeman, J. Trapp, J. Wheeler, and K. Wohl. 2002. Waterbird Conservation for the Americas: The North American Waterbird Conservation Plan, Version 1. Waterbird Conservation for the Americas, Washington, DD, U.S.A., 78 pp.

LAмвеск, R.J. 1997. Focal species: a multi-species umbrella for nature conservation. Conservation Biology 11:849-856.

Laymon, S. A. 1998. Yellow-billed Cuckoo (Coccycus americanus). In The Riparian Bird Conservation Plan: a strategy for reversing the decline of riparian-associated birds in California. California Partners in Flight. http://www.prbo.org/calpif/ htmldocs/riparian_v-2.html

Lindenmayer, D. B., A. D. Manning, P. L. Smith, H. P. Possingham, J. Fischer, I. Oliner, and M. A. McCarthy. 2002. The focal-species approach and landscape restoration: a critique. Conservation Biology 16:338-345.

Littlefield, C.D., and G.L. Ivey. 2000. Conservation assessment for greater Sandhill cranes wintering on the Consumnes River Floodplain and Delta Regions of California. The Nature Conservancy. Galt, California.

Littlefield, C. D., ANd G. L. Ivey. 1999. Conservation assessment for greater Sandhill cranes wintering on the Cosumnes River Floodplain and Delta regions of California. Unpublished report. The Nature Conservancy, Galt, California. http:// watershed.ucdavis.edu/crg/reports/crane2001.pdf

Loesch, C. R., D. J. Twendt, K. Tripp, W. C. Hunter, and M. S. Woodrey. 2002. Development of management objectives for waterfowl and shorebirds in the Mississippi Alluvial Valley. In Bonney, R., D. N. Pashley, R. J. Cooper, R, L. Niles., eds. Strategies for bird conservation: The Partners in Flight planning process; Proc. 3rd Partners in Flight workshop, 1995, Cape May, NJ. RMRS-P-16. Ogden, UT: U.S. Dept. Ag., Forest Service, Rocky Mountain Research Station.

Loesch, C. R., AND R. M.Kaminski. 1989. Winter body-weight patterns of female mallards fed agricultural seeds. Journal of Wildlife Management. 53:1081-1087.

Loughman, D. L., G. S. Yarris, and M. R. McLandress. 199i. An evaluation of waterfowl production in agricultural habitats of the Sacramento Valley. Final Report to the California Department of Fish and Game. California Waterfowl Association, Sacramento CA.

Manley, S. W. 1999. Ecological agricultural values of winter-flooded ricefields in Mississippi. PhD. Dissertation. Mississippi State University, Starkville, MS.

Margules, C.R., and R.L. Pressy. 2000. Systematic conservation planning. Nature 405:243-253.

Martin, T. E. I995. Summary: model organisms for advancing and understanding of ecology and land management. Pp. 477-484 in T. E. Martin and D. M. Finch (Eds.). Ecology and Management of Neotropical Migratory Birds: a synthesis and review of critical issues. Oxford University Press, New York.

Mayfield, H. F. 1975. Suggestions for calculating nest success. Wilson Bulletin 87:456-466.

Mclandress, R. M., G. S. Yarris, A. E. H. Perkins, D. P. Connelly, and D. G. Raveling. 1996. Nesting biology of California mallards. Journal of Wildlife Management 60: 94-107.

Miller, M.R. 1987. Rice available to waterfowl after harvest in the Sacramento Valley is estimated. U.S. Fish and Wildl. Serv. Research Information Bull. No. 87-113.

Miller, M. R. 1986. Northern pintail body condition during wet and dry winters in the Sacramento Valley, California. Journal of Wildlife Management 50:189-198. 
Miller, M.R., ANd W.E. Newton. 1999. Population energetics of northern pintails in the Sacramento Valley, California. J. Wildl. Manage. 63:1222-1238.

Miller, M.R., And G.D. Wylie. 1996. Preliminary estimate of rice present in strip-harvested fields in the Sacramento Valley, California. California Fish and Game 82(4): 187-191.

Miller, M. R., D. E. Sharp, D. S. Gilmer, and W. R. Mulvaney. 1989. Rice available to waterfowl in harvested fields in the Sacramento Valley, California. California Fish and Game: 75:113-123.

Moore, S. B., Winckel, J., Detwiler, S. J., Klasing, S. A., Gaul, P. A., Kanim, N. R., Kesser, B. E., DeBevec, A. B., Beardsley, K., and Puckett, L. K. 1990. Fish and wildlife resources and agricultural drainage in the San Joaquin Valley, California. Vol. 1. Report of the San Joaquin Valley Drainage Program, Sacramento, CA.

Moss, R., S. Blumenshine and J. Fleskes. 2006. Aquatic insects and waste agricultural seeds in post-harvest flooded agricultural fields in the southern San Joaquin Valley, California. Final Report. Fresno State University and U.S. Geological Survey, Dixon, California. 30 pp.

Naylor, L, E. Burns, J. Eadie, M. Eichholz, M. Petrie, and D. Smith. 2002. Evaluating moist-soil seed production in California to determine habitat needs for waterfowl. Unpublished Report.

Nelms, C. O., And D. J. Twendt. 1996. Seed deterioration in flooded agricultural fields during winter. Wildlife Society Bulletin. 24:85-89.

North American Waterfowl Management Plan, Plan Committee. 2004. North American Waterfowl Management Plan 2004. Strategic Guidance: Strengthening the Biological Foundation. Canadian Wildlife Service, U.S. Fish and Wildlife Service, Secretaria de Medio Ambiente y Recursos Naturales, 22 pp.

North American Waterfowl Management Plan, Plan Committee. 1986. North American Waterfowl Management Plan 1986: A Strategy for Cooperation. Canadian Wildlife Service, U.S. Fish and Wildlife Service, 19 pp.

Nur, N. 2004. Diversity and Abundance of Riparian Birds in the Central Valley: Identifying and Evaluating Indicator Species. Paper presented at the biennial California Bay Delta Program, Oct 2004 Sacramento, CA.

Ohlendorf, H. M., Нothem, R. L., Aldrich, T. W., and Krynitsky, A. J. 1987. Selenium contamination of the Grasslands, a major California waterfowl area. The Science of the Total Environment 66:169-183.

Ohlendorf, H. M., Skorupa, J. P., Saiki, M. K., and Barnum D. A. 1993. Food-chain transfer of trace elements to wildlife, in Management of irrigation and drainage systems: Integrated perspectives (R. G. Allen and C. M. U. Neale, eds.), p. 596-603. Proceedings of the 1993 National Conference on Irrigation and Drainage Engineering, Park City, UT.

Oldenburger, S., J. Eadie, M. Petrie. 2005. Breeding ecology of mallards in the Sacramento Valley, California. Interim progress report. California Department of Fish and Game contract number P0280113.

Parsons, K.C., And T.L. Master. 2000. Snow Egret (Egretta thula). In The Birds of North America, No. 489 (A. Poole and F. Gill, eds.). The Birds of North America, Inc., Philadelphia, PA.

Pashley D. and G. R. Geupel 2003. The California Way. Science guides California's bird conservation efforts. Bird Conservation 21:8-9.

Paveglio, F. L., Bunck, C. M., and Heinz, G. H. 1992. Selenium and boron in aquatic birds from Central California. J. Wildl. Mgmt. 56:31-42.

Paveglio, F. L., Kilbride, K. M., And Bunck, C. M. 1997. Selenium in aquatic birds from central California. J. Wildl. Mgmt. 61:832-839.

Poiani, K. A., M. D. Merrill, and K. A. Chapman. 200I. Identifying conservation-priority areas in a fragmented Minnesota landscape based on the umbrella species concept and selection of large patches of natural vegetation. Conservation Biology 15:513-522. 
Pulliam, H. R. 1988. Sources, sinks, and population regulation. The American Naturalist 132:652-661.

Ralph, C. J., G. R. Geupel, P Pyle, T. E. Martin, and F. DeSante. 1993. Handbook of field methods for monitoring landbirds. USDA Forest Service Publication, PSW-GTR 144, Albany, CA. 41p.

Raveling, D.G. and M.E. Heitmeyer. 1989. Relationships of population size and recruitment of pintails to habitat conditions and harvest. Journal of Wildlife Management 53:1088-1103.

Reinecke, K. J., R. M. Kaminski, D. J. Moorehead, J. D. Hodges, and J. R. Nassar. 1989. Mississippi Alluvial Valley. Pages 203-247 in L. M. Smith, R. L. Pederson, and R. M. Kaminski, eds. Habitat management for migrating and wintering waterfowl in North America. Texas Tech Univ. Press, Lubbock.

Rienecker, W. C. 1990. Harvest distribution and survival of mallards banded in California, 1948-82. California Fish and Game 76:14-30.

RHJV. 2004. Version 2.0. The riparian bird conservation plan: A strategy for reversing the decline of riparian associated birds in California. California Partners in Flight. http://www.prbo.org/calpif/pdfs/riparian.v-2.pdf

Rich, T., C. Beardmore, H. Berlanga, P.J. Blancher, M. Bradstreet, G. Butcher, D. Demarest, E. Dunn, W. Hunter, E. Iñigo-Elias, J. Kennedy, A. Martell, O. Panjabi, D. Pashley, D. Rosenberg, M. Rustay, J. Wendt, and T. Will. 2004. Partners in Flight North American Landbird Conservation Plan. Cornell Lab of Ornithology. Ithaca, New York. http://www.partnersinflight.org/cplan.htm

Robbins, C. S., D. Bystrak, and G. H. Geissler. 1986. The breeding bird survey: its first fifteen years, 1965-1979. USDI Fish and Wildlife Service Resource Publ. 157, Washington, D.C.

Rosenberg, K. V. and P. J. Blancher, 2005 In Press. Setting numerical population objectives for priority landbird species. Pp. 57- 67. In Proceedings of the Third International Partners in Flight conference, C.J. Ralph and T.D. Rich (eds.). USDA Forest Service PSW-GTR-191.

Ryder, R.A., And D.E. Manry. 1994. White-faced Ibis (Plegadis chihi). In The Birds of North America, No. 489 (A. Poole and F. Gill, eds.). The Birds of North America, Inc., Philadelphia, PA.

Safran, R. J., C. R. Isola, M. A. Colwell, and O. E. Williams. Benthic invertebrates at foraging locations of nine waterbird species in managed wetlands of the Northern San Joaquin Valley, California. Wetlands 17: 407-415.

SAnds, A. (ED.). 1977. Riparian forests in California: their ecology and conservation. Institute of Ecology Publication 15, University of California. Davis, CA.

Sedinger, J.S. 1992. Ecology of prefledgling waterfowl. Pages 109-127 in B.D.J. Batt, A.D. Afton, M.G. Anderson, C.D. Ankney, D.H. Johnson, J.A. Kadlec, and G.L. Krapu, editors. Ecology and management of breeding waterfowl. University of Minnesota Press, Minneapolis and London.

Sherry. T. W. and R. T. Holmes 2000. Demographic modeling of migratory bird populations: the importance of parameter estimation using marked individuals. Pp. 211-219 in R. Bonney, D.N. Pashley, R.J. Cooper, and L. Niles (Eds.). Strategies for Bird Conservation; Proceedings of the 3rd Partners in Flight Workshop 1995 October 1-5. USDA Forest Service RMRSP-16, Ogden, Utah.

Shuford, W. D., Page, G. W., and Kjelmyr, J. E. 1998. Patterns and dynamics of shorebird use of California’s Central Valley. Condor 100:227-244.

Shuford, W.D. 1999. Status assessment and conservation plan for the Black Tern (Chlidonia niger surinamensis) in North America. U.S. Department of the Interior, Fish and Wildlife Service, Denver, Colorado. 129 pp. www.r6.fws.gov/blacktern/index.htm

Shuford, W. D., Humphrey, J. M., And Nur, N. 2001. Breeding status of the Black Tern in California. W. Birds 32:189-217. 
Shuford, W. D., Humphrey, J. M., Hansen, R.B., Hickey, C.M., Page, G.W., and Stenzel, L.E. 2004. Patterns of distribution, abundance, and habitat use of breeding black-necked stilts and American avocets in California's Central Valley in 2003. Draft Final Report for the Central Valley Shorebird Working Group. PRBO Conservation Science, Stinson Beach, CA.

Skorupa, J. P., And Ohlendorf, H. M. 1991. Contaminants in drainage water and avian risk thresholds, in the economics and management of water and drainage in agriculture (A. Dinar and D. Zilberman, eds.), p. 345-368. Kluwer Academic Publishers, Norwell, MA.

Small, S., J. DeStaebler, G. R. Geupel, and A. King. 1999. Landbird response to riparian restoration on the Sacramento River System: preliminary results of the 1997 and 1998 field season. A report of the Point Reyes Bird Observatory to The Nature Conservancy California and U.S. Fish and Wildlife Service. PRBO contribution \# 909.

Sмith, F. E. 1977. A survey of riparian forest flora and fauna in California. In A. Sands (Ed.). Riparian forests in California: their ecology and conservation. Institute of Ecology Publication 15, University of California. Davis, CA.

Soulé, M. E. 1995. Biodiversity indicators in California: taking nature’s temperature. California Agriculture 49:40-44.

Stafford, J.D, R.M. Kaminski, K.J. Reinecke, and S.W. Manley. 2006. Waste rice for waterfowl in the Mississippi Alluvial Valley. Journal of Wildlife Management 70: 61-69.

Steele, N. L. C., and Bradford, D. F. 1991. Habitats, siting, and management of potential wetlands in the southern San Joaquin Valley, California. ESE Rep. 91-07, California Department of. Water Resources, Sacramento, CA. <sda.gov/oce/waob/jawf/ wwcb.html> Accessed 2003 June 3.

Tacha, T.C., S.A. Nesbitt, and P.A. Vohs. 1992. Sandhill crane. In The Birds of North America, No. 31 (A. Poole and F. Gill, eds.). The Birds of North America, Inc., Philadelphia, PA.

Tacha, T.C., S.A. Nesbitt, and P.A. Vohs. 1994. Sandhill crane. Pages 77-94 in T.C. Tacha and C.E. Braun, eds. Migratory Shore and Upland Game Bird Management in North America. International Association of Fish and Wildlife Agencies, Washington, D.C.

Taft, O. W., M. A. Colwell, C. R., Isola, and R. J. Safran. 2002. Waterbird responses to experimental drawdown: implications for the multispecies management of wetland mosaics. Journal of Applied Ecology 39:987-1001.

TBI. 1998. The Bay Institute of San Francisco; The Sierra to the Sea: the ecological history of the San Francisco Bay-Delta Watershed. http://www.bay.org.

The Bay Institute. 1998. From the Sierra to the sea: The ecological history of the San Francisco Bay-Delta watershed. A report of The Bay Institute of San Francisco. (http://www.bay.org/news.htm>).

Thelander, C.G., and M. Crabtree. 1994. Life on the edge: a guide to California’s endangered natural resources. Vol. 1: wildlife. Biosystems Books, Santa Cruz, CA.

Thompson, T., K. Freemark, B. Maurer, L. Petit, S. Robinson and V. Saab. 2002. Setting local and regional objectives for the persistence of populations, pp. 53-59 in R. Bonney, D.N. Pashley, R.J. Cooper, and L. Niles (eds.). Strategies for Bird Conservation; Proceedings of the 3rd Partners in Flight Workshop 1995 October 1-5. USDA Forest Service RMRS-P-16, Ogden, Utah.

U.S. Bureau of Reclamation. 1986. Central Valley Fish and Wildlife Management Study: Refuge Water Supply, Central Valley Hydrologic Basin, California. Sacramento, CA. 156pp.

U.S. Bureau of Reclamation. 1979. Central Valley Fish and Wildlife Management Study of 1979. Unpublished Report.

U.S. Bureau of Reclamation. 1978. Total Water Management Study for the Central Valley Basin of California. Unpublished Report. 
U.S. Bureau of Reclamation, U.S. Fish and Wildlife Service, California Department of Fish and Game, and Grasslands Resource Conservation District. 1998. An Interagency Coordinated Program for Wetland Water Use Planning: Central Valley, California. Sacramento, CA.

U.S. Bureau of Reclamation, U.S. Fish and Wildlife Service, and California Department of Fish and Game. 1989. San Joaquin Basin Action Plan/Kesterson Mitigation Action Plan Report: Merced County, California. Sacramento, CA. 78pp.

U.S. Department of Interior: U.S. Bureau of Reclamation and U.S. Fish and Wildife Service. 1989. Report on Refuge Water Supply Investigations, Central Valley Hydrologic Basin, California. Sacramento, CA.

U.S. Department of the Interior, Fish and Wildlife Service. 1989. Wetlands of the California Central Valley: Status and Trends - 1939 to Mid-1980s. Portland, Oregon, 28pp.

U.S. Fish and Wildlife Service. 2005. U.S. Fish and Wildlife Service Manual. 721 FW 6, Joint Ventures (August 24, 2005).

U.S. Fish and Wildlife Service. 2002. Birds of conservation concern 2002. Division of Migratory Bird Management, Arlington, Virginia. 99 pp. [Online version available at http://migratorybirds.fws.gov/reports/bcc2002.pdf].

U.S. Fish and Wildlife Service. 2000. Central Valley wetlands water supply investigations: CVPIA 3406(d)(6)(A,B): a report to Congress: final report. U.S. Fish and Wildlife Service, Portland, OR.

U.S. NABCI Committee. 2000. North American Bird Conservation Initiative bird conservation region descriptions. U.S. Fish and Wildlife Service, Arlington, Virginia. 38 pp.

U.S. NABCI Cомміттеe. 2000. North American Bird Conservation Initiative: Bringing it all together. U.S. Fish and Wildlife Service, Arlington, Virginia.

Van Horne B. 1983. Density as a misleading indicator of habitat quality. J. Wildl. Manage. 47: 893-901.

WeLler, M.W. 1956. A simple field candler for waterfowl eggs. Journal of Wildlife Management 20:111-113.

Werschilll, G. D., F. T. Griggs, and J. M. Zaninovich. 1984. Tulare Basin protection plan. The California Nature Conservancy. San Francisco, CA.

Wood, J., R. Digaudio, C. Howell and G. R. Geupel. 2005. Songbird monitoring along the San Joaquin River National Wildlife Refuge: Avian responses to riparian restoration. Report for the 2003-2004 field seasons PRBO Conservation Science \#1246 (unpublished report).

Wood, J., T. Gardali, and G.R. Geupel. 2001. Neotropical and Resident Songbird Populations in the Lower Creek Floodway Restoration Project: a progress report for the 2000 field season. PRBO Conservation Science \#810 (unpublished report).

YARRIS, G. S. 1995. Survival and habitat use of mallard ducklings in the rice-growing region of the Sacramento Valley. Final report to California Department of Fish and Game. California Waterfowl Association, Sacramento.

Yarris, G. S., M. R. McLandress and A. E. H. Perkins. 1994. Molt migration of postbreeding female mallards from Suisun Marsh, California. Condor 96:36-45.

Zeiner, D. C., and W. F. Laudenslayer, K. E. Mayer, and M. White, eds. i99o. California’s Wildlife: Volume II, Birds. California Statewide Wildlife Habitat Relationship System. State of California, The Resources Agency. Sacramento. 731 pp. 
